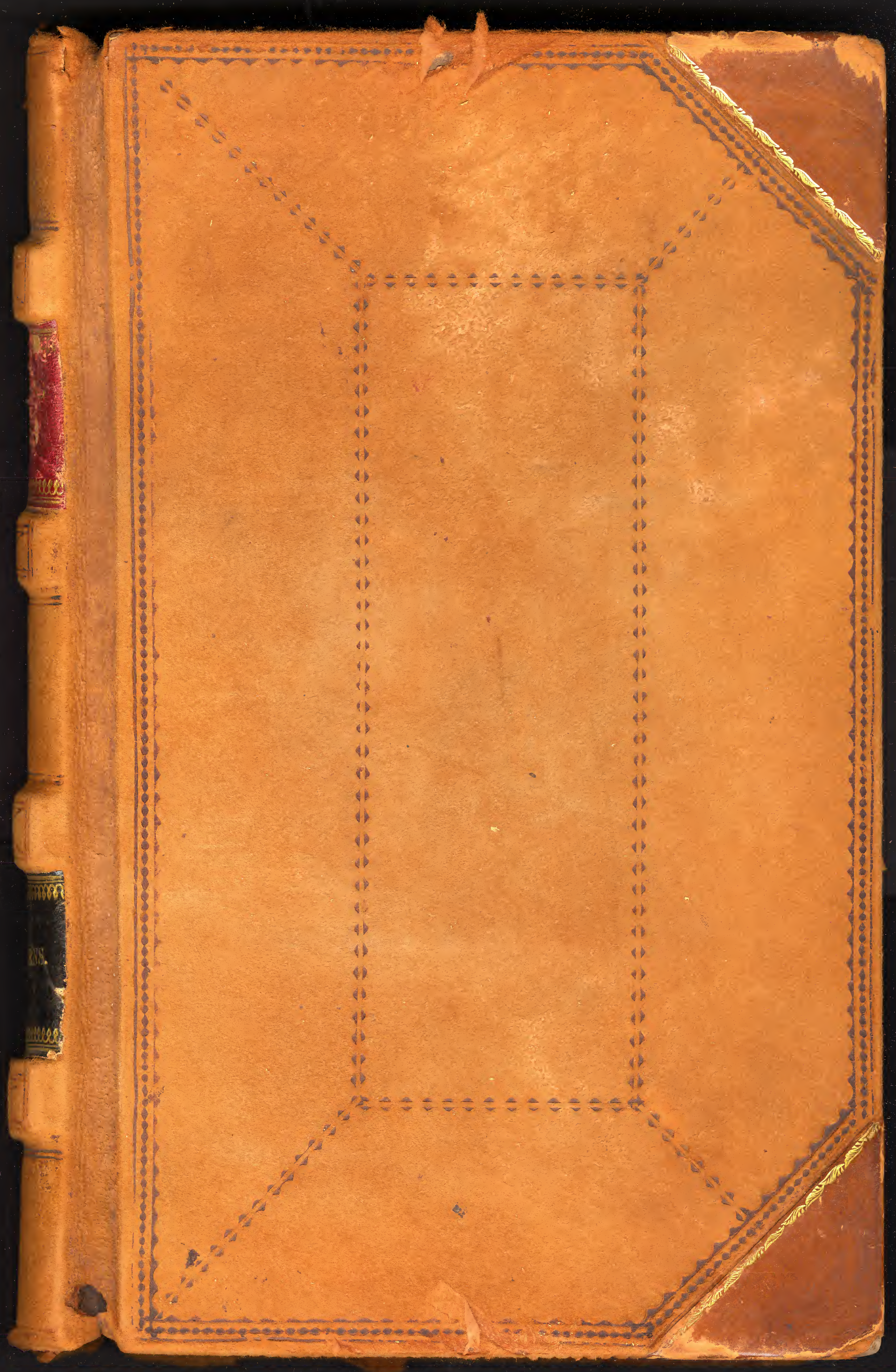



C.t.

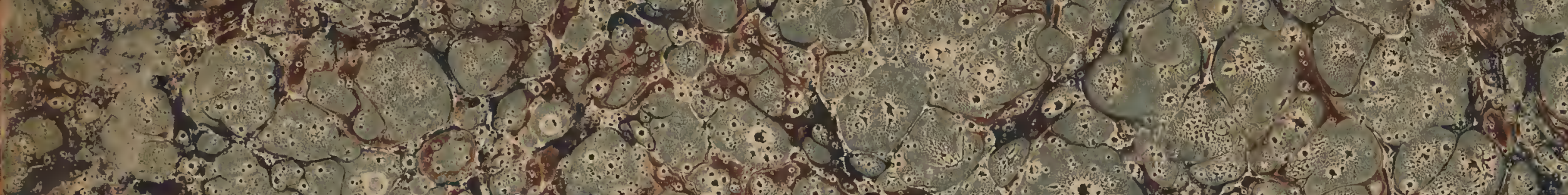

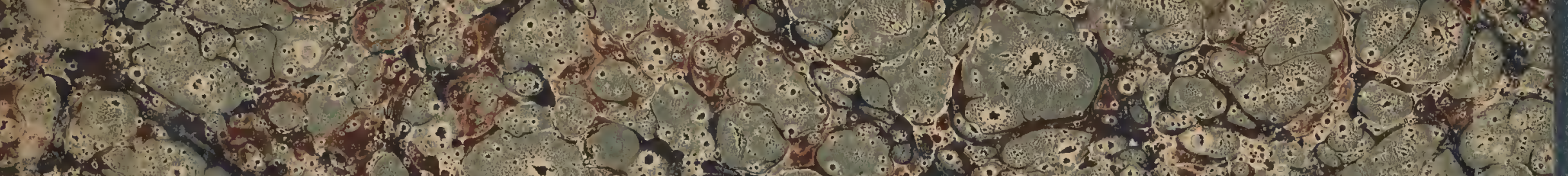

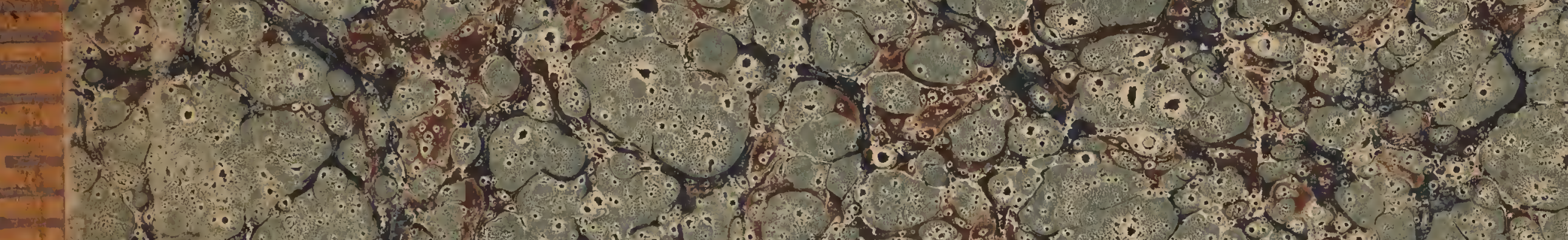

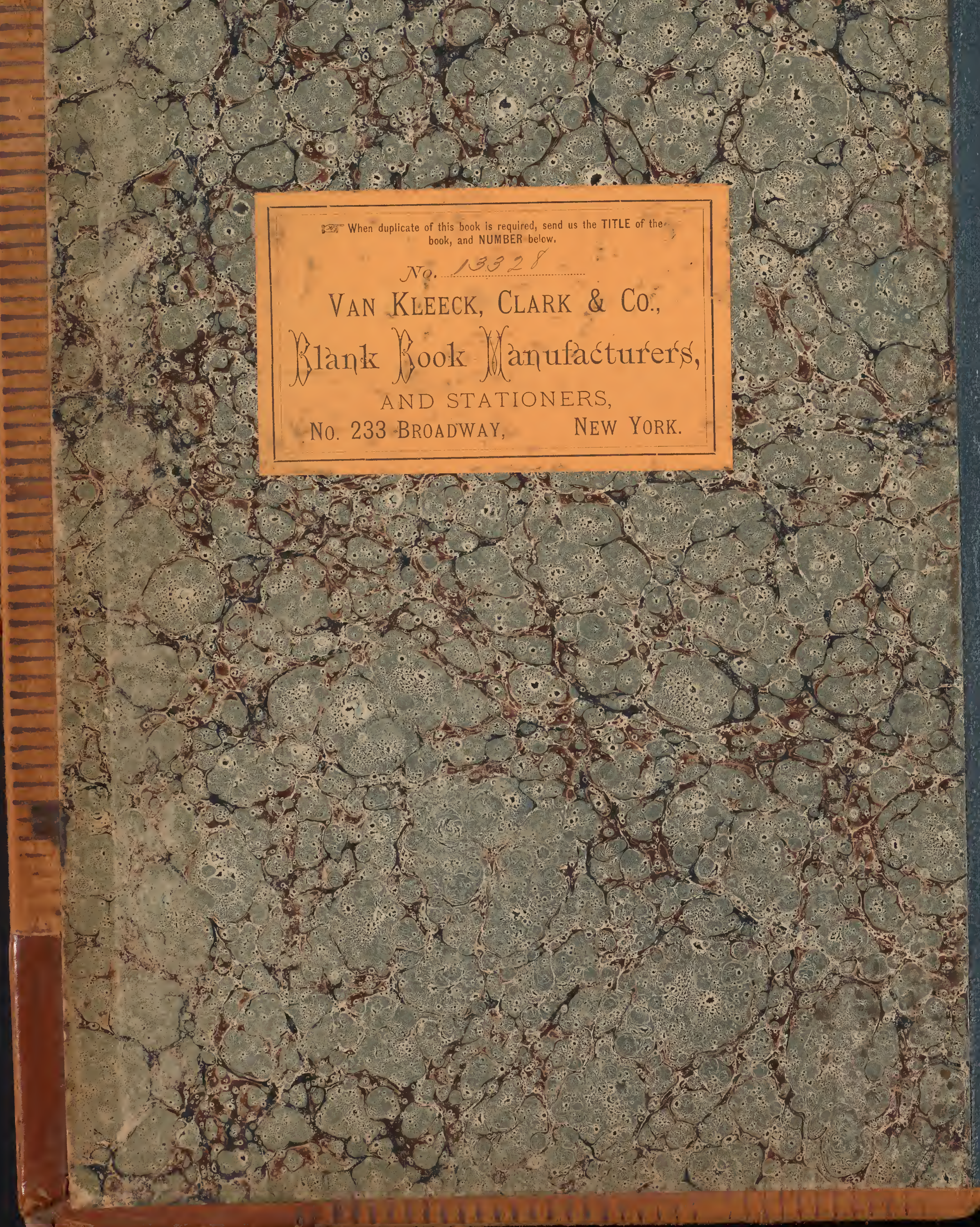

3

政

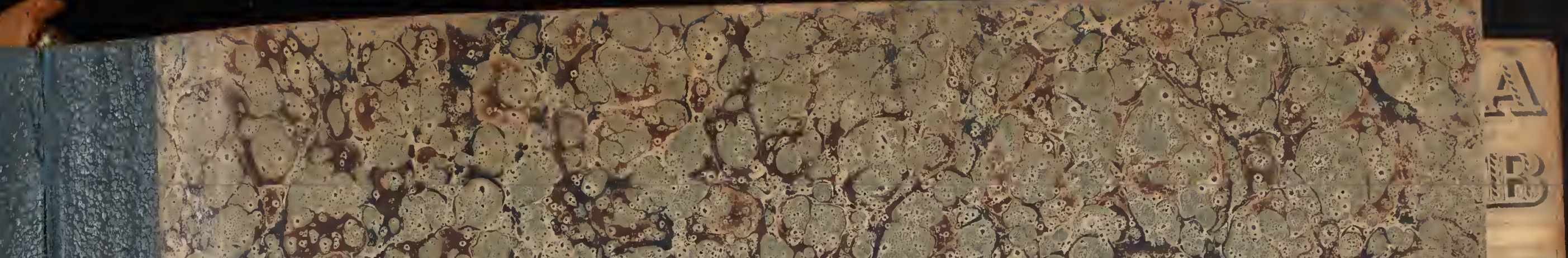

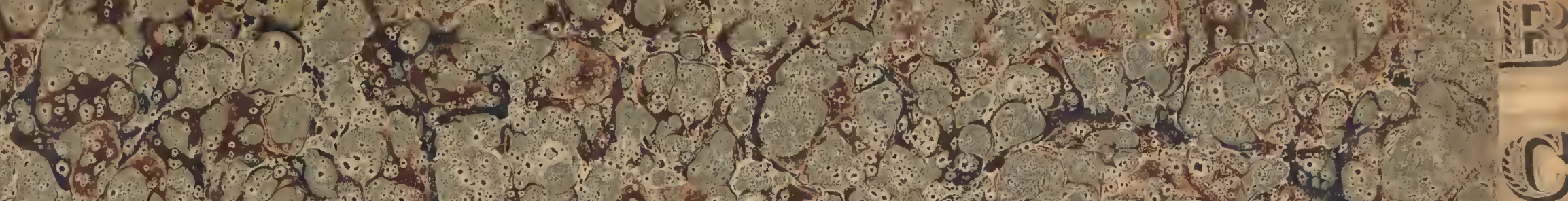
$3 x^{3}+5 x^{2}=8-2$ $46-5,5230$

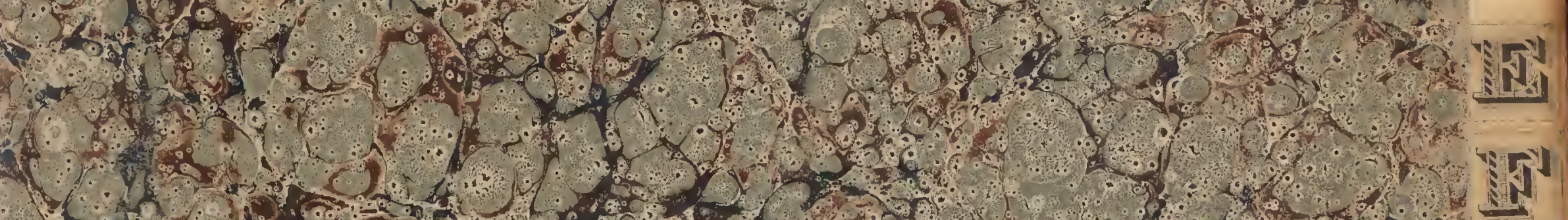

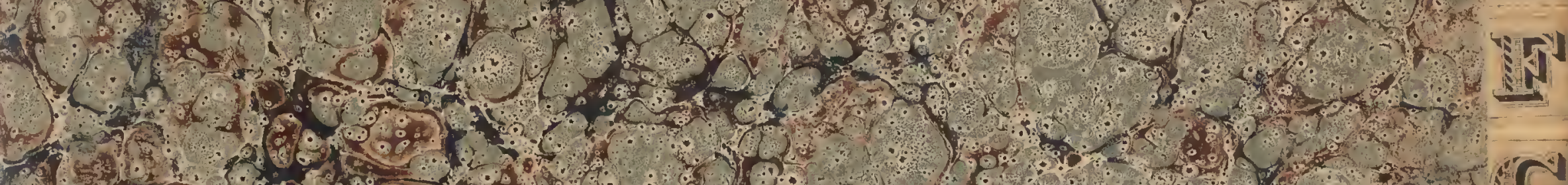

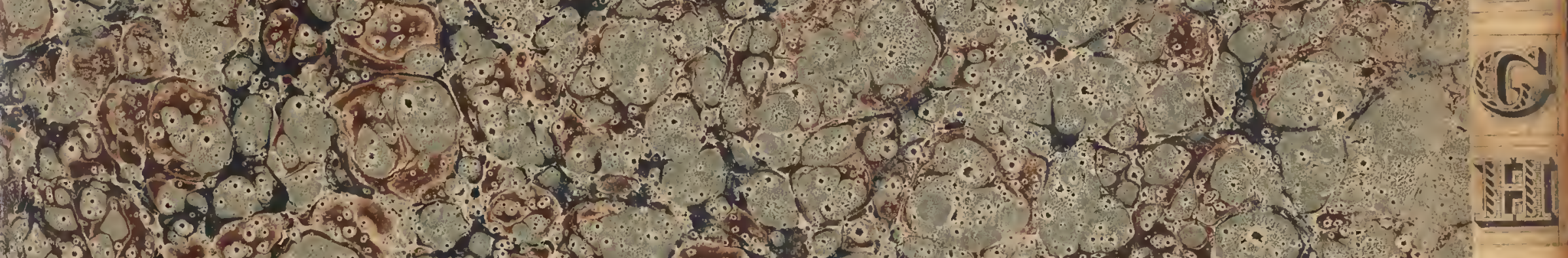

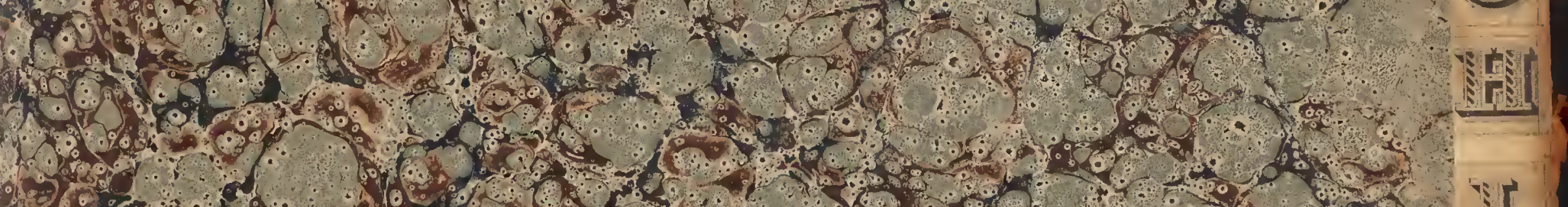
19. 50 .

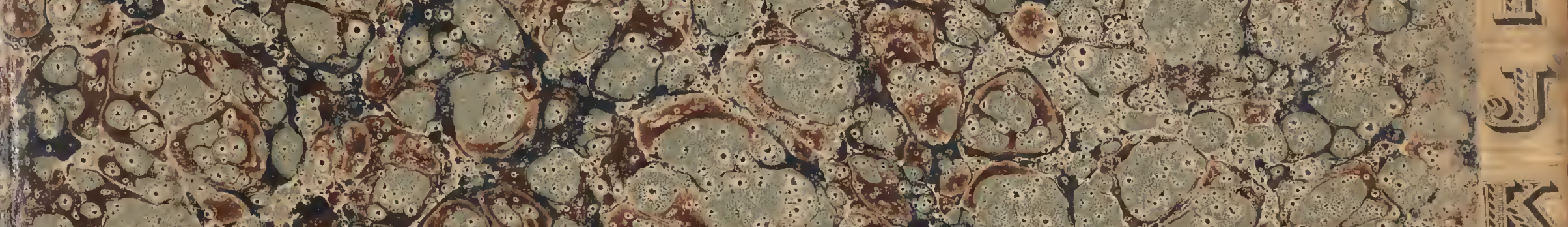

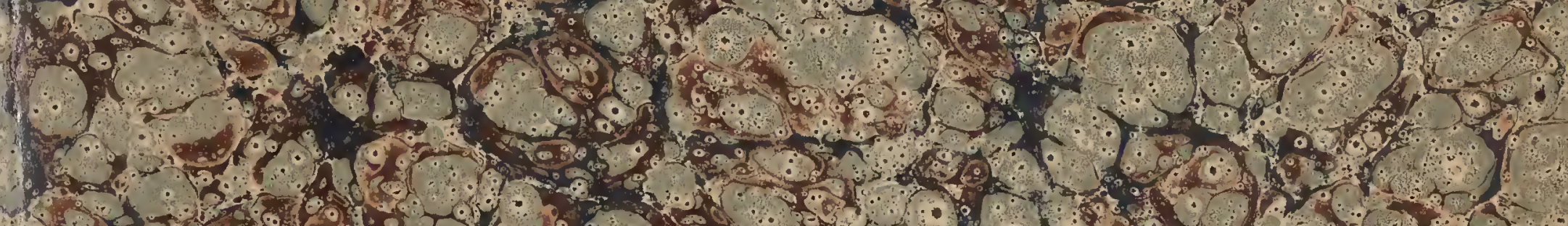

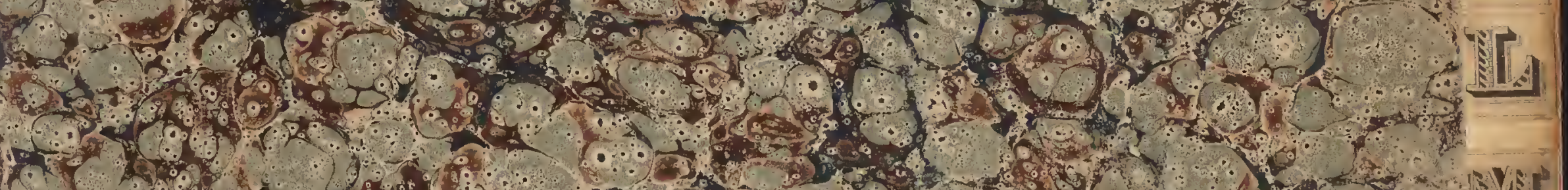

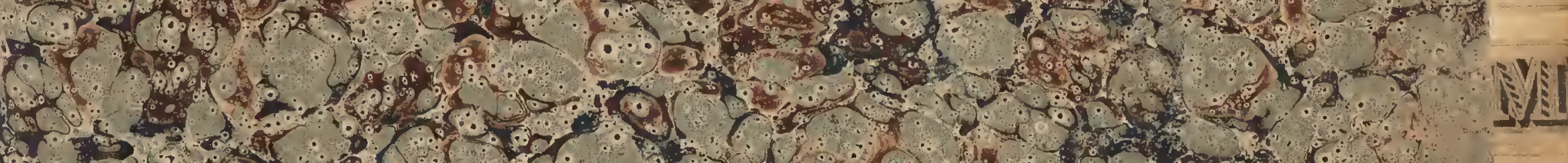

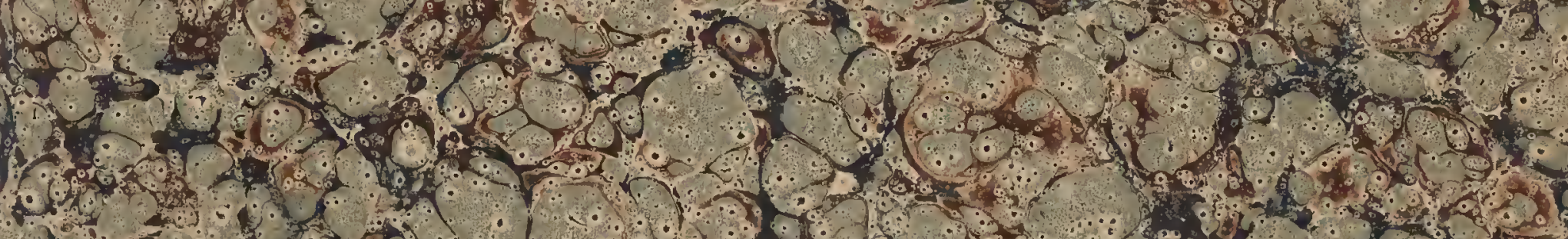

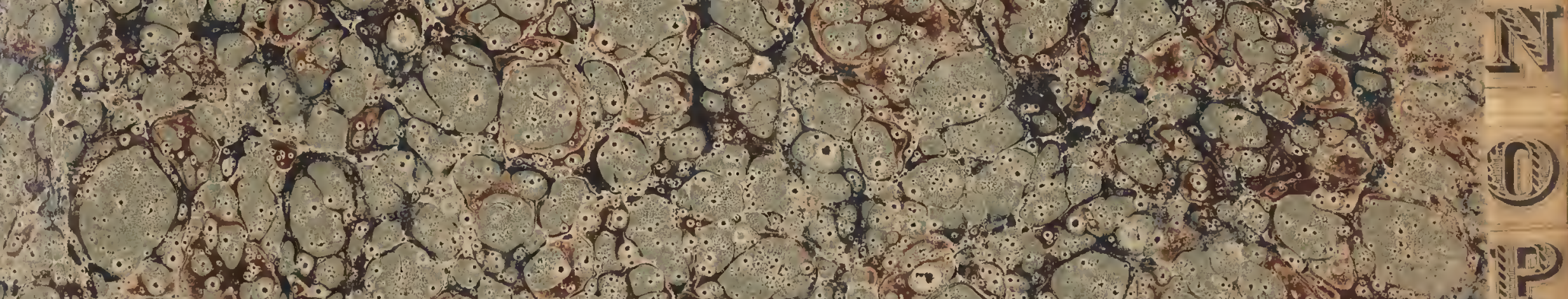

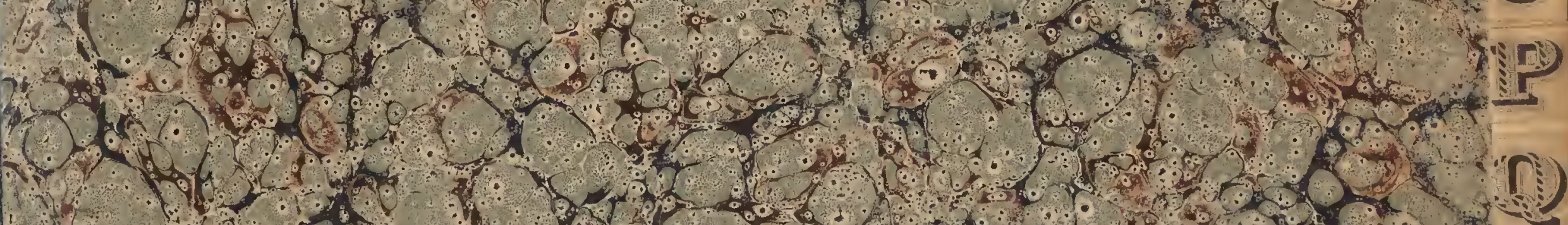

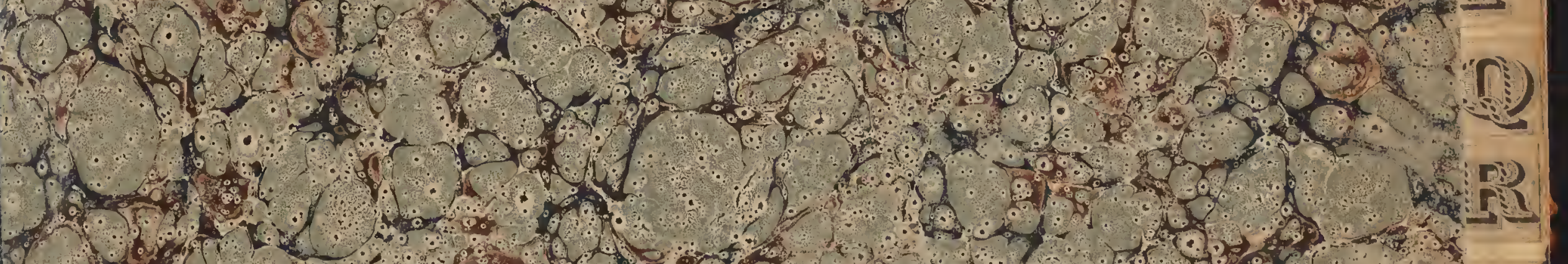
(6)

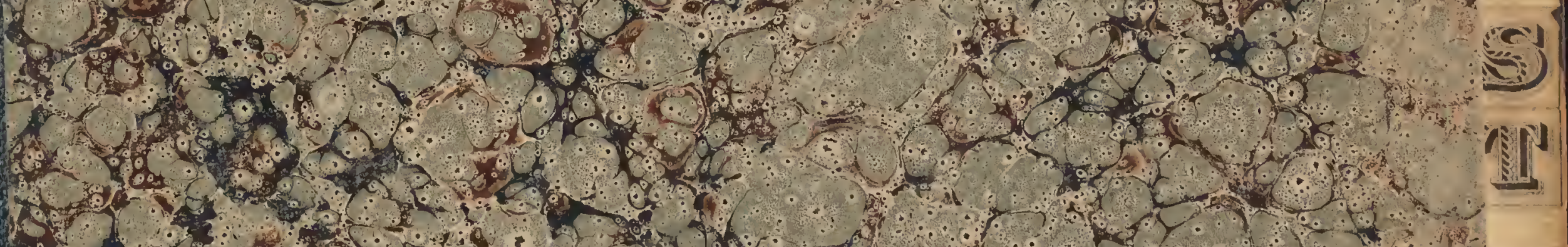
1.t.

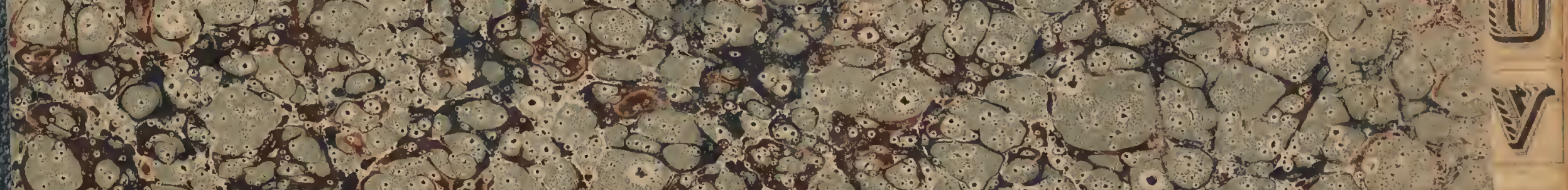

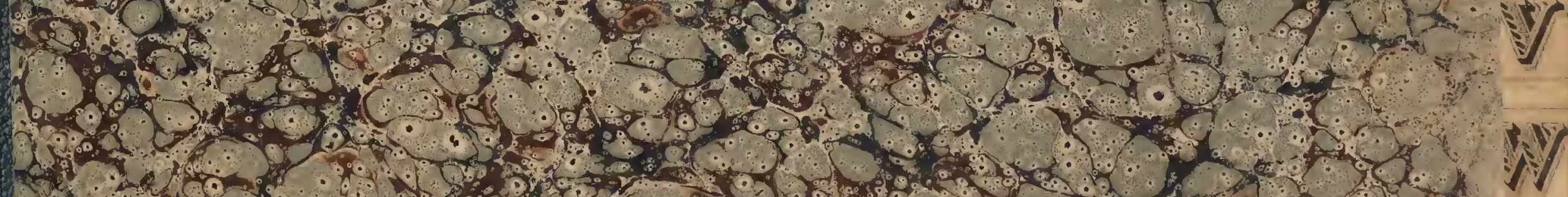

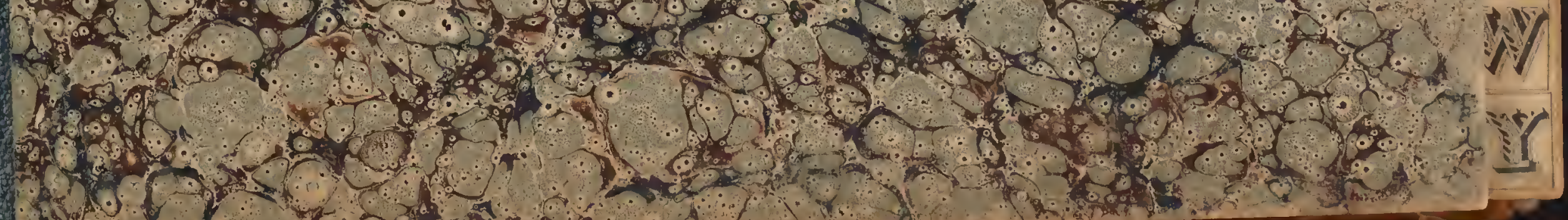




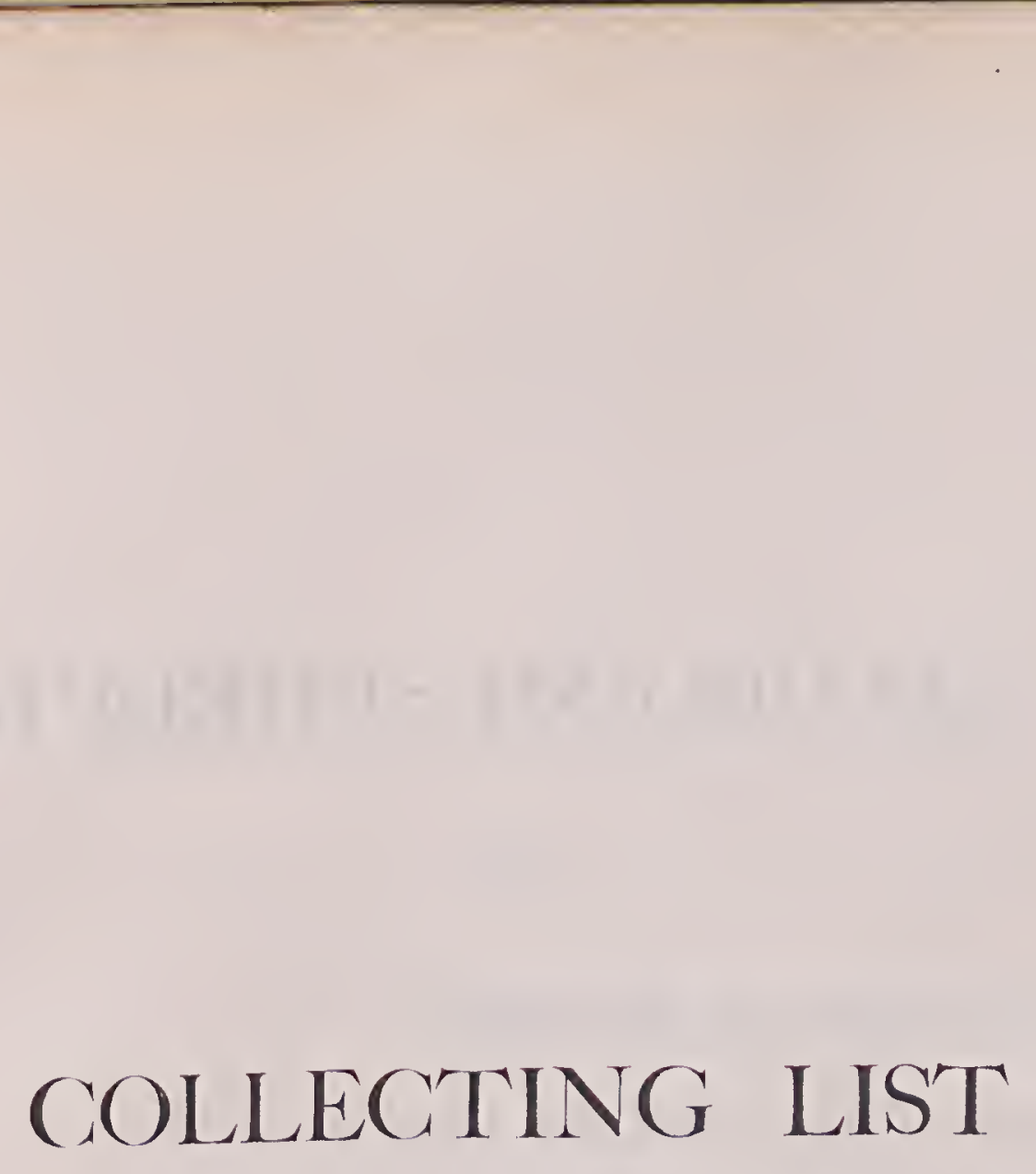

$\begin{array}{r}-1 \\ +5 \\ \hline\end{array}$

6

(1)

跑

is

in

$\mathrm{OF}$

WDGAR A. MHARNG,

HIGHLAND FALLS,

Orange County, New York. 


\section{RECORDING SCHEDULE.}

1. Observations on Birds Shot.

2. Color of Fyes, Bill and Feet.

3. State of Plumage.

4. Contents of Stomach.

5. Description of Nests Collected.

6. Recoid of Trip.

¡. Haunts and Habits.

S. Manners and Actions.

9. Pairing.

10. Songs.

11. Migration Notes.

12. Birds Seen not Shot.

13. Absence of Birds Seen Before.

14. Mbundance or Scarcity. 


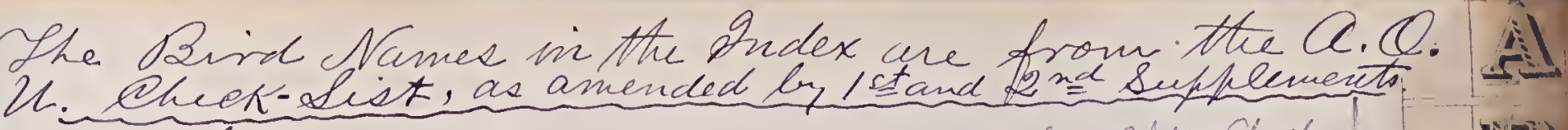

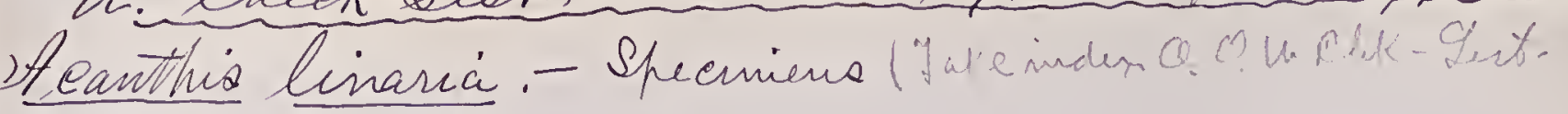
Sec Index to spreninus, p. 466. 


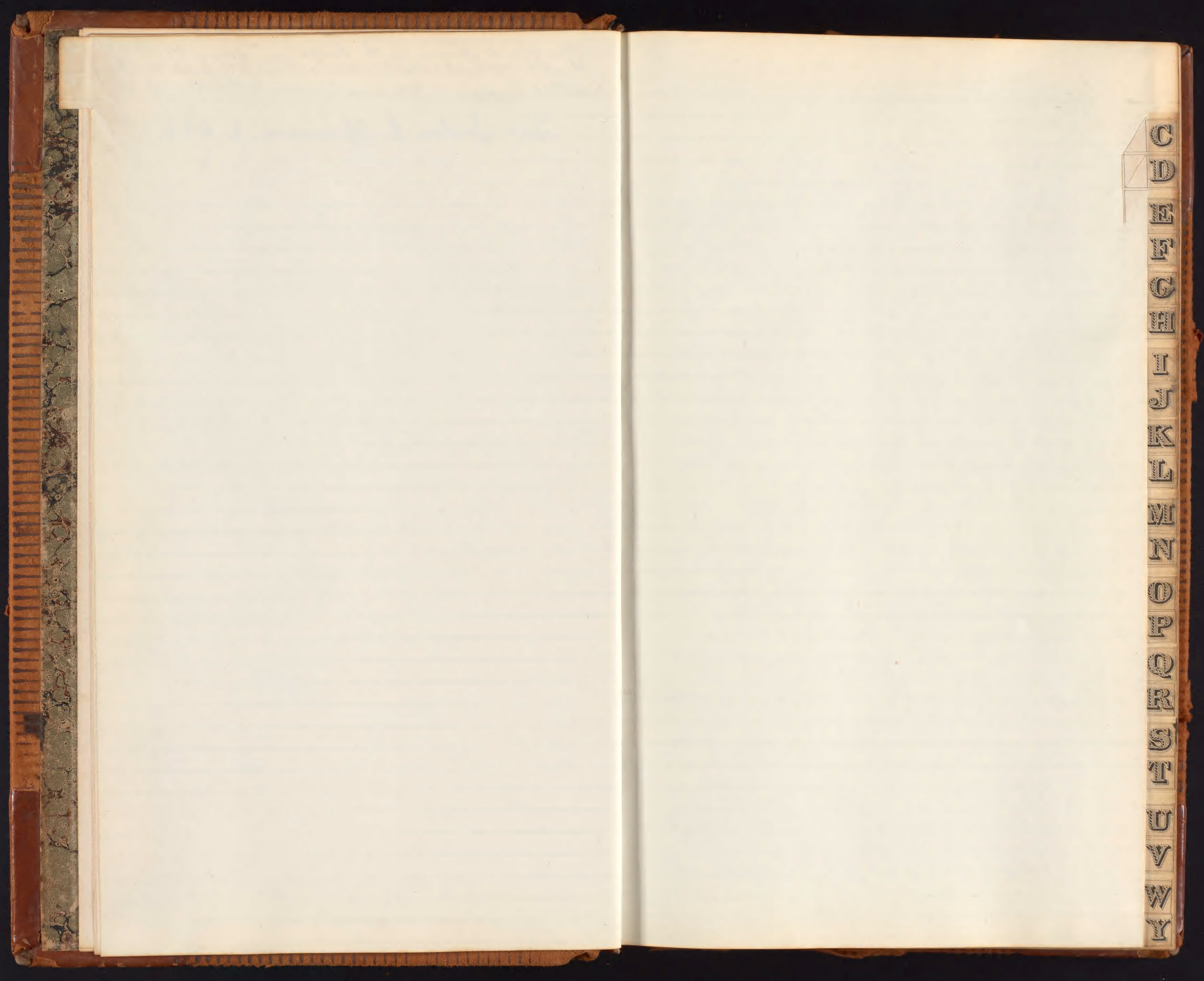




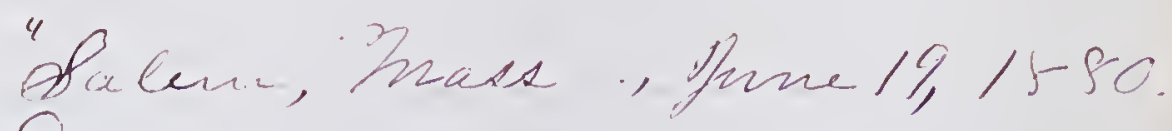

in, zear hr.

Liat of Birc. of thulson ifighlauds.

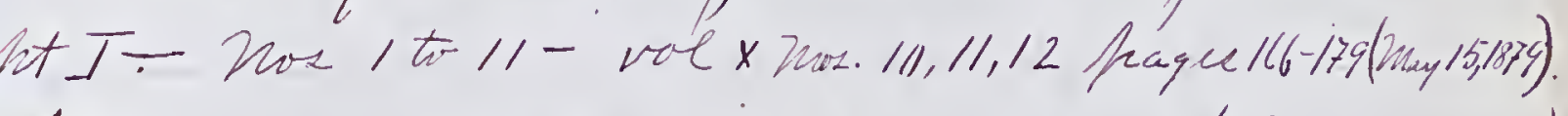

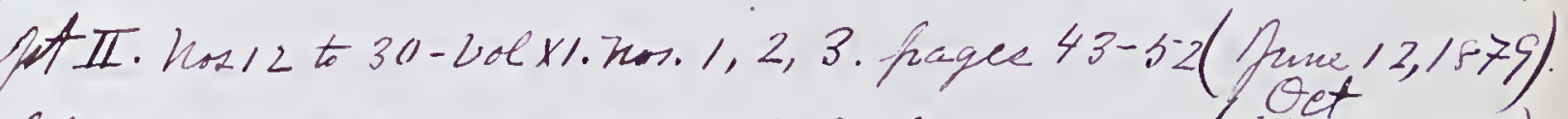

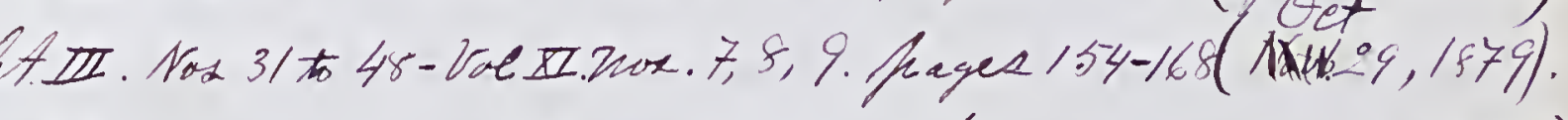

AIII. Nos.49to 71-Vob. It.2us. 10, 11,12. frages 189-204(Afrie 26, 1880)

the above containis an answis to your

question - the dates are those when received

at the revous of the Institute frow be

frontor t distritution followid inmedeatey

Your MPfhas besen secisvid

ipos te

Ateptreacland:" 
1

march 14 th, 1879 . the She following in a complete catalogue of all ing only my original collection of mounted sflecinms, land unlabeled sterns sleeted for exchanges with the dealers:

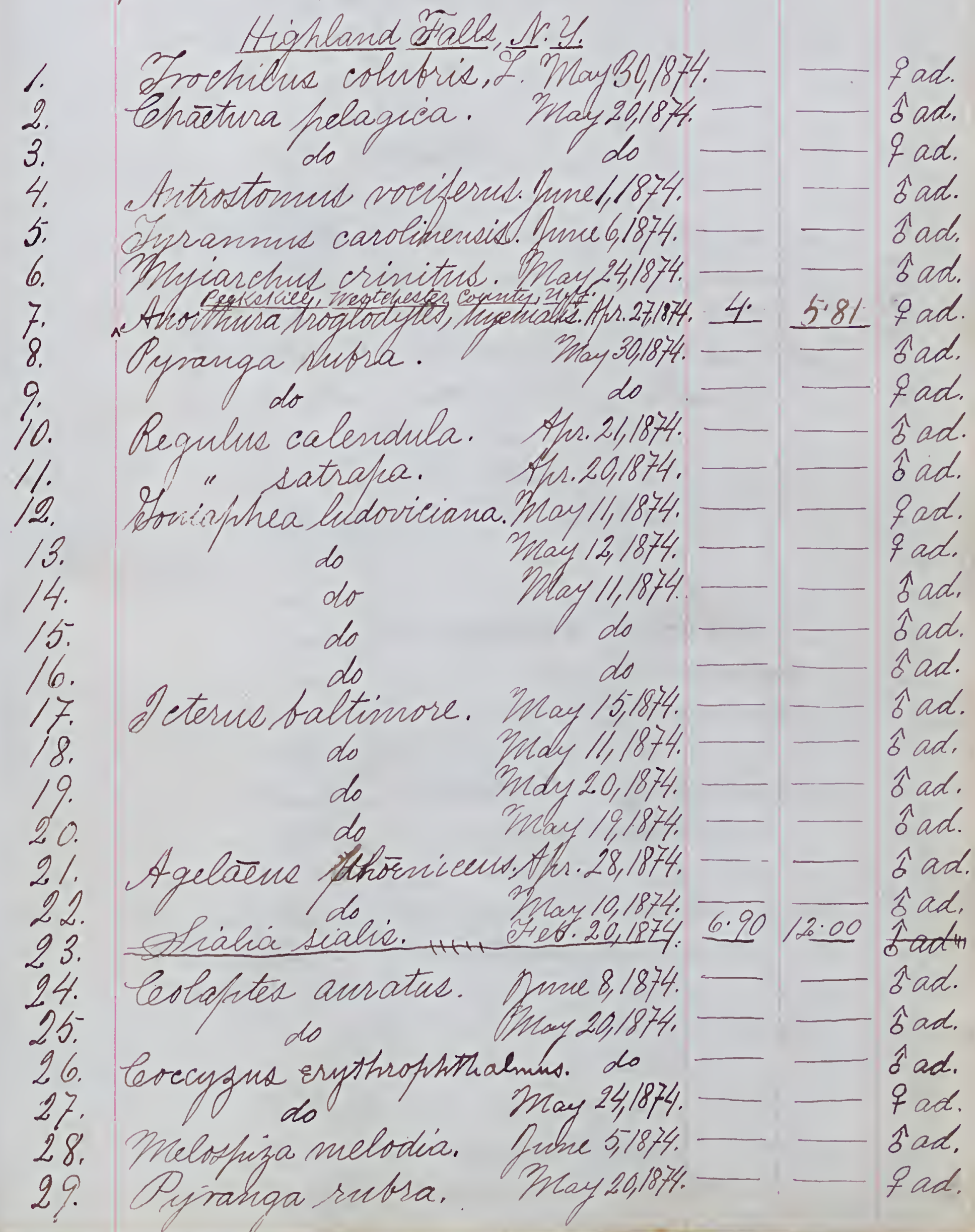




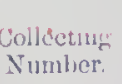

30.

$3 \%$

32

33.

34

35

36.

37.

38

39 .

40.

41.

42

43

40

46

4F Dendroca virens.

48 Sialia sialis.

49

50.

$5 \%$

52.

53.

54

53.

56.

57.

58.

59.

60.

61

62

63.

64. 65

leolaptes auratus.

do

do

do

Ceryle alcyon.

do

Orieo olivaceoul.

do

Molothrus ater.

do

recis protascens.
Atighland
Preis funtrscens.
I achif cineta ficolor.
do

L.OCA IITY.

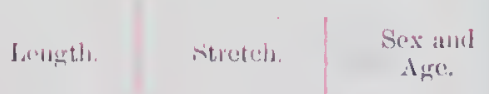

Petorehelido do lunifros do

Ayiundo esythogastra. Onne 10.

Anter fennayhanieus.

Pandeon haliaîtus.

Eialia sialis. Sor.

Dhay 1.

Mny 2. — - Bad.

Maly 6. —u sad.

Gine 21,1873. —— Fjin.

Mhay7. Gad.

Melay 4. 14.8837 .38 9ad.

do 25.00 - a ad.

Nor. 25, 1873.23 .40 65re qad. may. - Bad. May2. - Bad.

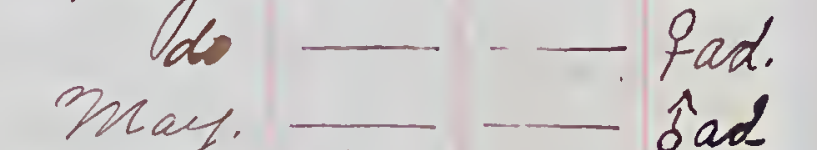
May. Sôd

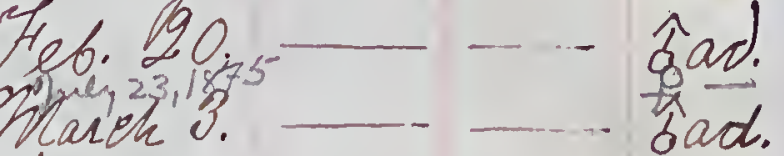

D. endroech virene

leorvus amerieanus

ofiurus motacilla

Sirus amrocafillus.

Warec 3.

Parula americana.

Ahril $12 \ldots$

Haly 2. —- sijur.

may 6._- gad.

mby 7. — Bad.

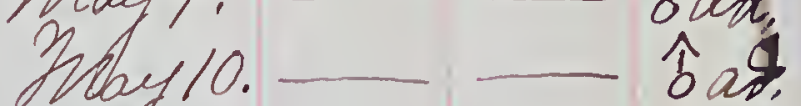

Zthay.

Lyranms carolinensis.

Dime 3.

는

May 25:-

fad.

maly 27. qadi

Juhe \% - Sad.

May 21 — fad.

thatis. - o ad. Sifilo enthrophthaluuse.

Ime 10.

$\hat{\delta}$ ad.

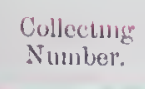

66.

67.

68.

69.

70

$7 \%$

72

73.

75

76.

78.

80.

81.

82.

83.

84.

85

86.

87.

88.

89.

90.

$9 \%$

93.

94

95, Empidonax minimus.

96: Dindroeca Blackburniat.

9.: "Mino flavifione.

10.

100.

10\%. I"terns baltinore.

S'cterus spurius.

Fringoides macularius.

of frizella frusilla.

Chrysonitris tristis.

Bendiorea maculoza.

$$
\text { aestiva. }
$$

Striata.

Mmotilta varia.

Sesthyfris trichas.

o) cterlis virent.

Dendröra cārulucent.

coronata.

castanea.
Belmatodeftes frabustirs.

Trune 2.

Maylo.

penneyhranica. May8.

coronata. Stay.

fensushanica. Malys.

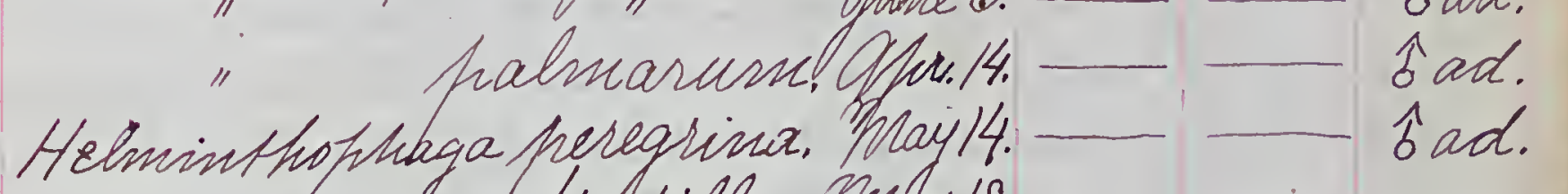

May.

?

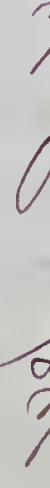

firme 6.

May.

Selu. 1.

Sepr. 1. sad.

juv.

sad.

sad.

Sad.

sad.

qad.

sad.

qad.

fad.

sad.

sad.

sad.

$\hat{o} a d$.

o ad.

bad. ôad.

îad.

q ad. sad. fad. $\hat{b} a d$. sad.

今ad. ŝad. fad. $\hat{s}$ ad. sad. $\hat{\sigma}$ ad. jiw. jin. 
Collectilu.
Sumber.

103.

104

105

106.

107.

108.

109.

110.

111

$1 / 2$

$1 / 3$.

114.

115

$1 / 6$.

$1 / 7$.

$1 / 8$.

119

120.

121.

122

123.

124.

125

126.

127.

128.

129

130.

131

132

133

134

135.

y 36.

137.

138.

139
Melosfiza melodia.

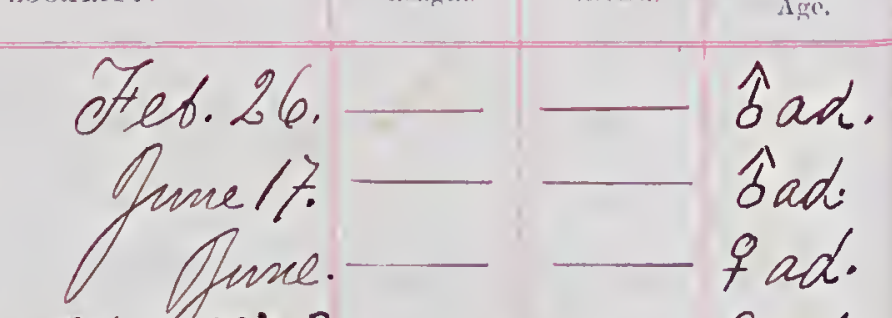

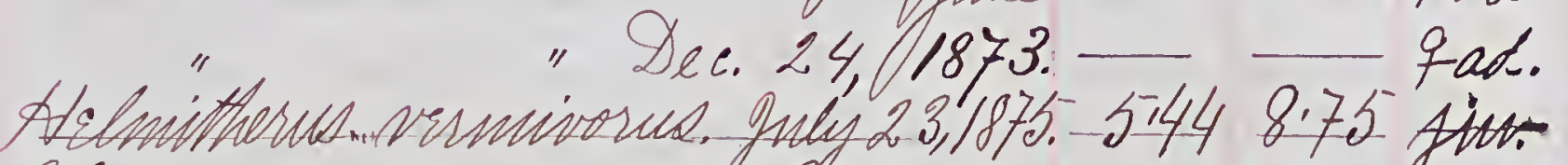
indus migratorius. Mnarch 10. - Sad. a cterus bolltinore. May 14._- 1 ad. Siala sialis. Mashll. S Maseh $\%$ - $a$ ad. "Dec. 1, 1873. - bad. Padserella iliaca. march/s. - qad. Afizella socialie. Mnareh 20. - Tad. ifustus frallasi. Aht. 2\%- Tad. ayanosfliza cyanea. May /3. —_ Sad. " " - Sad. eterus spminus. Mayll. _- bac.. Mimus carolinensis. May. - - Sad. Q) Cterus baltmose. May $14 .-\delta a d$. $\infty$ " " Gonotrichia albieollic.5.19,1872._- Sad, Sialia sialis. Marde 10 - bad. Nyctiardea griea, naêvia. June 4__ S Sad. Sonotrichila albieollic. 187\%. şad. Oyranne carolinensis. May 12. Huiaschus crinetue. Gume/7. elly ctiandea grisca, natifa. Junet.

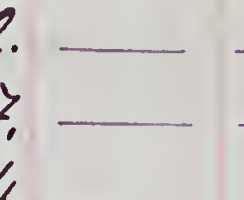
" " "_- - - \$ad. " " " " " " "Guinglivets mitratus. Guly 13.- - qad.

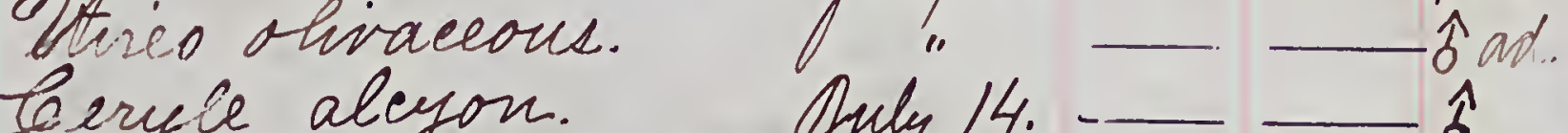

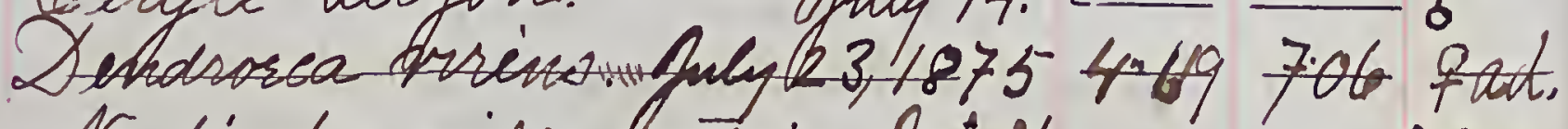
Nyctiardea grisea, naevia. Gumel6. - o jour.

1874

140

140

141.

142.

143.

$-144$.

145

146.

147.

148.

149.

150.

$15 \%$

152

153.

154

155

156

157

158.

159.

160.

$16 \%$

162.

163.

164

165

16.

$16 \%$

168.

$16 \%$
$5 \%$

$17 \%$

$17:$

174

175

176
Pyetiardea grisea, nāevia. Jume 26.

teyanospiza cyanea. July 24.

Doudröea vriene.

ondy 24.

Aclmitherut vermivorus. July 25,

Atarkoshynchus sufus. Glly20.

Pifilo enythof sthelmus. Shly 20.

leyanosfiza cyanea. "July24.

Gerthia sanifeiaris. 24h.24.

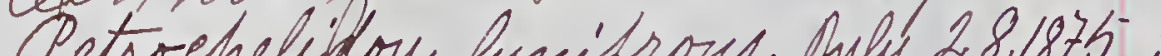
fiw. Ampielis cednorum. omyiardues crisitus.

Parula americana.

Dendrorea striata.

olumenius longinostris.

- fitta canadentus

Mrieo olivaceons.

Anfrelic cedrorum.

Dicus jubrseens.

- Agelaetur phornicene.

durdua migratoriss.

$\because 30, " 8.5012 .62$ ôjur.

"Sune 10. 8.62.12.62 juw. Qume.

Ang. 18. 24.00 40.00 î ad.

Ay. $3 \%$

Lefr. 4.4.75 8.25 定

Oug. 3\%

Seff. 2.

Cug. 30.6.00 10.00

Aleg. 3\%.

Sth. 3.

कि मे.

Lef1.10.8.75 14.50 olyin.

" " " "

picus villosus.

Aicifiter fuscus.

Dojara garohina.

Ceryle aleyon.

Acisis

esefi. $\%$

2. 1.4 .11 .50

Sen.8. $8.87 \quad 14.19$

sefr.9.9.37 14.00

Ang. 3\%.

Afeg. 31.

Helntherus vermivorus. Alg. 4.

Prins hubrscene.

theg. 26.

Ageläus fitornicur. 
177. Golaftes amatud.

178. Misardus crinitus.

179. Itrdus migratorius.

180. macularius.

181. Emhidone\% minims.

182. Tendrace àt tiva.

183. J atame solitioris.

184.

185 Pereo noves oracensie Emfidonax minimus. SEtohhaga uticilla. frochilus cohrbrie. leolaftes auratus. - cterur faltinore. Ardea virescent. Sayomis fuscul. - Aaserella iliaca. Cumansfirza cyanea. Atiliaitul lecerefinalus.

- vice herodias.

- Sordion haliaëut. Anfelis cedronu. - fotanus solitarius. Cgelacus fhornicens.

201

2.02.

203.

2.04.

205

2.06

207.

208.

209.

210

211.

212

213. Pireo olivaceout. "Preo" olivaceons. oprelospriza melodé. Przana carolina. Q) endrotea henses y wamén

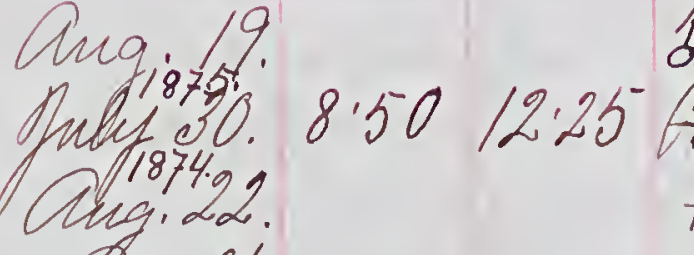 Aug.26. Alg. 12.} Alog, 26. Alag. 14. Afeg. $1 /$.

Aneg. 10. Ang. 19.

Ang. 20.

Sefr. 29.

Otune 10.

May 10.

Aug.19.

Way 20.

March 24.

May 12 .

sad. ter. 15.2584 .00 f jun. Aug.17. fin. sh. 8.21 .0061 .75 字ju step. 26. — Lefi.16.8.00 16.19 Séz. 25. 8.0014 .00 cjim. Sth.25. 8.44 13.38 Ajuv. seff.25. 6.7511 .87 o Selp.20.6.06 10.00 sad.

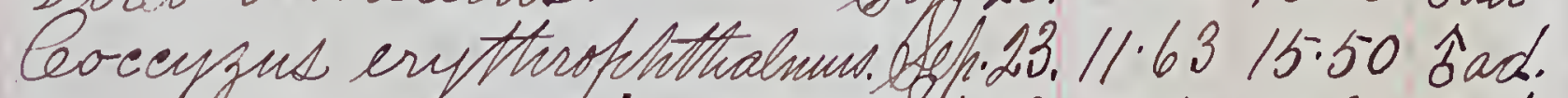
americanus sffi.23. 12.5017.31 9ad. Pipranga rubra. iyanurus cristatus. sefr.23. 7.0611 .75 s.ju. sef,23. 5.709 .19 के Sefr.23.55.63 8.88 क olefr.23.6.06 10.00 sad. otefi.2511.75 16'50 qad Sefe. $25.8 \cdot 1212.88 \%$ Leff.25: $8.4213 \%$ ? Sefv.23. 612 8.48 命ad.
214. Dendrorea striata.

$2 / 5$

$2 / 6$

$2 / 7$

218

219

220

221.

222

223.

sad.

qad.

band.

qad.

q

adi

224
225

226

2.27.

228

229

230.

2.31

232.

233.

234.

235

236.

237

238.

239.

240.

241.

242.

243 .

244.

246

247.

248.

249.

250.
Agelãus hhornicus.

Flachuneta biélor

\& otamus solitarius.

Aqeläns fhionicend.

Ardea herodiás.

Stuins motacilla.

teeryle aleyon.

Cersanmis criotatud.

Aifilo. eriftrro Whthalmus.

Cearfodaleut furfureus.

Sitta carolinensie."

$\mu^{\prime \prime}$

cturdus suainsoni, alieiat.

Parula amerieana.

D. indróca coronata.

Prío iniacous.

Ceorvel amerieanue.

"

Sthmruipus variul.

Thotrichía albcollis.

Agelāens huornicus.

Esofis asio (red).

sthurafieus varius.

Aix sfonsa.

Melospra palustrie.

Ammodromus caudaeitus. Qet.16.

Coarfodacus purpureus.

lefanurus erietatus.

Cefrusonitris finis.

Ceyamus cristatus.
Seffe. 24.

setr. 25. 8.00 14.00 ôju.

uly $28,1875.575$ t2.25 for.

Stepr. 16. 8.0016:19.0

Sef. 26.7.7512:50 o

Duly 30 . _ _ _ ins

sufy 21 —

Sef. $29.12 .6821 .12 q$

sef. 30 .

$\begin{array}{lll}30 & 137 & 1 \\ 0 \text { ad. }\end{array}$

cot 6.129 .60 .

Qet. 8.

Qet. 7.

eet.7.

eet.8.

eet. 8

Cet. 8

eer. 7 .

Cet. 7.

Qcts.

Qct. 7 .

bext.

$175-39.00$

sad

Lefi. 29

Cet.8.

Cet.8. 7.00 9.320 jiv

Qet.15.

Oet.23.

Cet 7.6215 .25

Cetis:

Cet.11.

Cet.1.

Qet. 16 .

Qert.14. $q$

sad.

q

q

q

ôju

Pad.

q ad.

fad.

今ad.

全jir.

$q$

今

jur

ôjin.

9

$\hat{s} a d$.

bad.

q

sad 


\begin{tabular}{|c|c|c|c|c|c|c|c|c|c|c|c|}
\hline 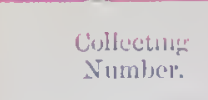 & Singe & LOCALATY & I.mingth. & surertih. & 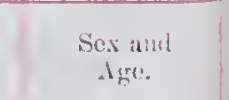 & 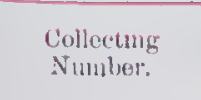 & valle & LOCALATYY. & Ioverthe & Strecth. & 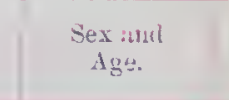 \\
\hline 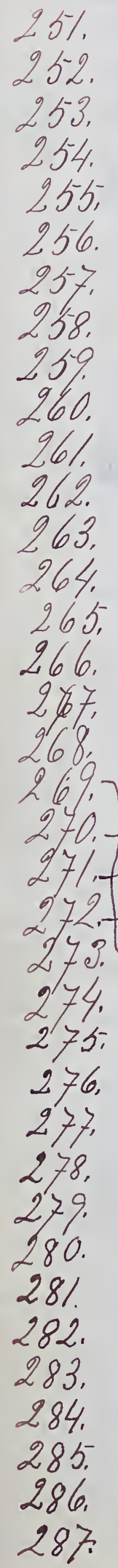 & 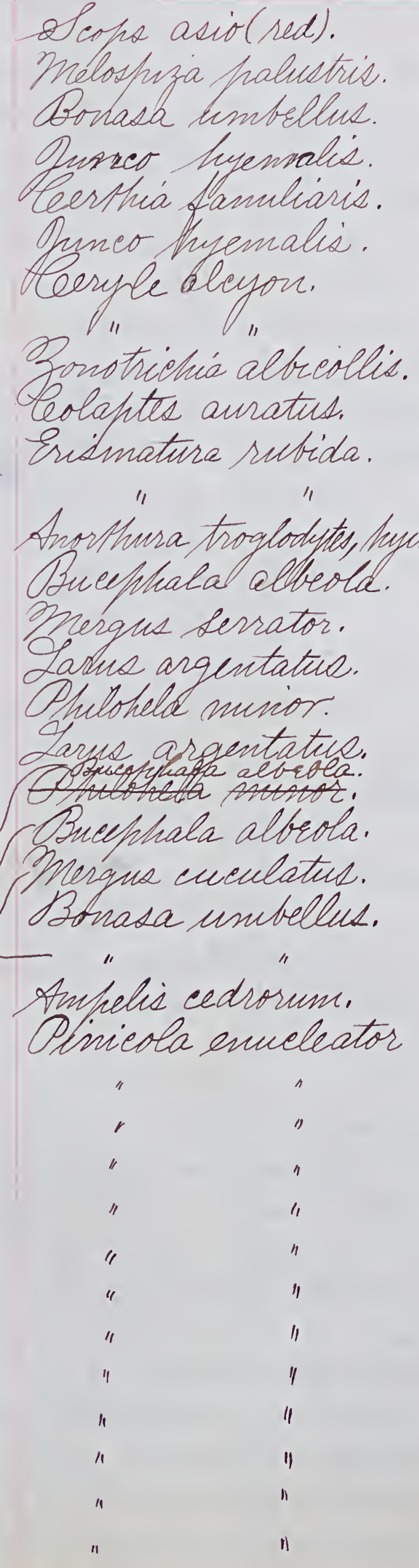 & 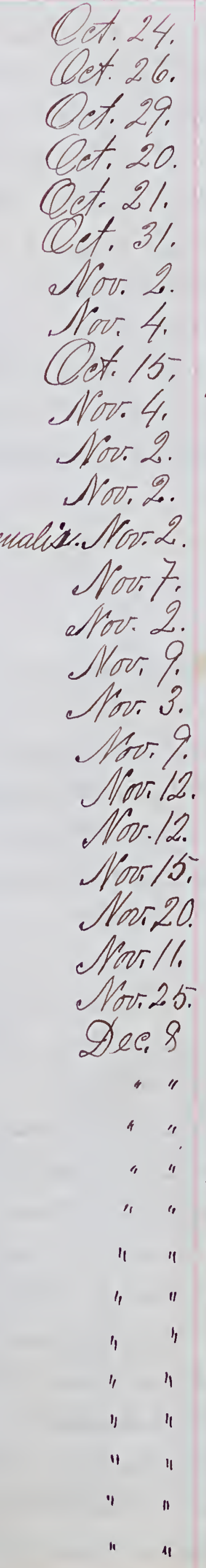 & $\begin{array}{l}9.25 \\
8.69 \\
8.75\end{array}$ & $\frac{14 \cdot 00}{13.00}$ & 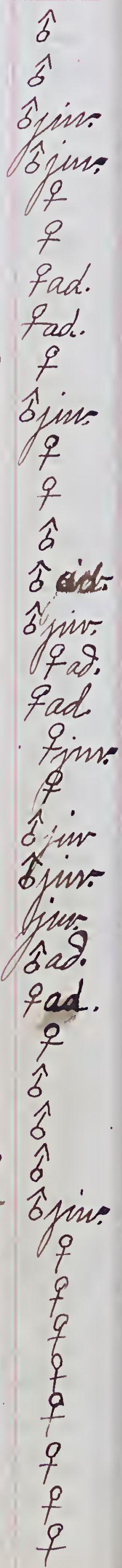 & 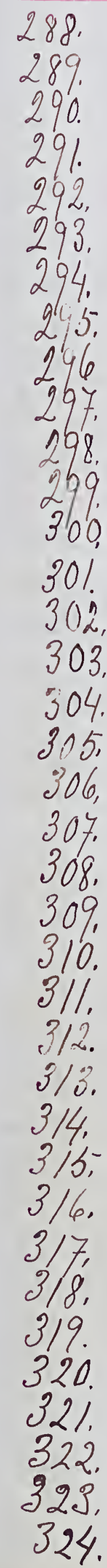 & 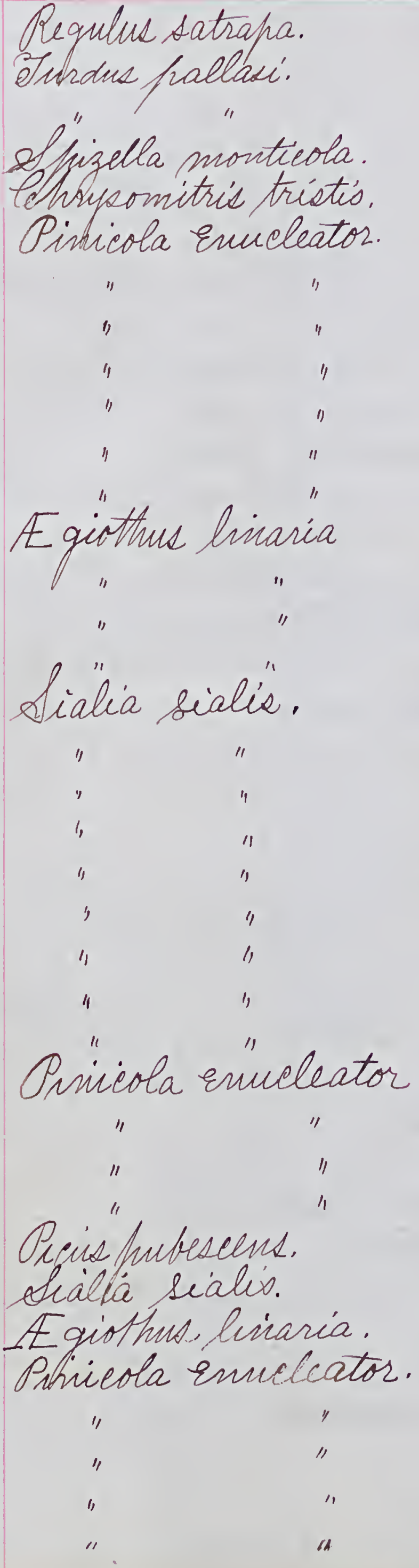 & 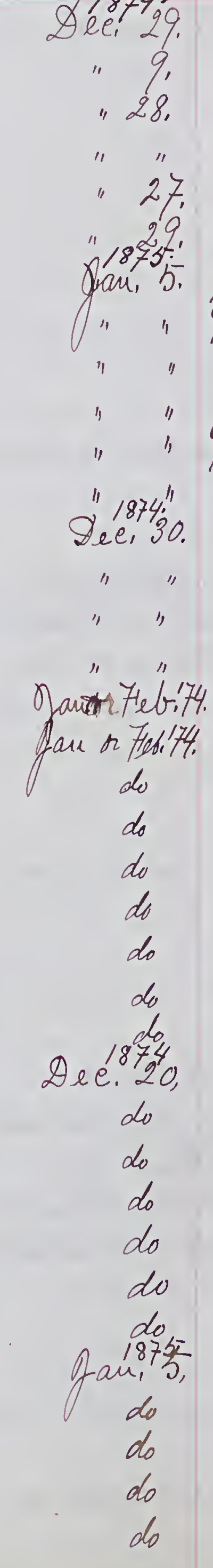 & $\begin{array}{l}8 \cdot 56 \\
9 \cdot 00 \\
9 \cdot 06\end{array}$ & $\begin{array}{l}13.19 \\
12.63 \\
13.75\end{array}$ & 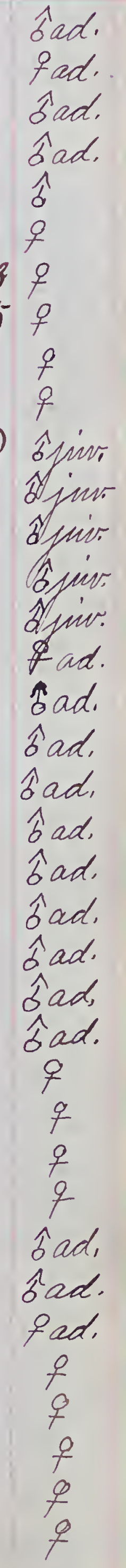 \\
\hline
\end{tabular}




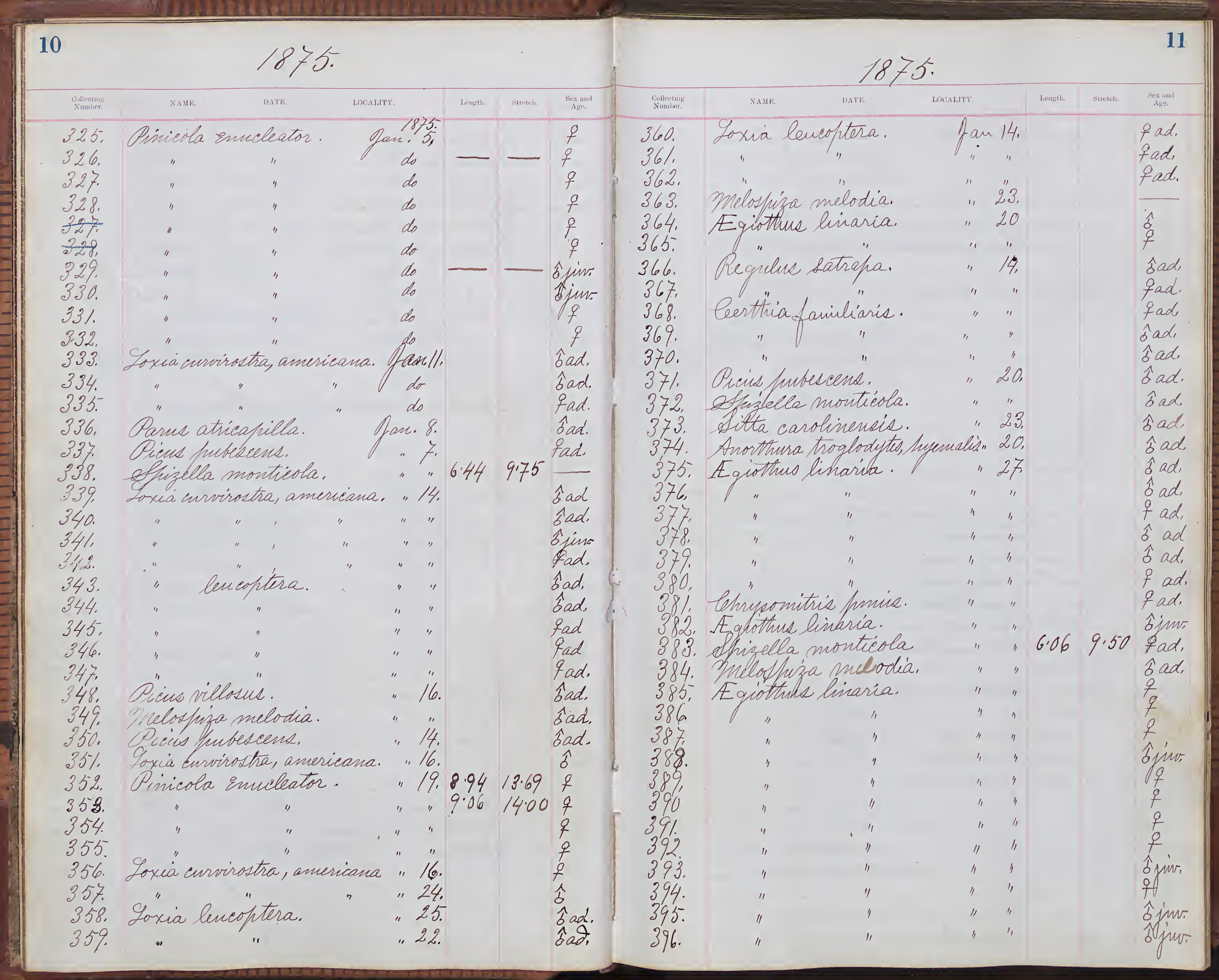




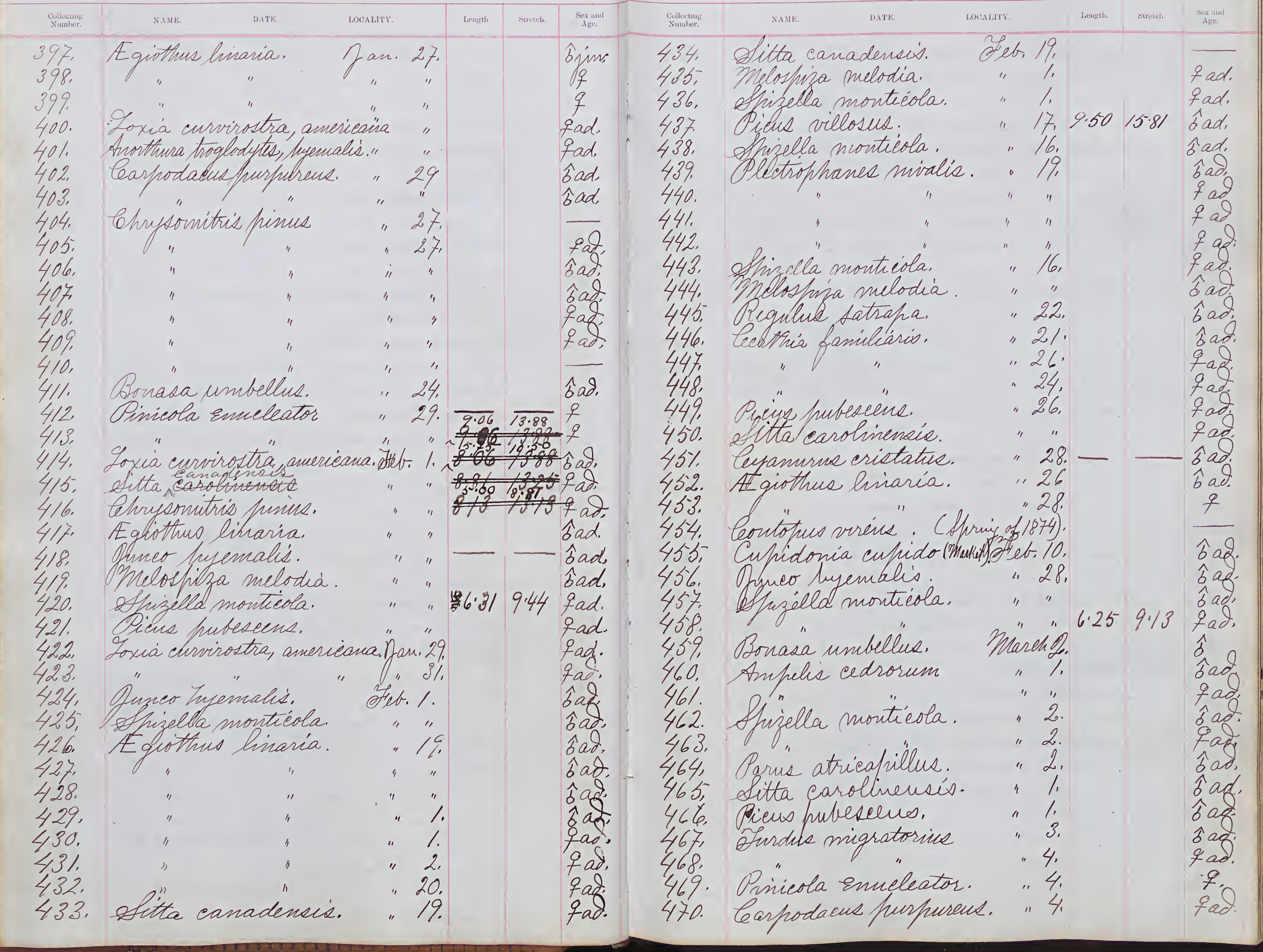




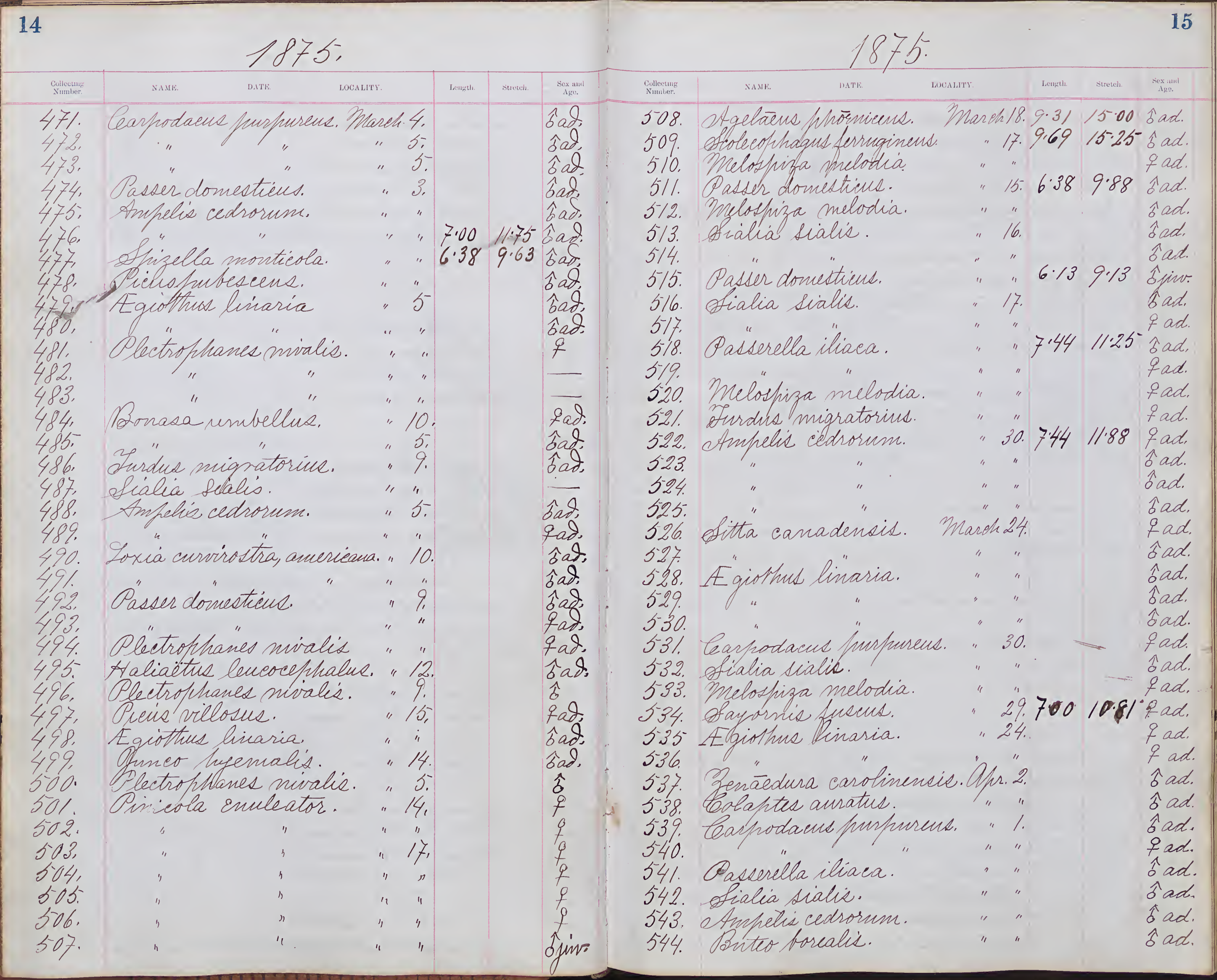




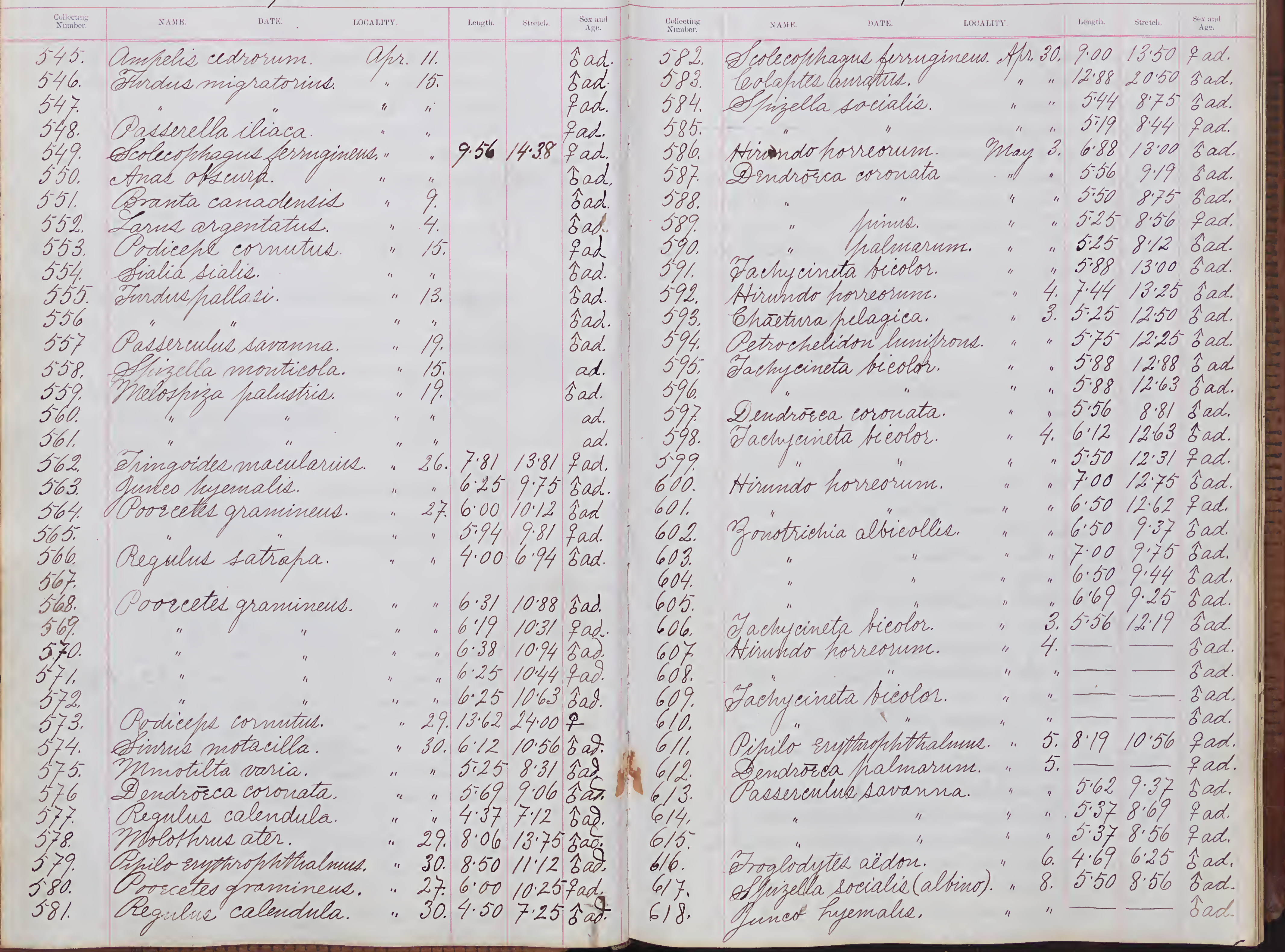




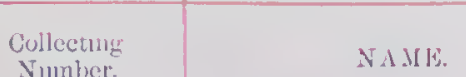

61\%. Afrizella fusilla

620. Mniotilta varia.

62\% Simins motacilla

622. Dendrōea fralmanm

623. Aviundo horreorum.

624, Stranne carohinensis.

625, Limus aurocafielus.

626. Sestheyfuis trichas.

627.

628

629

630.

631

632

633.

634

635

636.

637.

638.

639

640

$64 \%$

642

643 .

644.

645

646

$64 \%$

648 .

649 .

650

$65 \%$

652

653

654.

655

Amranme carolinensis.

Mimus carolinensis.

deterus faltimore. Ehaeturla freagica.

(2) endröea maculosa. caernleseens. Mriodiveted mitrafus! Aatrostonne vociferue. myiodioetes mitratue strrdus swainsoni. fringoides maculariue Muplodioetes mitratus. surdus surainsoli.

Q." mustehinus.

Q) endrorea maculosa.

Setophaga ruticilla.

Parnla americana.
Difilo ereftrofhthalmus." Helminthothaga huficafilla"

Dendröca catrulescens. virene. " 5.007 .56 Sad. " hemeyhanica." 12.5.00 7.88 Sad.

Emfidonax minimus.

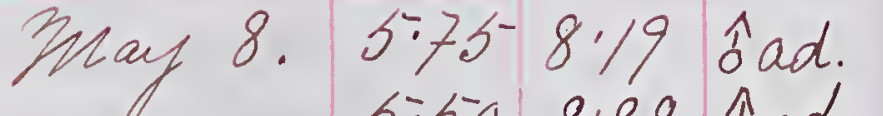
$5: 50 \quad 8.88$ 今adk $6.50 \quad 10.62$ fad.

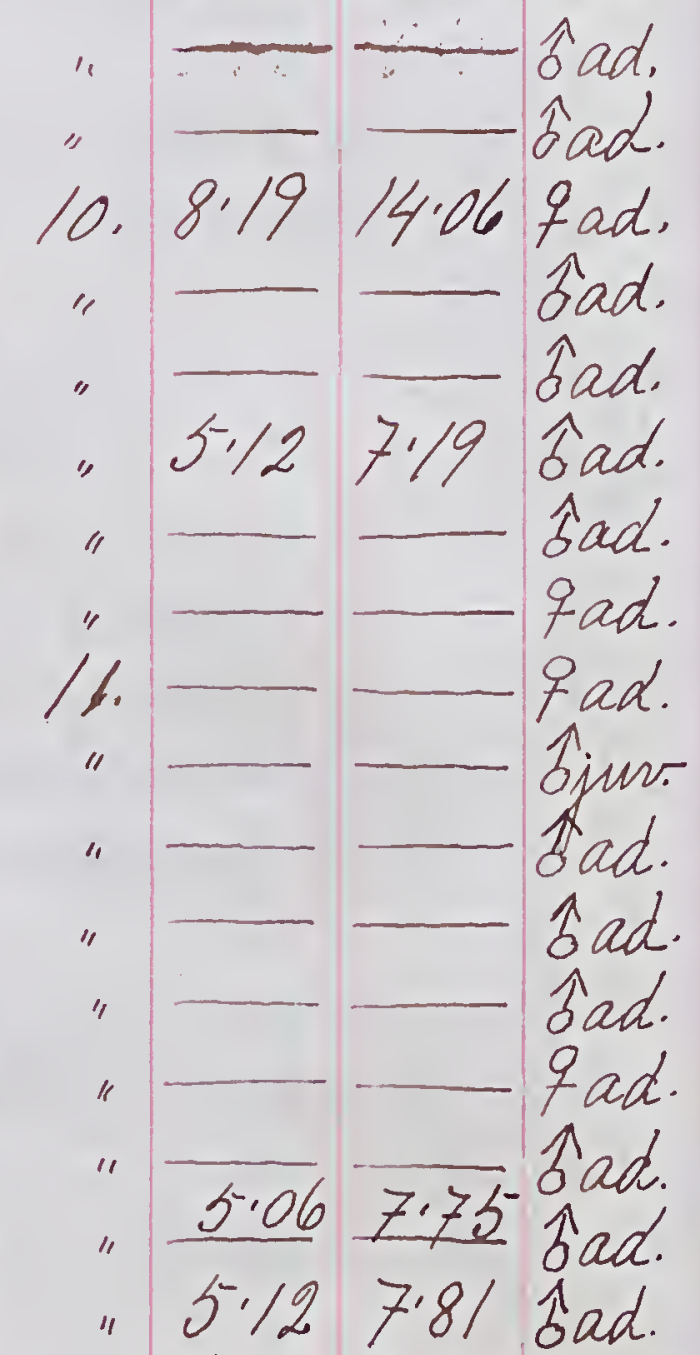
"4.317.81 qad. 5.257 .81 qad. $9.5 \% 18.56$ qad. 12. 5.1.4 7.75 sad. 11. 6.81/2.00 9ad 10. 8.0013 .81 sad. 12. $5.447 .75 \mathrm{bad}$. 11.5 .127 .81 1 5 ad. "1 819 ŝad. 124.947 .50 bad. 11.5 .258 .25 iad. "4.94 7.50 qad. "5:197.88 今ad. 12. 4.377 .37 ôd

\section{5}

Collectung
Number.

656.

657 .

658.

659

660

661.

662

663.

664

665

666.

667.

668.

669

670 .

671

672 .

673 .

674

675

676 .

677.

678 .

679

680.

681.

682.

683.

684

685.

686.

687.

688 .

689.

690 .

$69 \%$

692.
Myiodioctes pusillus. May 12. 5:00 7.06 हैad.

Surdus swainsoni. "13, "i iad.

Acterus faltimore.

Pyranga rutra.

Cecryle aleyon.

Mnistilta varia.

Adminthothaga celata. suficafilla.

Parula americana.

Pyranga rubra.

sivilita varia.

Pyranga rubra.

Q endröra eäerulea.

Ptrochelidon hunifrous.

Qindrorca maculosa.

" cärulescens.

Strochilus colubris.

vireo noveboracensis.

- Parnla americana.

tehordeiles virginianus. " Steterí virend.

sirdue migratoriue.

" " $"$ " Soniahhed udoviciana." 20.8.25 12.81 q ad.

Q endrörca cäerulescene. " "4.94 7.37 fad.

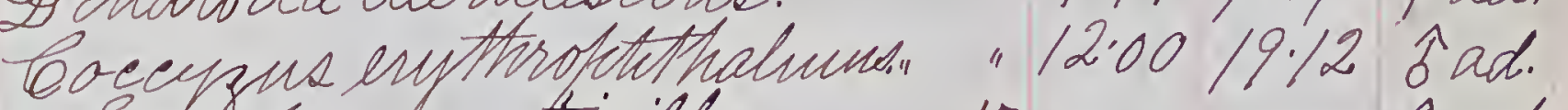
- Setf haqa rutieilla. "17- É ad. Aehninthofitiaga rufieafilla. "19. Sad. Q) endrorea cầruleseent. "20.—— îd viens. " " fad. fennsylranica." trad. 
\begin{tabular}{c|ccc}
\hline Collecturs \\
Number.
\end{tabular}

693. Cearfodacut furpurent. May 20 —— Sad. 694. Dyranga Mubra. "- bad.

695 . Parrefa americana.

696. Prieo gibus

697 Etrackicus colubris.

698. Dindrorca àstiva.

699.

700.

701

702.

703 . Himinthophaga "heregrima."

704. Aqeläens phornceuls.

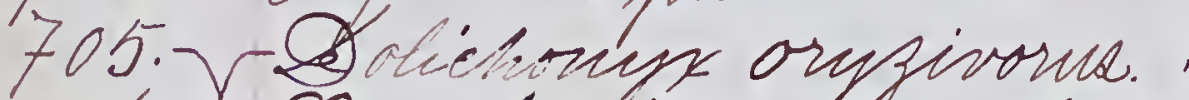

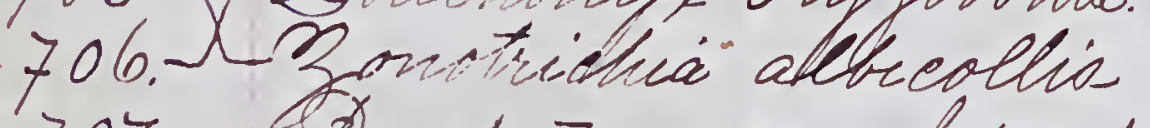

$70 \%$ Z. endrirca carrulesent.

708

709

710 .

$=11$.

$7 / 2$

$7 / 3$

$7 / 4$

$7 / 5$

$7 / 6$

717

$7 / 8$

719

720

721

722

723

724

726

727

728

729 "reser afiraceons.

Pavila smericama.

Seifos asis- (mestarig)." "31.

Dolichonye oufivohus. Em hidanax Allavivitris."

Astrochelidoft linifrove."

2 -elmatodytes falustrie.

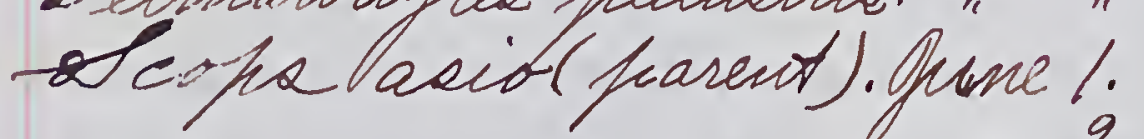

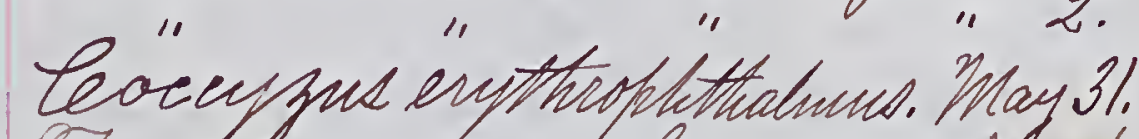
Duranmo carolinensid. Dhe 6. offeterus faltinore. Tirer oniraceous. Prelostriza meledia. Oiurus motacilla.

Qicis fubesecus. f Itohhaga ruticilla. Hujiablio ctes mitratus. eomtofue vireus.

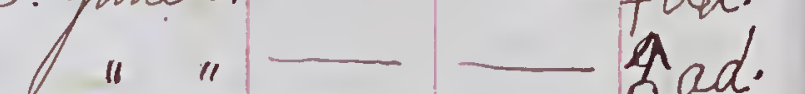

Muly 12.6.44 10.50 今ad.

6.6211 .750 jim.

- -3 jim.?

5.568 .00 gad. 6.5610 .50 sad.

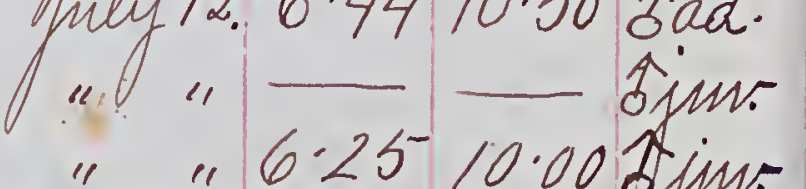

1875

Collecting
Numbler.
.

730

$73 \%$

732

733.

734

735

737

738

739

740.

741.

742

743.

744

745

746.

747

749

7.5011 .94 as. 5.698 .75 tad. - 1 sad. 5.126 .50 ad. 9.3724 .50 qad. $9.002212 \mathrm{bad}$. - + ad. 750 $75 \%$

752

753

754

755

756

757.

258.

759

760

$76 \%$

762

763

764

765

766

o) cterne sthurius.
Indus migratorins.

Helmatodytes falustria.

Mriarduls. crinitus.

Ceryle alcyon.

Mniotilta varia.

boutopus forealis.

sicis nibescens.

Atmpelis cedrorum

Q endrorea finut.

Pireo solitariud.

Pyranga subra.

fialid sialis

- Przana carolina.

Pidus fubes eens.

Disudroca virens.

Setofhaga ruticilla.

contorus borealis.

Porzana carolina.

Dendrorca virens. maculosa. striata.

\section{castanea.}

Mrjiarchus crinitus.

Adea vireseens.

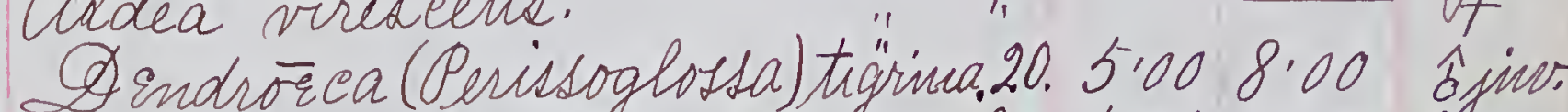
tha elvturniat." 20.4.56.7.50

sivins aurocafrillus.

(2) indrozea striata.

Hshmisthofhaga ruficafilla." "4.447.00 9 jur. Anfelis celdrorum." "F.31 11.56 "̂̀ad. Slalia sialis.

Ceolymbut torguatus july 10, — jin.

6.509 .75 fiur. 5126.62 a ad.

30. 8.6912 .50 бju. $8.8813 \% 2$ Dju. 12.8121 .44 bju. 5.258 .50 бju.

Ang. 27. $7.31 \quad 2.50$.9

Hel. 1. oad. Ang.16. 7.06 11.50 ô jur. Mam $187.56 .56 \cdot 96.9$ elef. 1,1874 - o jiv. Sep. 1.7.00 12.62 jum. 4.8 .8814 .00 全 jiv. 7. 6.7512 .00 क्य. 5.067 .75 bju. 5.067 .50 iad.

$187.5012 .88 q$ $7.56 \quad 12.88$ q $9.00 .14 .69 q$ 5.067 .62 i jim. 5127.50 余

195.508 .06 $5.567 .69 q$ 5.447 .44 of ju. 8.75 保

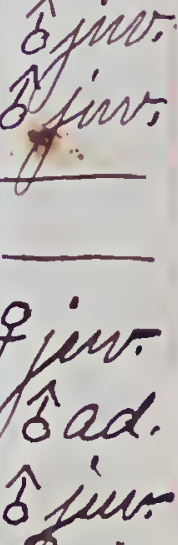
21.30 .5054 .00 quin 


\begin{tabular}{|c|c|}
\hline $\begin{array}{l}\text { Collectury } \\
\text { Numberer. }\end{array}$ & xame. \\
\hline & 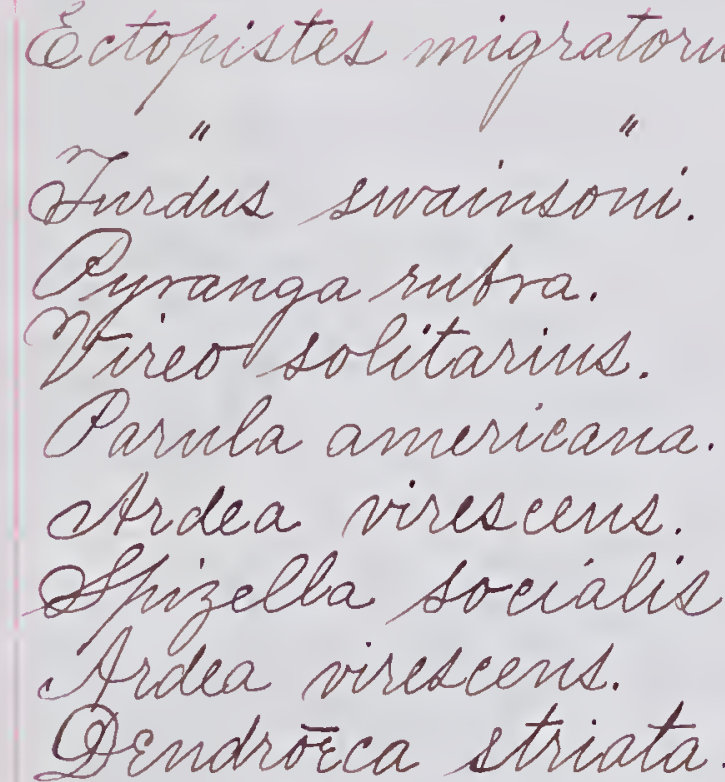 \\
\hline
\end{tabular}

coronata. virent. leeryle aleyon. D) Eudrö da virend. o undus aliciāe. teeryle aleyon. \&urdus Lwainsoni

IOCALITY.

Sept. 2\%

5.3124 .00 o jum. $16 \cdot 6224: 25$ 令

23. 6.5011 .12 7.0011 .12 âd. $5.56 \quad 9.319$ ? 4.627 .50 $-19$ Dnly 21,17.75-26.75q befefet. 28.5.37 8.75 के

$$
\text { " } " 5.508 .75
$$
5.478 .69 \% Emfidonax flaviventril. Podilymbuts fodieeps. ctintrostonus vociferud. Q) indrorea castanea. Jurdus swainsoni, aliciāe." OEdenia fusca, velvetina. Surdus Surainsoni, aliciōe.

$\overline{O E}$ demia americana. Cearpodacus furfmureus. E) endroica coronata. Hulca anuricas a. OEdeinia americana. "5.50 9.12 "4.887.56 f "5.50 8.75 $30.12 .502200 q$ "13.00 $21.81 q$ $5.06 \quad 8.00-$ $9.5019 .00 \%$ Oct. 2. 7.4412 .31 q Suly $2 \%$ Shat, 1872. —- ôd Oct.6. $\neq 1212.00$ ô $7.50 \quad 12.50$ 定 $7.50 \quad 12.44 \quad 9$ 7. 22.0040 .00 âd. 6. $7 \cdot 121212 \hat{0}$ "7.7513.00 众 "7.44 12.25 9 9. 20.5033 .62 sad. $6.371044 q$ 6.121044 ajum 6. 5.699 .12 L $11.14 .5026 .00 \hat{b}$ ad. $18.3732 .75 \%$ fersficillata.
18.7532 .759 3. 181931.88 .7

$1875-76$

Collecting
Nunulber.

804. Ceeryle abeyon

805

806

807

808.

$80 \%$

810

811.

$8 / 2$

813

814

810

817.

818

819.

820.

$82 \%$

822.

823.

824.

825

826.

827.

82

829
830
$83 \%$

832

833.

834.

835

836

837

838.

839

840. - cofrs asiv.
Sthriaficis variul.

Harelda glacialis.

- colecohthagus oferugineus.

snergus cuculatul. Inndus migratorius (albinist."

teaspodacule hurfureud.

eerthia farniliaris.

Corvus americanus.

Cenreponitris tristic.

LoCathT:

cfyletea nivea. (Fong Sland). Dee. isinga alfina

s autatarbla helvetica. do

Aringa canutus. do

Sucefria clangula.

lehrisomitris thistis.

Gollurio forealis

Parre atricafillus.

leerthia familiaris. offizelld monticola.

Certhia familiaris.

Qot.13.13.06 22.56 के $8.6215: 25$ i jum.

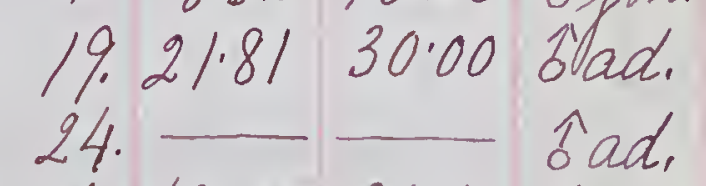
lon. 6. 18.3726 .50 sjew. " 9.5624 .00 $1.10 .0016 .00 \hat{0}$

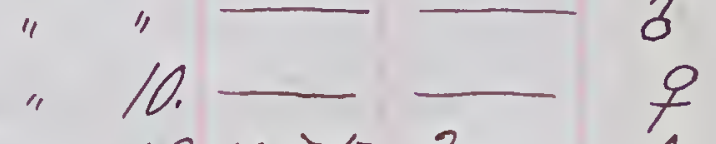
$13.187530 .00 \hat{\sigma}$ $25.5 .00,8.88 \hat{\sigma}$ Anorthmb troglodytes, hyemalis." Sfrizella noutidola. $1.23 .50 \quad 58.31 \mathrm{sad}$ " 8.8115 .50 .7 "12.19 24.69 रे? . 11.0621 .2 ô 8. $171229 \cdot 009$ $9.5 .06 \quad 9.12$. $5: 128.91$ है 5ila 8.94 5.068 .81 $11.10 \cdot 0014 \cdot 00$ quiv. $5.06 \neq .75$ \$ad. 5.818 .06 qad. 86.199 .62 bad. 7 5i75 8:00 bad. "4.00 6.12 ôad. 18. $6.44 \quad 9.44$ sad. 17.4 .888 .62 $4.88 \quad 8.62$ 4.758 .69 "4.006.81 $\mathrm{qad}$. 16. 5.8810 .56 Sad. $21.10 \cdot 1215 \cdot 19$ gad. 2 in bi44 10-30. ad. 24. 5.507 .75 sad. $214 \cdot 256 \cdot 81$ f ad. Regulus satrapa. - Sitta carolinensis. Ortux virginiamus. Campodacuk fuspureue leenthia damuliarie. Deguluk satrapa. 


\begin{tabular}{|c|c|c|}
\hline 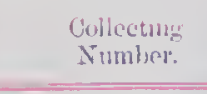 & Naxke & I.0СA AITY. \\
\hline $\begin{array}{l}841 \\
842 \\
843 \\
844 \\
845 \\
846 \\
84 \% \\
848 \\
84 \% \\
850 \\
85 \% \\
852 \\
853 \\
854 \\
855 \\
856 . \\
85 \% \\
858 . \\
859 \\
86 \% \\
86 \% \\
86 \%\end{array}$ & 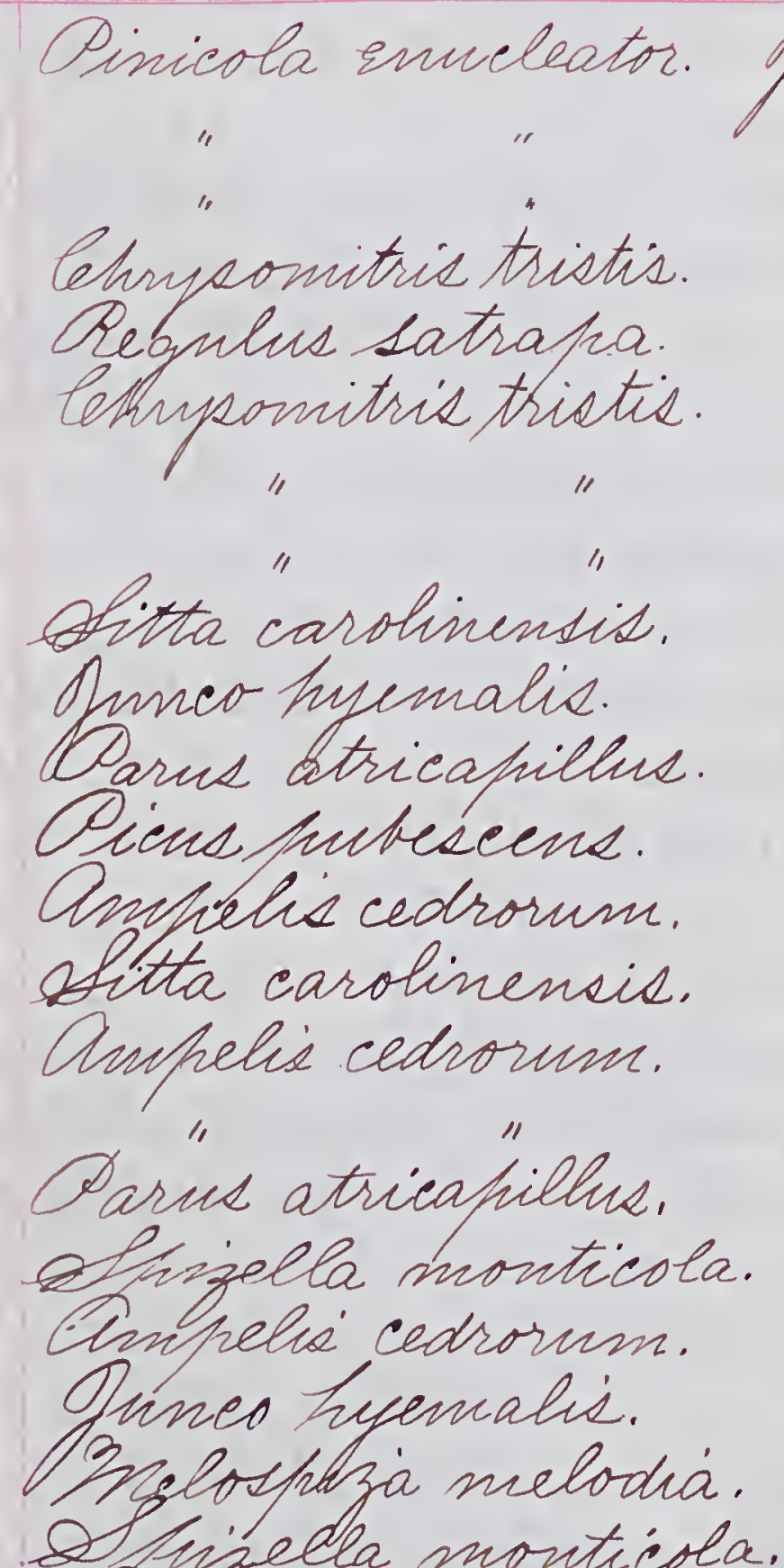 & $\begin{array}{c}\text { fan } \\
\text { " } \\
\text { " } \\
\text { " } \\
\text { " } \\
\text { " } \\
\text { " } \\
\text { " } \\
\text { " } \\
\text { " } \\
\text { " } \\
\text { " }\end{array}$ \\
\hline
\end{tabular}

863. Parls atricafillue.

864

865

866. Picisf pubseens. Ḧ'et.

867. Gunet hyemalix.

2. 8.7512 .75 bjum
" 8.2513 .62 bjum

"8.31 13.37 कad.

$11.4 .698 .75 \hat{6}$

12. 4.316 .88 bad.

11.5 .008 .319

$5.06 .8 .94 \hat{.}$

"5.06 8.75 के

15. 6.12 1/12 $\hat{b}$ ad.

17. $6259.94 \hat{b}$ ad.

12. 5.00 7.81 bad.

$6.2511 .75 \mathrm{sad}$

15: $7.0011 .62 \mathrm{fad}$.

"6.00 /1.12 qad.

"7.00 11.759ad.

$" 7.0011 .56$ fad.

17. $5.258 .00 \mathrm{fad}^{2}$.

12.612 9.50 Fad.

15.7 .0011 .37 a ad.

12. 6.12 9.06. 1.ad.

21.6198 .50 îad.

" $6.379 .50 \mathrm{bad}$.

12. 4.947 .62 . 1 ad

13. 2.756 .88 19

12. $3.94 \quad 6.62$ qad.

simime

878. Ceorriz americanus.

879. Prens/pubedeens.

880.

881. Bonasa umbellus.

882. Stshyrafieus varius.

883. Sidlia sialis.

884.

885

886.

Passerela iliaca.

887. Ifelospiza melodia

888. Mareea americana.

889. Sfialia sialix.

890. Cehrisomitris tristis.

89. Atruelis cedrorum.

892.

893.

894.

895. Amner hyemalix.

896. Melosfiza melodia.

897. Passerella iliaca.

898. Aundue migratorius.

900. Cefanurns cristatus.

901 Passerella iliaca.

902. Aunco hyemalis

903.

8. $7 \cdot 00 \quad 12: 12 \hat{6} \mathrm{ad}$.

"6.31 $10.00 \hat{\mathrm{bad}}$.

"6.37 9.69 âad.

869

870.

$87 \%$

872. Anorthmatroglodyter, munalia

873

Certhe familialie." "

" $6.19 \quad 10.12 \mathrm{Fad}$.

"6.37 9.81 3ad.

$6.50 \quad 10.06 \hat{\mathrm{bad}}$

874.

$4.25612 \frac{5}{0}$

904

Ampeli cedrorum.

905

Chrysonitris trietis.

LOCALITY.

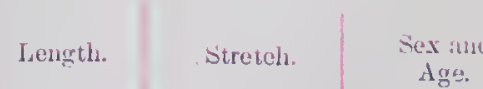

907.

908.

melostriza melodia.

Preins fubeseint.

875

Bonasa unbellus.

877. Deics fubescene.

909

Ampelis cedrorum.

of colecophagus ferrigineut. Ahs. 15.9 .1213 .75 . $\mathrm{F}$ ad.

$22.5 .55 .8 .06 \mathrm{fad}$. $5.75-8.067 \mathrm{ad}$.

"7.12 12.31 qad.

910 .

Passer domestiens.

Androrea halmarum.

nolothus ater.

Requlus calendula.

"2. $\overline{7 \cdot 00} \overline{12 \cdot 12}$ 客 ad.
911.
912
913

$9 / 4$
" "7.00 1.75 全ad.

185012350 bad.

$7.8 .3715: 31$ qad.

6. $7.1212 \cdot 50$.

$7.0012 \cdot 56$ bad

"7.00 12.3\% fad.

7.7 .2511 .009 ad.

5.6 .628 .75 îad.

12. 20.2534 .50 sad.

"7.12 12'50 ô ad.

10. $5.258 .88-$

23. 7.0011 .81 ôad.

7.0012 .00 q ad. 6.7511 .75 g ad. 7.3712 .00 sad.

$24.6 .25 \quad 9.75$ î ad.

6.448 .69 q ad.

"7.31 1/.50 今ad.

7.0010 .75 qad.

28.9 .9416 .37 sad.

"11.7516.75 $\hat{\mathrm{s} a d}$.

$27.7 .69 \mathrm{l1} .88 \mathrm{i}$ ad.

28. 61/2 9.50 今ad. 6.3710 .00 âd.

"1 5.50 Fad.

$315.50 \% .06$ sad.

6.448 .88 îad. "9.31 14.00 qad. 11.6 .319 .37 ôad. 15. 5.50 8.12 ô ad. "17.7.88 13.75 ôad. "4.25 7.00 ô ad. . 5.568 .00 fad. 
Collecture
Xumber.

915. Regulus calendula.

G) indrorea cormata.

917. Melospiza fualustris.

9/8. Poveetes graminent.

919. Sialia silalis

9. Dajonis fuscus.

921. Eelshí Lmiliaris.

92. Requlut calendula

923. Elurdus halladi.

924. Bachucueta beolor.

925. Ooosetes gramineus.

926. Requlus Calendula.

927.

928.

929

1930.

931

932

933.

934

935

936.

937.

938.

939

940.

941

942 .

943.

944

945

947.

948

949.

950.

95

Q) endrosea hinus. jalmarum. vaner s alendula. Q) endrorea coronata. moals hrus ater. Passer domesticios Anims onolacilla.

Kegulue satrafra.
Afer. 18. 4.50 7.19 sad. 21. 5:75 9.06 fad. 5.887 .94 bad. 6.1210 .259 ad. $7 \cdot 0012.31 \mathrm{bad}$. $6.6910 .37 \mathrm{gad}$. $5.75-8 \cdot 19$ gad. $4.37 \mathrm{Fi} 2.2$ Ead. $7.0011 .37 \mathrm{qad}$ $6.00 / 3.06$ sad. 6.19 10'12 9ad.

- 1 ad.

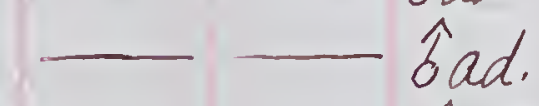

- - ôd.

22. 5.75-9.12 5ad. 5.628 .62 sad. 5.378 .12 and. 5.318 .56 ad. 5.75 9.25 sad.

"5.50 8.31 Fad. $6.2510 .50 \hat{s}$ ad. "5.31 8.06 7ad. 7.0611 .25 bad. 7.2511 .37 qad. 5.377 .88 5.258 .88 sad. $" 7.06$ 11.12 bad. 24.5 .57 .06 ciad. 24.6 .00 .9 .25 ad $5.62 \% .00$ bad. $7.88 \% 3.50$ sad. 6.379 .88 îd. 6.2510 .69 ad. $6: 19 \quad 10.50$ bad. 6.1910 .50 sad. 26. 4.19 - ôd.
952.

953.

954

955

956.

957

958

$95 \%$

961.

962

963

964

965

966.

968

$96 \%$

970

971

$9>2$.

973

974

975

976

977

978

979

$98 \%$

1876

LOOALITY.

Lourtit

Regulus calendula.

othril 26

Qlinus motacilla

Melostina paluetris.

Acicue nublecent.

Regulus calendula

Stailia sialis.

Fringoides macularius.

- Pasber donectiéus.

Q) indrorea halmarun.

- inaedura carolinensis. s mirus motacilla.

Molothrue ater.

Melosfiza fraluetrís.

Dendröca coronata.

Fordue surainsoni.

May

of".ingoides maculariul." As suinthophaga sufieafilla.n

Q) indrorea driend.

"Tireo solitariusf.

Muriodeoctes mitratud.

Dendróca vireus.

$$
\text { coromata }
$$

Mniotilta varía.

982

983.

984

985

986.

987

988.
Regnlus calendula (nored)." nojiodioctes canadeneit.

Q)endrorea maculota. Hacthurniāe

mupiodivetes canadencis.
6. $4.507 .25 \mathrm{sad}$. 4.37 .14 âd. 4.507 .25 and 25: 6.06/10.31 sad.

26.

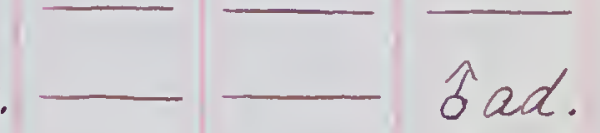

6.7512 .00 qad.

29. $7.7513 \cdot 62$ fad. $28.6 .44 \quad 1019$ fad. "5.50 8.69 cad.

29.11 .81 18.25 had. 6.50 10.50 ô ad. "7.75 13.50 âd. 6.06 8.31 bad. 612 8.25 sad. 5.759 .00 bad. 5.69 9.00 $\hat{\mathrm{s} a d}$. 5.819.06. 10ad.

9. 7.2512 .25 a ad. $7.1912 .06 \mathrm{bad}$. $10.8 .31 / 4.00$ fad. 4.75 7.50 $\mathrm{s}$ ad. 4.947 .25 o ad. 500 F.81 fad. siso 9.50 gad. 5.81 8.31 fad.

5.258 .06 cad. 5.448 .44 fad. 5.318 .44 cad. 11. 4.126 .88 f(ad.i) 22.5 .56 8.06 cad. 28.5.25 7.56 cad. 17. $5=258.37$ ôd. 2.8. 5.75 8.06 âad. 22. 5.56 8.06 fad. $255.698 .44 \mathrm{sad}$. 
989
990

992.

99.3

994

$995:$

996.

997

998

999

1000.

1001.

1002

1003

1004.

1005

cocte.

$100 \%$

1008.

$100 \%$

$10 \%$

$101 \%$

102.

1013

1014.

1015

1016.

1017

1018

1019

1020

1021.

1022. Dindrorca castanea

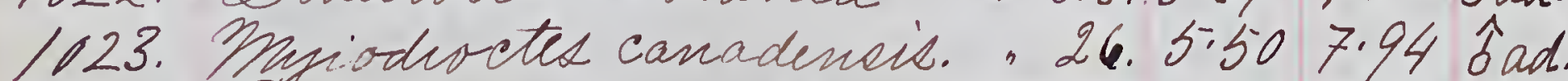

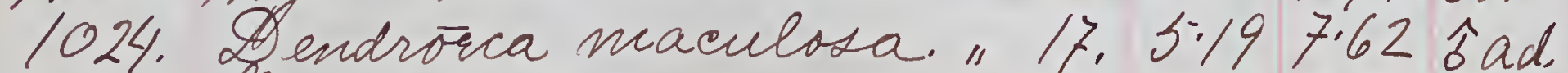
1025. Myiodioctes mitratus." 18.5.75 8.50 âad.

Q) indrorea caèrulescent. May 18. 5.44 8.06 $\mathrm{bad}$. Arminthothaga ruficafiella. 12.4.94 7.75 sad. stinus naêfiul. "26.6.12 9.88 sad Misodioctes mitraturs. Halmitherus verminosus. 5.318 .56 ad. Dendrorea castanea. Darula americana. (Q) indröra maculosa. " caenulescens. Beothly fris triehas.

Q) " philadelfhia. 26. 5.819 .06 bad. 18.4.817.65 今ad. 16.5.25.7.75 sad. 18. 5.25 7.949 ad. 27. 5.627 .44 bad. 18.5 .198 .19 bad. Aminthothagaticahilla." 17. 4.69 7.25 fad. Estohhaga ntticille. Siurus aurore a illus.

() indrsea Hlact burniaie 5:25 $7.62 \mathrm{bad}$ $6.009 .37 \mathrm{fad}$. 5.448 .50 sे ad. "Mniotilta varia. 2) Endrorea blackburniae. 26. 5.25 8.25 q ad. 18. 5.318 .12 qad. 13.5./2 8.62 sad. 26. 5.56.9.06 5ad. "5:25 8.62 aad. $\begin{array}{ll}\text { maculosa } & 16.5 .197 .88 \text { 今ad. } \\ \text { striata. } & 26.5 .759 .25 \text { sad. }\end{array}$ maculosa. "17.51/27.62 $\hat{\mathrm{b} a d .}$ blackburniàe. " 5.448 .56 bad. Mípiodioctes canadensis. "2.3. - Sad. Q) Endröca maculota.

$$
\text { Haefburmiä." }
$$
Osothlifhis triehas. (e) indrorea virens.

16. $5 \cdot 25.75$ sad. 5. 19 8.12 sad. 17. 5.37 ₹12 $\mathrm{bad}$. 18.5.25-8.06 ôad. 12. - - fad. 25.5 .69 9.25-5ad.

\begin{tabular}{c} 
Collecting \\
Nunuber \\
\hline
\end{tabular}

1026

1027

1028

1029

1030

$103 \%$

1032

1033.

1034

1035

1036

1037.

1038.

$103 \%$

1040

1041.

1042

1043

1044

1045

1046

1047.

1048

1049

1050

$105 \%$

1052

1053.

1054

1055

1056

1057.

1058

1059

1060

$106 \%$

1062
Q) endrosea striata. castanea

E) cteria virens.

Aclmitherus vermivorud. "

miodioctes canadensis."

Dendrorca henneylvacica. "

$$
\text { Alacktourniàe. }
$$

Stinns auricafrillus.

Q) indrocea fremsylwanica. striatd.

$$
\text { castanea. }
$$

Haekburniāe. hemnsylvanica." àstiva.
castanea.

"nfisdioctes canadensis." E) Endrozea càcrulescus. " castanea. striata.

\section{Myiodioetes canadensis.}

(A) endrorca Blackburniāe.

Muiodioctes canadensis. Stofuaga miticilla

Q) indroeca striata.

$$
\text { maculosa. }
$$

Muiodioctes mitratue.

L teriá vrins.

Dendróca blaekburniāe.
23. 5.81 9i50 tad.

$\begin{array}{llll}22 & 5.62 & 8.94 \\ 22 & 5.62 & 8.94\end{array}$

26. 5.81 9.06 sad.

22. 5.75 9.19 sad.

25. 5\%2 8.94 qad.

23.7 .501019 îad.

5.629 .00 sad.

5i62 8.00 ôd.

2.2. 5.31 7.88 fad.

23 - fad.

18. 5.15 8.31 sad.

16. 6.31 10.00 bad.

12. - îad.

22. 562 8.81 gad. $25.5 .56 \quad 9.19$ sad. 20. 5.819.25 1̂ad. 23. 5.37 8.69 bad. 20. 1 fad. 23.5.19 $7.75-9$ ad. 12. - ôad. 25: tod.$$
5.698 .44 \text { ad. }
$$

20. — 1 ad. 25:- 1 bad. 23. 5.69 9.00 fad. 18. 5.62.8.00 bad. "5.19:8.44 sad. 22.5.698.06 3ad. 26.5 .568 .00 sad. 25.5 .69 9.25 ह̂ad. 5.007 .37 fad. 23. 5.378 .75 sad. 17. 5.62 8.37 $\hat{\mathrm{s} a d .}$ 23.7.319.81 sad. $25 \div$ qad. 


\section{6. 1138 $1 / 39$ \\ 1140 \\ $1 / 41$ \\ 1142 \\ 1143 \\ $1 / 44$ \\ 1145 \\ 1146 \\ $1 / 47$. \\ 1148 \\ Geryle alcifon.$$
\text { minimus. }
$$ \\ trailli: A anfrostienctius aufus.}

1876

1137. Emfidonax Llavirutrie. May 26. 5i62 8169 5ad.

1149

1150

$115 \%$

1152

1153

1154

1155

1156

1157

1158

1159

1160

$1 / 61$.

1162

1163

1164.

1165

1166

1167

1168

1169

1170

$117 \%$

1172

1173.

23. 5i69 8.75 sad.

8. 5.37 8.12 fad.

12. 5.56 8.37 $\mathrm{qad}$.

$26.16 .009 .19 \mathrm{bad}$.

27. 6.25 9.50 $\mathrm{bad}$

8. $5.508 .25 \hat{b a d}$.

23. 5.698 .88 bad.

5. 12.8122 .81 bad.

2. $8.0010 .569 a d$.

8. $11.501362 \hat{b a d}$. Ceranurese cristates.

2. $11.81 / 7.37$ bad

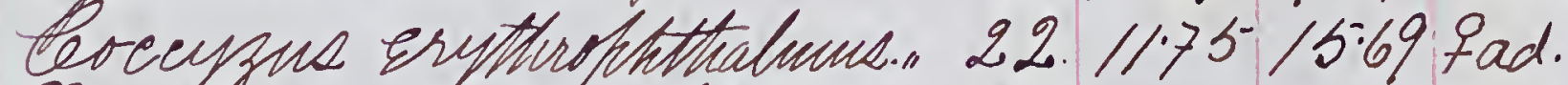
Gouttictuia albriollic. "20. Arelaene thornicus. "2.8.06 $12.88 \mathrm{fad}$ Sherdus swainsoni, aliciase." 25.7.6212.75-7ad. " hallasi. "3.7.00 11.12 9ad. Aifilo ereptrupththalums." 27.8 .5011 .62 sad. Ageläus fuhorineue. Surdue fuscesent. " aliciā. eTotanus solitarius. Agelāeus fhöriceus. Hurdus swainsoni. syranue carolinensis (j)urdue suraineoni.

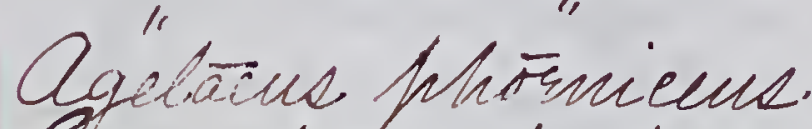

3. $8.06 / 1.06$ bad. 2. $9.4415: 12$ sad. 26. $7 \cdot 3111.75$. ad. $25.7 .88 \cdot 1312 \mathrm{bad}$. "19.8.75 16.37 हैad. 2. $9 \cdot 50 / 5.255$ ad. 11.75612 .949 ad. 13. - - $\mathrm{sad}$ "- $\hat{\mathrm{o} a d .}$ $25.7 \cdot 4412 \cdot 31$ 占ad. 23. $9.50 / 5.50$ 余a Carfodicez surfureus. - notriehia albicollis - Purana rubra. el oniabrluca ludoriciana. Mmiarchus crinitus. Prymana subra.
5. 6.199 .75 全ad. 2. 6.759 .50 sad. $27.7 \cdot 31 / 1.81$ sad. $12.8 \cdot 0012.50$. ad. 13. $9.12 / 3.50$ sa. 25. 7.3111 .75 sad. 16.71911 .88 qad.

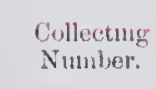

1174 1175 1176

1177

$1 / 78$

1179

$1 / 80$

$1 / 81$

$1 / 82$

$1 / 83$

$1 / 84$

$1 / 85$

$1 / 86$

$1 / 87$.

$1 / 88$

$1 / 89$

1190

1191.

1192

1193

1194
1195

1196.

1197.

1198

1200.

1201.

1202

1203
1204

1205

1206.

1207.

1208

1209

1210
Prranga ufra.

- terdes shrrius.

Sringoides macularins.

Onbtrichiad rucohhrys.

Q) plichorux oryziororne.

cteme baltinore.

Petrochelidon hunifrone.

Sonotrichia lexeofhryd.

Dyranga sutra.

Furdus swarissoni.

Q Cterue baltinore.

Pyranga nubra.

'Jundus swainsoni

Aqeläeus phöniceus.

Mrieo flavifrons.

- omiathea lidoviciana.

Pyranga nubra.

\section{sundus fusececus.}

boniafthea hdoviciama

jeterne faltimore.

leotjle riharia.

Nires solitarine.
May23.7.31 11.69 Sad. $7.25 \quad 10.50$ bad. 8.1213 .88 qad. $6.88 \quad 9.75$ fad. "7.6912.37 âd. 26.7 .5011 .31 fad. 2.3.5.88 12.75 7 ad. 6.889 .88 fad.

"- îad.

$7.4412 \cdot 12$ îad. $7.3712 \% 2$ 字ad. "7.31 11.81 âad. 16.6 .9411 .75 îad. 23. 7.2511 .62 qad. 18.7.37/2.69 3ad. $11.7 .25 / 1.31$ sad. 23. $7.1912 \cdot 00$ îad. "F.19 12.00 今ad.

7.0611 .44 fad.

"F.00 11.31 $\hat{b}$ ad.

"8.00 12.75.9ad. 27 - 9 ad. 19.- $\mathrm{b}$ ad. 23.7.06 /1.75 çad. "7.31 12.12 sad. 18. — iad. 5.76612 .25 âd. 1\%——ad. $" 18775$ 19.00 $\hat{0}$ ad. 23. 5.1910 .88 îd. 18. 5i81 9.69. ad. 9.51759 .69 sad. 11.5 .6 .99 .50 京ad. 9. $5.62 \quad 9.62$ qad. 


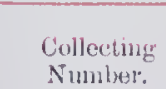

1911. Mrea flavifrond. May 13.6.00 9.69 b̂ad. 1212. 1213.

1214

1215

$12 / 6$

1217

.218

1219

1220

221

1222

1223

1224

1223

1226

1227

1228

209

1280.

1231

1232

1233.

1234

1235

1236.

1237

1238.

1239

1240.

$124 \%$

1242.

1243.

1244

1245

1246

$124 \%$

8. $5.9410 .00 \mathrm{bad}$

" $5.949 .25 \hat{b a d}$

18. 5.758 .94 âad.

"Sif5 9.19 bad.

22. 6.4410 .31 îad.

17. 5.318 .007 ad.

22. 5.698 .81 îad.

27. 5.75 8.50 9 ad.

$5: 127.75$

Parns atricafillud.

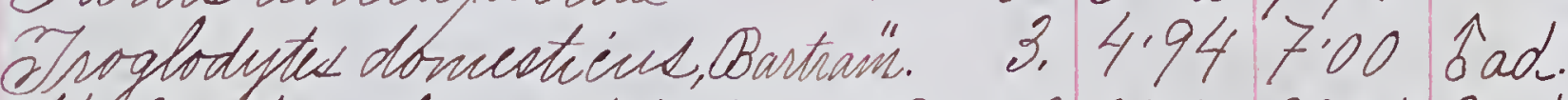
Abliatus leverefhalus. Gune 2.35.50 89.25 9 ad. Mhisdioctes mitratus(harent)." f. - - $\mathrm{qad}$. onteo hennsylvanica.

May 3.15:69 36.69 sad. Accifiter cooferi.

Honistilta havia.

esimus auricafillus. Onteo hennayluanicus. Gontshus sirens.

Cotele rifraria

Hbliä̈tus leucocefthalus

"S. 17.503869 q ad. $10.19 .7535 .001 \mathrm{fad}$. Duly 26.5.758.88 âjur. labg. 16. 6.449 .81 \#ad.

17.163736.75 sjum. 16.6 .3710 .37 ine.

"17.5.06 10.75 aurdus surainsoni. Oot. $6,1875,7 \cdot 1212.00 \hat{b}$ Deterue stewrie. Ampelis cedroum Contofus virens.

esothlyfie trichas. Breo divaceous. Peranga subra.

Qeterus baltinose. actens shurins. Dohichonye oryzirorne.

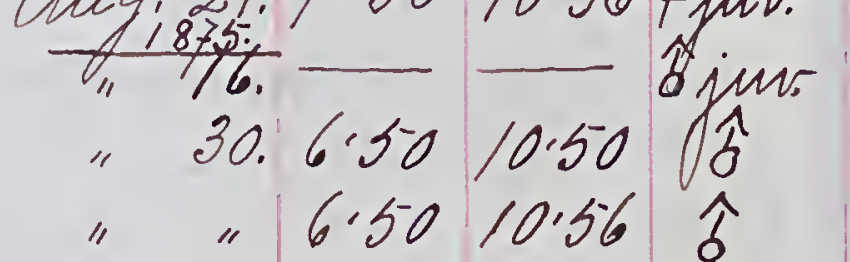

" 6.5010 .56 余

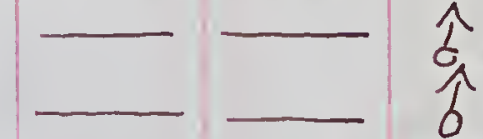

16. $5.00 \quad 6.62 \%$

"- -

"30.7.37.1/.88 q

$31.7 \cdot 3711.817$

7 . 5011.88 今. ju

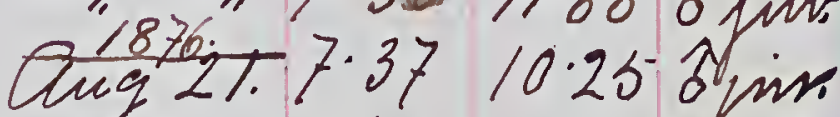

$17.5011 .50 \mathrm{rad}$

"7.31 11.75 रे

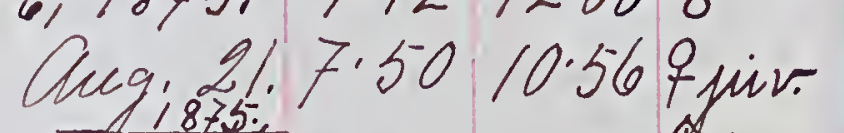

(d) olichonyx oupivorus

1250

Contohus borealis.

125\% Sinno nâtrius.

1252. Porzana caroliná

1253. mptims carolinensit.

1254 Dyranga subra.

1255 otashe solitarius.

1256. Teonto/us vrins.

125\% Sinis nâvius.

1258

Hiundo horreorum.

1259. Myisdisctes canadeisis.

1269 Masserculue Aavanna.

$\operatorname{lug} 21.7 .6 \% 11.94$ है

"Lefu. 5. $7.19 \quad 12.00$. 12.25

Aug. $31.6 .00 \quad 9.25 \%$

Self, 6.9.75 15:25 5jum. 8. 9.0011 .75 . 12.7 .3711 .6919 $11.8 .12 \quad 16.00$ sjuw.

$14.6 \cdot 50 \quad 10 \cdot 50$ q

11. 5.949 .379

12.6 .2512 .56 o jum. $11.5 .508 .00 \%$

12.5 .819 .19 q

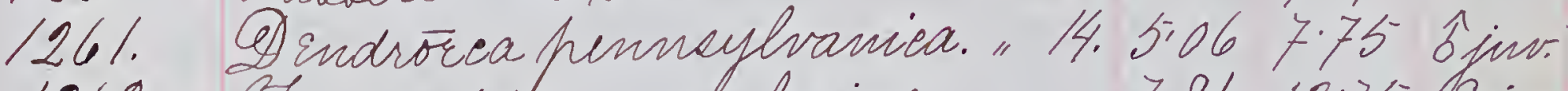
1262. Afrinosidé maculariue. "7.81 13.75 fiu. 1263. Tirifolivaceoue.

1264

1265

1266.

1267

1268

1270 . Thrssonitris tristis.

1271

1272

1273

1274

1275

1276

1277

1279

1280

Dendrorca maculosa. virens.

Direo olviaceout.

Panla amerieana.

nniotilta caria.

Nireo olviaceous.

Q) endrorea vireue.

8.6 .1910 .379

11. 5.00 7.56 qjum.

12.5.19 7.81

8. - 7 jin.

11.4 .817 .62 sin.

15. $5112 \quad 812.7$

11.6121019 jjin.

12.5.00 9.00 Bad.

11. 5.00 7.62 \&?

Parula americana.

Dendrorca virens.

8. 4.25 .7 .44 óju.

Fralodytes donestiue.

Qindrora (Perisoglossa) tigina." 8. 5.22 8.31 castanea.

Achimthothaga suficafilla.

Selmato defte fralustris.

$16.4 .75,7.37$ a Asluinthothdga fregrima.

18.4.75.6.00 qjur. Q) endrorea virens.

pemsylvanica."

20. 5. 00 7.6 क्राn

29. 5127.81 sju. 1282

1283
1284
Ahnuraficire varine. - oustrielía albiellis. Parns atrieapillus.
" 4.947 .50 6.449 .00 $5 \div 628.25$ 鉎 8.0014 .5013$. 


\begin{tabular}{|c|c|}
\hline $\begin{array}{c}\text { Collceuthe } \\
\text { Sllumber }\end{array}$ & XAME. \\
\hline $\begin{array}{l}1280 \\
1286 \\
1287 \\
1288 \\
1289 \\
1290\end{array}$ & 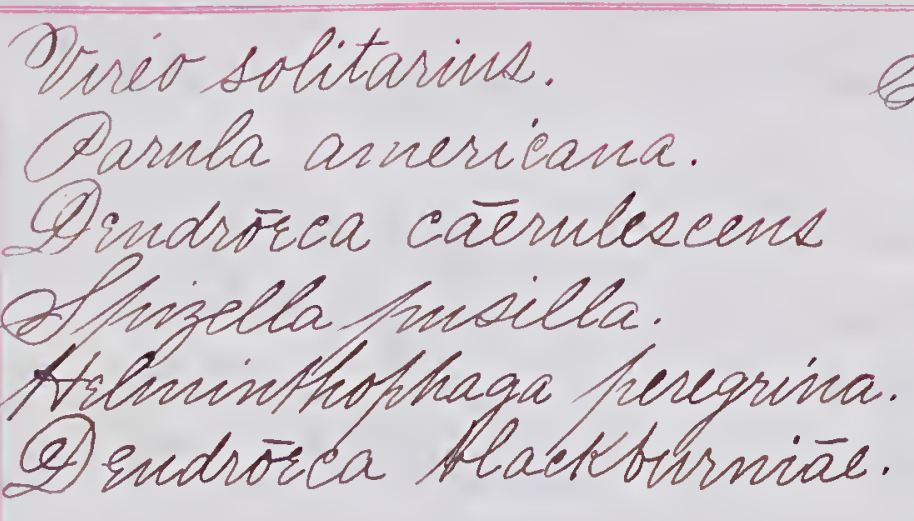 \\
\hline $\begin{array}{l}1291 \\
1292 \\
1293\end{array}$ & $\begin{array}{l}\text { Offhiprafucius varius. } \\
\text { Meloshiza halustris. }\end{array}$ \\
\hline
\end{tabular}

1294.

1295

1296

Aasforhynchus rufus. " "5.81 7.37 fin Dlturhaficise vorius. OHrdus swainsoni.

Dindróra maculosa. castanea. câtrulescens. 1300 1301 virens

Regulus satrafia. Qot. 3. 1125:12:69 11.n. 1297

1298

1303. 1304 1305 1306 1307 1308 1309 310. 1311 $13 / 2$ $13 / 3$ 1314 Sfluyraficis varius.

Qef.29. 5.75 .9 .37 gjum
" " 4.94 .7 .50 3jum.

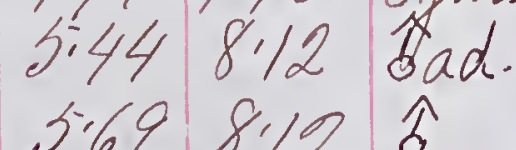
30. $4.72 \quad 7.259$ jum. 3.008 .25 sins $5.4187 \%$ ad. 8.8115 .50 a jur. 7.1211 .697 5:197.56 $\mathrm{fad}$ " 5.69 9:00 sjur. "5i25 7.75 . "5.067.50 q "4.447.69 ind. " $4.196 .627 \mathrm{ad}$. 4. 8.6915 .509 ad. 8.4415 .00 ajum 6.259 .88 a ad. 8.7 .514 .007 sim. 14.066 .00 gir. 5. 5.067 .44 t5im. "5.257.94 ad. $5627.75 \%$ Anner hyemalis. - Orzana carolina. Anosthura troglodetes, hyemalix. Dindrorea maculosa. esthia familiaris. Sallinego wilsoni. Ceas "odo us inimfurens. Iróglodytes Lomestiens. Dendrorca caerulescene. Mniotilta varia.

16.11.2.17.25 âd . $10.5016 \% 12$ sjiv. 6. 612 10.44 blad. 1316 $13 / 7$ $13 / 8$ 1319 1320. Regulus calendula. Jedrdus swainsoni, aliciae." Coolaftes auratus. 132\% Sialia sialie.
16. $4.816 .37 q$

14. 5.317 .88 ad. "5.50 8.56 9ad. " - Sad. $17.8 .25 / 3.00 \hat{\sigma}$ 18.13.00 20.81 㑒ad. $7.00 / 2 \cdot 31$ ôd.

$1876-77$.

Collecting
Numbler:

1322

1324

325

326

327
329

1399

1330

$133 \%$

1332

1333

334

1335

1336

1337

1338 .

1339

1340.

341.

342

343.

1344

1345

1346

1347

1348

1349

1350

$135 \%$

1352

1353

1354

1355

1356

1357.

1358 .
H modra fuallasi

Bubs virginianus

\& allinado vilsoni.

OAś Shousa.

OSfujraficus varius

Suprim nebulosum.

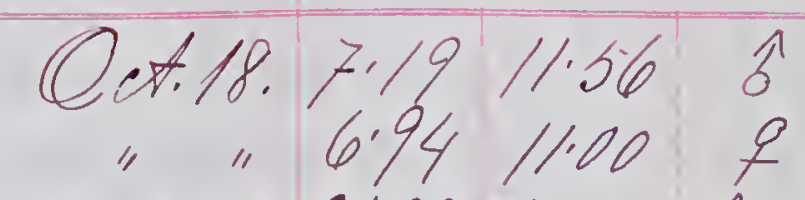

17. $21.88 \quad 55.25$ ôju.

19.11 .0017 .19 ad.

23.161229 .44 .5 (adi) 21. $8.88 \quad 15.37$ sad. 23.19 .2544 .75 q ad.

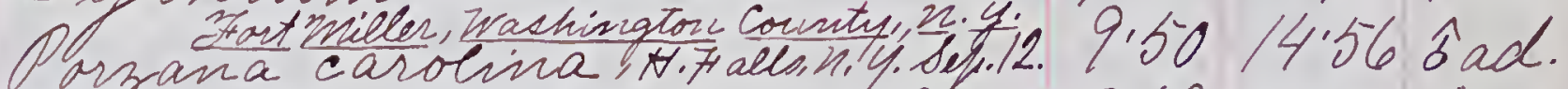
Pichs villosut. Fort miller, 21.Y. Novi 12.9.69 15.88 5ad. fubescens do "7.00 11.88 sad.
villosus.

" "tigfeand Fafes, do " $9.5015 .62 \mathrm{qad}$

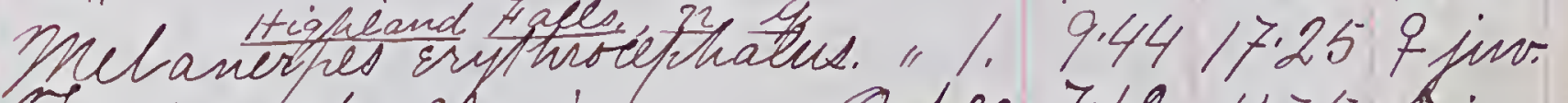
Hurdus pallasi Hearelda glacialis.

Orter virginianus.

Qet.30.712 11.75 ojum. Por.29. $13.94^{*} 29.69$ bad. setirs alio.

collurio "orealis. Ace.21,1875. 11.00/5.75 îad. 8," 9.6924 .00 q $2 \operatorname{2l} 27.911922699$ ateb. $12.10 .0614 .00 q$ "tuligula vallisneria. Mar.23.22.3135.12 $\mathrm{b}$ ad. mergus merganser. 22.3134 .75 and. " "24.30 34.00 qad. Sthrnella magna. Fairfild, conn. Ap.7. 10.8216 .43 s ad. Fachyeineta Piesolor. " "6.25/3.50 sad. sucheo hejemalis. Passerella iliaca. iccihiter fuscus. teolaftes auratus. vireo solitarius. Dendroiea finue. - Linur motacilla. Requlue calendula. Haleo Afairverine. "Apr.2. 6.56 10.00 bad. "7.25 10.81 qad. "28.11.2520.75 $\mathrm{sad}$. "21. 12.7320 .20 bad. "23.5.50 9.07 qad. 24.5 .508 .90 sad. 6.2010 .28 sad. 4.506 .80 sad. "25.10.42.22.38 $\hat{\mathrm{s} a d .}$ Tearpodacue funfureut. "28.625/0.20 今 ad. mmistilta Maria. May $1.5308 .70 \mathrm{bad}$ Sthmeraficus variue. "I 5. $8.62 / 5.50 \mathrm{bad}$ 

Mmiotilta varia. May 1. 5.308 .70 fad.
Comme ostifragus. $7.16 .0033 .20 \mathrm{qad}$. Corvus ostifragus ¿ vingoides nacularius. 8.7 .7513 .559 ad. 7.8213 .857 ad $5.50,9.25$ îad. 5.427 .30 ôd.

vireo solitariue.

Seothlyfis triehas. Setofraga ruticilla.

1365

1366. Dive solitarius

1367

368

1369

1370

137

1372

1373

1374

$3>5$

1376

1348

$1,>0$

1380

1382

1383

1384

1385

1386 1384 1388 1389 1390 $139 \%$ 1392 1393 ailvus.

smime awricafillus.

Oonotrichia albicollis.

GAgeläne fhornicul.

on motilta varia.

Setophaga ruticilla. Dipilo terifthofuthalume." Afirundo horreorum.

Mnims carolinensis. - eto/nhaga ruticilla. Chrusonsitris tristis. ficure motacilla. auricafrillus.

Parula americana. Seothly his trichas.

Parulba americana.

Antrostome vociferus.

Picus villosus.

A arpormpnchus nufus.

zomotritchia albifeollis."

Qendrorca catrulescene."

- Ftanue solitariue.

toyansyliza cyanea.

Hiuries maêstius.

"

15.

"5.50 8.61 sad.

"6.00 9.75 t ad.

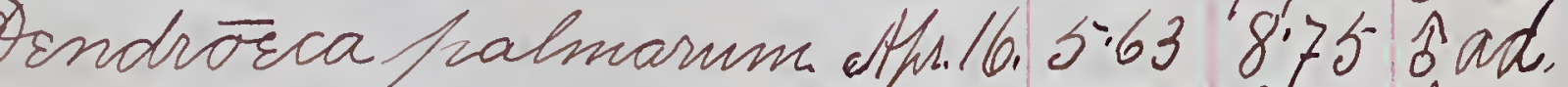
$1394 . "$ "Si50 8.7. is ad. 1395. Bayomie qusent, marde26.7.0611.12 7?

"5.96 9.54 Sad.

"6.25 9.80 ôad.

"7.00 9.60 sad.

11. 7.62 .12 .509 ad.

5.258 .00 qad.

"5.377.75 sad.

12. 8.5011 .48 sad.

"6.94 12.53 fad

11. 8.9411 .50 bad.

12. 5.50 8.25 今ad.

$11.5=259.06$ bad.

"6.91 10.19 fad.

12. 6.099 .75 sad. $5.007 .63 \hat{5}$ ad $5: 257.19$ sad. 4.817 .62 sad.

14. 9.91 18.70 命ad. 9.001512 qad. 11.2512 .75 -ad. 6.87 9i52 ojm. $6.809 .00 \mathrm{ft}$ ad. "5.25.8.00 sad.
Ectofistes migratorius. March 26.16.75.24.31 sad.

1399

1400

1401

1402

1403 1404

1405

1406

1407

1408

1409

1410.

1411.

1412.

1413.

1414

1415

1416

1417.

1418

1419.

1420

1421.

1422.

1423.

1424

1425.

1426.

1427.

1428

1429

1430

1431.

1432 of undus mutelinue. swainsoni.

" quscescens.

Harhortofechus rufus.

Oifrilo erythrophtitalnus.

at urdue fuscescens.

Drrangal rubra.

Q) indrorea maculosia. flackburnate fennsylvanica.

Mayls. 8:50 14:3 -ad. " "7.39 12.39-ad. 7.7512 .00 áad. 11.2513 .24 -ad. $8.50 \mathrm{ll} \cdot 41 \mathrm{sad}$. $7.60 \cdot 12.00$ qad. $7.3812 .00 \mathrm{gad}$ sill 788 sad. $5: 388.40$ sad. 5.347 .81 今ad. 5.407 .99 î ad.

Parula americana. $5.827 .50 \mathrm{sad}$

Q) indrórea blackburniās. cāerulescene.

Prieo olivaceous.

cterue faltinore.

Atelminthothaga fimus. miodiocted fusillus.

E) Endrorea Eestiva.

octerus spurius.

Goniahhea ludoviciana.

Prranga rubra.

D) endrorea blattburniat.

Myiodioctes mitratus.

Andī"ca Hlaetibuniāe

Mujidiveter cangdess.

$5.258 .64 \hat{b a d}$. 5.408 .48 sad. 5.307 .82 qad. 5.398 .25 sad. 6.3910 .25 îd. 7.50 ll.96 sad. 7. 4.80 7.24 fad. 5.01 6.88 cad. $5 \% 87.87$ ad. 7.3810 .50 âd. F.50 10.36 sad. 8.2513 .25 sad. 8.0012 .39 sad. 7.2511 .88 sad. 7.1410 .04 fad. 5.328 .39 sad. 5i26 8.78 bad. 5.75 .96 fad. 5.707 .98 qad. 5.658 .00 of ad. 18. 5.35 8.40 iad. 5.528 .23 1ad. 7.3311 .79 a ad. 7.5011 .96 ôd.
- cterns sfuniue.

Pyranga rutra. 


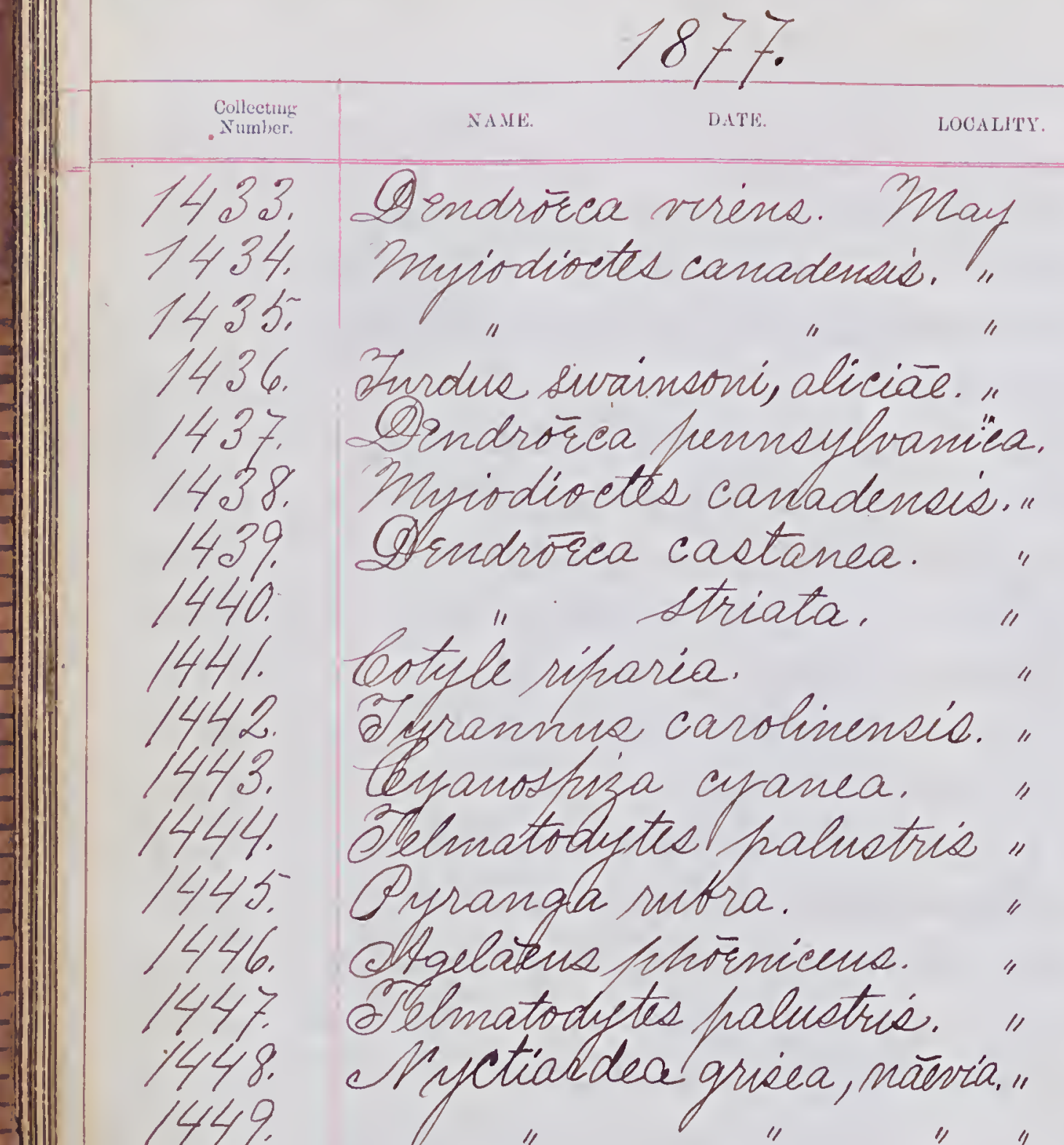

1450

$145 \%$

1452

1453.

1454

1455

1456

$145 \%$

1458

Petrochelidon lunifrous."

Coptele rifraria.

Olichohps onjiorns. \& cterus spurile.

1459

1460.

1461.

1462

1463

1464.

1465

1466.

1467.

Melosfira halustris.

oleothlypid triehas.

Cetrizobinitrie tristis.

Covous americanus.

suteo fennsyhranieus.

Corvib ancheanue

Myiarchese erinitus.

D) indroeca castanea.

Alelnitherns virnivorus.
18. $51 / 47165 \mathrm{fad}$ 5.627 .55 - 9 ad. 5.658 .09 bad

19.7.75.13.00 合ad. 5.047 .33 qad. 5.387 .75 f ad. 5.789 .49 合ad. 5.649 .00 onad. 21.5 .3910 .88 fad. 8.5814 .96 bad. $5.40 \quad 81129$ ad.

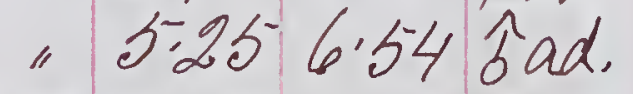
2.2. $7 \cdot 13 / 1 / 63 \mathrm{bad}$ $21.7 .88 \quad 12609$ ad. "si25 6.30 a ad. 23. $27.00 \quad 46 \%$. $\mathrm{adh}$. 25.684615 fad.

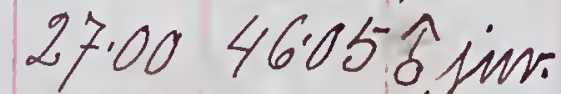
$6.0312 .54 \mathrm{~d}$ ad 5.8512 .50 bad. 6.5512 .459 ad. $6.0012 .02 \hat{b}$ ad. $5.2710 .82 \hat{b} \mathrm{ad}$. $71611.259 a d$. 7.3010 .50 âf 6.008 .14 ad. - 5i27 fion qad. "5i269.07 合ad. 4.828 .50 qaq.

"19.20 3675 官as. 25: 18.8536.70 9a8. 23. 18.853670 qad. $26.19 .30 \quad 36.80$ a ad. $25.8 .86 \quad 13.50$. $\mathrm{a}$ aी. "560 8.60 qad. 5.508 .75 âd. "5.52 8.50 qad.
1877

Collectumg
Number.

1470. Dindrorea striata.

1471

1472

1473

1474.

1475

1476.

1477

1478

1479 .

1480 .

1481 .

1482.

1483

1484.

1485

1486.

1487

1488 .

1489.

1490.

1491.

1492.

1493

1494.

1493
1496

1497

1498.

1499

1500 .

1501.

1502

1503.

1504.

isot.

1506.

Turé noveboracensia.

Sonasa nubellus.

Prié olivaceous (harent).

Bonasa imbellue.

Q) endröea discolor.

Gothlyhie trichas.

temandstiza cyanea.

Sthirafieid variue.

leyanosfuza cyanea.

- indrorea viens.

e eteria virene.

Hurdue fallasi.

Agelāele Nhorniceus.

- notrichía albicollie

Accipiter fuscue. OMrdus hallasi. fusca

itmdue pallaec. " " myiodioetes mitratus.do. (2) Indrorea hennoulvaniea. Gune 4.5:5 7.70 gad.

Shirue motacilla. "30.6.30 10.50 今ad. oniaf thea ludoviciana. July28.8.05 12.85 ŝju. Fyetiardea grisea, naevial. Clug.27._- 1 jin.

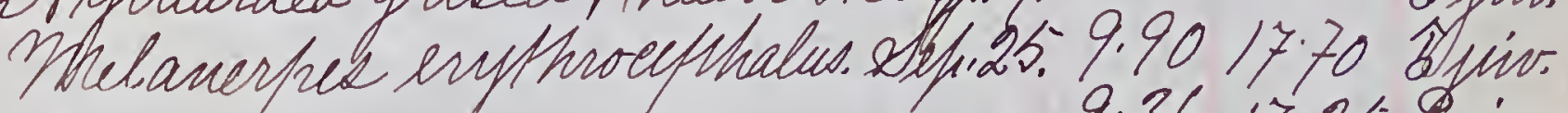

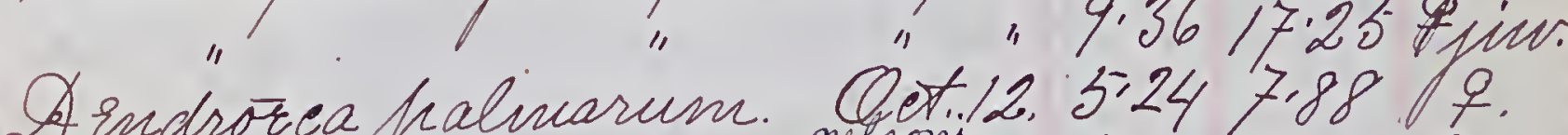

Ammodromus caudacutuen" "5.50 7.50 9.??

Q) Endrored halmarum.

Dmme18. 6.0011 .00 ô jin.

23.4.88 7.15 6ad.

"21.5.557.48 5ad.

"23. 5.63 8.60 5ad.

Apr.26.8.25/5.30 9 ad.

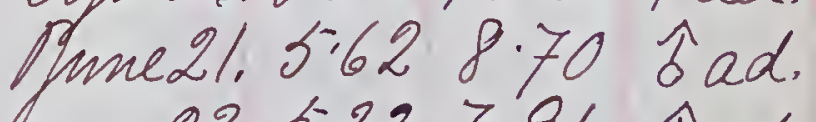
23. 5.22 7.91 今ad.

$21.7 .75 .10 .12 \mathrm{~L}$
May $2.7 .0911 .30 \mathrm{qad}$.

Rume23. $9.60151 / 2$. 1 ad.

OEdemia amerieana.

merque serratos. 11.11 .5522 .00 a ad. $13.5 .628 .63 q$ $7.3 / 1.38$ ŝ(ad?).

33 - 7 ad. "I 7 qad. 26.22 .4037 .90 âd. $" 21.0037 .50$ q ad. 27. - 1 ad.

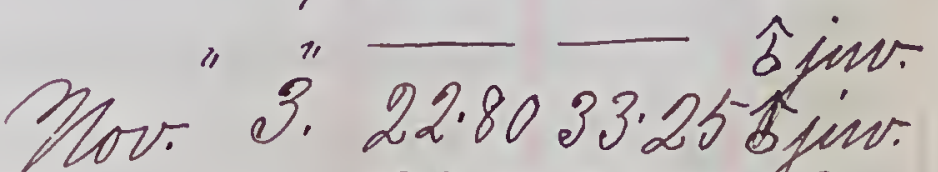
Mov. 3. 22.8033 .25 bin. 
1878

\section{Collecenng
Sumble:}

$$
1877-78
$$

Passerella iliaca Sialia sialis.

1508

1509

Q) endróca coronata.

1510. Regulus satraha.

$151 \%$

1512

1513

1514

1515

1516 .

1517.

1519

1520.

1521.

1522

1523

1524.

1525

1526

1527

1528

1529

1530.

1531.

1532

1533 .

$15-34$

1535

1536.

$15-37$.

1538

1339

Gerthia familiaris.

Passerella iliaca.

Passer donestiés.

Larns fhiladel hhia.

Q indrorea coronata.

Regulus satrapa.

- Strizella monticola.

Ampelis cedroum. adrfodacue furfureul. " "6.13 10.12 qad.

stor. \% $7.00 \quad 10.80$ qad. "7.00 12.60 bad. $15.5 .50 \quad 8.759$ ad. 17. 4.246 .92 bad. 4.116 .56 fad. 5.628 .03 bad. 7.5211 .39 îad. 6.509 .75 qad. 14.7033 .00 今ad. "14.52 3365 ôd. 24. $5.68 \quad 9.18$ הad. $4.216 .63 \mathrm{qad}$ 4.186 .60 qad. 6.589 .65 sad. 6.259 .10 qad. Qse. 7.7 .2711 .757 ad.

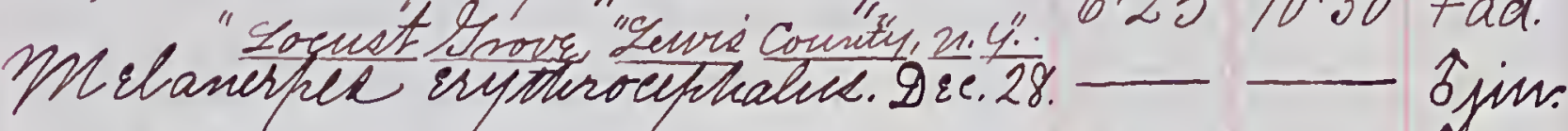

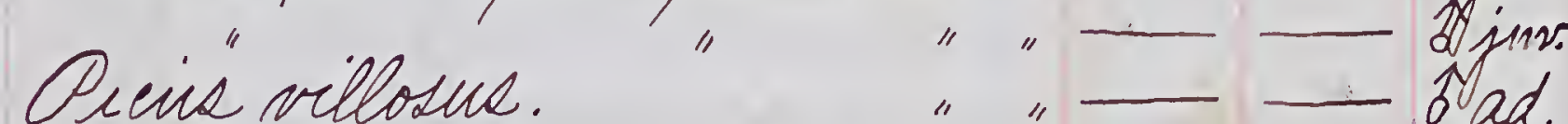

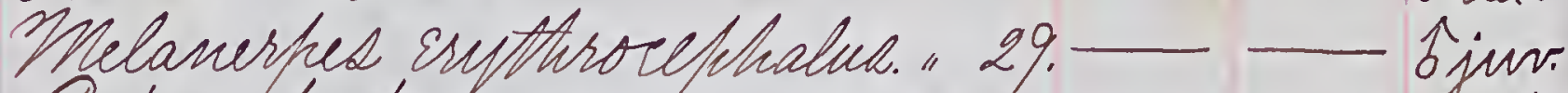
Quén / wubescent. 1878." "- Bad.

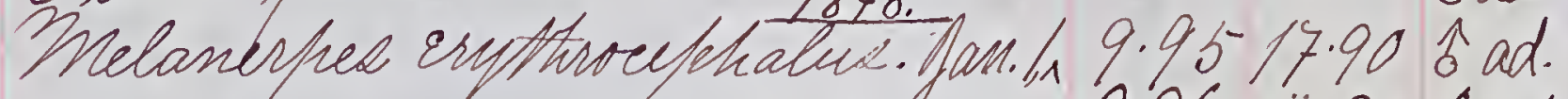

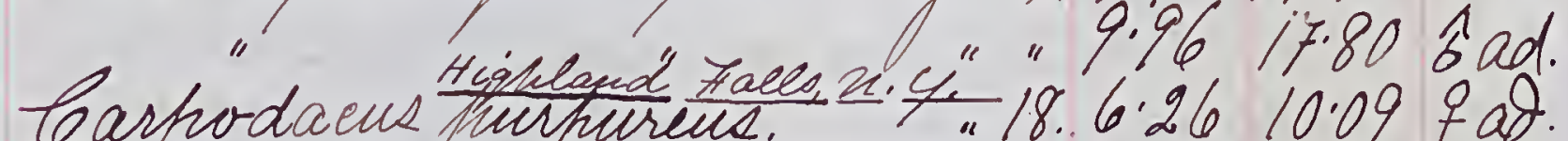

Teloyomitris tristis. "12.5.15" 8.89 sad. Sialia sialis. $15 \% 0$. 1541. 1542 $15 \% 3$ Cehreomitrio tristio. Carfrodacus furfureus. sffizella nontiela.

"

"10. - qad.

"12. $2 a d$.

"20.6.50 1028 ôd.

Carue atricafillus.

"22.6.28 9.38 今̂ad.

Regulus Latrapa. $5.39 \quad 8.10$ 9a.l $5.36 \quad 8.36$ ôे. $24 .-\hat{0} \ddot{a}$. 25.4 .246 .64 qa? 4.207 .04 रेके
1544. Dendrorea coronata.

1545: Ofrizella monticola.

1546

1547.

1548.

1549.

1550.

$155 \%$

1552.

1553 . Aaliaëtue leucoephalus.

1554 . Earpodacue purfureud.

1555

1556.

1557. Oreire pubseene.

1558 . Ampelie cedrorum.

1559

1560.

1661.

1662.

1663 .

1964.

1665

1566.

1067.

1068.
1069.

670

1671 .

1672

1673 ?

1674 . Passerella iliaca

16.5. Passer domestieus.

Parms atricafillus.

Amfrelis cedrorum

Easfodaeus /morpmene.

Orins hubescene.

Atwhelie cedrorum.

Passerella iliaca.

SALITY:

gan. 25.5.75 9.08 sad.

"6.41 9.5.

" "6.50 9.50 ह̂ad. 6.519 .50 sad.

6. 5.06 8.76 qad. "4.93 8.75 îad. "5.61 9.81 sad. 5. 7.1312 .34 bad. 9.7 .0412 .82 sad. $15.32 .8784 \cdot 10$ âd. $21.6 .42 \quad 10.52$ हad.

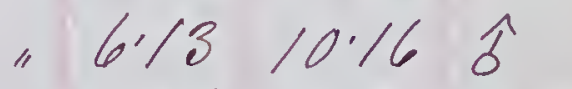
"6.06 9.90 qad. "6.87 12.00 fad. 23. 7.3111 .79 âd. "7.28 $11.86 \mathrm{bad}$. "7.49 11.98 fad. "5.37 8.00 10ad. "7.37 12.05 今as. "7.20 11.81 qad. "6.18 9.99 fad. "6.38 10.15 qad. "6.25 10.25 9ad. "6.87 12.10 . ad. "7.04 11.80 है(ad?). 28.6.97 10.62 fad. barpodacus furpmens. Mtarch 6.6.26 10.25 tad. "6.27 9.92 1 ad. "6.19 10.12 fad. "6.07 $9.83 \mathrm{fad}$. $" 7.1511 .00$ iad. "6.23 9.50 îad. "6.40 9.70 fad. "6.13 8.59 sad. 7.2311 .40 î ad.

Melostiza nelodia. ctmhelie cedrorum. Dasser domesticios. 
682

1683. Ofitta carolinensis.

1584

1583

1686

1687

1688

1689

1690 .

1691.

1692.

1693.

1694.

1695

69

408

1099

600.

1601

1602

1603

1604

1605

1606.

1607

1608

1609

1610

1611

$16 / 2$

$16 / 3$

$16 / 4$

1615

1616

1617 .
Cartrodacus histurens.

Drins fubescens.

Atmpelis cedrorum.

OAndus migratorius.

Atmpelis cedrorum.

Carfodacus purfureus. QAayornic fuscus.

Sturdus migratorius.

Juneo hifemalis.

Dasterilla iliaca.

sfayornis fuscus

Cedrodacne furfurens.

Slayornie fuscue.

Aasserelle iliaca.

Dindrorca coronata.

Melospiza melodia.

teolatuls auratirs.

molothrus ater.

Ourdue nigratorise.
Mlareh 6. 7.28 12.05 9ad. $7.381 / 62$ âd. $9.61211 .18 \mathrm{bad}$. $6.00 \quad 10.94 \mathrm{qad}$. 2. 5.158 .88 a ad. 13. $7.18 \quad 12007 \mathrm{ad}$ $.7 .2511 .81 \mathrm{qad}$. $7.0211 .77 \mathrm{fad}$ 7.3511 .84 3ad. $" 7.1512 .04$ a ad. "7.10 11.85 bad. $15.6 .2910 .39 \hat{\text { cad. }}$. "7.02 12.25 a ad. $13.7 .25 / 1.62$ bad. 7.1911 .60 fad. 17.1411 .75 ad. 11.7 .2511 .85

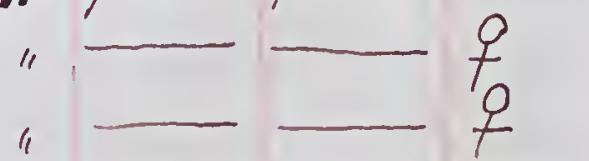

15.10.10 15.96 今ad. 11. - -

$26.624 \quad 10.389$ ad $25.7 \cdot 18 / 1.38$ iad. $1726 / 180$ ôad. 20. $9.8315 .50 \mathrm{fad}$ $29.6 .3510 \%$ îad. Apr. $\% 7.18 / 125$ sad. "7.24 1/.52 bad. 4.\%.10 - bad. 3. $7.27 / 1.32$ sad. 4. 7.6511 .78 sad " 5.71 9.32 हad. 10.6258 .70 sad. - 11. 11.8020 .40 fad. "7.75 13:30 sad. $12.9701540 \mathrm{gad}$.

1878

1618. 2urdua frallasi.

1619. Sfrizella socialis.

620. If turnella magna, Fishrill, n.Y. "18.10'60/16'45 Sad.

$162 \% . " 11121675$ sad.

1622. Aquläur phraniceuse do "10.13 15:53 sad

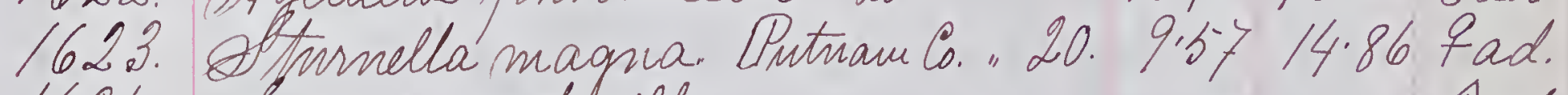
1624. Sirins motdeilla. " "- "Bad.

1625 . Regulus calendula." " "- Sad. 1626. Shmeraficus varine " " $8.5615 .00 \mathrm{fad}$ 1627. Mofbthrus ater. " " "7.38 $12.53 \mathrm{fad}$. $1628 . " .8 .0713 .75$ sad.

1629

1630

$163 \%$ 1632. Sofinrus motacilla. dol "23.627 10.54 îad. 1633. Ageläue phöricue do "249:50 15:60 âad. 1634. Disdrorea palmanum do "24.5442 $8.60 \mathrm{bad}$ 1635. Shhuraficus varius. do "25.8.80 15.85 fad. 1636. Siume motacilla. do "6.36 $10.77 \mathrm{bad}$. 1637. 1638. 1639

1640 1641 1642

1643 1644 1645 1646.

1647.

1648.

1649

1650.

$165 \%$

1652

1653

$165 \%$ do " "6.07 10.40 bad.

do "26.6.04 9.40 îad. Pifilo ensthrohththalmus. " $8 \cdot 4011 \cdot 10$ sad. Aliundo Lorroorum.

Shirus nāerius.

Passer culue savama.

Q indrorca halmarum.

Letohraga niticilla.

Oipilo bsyphrophthahnua."

Chrssomithic tristis.

Pahns atricafillus.

Melospiza palustrio.

Passerculis savanna.

$27.7 .3213 \cdot 10$ âd.

"7.06 12.90 占(jur?)

6.14 9.52 30 ad.

"Sif8 9.12. 3ad. 5.88 9.40 sad.

"5.27 $8.06 \mathrm{fad}$. "5.60 7.92 sad. 8.2410 .65 qad. 29. 5.19 8.90 ôad. 5.307 .97 fad. 5.28 8.00 5ad.

30.5 .877 .73 fad. 6.46.8.66 Ŝad. Melospiza melodia (parent)." "6.30 8.40 fad. 
Collectury
Sumber:
Sul

1655

1656

$165 \%$

1658

1659

1660

$166 \%$

1662

1663.

1664.

1665

1666

1667

1668

1669.

1670

1671

1672

1673

1674.

1675

1676

1677

1678

1679

1680

1681

1682

1683

1684

1685

1686

1687.

1688

1689

1690

1691

\section{8}

Indure migratorius

tarfortnychus rufus.

lespamins cristater.

Oifilo eriftrofsthalmus.

Nolothule ater.

Groglodytes domesticis.

nellanerhed sufhochhalud.

Myiodioctes mitratus.

ES elmatodytes palustris.

I indoides macularins.

Eeothlyfis trichas.

oogreftes aramineus.

molothrue ater.

\& cterus baltimore

Eurdus mustelinus.

Mniotilta varia.

leoceyzue americamue

- Linus motacilla. Treo olivaceous. \& Etorhaga suticilla.

Mifiodifetes mitratus

\section{Shmyrafucus varius.} \& ortia thea hudoviciana.

Apr. 30. 10.10 16.25 $\hat{\mathrm{bad}}$ " "1.85 1325 5 ad. $11.50 \quad 1640$ fad. 8.5011 .87 î ad. $\begin{array}{ll}7.90 & 13.65 \hat{b a d} . \\ \text { "May 2. 5ilo } 6.42 \text { tad. }\end{array}$ " 9.60 18.00 fad. "4. - 1 ad. 5.678 .38 ôju. 5.356 .62 ad. 7.9513 .50 qad. $5.30 \quad 7.30$ sad.

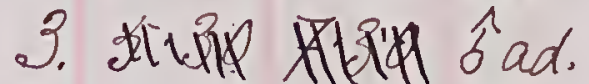
4. —— - fad. - - sad. $8.201375 \hat{s}$ ad. 8.5013 .75 tad. 5.408 .539 ad.

6. 11.8816 .75 fad. 12.4017 .357 ad $12.00 \quad 16.75 \mathrm{fad}$ 7. 6.25 10.38 fad. 6.3310 .15 sad. 5.387 .90 ôd. 5.758 .47 cad. $5.758 .55 \mathrm{sad}$. 5.648 .40 bad $5.628 .25 \mathrm{fad}$ $8.6215 .70 \mathrm{fad}$. 98.1513 .40 sad. telminthophaga chrepotetera. 1/. $5 \cdot 258.35$ sad. " nuficafilla. 10. qad. miodivetes mitratus. "eterus" baltimose ineo flavifiono.
1878.

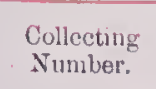

1692

169

1694

1695

1696

1697

1698

1699

1700.

$70 \%$

1702

$=13$

1704.

1705

1706

1707.

1708

1709

170

711

1712

1713

1714

1715

1716

717

$7 / 8$

1719

1720

1721

1722

423

1724

1725

i> 26.

1727 . Auranga rubra.

1728. Ollyiarchuse crinitus. mides mustelinus. mustelinus

Pyzanga rubra. * Sincer motacilla. Prranga mbra.

deteruk baltivore.

Ageläen hhönicus

Snochilus colchis.

Myiodioctes mitratus. us poreblik.

- cteriá virene. vieo qlavifrous.

teyanospiza ejanea. Dendrogea aietiva. Q) blichonys onziorne - cterne balturiore.

iturdus metelinus.

contofure virine.

\begin{tabular}{|c|c|c|c|}
\hline LOCALITY & Lengrth. & Siretch. & 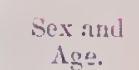 \\
\hline
\end{tabular}

May 10. ôad.

Sialia sialie (parent).

Dindrorea caèrulescens

" "——

ad.

1 - ôd.

10. $\hat{b} a d$.

" "16.572 81/5 5ad.

Aicue hutescene(parent)." "

Lindrorcal virene.

Coturinenlue, fasesinus. "

$1 /$

13

$15.3 .78 \quad 4 \cdot 12$

14.5.80 8.60

15.5 .85 .8 .10

ad. Syctiardea grisea, naevia

tiriundo horreosum.

"7.37 12.88 bad.

$157.409 .90 \mathrm{bad}$.

17 - fad

$1 / 6.5 .759 .80$ sad.

15 - 1 ad.

16. - $\hat{\text { sad. }}$.

$"$ -

$18.5 .35-8.30$ fad.

"Si30 8.60 cad.

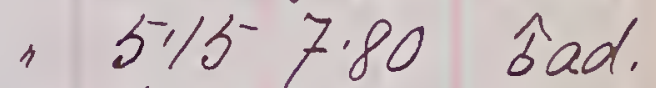

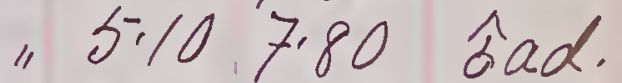

"25.0045.25 qad.

$" 7 \cdot 6512 \cdot 10 \mathrm{bad}$.

"7.65/1.85 qad. 15. - - sad. 20. 5.60 10.95 cad. "7.35 12.80 sad.

"W - Bad.

'bad.

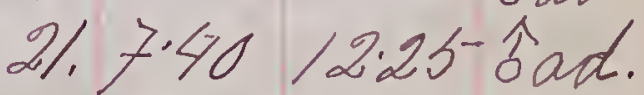
"9.05 /3.45- ôad. 


\section{- Acteria vrine}

mujidivetes mitratus.

Ofundus migratorius. - cterna sfurius.

Aclmithenes vemivouns. Oachucineta freolor. Otelionatodytes palustris. Gondrozca castanea. E. Slackbumiàe. Q endroica Afactiburnice. tehaietura frelaguca. ecterus Afurcis. Q indrocea Slachturniāe." Ofyrannus carolinensis. " Treo olvíaceous. Mmiotilta varia. Asmfrelie cedrorum Atgelaent fichunceue

othims carolinencie. Pyranga nubra. \&urduL swainaoni aliciāe. Dirundo horreorum

Q in drorca hemnsylvamica. teoccy zue erythof ththalmul." Dytanga ratra. - " Oindas migratorin Anufelie cedromunf(farent)." jodiocies onitratus Aargorluyncture nufue Elotiheqa riticilla.

\section{may 21. ₹-50 10.00 bad} 5.458107 ad. 6.00 8.75-6ad. 10.0015 .677 ad. $6.8510 .05 \hat{b} \mathrm{ad}$ 212. $5.60 \quad 8.62$ qad. - $10 a d$ - - Bad. $5.859 .30 \mathrm{bad}$ $5.288 .35 \mathrm{bad}$ 5.45 8.20 fad. $5255-8.40$ had 23. 5.3512 .37 qad. $7.56-1060$ bim. 5.20 8.40/ 8.75 14.80 sad. $25.6 .40 \quad 10.20 \mathrm{bad}$. $5.358 .557 \mathrm{ad}$. $7.3012 .00 \mathrm{fad}$ 93015.00 bad. 9.7515 .60 âd 28. 8.12 12.85 fad. $8.9511 .653 \mathrm{ad}$ 7.3011 .85 bad. $17.5512 .90 \mathrm{fad}$ 10 - fad. - fad. 3. —— - iad. 27 - S fullue. "— Nade 12. - fulho. 75o 12.22 fad.

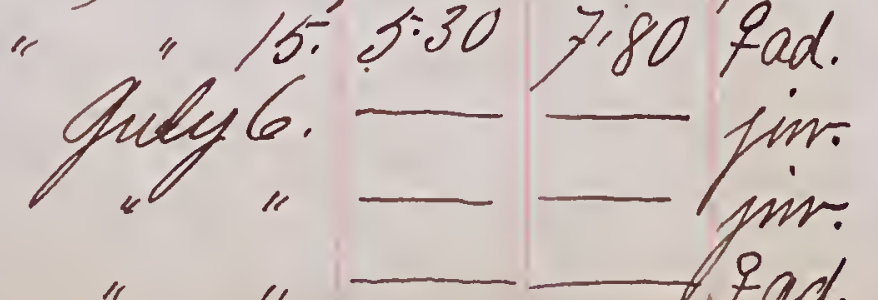

176 7768 1,76 $7 \neq 0$

77 77 177 F 75 1776 1777 1778 1480 1780 1782 1783 1784. 1785 1786 1787 1788 1789 1790. $179 \%$ 1792 793. 1794. 1795. 1796. 1797 1798 . 1799 1800

XaMF.

Myiodioctes mitratus. Dayor

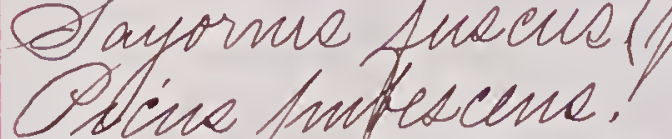

Afroglodeltes aidont=dometrivis). Alu

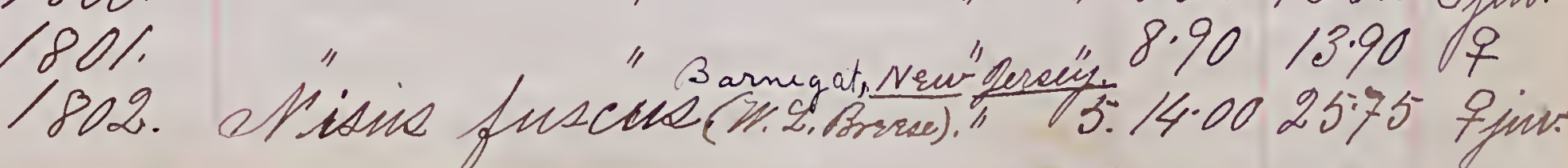

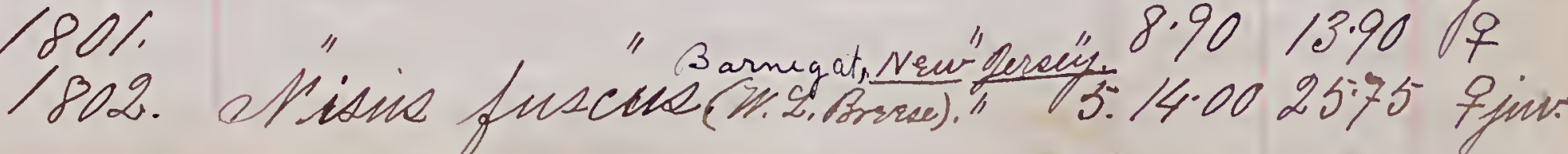

Atymanture carolinensid. Hterna fuliginosa. shdea herodics.

Odilymbus podicefis. D) Endrorea caerulecene.

Panula anesjéana.

Châtura filagiea. Onrdue Swaisleovi, aliciāe.

26. 8.30 10:20 f jiu. Stp. 13.17.05 34.70 ad. "2.3.43.75 69.50 q juw. 131021.407 b.38 8.25 $\hat{\mathrm{sad}}$ $4.807 .65 q$

Ofhrofiene varius. $5 \cdot 38 \cdot 12 \cdot 30$ 28. $7.5512 .65 \hat{~}$ $17.40 \quad 11.88 q$ $8.3015 \%$ f jum

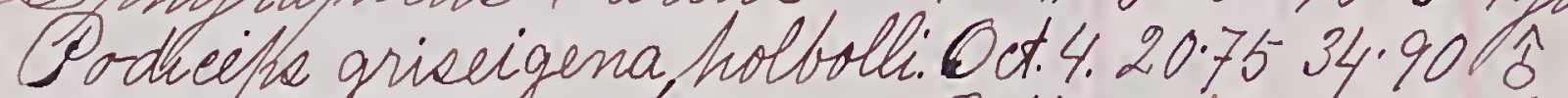

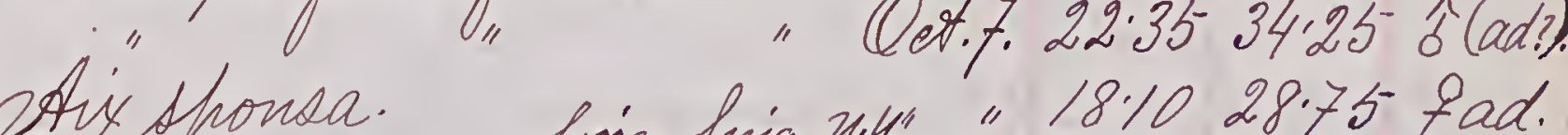

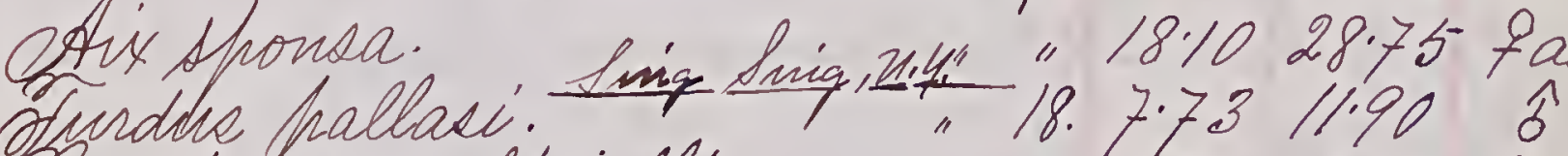
Gonotrichia albicollis. "6.90 $9.40 \mathrm{fad}$ D) endrorea coronata. 5.558 .50

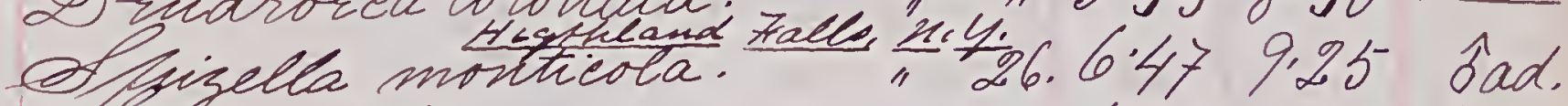
Aitta carolinensis " "6.12 11.05 ŝad,

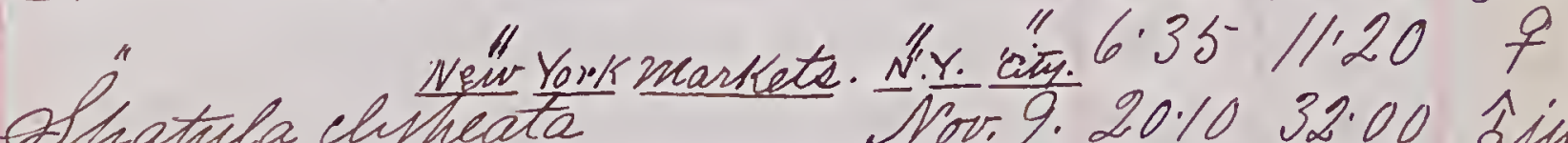
oriematura rubida.

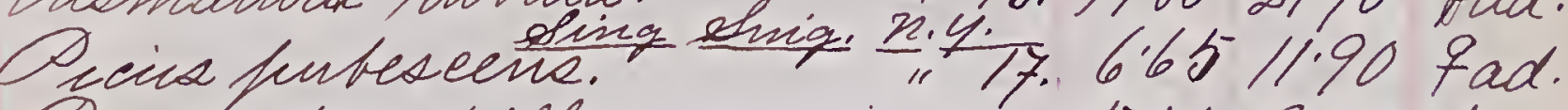
Parus atricafrillus. 5.458 .25 ô " "Hohland Falle, hy." $5 \div 60 \quad 8140$ ô

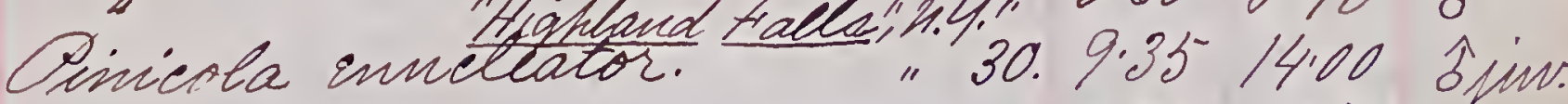
" $9.20 \quad 13.75$. 4 299.5014 .50 s.jum. " $8.95 / 3.45$ 9.0014 .05 ôn. 8.6213 .62 s.im. 


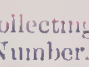

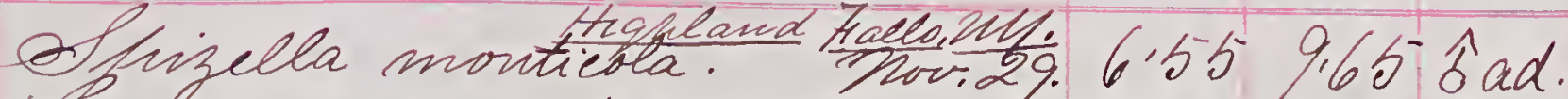
To yanume cristatue. "30.11.50 17.009 ad.

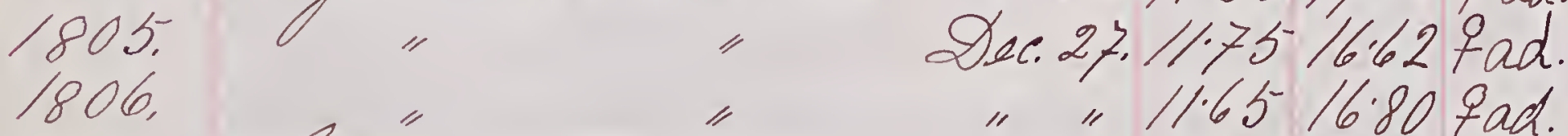
1807. Sitta carolinensis. "625 "11.30 $\hat{\mathrm{s} a d}$. 1808. Bonasa umbellus. 1809. Egisthus hinaria. 30.1712 .3355 and. "5.52 9110 bad. " 5.358 .65 binr. 5.358 .80 ad. 5.508 .80 bad. $5.609 .35 \hat{\text { sim. }}$ 5.509 .05 sint 51608.85 a jin. $5=15.85$ fad. 5408.80 全im 5i/2 825 fad $1+8 / 8$ 1819 1820 $182 \%$ 1822

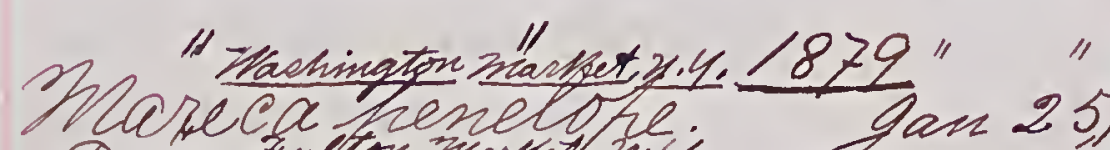
19.503360 bad.

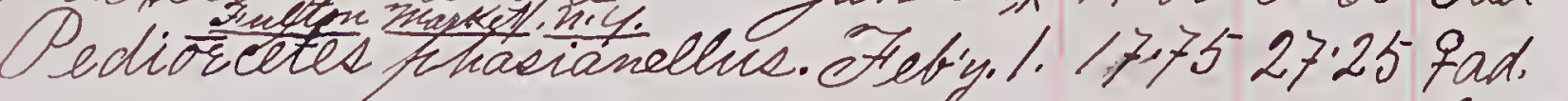

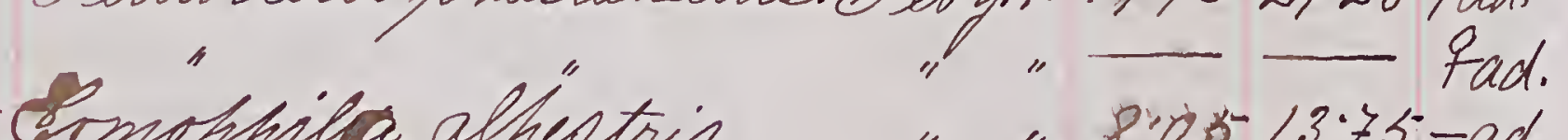

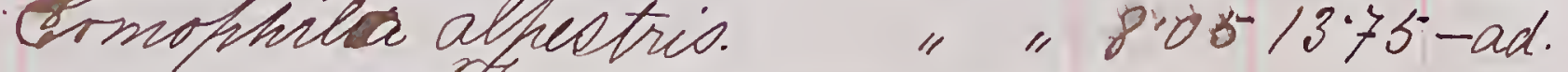
etrosterontgomeny, He.4.

1823. Previe fublecent. mparch 3. 6.7011 .65 bad.

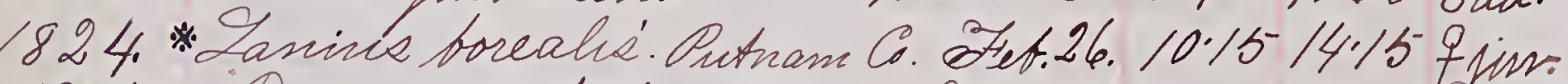

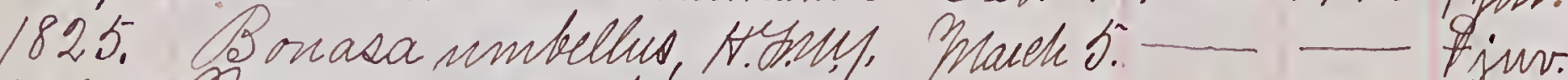
1826. 2niecalus purpureus "12.12.50 17.75 1 ad. 1827. Omduse migratorius. 1828* Melosfizá melodéa. 1829. Piens arilosus $1830 . * 7 \%$

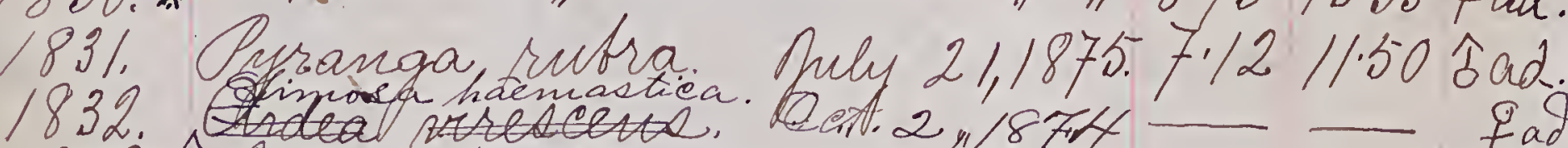
1833. I cterus baltinore Mai 18,1876- - i 1834 Asmitherus vrimivorus Gucly23,1875.6.37 8.62 7 ad. It is to be understood that when not otherwise stated, all of the above opecinens were shot by muself somewhere ofi the nerightorhood of ny house; all of them in the thdson tighlaude. Some wrre sleot on the offrosite bank of the rwir, in Putrame counte, Pthers to the sonthward, in Rockland. A Lew wide taken higher up the Andson, in Mester \$ utsan countiul; and not a few wre obtanied ufon the islands of leonstitution, leousoos and. Lona, in thet Andson River. Those Lathen at a greater distance are so descrited in the headiugh.

Saturday, Mareh 22,1879.

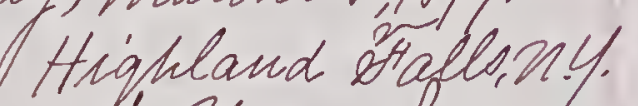

left the leallege of Plups. Y Aurgeoue, Hew Y ork, on the 24) It of Bfebruaky last. Ifound the Andeon completely rie-bound. All of the air-holes urare cloked teiftet. A sleigh with one horge was awaiting at Sarrisonk, which frought me and mity heavy baggage acrost the hiver. Ihdd hotefl to find the Pine Grosbeaks Torstille, Lesoer Redpolla, Pine Fininete and Af sour. Buntings still here; but 9 have seen none of those thide pince nu return.

$I$ walked acrosf the river on the 26/h. and walked through See'y Fish's flaec to the' jublie road, offisite to the Coborn's.; Thence uf to the Constitution ineadows, Cold effring, id Constitution Asland. It he only noterborthy thids, wre Buteo hineatus, of which I taw seviral, and Lamine foreplis. Ishota young female of the latter specie, on the mieldurs, aft: a lilong chase, and ourral unsuceesteful is. Waffinig down upon the railrotad. At im. Hiotis freace, I started a funco hyen. Arom Atu traeks a few fraces in frout of me. A phiske dashed doshre from the lfolge above, in hot ursint. The fuowbid shade everu iffort to escafe, doubling and twisting, and pehying 
most firterusly as it endeavored to escahe by dashing into a cluesh of hemlocks, but the shritel followed closely afl of its windinas, till at last the terrified creathre Llew on to of the ledge, followrd closely by its enemu. of could hot see the result, but have ns doubt that it ended pir a tragedes.

On Innday, Gharest Ist, 2 took a walk, in the deef snow. Is aw thee Buffed Brouse, Bonaea umbellue, below mr. Pelles, among the cedare. Isaw the ferst one when at apite a distance. I afflroacked cautiously till within a bew fraced, where 9 had ash excellent ofofortinity to observe its actione. At first At stood epeet, with neek outstretched hutlas I rmaiced quiet it seemed lest alarmed, and disfiosed to git away without tothing to fleight. Sfreading ite thil, and witth drofting unigh, itf sallied softly through the show to a tree or stumifs meardng

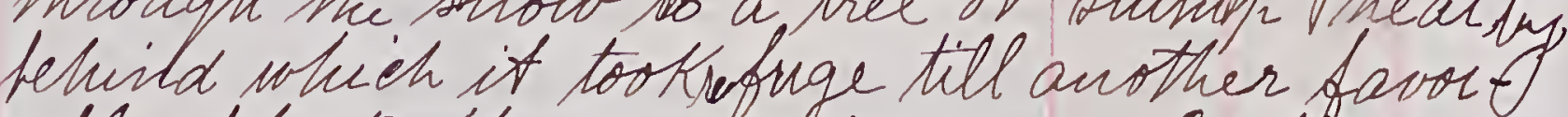
- able offiortinity seuned to oceur. In the mean tine another brouse was seen to start from a nearer situation, and seeming as little diofosed to flight as its fredecessor. they stulted behind stones and trees, slowhy retreating. Their taill wre widelef apread, their rutfs reet, and evrry attitude hetoting gra at bblicitide and alarnf; also indicatedby their seared, cluctmin notes. Af every step their tails wre alternately ireeted ahid depressed in a jestry manner, While their heads mere acillated spasmodically mi a longitudinal direction? Mus they moved awray mi divirgent direetione, reeasionally encountehing a small ledge, which they sealed by mealis of their wings, muchas a hen attains her ferch. At kength. much to my surprise, a third bird started from a funch of tall grast, Where it had renclaried concealed, I and utitt a loud chethig note started in a direct line ni thr sance ditection mi which the others had by this trine disapheared. It seemed greatly alarmed, and made little attempit at concelalment, but ran cluefting ofter its confrarious, seening to frefer thic meane of esteape, as it had beef suceusfully adofted Fu its comradis.

It was a viry feleasant seght to see these handsome bribes onder sudn favorable circumstanees, and exhibiting sommels avimation. Such offortunities are not frequent

Early wi March there wre heavy ramis, and considerable foggy and windy weather. Qur the morning of 10 th, I heard the Acring Sulle screaming over head. Oconcluded that the vee must have troken wh in the

Hotat ou, and, on going, to see, found that I war correct.

Po Robins or Bhiebids wire here on my firat arrival. The fist Bhebrids wre seet in Putrain Conntef on March 3 sol. The first Robin two or three days later, at the Erosest-o-Dean mier, wheke I shent two days fox hunting.

No Phrple Finches wre seen; but thin I heand one a bew dayp enice.

$I$ have not seen or heard a Ceidar Bard sinee ny return from Neurfork.

Znscalus purpurene. Firit seen Mnar de 12 th. Passerella iliaca.

Sayonini fuaene. 
54

55

1879

1879

The Shorbes have onlef nttered thei ohasf 1835. Mergus merganser. Mareh 2024.0033 .009 ad

"Chif" till this morthing (March $22 \mathrm{nd}$ ) when

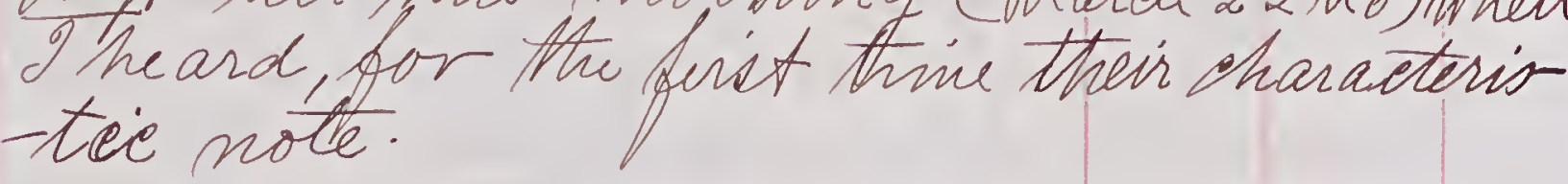

The Soshawk, Astur atrieafullus, I have seen tureer, - mareh 13 th 52 the.

Ameo hemalis. The showbirde are tuitterine evrrumhere, ni great abundance. Decasionally one of them estays a song, which is ex zentell withe realy od iffeet, Henig viry funey werts. singmi for stone dape hea has been singing for sone daye fast.

Candion haliactus? "Saw the ferat Es:preef?to-dae." [Gtide C. Dingee.] Ampslis cedrorunc. Finct seen yesterday. At Aflock remained ni the trees about ther sefarated into hairs, and Dhey are frotably mated altrady. Fos wouffe separate theneclve ffom the mass of ther, matimiq allerinate advanees, apflyin of caressingettier - doutiless a meanfs

Shot the Wurtirate on the Cousook Marsh. Ductes are quite zumerous. A number of Dagles Haliaetus bueveephalus I are kishabiting the Sarritons Corr, as Ed, the exfrestmas inforned me this morring. Dintend goting uf there to nugrow, ak phere are sait to be numbers of Duets in the Corr. Winty 9.00; tail, 4.35; culmen, 1.92; 7arsus, 2.00. aribles deef brown

836. Shat on Consook Leland. H. R. Itelgidopleryk serrifennis. May, 1872. Fad. the Rough-winged Swallow that I have evir cah-tured, till now. I took her off her nest, in a bank beside the Parry Poind, along with one of the foun eggs that the nest contained. Mns. Freld Ditchett secured the other there eqgo. See Bulleteri of Huttall Clut, Tol. III, fo 46, 11878. tho see my thalogical foumal, 11067, Set $\frac{a}{4}$, fe. 34. Inesday, Mareh 25 th. Lo-day wrot ducting on the nir. Saw a lorgh number of Dwethe, and sevirial Sarrisons Cove. Crue fine fellow sat on the wo fif a large dead tree, fist north of Parrobies. Itre cauded but failed to get hini for the same rrason Detat Simple Siscotr could not

The got nothing; itayed all day. Trednesday, Whareh 26 H.

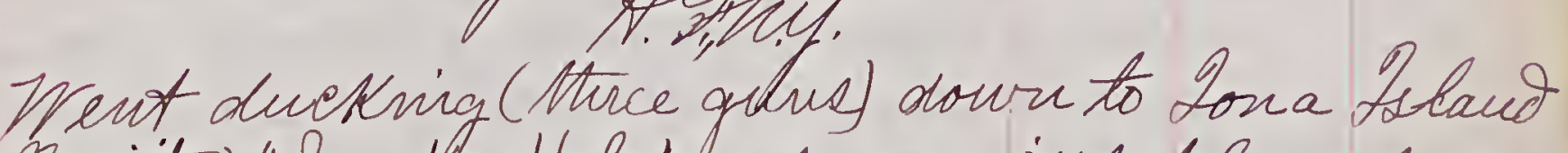
risited "fuarle Hole" and wariour place. he following species of Duete wre noteed sterday and to-day. Atlas toschae, If. Mnallard. Stuligula marila (b) Irreter Blacthead. " fermia amesicaua. Redhead. Husphiala clangula Lolden-eye 
Buechtrala albevla.

Aarelda glacialié.

Therqus merqauser

"sertator.

Red-brrasted Meryauser.

Buffll-head.

Loly-tailed Duek

Hoozander.

shot by Reed, last funday (Muareh 23nd),

mifrout of Haveno' Lauding.

Zull seen.

$$
\text { Larns argutatio is the only }
$$

$$
\frac{\text { March 26. }}{2 \operatorname{on} \alpha 2}
$$

\section{Loma Lsland, ti. Riv.}

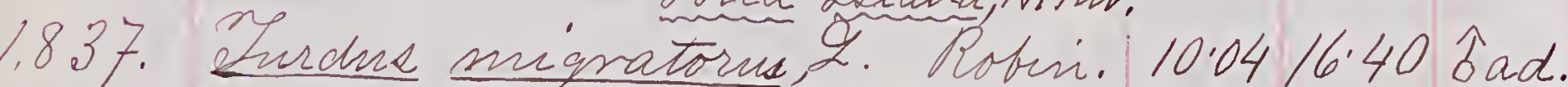
Hanig, 5:10; tail, 4.5: His hazel.

1.838. Anmpelie cedrorum. Cedarbind. $7.3511 .75 \mathrm{tad}$ Ifing, 3.70;tail, 2.50.

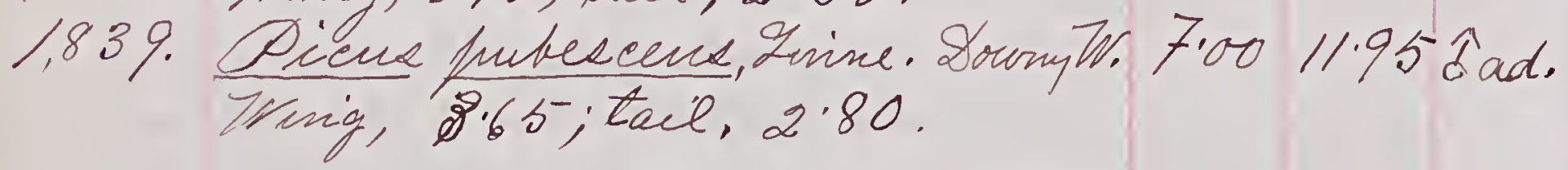

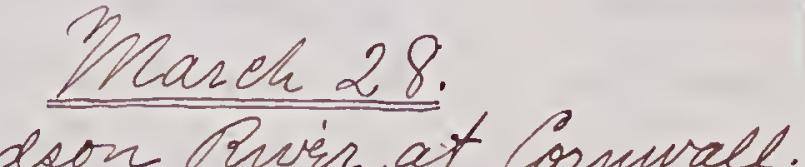

1840. Anas ofseura Dusky Duek 24.50 $38.50 \hat{b}$ ad. Ninig, 11.00; tail, 4.35; Culwen, 2.33; gape, 2.65; tarsue, 2.00; middle tor, $2 \%$; its claw, 44 .

From fosh Ward. Iris hazel. Bill with base of mandible, bright qrarieic yellow, shading into olvi-green towards tip; nail blaetuis. Tonit of mandible black, like nail of maxilla; resedicu of mandible, ohir. Feqk and Tors uniform red; wres blackish red.

1841. Suliquin marila Bhu-bill. 196533.75 sad. 7 ining, 8.80; tail, 2.85; culven, 169; gahe, 2.23 ; tarene, 1.58 ; middle tor, 2.50; its clar, '38. Mentranes. betwern rami of manibe, purplish. His bri yt orange. Bill, pale blue on maxilla; nail blk. lowit enandible Back, with edges blue (like

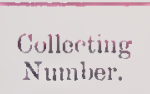
NAMF.

LOCALI'I'T.

Length.

\begin{tabular}{l|l} 
Streteh. & Sex ind \\
\hline
\end{tabular}

maxilla vearly to ponit; resediew mottled with furplis Hue. Legs y feet, bluish ash; writs, blackich. Shot by posh Ward, at Convall.

\section{Ahril 2.}

Ageläns Aihorridene Red-winged Blacktird. Flist seen March 29th. Ectopistes migratoria Fild Prgeon. Alargeflock was seen twiel, to-day, Slying over ther woode at the south, trough Atwy Werrebnot seen to alight there.

1,842. Passerella iliacal. Fox sofrrsour 7.35 $10 \cdot 80$ a ad. Nhing, 325 ; tail, 2.85. culmen, '50; curns, 95 .

843. Ampelix cedrorum. Cedar Beid. 7.50 12.00 q ad. Fing, 3.77; tail, 2.50; culmen, 99; from nostril, 27 ; qape, 70; tarsm, 70.

Rectried, reddich at tif.

1844. Atmpelic eedroum. Cedar Bind. 6.95 11.25 f juo Fring, 3.55; tail, 2.35; culmun, 40;

from noatrie, 25 ; qape, 71 ; tarsus, 64.

Jail just aequireng the yellow tifh; greanié, growniz bright yellow at teir.

\section{April 3,1849. H. Thy.}

1,845: Passerella iliaca (Murrem). Itox th. 7.50 11,35 is ad. Mnig, 3.40; tail, 2.90; culmew, '50;

tarsu, 95; middle tor, 165; th claw, :3.1.

1846. Passerela iliaca (Murrem). Fox tharrow. F.08 11.05 is ad. W.mig, 3.35; tail, 2.90; culnen, 50;

tarsus, 94; middle tor, '60; its claw, 30 .

1,847. E.torietes migratoria (finnel. Tr. Rem $156023.85 \mathrm{qad}$. Whing, 7.75; tail, 7.00; culmen, 74,; gaf ue, 1.10 ; tarses, 1.08 ; niddle tor,

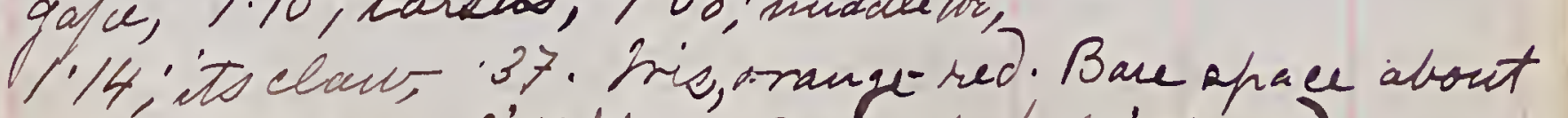

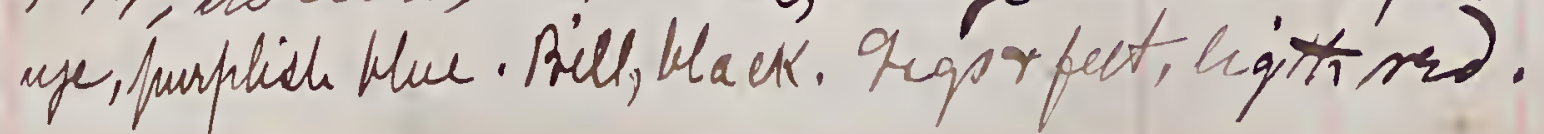


Collecting
Sumber.

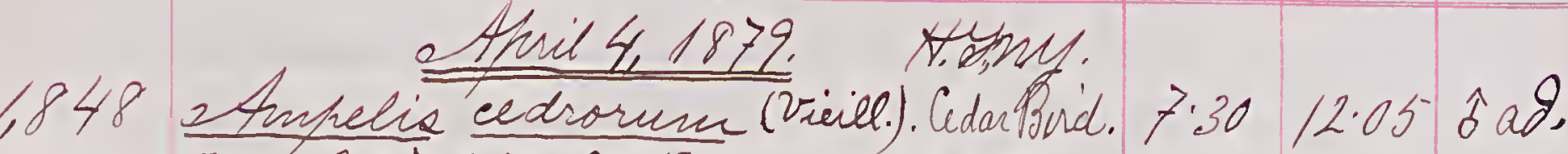
Whig, 3.87: Tail, 2.45; culmen, 41 , Tareus, '70; middle Tor, 61; its claw, 24 .

1,849. Ectopiates migratoria (Anve'). Wild Prgion. 1675 24.00 îad. Wing, 7.80; tail, 7.75; culmen, 75; gape, 1.18; tarans, 110; middletor, 114 ; its claw, 35- Colors the 2ame as No. 1,847.

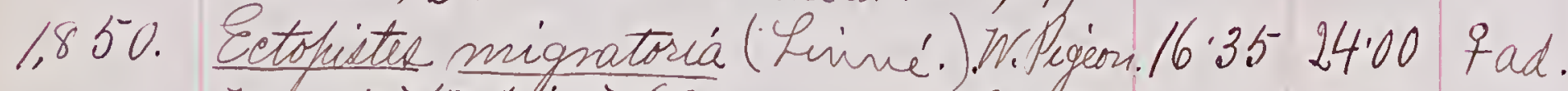
bing, 7.75; taie, 7.60; culmen, 72; tarsure, 1.05; middle tor, 1.10; its claw; 35; gape, 1.06. Colors a ame ar No.1847.

1,85\%. Eetopietes migratoria (Limne'). W. Pegion $15.75-24100$ qad. Fing, 7.75; tail, 7'15; culmen, 68; gafe, 1.05; tarsue, 1.07. Colors ithe' zame as Ho.1,847. Midille tor, 106; its ciaw, i33.

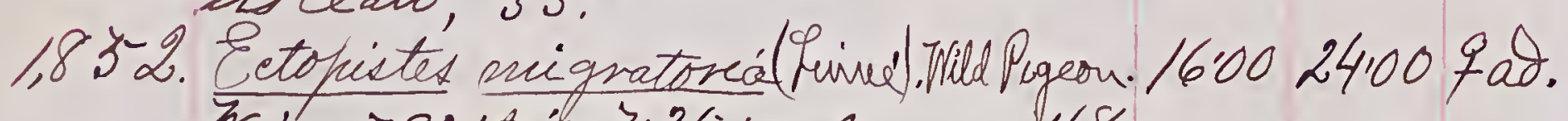
trin, 780, thaie, 7.35; culmen, 68 ; gefe, 105; tarkw, 1.09; middle tor, 1.06; its claw, 35: Colorslike 20.1,847.

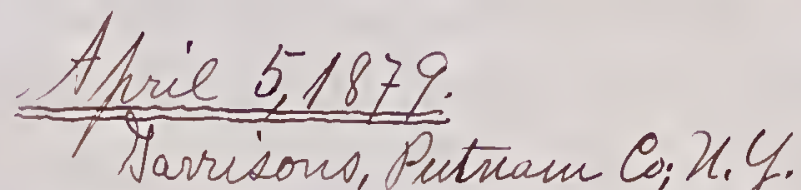

Molothrus ater, Cov=Bird. First zen Seolecophagus dernginent, Rustef Tradk. Fist been. sturnella naqua. Meadow Lark. Af the Q2bom's.

1.853. Suter borralis. Red-tailed Xfawk. $21.90 \mathrm{5 \%} .00$ i ad. Ning, 14.75; tail, 9.00; culney 1.07;

cere, 54 ; gape, 1.80 ; tarrus, 34. middle tor, 1.60;'ts claw, 88; hallux, 1.05; itts clanr, 1.21. 2rís, yellow; legs and fed, yillor i Cere, gramist

- at tase. Shot with a reple fullet from a wagon, and preseutio to the by Capt. Ereyant, of
Collecturg
Number. DATE

$\frac{\text { Ahril 8,187\%. }}{\text { Cormwall, on the Hudson }}$

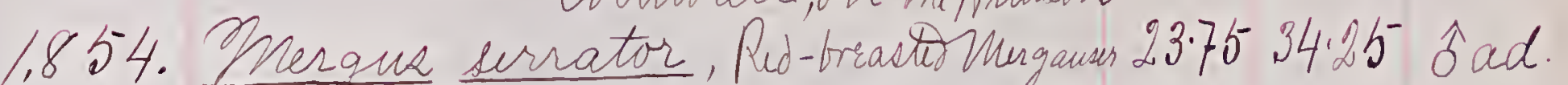
Fring, 9.25; tail, 4.25; culnen, 2.27; gafe, 2.8.7; tarsus, 1.87; midele tor, 2.40; its claw, 43. Dris, breght carmine. Bill, furphish thack bu ridge of maxilla: resedin, ret. Legs ano keet, bright ord; wrbs dustiy; nails, tusky at base, white at tip.

thot bu Josh Wais

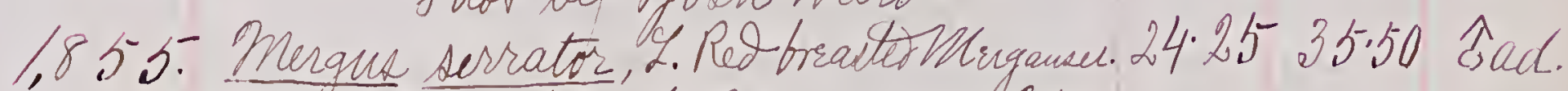

7 ising, 9.50; tail, 4.20; ulmen, 2.42; gafe, 2.92; Tarsu, 1.85; middletor, 2.33 ; its claw, 37 . Clors the same as No. 1854, above discribed.

1,856. Wnergus serrator, L. Red-frasted Heiganer.21.60 $33.00 \mathrm{f}$ ad. Tring, 9.05; tail, 3.75; culmen, 2\%; gafe, 2.61: tarous, 175; midde tor. 2.2\%, ito claw, 35. Colors the same as $110.1,854$.

1857 . Corves anmicanne. Crow. 19.50 38.250' ad gafe, 2:23; tarsus, 2.37 ; itasdato 1.50; its claw, 52. Jideshazel.

1,858. Smmer hizemalis. Snow-Bind. 6.039 .30 qad. Tring, 2.80; tail, 2.55; culmen, 44;
taisus. 8 . Fri, hazel

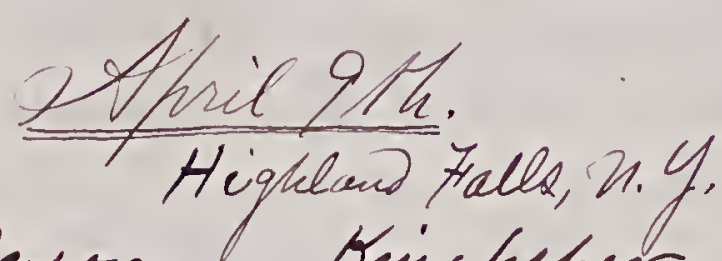

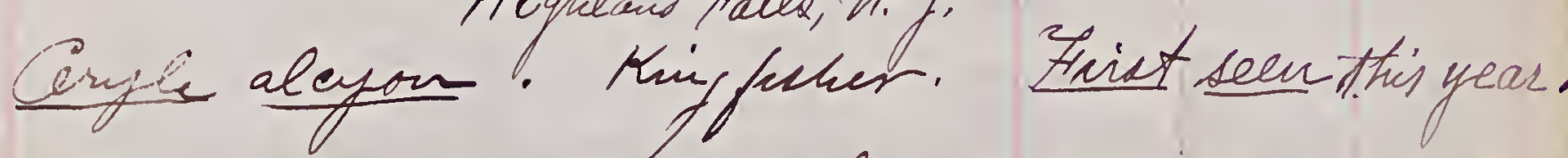
1,859. Prdicefer cornutus. Horned thre. 14.00 24.00 \& ad.

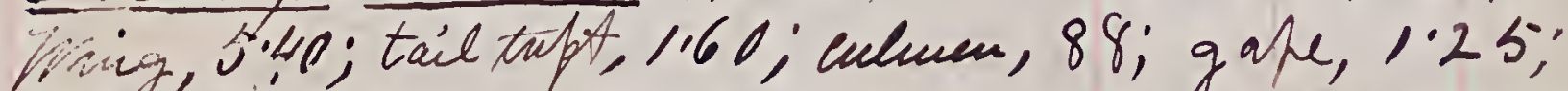
tacus, 1'7\%; midle wo, 1.67; "its nail, 30 ; both.

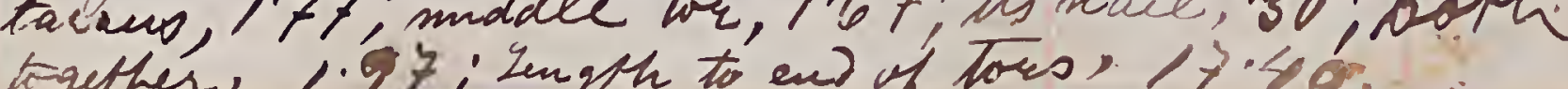




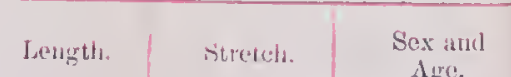

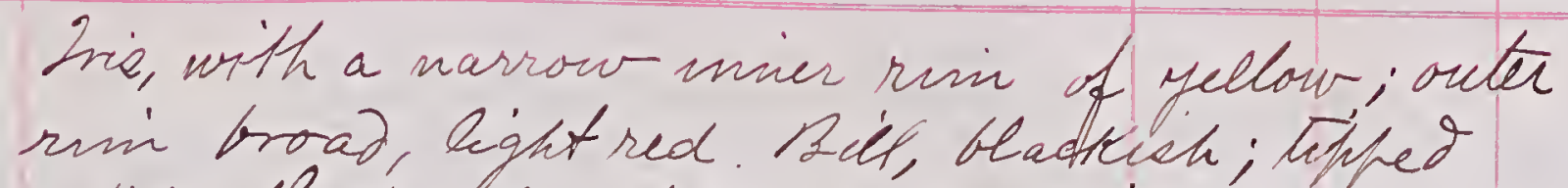
whit: flrsh-wlor at base of mandite

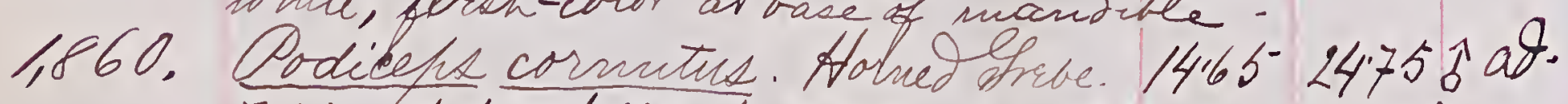
Wrig, 5.40; tail thpt, 1.50, culmer, 93,; gafe, 1.37, tarsuo, 1.93; middle tor, 1.75; its claur, 32 . A bar shace, extending from conver of mowth th eye, red. Larsi and tors, lead color anteriorly; thak posterivily. Rest of prasts colored as atoon, $20.1,8599$. Both of the atore were shot by fosk Wrand, at Comurale.

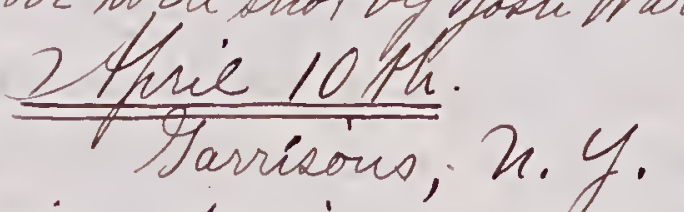

The followrig specie wre seen for the friet timid this season:

Colaptes auratus. Yellow-shafted Hficker.

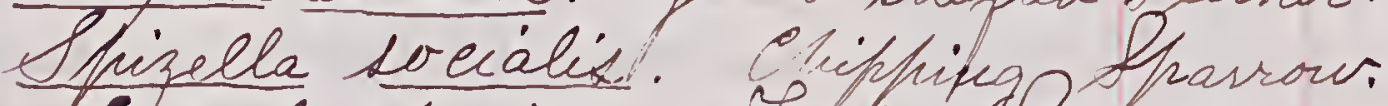
Afizella frisilla. Ffield Sthairow. Regulus calendula. Auby-crouret Huiglest. Poorectes gramintul. Say-uriged Strarrour The follownin shecies wre che ohserved: Regulur Latrapa. Hodden-crested Kunglett. etmpelis cedromu. Codar Bird. Buter drorealiz. Red-tailed Hawk. Nisue quecus. Sharh-ahined tavk.

1,861. Etherrafiens varius. Yellow-bellied WI. 8.8515.80 3ad. hrisis, 480; tail, $3 \%$; euluen, 97;

"yape,113 itarsus, 87 . Iris, hazel; bill, black;

1,862. Jurdus migratorius. Robin 10.0016 .25 is ad Wring, 5.03; tail, 4.35; culnum, 87, from nostril, 's6; gape, /' /5;

186.3. Passerella iliaca. Fox Stharrow. 6.90 10.80 tad. Viniz, 315; tail, 2.60; culmeri,49; gafe, 37; tasus, 95 ; middle to 63, its elaw, 28 .
1,864 WATE.

Melospiza melodiá. Song Sharror.6.25 8:70 ì ad. The bollowins Aprecies wre seen to-day for the first thine, this Jear:

Dendrorea halmamm. Vellow Red-hall Warbles. of number were oeen whon the Conetitition Mneadous' Sreapentrig the burnt Shaces. Nill Oeborn shot thro at a thot, amougit the burnt hesocts of grass I fowind then about Pell's Pond, after rraching hone. Passerculus savanna. Savannah Rtrarrow. y ill Clobru ahot a vary handeonce one, ou ther Railroad, at Constitutiou Ltand. The rellow thife on its head was unusualle bright.

Ather species seen:-

The Eagles vere seen about the Cove; most of then icmature.

Ire walked dourn the brack jist after servial friqut trains had frasked oveh Ater fridge. sill was avar a head, and surferised sue by qivin at a Onerganser (Merque merqanes if) Prat hose from beneath the bridge, while he was paesing over it. This bird suest have bein in the Lame flaee while the traine wre hatsing night avgr her head. She got away, mahust by either of his barrels; and she flew will and vigoroushy, showing that she had not Leen previodsle injured.

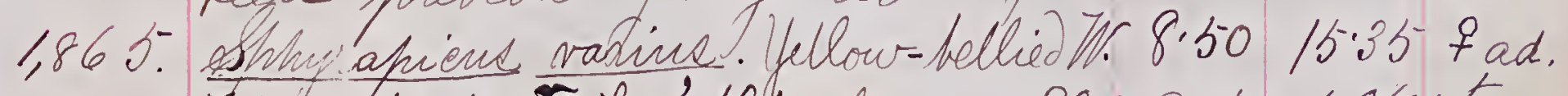

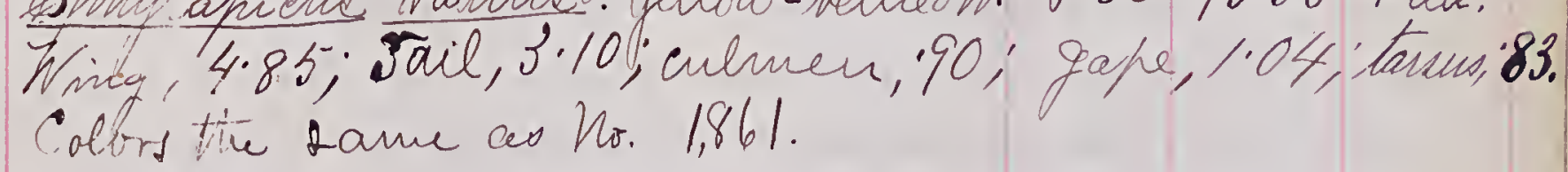

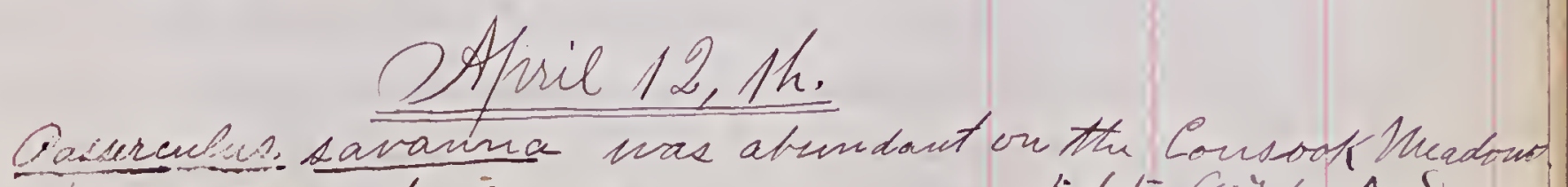
1.866. Sendröea halnarum. $5.6597 \%$ Sad. Aniz, 2.70; tail, 2.33. 
62

63

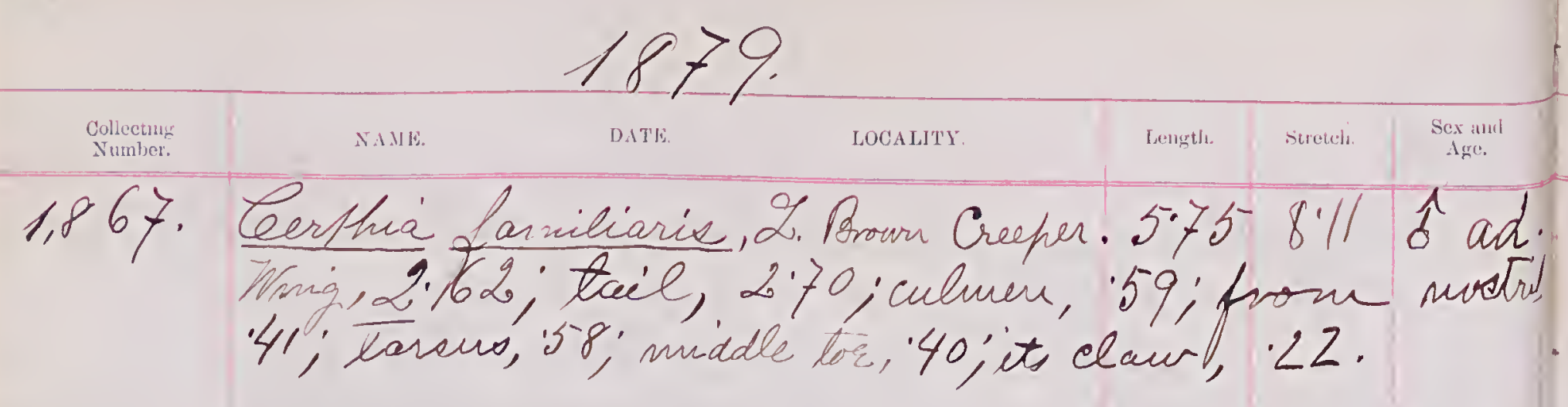

1879

The following 33 shecic were ofserved on Mrarter 18 Atand 191h, 1879, at Brostharen, Fiveoln Connty, Prisissiffi',

By im. Churene Qsbom.

Iurdus miqratorius. Rotin.

Harpostymbluse rufue. Brown Ohracher. Mnimb folyglottus. Mnochrig-Bird. Conmov.

Plioftila càerulea. Shue Prey Hrat-catetur.

Porolinumeromentat numeroue.

Parre atrieapilivi. Clickadec. Common.

Iophophaned bieslor. Dufted Dituruse. Common.

fitra carolinencie. Thite-helied It whateh.

Sitta fusilla. Brown-headed In thateh.

Common. Af fenale shot contaried a sonewhat depelofed ormen.

Dendrorea coronata. Yollow-rumped Narbles. Lanir ludovieianus, Fo ggerhead thrike.

Progne subie. Prirple martin.

Paserculue Lavanna. Savannate Sharrow

Common.

Proceter gramineus, Bay-winged Lfarrow. Melospuza palustris. Luzup Shanrow.

sclospiza melodia. Song Sharrow.

jonotrictia albiollie. White-crowned fharrow. Viry common

Juneo hyentalis. Luow hird.

Coturniculut henslour. Ansours Bunting.

Cormon; sxecedinigly eny our difficult to

frocure. At hair wre freserved.

Pifilo erythrofnthalums. Cheirik. Connmov Surnellar nagna. Ine a dow-lark.

Seolecofleagus ferrugueios. Rusty 务aekle.
Coorme americanus. lerow.

Cyanurre cristatur. Blue fay.

Preis pubescene. Dourvy Hroodpeckes.

Prick foraalic. Red-cockaded Mrodpecker.

Cinturus carolmis. Red-belied Frodpecter.

Colaptes anratus. Yellow-ahafted Flecier

Haleo sparverius. Arasrow Hawk.

Znite munerone; tho specinems eslected.

Denaedura carolinensis. Carohia Oose.

Ertyx virginianus. Inail, Bot Hhite. Connon.

Bonasa nubllus. Ruffed House.

Ceathartes aura. furrey Bu

CAdril 13 th. Atsmy.

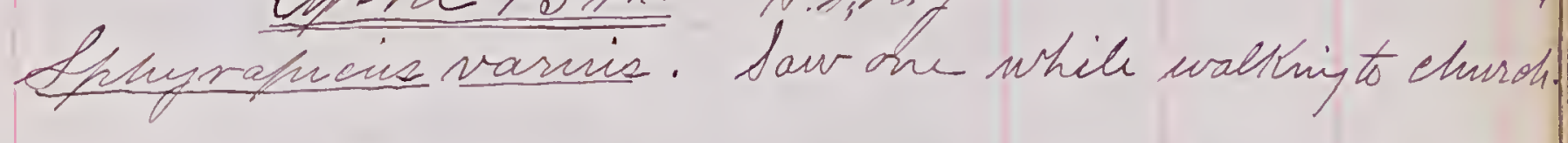

Aprie 15th. Nthy.

Buter borealis. Leviral abserved.

Cevlaptes ansatas. Now conmon for the furit.

$1,868:$

Cpril 16.the Hismy.

$8.58 / 5.45,3 . \%$

Winig, 4.68; tail, 3.20; culmen, 94; gape, 1.04; tasen, 80. anallows. At minber of Livallows Llew over the woods; fut 9 dic not get a yood piru of them, and 2o could Not tell the spicies. Che that' I sav afterward, was, without doubts th Petrochelidon hnifsons. Clift Lualow. Anstseen Qwe. Callinin in the everimet to enquine abollt the health of mur. Chas. S Intith, I was rugaged the servant came, in Some excilenent, to tell of an Cur that she had seen in the garden. the all refrared to the litetuen, whent, to

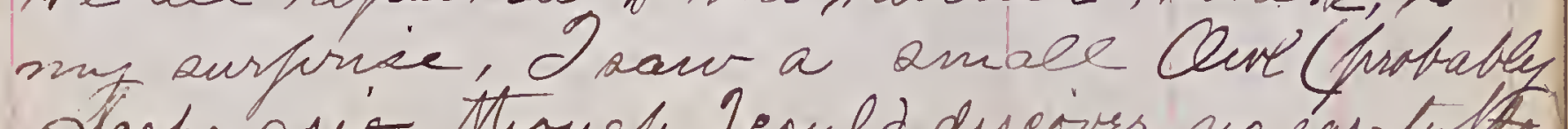

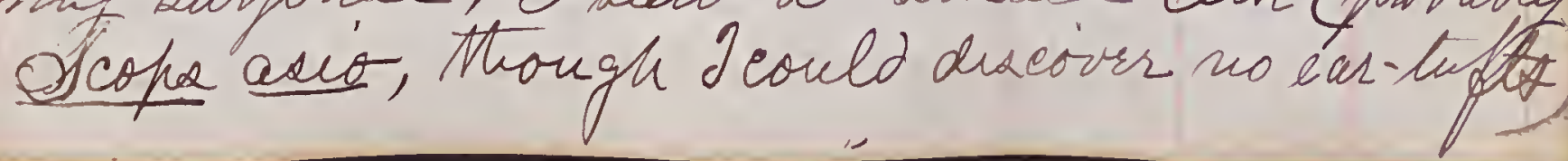


which oupposed miyht be Hyctale acadica; it sat upon a fapomica-buth close to the urindow, where it was flarily visuble in th torlicht. I ran home after huy gun, but, befors 2 got back, another Clwl had. Cesme ufon the seene, and they had flown away togithes.? hunker about the grabe-y ard anto varions plaees in vain; but met Miss Yheeler, who told me that they had"been two erols about their nouse for sevoral evemige frast."

Sat up with Franditather, who is ill. If began to rain about 2 delock, and has continted all day. Blackbirde are about thic house.

\section{Afuril 18 the Nime.}

Rained havd all might; Wind north, and cold. Inrued into know this noming. The mow is deef on the nountanis. Hound coveres, hera, witt slushy snow, thail. Jhe Chiffues and stield Srarrobs seem unhapfic; but the elong etparrows are singing bravely. I minber of Pay-uringed thassow are about the housel. A flock of Lix (6) Sions wise a gim; found them ni another freact, Shot onle bentale.

Mrthat has haphereed to the Lurallows? Ehordeiles virginianus. Nighthawk. first seen. one flepric over the garden; th funt peen

\section{April 19. Astruy.}

turdes pallaxi. Hermit intrush. The one Eallinago wheown. Milson's finiph.
The ground is covered with enow in most flaces; yet the frotted Sandpipere, Ifringoides macularius, where throd (3) wrte seen at once, besides anotter suigle one.

I shat a Mnutirat, whose Keleton I will preserve. Passerculus Lavamn. Only saw the one shot. Fild Pegeon, Pctopistes mighatoria. The remainin fivir Pegeons wre seen this morminf buttieef

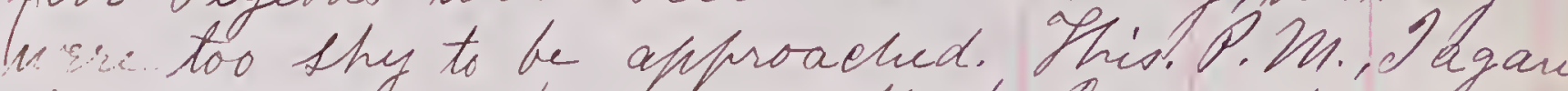
sound them, but so shy that I only froversed onc, un ald male, at long vange, after

they had taken to fleitht.

Ce-1se alejoy. An olde male shot at Edes Lake. Firather. Lained hard all miglet; moved a this suoruning; wira blownig hacd from

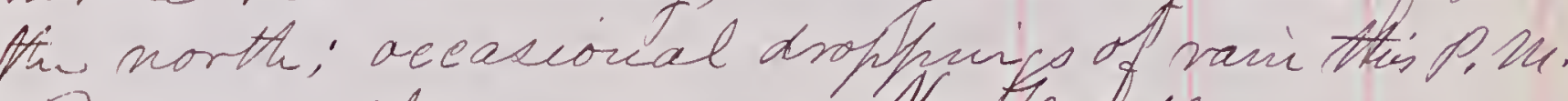
Pirds quite numerous, No Tediblers, seen;

Just recevid the following Osds fone Atrusher - Eremophila alpestris, ["Var?"]

2. Passerculus Lavanna, [alaudinus"].

3. Melospiza melodia, ["fallax."]

the above spes. wrer collected at Hont hlamath. Cregon, and sent to Henshaw to determu vars.

Corrut americanue, Audubon.

Found a Crow's nestrir a fince -tree (P. Niqida), on Cousood Leland. Joo windy to chint to it. $1,86 \%$ Ectopistes migratoria. Wild Pizeon! 16.5524 .75 - 3 ut. Fving, 8.00; tail, 7.75; culven, 69; gape, 1.06; tarsius, 1.13; middle tor, 1.18; claw, .38.

Znis, bright carmine; bill, black; legst beet, rivo. 1,870. Sallinago wilsoni. Nilaon's Smipe. 10.5017.00 10 ad. middle tor, 1.18; its claw. 28.' Mis, hagel. Leg." $>$ feet, greanieh. 
Collecting
Number.

NAME.

DATE.

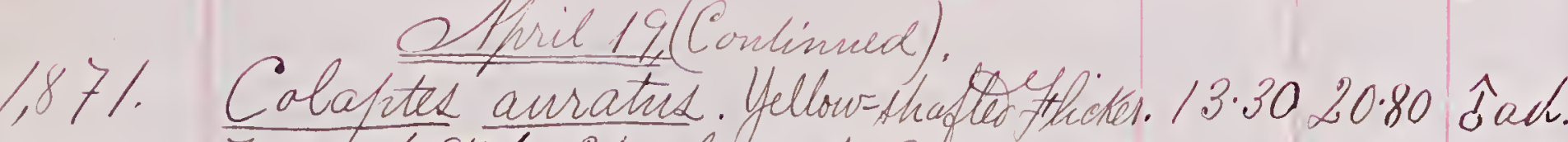
Innig, 6.25; tail, 4.96; culmen, 1.47, gape, 1.65; tarsus, 112. Dill, blue-black; legs and feet, lead-color.

1,872. Dasserchlest tavanna. Savannuth. 5:50 9.25. 今ad. Wring, 2.67; tail, 2.03; culven, 39; gope, 47; tarous, 80 .

1.873. Jurdus hallasi. Hermit Thush.—- Sal.

1873 a Cergle aleyou, Melted Kingfisher. 13.3522.00 Sad.

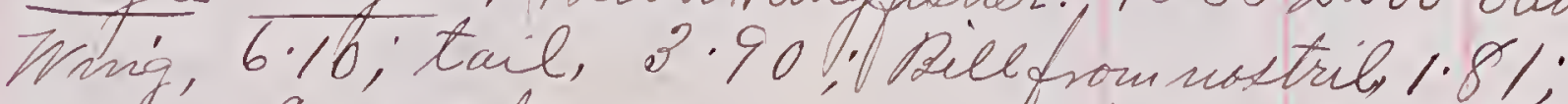
gafe, 2.92 ; tarsus, '41; nudedle tor, 5.8. its claw, 40. (Wot preserved). Hirindo horreomm. Parn suallow. Finit seen.

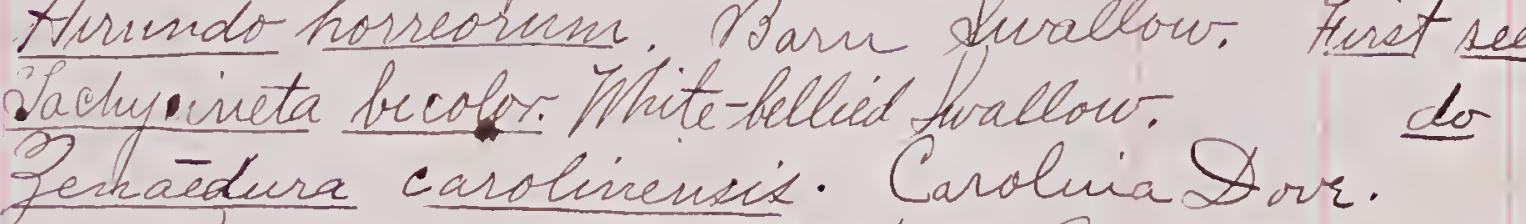
Lite numerons about the Constitition Marehes.

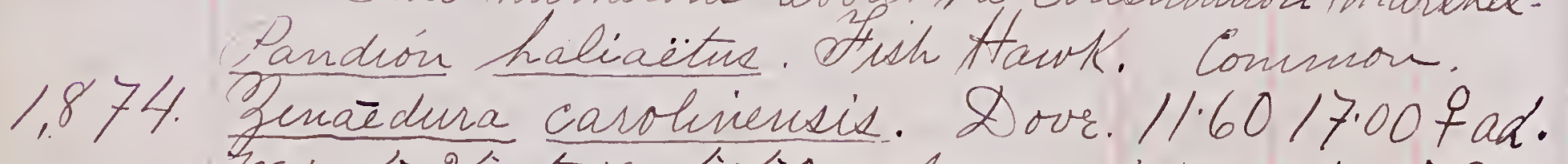
Mrnig, 5.25; tail, 5.50; culneu, 30; ga/c, 72; tarsux, 75 ; middle tor, 72 ; its clanf, 1/8. Sis, hazel; bill, black; feet, red.

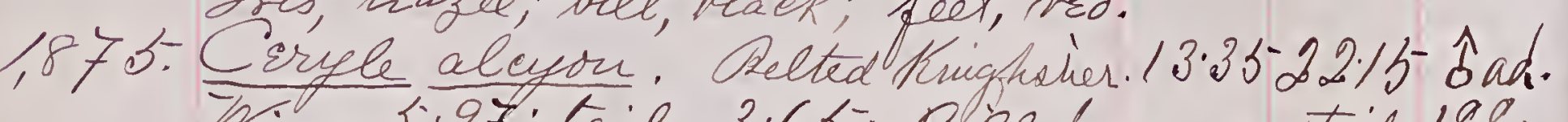
Wing, 5.97; tail, 3.65; Bill from mostril, 1.88:

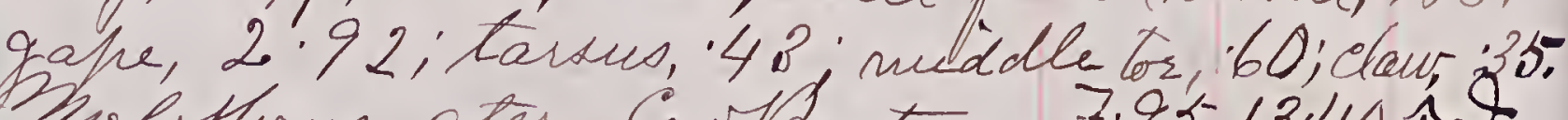

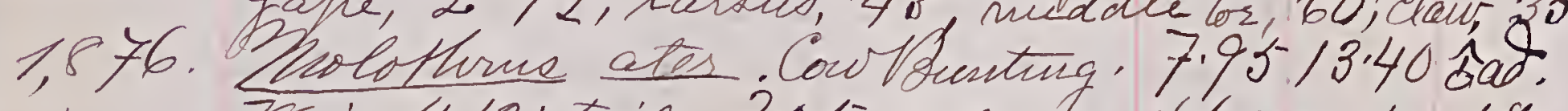
Yring, 4.12; tail, 3.05; culum, '66; gafe, 68; tarkus, 1.00; middle tor, '72; chaw;. 25.

$$
\text { Qfhrie 2s. }
$$

Ionotrietia alvieollis. If hitc-theroated Dharrow: the pint anvivals mare seen to-day, kry lale:
1879

NaML.

\section{Athil 25 Tth.}

a saw the first mest on the 21 st. It was sitrated jist above the door, ni the Luard Atouse, at the Louth Sate, West Point. Yhe harent was sitting upou it.

$$
\text { Shave seen obtur neste sinee, Atat }
$$

Are also seeminigh frishod. Queseen Buterpensylvanicus. Proad-uniged H awK.

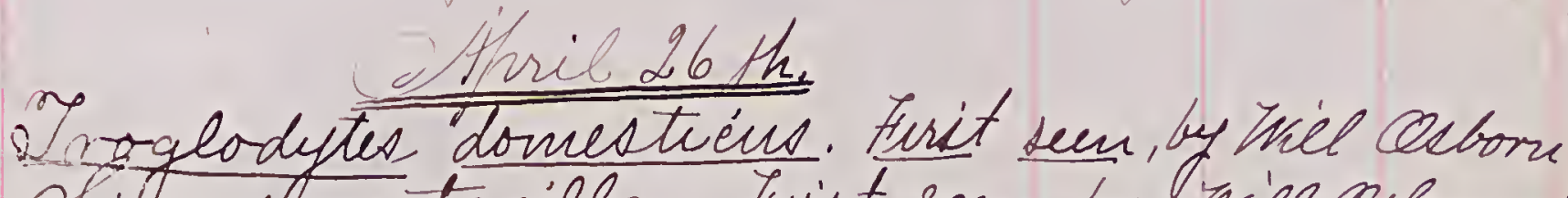
B idrus motacilla. Firit seen, by vill Cubornat rarrisons. None seen on the pide of the imiotilta hraria. Hirt seen, at tighland fallo.

\section{Otril 2 Fth.}

feirus motacilla. been at Aighland Halls. Minne carolinensiv. Firit seen.

Harforhynchuo rufus. Firdt seen.

Pifilo Erythrophthaluys. First seen

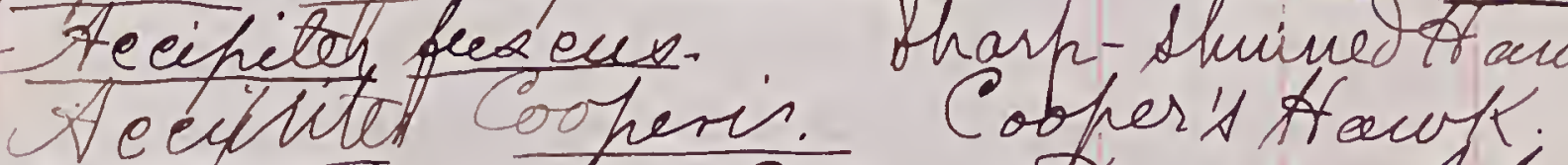

Anas obseursto. Dustly Duek. Af pain are staying at the Shopilen Poud, and will frobably breed there.

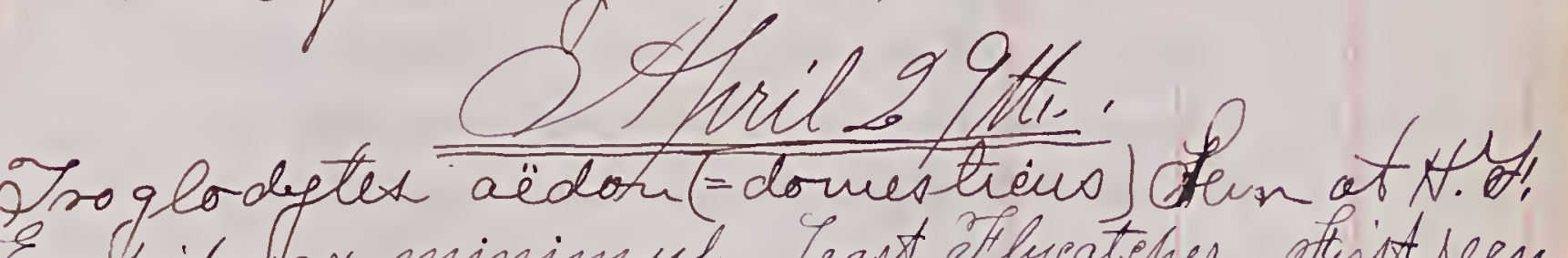
Enspidortax minimul. Least Ptlyeateher. Ntist seen.

$$
\text { Blay } 2 \text { ad. }
$$

Dindrozea coronata. Yellow-sumped VTarbler. Firit seen enice lad antumen, Though Z have watehed for them since my return from thew the 
Sollectum
Numbler

Setophaga rutaieila. Reditart. Stint seen. Anidus mustelinus. Woot Chush. Irist seen. Dinur anrocapilms. Aven Sird, thist seen. Donara umbellus. Putfed house.

Buteo pinnsylvameeds. Proad-uringed Hawk.

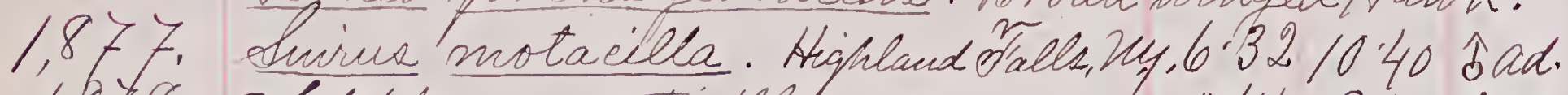
1,878. Eletohnaga ruticilld.

1,879. Mnistita variá.

1,880 . Dendrorea coronata.

3.458 .10 全ad.

do $5.458 .95 \hat{b a d}$.

do 5.758 .95 gad.

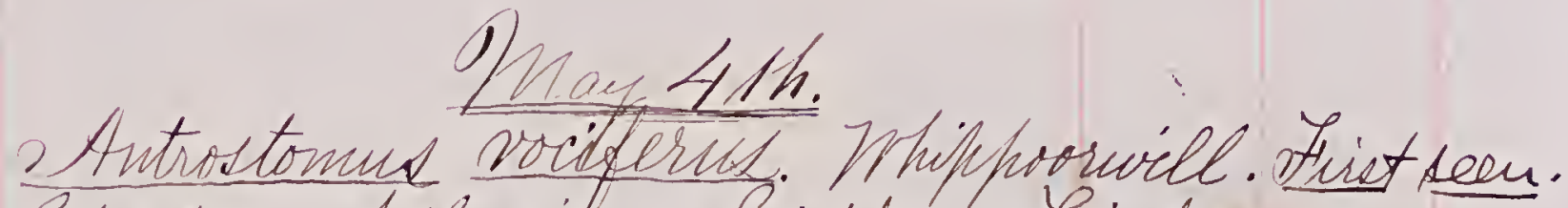
Chätura pelagida. Sirit. Hirtseen.

Nhay G the

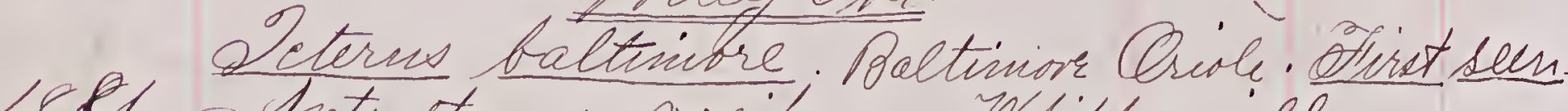

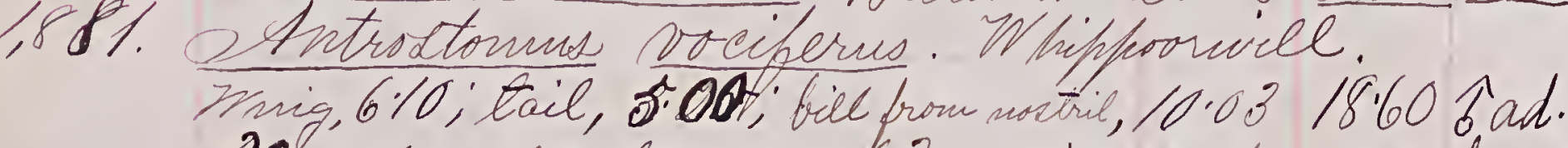
30 , gafe, 1.28; tarsus, 63; middle to , 65, claw, 23.

\section{Dhar Fth.}

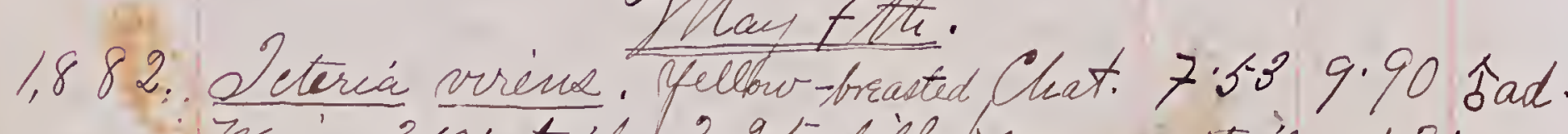
Fring, 3\%; tail, 3.25; bill trom siodtril, 43; gapo, 77; tarrus, 100; middle tor, 65; clan, 27.

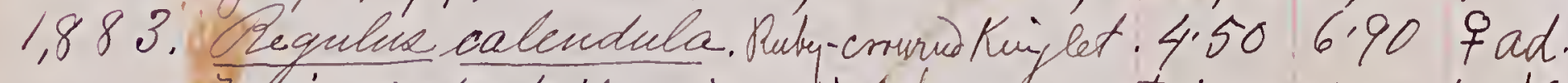
Tring, 2.15; tail, 1.70; bill from nostril, '25; a ahe, 48; tarsus, 73 ; middle tor, 36; claw, 16.

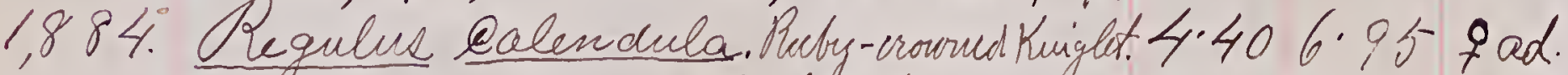
7 sing. 212: tail, 1.65; bell from notrie, 25, gape, 50; Tarans, 75; middle Tor, '37; Claw, 16 .

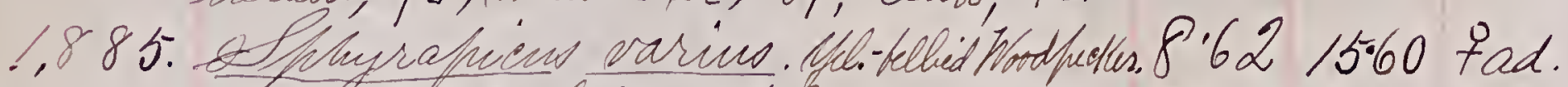
Dinif, 4.92; tail, 3.43; culinen, 92; gape, 1.06; tarsug V8.

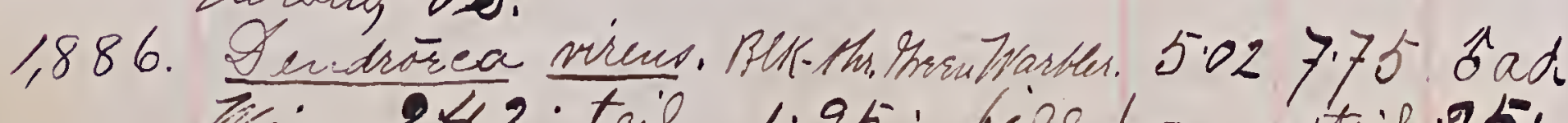
Fing, 242; tail, 1.95; biel from natril, 25; taraco, '6?'

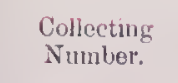

1,887

1879

1,889

Misotilta varia.

Inims auro-cafulma

H.2, ney, 5.38 8.65 余. tarsue, 9.9

1890. Paster domestiéns A. Tring, 2.90; tail. 2.40; culmen, 58; gape, 164; tar - Anv, .77; middle tor, 63; it Claw. 21.

1,891. Carpodacus purpurens M.Mn 6.20 10:30 Sad, Andus miqratorius do $9.75-1560$ fad. Bonasa uxpellux do 17.0023 .35 fad. Dní, 6.55: tail, 540; bill from nostril, 48; galpe, 1.05; tossus, 1.75; middel tor, 1.40; Claw, '92. Hilmithophaga ruficafrilla. Snist seen.

Dendrorca virens. Firit seen.

Dendrorea henneyhanica. Strist seen

Cteria vere

Oplay 8tht Hony.

Ailminthophaga sufie afilla.

Denitherus vernivorus. Anist seen.

Dothlyfie triehar. "Sirst seen.

Parula amerveance. Mirit teen.

Direo solitarius: Divist keen

Trieo yilves. Firiet teen.

Dranca rubra. Firit secm

Munco hijencelis. Ane oberwed.

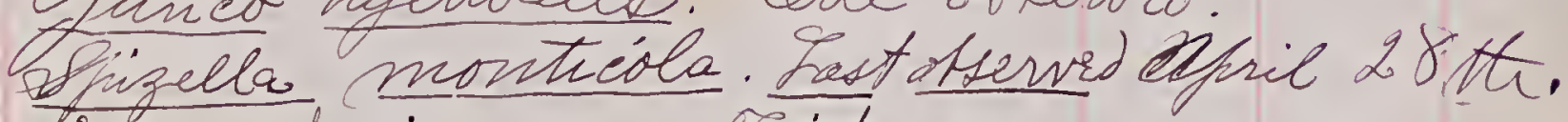
scerus spurine. Ptist seen.

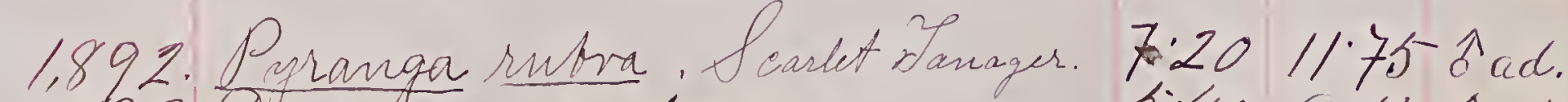

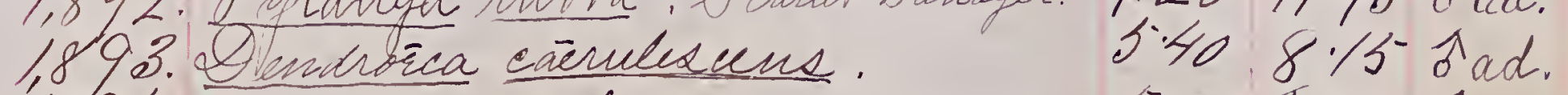
1,994. Duzdrozea virens. 5.208 .00 bad. 1,895. Stetophage mitieilla. Rettut. 54407.855 ad. 
70

71

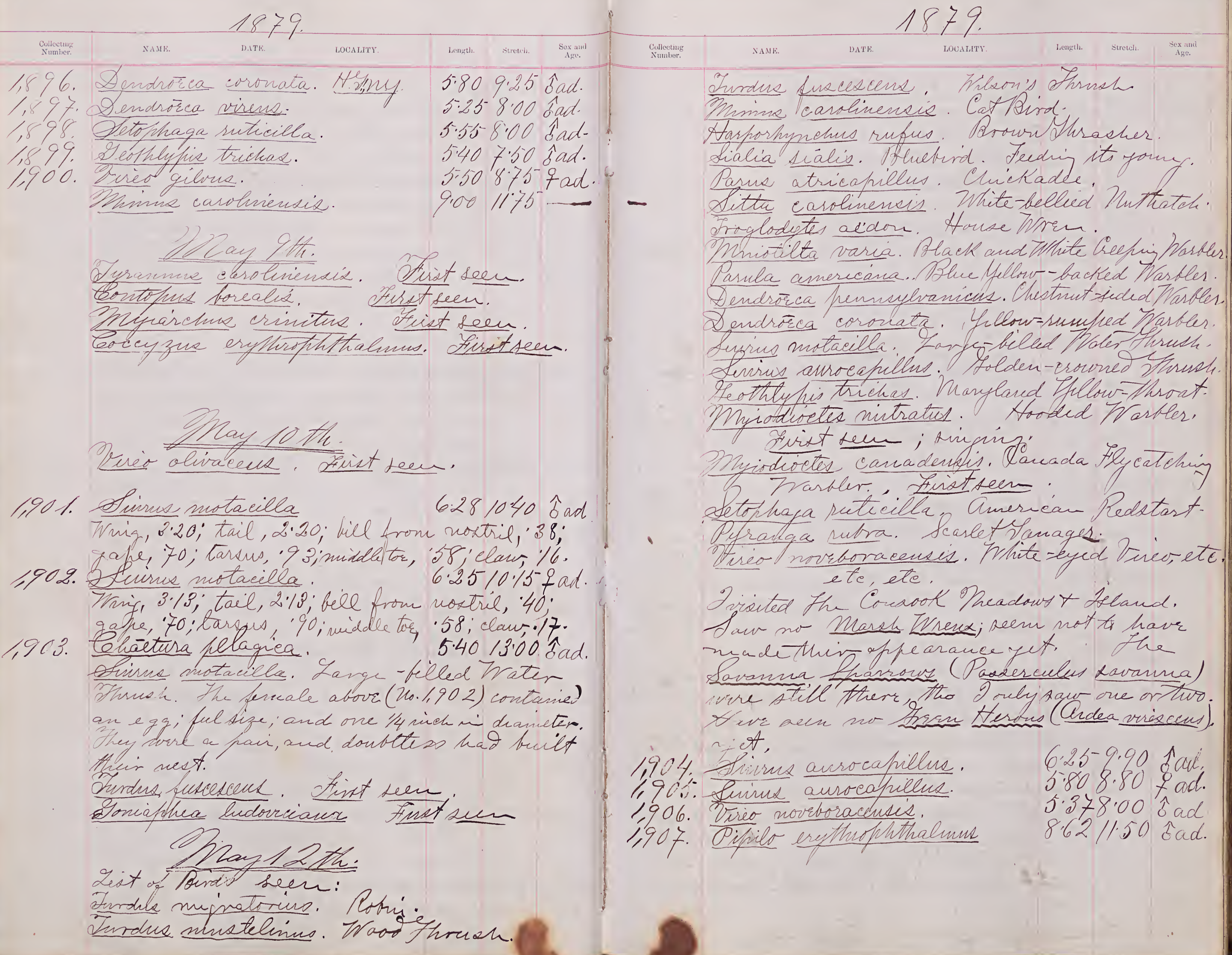


72

73

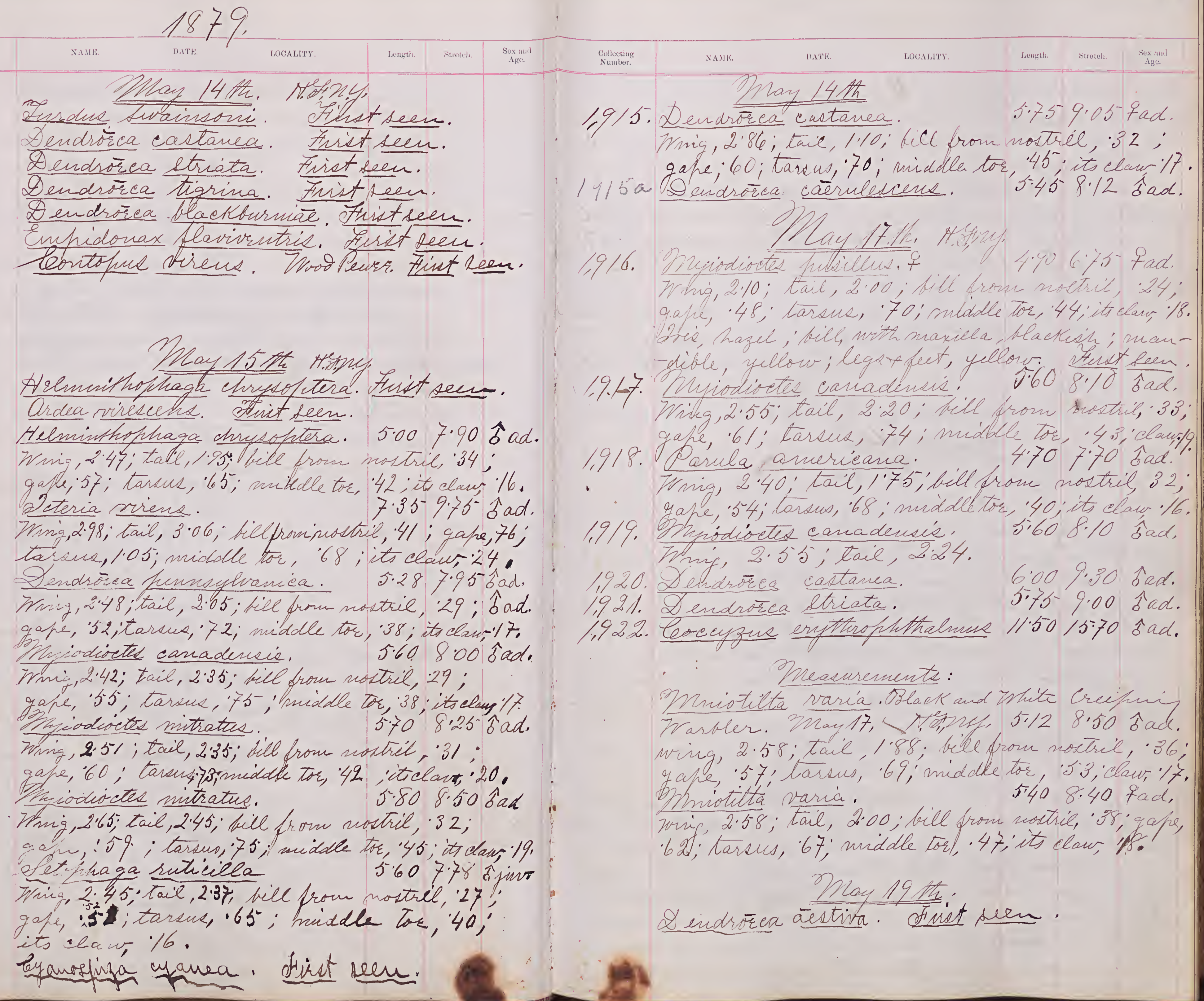


74

75

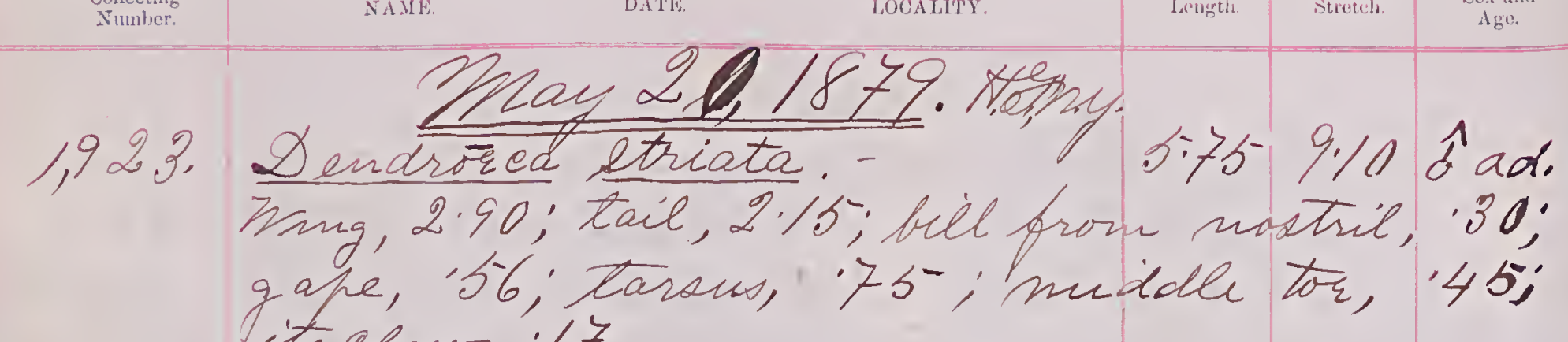

1,924. Qcterns spurius. $\quad 71401060 \mathrm{8aa}$

1925: Hepranmis, earolinusis 8.501460 9ad.

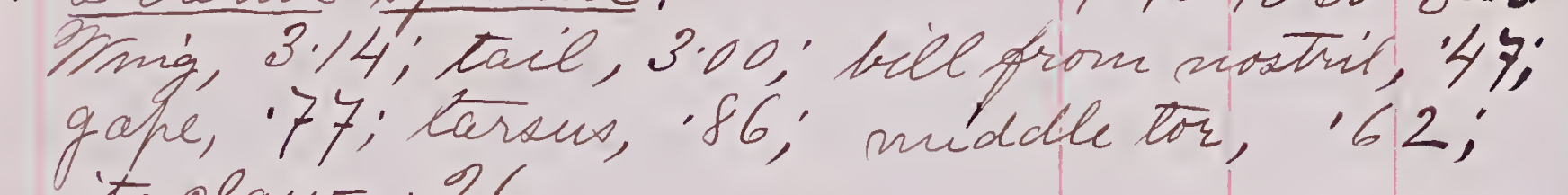

1879

$1875^{\circ}$ An thrusting niy hand down inter The hole, Ifound a shigh e burd, and an abdled egg, whe hi copured and preserved. The turdseed Aur bills bont the place, but Idid not get a distivet vinu of them; their cry was very the Hrace in the day - thrie and get the birds.

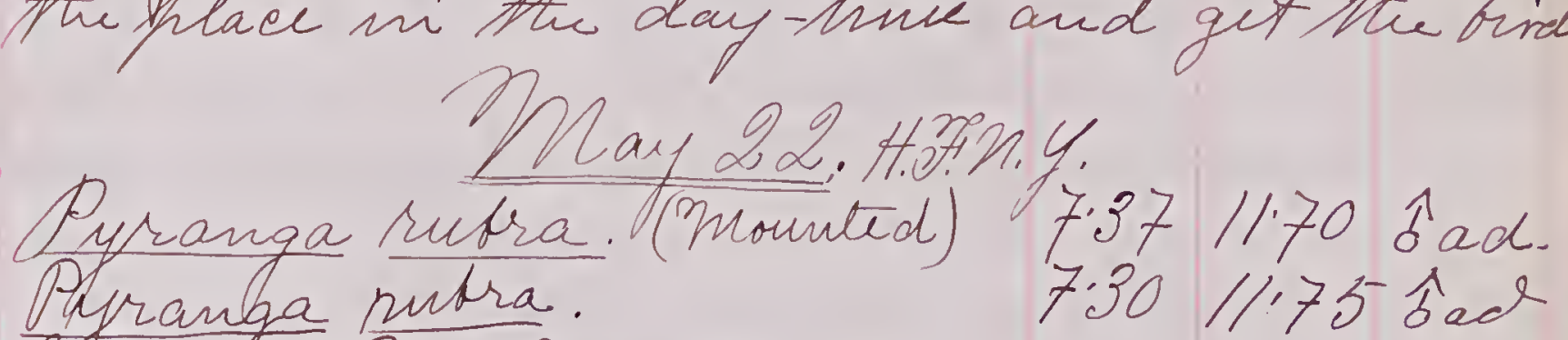
its claw, 30 .

1926. Dendrorca Striata. . 570 9.10 \$ad. wing, 2.90; tail, 2.00; bill from mostil, 31; gafe, 59; tarsu, 76; midble tor, 45,

1,927. Dendrorea maculosa. billf 5i/2 7.55 sad.

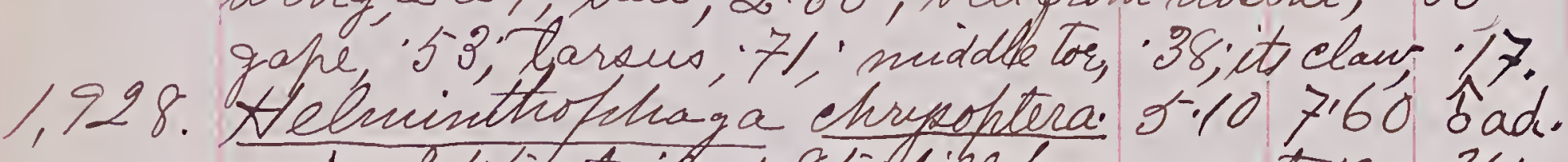
wrig, 2.45; tail, 1.85, bill from noctril, '36;

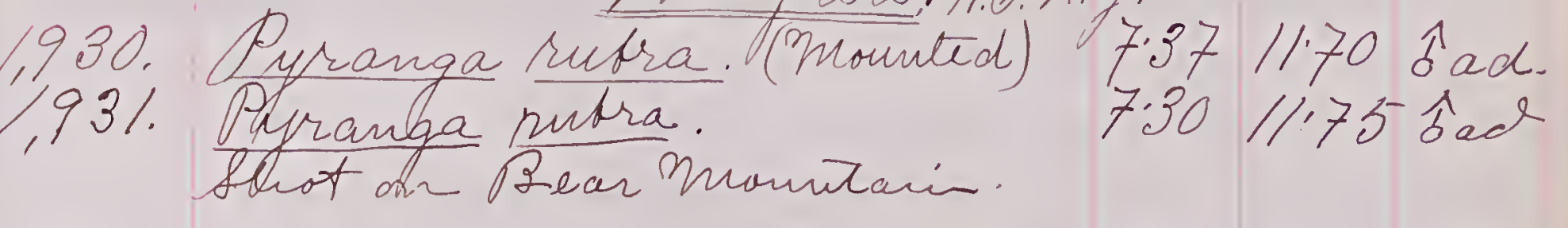
Io-day I visited the Cwl's nest. Icafitured the female in her hest, along with the mang bird. After a search, I saw the tree, in the midst of a cluntef branchlets; his ears wre very ctmeficuons, and his weet exterded, as the endeavret to get a better virw of me. Both of the rarente vere red; He young graul, like those? 3,56759 ad.

1932. Seope asio (Linne'). Derecen Clul (Red). Fad. Leveral ofecisicenos of Xt. Chrypotera wre Holkin Through Patterllei's flace mi the ersuigh, a fird feurfirom discovired that it was an Cul. The nest was discovrred in the tof of a decaced tree, groving beside the fonb: the sarne

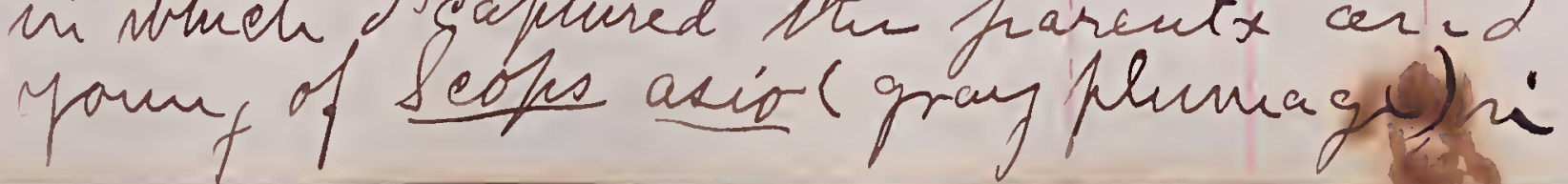
Wring, 6.45; tail, 3.10; culmen,65; 101525225 gafe, 1.00; tarsur(about), 1160;

middle tor, 180; ite claw, 48. Hri, yellow. 1933. Seops asio (Trive') red. 9.25.23.50 bad. Wring, 6.50; tail, 3.00; qafe, ,95; culver, '60, 1,934. Serps asir (2ivne')

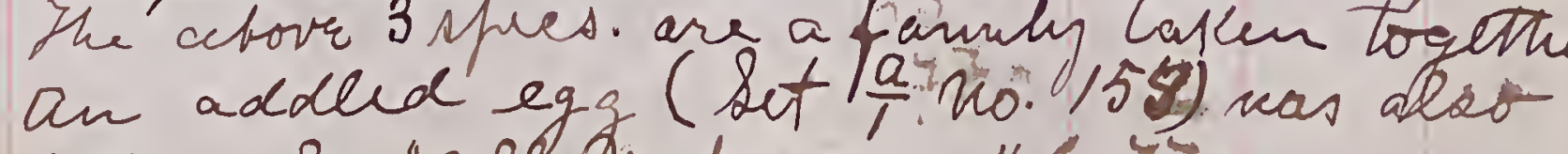

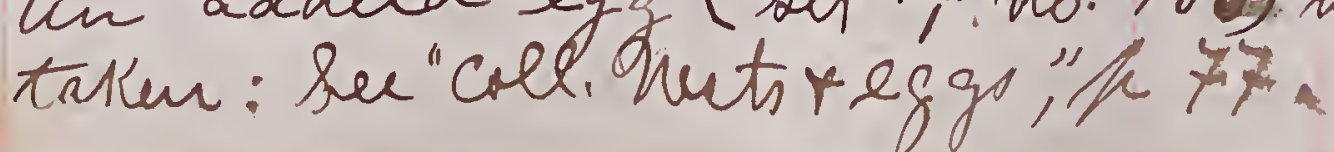



Tring, 3.06:; tail, 2.45; biel from nostril, '41; gafe, 82; itarsus, 64; middletor, 40 it toclaw, 82 .

\subsection{H.M. H.}

To-day, ofter a long search, Didicovered a nest of Sirrus motacilla, Which contanied fir nearly feedged young tirde. tendes followic migrants wre seen:-

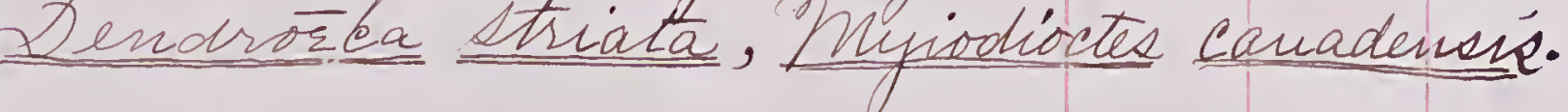

\section{May 30 Ath. Min}

Prisited the Rookery of Right Atrone, on Consti. - Tutroí Laland, vin confacuy with Lesit. Msitich and Mns. Phett. Pre stophed at the lower falls, on our way wh; There we wre ale somewhat starttede of tow accidental diseharge of a guri, braded with large shot, the contriets of which hassed within a bur feet of san Lelt criresfondingly fookich, hut Thantfful that it hesulted so hormlessidy. Lunt Mrithich abserved, quitty, that 1 "Litutinng never strikes Tur'es; while Mm. netr fhelanthrofieally remarked that a "miss is as jood as a mile".

the Herous before ne entered the swant and wre glad to find that wr wre not yoing to be dicapfrointed. As wr entered a litth way, wr btarded the pirstitheron from its niet quite Close ta th. Railvoad, and soon there wre numbare of this flying about over the swank. Fheir

numbers have gaclef sinereased winee last season. D succeed un Rilling three adult firds out of a number of snap shote on the winj; and Kintenait Waithich maye a beartiflel wing sot, at very long range, to that we secured four fine opecimerk. Ope arriord too leate to get any fresh eggh, Though Daw a hid Alifing with a ohek ni its biel. Firntenant Ift. chred to a nest which contanied fir egas that were about to be halched: the llaving brought on eggdown for trial. chimed ufr and examsied teronecte, one f which contamied firr, and the other four bogs. The shells of the former watre abready cracked, while an egg frow the lather neat was found on thril to contain a wrll devrlofed Rubryo. Thelle wre found under onmerous neste,

- frovoling that the egge ware alveady hal thed aud the young tirds were heard erying in some nett. Y/ac wounded firde were sme to lodge mi some tree = tof, when It was infrozithe to dislodge Btum. After a great deal of effort and sixpping of urnigo, its ferch; Then, wher the bree was shaken. rigoronsly, he would Cose his hold and Spple over, but irivariably secovered his hold by ineaus of his bill. Witth tris strong feet, auld a bill that could be hooked wpon a tranch, it was out of the questroi to dislodge a bird wihout clinoming An tree, and the the fird war alsopyt urtain to excape into a reightorio. foll. The tird should alvaya be eanght by its bill, for thy always atrite foricel 


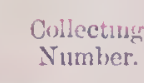

with that fowrifel organ, thus endangirin anes eyes. Cur the ground they ofitur

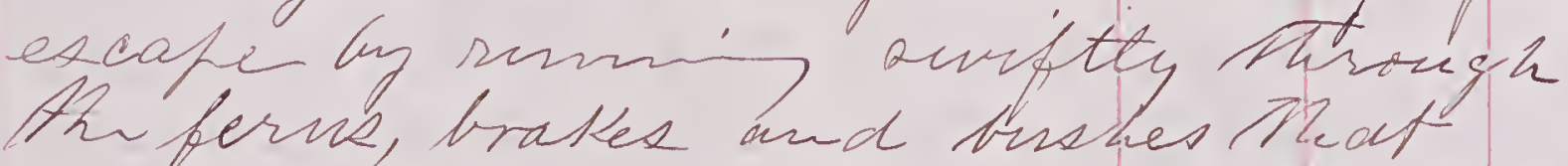
grow so atundartity

1,936. DLyctiardea grieea, var naevia (Boddart). intmi, 12.50; tail, 5.10 27.504750 is ad. Dill(euluen), 3.04; gape, 4.25; tarsis, 3.40; middle tor, 2.96; its claw, .57. Aris, carmic. Bill, blue-black, exceft cxtrine the man- dible, whieh is hom-eotor. Pare shace abut paee, yramich; about eye, blusith. Lega, hale yellour.

1,937. Nyetiardea quicea, van mariva. 28.00 47.50 1. ad. Ting, 12.20; Tail, S.05; culnuen, 3.15; gape, 4:35; tarsus, 3.4to; middle tor_ 2.95 ;ito claw, 35

1938. Nuctiarde griea, nas navia. $25.0044 .25 \mathrm{~T}$ ad. iving, 12.10; tail, 4.70; culven, 3.03; laves, 3.20; zape,4.12; middle tor, 2.85.; it daw, 54 . 1.93\%. 1lyetiardea qriea, var. uatria. 27.1047 .75 is ad. Finis, 12.60; tail, 5:20; culmen, 3.27; gof, 4.40 ; tarsue, 3.46 ; midde tor, 3.12; its claw. :58.

Calors of parta minall the rame ax No 1,936. Thetre are, reecesionally, a few leaet tpots on the tarsi and tore of Dese opeds.

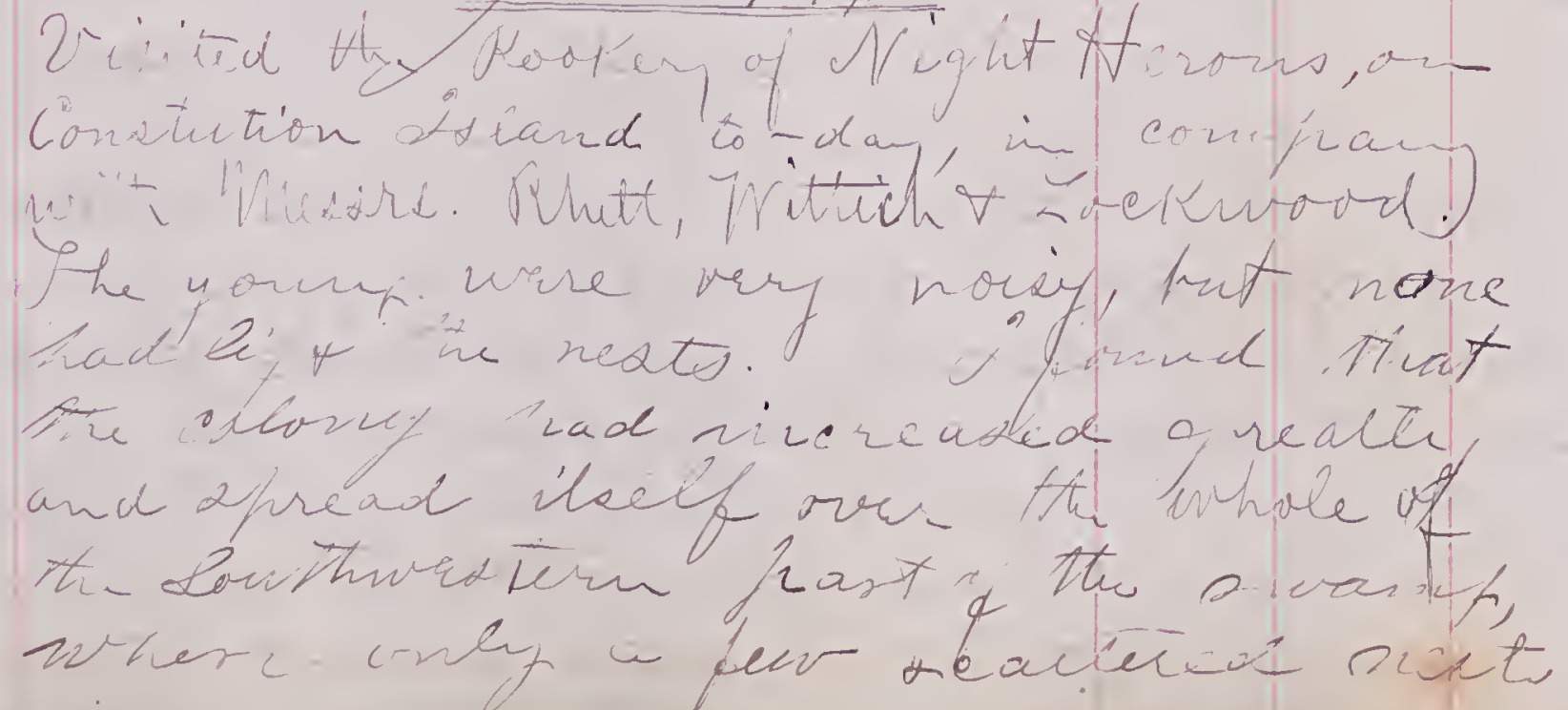

\section{.}
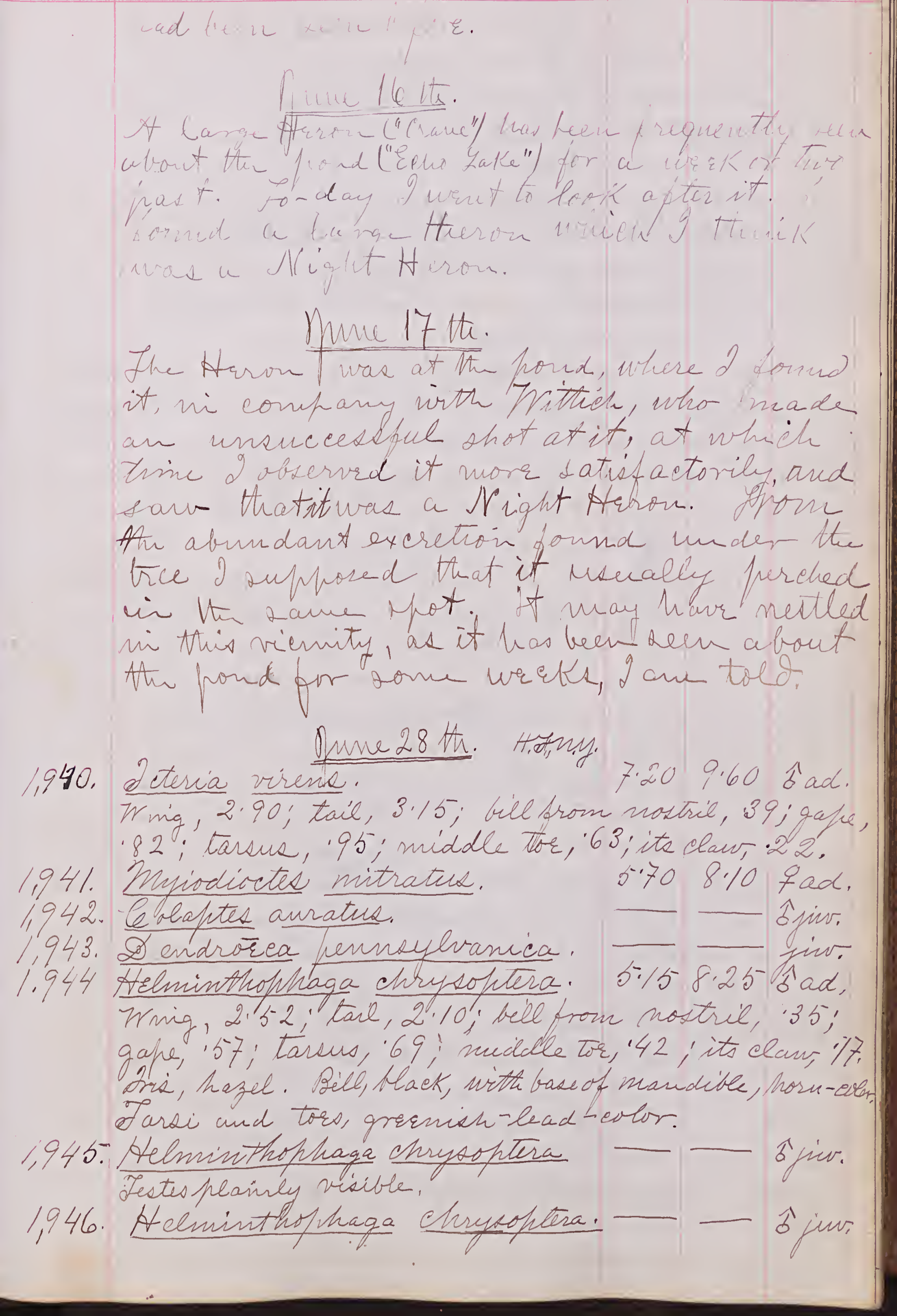


LOUALITY.

Lougth

\section{Lit of Airde 28 th (cen:- \\ Inrdus miaratoris.}

Furdus mistelinis

minus carolinensis.

\# arporhynchus rubus.

Alalia silalis. Incubatrig pecond frood

Froplodestes domestiens. do

" nistilta varia. Zrite munerous.

Cleelminthophaga Chrysoptera.

Stut heard the rote of the joung tirds;

presentty sav an old male, and shot it; corld

hot find the female, but succeeded ni getting

a alood speeinen of a young male. dearbel carlfully of thoroughly, but dould not see the motar. I afterubards heard anotier yourig one, whiè g walched carikully for a halk-hour, holwiia, as it Kent wh aninussant call, that its mobtrer miaht come to bud it. The run was excestively hot and mu hatience at length bearne exhansted; so $?$ Snot the young bre, and came home. If could Fuly nate short fliegts from branch to braneh, ared nust have beus reared in the inmesiate suighbork where of found it. Ito casl, was a monotriout, rasprig beetle-like note, which, Ttol mulike the sirigular neterance of the old bird, brought ite opecies of un thind before Ihad aeen amy of the birds Dendrorea àstriva.

Dendriaca lnemusulvarica. Conmon Lirirre aurieafillos

LOCALITY.

Lengrth. Stretch. I Sex: : sud

Drier ohvacens

Enviarches crinitus.

impidonax (acadicus?) Shot at a Flycateher which Irochilus colubris. Levaral seen.

Nyetiardea arisea nāevia. Night Herono are constantly sen, flying toward the hotheast ni the evanif; frobably veturnivg frou to pond, to the Rofoling on Constetution Lland:

\section{The $29 t i$}

co-day drealled a trie male treminthophaga Chrseotera close Mt to me, when calling the various specils of nestling apceies from the recirity of the artect to Prel's Proind

947. Musiodectes Dine 30 th. 8.10 inad wrig, ; tail, Inis, darkhazel

1948. Firro flavifrous. 6.009 .65 sad. Nmi, 2.90; Evil, 2.08, Gill trom nostril, 35; gape, 71.0 ; tirsus. 76 ; ruiddle tor, 47 ; it claw, 20 .

Note. - Vireo luly 7tta. numbers here this scason. I see or hear it very frequenty, and ni variois localités.

949. Aquatus hotrnicus. $\quad 9.4515 .00$ bad. vmig, 4.53; tail, 3.85; culver, 97; gafe, 1.00; tarsus, 1.14; niddle tor, 80 ; its claw, 33.

1.950. Areminthothaga chrydoptera 4.85 7.30 fad Nmis, 2.21; tail, 185; fill from nostril, 32; gapi, .55. lassus, '66: middletor, 37, its claws. 15. Iris, dark hazel. Bill Gounish-bladk abors; hom. - color at base of mandible. Jarsitrtoro, trmuít - lead-color; ventral surpace of tors, yelonisen. 


\section{D.TR}

\section{Duly 7 th (continued) Het,ins.}

1,951. Halnimhoptraga chrosoltera.

1,952. Falminttiphaja. chrofoptera. This and the precerdin are the

1,953. Prent, pubre (no, 1,9 so o ad).

1.954. Teothlyhis trichas

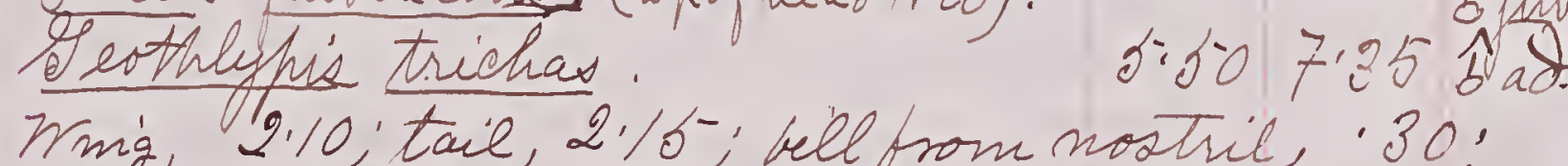
gahe, 's8; tarcus, 80; middle tor, 48 ' it cicu-'.0 goce gray on forshead less restricted than noual. 1,955. Seothlifhis trichas. 5.25 7.95 ca. trmi, 2.15; tail, 2.06; Gillfrom nostril, $32 ; 902,157$; tarsus, 78 ; middle tor, 52; its claw, 20.

$$
\text { Duly 10 th. H. H, }
$$

1,95. Deterus Galtinore: nape, whieh lead me to suppose that it urie a younc s. It froved, on disiection, to be an inmir-takable feinale (q). I shourd the ovary to Louis Zeiega ard lifted out ore of the largeat ora on the ponit of my dealpel.

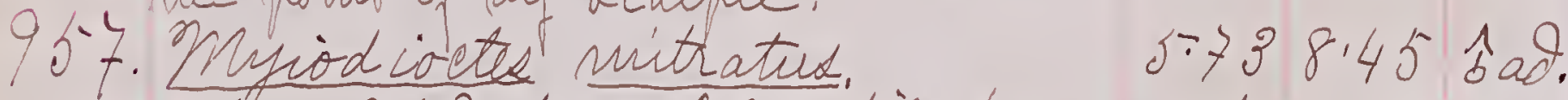
Irng, 2.63; tail, 2.32; bill from noxtrit, 32;

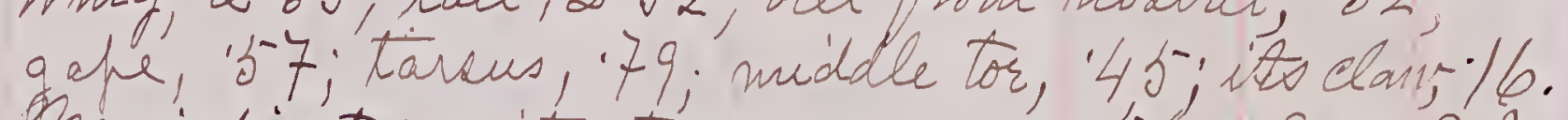
1958. Muidioctes mitratus. 5.60 8.00 9at. Wnig, 2.40; tail 2.40; bill from nostril, 32; c.ape, 57 ; - Felintheme renimorus. - Jaur a male biro (forbably î). ni vrry good hlumage, which wteric) -aint wetallie vite, and cane clorinir, as d 'callez; afterwards of four down thr hill, and began toring a jettr, metalle, trill, at it sat intron the $\mathrm{kn}$ of a dead hink of $a$ Lange tree, mi peani virn.

Arlmitiofhagãe. - Woue were aberved.

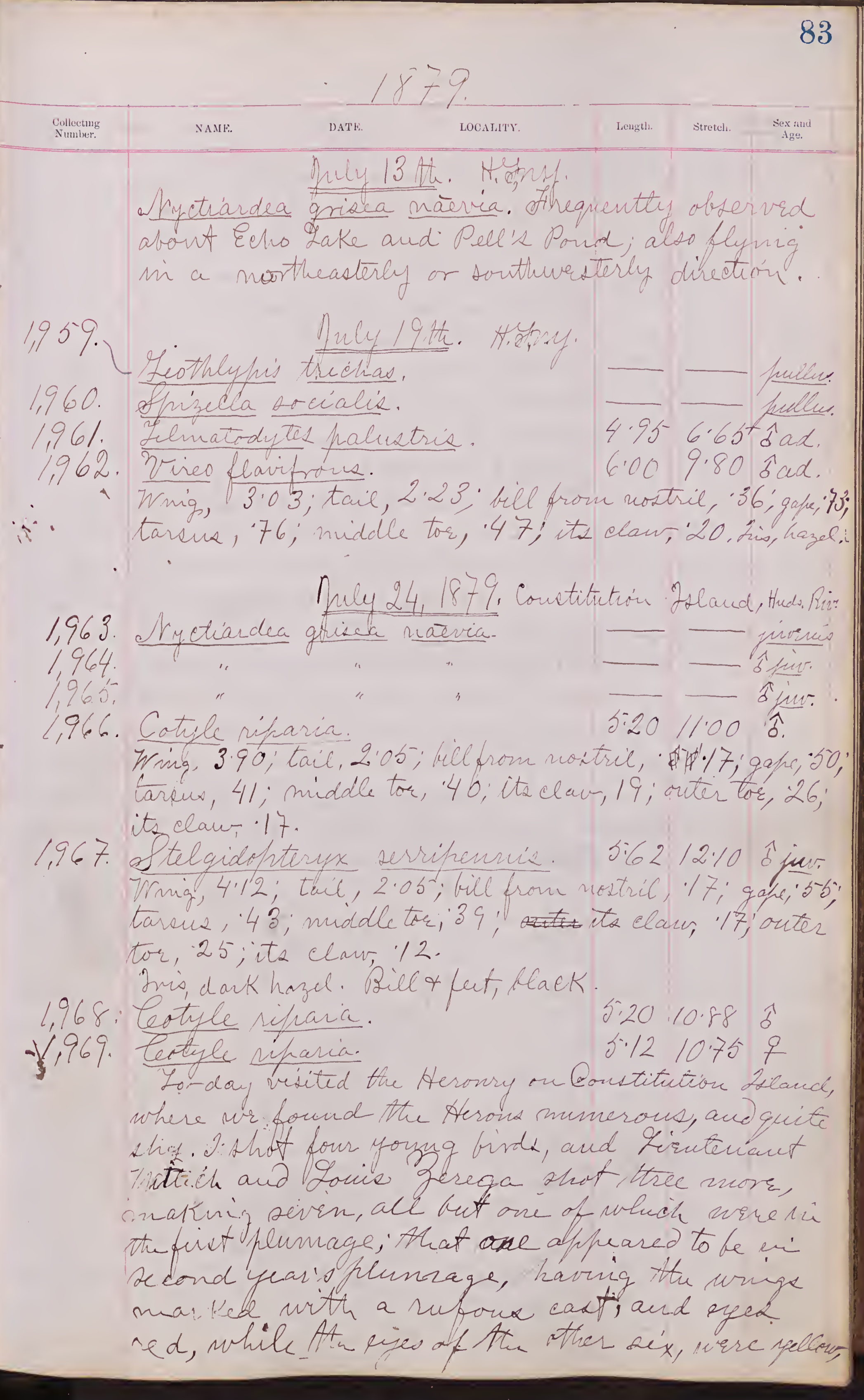


Collecturs
Number. L.OCALITY.

oryellowith-red. Loniz \& myself prepand five speciniens. Lix of the binds nerse cooked, and sesved upat the table; cell of them wrre eater, and pronounecd very yood, though I did not consider it to be much of a delicacy, tho $D$ meareaged nuet fortint with a vern good graee.

The tollowrig Areeies wre seen in the awamp:Helnitterus vermivorus, Vireo novboracensis, ind Mnjiarches crinitus.

Ch the southelastera korit of the Heland the varions Apcies of duallows vire, asis usually the case at this season, collceted ri inmense munbere, I procured speencens of no. 5 shot (Cotyele, Firuedo, Petrochelidon). Levrral Rough-wriged Luallowa (Atelgia- optery serrifunis/ vrre observed, and. one fine offecinien was procured, Diongh the mimanse numbers of the other sfeces (Alirindo, Yachycincta, Stéc o Petrodielidon) made it diffeicult to discern the care shecie in time for a vhot. Fine os suall shot being limited, wr wrre obleged to ecave inthont thoroughly investeg ating this arruy of Suvalle

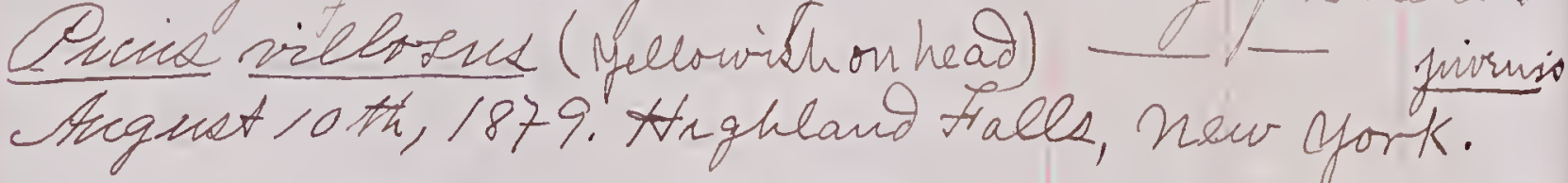

$$
\text { August/2 th. }
$$

Sarrisons, Putñam Connty N.y.
téle rifraria.

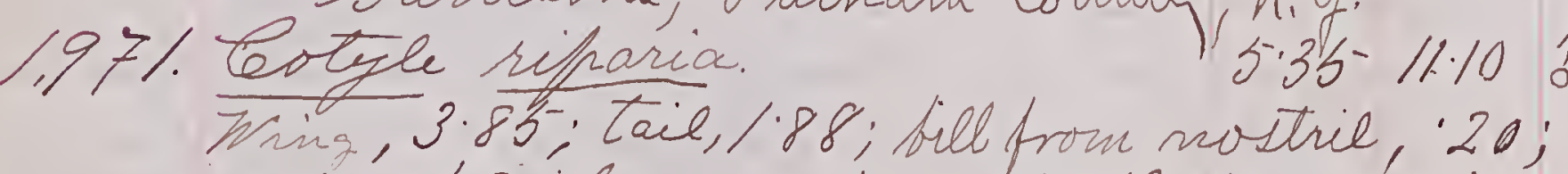
gafe, 48 ; tarus, 45 ; middle toc, 39 ;its claw, 22; outer tor, 27 ; ite claw, : 2 .

1972. Cotzle rifiaria.

1,973 . Avirundo arytrogantra $5.0010 .60 \hat{\text { jim. }}$ 6.9013 .007 ad

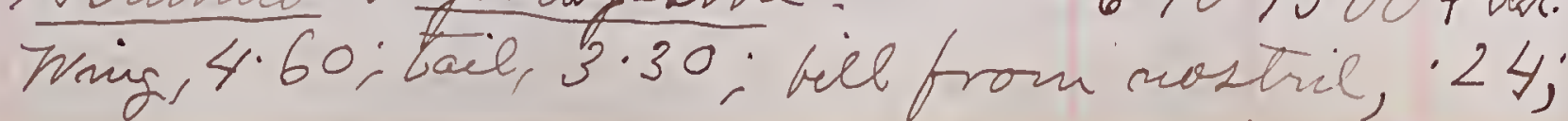

1974. qafu, '57; taraux, 45; middletor, 45; its claw, 22 Ceganosfriza cyanca 5.608 .50 óad. Drani, 2.60; tail, 2.25; culmen, 44; gape, 47; läsur, 65; middle tor, '50; ita claw, 20 .

$$
\text { Aruguat / Sth. }
$$

Lo-dan Lowie Jerega and myself drove down to Stom Point, mi the hhacton. We Law the Yrlite-headed Ea gles about Atrghland Lake, and nothing else in the bird line that was hartecilarly remarkable. Enjoifed the

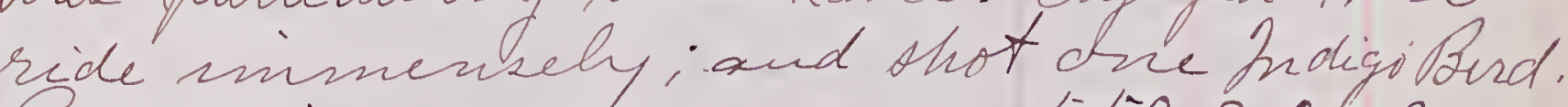
1975 . Teyanosfiza cyanca. 5.50 $8.30 \mathrm{fad}$. Invig, 2.48; toill, 2.05; culmen, $42 ; \mathrm{gafe,} 47$; tareus, 70 ; middle tor, 52 ; its claw, 22 . Shot it on the telegraph

Eapture of a fish Crow (Carvus otifrague ) near Ledonidet, Moumouth Gountry, hum Dersen. me a "Rea Crow", stating that if was allot the day before, in confhainy with many "Land Crows" (puobably C. americamn; but C. cordx also recurs); all wre viry ohy. It proved, on diskection, to te a male biro; and of rimarkably large oic. Its dinenaions are greater than any $J$ can find on record, viz.: length, $17.50 ;$ extent, 34.00; wing, 11. So; tail, 7.10; culven, 1.63; ga/e,1.92, larsue, 1.90; mid 2le torand clan, 1.96; graduatón of tail, is. flomach contaried two whole otrrinew, bebides several fragments of the same."

Lovie A. Jertega, 23 North Vashington Souare, N.Y. City, augut 23,1879.

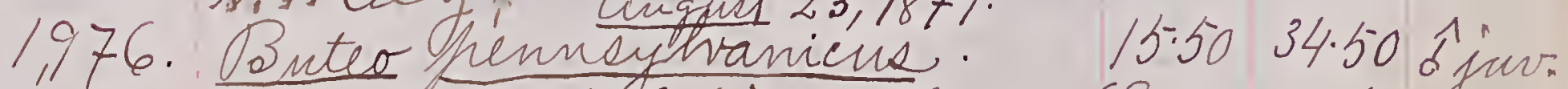
Tring, 10.25; tall, 670; culmen, 68; cere, 45 ; yape,

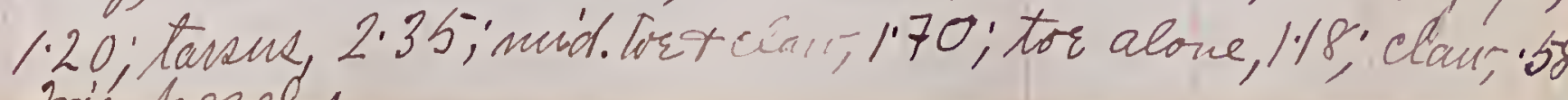




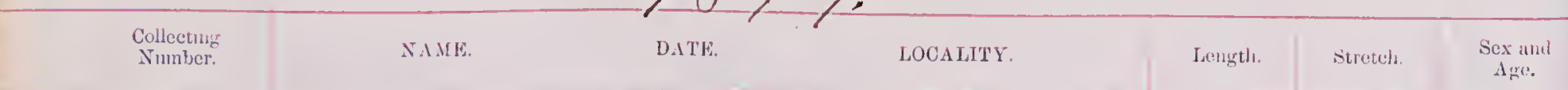

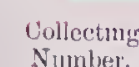

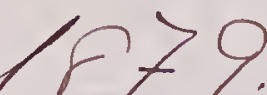

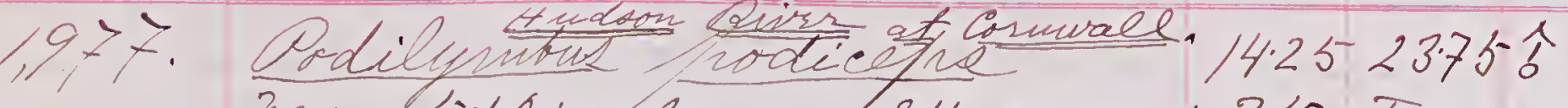

inig, 510; chlouen, .84; gape, 1.35; Tarsus,

1,983. Przana caroliria

Fing, 4.02; tail 2.00; culmen, 78; gafe, .87;

tarans, 1.27; imiddle tor. 1.37; its claw,. 32

Felmatodytes halustrix. Levrral seen in the Consook

\section{Qfeftember 14t if 79 ,}

elaw two Qlive-Rided Hlycatchers (Coutotus Lorralis) sitting on a dead fiue-tree, in Rockland County, Nefiosite Peetrotill. massh Siftember 10 th.

Melanerfes irythroefthalus. A young bird seenon the wild cherry tree, near the house, on the IIth. efialia sialis. Iarge flocks wre sen flizis, on the evaning of the 12 Pt!

\section{BLeftember 6, 1879 .}

Shot sfecinent of the Reaek and. Hrellow Wartler and Deack-throted Blue Warbles (D. D. maculoza

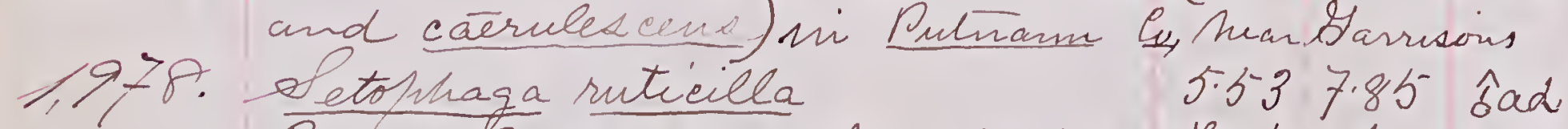
Putram County, N.Y., Near Harieton Hiskis hause

1979. Dendrorea virend. 4.98 .7579 1,980. Porzana carolira. Coubok Heand 9,1214.40 ôj. Hrig, 4.32; tail, 2.25; culven, 89; gefe, 901; tarsus, 1.40; middle tor, $1.45 ;$ ite claw, 31.

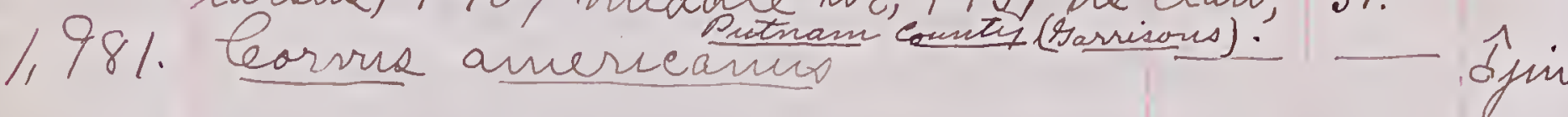

\section{Sepleñber 9}

Crisook Heand, Audsou Riirr, Ir. I The Reed Birds (Dalichonys orygivoruk) wire very aurnerous on the 6tte, when Mundrede were seen by Mies. Ella Wittich and myselt.

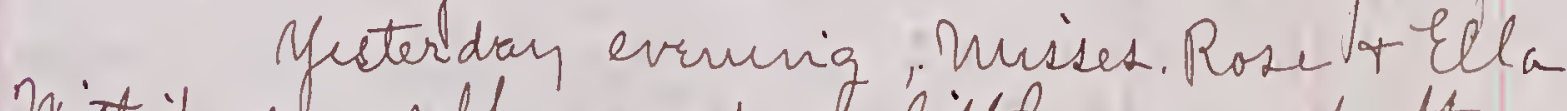
Wittich of myselt rowred a little way ML Mh creek, at high tide, in the evrnin: llarge numbers It Raile flew at aloug tt- creek, or tran Atrough Parzare caroliva smin 4.20itail, 914001450 ijme Tarm, 4.20; tail, 2.12; culwen, 8 8; a afe, 96; larsus, 1.39; middle tor, 1.48; its claw, 34.

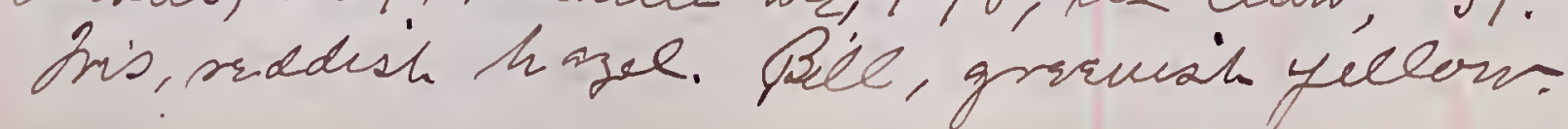

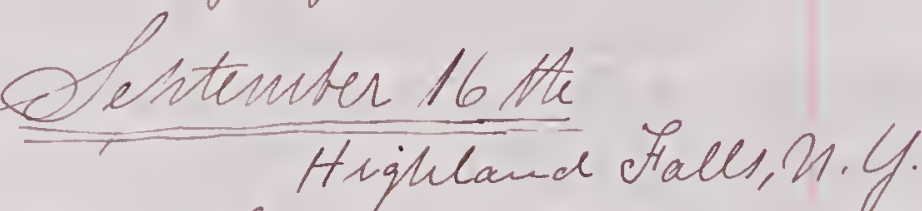

1,984 . Aurdus mustehine

1,986 . Dendrorea eaerulescens

$1,987$. Chaetura nelagica

bit5 12.50 sad. 1mig, 490, ail, 190, bill from nostril, 16, 'gahe, 's9. tarsus, 48; middle tor, 27; th claw 21!

1,988. Cièetura helagieir 5.4512 .25 Gad. Mnig, 4.90; fail, 1.88; bill from nostril, 14; Gahe, 60; tarsus, 148; middle tor, 27 ; its claw.22. 1,989. Châtura helaquéa

$5.5012 .65 \mathrm{sad}$.

Nomig, 5.00; taill, 1.90; bill from nostril, 1.4; gape, 60 ; tarsus, 47; middle tor, '28; its elaw, . 22 .

$$
\frac{\text { September } 181 \mathrm{~h}}{\text { Hegleland tial }}
$$

1990. Telmatodytes palustrix

1,991 . Lenatodytes palustris

1,992. Sayornis fusar2

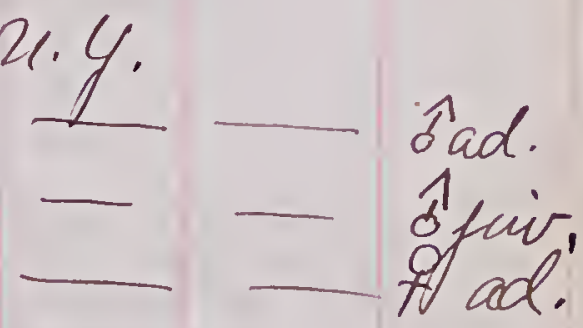
Dolichonjx aryzivorus was still quite mu- meroustan bel Consook March.

Mate, - the last Barn Lwallons ere seen on the Cousook Mare Lefileuter 6 th. 
Collectury
Number. $87 \%$

Length.

Sefteuber 19, Hh. H.F. N.K.

1993. Osanospiza eyanea. Leviral reenat the gate.

Aris, bright red.

1,994. Podilinubus podiegus.

8.35 11.00 fad.

$14.7523 .25 \hat{8}$

Shot at Cornuall, on the thedson, by" foste" Ward.

Pring, 5.05; tail, 1.50; culualu, 88; bile

fron mostril, '54; tarsus, 166; middle tor and

claw, 2.30; tor alone, 2.00; claw, 30.

1,995: Dendrörea Cepteruber 200te. H.F., N.Y. 5.30 8.5 Sad.

1,996. Dendrorea Atriata. 570 9.30 今े(ad.2)

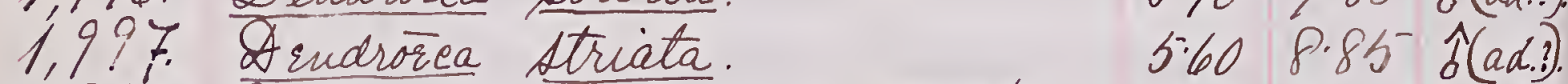

1,998. Dendrorea palmarum, hyporenyea 5:358.05 9ad. Seftember $22 \mathrm{md}$, Atugheand Halls, X.Y. Chaitura helagria. Sevrral wrre neen at Echo Zake; one that 7 thot could not be recorred.

1999. Pereo solitarius $5.629 .15 \%$ ad. Mring, 2.87; tail, 2.20; bill from nostril, 28; gape, 65; tarsus, :75; niddle tod, 45 ; its clans, 21.

\section{Qfeptember 23 pd. H. F, n.y.}

Chaetura helagiea atill fresent.

Ardea herodiat. Que reen ni the consoot Creck.

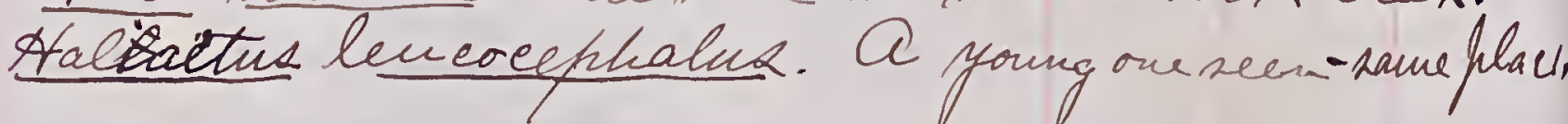
Sefetember 25-th. H.F.N.Y., and Corid, inimg N.Y. Hydrochelidon lariformis. - Mr. Thos. W. Wileon, of Cold ofring, descritbed two terme which he saw in the "Uppol Cove", near Cold Strini, about Sefu- terwain "It 1879, which were nudoutley of thic present precies.

Dadicrmbur hodicefs. - Tre was chased inurecespolly mi the mpher cove; it dive wheneves depiroacled, and escaped by retreat-
1879

- viq into the edge of the bulrushes; on risuig to the surface, after divin, if freqreentts bx- posed. No nove than ith hitablpbore th surface oducipe cornuture. - A frair was chased ni The eipper Cove; they Kefft close togettier, van when persued. Cue that was sevirely woin ded divid to the botton, where it remanid, and the altur escapid ritoth bulrushes. Finga mintilla. On firing a ohot near th Slucei, at the north end of the Lowrs Coven? saw a floek of about threlve suale sinifer, which alose. from the edge of the bubustiee at thw ride of the cove (it wastien low tide), and blew norfturard in a very crooked and executrie manner sowntugh, and again low, and, dwrigring from dide to side; their pure. White reutral selifaces made them appear distinctly sinainst the back ground of grour mountain, sho that ir could fallow their flught for a long diatance, when they rose above the horigon kile, and were lost to vriv. I knew that thiey were birds that 'I lead never seen hefore alvie, and new to this regioin; $20 \mathrm{wr}$ started toward the upper eov hofing that they had stophed there. After prassing from thw Railroad as far round the cove as Tte road, I saw four of the rame birds, 20 far ar I evied judge, which were fly fow about a large poll in the midet of the bulrushes to the soutte. My friend, Mur. Yhos. Yw. Wileon who acconf anied mel, advised me morta attempt to reach them there, but determad to do sonf poskble 2 so oplunged rito th reeds, and warled towards thel pove, which were several rods dielant, my friend having pronised to apprime ane of any movernent on He hast of the birde. Harthig treached the 
DATE:

margin of the fool, I auxwoisly looked around for the Hide which seemed no where bitable. Jwas already wet to ny Hinees, but the fool was black and muddy, but ifhunged in, regardest, mitil I sached a point whtre I coulb virw its whole extent. After scani the border of the nuthex carefully for a monvent, I desionted Atu four Shifrel Which wre feeding, deefly uninered, in the shing regetable truek close to the reeds. I furid from where I stood nearly waist deep ri mud quater. Clue bird was killed, and another slciktty wounded, but it escafied. I reloaded huy Gun, a sirgh barrelled Maynard, andfired a second ohot bfter the retreattrig flock, and succeeded in wounding the bind that was hut by my birt shot, so that it bell at Mr. Milsonis feet. Then J wadech. berost the fuol, witt suy coat-tails dragging on top of the water, ace soou had ril my hastd the firt Reast Dandfiper that hado heen cafitred ni this vegion. Ardea herodeás. - Hour wre torn in Atu Lover eore at low tide. He Milson and muself fird several shots frow the Unaynar rible but they wre never bloser than 300 yerde. Ifired bue shot which aplanhed water all oor the bind, and cearnd it out of its seven sensek.

Escunetes husilme Cold Shring, New York. Lept. 25 th

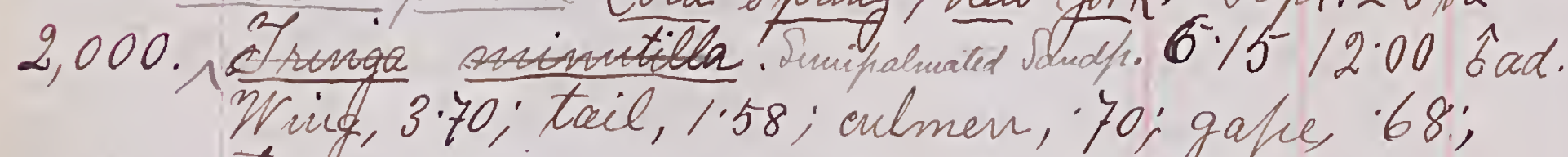
tardus, 83; middle tor, 60 ; its elaw, 12. Iris, hazel. Bill, legst fut, blad.

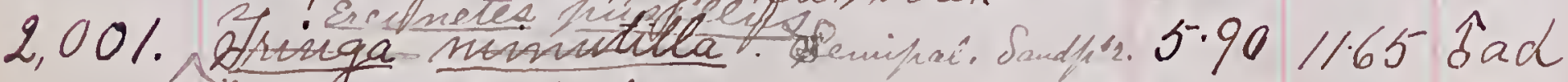
Waig, 3.62; tail, 1.56; culume, 66; gape, 45 ; tarsus, $79 ;$ midle tor, 57; th claw, 1/2. Colors like 2,000
1879

Collecting
Number: xAME. DATF. Highlard Fall, X. Y. (Pell's Poud)

2,002 Ootanns solitarius. $\quad 8751675 \mathrm{sad}$ Drnig, 5.12; tail, 2.45; culmen, 1.11; gape, 1.30; tarsus, 1:21; middle tor, 95 ; its claw, 17.

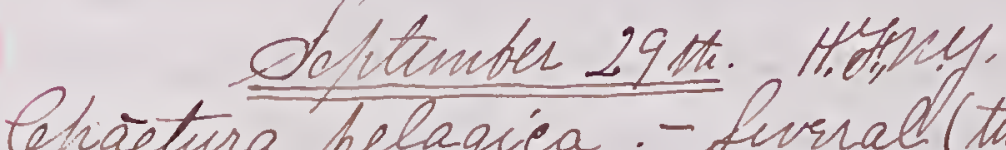

Chrietura helagiea. - Lurral (twrity or so) wrre seen

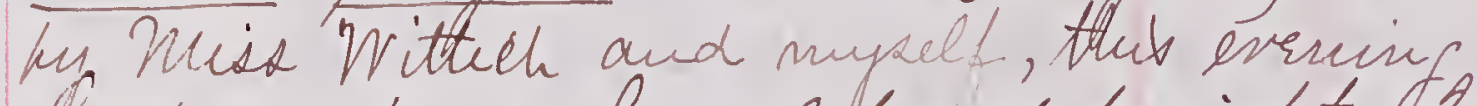
Heshe asio. - Sursal heard to-niglet. Oswact after one with my qum, but mif ohot only througlet down leabile.

$$
\text { Note. - Lamius borralis o jiw. No.1,824. }
$$

Measuremunte: length, 10.15; stretch, 14.15; wring, 4.35; tail, 4.65; fill from nostril, '55; gaps/10; culmen, .73; tarsua, 1.06; niddle tor, 61 ; itr claw, 28. tris, hazel. Bill, plue-ffack; baseo mandible, flesh-color. Legd aud peet, black. 2 irealus purpurens sad. No 1,82.6. Measurements: Ceupth, 12.50; otretele 17.75; wring, 5.55; tail, 5.40; culven 1.17; gape, 1.35; tarsus, 1.45; mid- dle tor, 1.00;its claw, 34. Iris, yellow. Billt fect, black.

Mélospiza melodia ad. No.1,828. Measurements: leucth, 6.40; streteh, 8.50; uring, 2.50; tail, 2.75; culfuen, 46: tarsus, 180. Iris, hazel. Bill, blech-color; maxilla, blackish brown. Fe ga and set, light fleshy brown.

picus villosus $\hat{s}$ ad. No. 1,829.

Neasurements: lencth, 9.35; otretch, 15.25; uring, 4.60; t.3.40; culmen, 1.31; tarsue, 84. Dris, hazel. Bide, leadcolor. Fet, grernich-bead-color. Pieus millodust ad. No. 1,830

Meaomimunts: lengh, 8.95; streteh, 15.35; wing, 4.50; tail, 3\%8; ulmen, 116; tarms, 75. Arie, hazel. Bill, lead-color. Fut, gresuienlead-color. Iurdure migratorius of ad. No.1,827. Measmenents: lengte, 10.80; stretch, 17.10; uring, 5.35; tail,

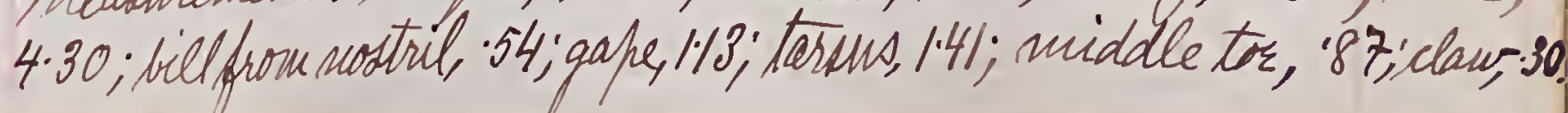


92

93

1879

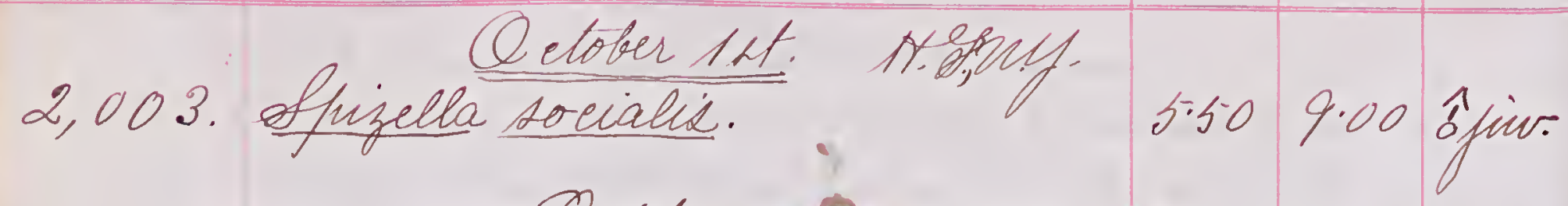

Qctoter 6 At. Andson Ruisr, hewryorts. Left home for the College of Plypucians and. oturgeons, Prew fork City, there to rimain till Afring. An mi way down, on th Ginds: Mary Nowrele", a naw the pollowing Larus delawarnsis, - Two Hulls which Ozaw about defosite Farrytown wire frobably of Colymbus torquatue. - Ame reen flyig wh the Atudson, not vervy far froin bur

Pote. - Enfidonax traillii. "I.7n. B. No. 1978. Cattrill Mountaris, M.Y. Dr. Lanue C. Herrill. $72 \times 53 ; 70 \times \cdot 52$. Cue of theis is vry nearly an unsfotted white." Forom a seharate oent me by or. Arrwer. "Proe. Mat. Muno. 79 -1 April 29,1879." fr. 4.

Enfidonax aeadieus, Baird.

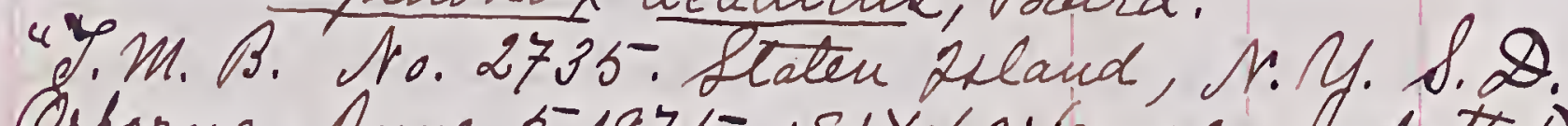
Cstorne. June 5, 1876-, $81 X \cdot 60$; (rearly mispotted) .80X.59; $79 \times .59$." Fon rame paper as above, fe. 5 .

Qetofer 18 At. Highlaud FTalla, N.Y. Returned thom the Thedical Colege last night: this norning 2 roze earls and The water was rough, but did not seens cold. Hull ware quite numeronsittersug Fulls wre the only species notreid.

Seofe asio- Cene Rereeding near my window, early ui the morning, fist hefore daybreak. Warbers. - D. coronata. Abuidant, the only specis

R. R. ealendula and satrapa wre numerone. during which tive veru few birde Wre ofserved. during which time viry few birds Wre ofsewed

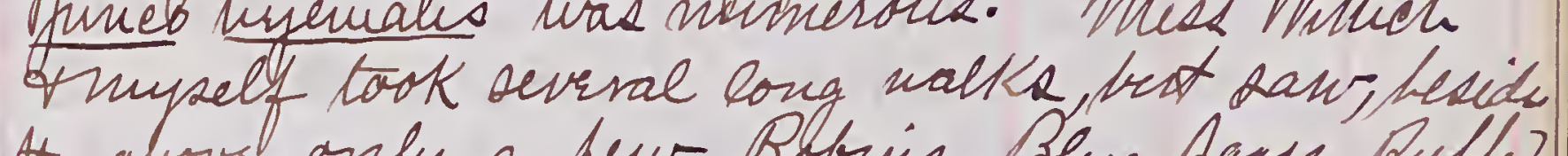
He abovs, only a few Robris, Blue farp, Ruffes

Qetoter-21.t5, 226 Wristh St, Niy.cits Mus. Amith jirst fronght "me a Aernit "Wruech (Iurdur hallasi) which "Lopsu" (the eat) canght and in beantiful flumage.

2,004. Imdus pallade', leabanis.
The bird was fat, and its bones soft, shoving that
it sas a youlng bird.

Qeloter 26.th. H.F,N.Y. Rawned from hew-Yoon last night. Lo-day I

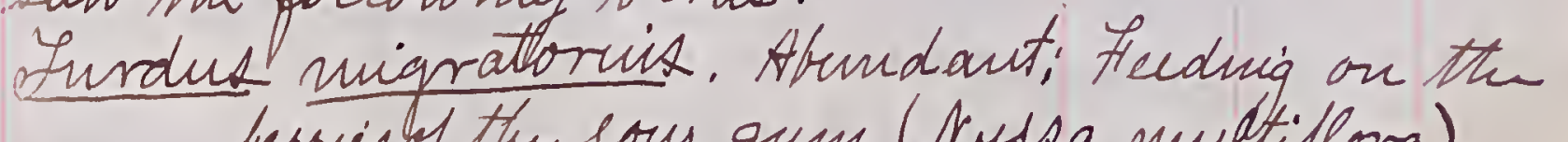
Iurdurisisf the sour gum (Arska multiflora). Lurdus paldasi. Counom, seen with tem Robrio. Revulus Lotrapa. Very comnon. Bialia tialia.

Threlis cedromur. Abundant Litta carolinensis.

Parus atricahilles.

guner hupenalic. Abundant hizella houatis.

Daserella ilía.a.

zonotrichia albicollis. 


\begin{tabular}{|c|c|c|c|c|c|}
\hline $\begin{array}{l}\text { Cullectuy } \\
\text { Sumbles. }\end{array}$ & NaME. & LOCA LITY. & Length. & sitrectil. & $\begin{array}{c}\text { Sex and } \\
\text { A gec. }\end{array}$ \\
\hline
\end{tabular}

Cornus anencianus

teuanunus cristatus.

Accifiler coofervi. Ane or tuo seen. Bornar unbellur. Iarne arqentatus. Houndant an the Arudson. elawomis susces

Pote - Oonis Jerega niformes nue that ther ire numbers of Arrhit thusher (I. pallaci) si the yarde adt the vear of 110.118 Wavrly Piace, hi this city during last wrek.

Novenber 3rd. new Yook Lity

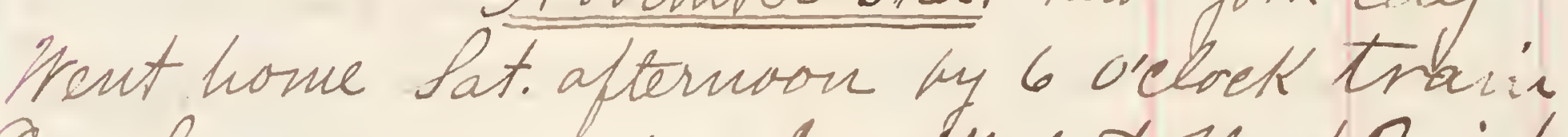
An Lunday morning \& walked tVertPonit, and hack, before going to church. In the afterion Rose \& I walked bown to the river. She following bide ure ofserved.

Iurdus migratorins; Lealia sialis; Regulus satrafa; Parus atrieapillus; Litta carolinensib; Certhía Laniliaris; Dcudroeca coronata, abundant; Ampllis cedrormu, in large flocks, by the rivr; lehrysonitris tristis; puner Myenalis; Passer donestiens;

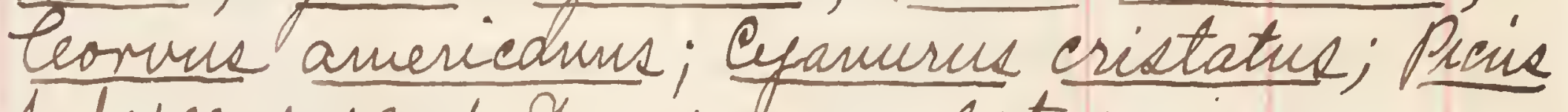
hubeseens; and Darus argentatus.

This morning of returued to heurfork by the earey train. The monntaius wre white with suovs, and the roofe thare phote along the rirs were white also, hs well as the filds lynig back of Sarrisous. Large flock of Robris Mret flying Worn

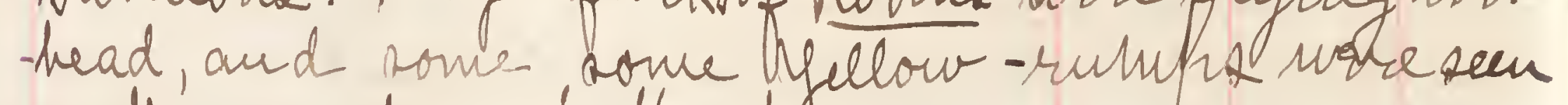
on the way down to the perry.

1 made the bollowing ofservation on the rapidity of flight in the goug-tailed Duck (Hareldeqlacialin)

while comuing dour on ttr Train:fevek of Celd Mivel was from the nater and folew in a duret course down the Audson. Hheir Whit

\section{Dane. \\ The New York Central \& Hudson River Rallroad Co. \\ HUDSON RIVER AND HARLEM DIVISIONS, \\ Office of the GENERAL SUPERINTENDENT

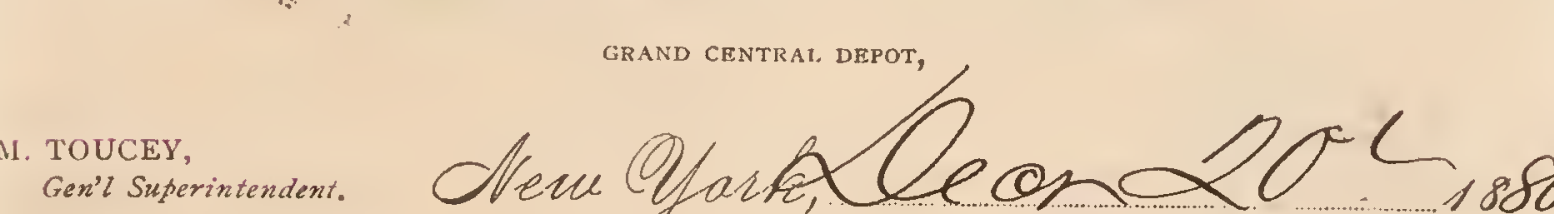

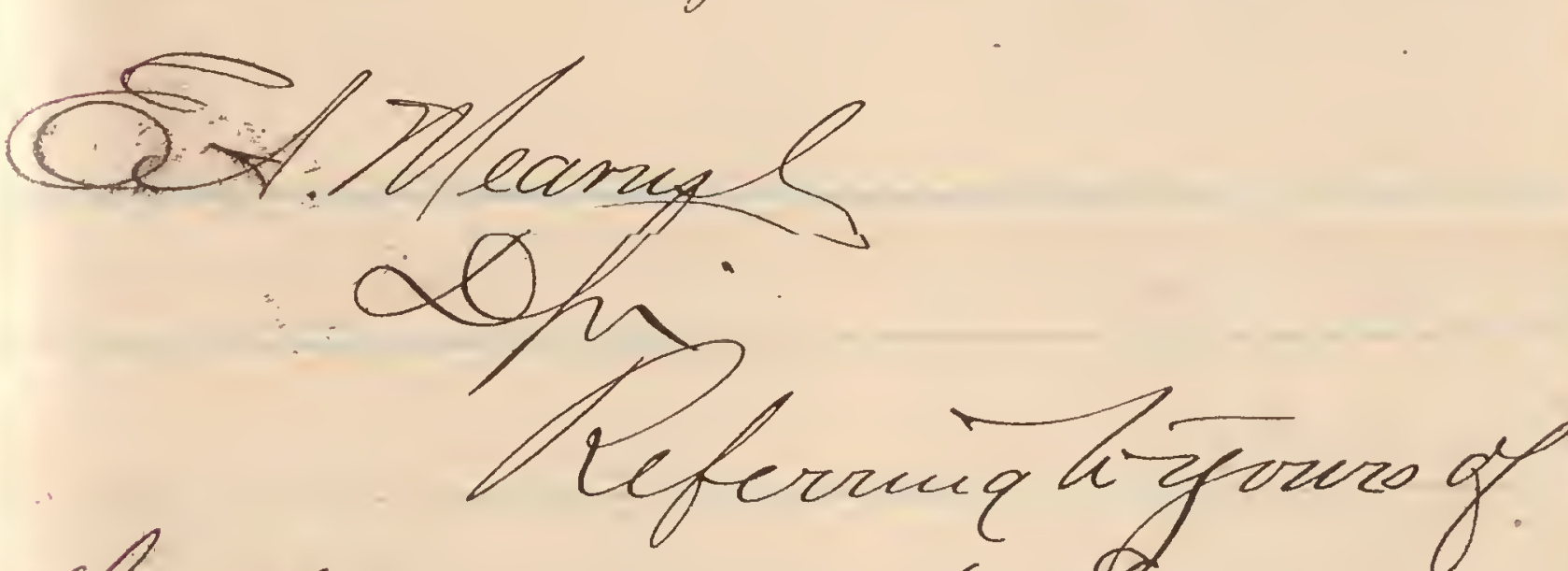

colort wre very distiuctly visible against the deep the of the river. I noteced that they maintaried about the Lame relative fosition with regand to the train, which had not yet, howerer, gotten inder full headway; fut the birds ckanged their course at intervals, and, also, at timies, they would rise ni the air, sefarating from each other at those timies, and then ther would deseend surftly to near the surface of the water, and thi dat redaline to hain, stotis

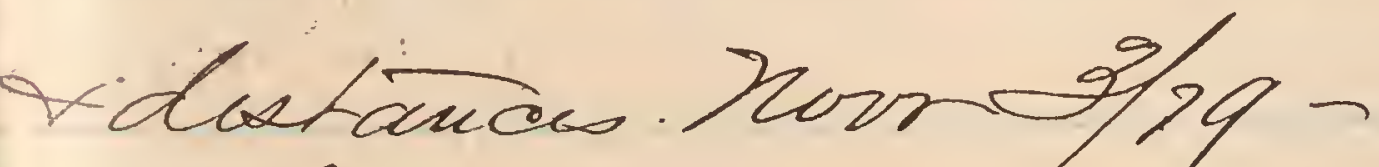

Stu hinam alluded ts lefk

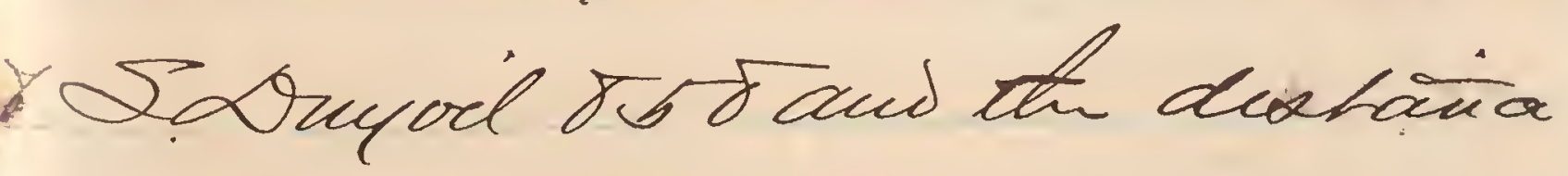

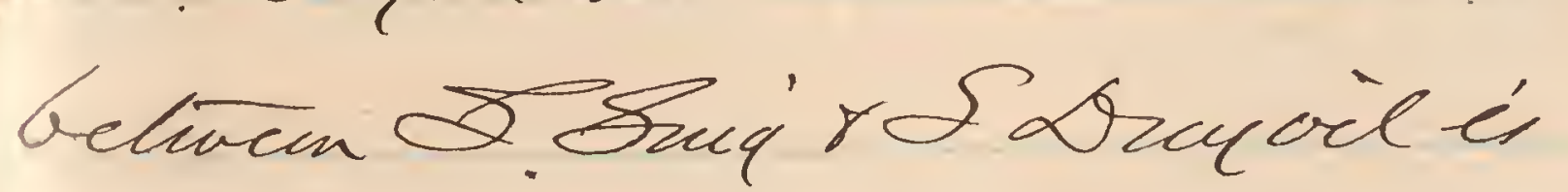

$19 \frac{66}{100}$ Nicter

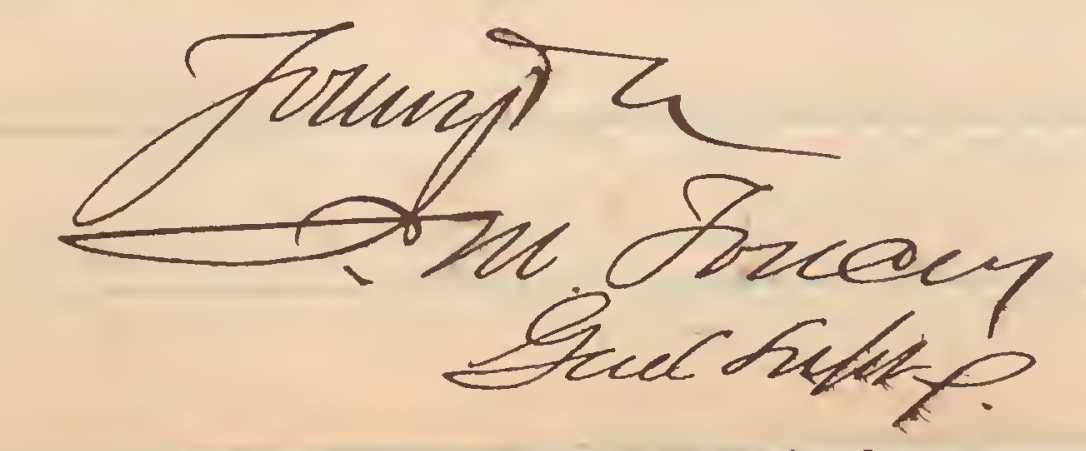

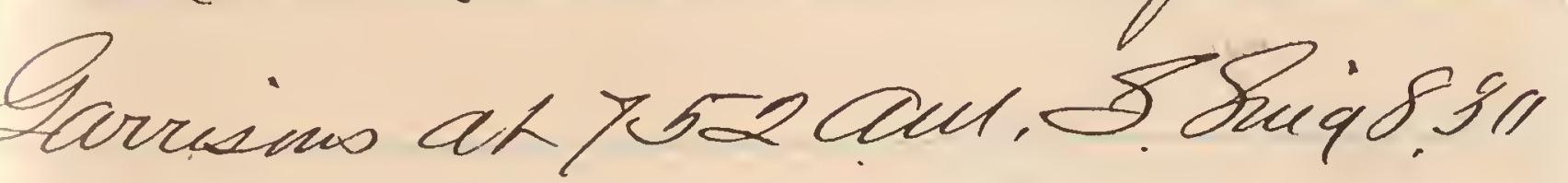
's thus asured would sed. Hs our trani inately for nus

$\because$ to movr indrectes, uninater if to thoferwed it which the trami the gait at which th they Keft their as long as our 'une blowed uh, udson, the Ducke - 9.10 oieloek by my ceording to mus the ratilroad - in gues. Thedistance 20 mili.

- Fine trom where werksalyo when? - Nlace, was jist

y with me at home d made. The follow-" - mipratornis, scali aticafilles, whon the rocks olvicusis, Aupelí cidrormin, Meloupiza melodia, thizella nuontiót 


\begin{tabular}{|c|c|c|c|c|c|}
\hline $\begin{array}{l}\text { Collectury } \\
\text { Numberer. }\end{array}$ & NaME. & LOCALITY & Lengugh. & sirertch. & 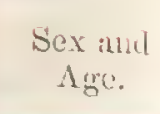 \\
\hline
\end{tabular}

teorrus anencionus.

Teisanum cristatus.

Acciliter cooperi. Ane or tur seen.

Bonar unbellus. -

Iarne arqentatus. Arundant an the Atudson. Sayornis duscys

Pote - Dovis jerega niformes nee that ther

erre numbers of trinit thusher (I.pallasi)

mi the yardk ait the rear of 110.118 Wavrly

Prace, hi this itio

Yent home
En Lunday
hack, before
Rose \& I wal

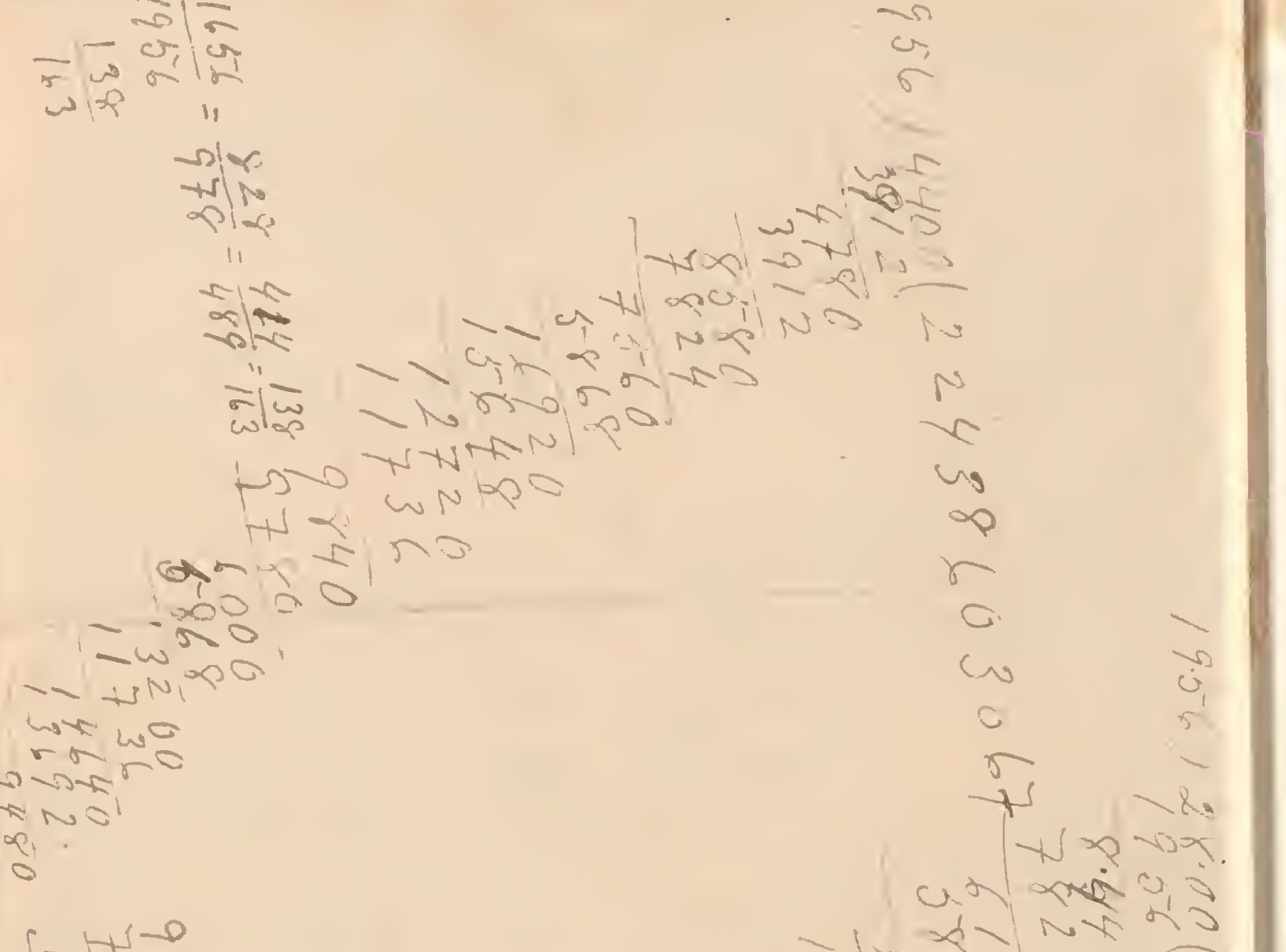

tristis; humes - s

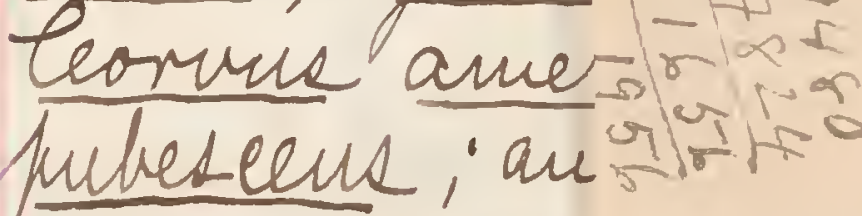

This morning

travi. The ul

and the roofk

white also, as

Tarrisous. Lar

-head, aud ror

on the way don

I made the bo

of flight in the

while coming dou

but alter lea

1evek of Celd II

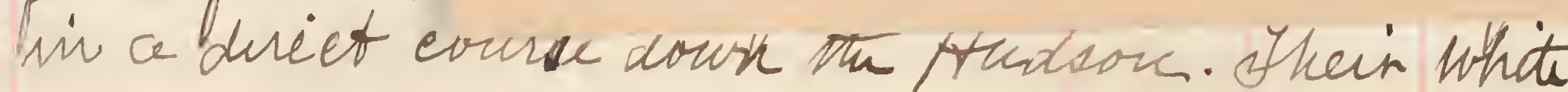

\begin{tabular}{|c|c|c|c|c|c|c|}
\hline $\begin{array}{l}\text { Collecting } \\
\text { Combuber. }\end{array}$ & SAME. & DATE. & LOCALITYY, & Lengytl. & sitrectih. & $\begin{array}{c}\text { Sex ximut } \\
\text { Agges }\end{array}$ \\
\hline
\end{tabular}

coloro were very distiuctly irsible against the deef blue of the river. I noteced that they maintaried about the Lame relative fosition with ugard to the train, which had not yet, hoverer, gotten mider fuel headway; fut the birds ckanged their course at intervals, and, also, at tines, they would ise ni thin air, separating from each other dt those timies, and then ther would deseend swiftly to near the surface of the water, and then for sone tinie the infetts this aspired would cavrytthm as an aecelsrated sheed. Hs our trani got faily under ury, and fortinately for nu ofichation, Atu Ducks cedsed to morr indrectes and shimmed along close to therinatern. If bo hoferued that the regular rate of speed at which the trani wond war exactly equaes to the gait at which th Duoks dlew, and, a ceordingly they keft their welatis fosetion ophosite to us as long as our course lay aloug the miri. Mhen wr blowrd uh, lefore turning baek from the Hudson, the Ducke lew ahead. He tilue was jist $9 \cdot 10$ o'elock by my watele. The time given wals aceording to mus oun pice and not that of the ratilroad ini Lact I had set nuy wateh fy guess. Thedistace ceceording to tine-table is just 20 milis.

Came down on earey train. Fine from where the floek of Sucks taited, two wraksaly when trined Atech, to The tummiy of place, was fist 27 minutes.

Dr. A.K. Fisher spent funday with me at houne No rniarkable bird noter were made. The follow:

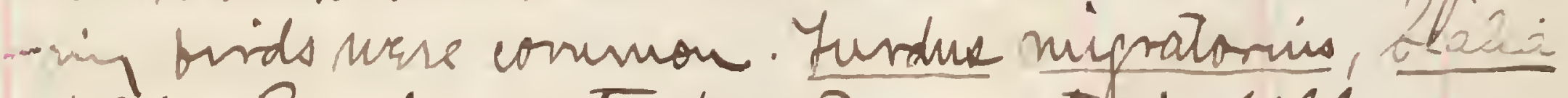
sialie, Regulus satrapa, Parus aticafilles, Arthia fariuliario-Clinbing wpon the rocke down ify the River, Sitta Carohisisis, Aupelis cedrormu, neloupiza nelodia, Hizella norition 
96

97

1879

$$
1879-80
$$

T.MH

OQALITY

XAN1

$\mathrm{AT}$

LOCAIITY

Puner hyemalix, Passerella iliáca - numerous, Passer domesticis, Chysonitus tristis, Conves amerceanus, Cyanurus osistatus, Prenopubesens, Itcipiter Cookeri, and Lasus argentatus.

"Clote.

"Qloter 31, 1874.-Hudsonian Lodwit?. Near the mouth of Conook Creek, 1 aw this bind stand-ing out one the mud-flat, knee-deep in water. Then fired at and wounded it flew about in circkes, uttering a plaintive chr consistiv of three sylebles, boudly repated; at last st fell into the rivar, but could not be reached."

Shizella Noverales - Seen yester day, Novi2q Passerelk ileica - Seen Nov: 29 k.

Catskill monitain, Nuw York. Dre.2d.

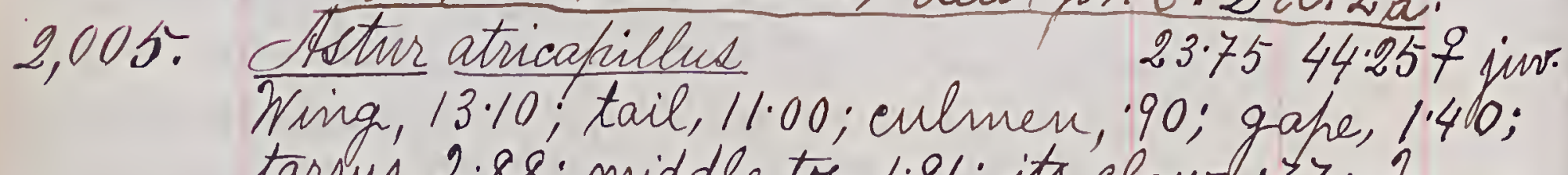
tarsus, 2.88; middle tor, 1.81; its claw, 7.7 ; mner tor, 1.15; its claw, 1.12; outer tor, 1.41; its claw, 63; hallux, 1.07; itte claw, 1.19. Aris, yellow.

3,006. Sialia Sialis. Bluebird. H. F.05 12.30 sad. Wm 3.90 ; tail, 2.80; bill from nostril, 35; gafe, 78; tarsur, 83; midde tor, 69; thelaw; 26. Ari, hazel. Bill ffect, black. Qhiside of moith, yellow.

Notes on Birds buen. Surdur migratorime. - Afur near fiont Montgomery.
Regulus satrapa. Shinging a swert and very singular song.

Parns atricafillus. Piens pufeseens. Sitta carolinensie. Certhia familiarie. lealaptes auratus. One or twot seen mear fitintoponiy. Afizella monticola. Junco hyemalis. chryponitris tristis. Bonasa unbelus.

The above wre all seen by me on a walk doun to Popoplen Breek and Back, This afternoon. The only, other Stpecies of Pirde

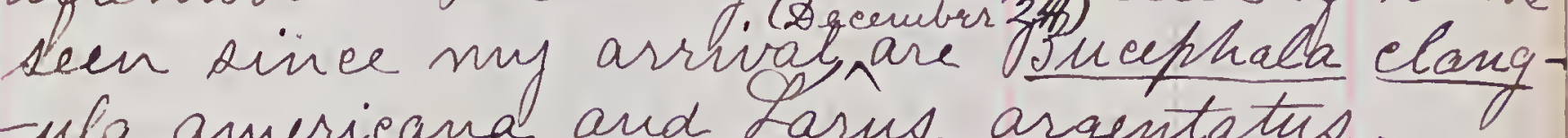
- ula americana and Larus argentatus.

Note.

Tannary 2. Saw sevral Bonafartís Aulla (Larns philadelfhia), near Peekakill, on my way to New-Yfork.

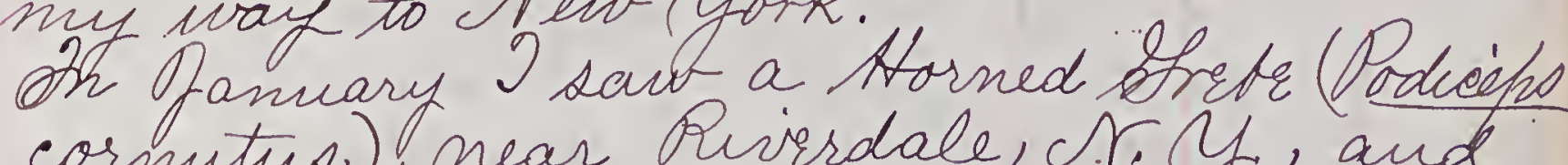
cormutus), near Riridale, M.Y. and informed mr. Bicknell of its securrence thtere, at a meeting of the Lirnatan vociety.

2,007. Larus glaucut, Brün, 29.0067.00 mmature Fing, 1800; tail, 7.55; culmen, 2.50; bill from nostril, 1.10; gape, 3.70 ; tarans, 2.88 ; middle tor and claw, 2.90; tor alone, 2.45; claw, 55. Bill, flesh-pink on basal one- half; succeded by a wide band of blueblact:; tip, horn-cblor. Lega and flect, fink- reh white; nails Pacrieh, tippes with horn-color. Jides, white.

Q prought this tirs of Our. Robin, at Fultore Orarket, d. Y H of lold me it wae shot on Long Preand, OF. M', and said it nese a verif rare fird, that not one Lerle wi a thothand was mhite above; that nearey 
98

99

1880

1880

all wrre saddle-backs. It isthe vimmature bird, descritid, as Le hutchinsii. All white. Note.

Sayomis fuscus appeared here March 2nd, when Pat Cax saw a hair at the dock. I have seen none yett(march s-).

March bth.

OTo-day the thermometer ranged from $60^{\circ}-70^{\circ}$, and the wratter was fleasant. in the morning, I saw turttes basting moun a rock ith Pell's fond: both Spolted (Tanemus guttata) arld Painted orrntes (Chryems hieta). In the everuirg, at 6.30 o'clodk, Isatw a hat flejing a bout. This is my first of hone fron the Medecial Collegte, and the falfowrig bride wreseen: Iurdus migratorins Abundartifuding on Rhus. Sialia Sialie. Abundant, singing.

Certhia familiaris.

Carpodacus purpureur.

funco hyenalic. Singing.

Apizella monticola. Shiging. Melospiza melodea. Arundant, singing.

Passerclla iliaca. One that 3 shat was 7.

Corrus americams.

leyanurus eristatus.

F Enaedura carolinus. Ishot one on the Consook 2sland.

Ceolafites auratus. Oru seen.

2,008. Zenaedura caroline. 12\%18.85-5ad. Iring, 6.05; tail, 5.20; culmen, 50; bill Arom noxtril, 36; gape, 80 ; tareve, 86; middle tor 4 Claw 1.05; tor alvie, 82; claw alone, '25'. 2ris, hazel. Shic about
Collectung
Numler:

DATE.

LOCALITS

rye, blue. Legs and fut, red; nails brownich bladk. Sill, black. Crop contairied trearigular-Shaped seeds which were preserved with stermun. Shot on Consook osland.

March 9 th.

Yesterday there was a light fall of snow, and somewhat colder wedther. Othe following birde are some of those seen yebterdayPans atricapillus. Fitta carolinensis.

Chissomitris tristis.

thas obscura. - In hile I was at Pell's foud, Six Dusky Ducks came, and, after cucling a. fivtine above. the foud, quaduallst. - cung lower they drophed demost wrin to the middle of the the frond, witing a loud splashl ithey made. a. end quacking when flyingl. At first riney renained quiet ist the suidd de then stem sirftly about, flappinig their isings and quacking, bud at timer wteiring a currous clanging ary, tell they sant me, when the raisted with a phlash and loud quacking, and left. cto-day the fiox Sharrows are stell abun- dantfind I heard a Purple Htich sing. No birds about Consook Daland, except Sang fparrows and Crows.

March 10th.

tad a severe anow-stom yesterday, with high wind: Thermometer $20^{\circ}$ at 9 biclock A.Th. Snow 3 inches deep this maning. Fleiten (Colaptes auratus) wre calling londly early in the morining, and Pobirienche aburidant 
100

101

1880.

1880

Anow nearly gone this afternov.

Pote.- Mr. Edward Conway, of 55 Camine At. Newlyork, showed me a shin of the Red-brleid Woodfrecter (Centurne carolinus) which he shot at "Dine Bsland," ( Ifounda Bine Busth" mear there on thi moff), on the wall hill, back of Newburgh, in Drange connty, h.Y. It wrob one of a number that he shot there turidelf. The Red-heade (Melaiurpes en throcefthalus) are viry abundant at the some place, and it may be that the same causes which erevent that bind fron bring conmon here, also Keep the Red-belleid Woodfechin from visiting us. Convall is the only

Clearch lttte.

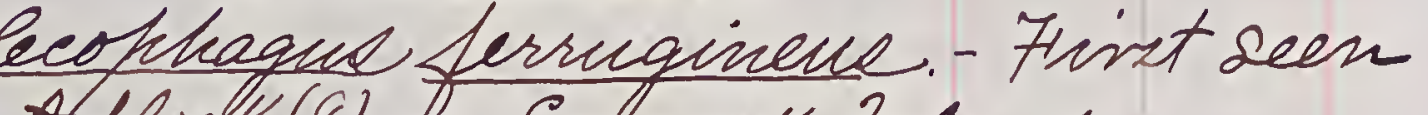
Aflock (8) on Colsook Diland. Theather cold. Snowed all day. Snow Hnieheo this evening.

Nearch 12 th.

thas ofseura. One seen in Pell's foud, which was covrred uitt thin ice. Mins villosus. - Luro wre secw.

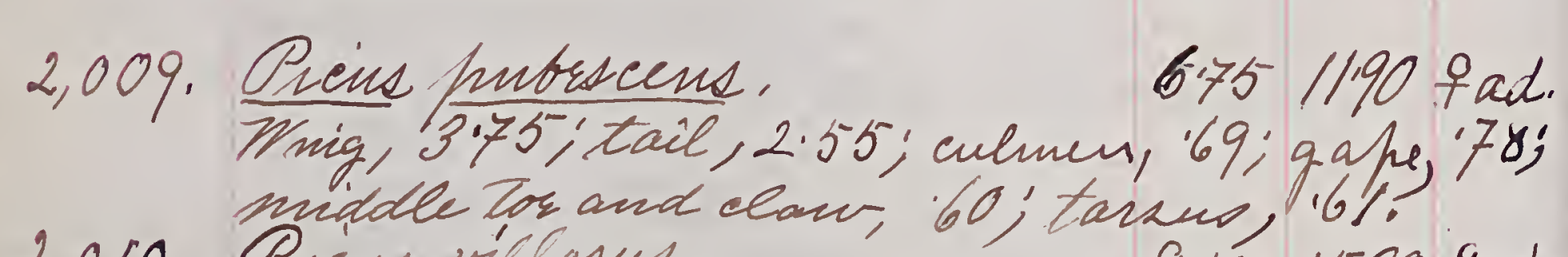

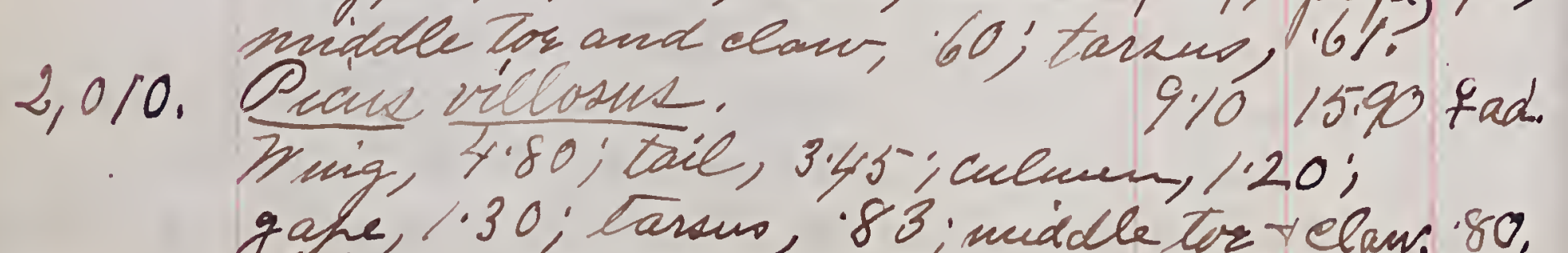
gafe, 130; tassus, 83 ; middle tor y Claw, benich-black?

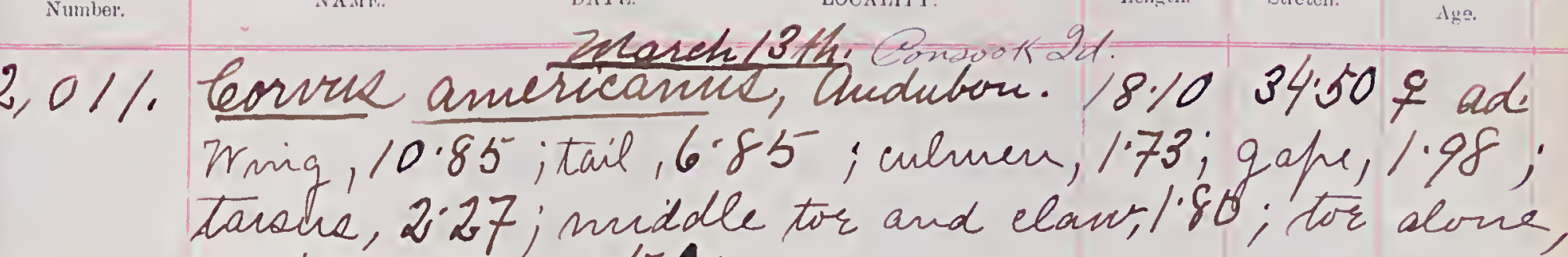
tarste, 2.27 ; middle tor and elaw,1.80; tor alone,

march $141 \mathrm{~h}$.

Apperella iliaca. - Singing Carpodacus purpurens. Singing.

Marde 15-14.

Hurdue nigratorius. - tinet heard singing, Dueke crumerone mi Pell's foud Durgue merganser. - Cne at Corfook 2sland.

Note. A Cow-Bird (Molothrus ater) was rearid in thi nest of the European House stharrow, in thighland Halld, antd live for some time in the village, an wonget the stplarrous.

March 23.

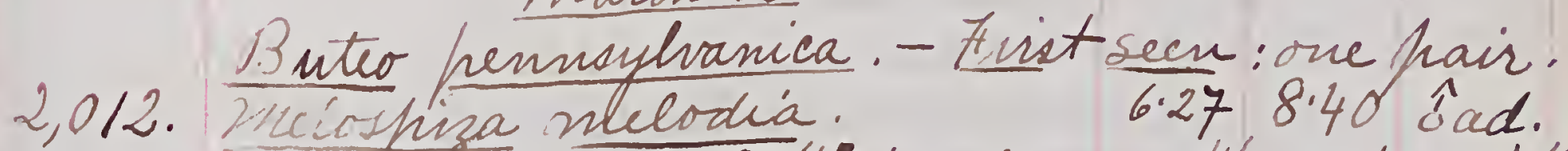
6.278 .40 îad:

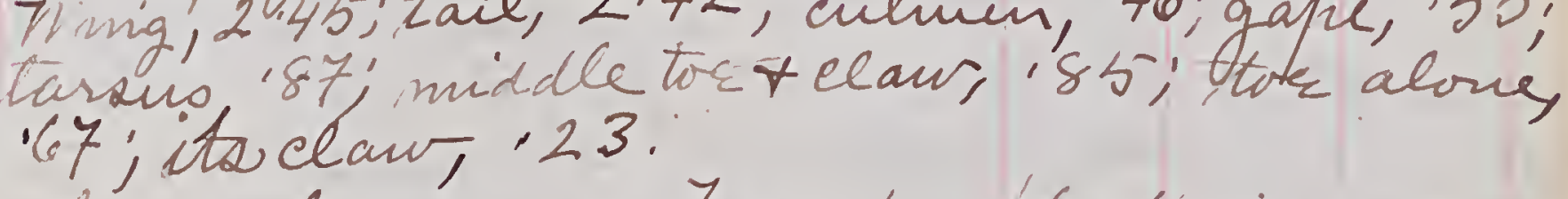

Anar obsenra. Fr. Hud a ólock ni a suranth settied. une was hieked ip on the salt marts, which had a hole eaten in its side; Fonnd one in the same hlacet condiling two ycare ago.

201 March 24.

$7 \cdot 201130 \mathrm{sad}$ Whing, 3.39; tail, 2.88; culmen, 48 ; gafe, 36 ; middle 
2,014. Pafserella inaca, (Therrem). H.5N.Y.715 11.50 Fad. Minig, 3.55; 2.92=tail; culmen, 's2; gafe, 60; tarsus, 98 ; middle tor and clans -96.

2,015. Afnizella monticola. $\quad 6.279: 25 \mathrm{fad}$ Whing, 2.88; tail, 2.83; culnum, 41; gafe, 47, tarsue, '80; middle tor and clalv, .76; tor alone, 36; clawi.24.

2,016. Ceyanumes cristatus

$12.2016 .75 \hat{0}$ ad nostril, nostril, 70 ; gofu, 1.19; tareus, 145 ; midelle tor and clater, - (shot offon bothe feds.). Agelāens phôricens. - First seen The Sollowing Sheciossentche following specossens were some of those collected in the year 1873. Hll wre shounted, and not munbred or recorded in fournats: leyanurue cristatus. Jau. 28,1873.12.00/7.00 -? Marus atricafillus Bonasa nubrllus. 2an. 31, 1873.4490 7.50 -? 7e6. $15,1879.17 .5022 .00$ ? leyamurue eristatus $7 \mathrm{~F} 6.22,1873.11 .0015 .70 \cdots ?$ Hhat, 3,1673.11.30 17.00 ? do 11.3016 .40 ? Iurdus migratorius. Mar.15,1873.9.20 16.00 -? Eetofistes migratoriul.War.19/1873.16'302370 qad. Helospiza meloda. Mar.15,1873.6.60 8.70 -? Aneo tryemalic. Mar.17,1873.6.40 8.90 -? Melosfiza meloda. Sralià sialis. do

XIII.

XIV $\frac{X V}{X V}$ Merque serrator. do 6.608 .80 -? Inar. 19,1893.7:20 12:10 îad. do $7.1012 .007 \mathrm{ad}$ Sitta carolicusis Mar.24/1773. - - qad. $\frac{X V 1}{X V I I}$ Mar.231873.6.00 1070 8ad. Mar.28,1873.6:10 11.00 —? Mar, $29,1873.550 \quad 10.30$-?
1880

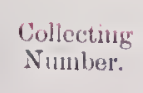

$X 1 X$.

$x X$

$X X 1$

XXI1

$X X I 11$

XX/Y

$\forall X V$

XXY1.

XXVII

XXVIII

$X X \perp X$

$X X X$

$\underline{X X X I}$

$X Y X I I$

XXXIII

X:XVV

XXXY

XXXVI

XXXVII

$X X \times \mid I I I$

$\frac{x \times X I X}{X I}$

$X Z$

$x<1$

$X L I T$

XLIII

$X L I V$

$X\llcorner V$

XLVI

XLVII

XLVIII

$X Z \angle X$

$\leq 1$

LIT

$\angle$ III

$\angle I D$

$\angle V$ Date. Lamin botrealis.

inas of scural.

Sayornis fuscus.

surdus migratorius.

Frochilus colubiris.

sialia sialis.

tirrdus frallasi.

Colaptes auratus.

Anfelis cedrorum. Mniotilta varia. jeterus baltinore.

\section{I}

LOCALITY

Deolesphagus ferruginens. Mar. 31,1873. 9.9015 .00 sad.

Larus argentatus thi.3,1873.24.00 59.50 5 ad.

do $9.5014 .00-a d$.

colecthague ferrigineus $9 / 4.2,1873.916015: 20$

Th1,4/1573.34.70 36:20 -ad.

Thn.13,1873.6.50 10.40 - ad.

do 10.40 -ad.

May 17,1873. 3.50 4.00 -ad.

loarpodacus purpment. Thil4/873.6.40 10.60 bad.

Porecetes gramineus. Th19,1873.6100 10.20-ad.

4 do 6701200 acad.

Bucephata albrola. Th.33,1873.12.60 21.40 fad.

Lusealue furfureus. \$4.29,187.3.11.20 16.60 fad. Dendrorea coronata. Mary,1873.6:00 9.00 áad. hunco hyemalie. do 6.20 9.70 ciad. Tearfoddens furfureut. May, 3,18736.30 10.04 àad. 7 " do 6:10 10.40 fad.

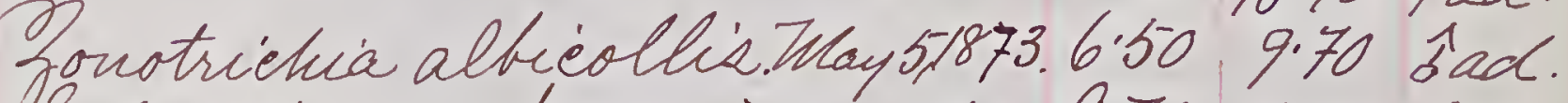
Peolecophagus Levruginens. do 9.70 15.00 îad.

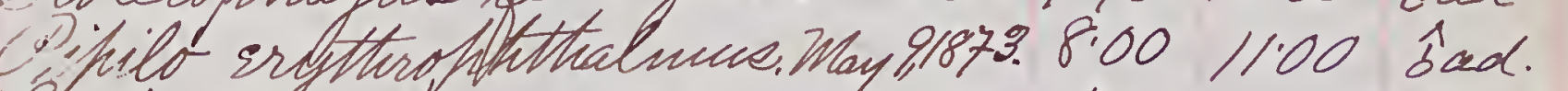
Enffidorlax flavivintris do biv - -? Sftohaga puticilla. Insylg,1873.5:20 8.30 dad. teontofue virens. Mayla,1873560 8.50 -ad. ofterus baltimore. do 7.7011 .40 sad. Arsfelie cedrorun. do 6.80 N.50 -ad. do $5: 207.70$-ad. may/0,1873.7.70 11.90 sad. do $7.601 / 60$ sad. do 7.50 1/.30 sad. Coniafhea hudornciana. do do $8.0012 .60 \mathrm{fad}$ sad. Eyanosfiza cyanea. do 5i70 8.50 dad.

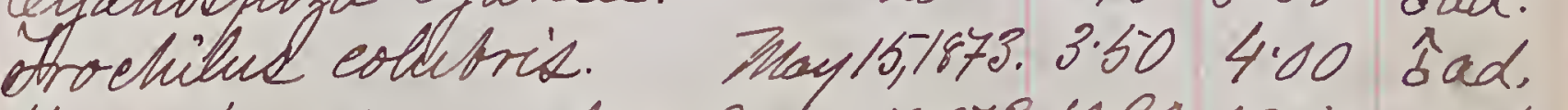
Harforhyndme ruqud. May $171673.10 .9012 .50 \mathrm{ad}$. 
Collectumg
Sumber:

IVI ecterus spurice. May19,1873.700 9:60 îd. LVII Mame carolinensie. Maylt, 1873.9.00 12.00 fad. IVIII of eterue faltinore. May19,1873.7.70 11.20 fad. LIX Eindrieca castanea. do $5.709 .00 \mathrm{bad}$. $\angle X$ Jeterus baltiniore. do $7.6011 .00 \mathrm{sad}$. LII Chactura frelagria. May20,1873.550 12:00 -ad.

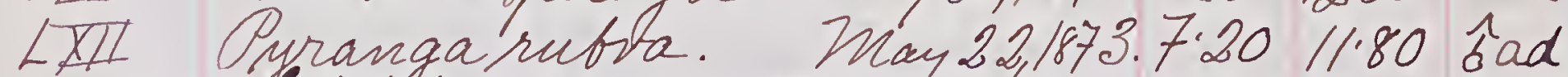

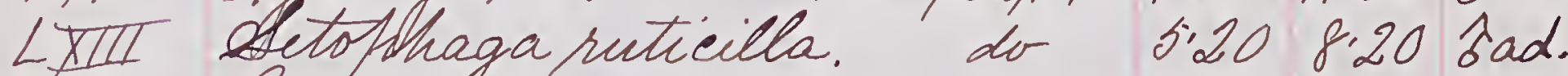
LXIV Pretangd rubra. do 7.5012 .00 sad. ZXV stelmatodytes fralustrie. Way291873.5\% 6.20 今ad.

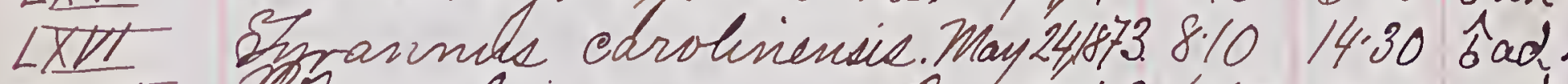
XXII Oïreo olvaceus. Sune2/1873.6.50 10.00 ad.

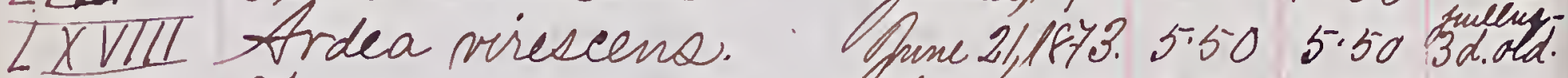
LXIX Ërranme carolinenals. fune28,1873. 8.30 14.50-

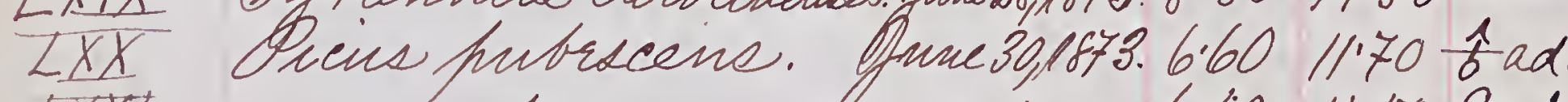
$\angle X X X$ do do $6.6011 .50 \mathrm{qad}$ IXXII Sthizella frusilla. July6,1873.5.90 7.s. Fad. ZXXIII Cejanosfuiza cyanea. do - sad. IXXIV Ardea virescens Jume $10,1873.17 .3026 .00 \mathrm{~g}$ ZXXV Ohilohela minor. fuly/1/1873.10.5019.00 qad. XXXVI Pcius villosue LXXVII Pyranga rubra.

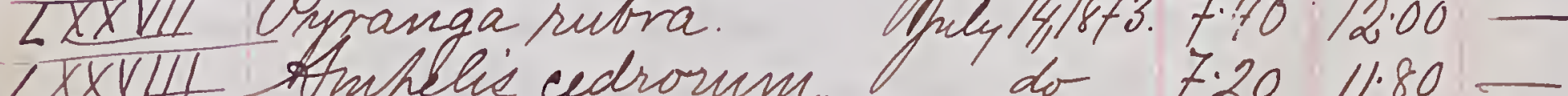
IXXIX Myjarchue crinitue. Suly/5,1873.9.00 13.50 है $\angle X X X$ Doliehonyt oryzivored. Puly25,7873.7.00 1100 XXXXI ZXXXII etanue solitariul. Af918,1873. - - ZXXXIII leyanurus cristatue. Slep.201873.11.50 16.60 ZXXXVV Cololaptes auratus. Sefp.24,1873.12\%1017.10 $\mathrm{Fad}$ ZXXXV Myrarchuecrinitue. do $7.5013 .00 \mathrm{sad}$. LXXXVI Ceganurus cristatus slef.271873.11.50 17.20 今ad. IXXXVII do do 11.901640 -ad $2 \times \times \times V I I I)$

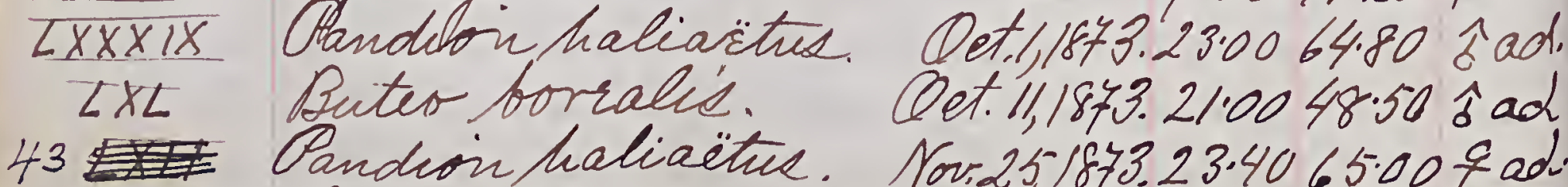

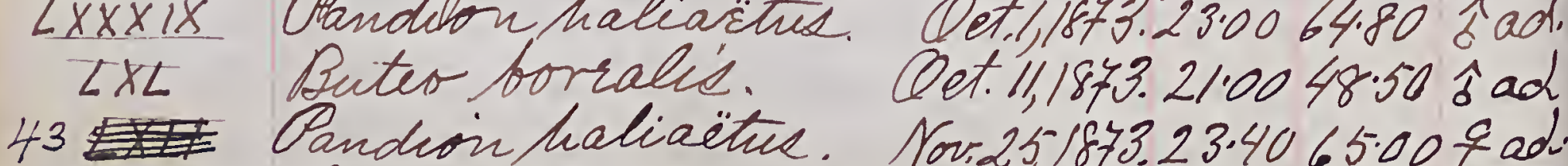
ZXLII Bucephala Clangula. Dee.5,1873.19.2530.88\%-
1880.

Collecting
Numilere.

ZXLIII. Fuligula offinis. Dep.6,1873. 16\% 28.30

IXLIV. Fulloula collaris. Dec.16,1873.17.50.28:00 $\mathrm{bad}$.

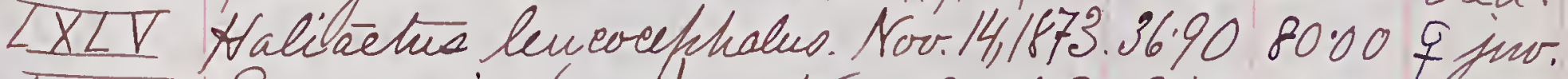
ZXLVI Scope asio. (red) Nov.19,1873.9.40 22.00 ad. The above is a nearly conflete list of all of the birds collected (all mounted) during the year, 1873.

At the teginning of the year 1874 of conneneed a eabinet of brd-stries as well as of monnted sheciment. The following specincus of finds are among those collected during that year; most of the earlici ones wre freserved as mount -ed specinerve; most of the later ones as Stive:

LXLVII. Sfizella monticola. Fah.28,1874.6.00 $8.60 \mathrm{-ad}$.

ZXLVIII. Realia scalis. do $6.6012 .00 \mathrm{mad}$.

LXLIX. Parue atricapulue. do $5.307 .50 \mathrm{-ad}$.

C. Sfizella montécola.

LIT

CII.

C IIT.

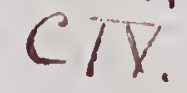

$C \nabla$.

CVI.

CVII

inelosfuiza meloda.

huneo hyemalis.

Sralia sialis

Fle6.26,1874.6.12 9.19 5ad.

do 6.069 .19 qad.

do $5.448 .00 \mathrm{sad}$.

Whar.2,1874. 6.09 9.88 sad. Pafker domesticus. do $7.0012 \% 19$ sad. Eftopistes migratoria.

mar. $5,1874.6 \cdot 25 \cdot 9 \cdot 38$

do $16.0023: 25$ fad.

vill. do do 6.751212 ôad.

CTX. Pafurella itiaea. Mhanll11874. F.50 11.38 sad.

CX. do do $7.1210 .88 \mathrm{fad}$.

CXI. Siäia sialis. do 6.56 $12.25 \hat{s a d}$

CxाT do do 6.50 $12.38 \mathrm{sad}$.

CXIII do do 6.6212 .43 sad

CXIP. do do 6.56 12.31 sad.

CXV. di- do $.6 .5612 .43 \mathrm{dad}$.

CXVi. Lurdus migratorius. do $10.0015 .75 \mathrm{Fad}$.

CXviा. Muner hyenhalis. Mar. $2,1874.60010 .81 \mathrm{fad}$.

cxvill. Mafserella iliciea. do $7: 2511.00 \mathrm{fad}$.

Cxix. do do $7.5011 .3 \mathrm{cod}$.

CXX. Melospiza meloda. Mardu13/874.6.06 8.69 -ad. 
Collectur:
Numiler.

cxx1. Subo virgimianue. Mar.14/1874.21.00 52.50 हैad. CXX11. Inrdure Mnigratorine. Man.20,1874. 10.06 16:25 Fad. Cxx111. Sialia sialis. Mar.19,1874.67512.62 $\mathrm{gad}$. CXXIV. Runer hyemalie. Mar.21,1874.6\%3 9.44 1 ad. CXXY. Anpelid cedrosum. CXXVI. tehriponitrie tristiv. CXXVII. Diene fubrsecus.

CXXVIII. Sayorhic fuscus.

EXXIX.

CXXX.

CXXXI. Preis villosus.

Man.20,1874.6.69 11.50 fad. do 5.139 .06 sad. Mar.21,1574.6.88 $12.00 \mathrm{fad}$. do $7.0011 .44 \mathrm{rad}$. de 6.069 .25 sad. de $5: 569.00$ fad. Sunco/hytemalid. Mar.25,1874.9.00 15.56 sad. do $9.8815: 56$ sad. cxxx111. do do $9.2516 .50 \mathrm{fad}$ cxxxix. Megulus satrapa. Ap.7, 1874.44.00 6.88 $\mathrm{fad}_{2}$. CXXXV. do do 4.25 7.25 1 ad. cxxxy1. Requlus calendula. do 4.50 $6.88 \mathrm{a} \mathrm{ad}$. CXXXvil. Megulue Satrapa. do 4.25 7.25 ĉad. cXXXVIII, do do 4.006 .75 fad. CXXXIX. Sayornis qusend. Ahr. 5,1874. 7.0011 .13 -ad.

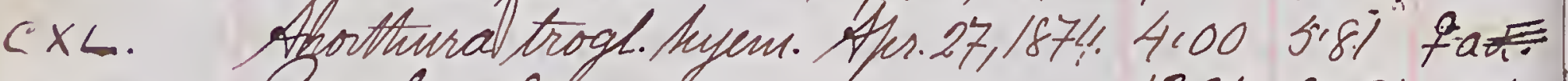
cx<1. Geryle alcyon. 13.2529 .31 ad. CXL11. effizella montiéola. A4r.291874. 619 9.31 bad. izella fusilla. do 5i56 \&s8 -ad. CXLIV. Sthizella socialie. do $5: 138.88$-ax. CXLV. do do $5 \% 8.81 .-a d$. cx<VI. do do $5: 259.00-a d$. cx<VII. - do do 5.25-9.06-ad. cx<vill. Ageläent fhornicens. do 9.06 15.00 ad.

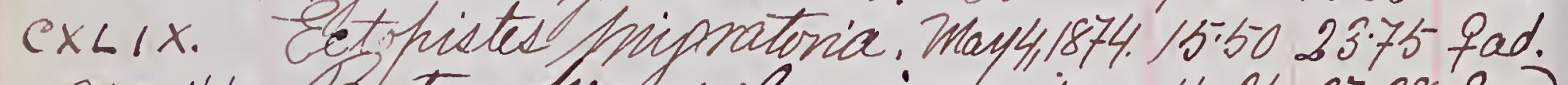

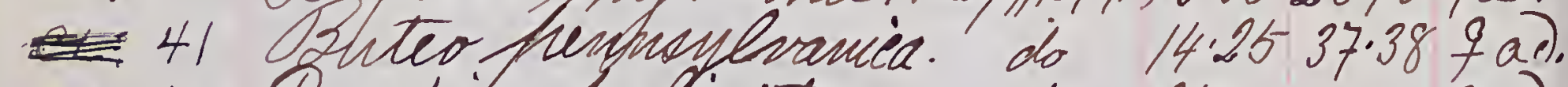
42 Pandibu habiaetus. do 25.00- rad.

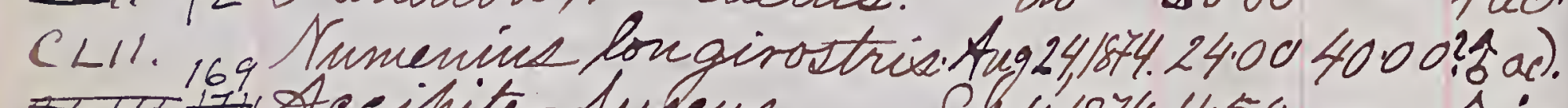
Aceifiter fukeul.

$C \angle I V$ Siurus antocafillus. $c<r$. Ohrifsonitis trietie cLVL. Sitta canadensie. cLVII. Colafites auratue.
Se.4.41874.11.50- ôju Sep, 0,1874. 5.00 8.5\% 5ad, Sep.4,1874.4.75 8.25 हad. Afu. $14,1874.13 .0621100$ हैad. der 6.319 .44 整ad
Collecting
Numulber: хмме DATES.

LOCALITY:

CLVIII. कैerdus migratorius. A/M.14,1874.925 14.62 -ad. CLIX. Dendrorcal/halmarm. do 5.56 $8 \% 3$ åad. CLX. Molothruk ater. Afr.16,1674.7.62 13:56 1 ad. CLX1. Pecis fubracens. Apr.14,1874.6.81 $12.00 \hat{b a d}$. CLXII. do do $6.8112 .00 \mathrm{Fad}$. CLXIII. Regulus calendula. Af $16,1874.4 \cdot 256.81 \mathrm{~s}$ ad. CLXIV. Shirus motacilla. Afr. 15,1874.6\% $10.00 \mathrm{fad}$.

CLXV. do do do $61910.13 \mathrm{bad}$ CLXVI. do Thr. $0.18746 \% 310.62$-ad. cixvII. Regulus calendula. do 4.196 .81 sad. CLXVIII. Sirbue motacilla. Afr.24/1874.606 9.94 śad. $C L X I X$ Ejurdus fuallasi. 7.2511 .62 bad. CLXX. Scius furbreene. Afr.20,1874.675 11.88 bad. CLXX1. Gonotrichia albicollic. May5,1874.675-9.75 sad. CLXXI1. do do 6.50 9.25 हैad. CLXXIII. Aarforhynchuerufues. do $10.5613 \% 3$ sad.

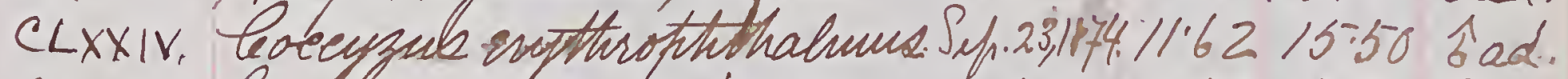
$C L X X Y$ leoceyzus dmericainut, do $12.5017 .31 \mathrm{Fad}$.

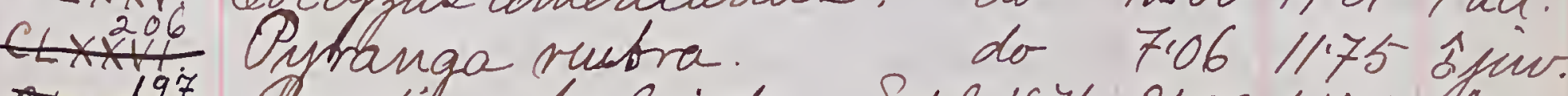

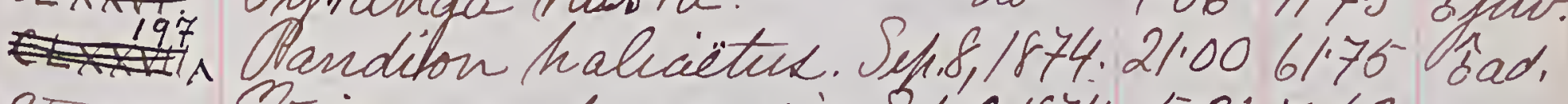
CEXXVIII. Mriev noveboracensid. Sef1.2,1874.5.317.62

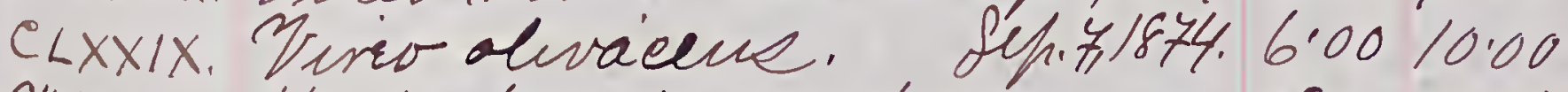
CXXXX. Harfrorhynchue rufus. do 130011.44 .

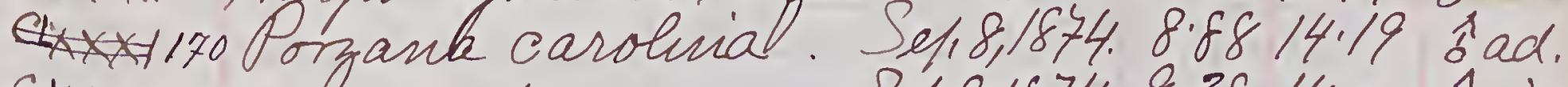

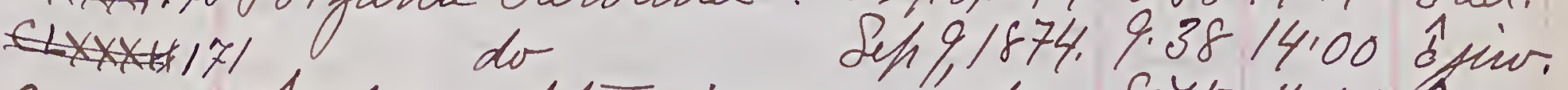

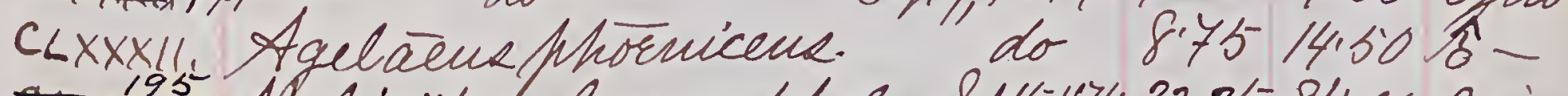

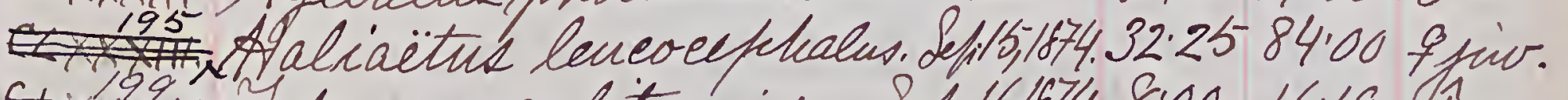

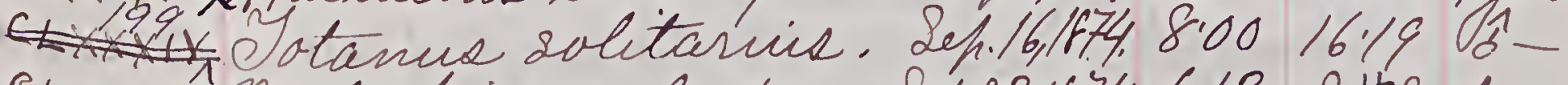
CLXXXV. Melospiza meloda. Sef123/1874.6.13 8.1p8 sad. CLXXXYI. Mireo blivaceus. do 5.949 .75 \%-. CLXXXVII, do do $60610.00 \hat{b}$ CLXXXVIII. Dendrorea striata. do 5.699 .19 o CLxxxIX. do do 5i62.8.88 f$C_{L X}{ }_{L}$. Cyanurus eristatue. Sep, 25,1874.11.75 $16.50 q-$ Cxit. Dorzana carolina. de 81212.88 \& jui. do do $8.4413 \% 3$ fir

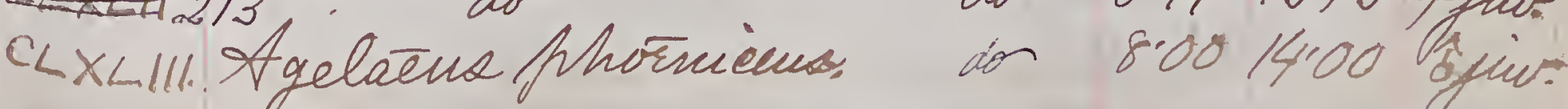


108

109

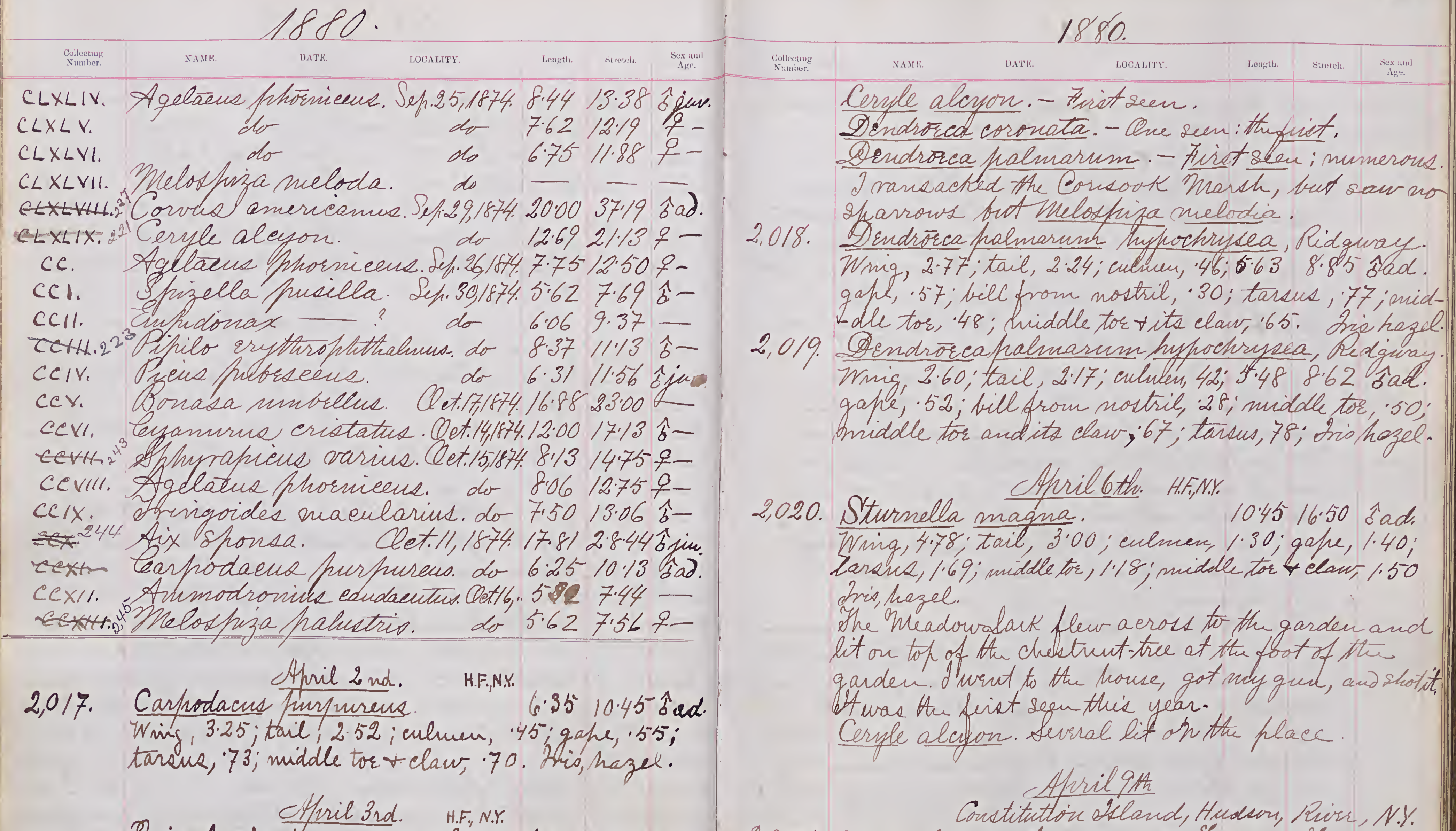

Zuiscalus hurfureus. - A large flock and sevid small ones seen. Then were the firift seen this year.

April 4 th.

Ofizella nusilta.- Firit seen.

Tegulus calendula. - Firt seen; singing. In comprany with the Galden-crested (R. satrapa).

Ahril btta.

Ofizella socialie. - Firit seen.
2,021

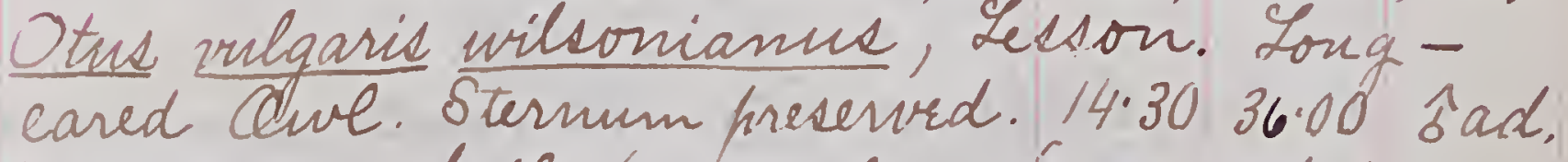
Wing, 11.00; tail, 6.00; culmen (measured from prontal feathere), 1.06 ; bill from noctril, .54; ape, 1.20; tarnu, 1.55; niddle tor, 1.11; middle tor and its claw, 1.65. Arrides, yeclow:

Antured by Mifs Anna B. Trarner. She hes a fragmentary egg in her catinet, taken on sta Fland which hobably relonge to this shecice Ar. A.K. Fisher hes an egg, tatken at sing Sing, 
110

111

1880.

1880.

r.Y, and identified by Prof. S. F. Bairct.

To-night dispected a frowl (Yallus domen-

- teind, which untained an ovarian tumor inches, and of hav it fresenroh in alcohol; it was encepsuled, and solid. disetoed on one side, to which thents attached by a hedielc; the other organe afheared to be quite normal, the the aseond structure wac deformed and its body fresented a square or flattoned

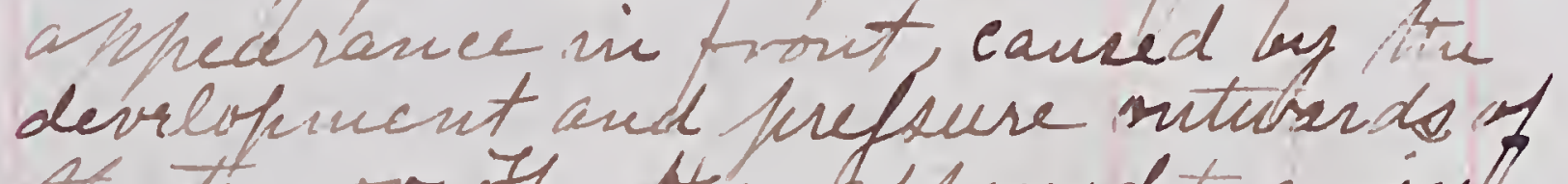

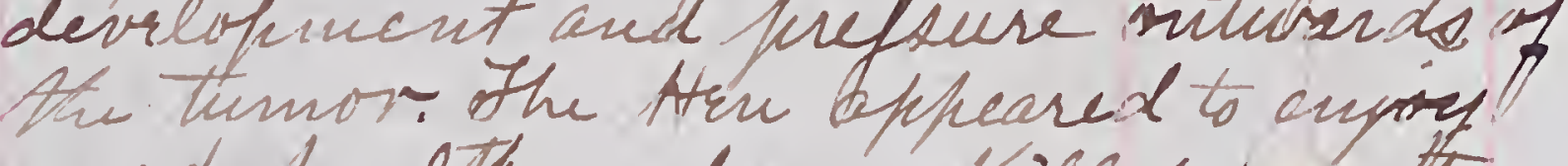
god health, and was Rilled for the table, and soed by the buleterer. Mn Prectior, D rH. P. Chace als sxamined the shecinem, and supposed that it might

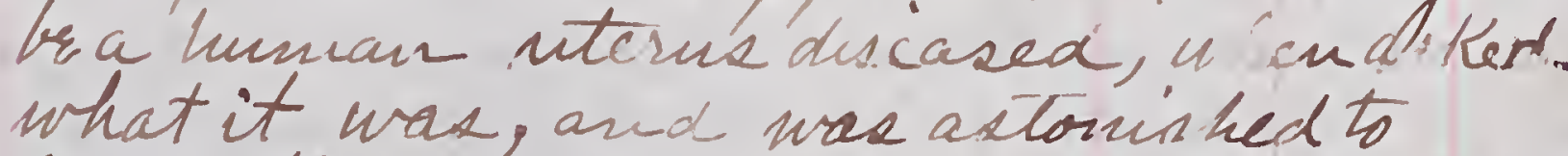
What it was, and was astonushed to had baw taken fons. onse. The label slif ni ale dot vafers ts th's note.

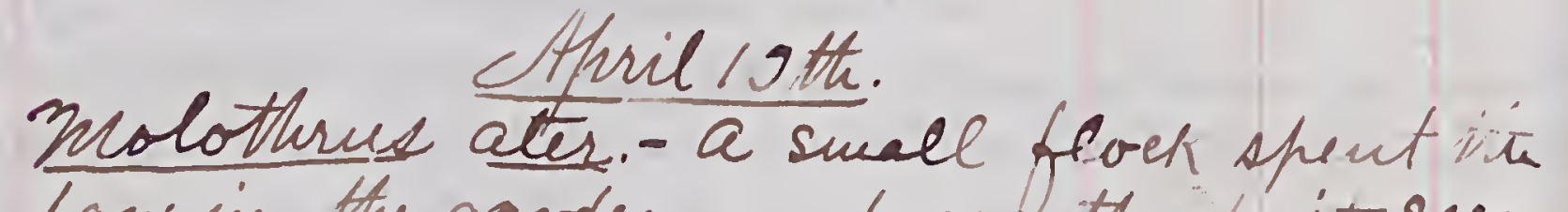
tays in the gorden, and are the perst reen. arrived some tine since.

Tenaedura clioril /Itt. varapram wo Dis, whe nat? searched for, but unsucecssfulci,.
Pame atricatillus. - A fuir mas seen Ate singe, which aphearect to te cogaged in brild-ing a nest in a wry slende, clead befing which loolled muele too sures

Oneks-

Tuceeded in cramling close upon a flock of D weks, ni Pell's Ptad, mont of whiek ture Duskr D weke ( Amas obseusla), int there mas one Mallerd Amas inowehas Hid si a lonely shot rin th aleep watods. Sayomis fusens. - A nest was notieed

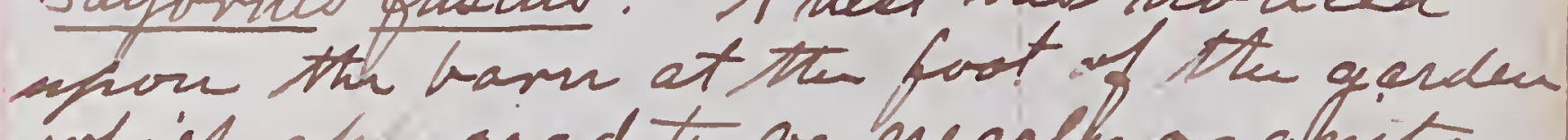
which of ared to ve nearly or enite finished on yesterday -the 10te. Yo-day in the nurgan's toride.

2,0\%2. Colaptes auratus. 11.9019 .40 fad. Thing, 5.88; trie, 4.15; culnem, 1.30; biel from tor., 82 ; middele tor and ite claw, 1.20.

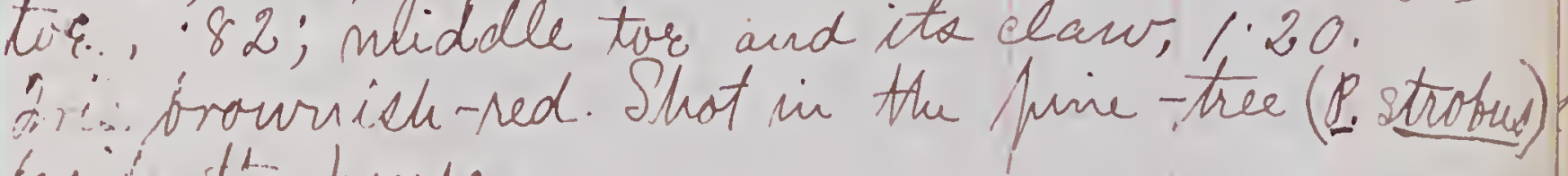
502.5 Mosthrus ater. $7.2212 .057 \mathrm{ad}$.

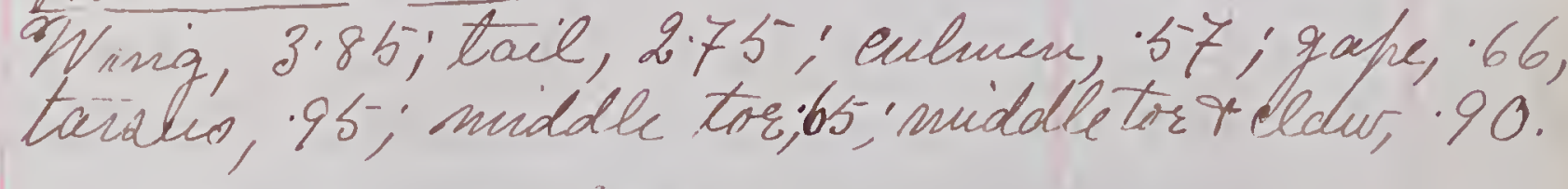

cthrie 13 m.

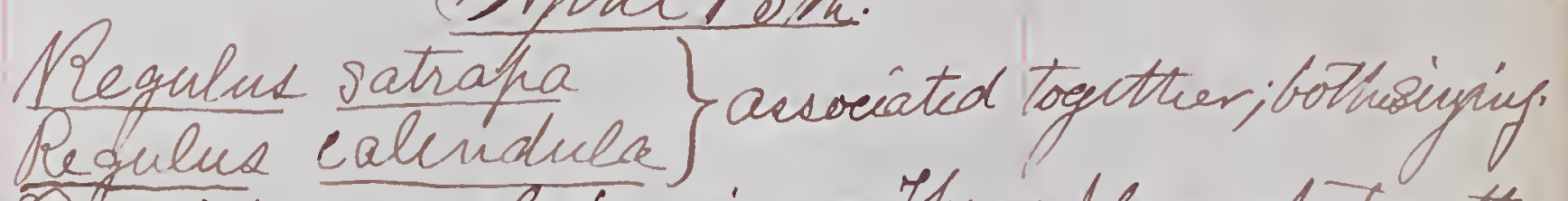
Znaidura carolinimsix. - Threc fleur nf Togettres. Fendirea falmarum. - Yhe piret Seen sinee the is: the Cene 
112

113

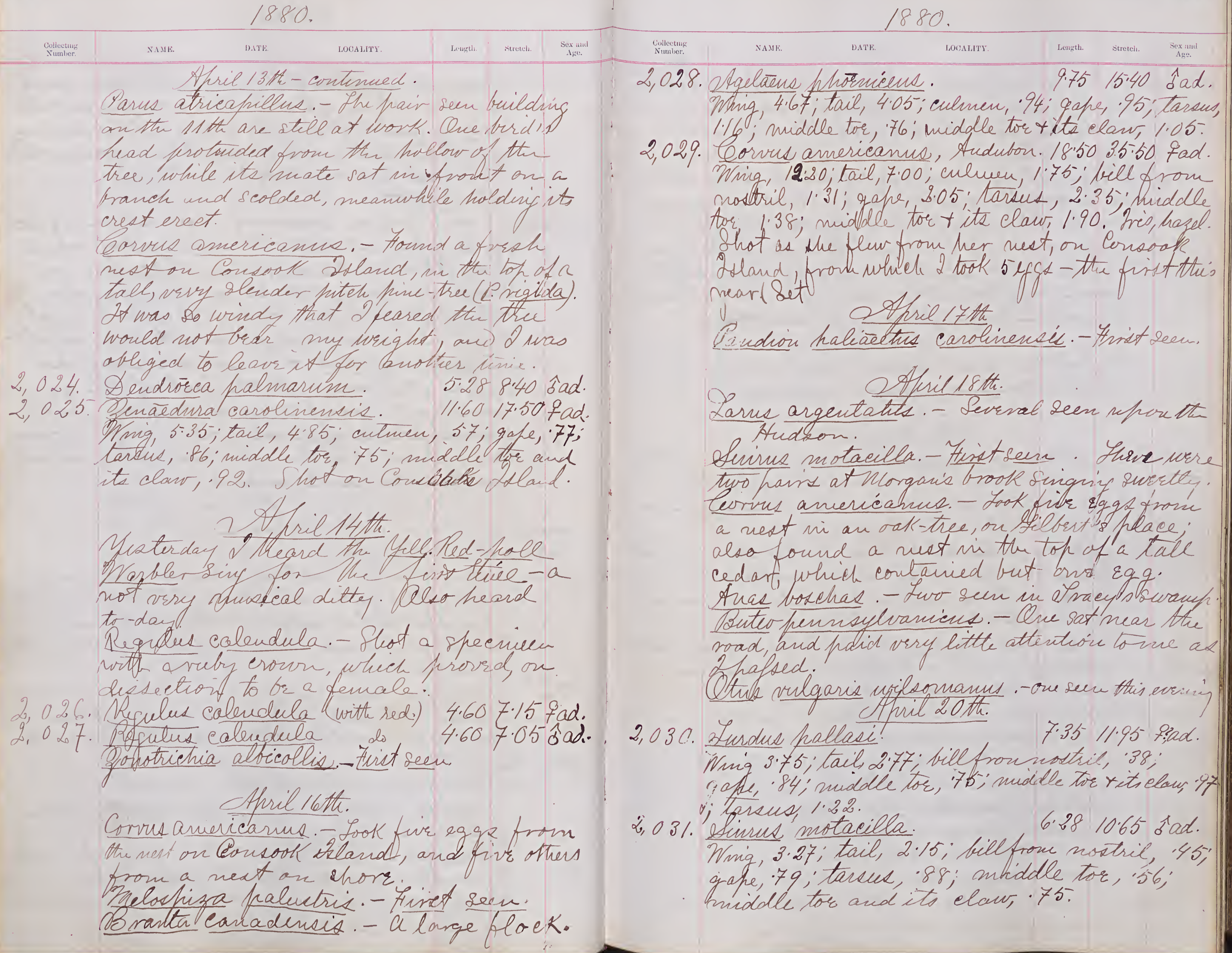


2,032. Simine motacilla. $6.2510 .40 \hat{b a d}$ Waing, 3.20; tail, 2.5; bell from nostuil, 41; gape, 76; tareus, 88; widdle tor, 56; middle tor and its claw. '74. Aria, hazel. Legerfeet, fleck-color; brfore death they have a berantiful glow of fuik. It was stuging in a tree-tot after seven ochek P.M. They are veually muscealitate in the evening thas Escura. - the livo Austy Sucke were sien this evming in Iracy's Swamp. Dindrorca halmarmu. Fringoides macularius. - First seer.. Antrostome vociferus. First seen

2,033.

$$
\text { Ahrie } 23 \mathrm{~d} \text {. }
$$

Halāens, phönicens.

8.9014 .60 sad. 'culmen, '85; gape, 90 ;

Lanuw, 1.10; middle tor, 80; middle tor and its claw, $/ .0$ s.

2,034. Shimus motacilla

$6.2010 .30 \hat{\mathrm{o}} \mathrm{ad}$ Wing, 3.15; tail, 2.05; bill from nostril, 44; gafe, 75; tassue, 84 ; suidde tor, 58; nidalle tor and ite claw, 75 . Dris, hazel. Bubo rirginianus. - A pair wre hooting this evaning, on the monitarsi toli- souttreact. fnned hymalic - Que seen. Haril 24 bu Aarporhenchus rufus. Firt suen; Singing Dendrorea virens. - First seen. Melospiza halustris. Numerous. miotilta varia. - Fist seen. Vireo solitaria. - Ecist seen. Buteo frennaylvarica. Whistling. turdus palbsi. - tar not becen wrin
Coulecting

2,035. Melospiza palustrix LOCALITS

ma, 2.33; tail, 2.20;. culmen 46; gahe, 49 . tardus, 84; middle tor, 61; middle tor andils claw. 85 .

2,036. Aarporhynems rufus. $11.8513 .75 \hat{\mathrm{d}} \mathrm{ad}$. Wing, 4.15; tail, 5.25; bill from nostril, '83. gafle, 1.40; tarsur, 1.87; midble tor, .91; middle Tor and its claw, 1.21.

2,037. Vureo solitarius. 5.659 .12 ad. Wrig, 2.85; tail, 2.27; bill from nostril, 30; gape, 60; tarsus, 73; middle tor, 45; niddle tor and its claw, 63.

2,038. Dendrorea virens.

2,039. Iindrorea vivens.

5257.80 के ad. 5.107 .85 sad.

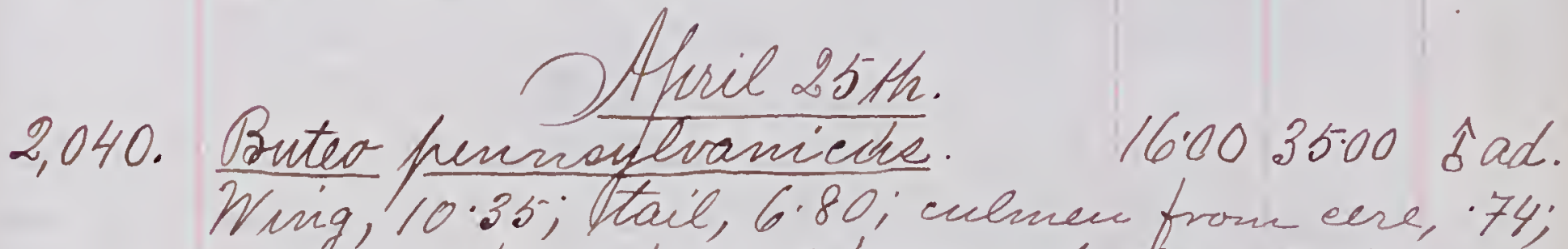

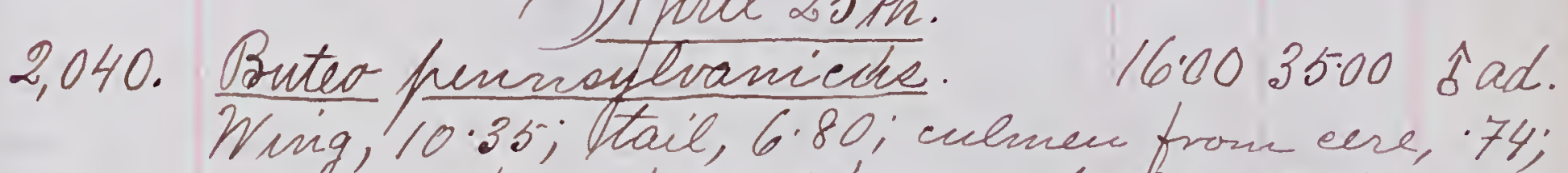
cere, 48 ; from frontal feattiens te the of bill, 1.10; tareus, 2.50; middle tor, 1.33 ; widdle tor y its lav, /.84; claw aloue, 65. Ardes fellow, except a traec of the brown of the im- mature bind. Cere, areanish-Hellow. Larsi and tors, sellow. Bill tclaws, blue-black. Fset muddy. Bencatt its eyelid wrre sone long, slendir white wornis, one of which is fresese in al coliol. Its stomach contained hair

of mier and moles, and some coleopterous thisects. Señmun preserved. Do nat. vinumber gor lo have found remain of Mirds in thirfomachs. Hnks find wak Mi viry hoor, emaccited conditroie, a< they mbually are at This deasou. 
116

1880

117

1880

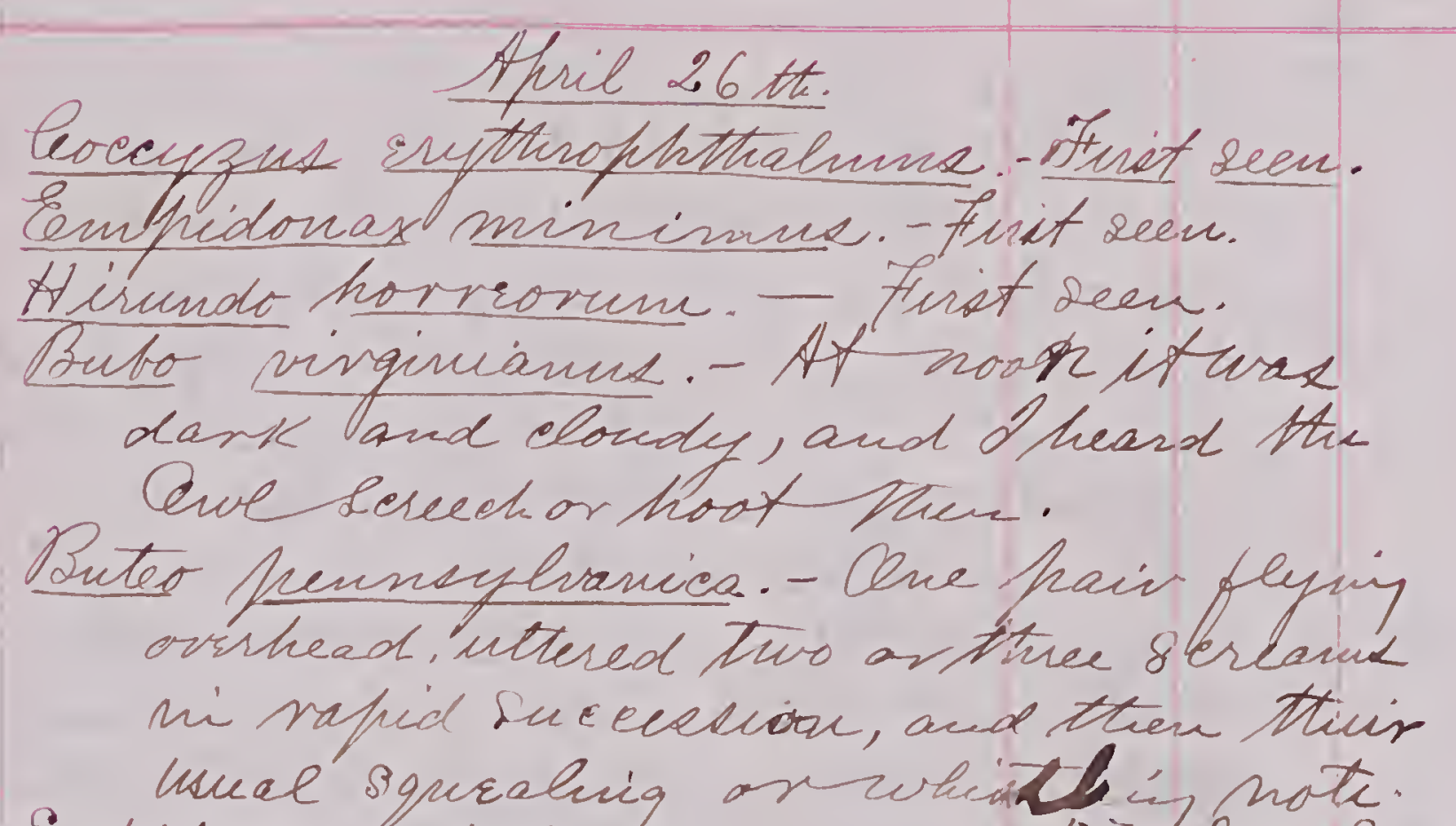

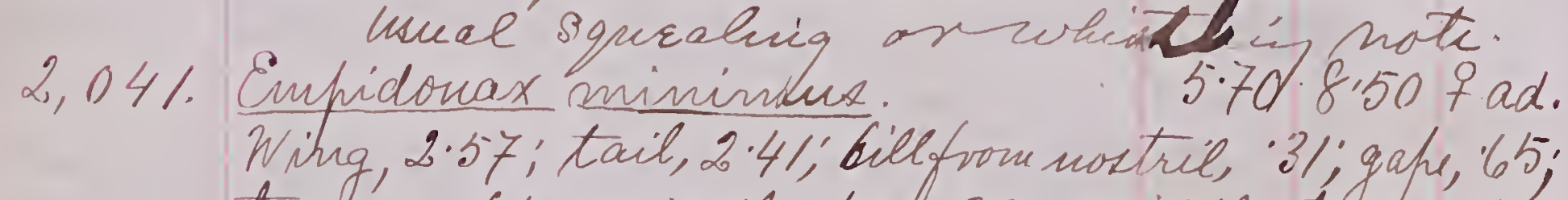
tardus, 65; middle tor, 32; middle to bind ite claw, 49.

so-dar look a tlong walk with the pur stor.

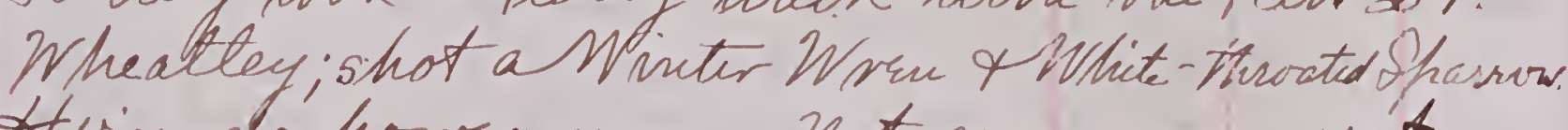
Heriundo howsorim. - Not numrrous yit.

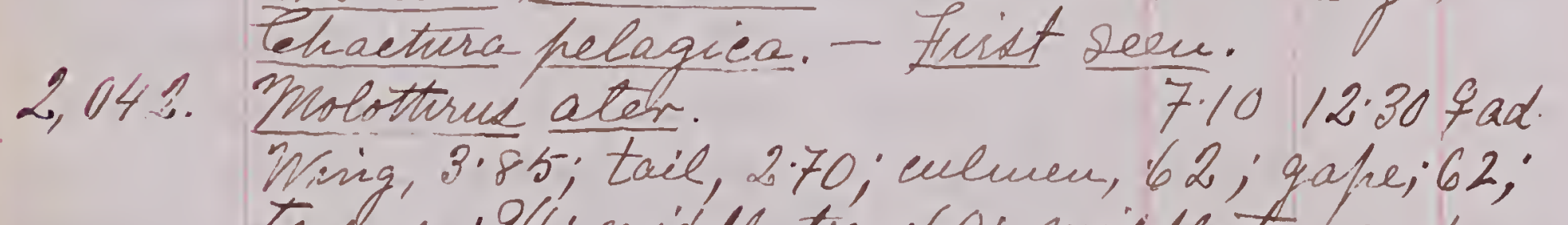
Wing, 3.85; tail, 2.70; culuen, 62; gape; 62,

2,1043. Mwlothrus 9.ter. 7.0312 .007 ad. 7.nin, 3.80; tail, 2.60; culmen, -60; gape, 60; Larkus, 90; middle lor, 65; middle tor and it elaw, 90 .

2,044. Jonotrielua albieallix. $6.0710 .00 \hat{\mathrm{s} a d .}$ tarkeus, 90; middle tor, 66; middle tore and its elaw, 88.

2,045: Anorthura troglodytes hyemalis:95.5.70 9 ad. Wrif, 1.65; tatil, Nios; bill from wortil, 32; gatre, 59 ;
Hroglodytes domptiens. - Forst seen.

Pifilo irythropththalmis. - Ationt seen. and drover it from the veinity of tris nest. 2,046. Colaptes arrature. $12.8521 .00 \mathrm{fad}$. Wing, 6. 35; tail, 4.55; culmen, 1.47; bill from mostril, 1.12; gape, 1.58; tarsus, 1.18;

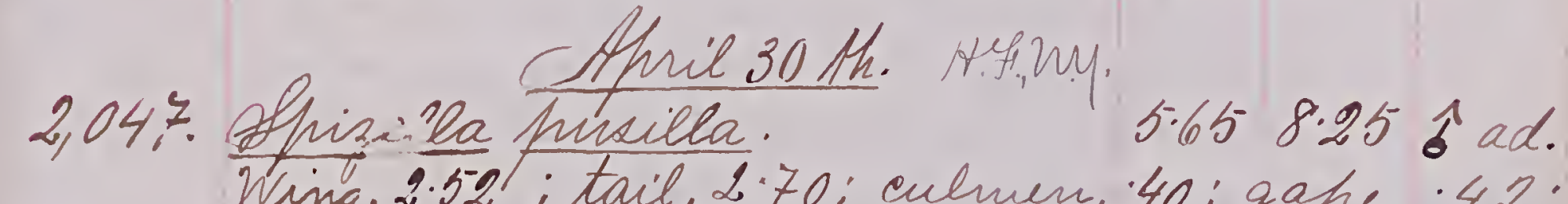
Wing, 2.52; tail, 2.70; culmen, 40; gahe, 42;
tarans, 74 ; middle tor, 50 ; midde tor and its claw, 65. 7 ris, red.

2047 a Airundo Enthrogattaca. 6.6212 .75 ad. Wning, 4.53: tail, 3.15; bill from nostril, 24; qafe, 62; tareus, 47; midble tor, 48; midde

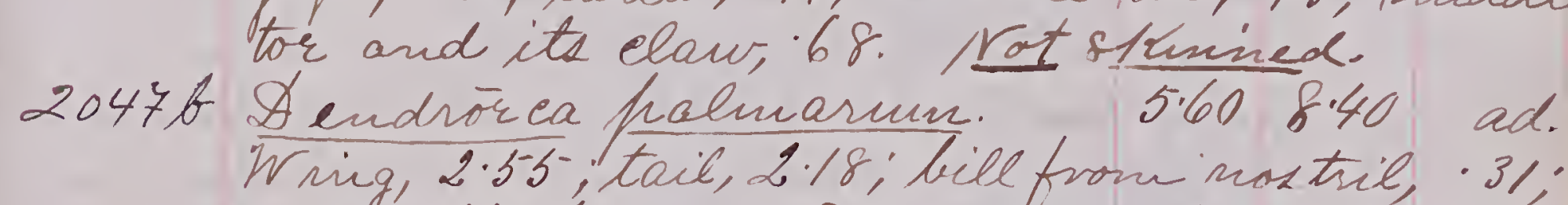
Wring, 2.55; tail, 2.18; bill from mostril, .31; tor and its elow, 67. Not stivined.

Mhrdus mostelime. - Frit sem. Cue was singing as I walked through Kirisley's coming from West Ponit. Stage form Newrirgh, to Cormwall. Mordua ereek bridge was bing cichilt, so stage wrens" má Vail's Sate. Saw numbrs of Shacklex of vars. pmpruene of andens. Of all the worribly sichety stages, Alest one was Phe it were filed sone long, butt, heary irou 
rods, which rattled dangerously overhewd. The horses wre lean, -ih fact shere steletous, and as the driver whifpeb 'in. up the long hills, " could mot help feching that "I was doing violecuee to my humduity by sitting on the driver's seat instead of fetting out and helping the horsue fruel, as my roads and fences wril hied with sturdy old cedart, and in three the gradeles were inseoneed. As we drove pastidencit bushing the branches, they hopped dour elase to us and leered at the bony mage aind peered into the coach and screamed derisively ot us and sfread their taild mi high geee as they. celled to the neighbork in advance tofioin mi the merrinent at our expence; and $d$ They wi turn fiered us as wr passed. ? coled not heif feeling asharned, ind involuntavily looked of the driver to

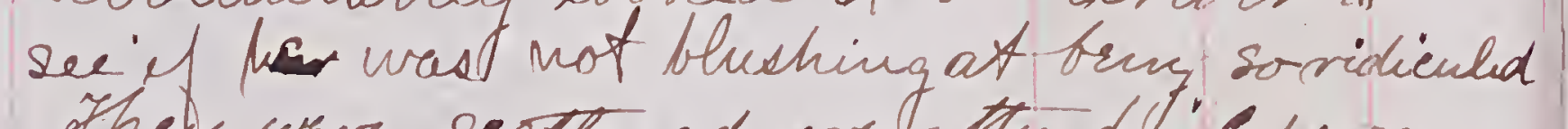
They wre seateried wret the flicds cre both fe: in of. the soad, and the Gronzed vakiety shone like gotid in the sunlight, while the fuirple ones geittered frilliantly ni ptrir metallic hlumage. I have never Rurwn Alew to fresd in the monitanis ibut in all the low-leping meadow country alme the thidson they cis so abund antey - especially where conifirons trees are aburta

Nyettardea qrisea näria.- Visited Strir Pharkeny on Constitution 28 and, and forme them abund arist. The flagman sand thy had Herm Nher. $\substack{\text { Collectiug } \\ \text { Nutumber: }}$
S

1880 Pandivin haliacetus cavolinensis. - Cre seen

Corvus ofdifragus. - An seen at Erimall. D got out of the stage at san Wrard's. Frund, the old gentleman very, ill, and his bor Lan was out Shad-fishrig. I wanted to sie a Black-headed Sull, ni their Mouse, but did not like to ask the danghter iso walked aromid the bay to Atre Conwall landin. On my way heard note mhich I reeognized to br Athat of a Fish Crow. I Sar Ha bird coming towards the, and if passed dirietty overt ming head so that is Mad a distinet vinu of it. Its note was munistakable; lunt 'l louged for a gien to make. rescord was also early ni May.

After dining with Mr.Ror at" Const.] Stlanur "Bofrdman" to Cold Shin and called upon Mr. Butterfart, a barter, who which he has made. Hi torks me up staris, and was extrenely frolite, and i sav the followin very interesting speciums which he took Minself at Cald ffri?:Larus atricilla. - Cne specmen in his evelectioin shot in Afprig, sevaral years ago, or the nir a few warles sice for mr. Clarkiboatbucilder at connale, where, Ath specmin was shot). He fromied to Show nue the letter which Ner.Clark sent him aceon; Io ? did mot learn the date.

nur. Butterfact saw arthind

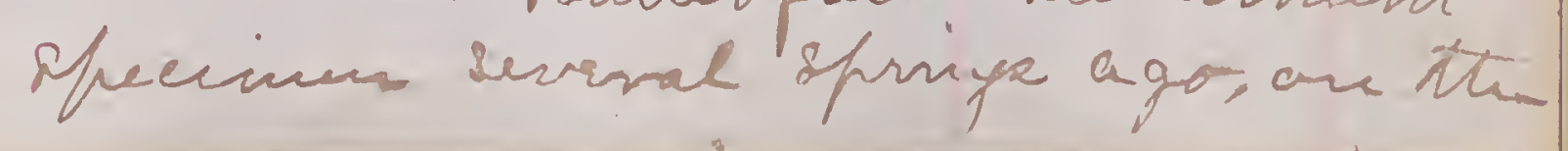


120

121

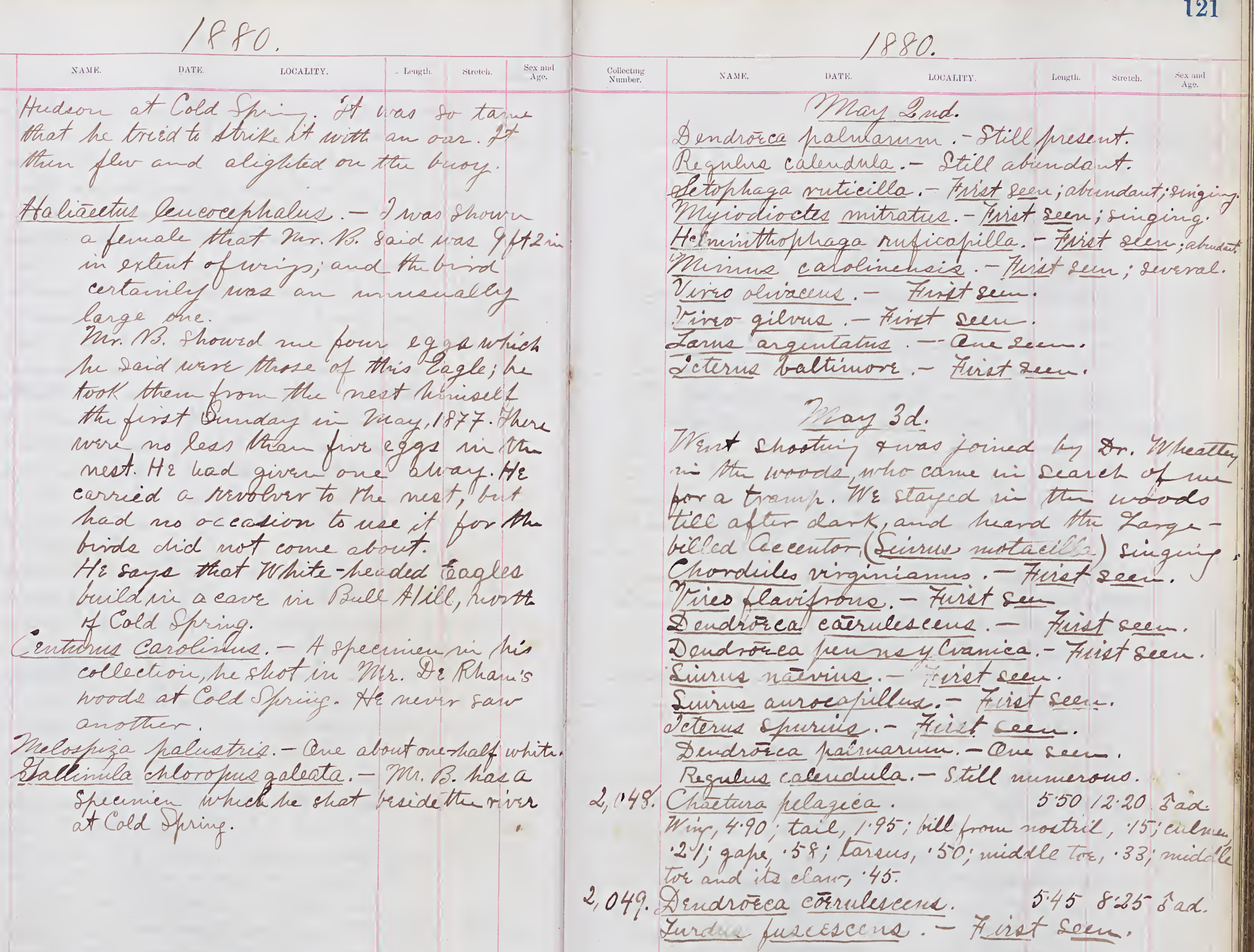


122

123

1880

2,050. Soniathea Maydoviciana. $8151325 \mathrm{sad}$. Win, 4.05; tail, 3.05; culmen, $72 ; .92179$ ; torsus, 92 ; viddle tor, 62 ; mididle te Regulus calendula. Still hresent. Pranca rubra. - Hist seen. Honiaphea lndoviesaina. - Tirst seen. Eagle. - Tur. Edward S. Dentou and mypelf, accouprasied by the Rew. D... Trheatley, shent a numbar of hioure in making a thorough exploration of the Cro'Ment clift and valley in Seaph of thr nest of thin Mhite-headed Eagle which certani large hemlodk (Abis canadessis) which he foriter out near the shouldn

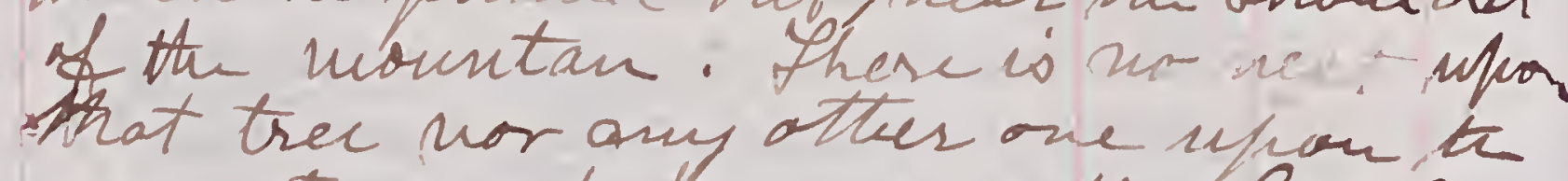
mountain ibit we. Saw the Eagle, and it doubttefs has a wert nitom Alc Cedge, sonewhere alou nue of th Al highest point of the mouritiani tho miflenton descended at the poot of the cliff and Iat the tor, all the wa to

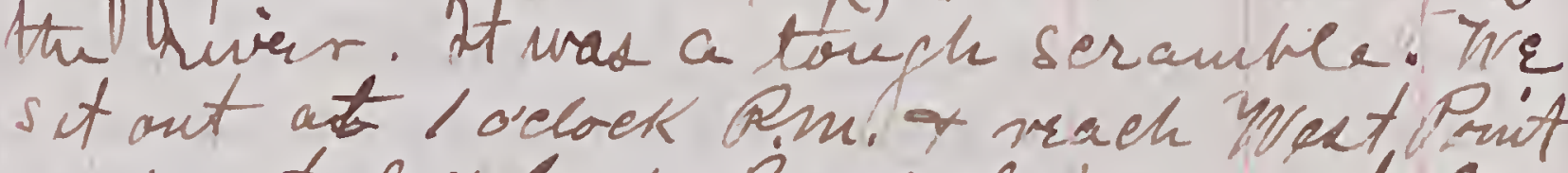
a rin of sorboek. Reached home at lleven , having sufped at the Ponit misth the othins. Bad brive + loss of miternine ent on shin, and no Eagl's sggo. No Duck Atarth

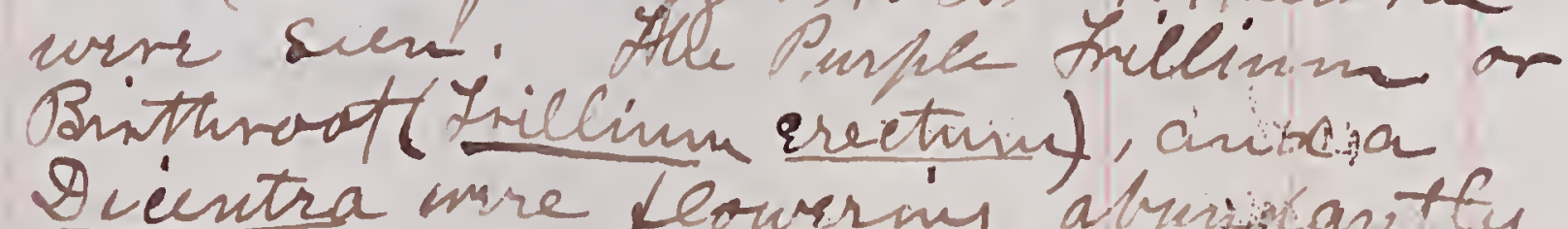
Dieintra mre feowerny abuisican tfy

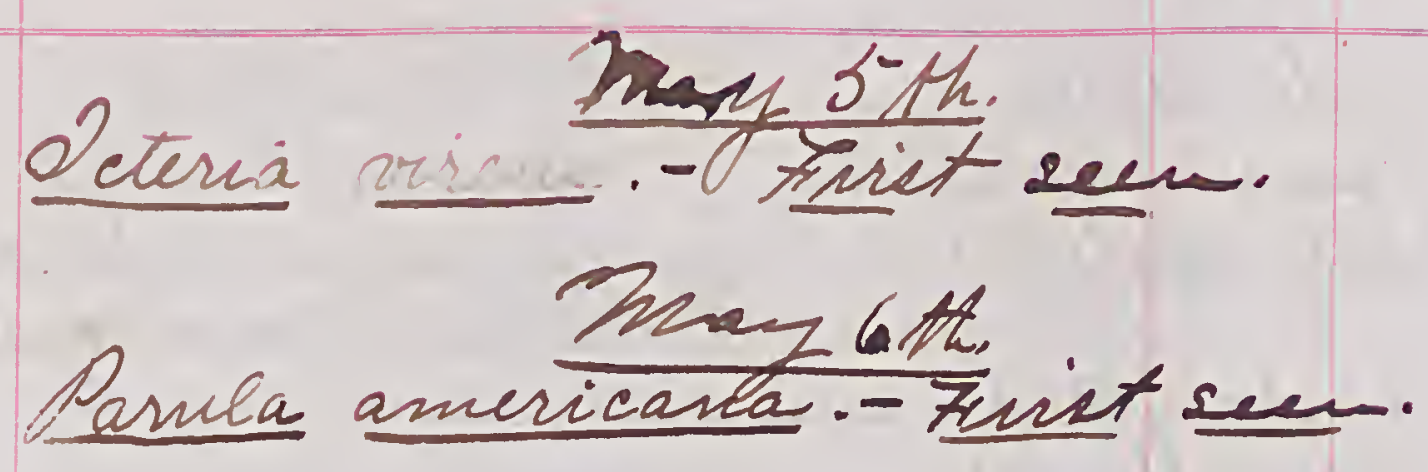

May7th. Hint seen.

Gipanospiza oydnea.

Sitta carshinensix. oliel present. Mryiarchus crinitus. Frist seen.

May 9th.

Lurdur swainstui. - First seen.

Dendrorea aestriva. - Hirat sen.

bendrorea maenlosa. Frist seen.

Dendroree striata. First sem.

Myirdiretes canadensio. - Hist seen

Almitherne verniviona. Frist sem.

eothlypis triehas. - Histseen.

Thay 10 th.

Sitta caulinentis. - Hrand to-day

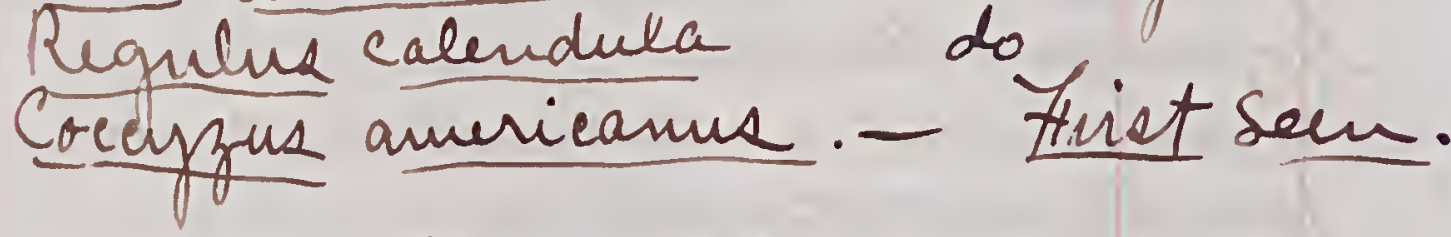

A list of all May / therds.

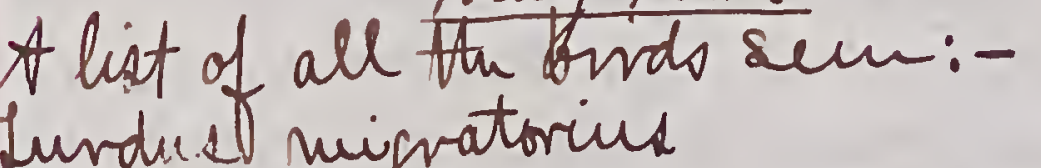

Lurduc nigratorius

furduc ancivion'

Inrdus fucesceus

Minut cartinensia

Harposhypehua rrefua. 
124

125

1880

Sialia sialis.

Parus atricafillus.

Sitta carolinensir. - One is probarly bresdin nearhere, an it is secu coustandty. croglodytes doniestieus.

Mstioticta varia.

Parula amerieana.

Helmitterus verruivorus. - Lite numeroue.

\$thinithsphaga chupoptera. - Must tre quite nu-

- metorla, for a nunber were den and heard; firtsem

Delmnthophaga suficopilla. - Seen in ofple-tres.

Dendröea cörulescens.

Acndrorea striata.

Dendrorea maculosa.

Dendrorea fensucylvarivéa.

Dendrorea atestival.

Limus ausocafillus.

Siusus naevicus.

Surrus motacilla. - Searched frittessly forsect.

beothlyfis trichas.

ederua virise.

Myiodioctes nitratue.

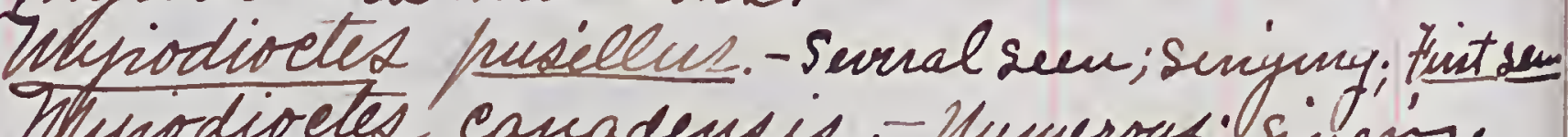
Mhiodivetes canadenkis. Humeroux; singin.

slophaga rutieilla.

Pyvartga rubra. - Abundant.

Hinuble horreoum.

Anpelis cedrorum.

Vires solitarius

ireo flavifons

Fireo noverovacensic. - Fist seen.

ries gilvas.

Viris olivaceus.

Carpodacus purfurens.

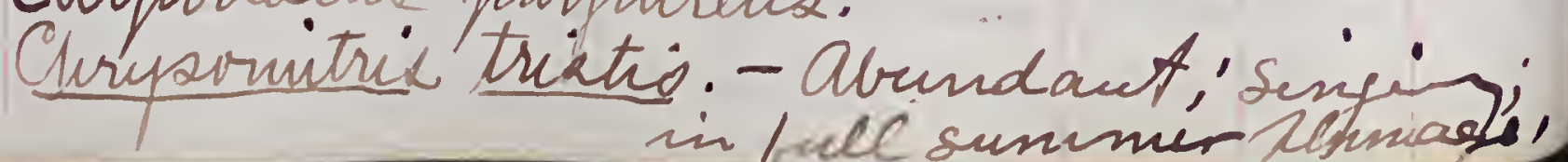

Fhelorfiza melodia.

Spizlel socialis.

shifella pusilla.

Prtrichia albieollis.

Passer donesteins.

Cyanospiza cyanea.

Philo shy that ophttealmus.

2 cterus sf pusius.

Q cterus Valtiniore (- galbula).

Corvus amescianus. - Verybury feeding young, which are hearly out of hest.

Mriardus crintus.

ifranus carolinersis

Shyormix quane

Contopus brine. - Fist ecen.

Enfidonar minimus.

infidonax flaventris:- Firt sem.

Intrabits suanfy fields frown

uf to uldest and has curcoiz mite.

Antrostonus veciferese.

Cleordciles virginianus.

Cliâtura pilagića

trochilus colcibris.

Cocenzus erythrofittialmus.

cocyzuk americanue.

Corsle alcyou.

picus fubrscens.

Olafite curatur.

Iringoides macularins.

Adla viraceens:

2,051. Enfidonax thaillii. $\quad .6 .03 \quad 9.40 \mathrm{sad}$.

Wing, 2.85; tail, 2.31; bill from nostril, -35;

gahe, 70; tarsus, 66; midle tor, '42; mid-

-dle tor and ito claw, 58 .

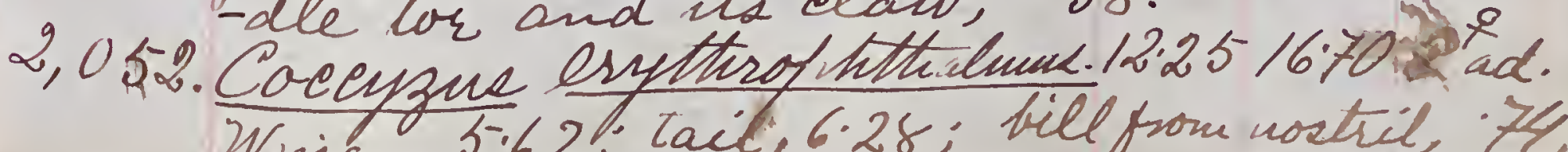

Wing, 5.62, Tail; 6.28; bill from notril, \$Y. 
126

127

1850

1880

yape, 1.27; tareus, 1.02' middle tor, 79; middle tor and its claw, 1.06 .

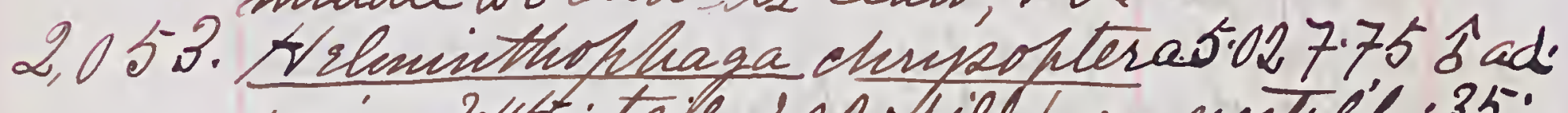
winf, 2.45; tail, 2.02; vill from nostrl', 35; gafie, 56; tarsus, 66; middle tor. .41; middle tor and its claw, 57 .

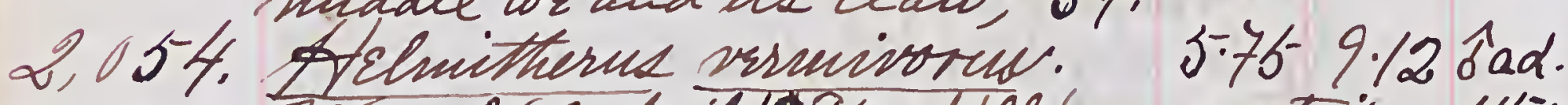
Prin, 2.82; taild $195 ;$; billfrom noatrie, 45; gahe, 71; tarsus, 71; middle tor, '53;

3,055. Midde tor and its claw, 67. 4.88 6.57 fack. Hhis, $2.02 ;$ tail, $1.85 ;$ bill from notrix, 25; gafe, '50: tarsus, 72 ; middle Tor, 46; middle 3,056. Mnjodivetes fusillus. 500 6.86 sad.

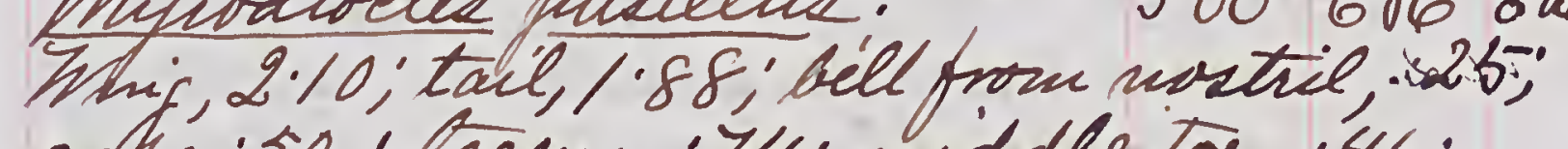
gofre, 's0, tarsus, '74; middle tor, 146 ;

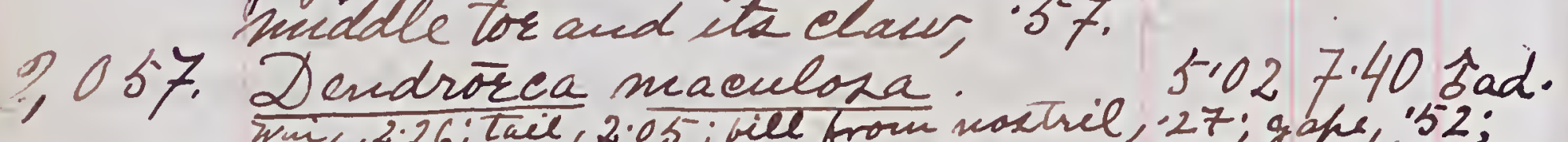

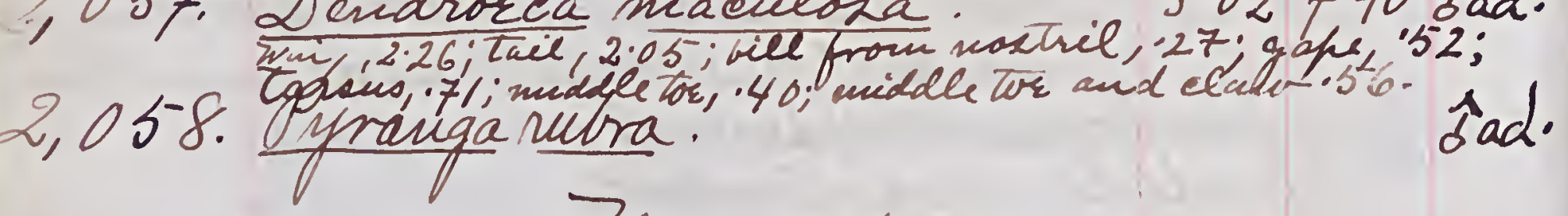

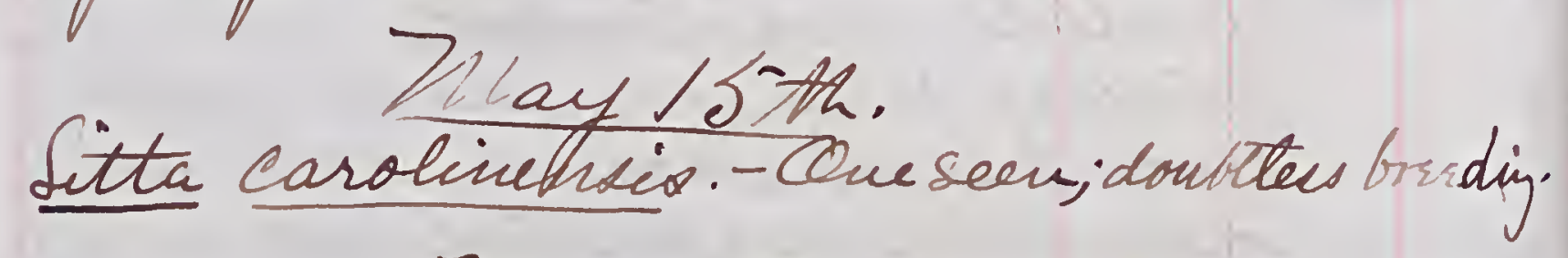
May 20 供.

Sitta carolinensis. Heve notied one ebor mi grandfatterís stable, where it is hrobabley bredin.

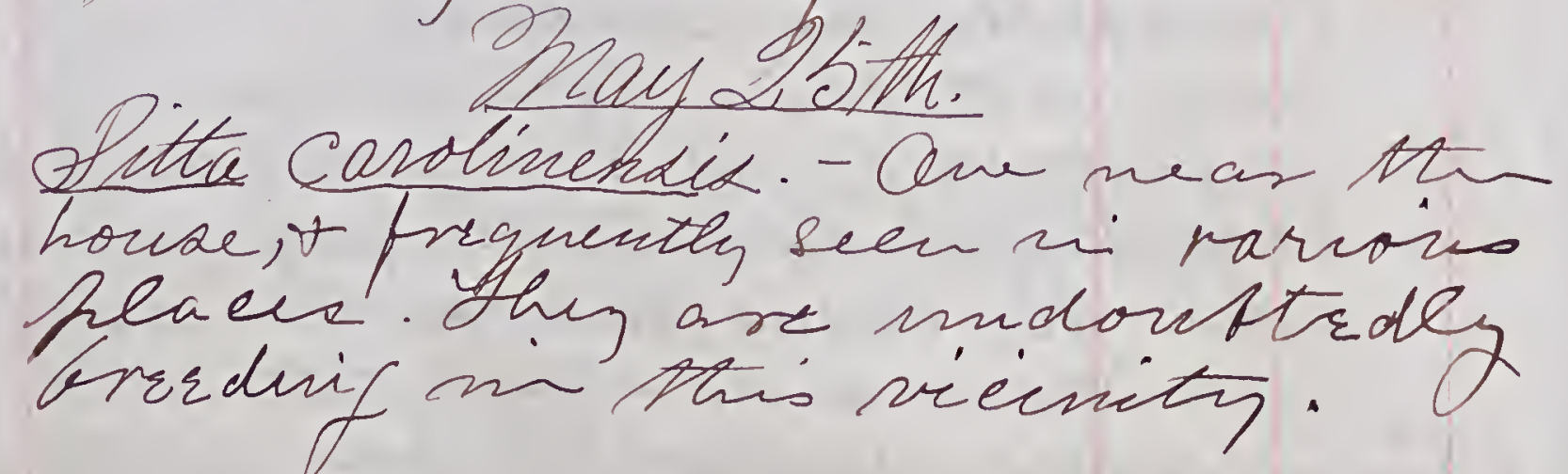

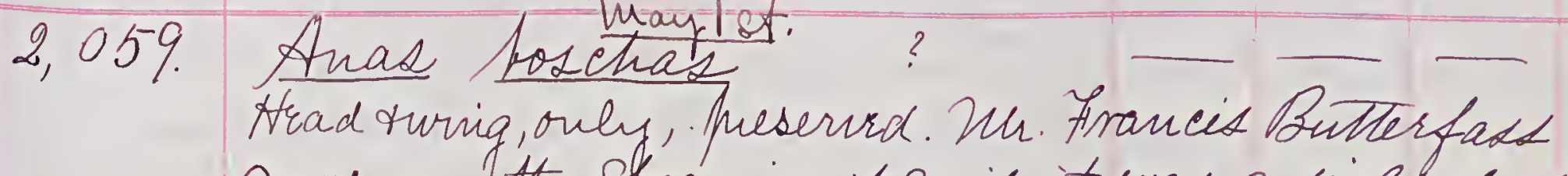
gave nue the sfecmien, $\forall$ said it was a wirld duse Whet had bren wounded, on the Atudsonj mear yard titl May ist, when he killed it for the

2,060. Nonasa umbifless.

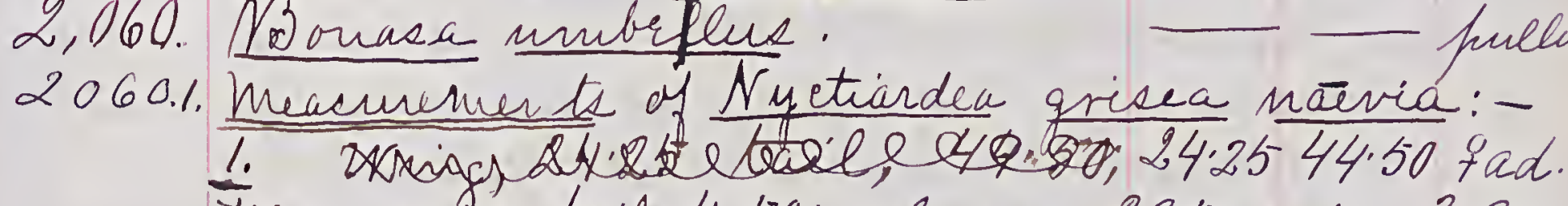
Wing, 11.40; tail, 4.50; culmen, 2.85; gofe, 3.90, tardus, 3.2.3; middle tor, 2.96; its claw, 62, middle tor and to claw, 3.57 .

2060.2. Nyctiardea grisea, natevia.

2.Whig, 11.60; tail, 4.55; 25.9045:25.10ad. culher, 3.10; gape, 4.10; tarsus, 3.20; midle tor, 2.92; its ceaw 62; middle tor awd its claw, 3.52. Shot on Coustitition 2d. by Ionix A. Zeregas and Sfoinead by he

2,061. Jrochilus calutrix. $37.754 .125 \mathrm{ad}$. tarsus, 18, tail, 120 , culonem, 67, gape, 80, This Aummingbird Killed itsef by flying against a telegraph wire. sura carolevenses. - Arequentty seen aboit. Zo-day is thin leongest of the year Returninig from new fork by rail, I saw behind ith montani wext of Font

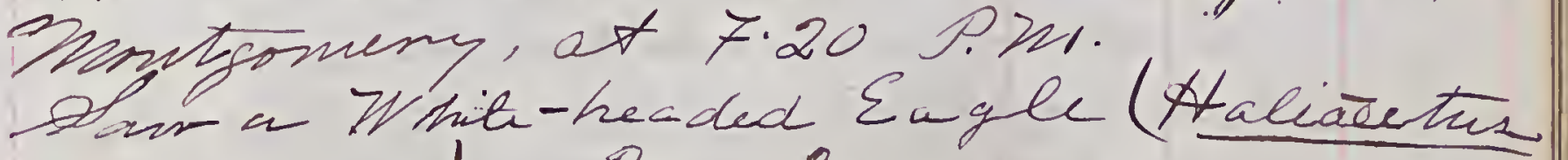

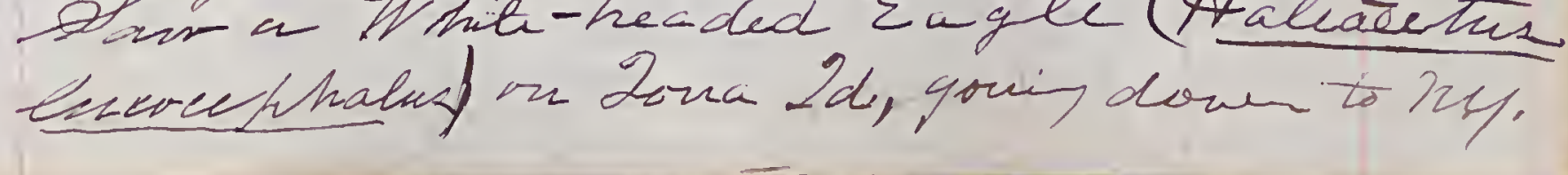


128

129

1880

1880

DATE. LOCALITY.

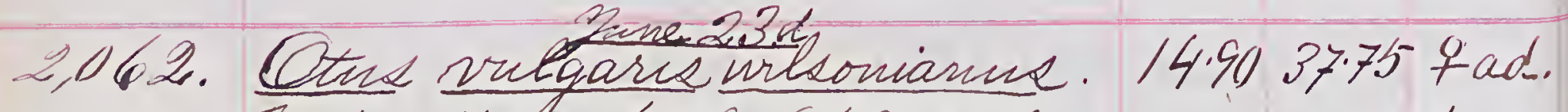
Wring, 11.01); tail, 6.40; culver measured pom portal feat here, 1.15 i measured front cere, '70; gape, 1'32; tarsus, 1.68. Os-dary sowed, wi the aflensisos, with Dr. Wheatley is to Conatituterie Leland, ire visited the floury, and found that mart of the young Atreus had left the nests; but a considerable unniber ware still e calling in the nexla. In sore of the young half-groun birds is most reiphlar. Lie a dulls were mumergar and very nocicis. Form Ruffed House were minuerais, that wire alreggle on wing pu 0 te, when Loris A. gera ga visited the tterourst procure a specimen, which I Akin ied. he came upon a family of Lng- Eared Ques (cetus vilgaris vilsonianus). Thu appeared on see wry red Nitugh the sun was dazzling bright. the sat tret ard frequenter fleck a short all fluid a way t could not again br found. An her 6 th

Sita cavolinenoix.- Coustanthy present. Predrogea rives. - Saw a fair that, from Their actions, I have no doubt wire near their nest or young one they wee in the herulock trees, fist South of Dais ow s.

Jo-dan (Lundoly) walked to Highland Lave, around Pta late, and so home. 2 Nt w oed fort to the north of Pojoflen Creek. There a young Black- Throated Prrentrarbler (Dendroeca virions); and, while calling it a fine WormEating. Warbler came close te where I stood.

Af fine Woodchuck (Arctonsus monas) was seen close to the shaft of a mine.

During the night, 2 the ard the Night Herons (Nyctiarblea grist ravin) sural tires.

At and Night trons ag aim last night. 2,063. Myiodivette nitrates, .. 5.658 .00 fad. Wig, 2.50; tail, 2.32, bill from nostril, 31; gape, 60; tarsus, 76; middle tor and clan; 60; middle tor alone, 44.

It was picked if dead in the main hall, at Cozzena West Point Atoll.

Note.

"Darg e-billed Water Threes. - The neat of this species $\overline{\partial d i c}$ covered in a marsh under some low bushes. It was situated in a tuft of sword grass one prot from the ground. The nest is come what elongated, composed of sword grass Municipally, and lined with five grass and hairs. It was six inches long, and contained

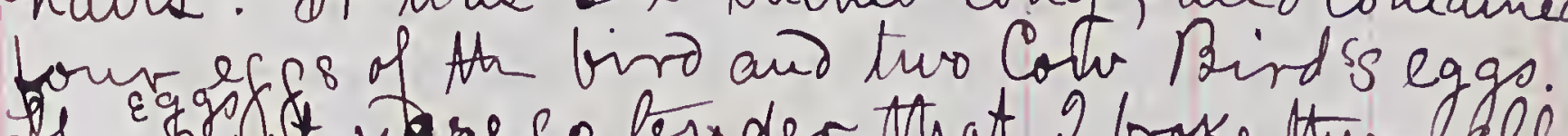
the were so be rider that I broke them all but one. I judge it to be about 65 by 50 inch. W. H. Below." $\therefore \quad \cdots$ IV, No.4, $1.27,1878$.

Lo -day visited mono in tralee with a party of Cardie. Coming out of the Cruck, a Rail flew in and 2 had a distinct viii of it. It was Ralline virginainus, which is probably the species whose meet 
130

131

1880

1880

Mils Anna Warner has, from the same masts. Alminthophaga unficapilla. - A very pretty Nashville Waster was seen in a frar-tree in my garden.

Trent thialaflemone in search of the Vii- livia Rail seen yesterday. Faded all Horregh the marsh but did not see so nimes as a feather of it.

Arden herodias. - Shot at a fie adult speerimenthat wo rs dancing about and flapping its wings in the most lively manes among a lot of lily-pads. An otter fir i was seevifor a long time past they have been seen flying towards the mountain at dusk -all sublimer in f act. The species is resident in summer, but its nest has not been yet detected.

2, 064 - Vjetiardea grieg native. I - in. The Night Arrows tot spong-ofthe -year, ash adults ware grith mu- mesons in the Arron ry on Constitution do, Having shot two of the young, 2 ascended to a thigh treetop and vising the swamp front my lofty perch, and saw a very interesting bight. Other crouching forms of the found birds, so hard to get sight of from the Ground wire seen distinctly and in the pine -trees farther off a mom- fer of old $\forall$ young ones were situs, winkle other old binds flew in wide circles over rh e ad. lota a hive Dore (Nenāedura carolivensis) on the RR. Track, and a hair each of karen Bank Swallow rus. We left the marsh at dusk when the Night Arrows were Firming to come out and feed on: the flats. They feed there all night on moonlight mights and come to the flats in large numbers fist at daylight - Especially should the tide bl ont, leaving their prey exposed. Bats were very, numerous; as we rowed across the cove at least so could br seen at on de. Is hot one.

Asminthophaga ruficafilla. - Que ni a swamp near Consort Ls land. Aremitherns cermivine, - Che si th swan: 1 . Came at call and staid near ne some thine iflew site a tree top and ratted a binmen of dryleavs, probably searching for fidel. Its note was sharp and neetalle.

Went shoots with A. K. Fisher. Shot four specimens of Mjiodioctes mitratus, and

Hremitherus errmivorus is spite numerous.

2,065- Pipilo arythrophthalmus aria hazel- - Eu. 2,066. Contopus vivas. 6.6010 .90 sad. Whig, 3.40; tail, 2.65; culmen, 65; gape, 83; bill from nostril, 42 ; tarsus, 50; middle tor, 32; middle tor and claw, 48 . Fyctiardea gorse naevi. Law it at Pals pond. Jotanue solitaries. - Sow track e which were probably its, at Dells Prod. Lives nootacilla. Q ne seen at Pele's Pond brook. 2,067. Imsiodioctes canadensis garza carolina. - Que shot: Th first seen this year. The only one seen,- at Consent Philohela minor. Consort suaver. 
132

133

1880

1880

NANL.

tugust 24 th.

Pandion halaretus carolinenses. Fist teen sinc Spring.

2 tuquet soth.

Mzyiodirctes Initratus. - A fine male seen. Nyctiardea grisea nâvia, - Serral wre seen ohn Angust 23d at "Eeteo Rake", brtino my house.

Leptember 1 st.

Dendrorca falmarnm.- Ane singing ito add little soug in a pear-tree in wif gandian.

September 7th.

Arodilus colubrix. - Seen at Aygheand 7 alls, and yite munersus nhon Dt. marshes near Cassetitiction Leland.

Ardea herodia's. - About a dozen arose at $x$ reprost of the first gin we fired in the lours Love, leveral lif on trees in frean virw of our boot, and one succeeded in eslablishing itself upon the very summitt of a high hemlock true after flappting oud balancing for donf wime is atternted to AtafK them , while Nur. Wheatley lay ambushy hi th boat drawn uf undes th low brenches of theed that shaded th. Crecti, he thus pro- cured. two shots, both of them unsuceessful.

Qne Ireat She flew out of the Noght tiroury on th island fiat at

this and flew doun upor

Haliäletur leucocephalux.- Anlyous , an adult bird sem in it lown con
Collecturg
Number.

NAML:

DATK.

Buteo fennaylvanicus. One flur close orr my head, and lit a liltle way in advare imy un was loaded with "B. "and "dust" thot i g fried the dust at the Hawk at it close to nu upon a hinb eyein me curionsly; I afterword shot it aglain; it fell in Ath trees and could not be recorro Ardea Nives eens. - Numerous.

Sitta canadensis. - Quefird.

dyrminm nebuloum. - One heand.

Scope asio. - Abundant; heand at nights. Selmatodytes palustris. - Still vrry flentibul. and very noisiy. Found in dryanteadows Autrostomur vociferus. - Arand to nizht; has baren heard regularly of ldte.

Se Aptember 8th.

Surdue suaineoni. - Que shot - the first sen

indrorea virins. -

Aindrorea maculoza. - Hirat secu. One shot.

Dendrorea frennsylvancia. - Cue shot. Sgothlypic trichas.

Simnk naeviux. - Several seen at Pell's Sond and alon the chore of Convore marsh Setophaga rutcella. - An adult male si qull plums was seen. Pranga rubra.

Dotannes minor. I fwid a slest at a bind whish g belicis to have bren a Bittern that was flyin high wind over Cousoote Nareh. Aceififter fuscus. Consman now. sciteo punsylvanica.

Pandion haliatetur carolinensis. Cne sen Ardea virescena.

Itrdea herodias. Plenty of its 
134

1880

1880

135

tracks about Pell's Pond.

Fotames solitarius. - Plenty of tracks

, but no birds ware about Dell's Pand when we visilial first but on returning we saw one jist aldeghtin; but it flent stececeded $\mathrm{m}$ shootive its mate. The Wrist bind flew very pligh and crookedly WV hen angratrig thery flef viry high.

2,068. Sotanus solitarius. $8.6016 .00 \mathrm{~d}(\mathrm{ad}$ ). Wrig, 5.03; tail, 2.20; culmen, 1.15; bill from nostril, $96 ;$ gape, $1.2 \%$; trassus, 1.25 middle tor, 95 ; chidócle tor tela claw, 1.13.

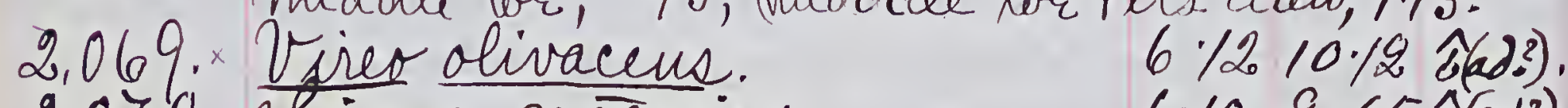

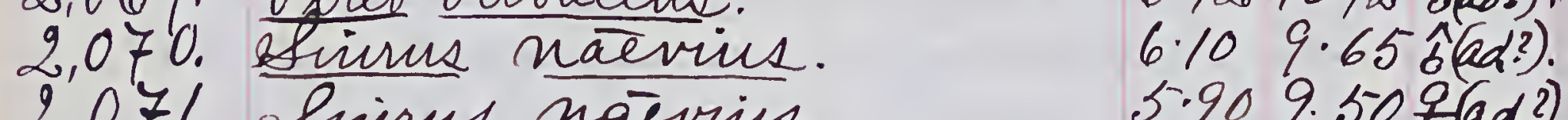
2,07\% Sirises natevius.

Oeptember 10 th.

Sitta carvadensis. One was shipifing Spruce tree in pront of the hourd. Dendrosea corruatea. best firist seento.day Lo-day is men. 24 th birth day.

Hies of armer. Sent me a Broadwriged A awt (Buteo kenneylvanica),

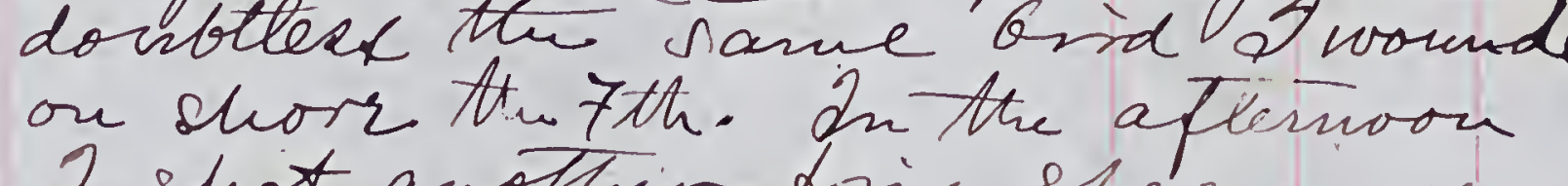
I shot another Frie sfeersoner th of Pele's. Dend. Q Totanne sdeitarine: - Qne at Pells Pond,
2,072. Buter pennaylvamies, Wils. 16153625 giv. Wing, 11.00 ; tail, $7 \cdot 10$, culven neasured from bake of cere, 1.10; measured from anterio gape, 1.33 i tarsus, 2.40; middle tor, 1.33; mid'dle tor and ite claw, 1.80; its elaw, s.

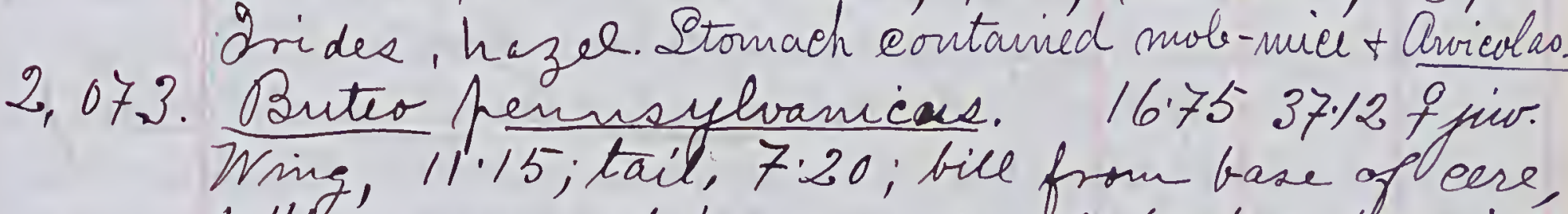
1.14 ; measured from antercor border of cers: 78 ; bill from nostril, 73; gafe, 1.40; tansu, 2.45; clavoalone, '62. 2ris hazel.

Seplentrer 10 th.

2,074. Prnjivichetes mitratus. Fust deen, one shot. Wmig, 2.55; tail, 2.20; bill from nostril, middle tor and ita claw, 160. 2,075. Myiodicetes mitratus $5.758 .45 \mathrm{sad}$. Wni, 2.70; tail, 2.35; bill from nostril, 30 , middle tor and ita claw; 66 .

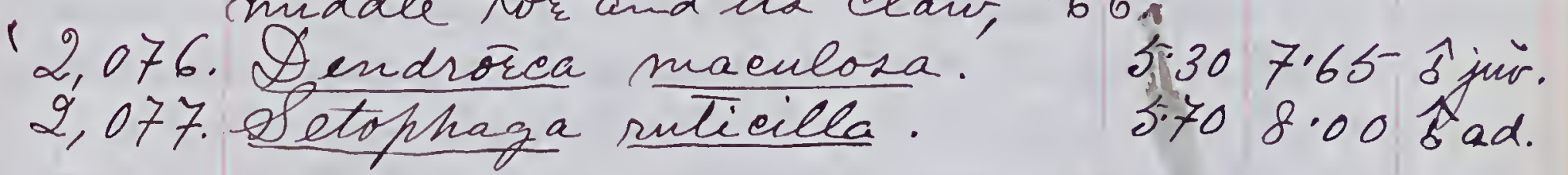
September 13 th. Arochilux colubrix. - Cene suen mi H. H. Dhis morming. This aflernoon one was seen it war raining hard. An the of temoon Xins. IT he atley and muself Lower Cove. 24 rained viry havd brfore we rached Trest Point, and wr took refuge 
136

137

$\angle F A O$

1880.

Ahe rasin ceased; and wr hoped for cerarni wratter; but it soon brgan to dozble-whik we wre rouring acrofe the surir - , and not a throu of any sort, nor yet an Eagle or thank was to be seen about th Car. We wre conflettly drenched, aw on andy consolation has in trying to shoot at the Rails (Porzana carolina) which wre numerous about the nouth Fr Andean fiall Brookibut our guns wre a succesaful ving shot ouring to thejome hanging firs; howrver, wr sencenged brfore dubte, to bag mine, only two of which wre adults. Ohe tide was hight, and cover was scarce, as ovey the fops. of the reqds wrre above uater, so wr Ofter had the Rails si full virw, Phough Arei wre vrry okillfue in taking arvantage of the slichteat cover. They oflen clane clos. bogether brin apparente, viry affectionat, but ferhape. ther wre one flesuldy, led ty the Rarente. At ofrequent iletirialls a Find would fly hep ni the air, and alight at a short destance. Shey wire retrench, frietly as they sat, or suran abouts

2,078. Parjane carolina! 9.3014./5. dad. Ning, 4,22; tail, 2.30; culucu, -89; Fill profh mostril, '45; qape, 9.3; taraue, 1.35; middle tor, XXt 1.37; middle tor and its claw, 1.67; claw alone, 37 . Iris, seddisl hase. 2,079. Pongana carolina. 9.3514.25. Trinl, 4.35; tail, 2.30; culwen, "87. bill from sostril, 43 ; gafe, 94; larsus, 1.32 ; middle tor, 146 ; , middle tor and its claw, 1.7's-; claw alone" 3.8. Oria soddich hazel. Bill, grevist-yelow,
2,080. Porzana carolina.

7.8514 .00 f jiw. No vratige of black on its Mroat.

d) picked out the plumpest Rail of the mie frids shot (a youry mail, whose throat was slightty murked hirtte Hack and its beast with drat. It wirghed $3 \frac{3}{4}$ oz., and fresented An following diridusions: 8.75 15.30 (s jur.) Tring, 4.50 , tail, 2.35; culmen, 84; billfrom noatril, '42; gape, 90; tarsus, 1.40; mildle tor, 1.45; middle tor and clav, 1.75; claw, 32.

Sleftember 15th

Ageläus phönicens.

2, 083. Steothlypis trichas

- - ôjur.

- Bfiur

The Wood Pewer (Coutopua Nring) uad hast seen on deptember II th.

Sefentem 16 th.

Frochilus calubris - Still fresent.

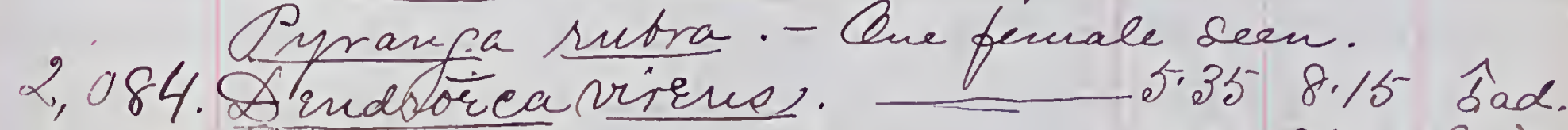
2, isiraleo colnubarus. 12.6026 .409 ju. Nini, 8.25; tail, 5.75; bill measured fhom we of cere, 72; culmen from cere, 59, bill from nostril, 54 ; gafe, $85 ;$ taraus, 1.57 ; mibdle tor, 1.45; middle tor and ita claw, 1.80; Claw alone, 48. 2mider, hazel. Lausé *tors, lemon-yellow; cere, fellow; rel bluish-black, shading inter hom-color ind then yellow at bask. finot in the aet of carryiz of a clincken. Its sternum will be freservas. 
138

139

1880

1880.

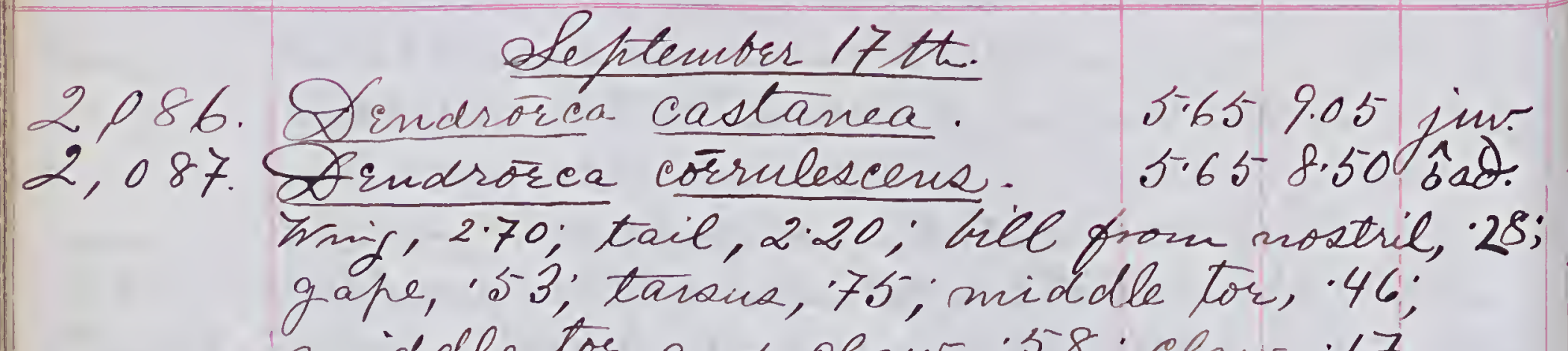

dle tor and clow, 58 ; Claw, 17 .

Seftember 18 th.

Chàctusa helasgia. - Dtill plentiful.

Cyanospiza cyanea. - Still present. Apheare and strulke stigly amougst the Gulrushes, of thi salt marshes. No blue males are seen.

2,0 88. Drudus swainsoni. 17.2511 .909 al. gahe, 80; tarens, 1.09 ; middle tor, 66 ; gadidle tor and ita claw, 88 ; Claw, 23.

Septembar 19 te.

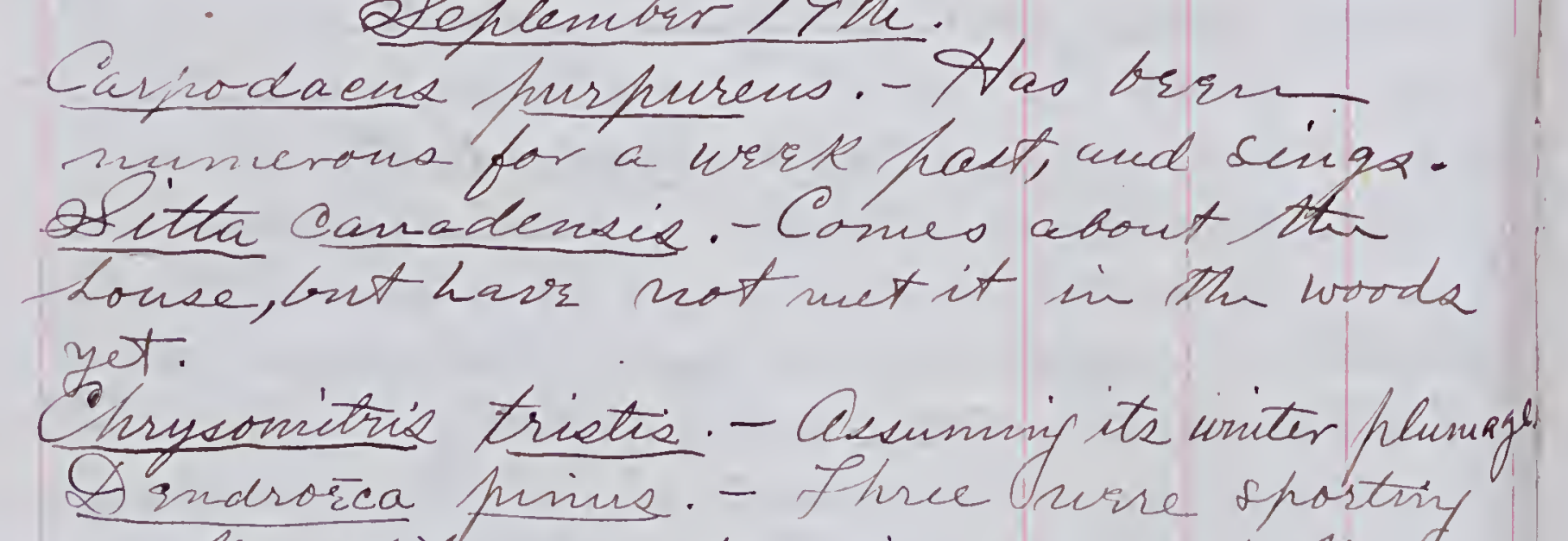
A endrocea pinins. - Three wine sporting fiazza. The, wre viry activi, and short, metallic ceickin, brarning seight rezenblance to the Prown Lhrasuers. brfore since the shrin of 1879, and Warber on Angust 31 antinn when ghot a vig: on Angust 31 tht, when I shot a fen sopt antum was sithis grietty sin the vild aherry
September $26 \mathrm{th}$.

This aftemoon rourd if to the Constitution marall, in compang with Wheatteg, to shoor Rails. Shose binds were not vrre wre immature. D firid into thit flock of Blackbinds, and brought three of the A bag; afterwards shot at two Blachergis al Anigficher sitting, with No.12 shot, and thilled arottiter at long range, flying, with the same sized shost.

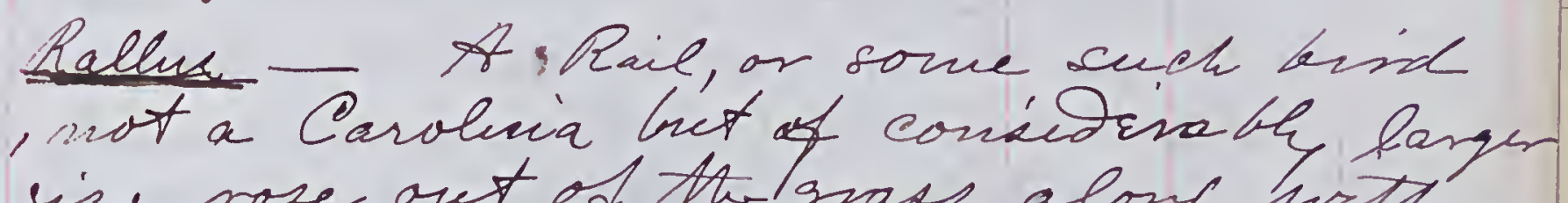
size rose out of thigrass alonf hith bulnusher acroos th creek. I uras pushing companion. did not shoot it. Ive could not git it up out of th bulnushes again. It may havr bren a Virginia Rail, but of Anink it was a larger specin; Rofsibly evn a Aloridadytes folustris. - Lone wre seen wind heasd ringing flessontey, are greatly reduced, and it riel frobably bi gone in a faw daye still rembin in the musth, all sil brown plunage. I shot one. Pandion haliantur. Cue alghted in

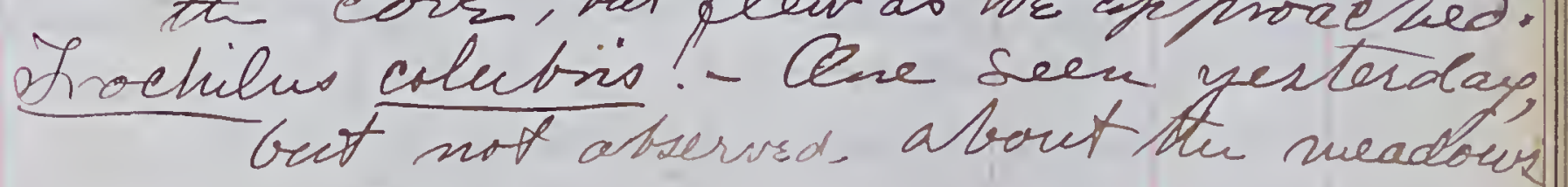


140

141

1880

1880

Zurdus dwainsoni aliciāe. - Che was brought to me that flew a ganis a elegrafuh-wire, and died soon after. Lh why one seen this aclemen.

Chactina pelagiea.- Notseen siner Leptembar 28 th

Cyanospiza cyanea.- Sevral seen to-day amongst the werds and blackebrries medor (the gate, and in the com-ficlds:

Weut to Perestill on Alu" "Priri Belle", and row a Atawk whieh was probably Haler colunbarvice, as wr saosed Patterlec': Paid then a fleasant visit at thir Peershill military Acadenny, and, after batking tea, returned by 7.1 a pru. Train.

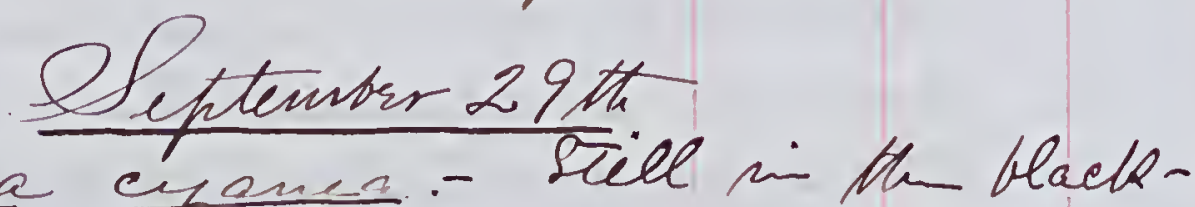

Cyanosfuza eyanes.- Sill in the black-berries by the gate.

Afrizella fiusilla - - Still mumerous. Minus carolninsis. - Sevral wai seem, as ur. defuze truyself wire goving to the rivin for what suan be mi laat surm of this seasoninint in yesterday Sonotrichia albicollis. - trist seen yesterian sinee the ane slest on Seflesution 10 tht.

September 30 th. Pifilo injthrophtrahme. - Que seen. Ectopistes mopratorine.- Qne flew if froun the grownd into a tree. It has a jood erofiful

Lirdus musteliniss. - Cens seen.
Qetobar $3 d$.

2) Came down on "Mary Powell" on firidan the first of Cetober, and registered at tha Coldege and attended the opening lecture Ahat avanin.

This aftenoon Morrie and 2 walked all the wor through the Central Park from one end to the otter. We had d vrry good aflewoon, and saw numerous binde. at frist wr found a griat deal of dust and a qreat crourd of heople. the luavis ware fairly igasfuinf for breath; and of course nio brids were seer solve th wbigitaus Sparrow ( Dafser domesteins); then came thady walke, frestier arr and less peofle. Hue friat waod $x$ bind was a handsome Red-brleiéd Nuthateh (Litta canadencix) in on to of a big ilantwus link, trigging and chigin concealed; at fast wr saw hin reize th lava o suallon it, then flit to a new bráele, witt its highe fieched houk, houk, houk. Wre saw Hivis Nithatele in sursal other flaces One was hammering at a dead tree-bo/; another was catelinid nisects in some bushes fordesing a froud, and we sar: two prying into the 'cones of the yellow pine-thees in search of seeds or uncicts. When we cam nfot a fretty. flock of Cedar Birds (Ampiliz cedromm)

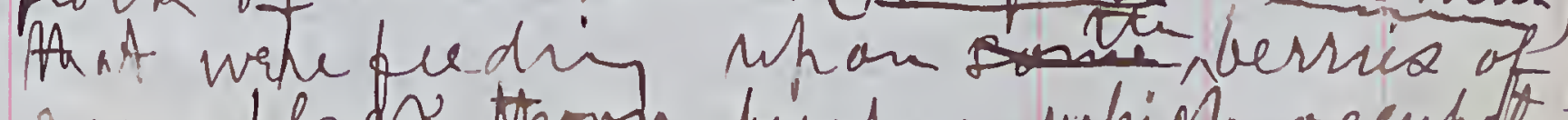
Itme bla $K$ thoon birshes, which oecupdtia. they varred by dartini in curvis of ter 
142

143

1880

1880

miscets: some of the still present the striate breast of the you birds. A Ped -Shouldered At ant (Butter lineatus) circled orrhead, and, a short tunic after wi saw a Bittern Botauns minor), which must have fireside some fond. Moping Lourdes migratorine ware numerous in one on the fee, and its familiars notes quite frequenter heard. We sam a few Ann g Sparrows (Nulorfica fascista) An ave Swank sparrow (2M. halustris) boride the hour. A Brown Thrasher is this war Shard, Constrichia albicolli') was gut 2 watched for Cattrinty Lither Bunting but we saw neither. he heard the notes of the Golden - crested hujiletionionet a clumps of Norway pluses; and ur case

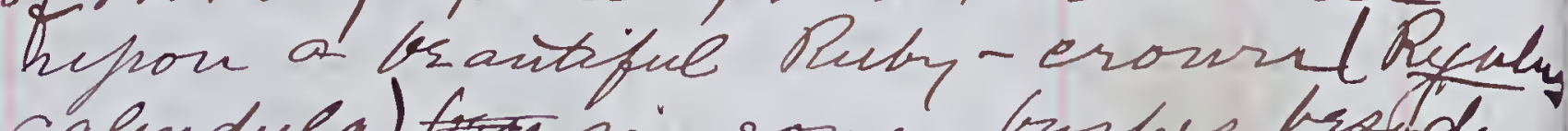
calendula) ni some bushes bale a frond: the fist I have seen stree last spring: H hen we came upon a a wild little ravine cored with underwood and curies. I he and thin rote of a burins, and succeeded it olin it if the ravine from th pond, to where we wire stand is. Then wi identified it as the Small billed Water thrust (Lures naiernis). A note was first the hears which was al mont new to me. It was, that of the Cardinal Redbird Cardinal io vigimianns). I chirruped until I brought it close mo to na. It he pt amongst the bushes, and appeared to be bring shy. It was unmonally dark red, and sat with erect crest. Its note was sharp and metallic like the Water Thrush's. Wee heard a fine song down versed the hond, which wi attributed to the SuralFilled Water Thrush, as it did not seem to be like the Cardinal's song. The Yellow rumpled warblers ware seen and heard everywhere. A feather was found why f canc from the left wing of the frat the ie Aaron (Arden lurodlas), and a Spotted Sand fifer was feeding on the margin of the reservide. In e saw tiv binds D warblers - which puzzled us very much for a while; brit when o gotta near view of sam that they cere Black -foll Warblers (Dendroteca striate)

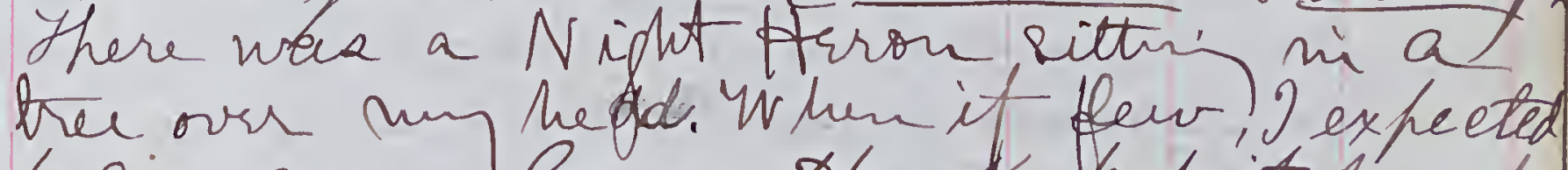
to sic som lar pe tank, but it proved to br Nyctiarded, and ane y flapped across the narrow fond and cliched now a slender bough of an oaleftre, lapped a moment, while Nierfectur a balance, sat witt reck exteubled for a moment, then alrewits head close ufo n ito breast', and summed to repose. White-bellied Swallows wee quite numerous; and $A_{t}$ Purple Martins (Drogue subs) were floeleng about some Shanties inch to lot outsides Ho Park. We Paw two Play Rabbits, and some Gray Rquiriels. Muskrat se gus wee about th pounds; and ane House Rat was seen bride a fond; it juinfed 
144

145

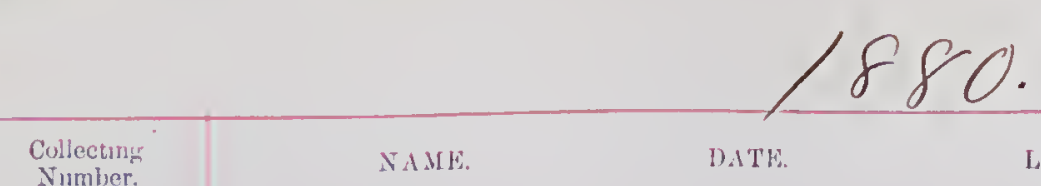

in a circle arvund ane and of a briek arek. Lo sum uf the binds sen wre as fallowz:Iurdue singratorius.- 2uite

2 Harporhenchus sufus. - Yhought we the ard its nots Regulis satrafra. - Arand mi th evergrans. Regulus calendila. - Ane taside our fond. Dendrozea coronata. - Numerous Dendröca striata. - Cue harr. hirne naevius. - Lwo wre Reen. Tachicineta bicolor. - Nmmerous. Progne purpurens. - Que flock Parns atrieafrillus - Numeroua. Anpelic cedrorum. - Sevral flocks. Melosfiza fasciata. Melospiza halustrix. notricháa albcollis. Aburdant.

funeo hjemalie. - Ave bride resurvis. Pafaer dornecticis. Cardinalie virginianus. - Clue seen-otters heord. Dayornio fuscus. - Buside th frond. Antrostomes vociferus. - Cue sithin on lowtranch $r$ Suter Anialus. - Ene slyin. Fringoides macularus. - Beride resurvis. Vyetiandea grisea nairia.- Cene at a fiond. Sotansue sunior. Aur plyin soutr. Ardea herodiaz. - Bownd a pealtior.

Octobr 8/M.

On Trusadan Q et. 5 th, 9 took 4.20 PM. Train from Aunter's Ponit for Sayrille, which plaer B rached ofter dark, and fornd some Croubh mi gitting sletted for the diflet; but, frinallyd at whose fecasant house d was very comportably entertained. That nights
1880

retired carly, after a talk about binds and shootrig with the kinid Captain. Earlefvest morning we emparked onboord the captamis littu sailboat bound for across the bour to At brach which separates the Atlantie ocean from thrat Soutt Say, The bay shore is distant from Capt. Danc's hourc a bout $3 / 4$ of a mile, and all along the way wr sau the miadow larks and many ather brids; Anaguy of them vere singin swritty. The Capt. Wheeled our eatable on a barrow, and onr traps and onrcelges veresoon safe in the little skiff, and we pushed ant At. Hh little floof o soon wrre ready to sit sail. A flock of "Sand Sripes" paped if icfore wi donld get hold of our cruns, wh when four more carne along, g ivanglit down two of them, one of inhich was iriged and aflerwards rask a bout Ath. stiff, and squealed whizever wr trisce to catch it, they were Semipalmated Sandpipers (Emnetes pusillus). Crofain the bay wr saw only a few "Broadills" ,t considered gnyself forlunate not to be leasick. The Lo hn fluw brfore wr could procure a shot. Fe landed at the narrow -est fuart of the Fach - Dtw "Cherry Shove Nouse" Vr parled at the brach; the Capeari wrut west, and I procecded eastwerd. Flue first fird Ifurt nh was a Buttern which of bus - mavily mussed with both barrele; another ane was seen a littl farther along, and it was also missed. A Savamah Shans and Puby-crowned hinglet were stiot ans cloo a Pail (Porzana carolina) uhiét could not recover. Then 2 risited the 
veean side of the frach, examined thr lou forrste about the higher pait of th beach, and then stahted towrads our boats. Prgeion Hawles were mu- merous, and I mifsed one that hafses merhead, as i likbivise did a fhonth tailed Lern, and a small Hull, which 2 thought firhafs erroneoush, wre withi range. At huge Cornorait flew hast close to the nater if the erazeiet lookin trid gever saw. Ifun of caune acrosk some Snifes, and shot about thisth ohecmiens of five defferent species oruer of whlich ithed never shot bifore, and thee wre seen aliv for the first tivire. Imas them joined by Caft. Stanes, xund wr frocured ten nove Sufiee, makkin a tolal of forty for ans firit das's bag. Ire then coothed distuer and resteda while. Them walked un aloug the bay, but, finding no smifes wrdt to thr ocean seide of the brach, and fathered some molluste, ande gradualey meandered sife a long Liflidarin Scatian, which ur visited, and where we wre most hospitably entertanied bry the Caftari of the orewy who flowed the whole sstablishment and all the affraratuses frertaming thereto. o shot a Preion Hawk (Halco cblum-barius), but it was flyin $\%$ fell anouget a langled groth bof busthet and cat onvise whiek was mpifsible to explore. Lo $I$ lost a cood bind. There is a hath across the wooded pritioni of the prach from the Sovts toure to the bay fide.

DaTt.

tovadiTT.

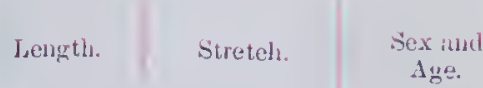

; crofoin it, wr saw a Prgein Hawk to froveure a shot at it, but failed; I if, and was revianded by pettin a chot at a hassurif Nright Hrron, which I brougld dom at lon vange in fine style witt a charge of No. 4 schot. I haphened to strike ufion a small pateh of sand bare of bushes , else I should probabl never has recos - ered it. Walking doun the bay shove of th beach, d) spridl a A awk sitting nthor a dry finic-tree mi the midelle of th coode. Isucceeded sin shooth's it, but was for a long tiriv nomeceseful wi binding it although we knew jist where sat when fill fird at; at length is saw dask object rithetarighe whileh of thouptet ipht be a thavt's wri, and so itf hroved, for I at length sucerrded in vaching it, and, to m baundlexe deleght found a brautiful Peregrine Fialeon or DueK trawt (Haler emmunis). This was the crownif success of the dary and we retursed to our boats with the following birds, all of which were carefued pluffed witt cotton * wappled in papers to peverst doili

1 Savannale Sparrow

1 Ruby-crourved kriglet

1 Blnebrid (shot by misotake)

Boberimpalmated Sandfipurz

1 Leard Sandpiper.

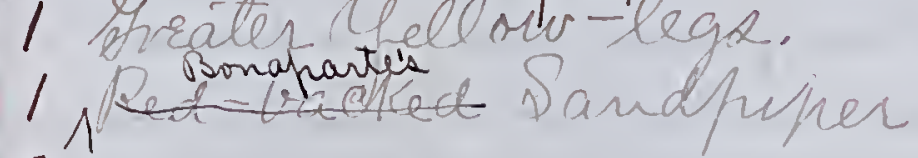

2

1 Nrght Hiron

' Peregin Fal eor
Tatal 47 birds 
LOCALITY

Tre set sail for home and had a ford Thif, which brought us in jist at dask. sumset. So ended Weduesday (Qet.6th)

On Jhurdary ur toot an earen start, and shot a flepir, Meadour Lark at louf narige on ons may to At suore. He crofseed to Cherriferov House as brfore, and ow the dar saw a few Eneve, Sulls, and ane. Loorr. Arey a bew flocke and scattered

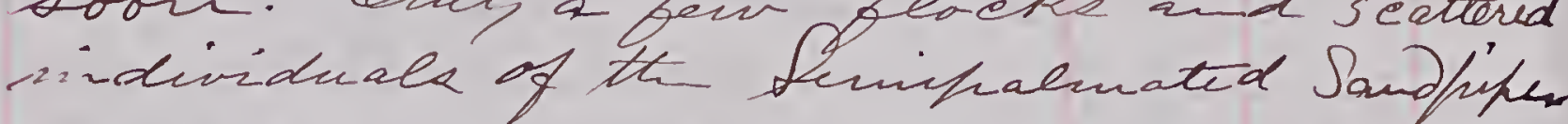
cerere seem, and sno atter sheecis wios observed. Cru Hedidiendas wr save a munter of Drifies which of did sot sseagnije and could not shost. Yhe Coptain aloo mises a food sliot at twr Pcacte brlleid Dovrse. Pre found the sunaller fand bisid even nors sunuerous then on Treduesday and followin 7 freyin sfrom then wre numbere of Preou trawted, and

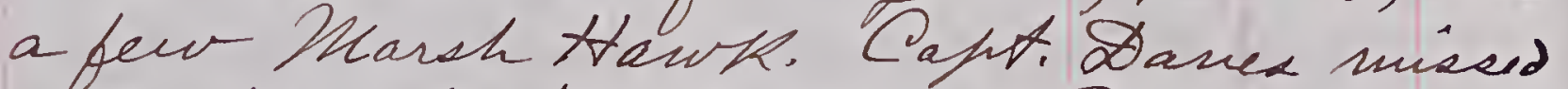
a good sleot at a n adult \$uck tawk that flew owrhead. The Prgein tharele ivere constantty dashi jast ns, and 2) firid a number of timiz at the fut ther are so axtrewehy swift that 2 did not lit on of the - Nee sow them coustanth striki, doun sumale birde ;and I sour one mias a flecker deveral one at the finis altempt; the poor Wrothech made a great moire when forst canght, fut its chico wre soon hushed in deats. Catbirds, Nuthatches, Alice's Laruches, Brom Thrachers, Robrin, Yellowtride, Filcievera and yellowbrllied inaodpeckers and especial

the Yellow-rumped Irasblers wre sxeecdifly abundant whon the beach. The legt Ahe brach at moon and sailed forductes. Mre chot two beantiful Atorned Strebes. Ou shore wr hunted the meadows for Eiglish Linte, lut only shot a Muadow Larte. in brantiful antumnal plunage, Anst caught Ah 4.1 PM. Trani where 2 said fotere Ay to Cafita - 8 ares and siached hurfork ni tive for dencir, and Q:A. K. Histur anvity me, Me mpaoly the birds wegetter

$$
\text { Lest of Brids Leen: }
$$

Iurdus migratorius. - Rather abundant on Kland $\nabla$ brach Invdue suainsoni aliciate. Very numrous on brach. tarporhynchus nifue. - N monerous on the brach. Mhma carolinenaix. - En the beach; nore abun- dant than Iever knew it to bs anjuntere Sialea sialis. - Crey found an the Leand (boyga?) Regulns calendula. - Rattur abundaut on brach. I shot one thinking it was the Shont-billed Wash Wran, judging from its Wra-lier note and from secing it ni the grase Regulus satrafia. - 2u the cedare on shoreg;. Parus atricapillus. - Very mumerons svrufuhere on the Loland shori and also on the brad. Sitta carohiensis. - Abundant on the Soy Drand shove and on the brach, where one wors sloot. Sitta canadensis. - Excedingly abundant upon the brach; also observed an shove si the cedars. Numbrrs wreseen on the brach on YV eduesday, but on PThursday there was on constant succession of flights of Redbellies, which were nost abuud oust in the cedare, but alighed mi a bund ance rufron th ground and in the grase and 
Certhia familiarix. - Nrumerois on the brach. Aendrorca coronata. - Excessirly abundant ufrow the seawrad, sand brackes, grass, bushes, trees, si the air, and sin short evrripuhere both on the brach and on bhore.

Dendrorea Lalmarum. - Surral seen ufrow the brach on thusday Atnfulie cedromu. Three bide seen trgetter on the brach on Thuraday Carpodacus furpurena.- Evryohere. Chryeonitria finis. - It notes wre heard all day Thursdas mhom the brach, and on the fallowing mon's a number of seatleris onez ware deen killed it witt a charge of No. 4 shots Dtrays to san, it was ishights mutilated and neade a good sfecinen.

Ampronitrie tristis:- Veri numeronk shore and eqpecially fo on th brach. Papreulus savanna. A Ar thor andrach. Melospiza halustris.- Seen on fhore. Mhelospiza melodia. - Errepuhere numerous. Lunco hrenalis. - a few oh shore. Spizelea monticola. - Sem on Shursday Qctobir 7 the for the first, on shore Sfrizella socialid. - Very atrindant on shork. Afinzella pusilla.- do do do Fonotrichía abicollis. - Abundant. - aper domesticue. - Abundand in Sayille Stumella maqna. - Very numenour: a two shot on shork, none on the brach. Corvus anericanus. - Evrryohere numerons. Cyanuries eristatus. Venyeommon on shore Soyornix quacus: - Veing conmm on th

Afhyraficus varins. - Mugrating in large num frequentey alightrig. flyin low and

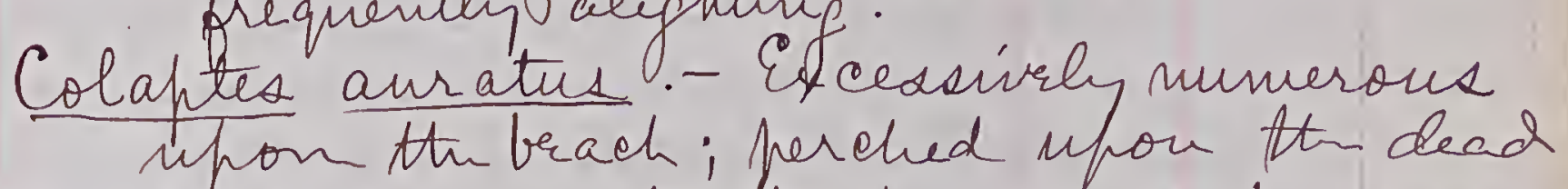
pines, and ate the brivis on buskes. Constanth morrin westward. I saw the Preion Howks strike at then, and one that was caught squealed loudly. \#aleo connunis. - Lub D nck Hawhe wre seen; ore was shot ufron a dry fine from' the fay side of the brach, and though Hilled dead, was creovired with great difficulty oving to the dewes, matted tanyle of cat-biners y bushes surroundling the ; another flew ovirhead on the following day (QCt.7) and Capt. Danes missld a good fliogt at it. None others wre slem. falco colunbarius. - Very lange numbes. wrire seen flying if on the brach. Que was shot on wing on the 6 th. If came ftraight down bes I frirad nuy second bakrel, but could not bi reebrigl in the Miek bushes. I shot a several that ware Alyin hast like lejtring on the folleburn day, but fot nond. They darted ritto every theiket ofter little brids, and wrre followi:

the nisninse numbers of suate birds thatwere onoving weitward orer At brach. Hhe sapidety of Theirfligt (Colafter auratus) sin suy presence. Then wre so numerous bhat they were scarcely ever out of ficht, thot, they constantey past out of uriur to 
152

153

1880

D. ATE
1880

LOCALITY

- Ane shot at lon

range from a fusing flock of 4. Que other sees= on brach ald Nyctiardea guise nutria. - Several you f wee seer fly in Fording on the beach on the 6 th en that aflemioon 2 shot one of a pair of adult birds that wee flying over th t beach. Now were seen on th 7 At.

Oolaurus minor. - Leo were shot at on the morning of the 6 the None others seen. Porzana carolina. - Que solitary Sora was shot as it flew over the massey fast of the brach. The only one seen.

Anas abseura.- Imo lit ni a small frond on the brach.

Huligula manila. Sural flocked dean. Edema fusee. - Cree or two floes es seen. Eraenlus ?- One was slut at ax if flu low above the water to the ivistward along the bay shore of the brach. Larne argentatus. - One or two young and a number of old bids see. Que or two small Sulla wee seen, bit not ideritefied

Aydrochelidon fissifes. - Cuenthat I supposed. to bi of this species was seem on the rad Padecefis commits. - Hor wee shot logettui sin the middle of the bay - both ni young homage; they dir ed several - lyrics bore piled, and about 7 shots weeping -olymbus torquatus. - Several Sous seen in tan hastily.

Note. - Al number of land binds doubtless escaped observation, and probably several additional species of Sups ware seen flynn, but ware not ideritipied. NoCwes wire seen, save a Screech Owe Serfs asir as 2 walked uh from th Elation on th site 
Collectury
Number.

2,089

2,090 .

$2,09 \%$

$2,092$.

$2,09.3$

$2,094$.

2,095

$2,096$.

2,097.

2,098

2,099 .

2,100. Italeo connmuie.

Nmig, 14.00; tail, 8.25; culmen from frontal feattura, 1.09; from cere, 85; cere alone, 30; bill from nostril, .81; gape, 1.85; tarsus, 2.23; middle tor and Claw, 2.78; middle tor, 2.15; clow, 75: 2ride varydark. Cropt gij. wre hacked witti fragncents of numervus brids -all ofefiarently Jasserine -, which had bisn soughly fueked brfore fleclown. Log $\alpha$ q wing urre suallowid entire, the latter with feathers on. I frescrved a menver of entive legs which afeferantly brlouged to th faclowis sfecies:Iurdus migratorirs.

Lurdus suamstin alieiāe.

inimins carolinensis

A Endróca coronata.

\section{0}

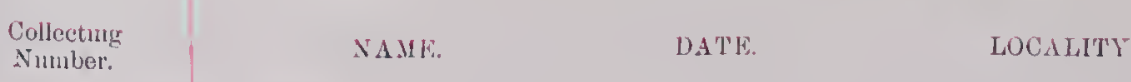

2,101. Nyctiardea grisea naivia. -25.5044 .00 bad. Ins red. Q.t.6.

2,102. Paferculus Lavanna. "5.889.60 $\hat{\mathrm{o} a d .}$

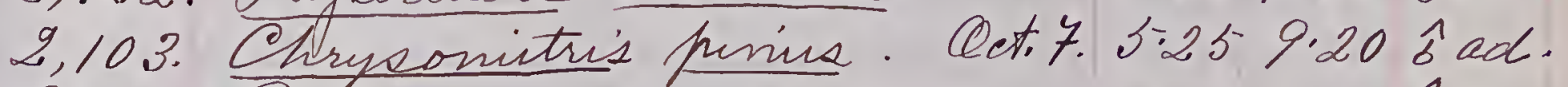
2,104. Podeceps cormotus. "- - - jiw. Sunday, Qetobre 10 the. Augheand Ttales, US. Anner hyenalis. - Now evmmon here. Afrizelca monticiala. Furt seen here Ifriclla pusilla. - do. eturdur alciére. - Very abund ant here.

Sunday, October 24 th. Highland Fall, N.Y Inrdus migratorius.

If rdis swaindoni aliciāe. - Very typical Aliè's Shrushes wre quite nunerous.

Hrdus pallasi.

Sialia rialis. - Has a loud vatting note. Regulne calendula. - Itill wbundathd and Sita casohnensiz.

Parne atricapillus.

- Aendrorca coronata. - Very abundant Elirysomitric tristic.

S/rizella socialio. - Sevrral Lem -imeo hyemalis:- Very flentuful. nelosfira fas ecata.

Ronotrictita albciallis. Offer domesticint. A coed wind prevailed trives frequented the evergreans, sin large, surisy flocks.

Comur americanus. - inoter sarfo tio Grows hav heowe mpiratnis Is large flocke for a wick frat 
Cumanus cristatis.

Haleo columbarizix.- Ane down by btu rivel Tharne argentatus. - H few on Atre rive.

\section{Clite.}

eq Sivan was shot on Qelotere 21 st (1880) on one of the lakes mear Highland. Halles. It was murchased by Mu. Harlex Butler of West Point, ande sent to Newbugh to br nounted. W hem it returna shall br able to see it and delermin. its spreis, thoigh there is levtle donbt of ita bin C. americame.

\section{Cetofer 28 the.}

Mr. Morris muzelt arsird at ifayile fon Zelawd, N.Y.tify the evsunif thain a daptain

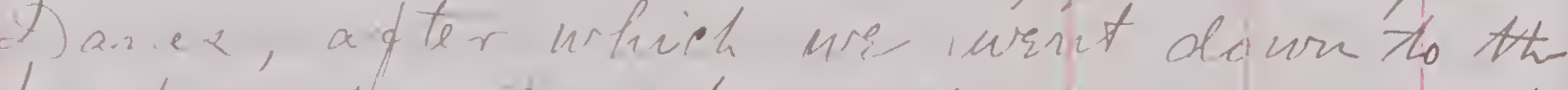
then all mi the losat. We lakd and fent 75 decoys in $x$, both duck ot prout. Then we dumiped thic water aut of the battery, got iverytting ready for an earey start.

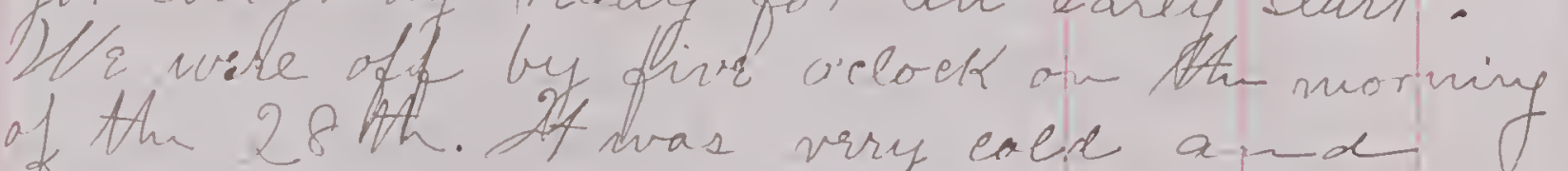
windre. Te erawled aut of the cabbin when we got to the groind, but fornd tha bay at that foint too rough to phit out to the levivard of five island ou do dom wr had sereral shot 2 at forne that were feying Gere. Jwomidfone, hut lic

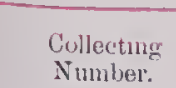
cot

co fol

Lengti.

Stretch. $\quad$ Sex aud$$
\text { . }
$$ 


\begin{tabular}{|c|c|c|c|c|c|}
\hline Mante. & D.ATE. & LOCALLTY Y & I. mingth. & Sineterth. & 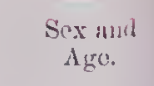 \\
\hline
\end{tabular}

Collectiug
Niumber:

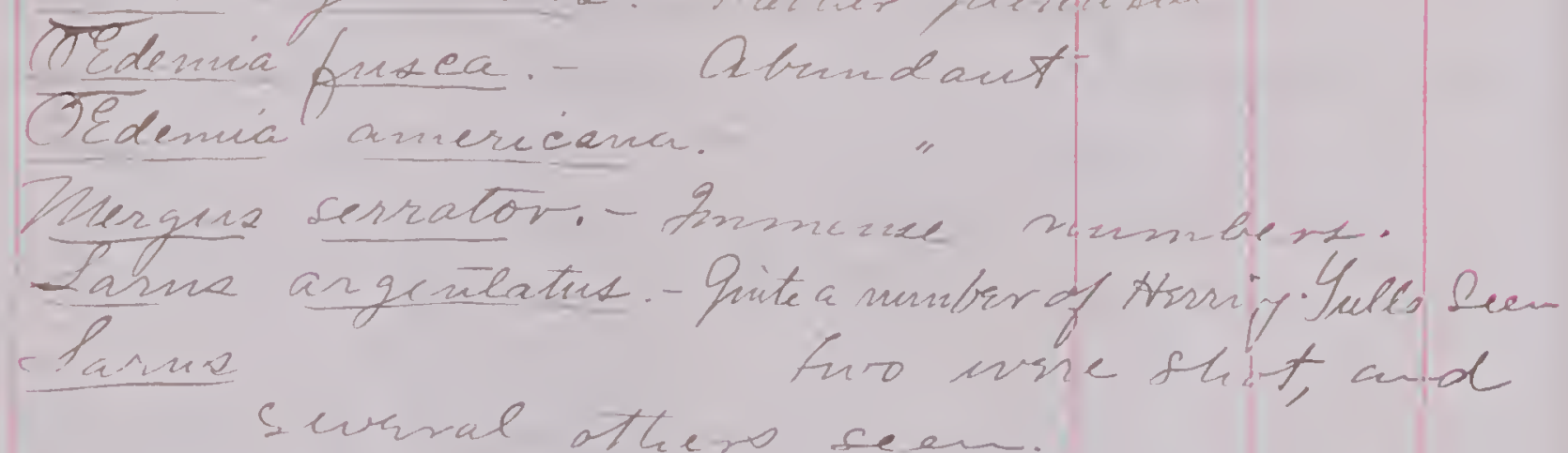

H White-tuaded Eagle flew arser th battern idelavarinsex a

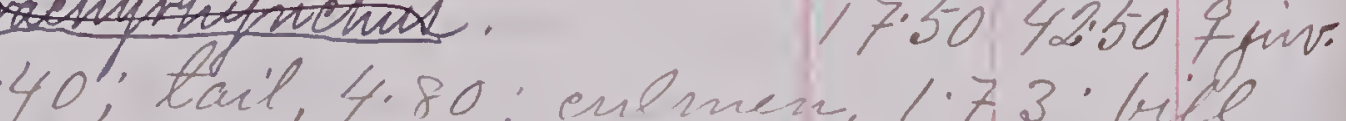
from wotril, if7; gahe, 20.32, larsur, 2.15; middle tor and claw, 1.73, middle tor, 1.40. the claw, 3.5. Mis, hazel. Bill blagk, with a reddish tinge at base of infercir mandible.

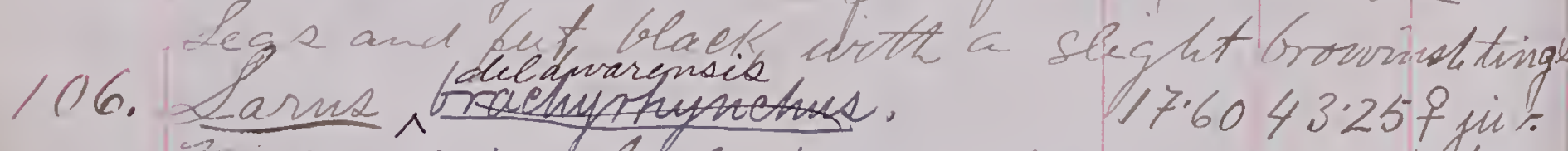

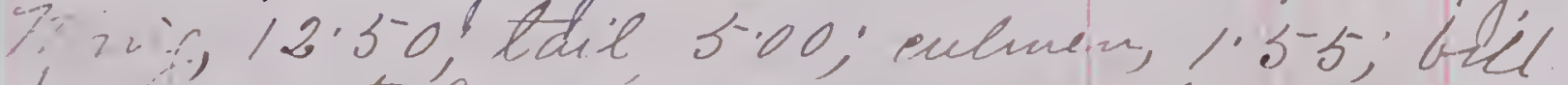

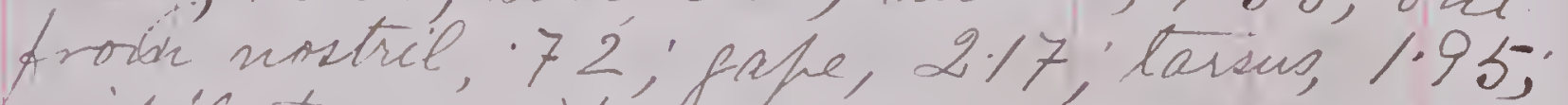

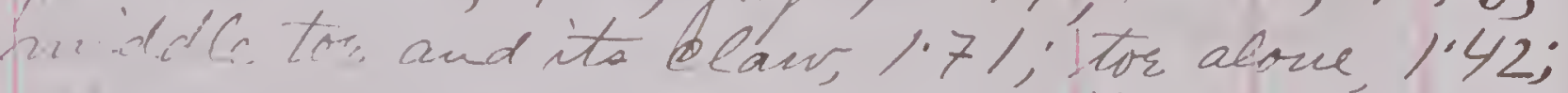
aw, 'in. Zis, hazel. Lerminal e-teof 1 bill (from -tefto postrix), blaok; inue, quech-color. Lefr Y feet, wite, slisht, 2106 a Tulcila marila. $19.45-32.25$ - 22 yers. Wnin, 8.65; tail, 2.65; culmen, 1.80; bill from modtril, 1'25; gafe, 2.3.3; tarzua, 1.66;

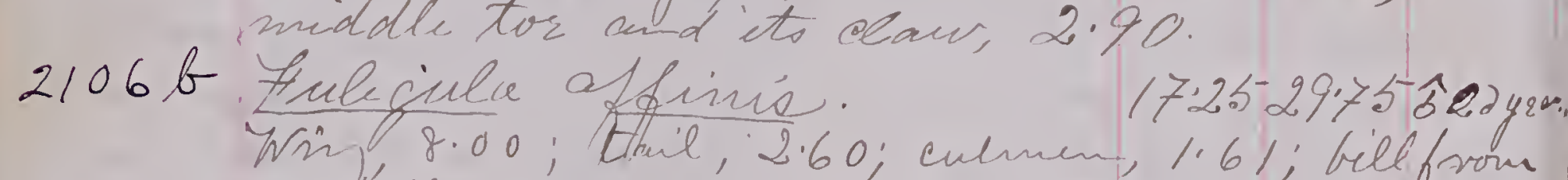
mottril, 1.12; gape, 2.0 .3 ; tazsns, 1.45-; miadl' tor and its elare, 2.50 .

The wind kept to worthand ale drey, a-d

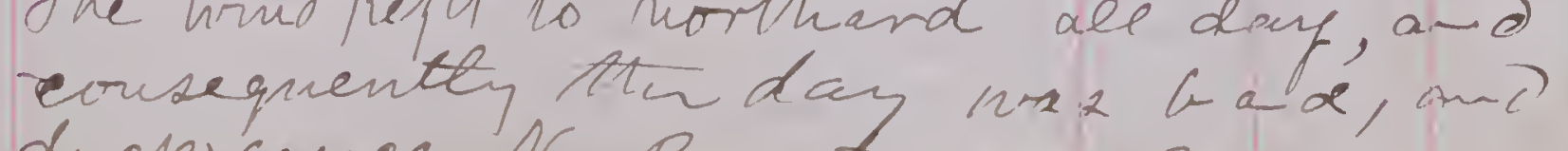

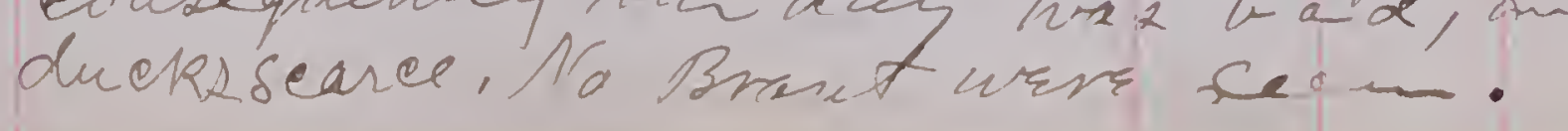

\begin{tabular}{|c|c|c|c|c|}
\hline XAMIV. & DATE. & LOCALITY. & Lengrth. & Stretech. \\
\hline
\end{tabular}

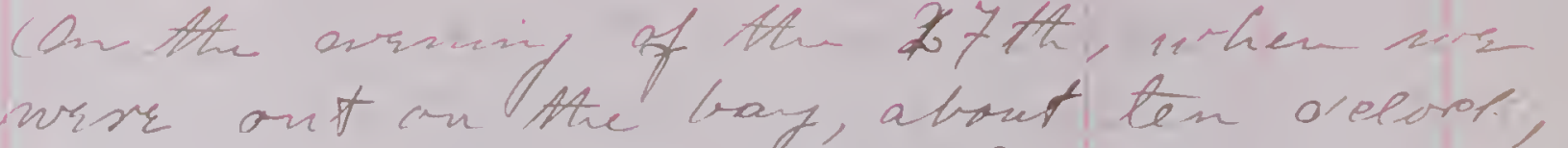
th mymad ureis of little mipating 'forito and, again before daylejht on tha 2 th on tha middle of the borf.

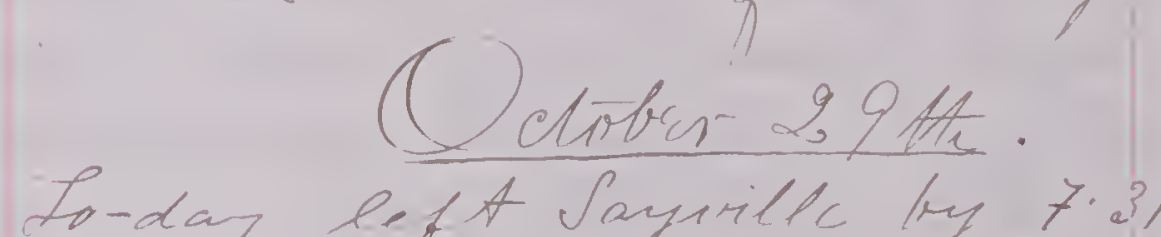

When wr cot wittasin the to starden Cify défot, Nrosis calle di athentioin to a Pnowy Quve (Niyeter minex) that the trani had ctarteid "lefrom wear the track'. Lf flew slourt? on a sandi, woll amongelf farme? Immmocko ine a sleftrt nike of around. 2 intended th juinf off the train Letreste

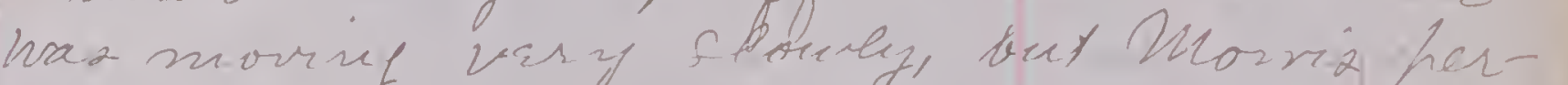
seraded mae to nrait and get off barden Qity, wheich Ideid, and uthest keft nuy valiae, firit tatuif out al Atu callvidges. I walked safrideng back tor miles to whers the kird nas feres, bef it ures not there. She cownethy on trots sudes of the trael uns a desslate traes

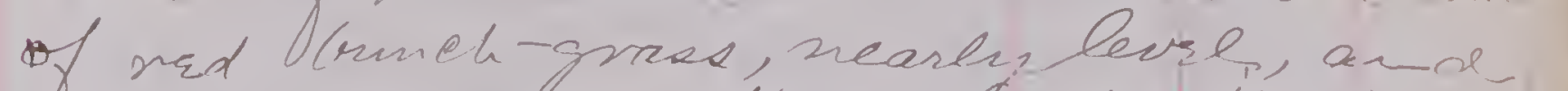

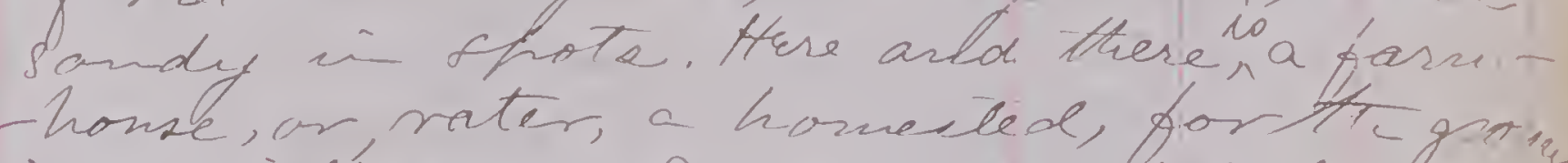

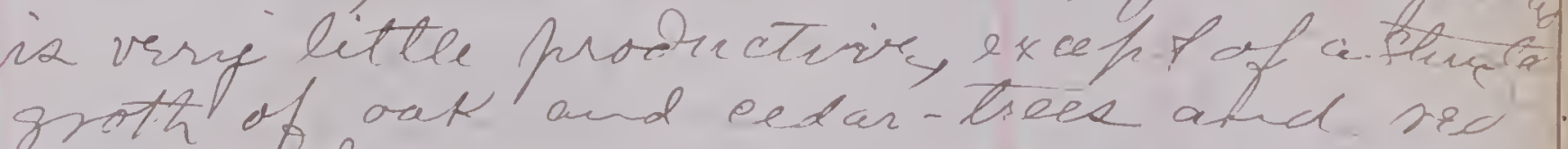
grast. I walked on anotiver mide ved ovak refraid by wering any humwy Cive

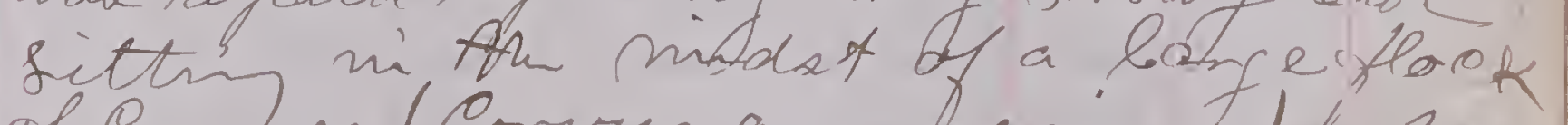

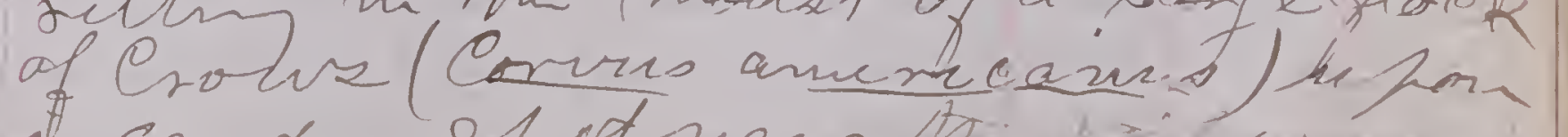

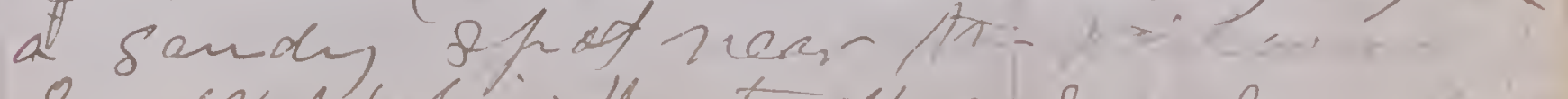




\begin{tabular}{|c|c|c|}
\hline Isength. & sirecti. & $\begin{array}{c}\text { Sex zumbl } \\
\text { Ayco. }\end{array}$ \\
\hline
\end{tabular}

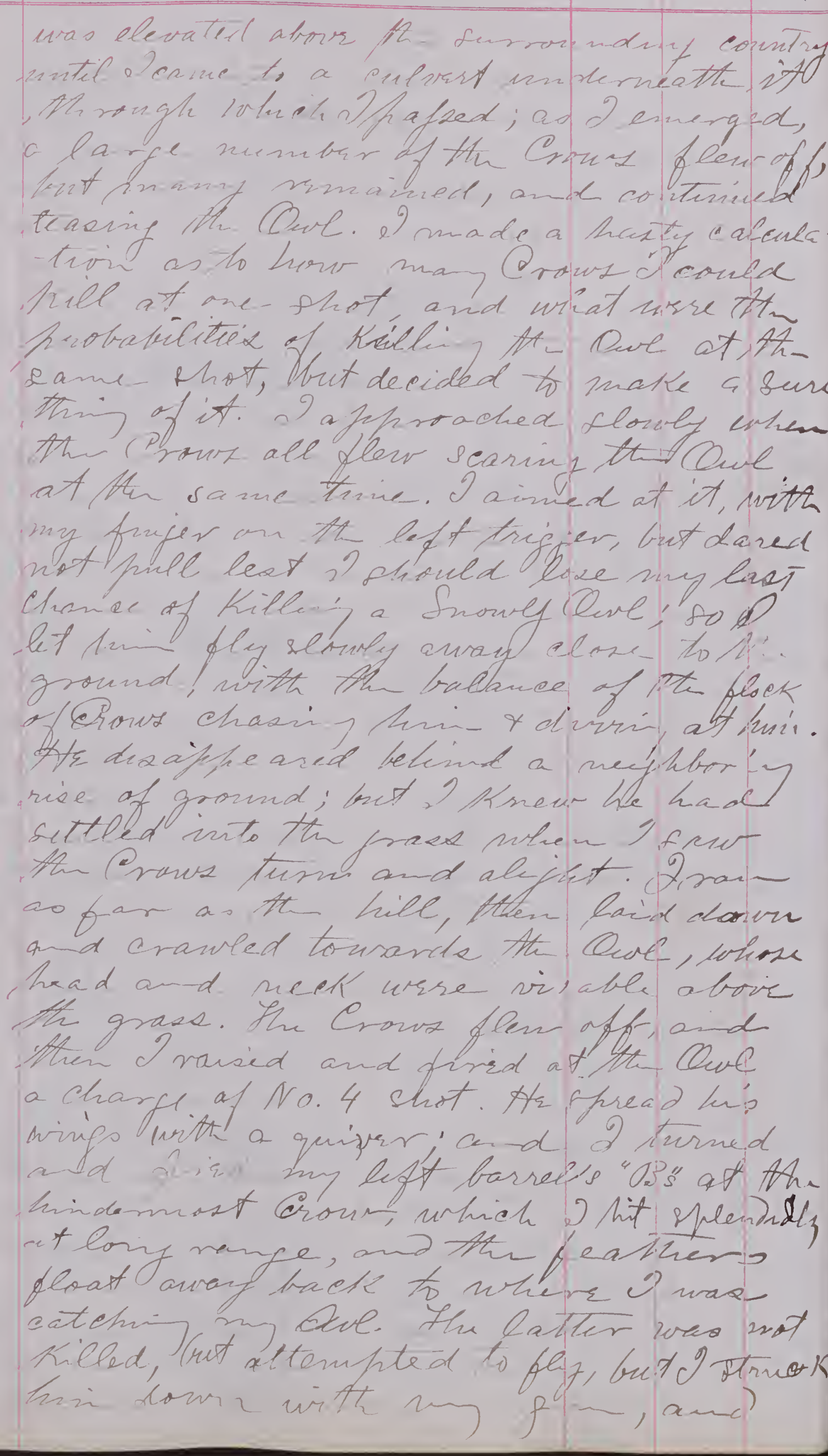

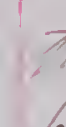

fints serzed oth husuri close over. the

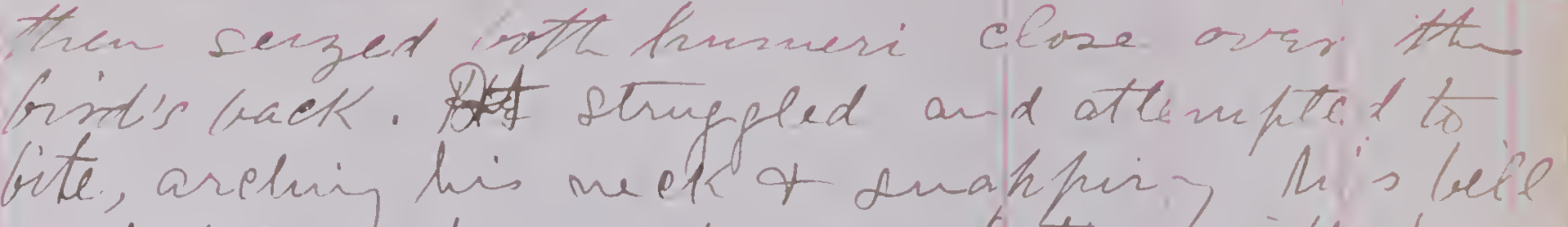
and tris his mech of suahfir, his bell

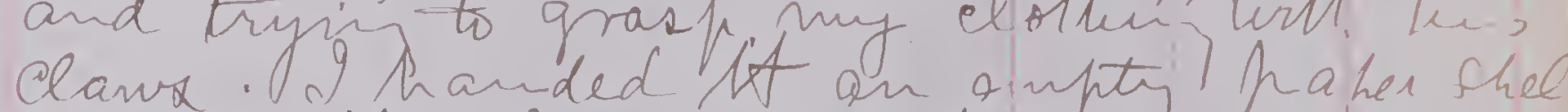
\& which it suized wittits bipe, and held untiltisurale or taste of bunt pouder caused it to drop it. Ther d poked an other at ist which it bit fiercen. Its bripht yellour efes whe wonderfileb frisce and handsoine. 3 friale, killed it, after carryin it

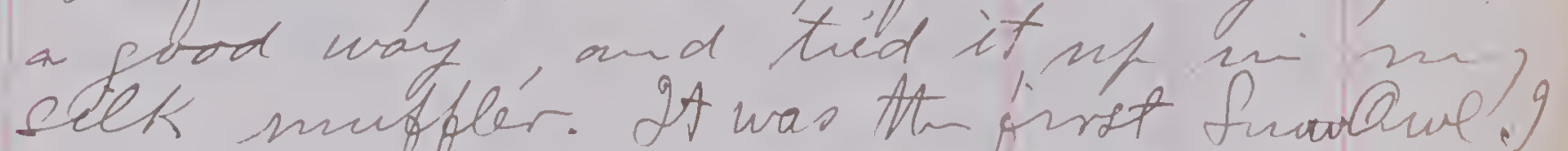
ever saw in a ired seats. It nillerid a curines Poferculue Lavania. Yhis was th spharrow seen about those desolnte nieador 8 , and, thouph qule evruln, diatributed. four or fire sindis, ane or two nould th If nott a whurr and a cirrvie litte rote.

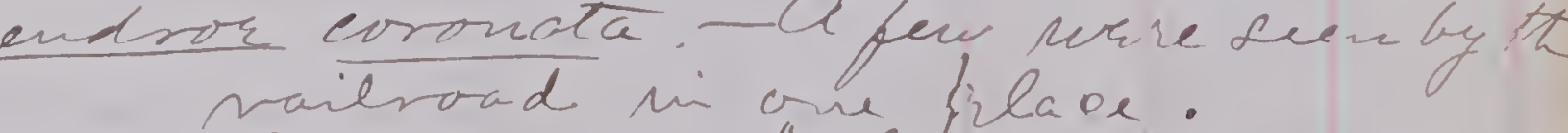

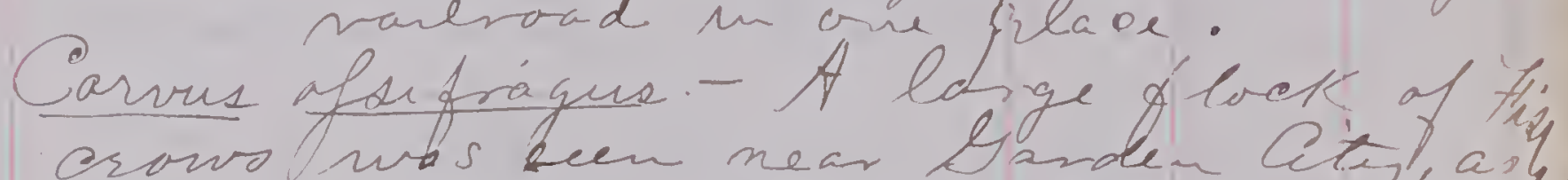

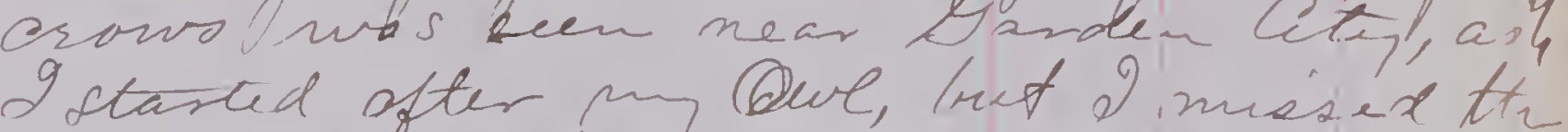
$\rightarrow$ this that parue vear e monthe for a shot. It saw sevisal ollets giragel' about, but evild mot oblan ashot. Htu floek \& wist cesu routanio a hinded ar sushe bends.

finuella magna. - In the frelds of funct grass, of farr viry few, an'd got one hask: mit in a large field of stubple $r$ ured mear Garden (ity, I dariv at least fiftry truadourbartes at one moniunt,

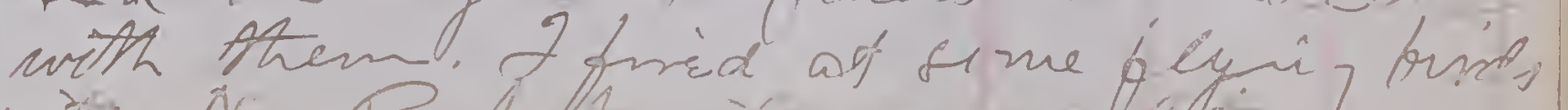




\section{Cclober $3 /$ st.}

Shis atemoon wre walked Atriench th Central. Pork to 100 th $d$ t. At lith littic

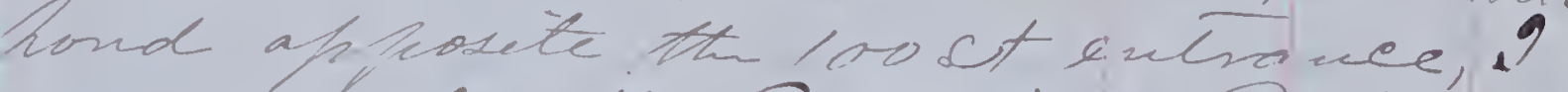
ran aerofl the Cardinal Dido again

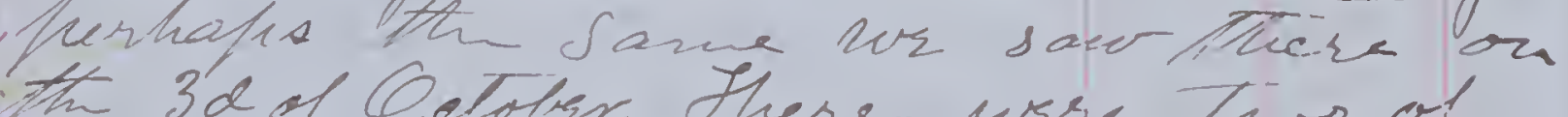
Ahena male $x$ feenale, in. the thet bushes rordesing oun th frond. Fherp whered a rather faint, metallec chir. th frowd. I fornd thene afcein on the other side ansonget ith usses. If hid anonget, At - brushes, and watel ed. them. Thle male klew ifh m - Cow tree over.thin edplid th uate mal hepan chifuhi lovder Dhan fafore the femate alwaip mouring

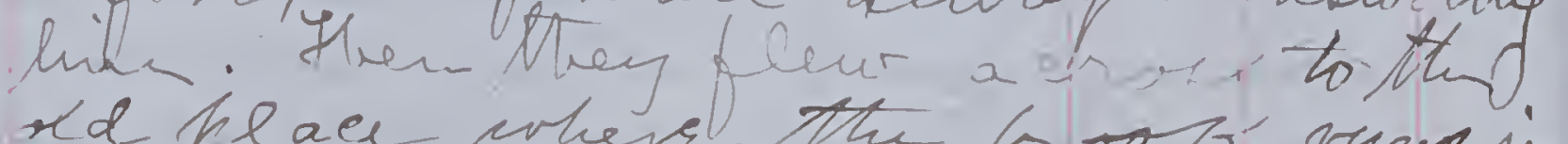

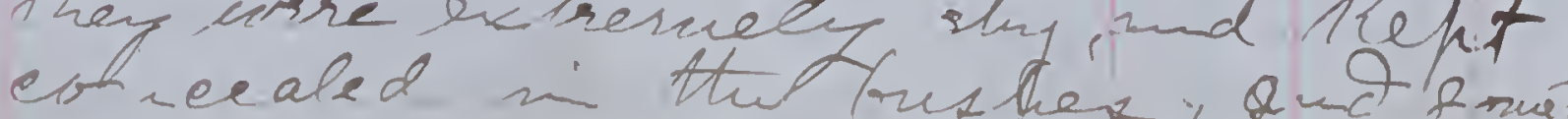
nearended th other side of th tree.

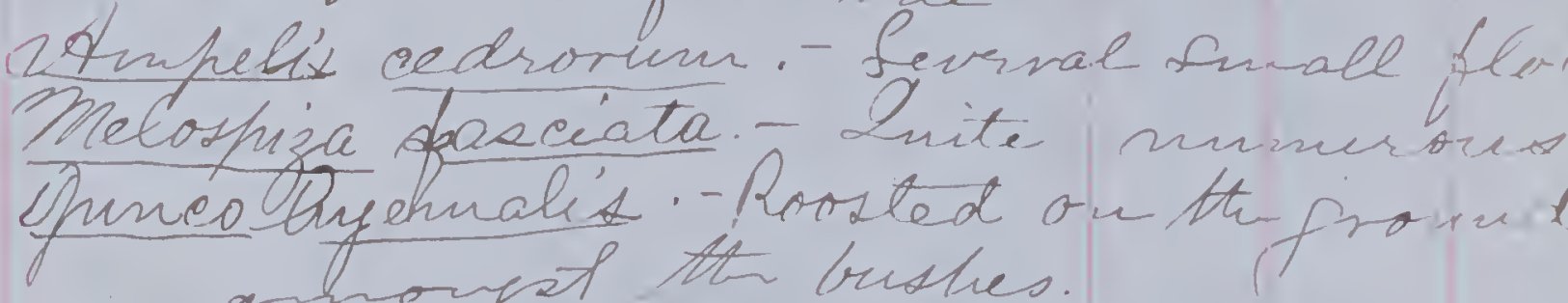

Zonotrichia albicollis. Abuotonst.

Dader domecticier.

a flerela ileaca. - Cur seen. Cardinalis Niffinionso. - Nale thenaie seen. Accifite edofreri. - Cue oursth laki. Haleo columbarive. Bne ceen $1 \%$ Gulle hase Gres seentin the hark the autamin, zett.

\section{Normber 2d - Election day.}

Shent the morming in the Central Park, Looking at the birds. The following sfecirs were notice. Hurdue migratorius. - Very heintiful. furdus pallasi. do

Sialia sializ

Regulure calendula Parns atricafillus. Litta carohirumeie. Dendrorea coronata. Chripenitire trietri. - Seattersd foorte Melosfiza fralustrié. - Cue beside a fond. ruelorhiza fasciáta. Not 2risy 
Effizella husilla. - One Fild tharrm senonotrichia albicollie. - Errywhere abundant, and singing its heenlear Tolser melalle chis. Cahdinalis sirgimianus.- If found sone cardinals as crenal, both triales andferuale, but not in the ald heace. thy atlentean mas attracted by a feculerir squealin noise upon the tillside new th prath brside th upher, sidede hates. These wrne ther male Candivial n/men it ground elose together, shathin thin feath and acting altogetter viry like an amarow hair of Eyclish Pharrowz. Ithat Nen -in virut for an hour or nevere duri? which time they seept constandey side ly side, feeding each other, and extistith Ac greatect iffection for each other! The omale bird Ahat accornframed then flew Coun mi the swanf beside the lsook and fond.

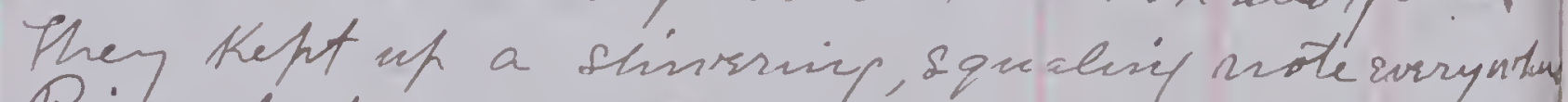
Peene pubescens.- Cue deew.

No Water-fiowl or uris of fray seinwith the exception of a Night Atrou nfininge, which flew fomm a tree direoter sir my head, osi th Aarbemlake.

\section{Movrubre Fth AEghland Foes, N.Y.} Walked through the words all the inorming, üurdus mig natorius. - Nott abundant. Lurdus hallasi. - Only one sun. Sialia sealiz. 

LOCALITYY.

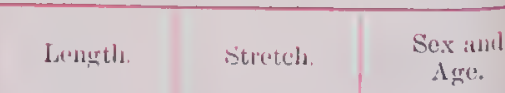

1) TTE.

LocastitT: L.enyth. Sitretch.

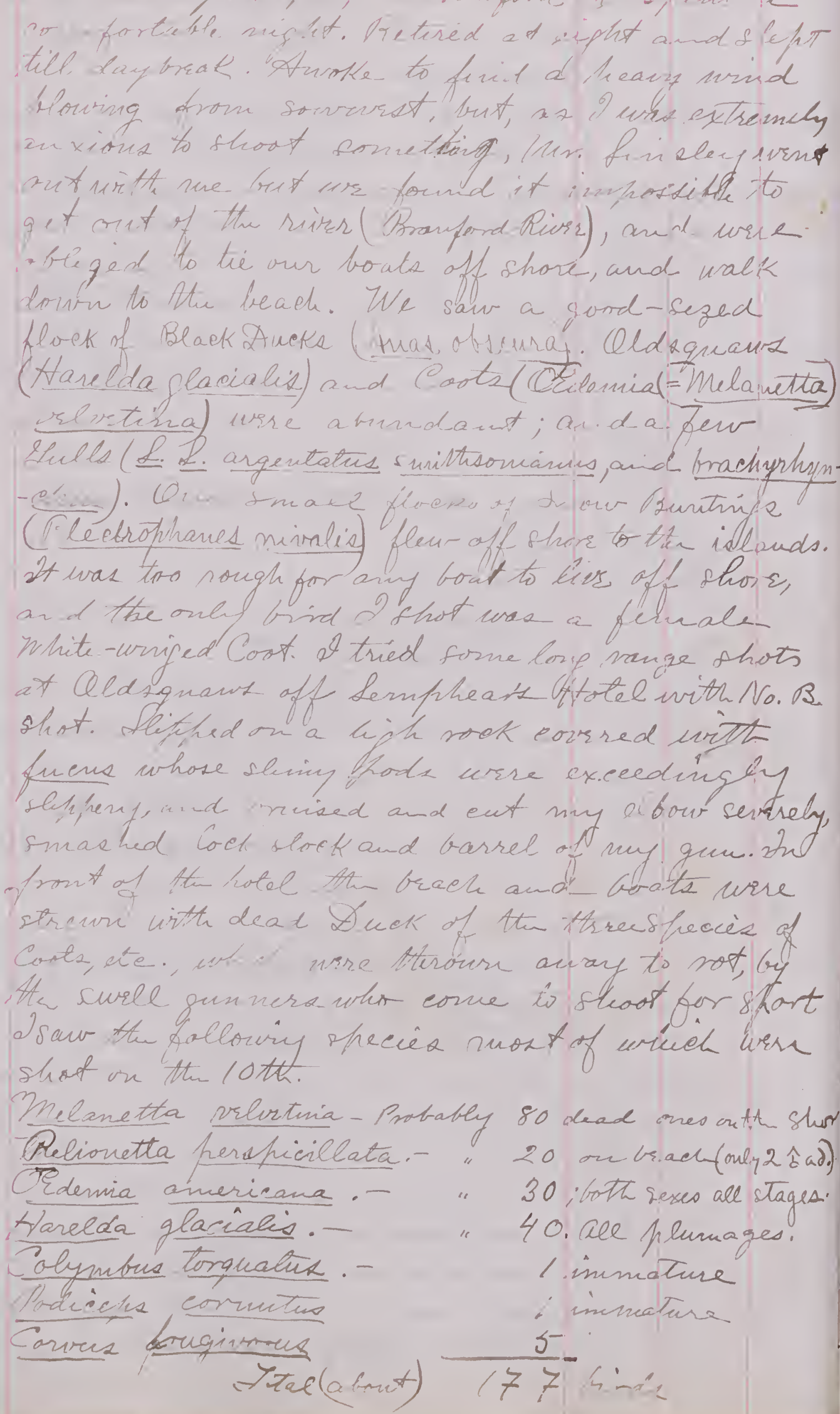


DATE.

LOCALITY:

\begin{tabular}{|c|c|}
\hline Length & Strtel. \\
\hline
\end{tabular}

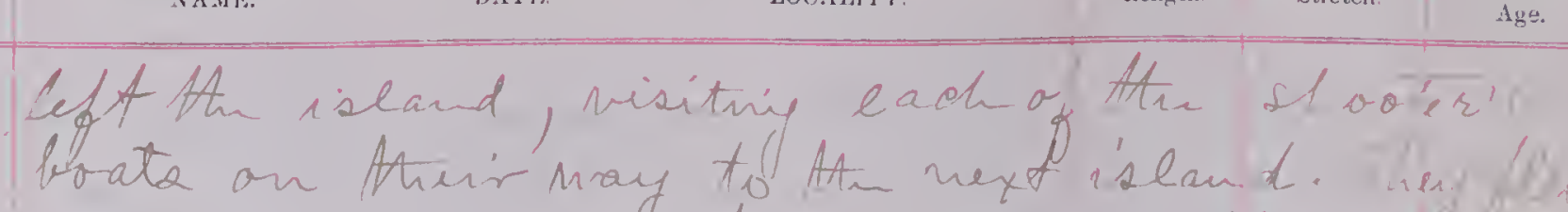

strachlnichs leaving the mook one affer aingthes.

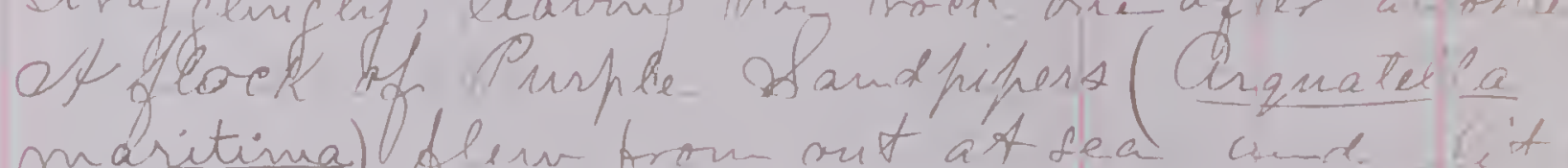
a ridge of voph orried usit seawird ( he whieh was bring

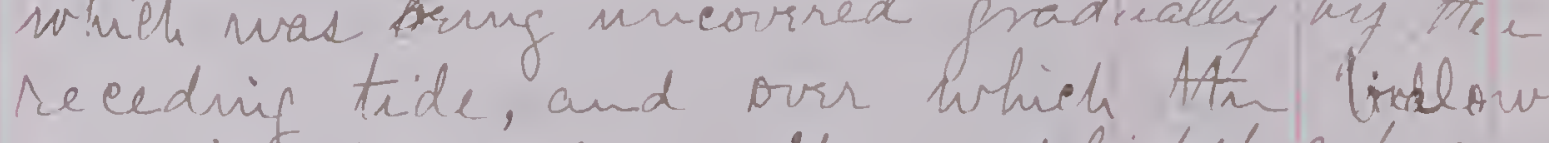
recarionally dashing. It was delichttall to foe Sandhifress rise ith the air to llett the bon hest crar from a grant comber, and thes settle doun upon the rock and fo on feet. By drit of thand pulluin, Imanaged to izet to unidura red if Atrem, and shot itwo writte som first bavell; they flew seattering, and e?

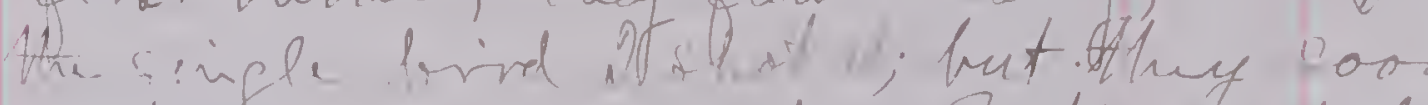

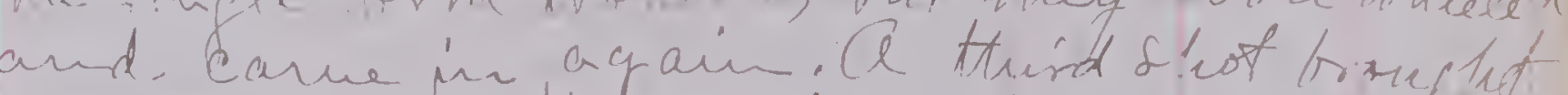

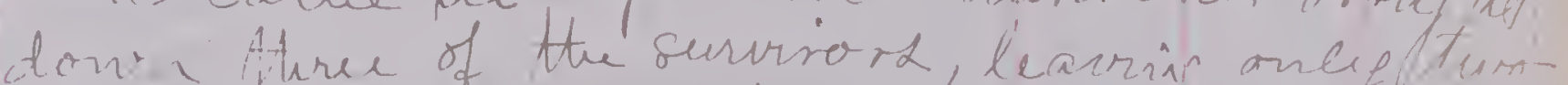
If the rricinal flock of severs. I Mrad glake to get ruy birds and det of thr hock withant arn mishof. 2. had then adl lying on the

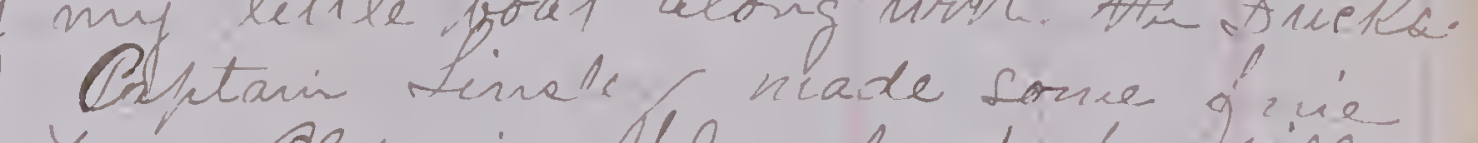
chote. Hour Qldurira Slew hast; he Tilled two witts each borrelithon oed drakes. Ensthe. time he killed twir hivd a ceratsone that came. orrer taking one with each barrel. Another time he Hilled an Oldoquans at an inmense "heipht, making what the funness call "me of Lil. Lirraley's tall shoto." Ofteu when a flock flew virs he would Rili wre with each the Sea Sester (Pelionetta huspicillata) is Thile shooting at anchor hoo slackst of Whit Snowtirds (Plectrophorea miralie) visted is iseand near by boat. In thin crevee's of the bore rock a four slrzaks of grasib

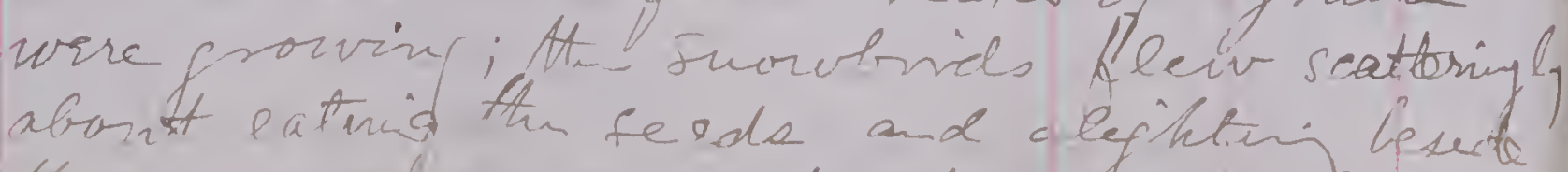
inoun only by the name of firnnk-heach or

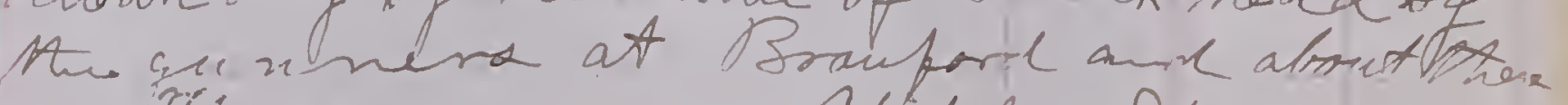

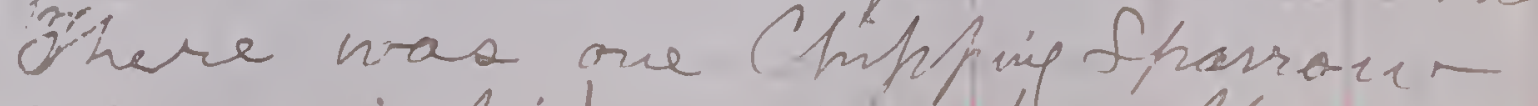

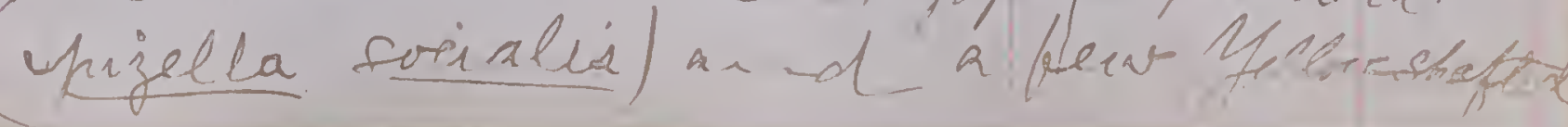




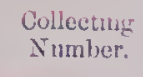

N.M.

DATE.

tiérte vare seorr

Pelionctta pursficillata. Shot Nov.10, 2010 34.00 Ŝad. Winc *9.15; tail, 3.10; culmen, 1.5.8; gahe, 2.58; tarbur, 1.82; middle tor and rlow, 3.00 ; nind. - dle tor alone, 2.67; claw, 40. chis, white. Stomach filled with clans.

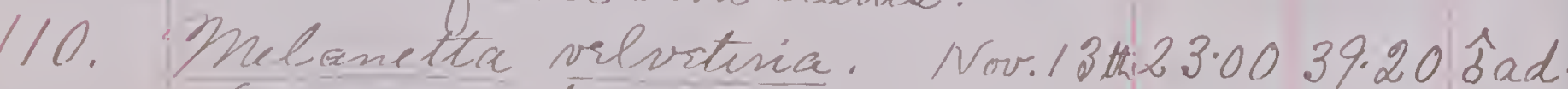
Wrig, 10.75; tail, 4.00; gape, 2.77; culmen, 1.50; larsur, 2.03; middle ter and claur, 3.2.2; middle toralone, 2.85; claw, 40 . Orix, whiti.

Stomadr filled with clarus.

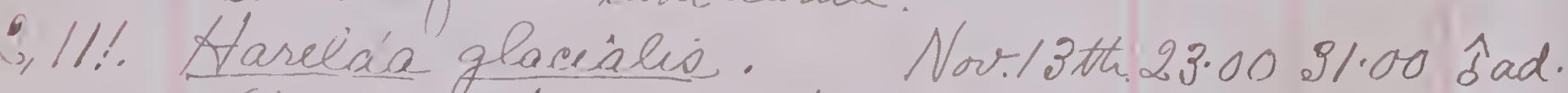
Wini, 8.75; tael, 8.75 (same ae wries'); enbuen, 112; gope, 1.77; tarsus, 1.40; middele tor and claw, 2:20; ninddle tor, 1.95; it a claw, 34. Bris, litht hazel. tuliqula marila. Nov.13.th.19.50 32.80 djur. Wring, 8.90; tail, 2.70; culmen, 1.85; sope,... 8; tarbur, 1.65; middle tor and elaur, 2.88; chav alone 38 ; tor alone, 2.5.8. Tria iris gold-color. Shot at head of fierth aí.me rauge 2,113. Arquatella maritima. Nm.1.34.9.35 16.40 o ad. Wnif, 5.00; tail, 2.45; culnern, i.37; gape, i.36; tarsur, 98; niddle tor and sean, 1.b8; midle tor alone, 91; its elau, 19. Fris, hase' deuts Bill, yellow at base, ste a ding into grevinch-yout min midle; lesminal one-tivir, black. Legs +feet, aliv-yellow- mails, beacke.

¿,14. Arquatella maritima. Nor.13th.8.9015.60 âad. Wring, 4.87; tail, 2.45; culmen, 1.10; qufe, 1:10 tarsus, 90; middle tor and. - lowr, 1.Cb'; midile toe, 86 ; claw, 2.1. 2ris, cilerfelt, same is. ather:

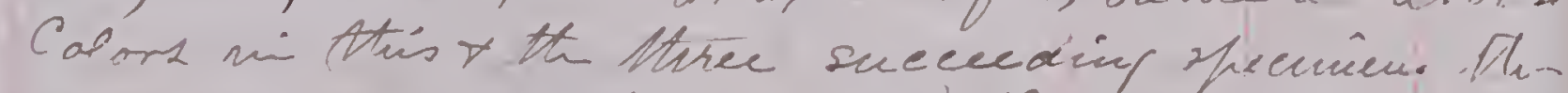

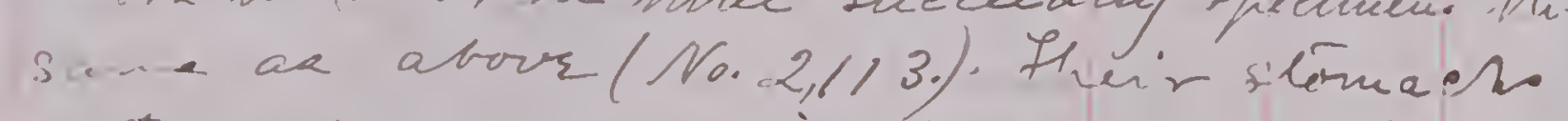
witiaice smale univalus and othor

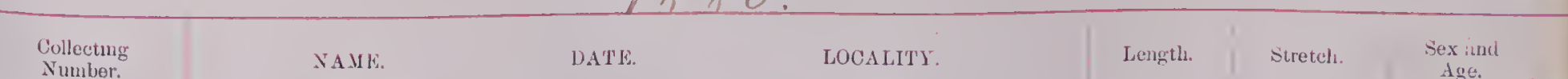

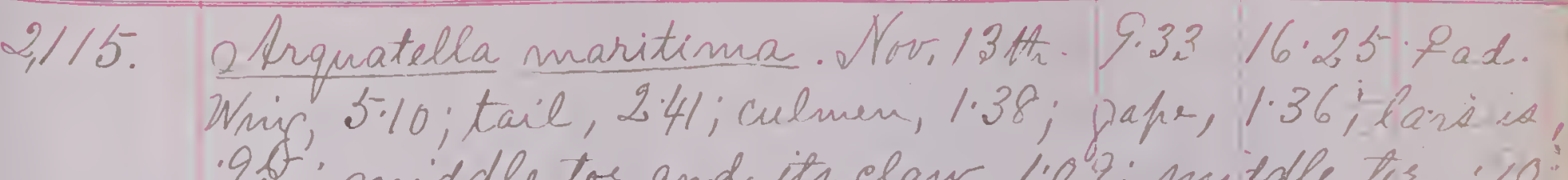
9); middle tor and its claw, 110 ; mitdle ter, '10; its plaw, 23. Irix, hazel. 2,116. Arquatella maritima. Nov.13th.9:10 16.00 fal. tardur, 95 ; middle tor and olar, 1.18; mildel tor 90 its claw, 28 . Iri" hazel

2,117. O Arquatella maritima. Nor.13th. 8.9015 .80 fad. Ning 4.85; tail, 2.40 ; culmen, 1.25; pafi, 1.28; , tor, 92, lear, is?. Fris, hazel.

\section{this afternow Unomis y? unith.} on the division betwern the tho harte oft It lavge resignois. Wre wre not hermithed to thote seeto see what specees" we int four ardinal Pedbirds. (Casdinaide virinials.) wise seen two males and tovo demals in

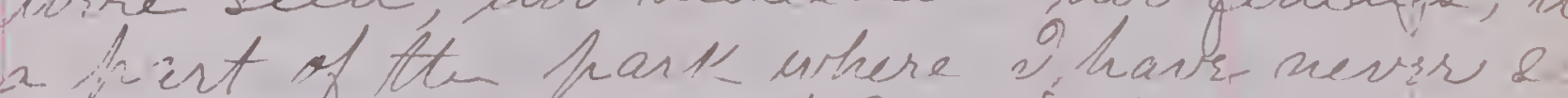
the sfreckis ingon; ibut Morre has seen it thi. in eprisig. Furofermales and a males wre in sicht lat onee- ft.., w. . usual.

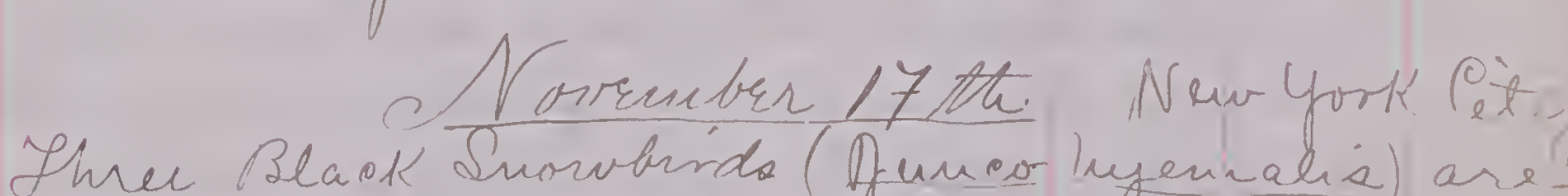

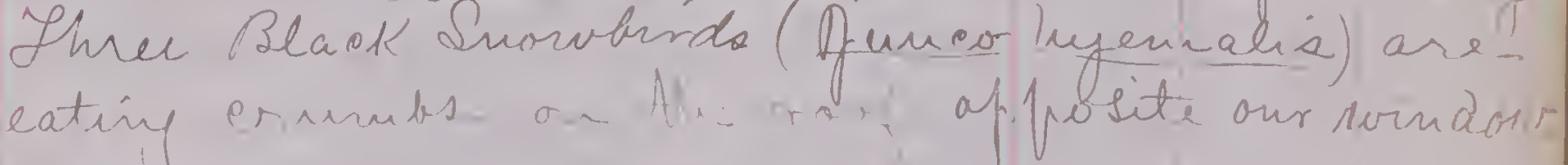
Novembir 21V2.2. Highland falls, v.Y. Aiacia sealic. - Bluebird.

Regulus ratrapa. - folden-crested tinglet. Parne atricafillur. - Chiekadee.

Pitla casplinensis. Mrtrite-hellied 1utratsh.

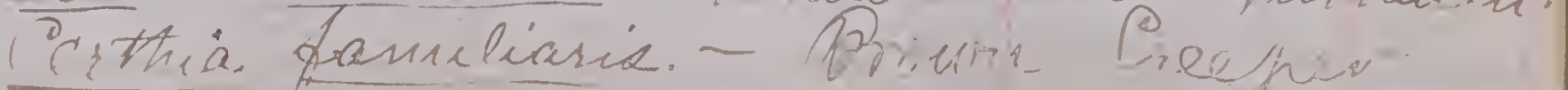




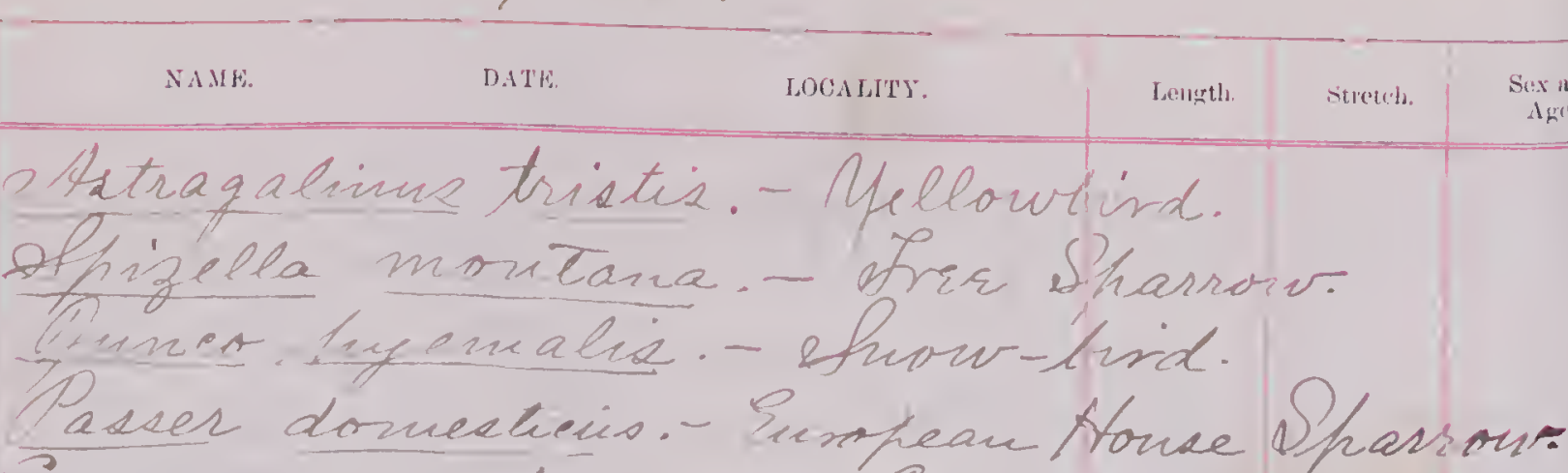

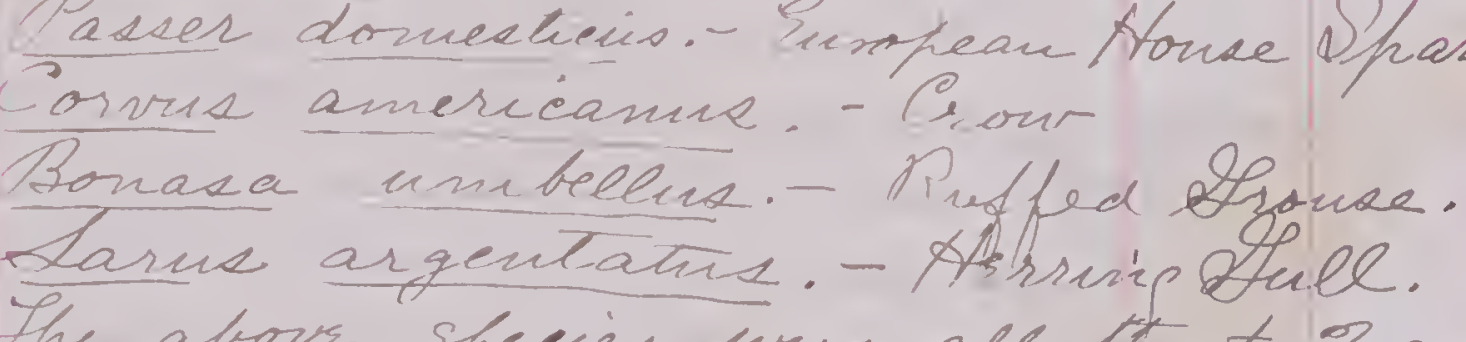

Co Hox Sharrous, edar-binds. Pobinis er

Hellow-sumped Narblert usse seen.'

\section{Loventert / th. Sayirle, S. 2., N.Y.} the followin briste urre seen dlony the

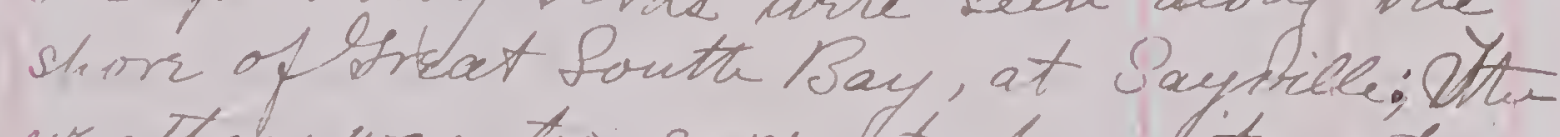
neather uras tow seire to persulit us to fo

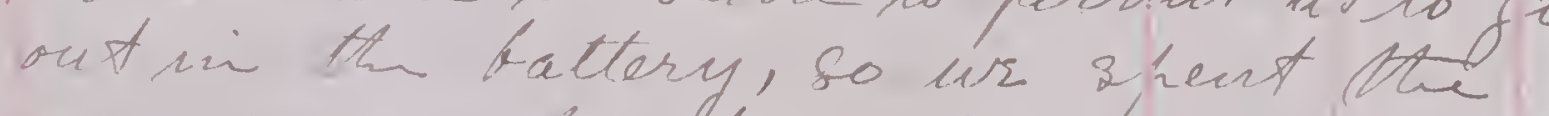
nermini, on the boy slesre, ind sailed acroskl the bay sin the aflerrioon und anchord on the slesotiti grounde near

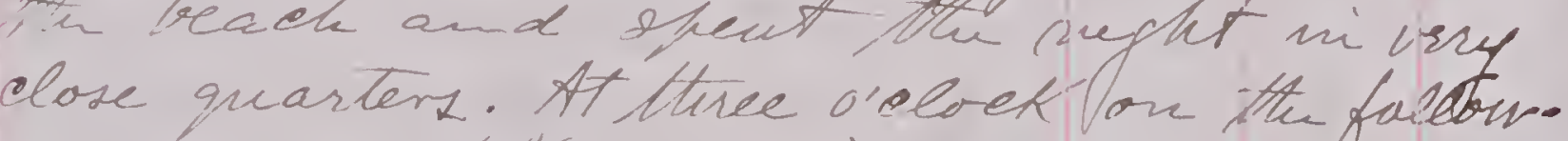
-ini morming (Now. 20 th) ur sore, a d, fiudui thend had again changex to the Vont and has rowin hard, wricked anclur ti. to get bredrosk the bay tiblayvele, in

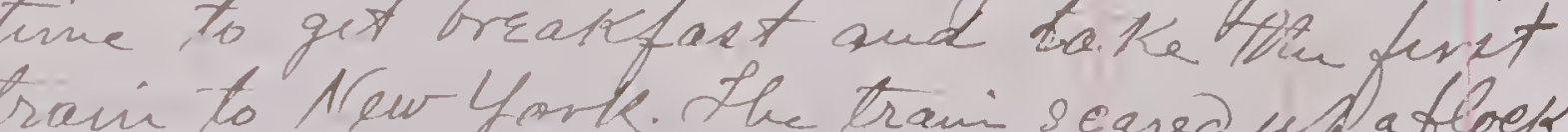
san to the trani scared u afloek of Qrtys ringiniamus. near Pabylin. of tarporhycehus nefees. Cue sepul in the woods Pans atricafullus.

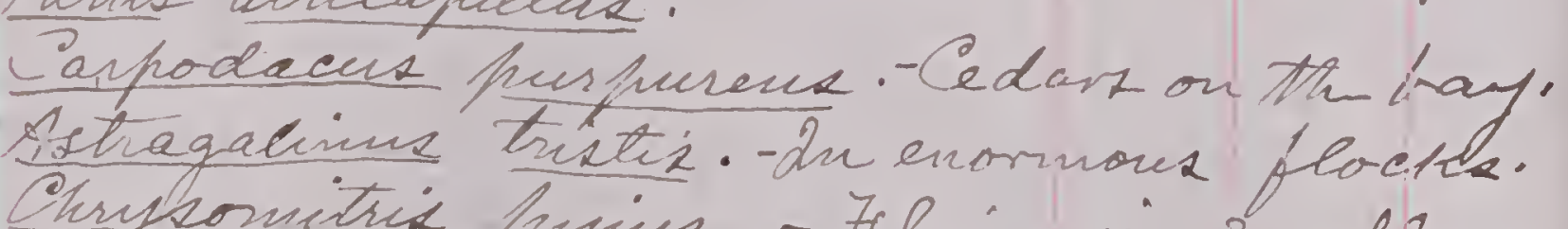

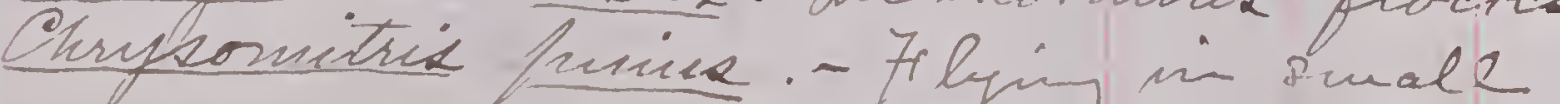
Melospiza parciala.

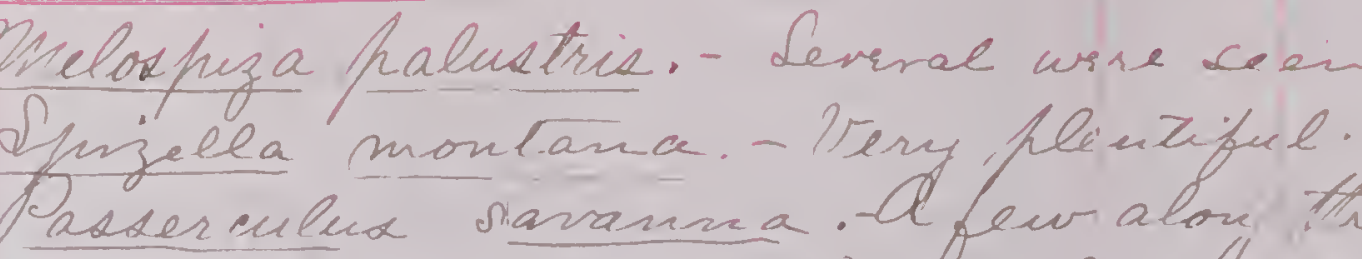
asberculux savanna. A few alon the ipanveltal orietata. - Arundant.

Prtyse virginiamus.

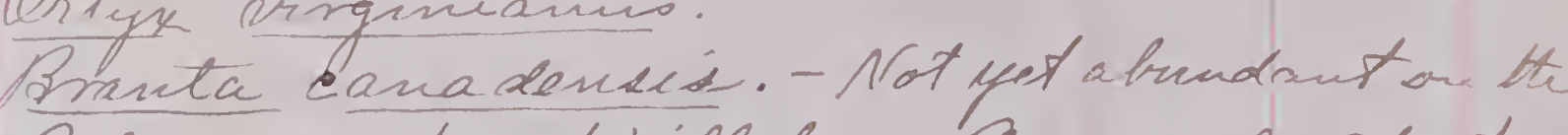
Pelionetta hersfucillata. - Cue. mal oteo of.

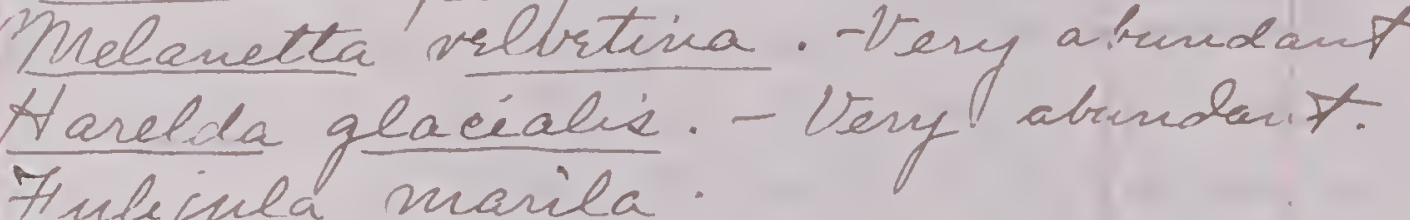
Hulifula marila.

Lanus argentatus. Hee only pull ReaPelionetta prapricillata.

$18.85 \quad 32 \cdot 10$ Wing, 9.75 ; tail, 3.65 ; culmen, 1.36 ; giafe, $2 \%$ iassus, 1.65 ; vinidrle tor and claw, 2.73 . middle tor alme, 2.40 ; law, 35 . Inid, hage? Thio urid was wry cuall, lacked, the white haten' on the tof of head, but froskessed. The qlosen, blapk hlumaqe of the adult male, and had the triangular white ficted on the nake wrel developed. Her bill lacked. The red evor of thr a dult, but had a few iriegular Tawny

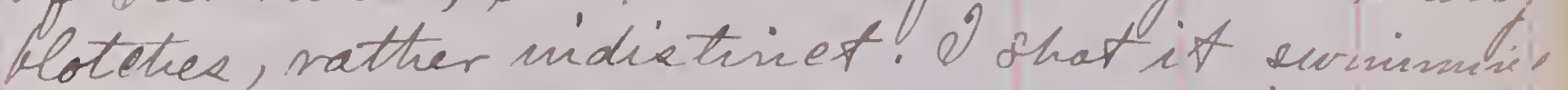
alon the edge of a mareh on the bag fhors. It this the last stage through whieh thithe male bird passes before ariming at, the hergect adult plumage? viz: hativie llaek flumage and white make conplet

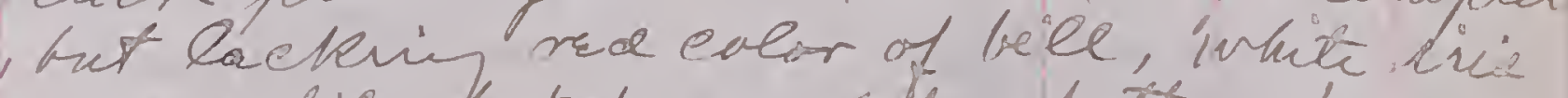
, and white fateh on eth of the heor

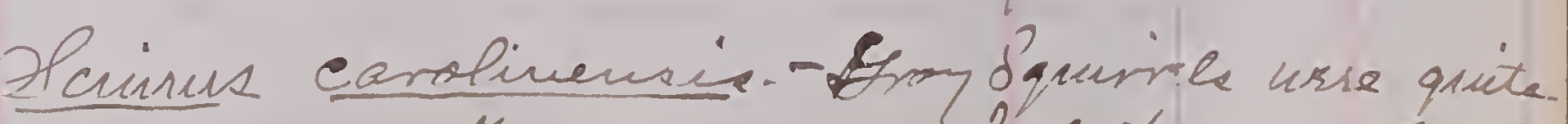

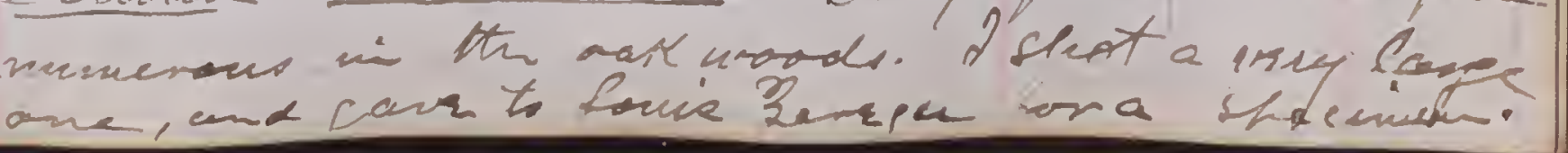




xaMs.

DATF.

Buteo borealis. - Quite mume sous.

train from Gerser City for ireleville; (Dhis. Pleptr confortably until daykipht: then shid Ah curtain v cossed out of the cas unistow form bed. Ne wre three of four houre

a ast of tillasin, and, altwough I keft fird (frobable a sparrow of some dort) was serinberiviele that city. From Pitsburs to

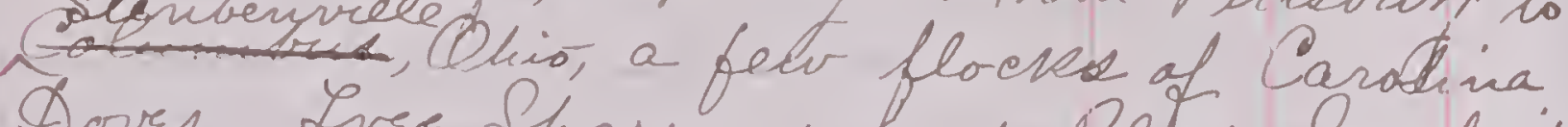
Doves, Lver Sharrous and Pldok Lnowinds urre all the binds soted.

tentreville is silicaled on thi wrst bank of Atu Qhio Brive, which formed the boundary beturan Pennaylvanid and Chio Sto proz ituis flace westurard to Calunibue the birds mereased constantly in mumbrund variaty. She following apecies wrer Moted:Lavine Gorralic. - Sevral Shrites, uhtéh of sucked at the tivice as fotreat Mortherin nere seen sittin whon trees at 12 mous forits. along the Man Handle Roadi. int Pr. Howerd porles thinits ther urere Lof ner-headied. Whikes. Dr. 2. Hu. Yheatode, hovever, in - formed me that ist dore not aceur in ininter about the city of Golinubus, nithere I saw specineme of IL. borealis that urre callected there by Mr. Qenirs Darie. I think that my obserratioin. wre corred, and that thet fhrikes seem esect of Coluntwow. wire all Atrat Narthern finckes ?

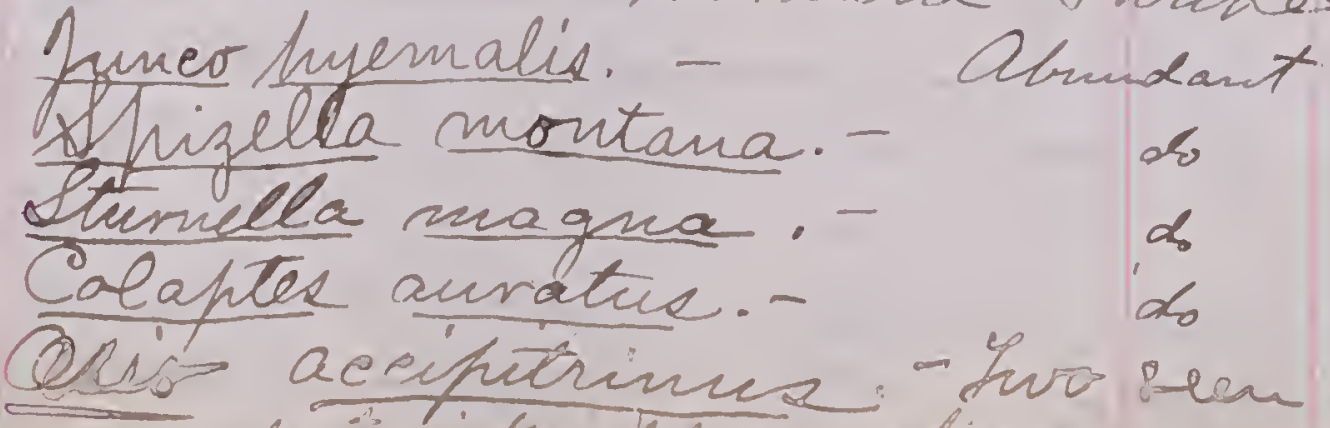

Buteo hineatus. - de Buter pennoylvarians. - Que set close to th railroad as wr passed. I Hinite sevral isre deen Lenatedura carolinensis. - 2 r flocks of cex to lurentr all alonf the road,frem Pilletire to Calunubus.

The trist snow nas enconitered fi'tly miles east of Pithaturs, $\mathrm{Pa}$, and the weatter durni

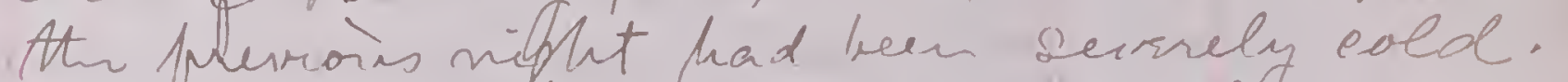
At colmubus the suow ares sivera? uichex alep and thr tenuperature severial degress below zero. the same at Arelerible, Where

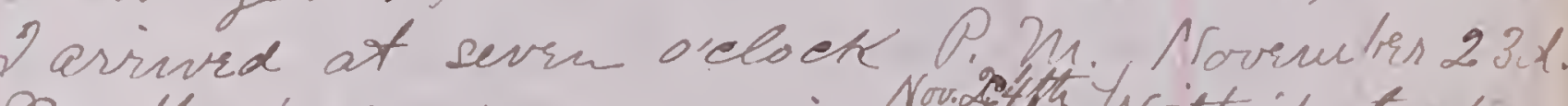

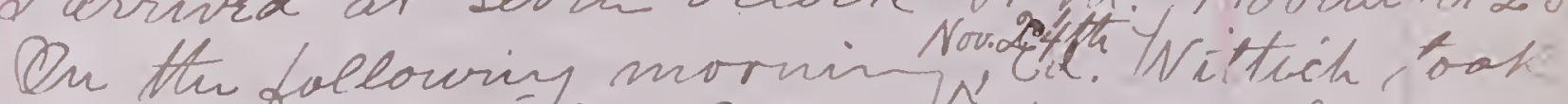
me down to Ers. C. M. F tomard fomes's offece andintroduced me to the bed itoelor A And his sm- Or. Aloward, who untes ts:text aecompanuin, the illuetraternis of the urork" entidted" "Illualrations of the Nevts

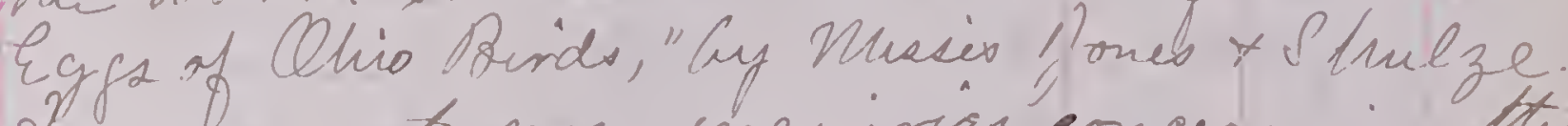
In anewer to my encuiriss eoncervin the uriter krids - that the Lurvey Buzpardiz go bे

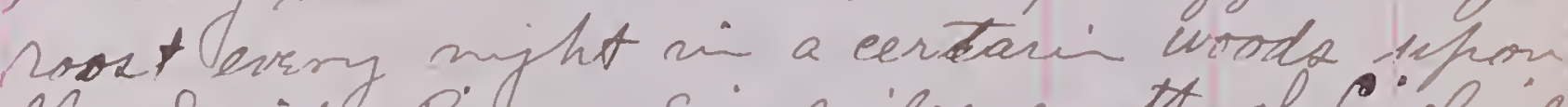
the Secioto Piser, six miles morth of Cicleirl? The red dvetor Frought in a ITirginia Tail which his of haviel hare cauchit. It was cheured into a pulf, but preserved its head whiel inpression of Atu fones's, anld pronused

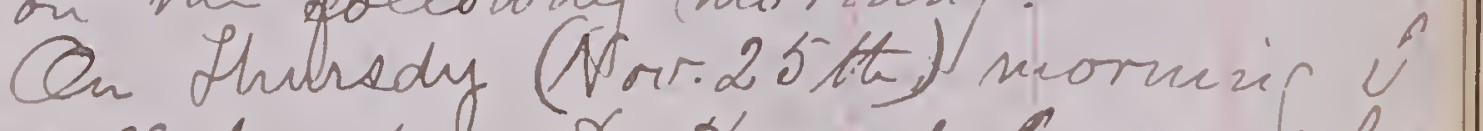
afain called upan Ar. Howard Fones, who shourd we three peates from ine. I?. A,

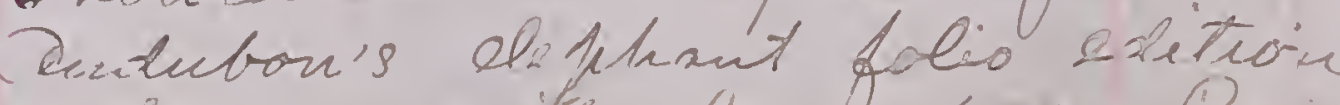

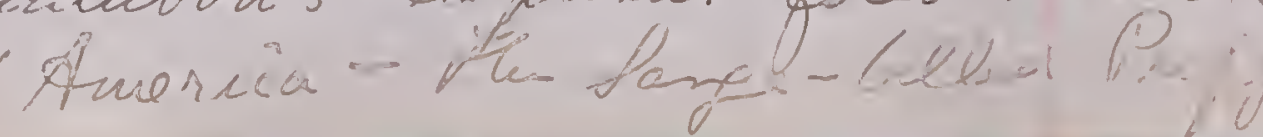




хам.

D.T:

LOCA AITYYY.

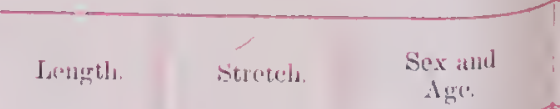

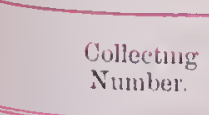

Xuck, which he had vecirrot sulated Wade, of Roekville, Connecteritt it war ther tatien m f starsis and fresented to Dhro. Dr. Joues (his nother), usho mias

infaged in drawing the medit of Sencedura for the eizeravi its two $2 \mathrm{ff}^{2}$, uhou stone Mnis riplecobs who was colorit one of the hlater. She was urotting slonty and barefully unon the foliage and bloxtoms of the ctandin blacktrerry (Rubus villosus). If Lum At recently completed draunin on the stone of the Blue-gry Snateatetier (Poliptila corrulea) un Pube-throated Atuming bird Corodilus colubries both nesto drawh on-tous plate, in a back room wre found the sreater hart of str. Shones's cellecteri of nests and ifft of Qhio Bride, each nest accon framied by its set of effor and. restuin upon the branch or mulaterials nist as it ures found, and aecompaneid by a paper giving a fell a ceount of its setuation environments miaterials, habitat of bisda.ete. all to be usedbot. Jones in tive bleceriftivie text. Down slaine " was shower a remartiatly: wive series of the nests and ufe of thi Deadiain Alycaleher (Eufialmax acadions) whoce nest Dr. Howard has been esfecially forlinate in firidir. Mus. Aores was very conteone; and. Arinclly shoned

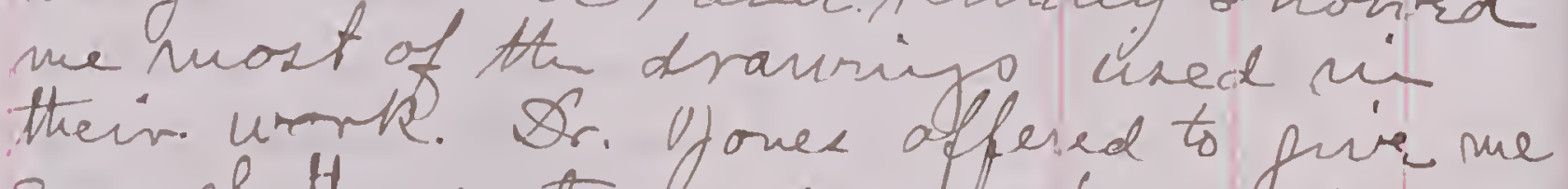
sone of the rests and effer fejeerd, and ad trutirds Granght ne a rest and cet of 2fis i. Her Virginia Carderial (Cardiualio)

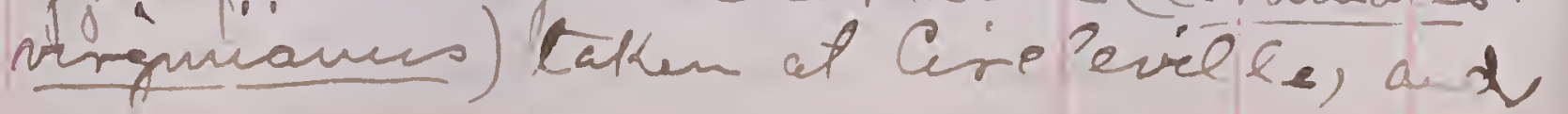

promised me the checrine fofirres in ther species has beer mritten. The Suctor promised to call for me to fo out witt him in search of Rpepmins as seron as his sore eyes would permit.

Inth ofltruom Nor.25tt. Cieleville, Dhis Gich Wittich wint out shooting with nive. We out seeins much Save Suail's traetes a. sme furam Sparrove. WR were foing n. short-eared Qwes (asio aecifitrinus) gly.i.s about the prairie to the peft. I ?

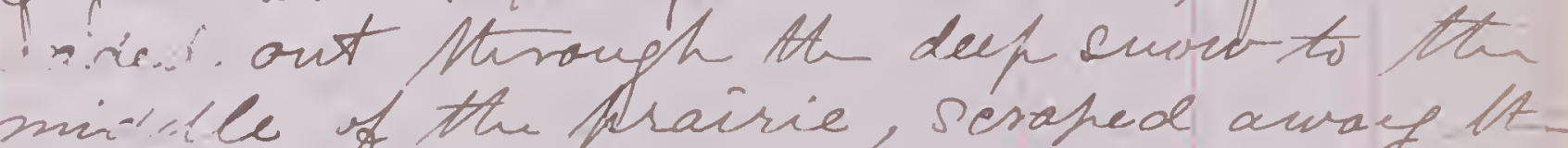

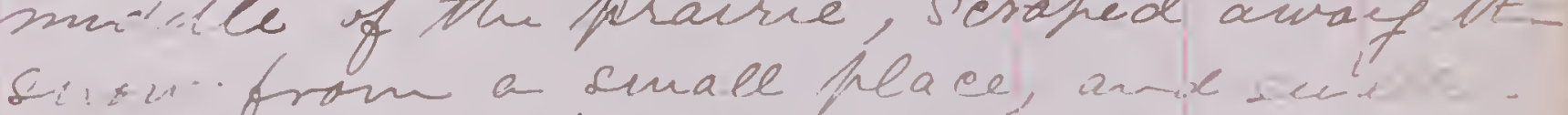
downe nd naited for owe of the Cuve हt óly near enough for a chot. form a we $3=\ldots$... ning and did rot notice me, for $y$ wit i eased in brown shooth; caotryelest cap. "'in he fot dwri.12 overkead obrose and, ter dettrin it ply a litte way off, chot th

m : 2) ware buried deep in the snow ilew out witt a loud whure wher

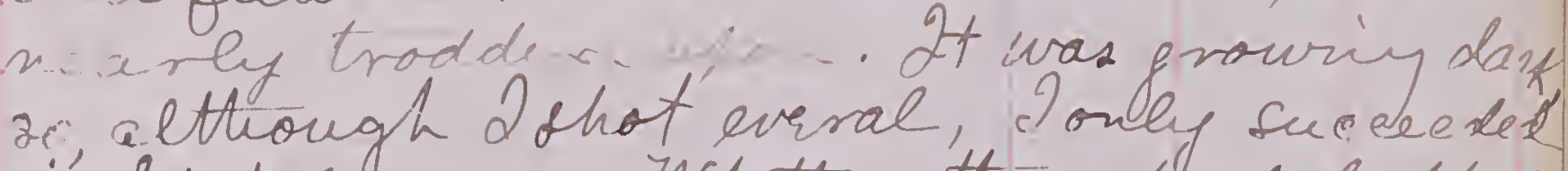
in pivelinif ane. Whether they Had diophed

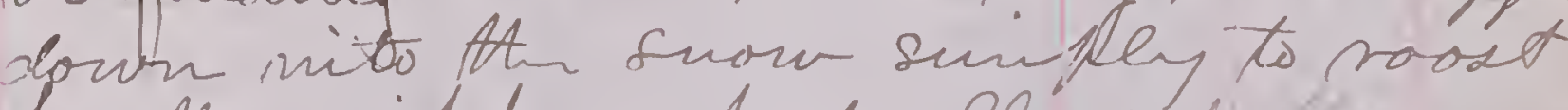
for At might, or had allou

to be cuoverd nuder at enulustell.

Ineade a fame-piece of the Lark. 2te lengtir

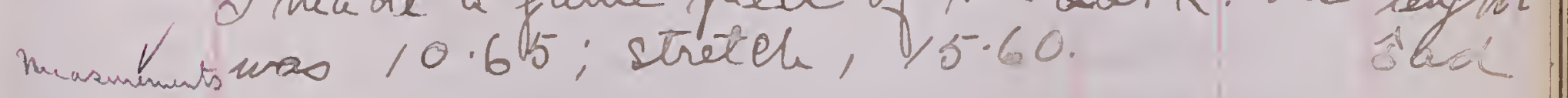
Finidaz, Noveruber 26 hith Cirelevill, Qhis 
Kaid Reohle; and thi Grotter, Iaciah He e

camal, and them walked a enass to be sif the Prise at at hoint north of Psui's 2 land. We crosued the rivis road, where a luige floek of Shor Lastik (iremoftila allhestuis) uas feedin, mi the road. thery uris the

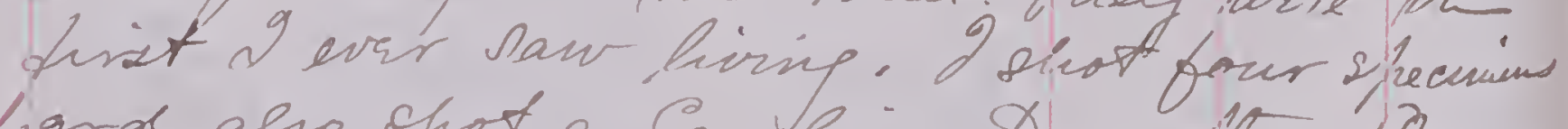

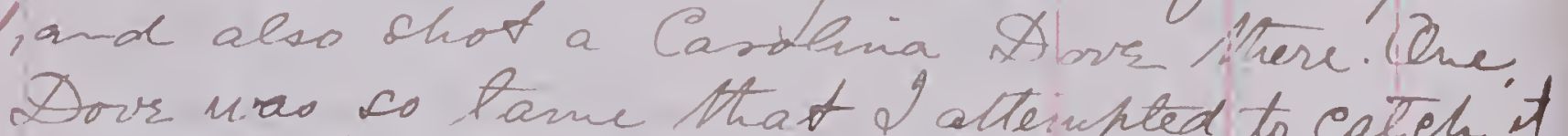
in nuy hands, and a ctually almos t ehitehed it refore it flew. On Craus's Leand wr saw several Redbird. (Cardinalis nirginimus); and Sthot tivo males and a ferrale. We aloo saw

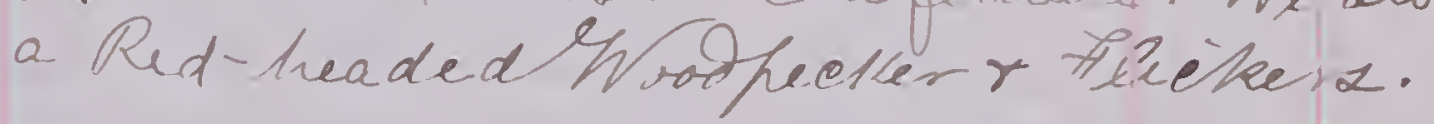

\section{Saturday, Nor. 27.th Circlinele, Ohis.} Ar. Gonet called for we with a sileight for his gun, ar his eyed still lsoubled hisil. ite drove three miles south finto a carce

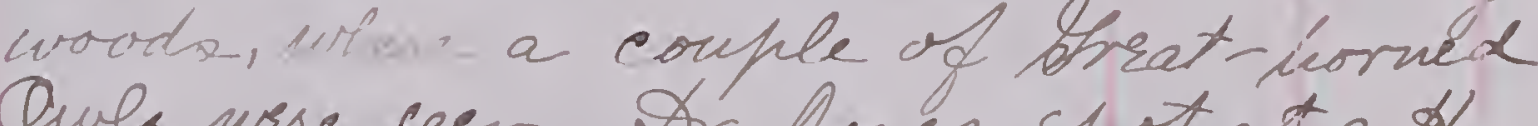
Quve nrre sen. Dr. fones st ot at a Mury Voodrecker, a Redbind, and at a dupten hitmonese, but th suact cha-mes fouled to kill any of then. The huit a carre Hoek suail. Juzted hinuce uere sery mumerous.'

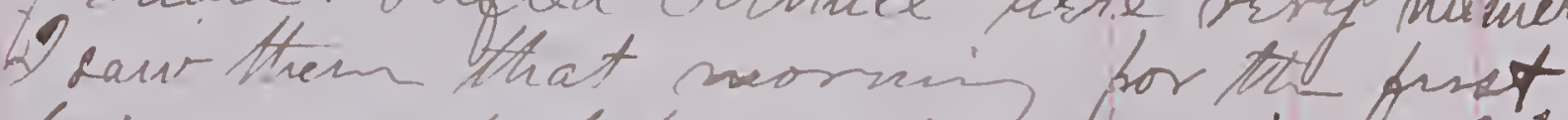
tinie and chot four niè sipecinen bisedes a male White-bellied Nuthate: We ure mly out a criple of hourd or so. Huree Redirizds wrre seen sin the trees in the citr.

$$
\text { dunday, Nov.28tt. Cireleville, Cino. }
$$

c) receird an sivitation to dive at vi stulse's, at their farm four iniles west of irelevile. The tivo younp $t$ indeis $\ldots . .1$

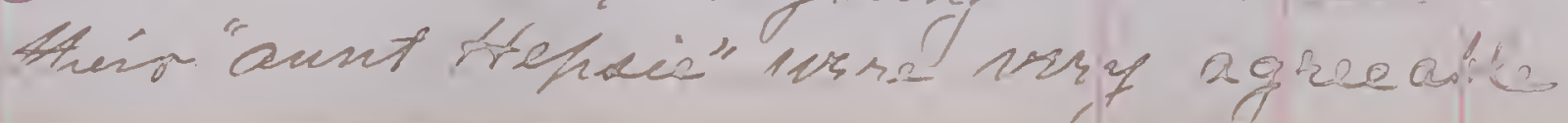

is a food fellour. Bores were ceer ale alory the read, pieking up the corn solice Inad spilled from the wagona on the prosions day. They wire in flocks of variable deze, aldo single, and ni hairs. "(ls a rule they weruld ballow us to drive close up to Ntitur, and Hien merely flew in vin th - berees bside the road or wpon th nearest inel. Hele. Flocks of tiverity to thirty Girds nere not mueomumon. Leveral trues ur slophed in carriage and lroked at those that is ise seltini on th ferces lreaide the mad-y with at dew deet of us. Shove Lark's wre seen ed

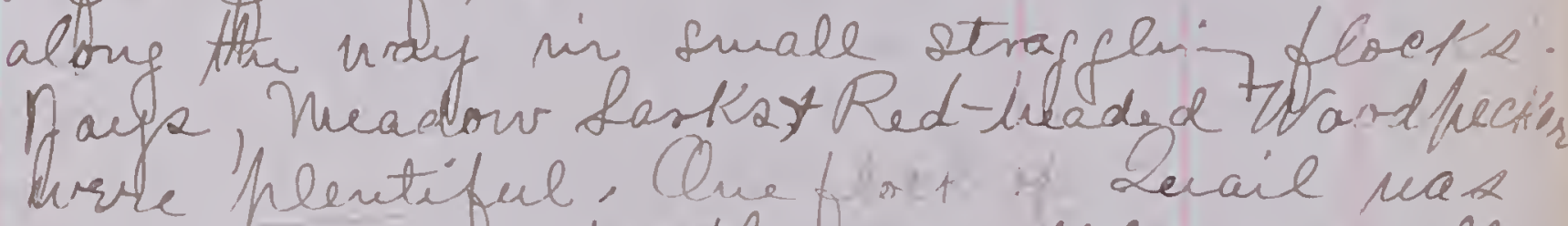
seem in a perfeetley opunfield, near th road, and mully a ariple of nods frou a horisi., of sav th fisit togjer-headed?

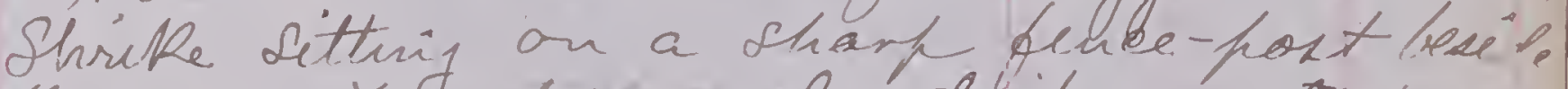
the rand. Mre clopice cloze to it aud tork a sood Cosk; as wr started on it flew-to th nearedt corm shork and uaffed ito tail untel ure resse out of Sifht this was the

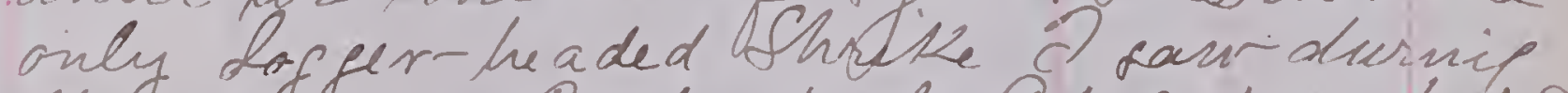
At 13 bajp of shent at Cireleville; irtt It M. M. IN heaton presented nue with a mee Somale shot by himsels it Alumbra, á April, 1876. Ed. 2 aecopted an nivitatio: to go out the next day and ofusot durming the afleñon, whith ure glad to der

Monday Nor,291t. Créleirle, Dies. vi: wre delayed in startin' for hulse's, bur got oif in a lejtet rug cy at haif prast one 
stasted wot soon after. I cheot a Dover Glyin mi the orehard, thee Rabbits woode, fur Luail And a Bank Mrivie, and a Red-headed Woodhether in the bij elm-tree beside the houpe.

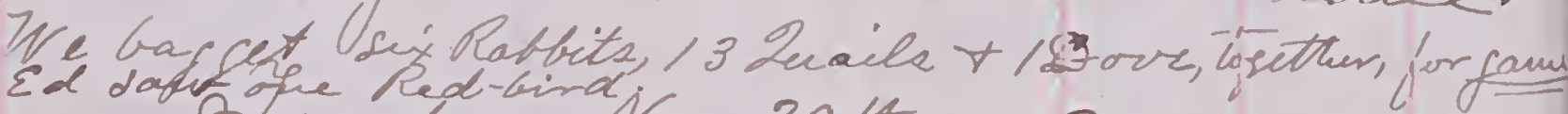

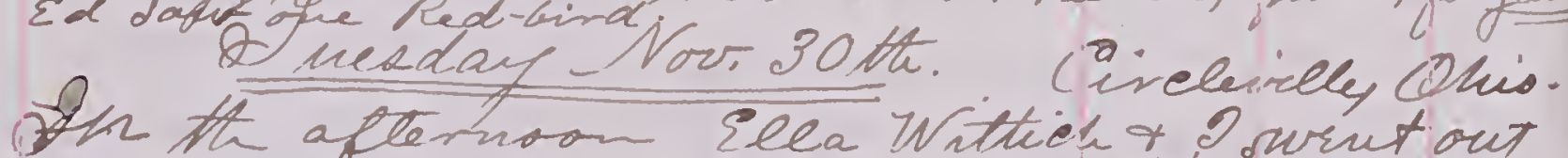
sic a buffy. We tried to get andiost at a levek of Doria ufour a boari-fenee, irut ther glew be pore ure eould tiee the horke. 7 chor two Zores at a chot, in ai aphle-tree, bexides a Neaciow-Lirk. there wrre numibrs of Nueadow forsts. and larger small flieks of fleorr Larks. We sour one Red-bind (f) and the perret Bluebrida I caw in Eicleville.

$$
\text { Wedresday, Dec./St. irelevile, this }
$$
turo Red-Girds + twon Reails. Mussed or failed to Kill a Shamour-Atawk, Hrat horned $\forall$ Barred Wulk. Sarr Lawher. Buntins $\forall$ larqe, loekt of red-birids Thursday Bee.2d. Areleville, thit. d.y of setant earlymi the mormi for thilse's farm. Jays $*$ Red-head. d. Thoodpeekere were very mumerous in the croods about th libuse. Whe she't 13 Woodpeckers 3 fays $\therefore$ : Short timin, and kiled some sebrits and werdore ufe to awoth of thelse's

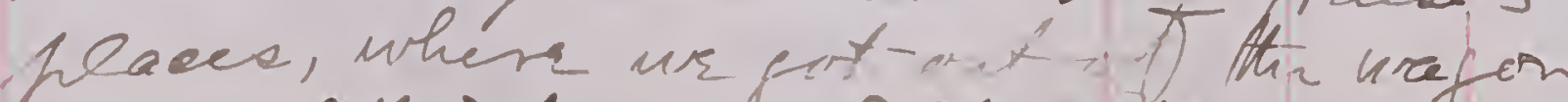
and ural kid home. Altog ther we

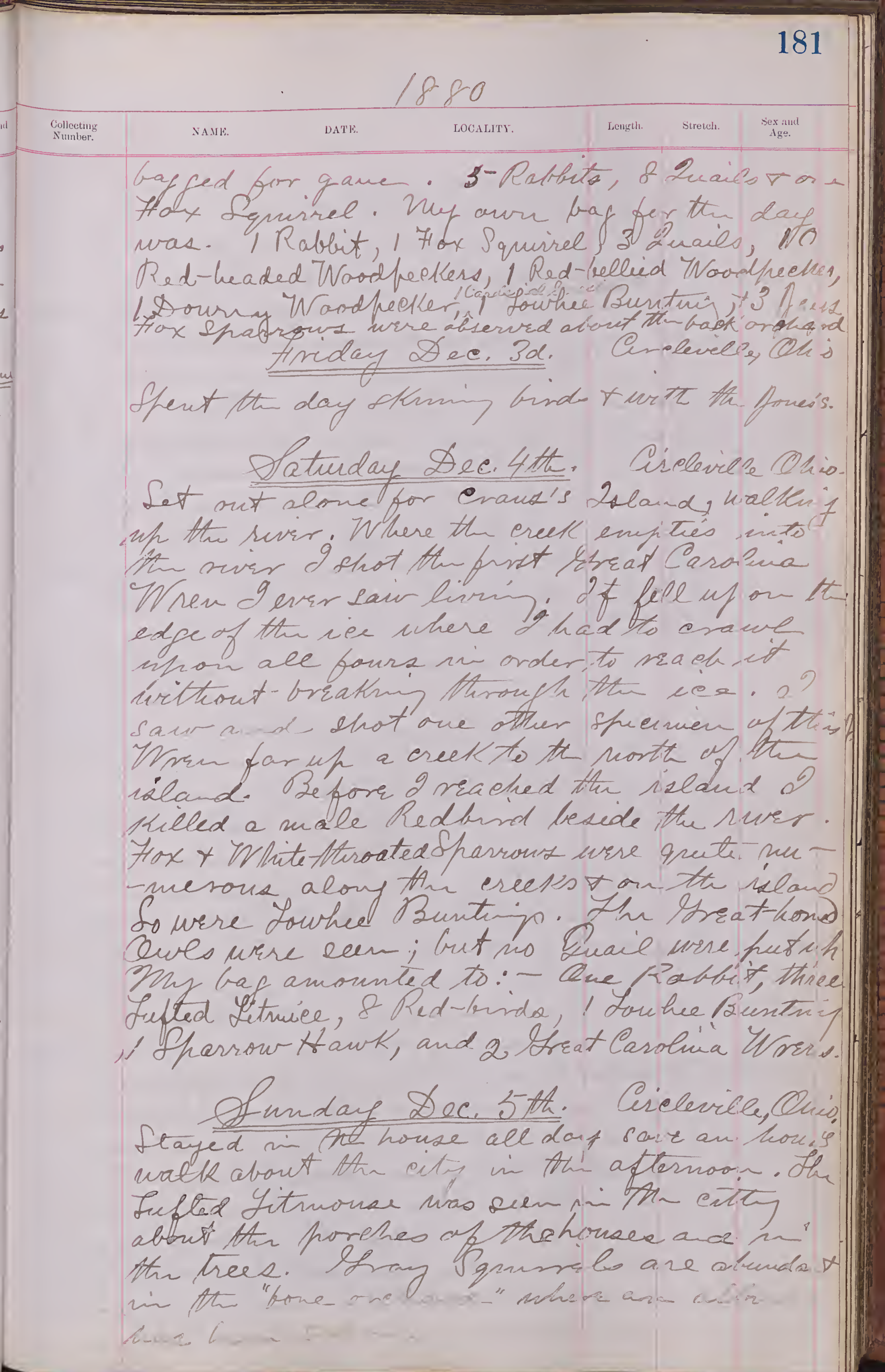




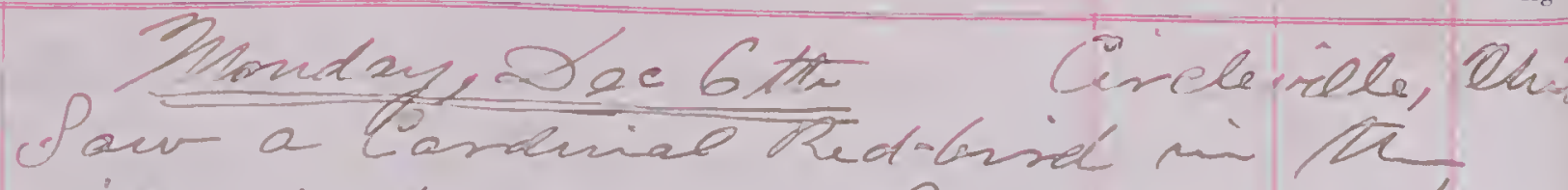

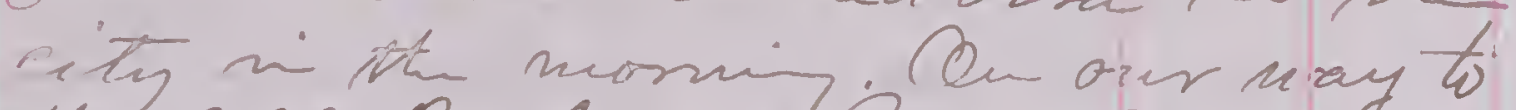

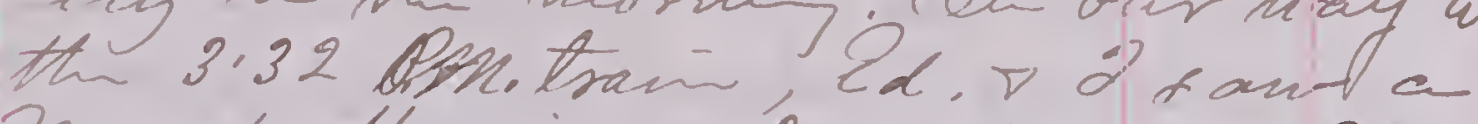
massh tarrier. If aruird at ishmires at H.5 P. Mi, and wrut directily to Er. f. M. YN heatowí, sund IA. n ervin. The ald guétiona. recewid ve viry eordially. At handed. m a Auplt's Arad to diaginse. Ifind it midut be a Blapt Duetis; but it

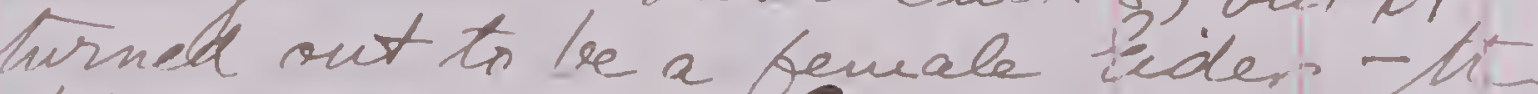

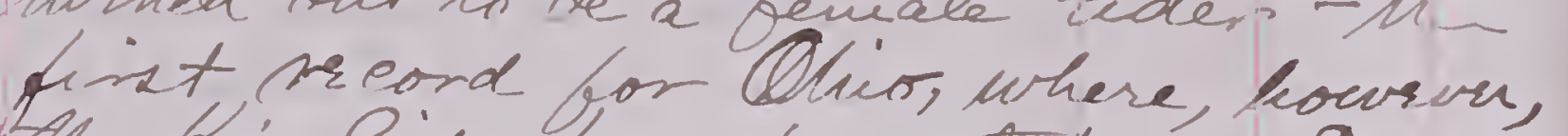

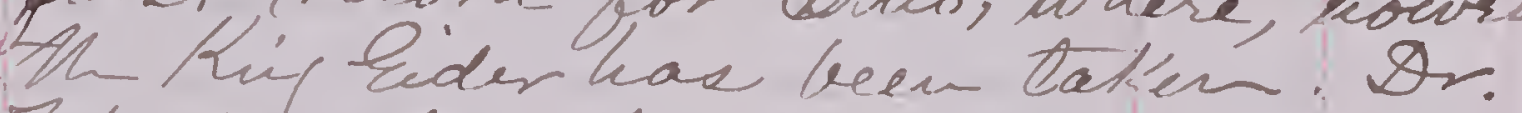
Thucation the hresented we with a cofry of his reprent on "the Fond of Burds as Related to Agriénlture" pr bleched in 1875; ofter makin serral additures in fiencil bod refraging to corres po with th pagin-aturi of th Egricultural rehont in which it ures frinted. Th thin presentex me wrtt fone sfresineme urhe'k the had collected, and chownse mue his. mode of boolbtheepin. At keehs ase hage of his isiti book for lis featerits ciende it oter for the bide. Wrederived it Cocil fanma; and he allided th th great differenee beturer tt at of columbus \& of th Scintovaller mi th irgiton of Cinchile where gthad been calcetin stating Atrat Atr fama of Cirelerille 1 .

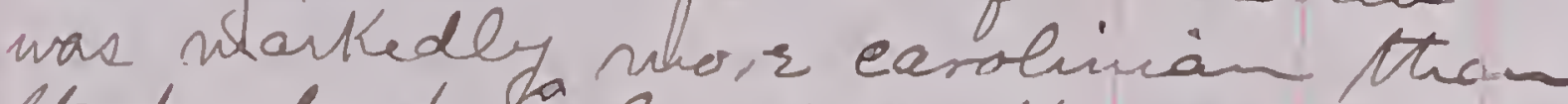
trat about Ealusubur. He, ures duspried

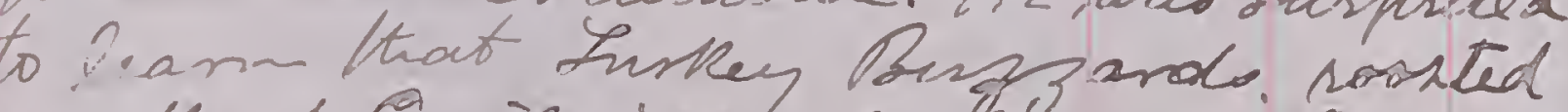
mortt of Ceréleville qurin, winter as Ar. Fones had mifornes' ne, mol

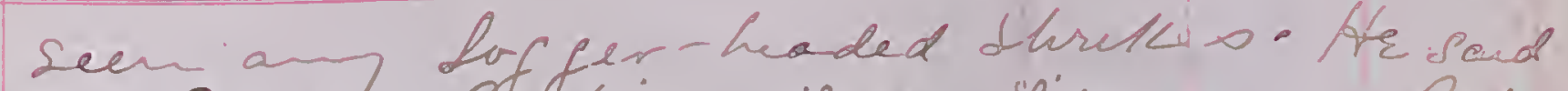
that Cardinal Medrisds, Lufted Litrucie and Red-

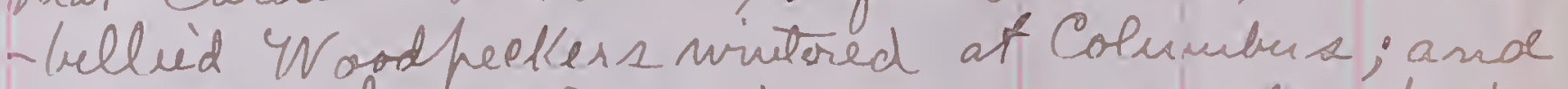
also the Hreat Carolina Nvrins, verely; but He Shrikes he has merer 12 - to do dor, and the Lurkey Buzgards have not been. been. there in vinter of late yeare.

Late at might, on huy way to the tran I called on Mr. Qluier Dllaviel, who kie he a Nalunal tistory ftore at $N_{0.170}$ North. Hijh st. Columbre. Ate showed me his ateir.

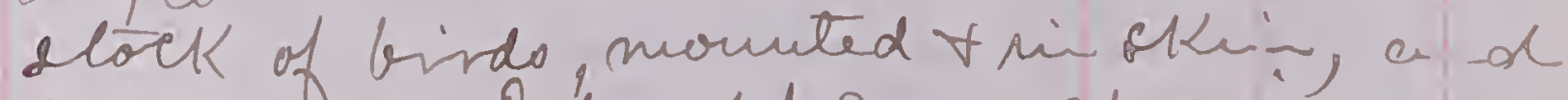
birt's effes. I bought forme fifecuireme, and had a hleasaut thent atrait tou loceal bith thiding Mr. Davie viry urall posted on the local avi-founa, as well as fene al.

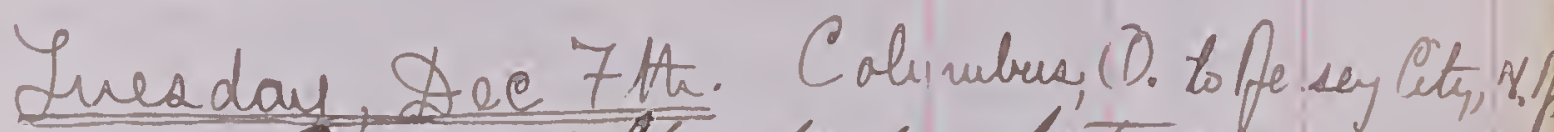
Saw a few Carduial Isrsbeates beturan Lleuban diele, 0 and Pittebury, Pa. Nivstey near the hio vally.

I saw no Luail on my "jouriey east, as Dhassed Atrouch for best quail country in the milht; (ritit, on my uny out time hare very Arindaut in torio. Is ain fix flosers retutern Columbino and the frist otateo east of there. Some were of Vtane that they ruerely fleur from. the traek inpon a. Noard-fenee at the side, and sat there until At train had rassed liy $i$ " Crours were seen withil ure wre is miles east of Nltuma, OP., where Isan the firs, Crover sien sines learine. Nuw York ou Nor, 22x. St. Whas uifornied we that it is noor $n$ arrite

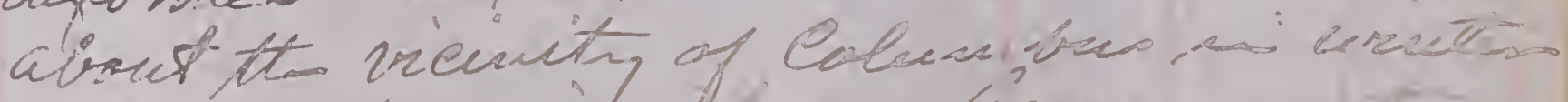

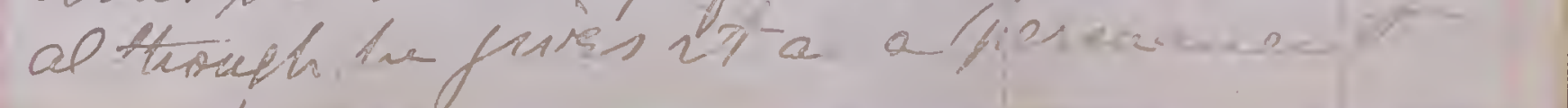




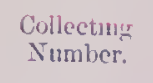

resident in his feit.

When at Dr. Wheaton's house, he slowizd

the a book wi which he records it vecurrever of biras in his fittl yark 100 ofhecier, only one of whieh is at all doubtful. Anong them are the Grran Arrom and Tuail: of the katter he says bu has sometimes fricured a mess for hin small ofaniles ghirnin this autinus nugiation hy fins, a eoufle of sleots.

Hon his baek dior.

Llitit of Aideseen at irelevieli, ohi. Vormubar $23 d$ to Aec.6 th

Pialia sialis. - Lite numerour; sinjing.

2. Regulus satrapa.

3. Cesthiá faimliaris

Hetophophaneo beilor. - Abundant mi all situatione; Extremely nusuersoue mi thi woode along the hiver yereeke. Miriey.

5. Prus atrubapillue. - Not very abundadut,

6. Lifta carolinemeis.

7. Blitta camadensio

8. Thing therus ludoriceanus. - Ir. fones shot one Now.27 the or 28 th, at liblsouse in the eity, and ackinied it for me. 9only saur two, both of which is shot Isaich tulse said they wre seen constorter abrut thir horse, and 9. Mruhelis only abrent when I eause after'sm.

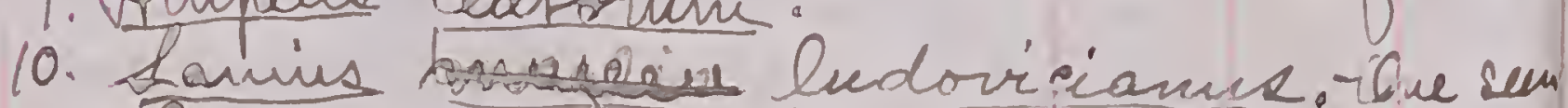
$\therefore$ Errowophila alfestris- Abundauss $1 \cdots$ -

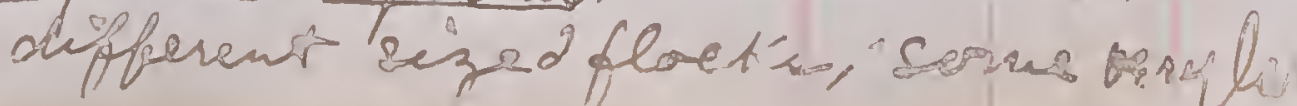

12. Astragalinus tristis- Abundar 7 .

3. Melospiza Lasciata. - In full song

4. Melospiza Nalustris.-2uite abund anst.

15. Nuneo hyemalie.

16. Shizella montana

17. Onotrichia albicollis. Lite mumerous

18. Pafserella iliaca.- do

19. Cakdinalis virginiamus.- Seen vea ef verrywhere: turces in the eity, for. Sloeds contanied thist tofifty ofecimens. Mas singing on the 4 th of Decerubrer.

20. Pipilo aruthroptthaluhis. - - rite hlentiful.

21. Pafser domesteins. Abudent in toin

22. Cunocitta cristrta. - Very abundant.

23. Crule aleyon. - Sen December / St.

24. Prena pubescens.

25. Piéio villosus.

26. Centurus carohnis. - Anly tus were see rottion Decembir 4 th. St chat the rue Isaur. Recognized it at ance it different note, alttough in a tree, top iiba woods where Helaverfed were

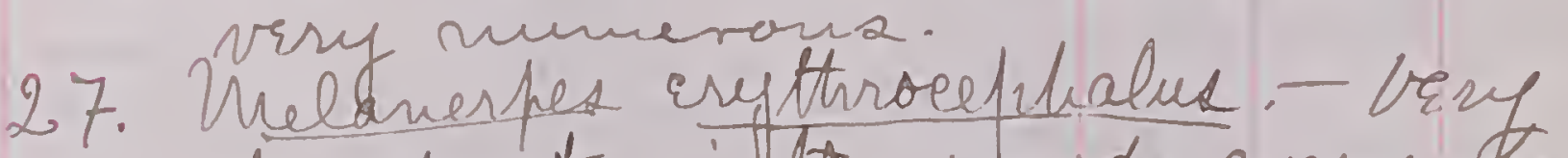
abundant mitht woods everyuthere, croakin and valter t chasih meands 28. Colattes auratus. - Abu dant esrre whare.

29. Asio aceifritrimus. - Seen on tuco days.

30. Senmirm nebulosum. - Lvo seen -

31. Scopd asio. - Cue seen.

32. Bubo vireinianus.- Cue or two in

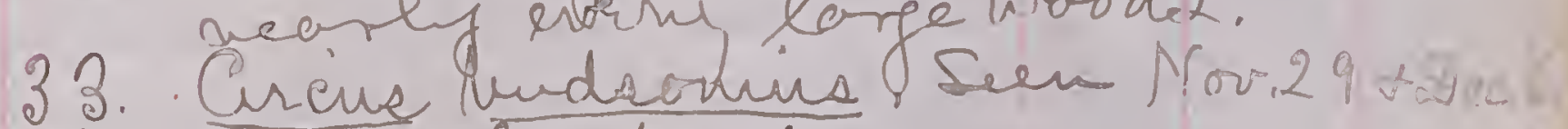
34. Faleo columbarivs.

35 . Halco shaverius. - Lite numerous. Que wos so guitle that we steffed tot carriage benboth btu fiter ou wherb nit sat and olvonted, before it urvele? 
36 Buteo borealis

of Buter liniatur

3 genate dura carvlinensio.- Numenou-

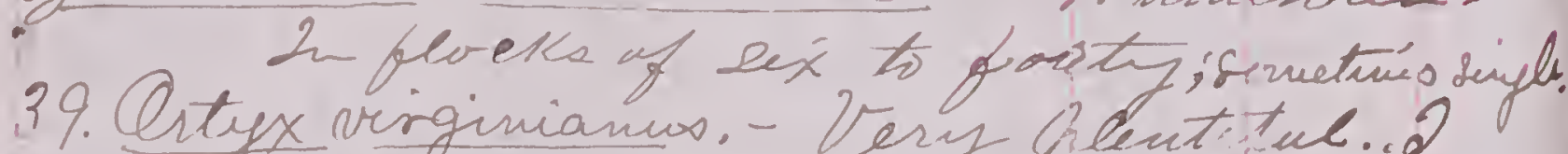
shot on quitt a black rer Plent sul.do cutre of the white throat. y int min frit Leail. Killed ten a "iegeties...?

40. Sallniago uilsoni. - Dr. Hourard jone 41. Rallio virginuainus. Ar. Arurari) Tneo shot the on Nor. 23 , when the hermonctir live near gero. and the fuow deep o. te trenid. Ald Dr. Sones ismulet ni ane which his Shaniel caupter wh the ciual, on Now. 24 thith saiv Alisec bu to would not shont then. I ipresersel the head of this forit, it. loody harring 42. Branta candotemas fin pir con-frelda

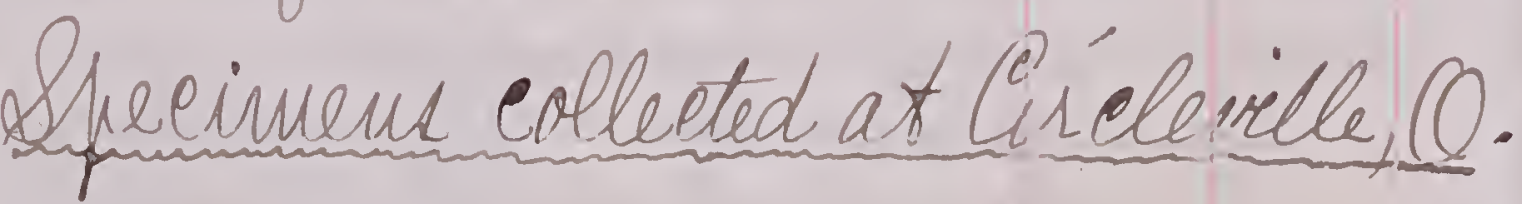

\section{Asio aceifitrinue}

\section{Nov.25}

41.00

Haleo sparverine. Dee.4.10.12 21.75.1ad. Wing, 7.00; tail, 4.65; exlinen from frontal Seattir2, 58; culnen from eere, sol. eer., 12; gape, 70; Lassus, 143 ; midele tor and' elav, '.20; middle tor,. '85; its elaw, 40. Ini, Giflet hasel.

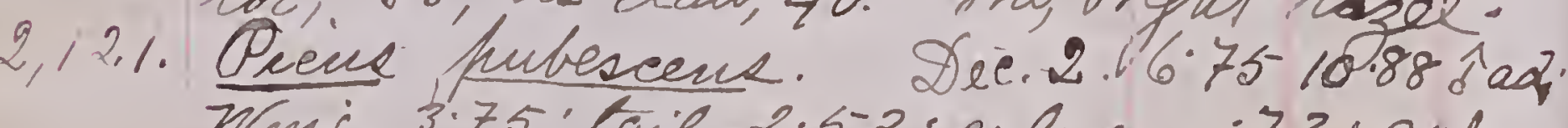
Nini, 3.75; tail, 2.5-3; enlmen, 73 ; gahe,

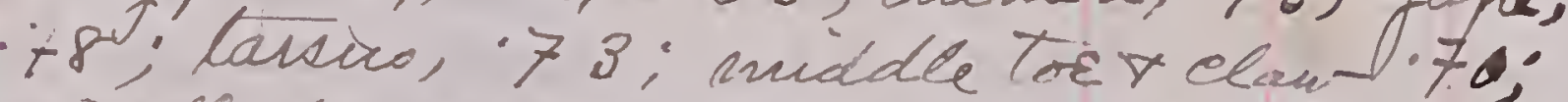

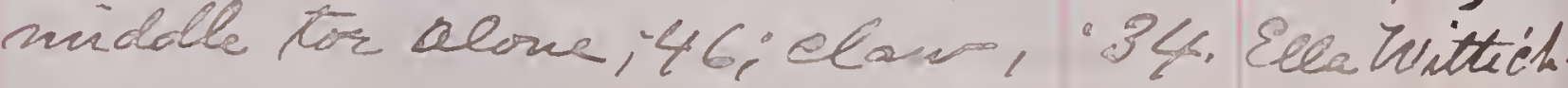

Collecti
Number

2,122. Cinturns carminus. Dee, 2.10.0016.6. Wnif, 5.20; tail, 3.45; culnem, 1.27; gape, 1.48; tarans, 182; middle tor and claw, 112; midde tor, 75; claw, 45. 2ris, bijlet carmine.

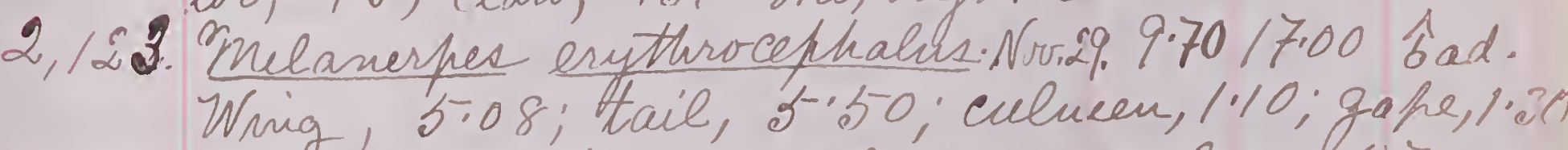
tarsus, 87 ; middle tor and cluw, 47 , ind dle tor, '70' claw, 3.5.

2,124. Melanerpes erythrocephahe Di.29.62 16.87 7 ad. Wriq, 5.3c; tail, 3.5-6; culmen, 1.07; qupe, 1'25, tarkus, 92 ; niddle tor oclan; . 95; híddle tor alone, 70; claw;.37.

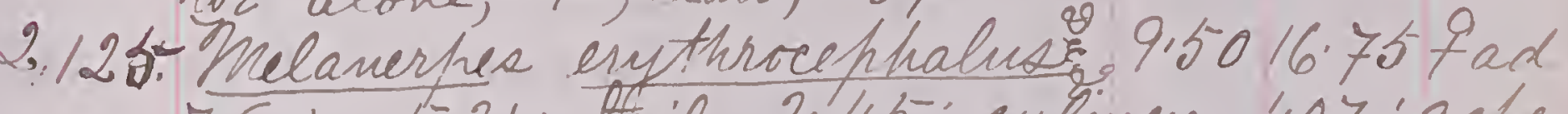
Iring. 5.?1; tail, 3.45; culinen, 1.07; qape, 1.7. tarsus., 9'3; middle tor and élaw, 97 , idre tor, i69. claw, 37. Esla títiéh

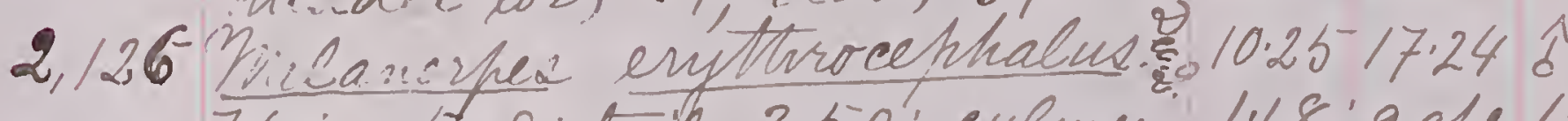
Wrig, 5.18; tail , 3.50; culmen; 118; gape,/37. tarsus, 91; middle tor and claw, 1.0?; iddle tor, '76, claw, 39

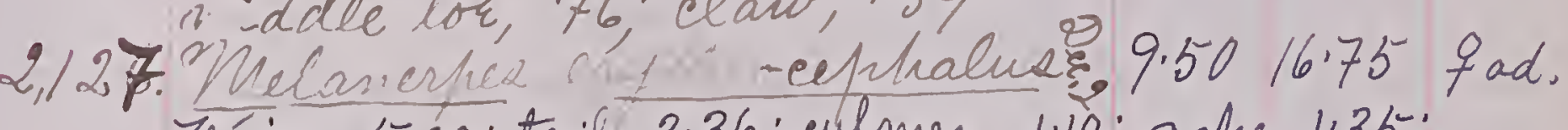
Tina, 5.00; tail, 3.36; culmen, 1.10; gape, 1.35;

tarsus, 96; middle tor and claw, 99; middle tor, 172;

2,128. Mnelaverpes 9 mythrocephahes, 10.2517 .24 Fiv. Vimi, 5.18 ; tail, 3.50 ; culmen, 118 ; gape, 1.37; tatrous, .91: middle tor and claw, 1.03; midele tor, 76;

29. Clanorita cristata. Dee. 2. $11.8516 \% 2$ ôad. , i. 5.13; tail, 5.25; culmen, 1"2; qa he, 1.: tarsis, 1.57; middle tor and claw, 1.20 midíle tor, 93: Claw, 36. Ella Wr ithils.

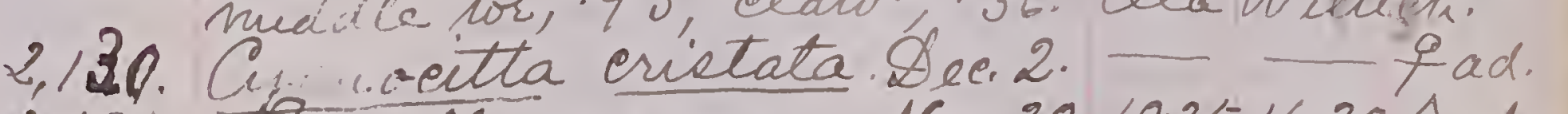

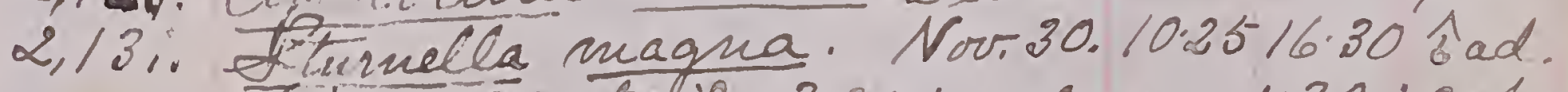

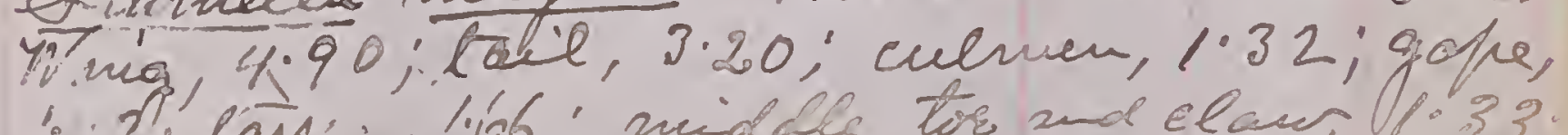

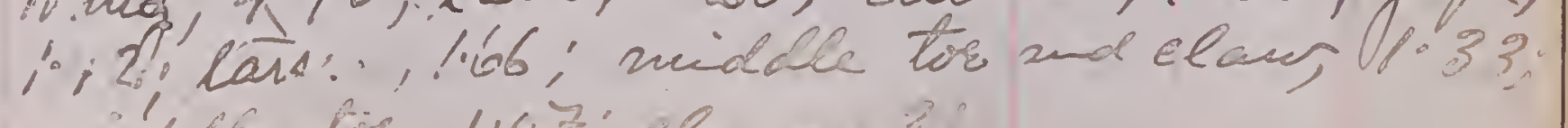




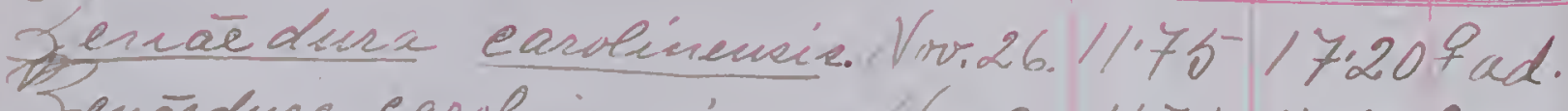

Senaedura carolinense, Ni30.11.75/7.50 9 ad. Wmig, 5.60; tail, 5.40; echenen, is 0 . gahe, '79; tarsus, '80; middle are and claws 1.00;

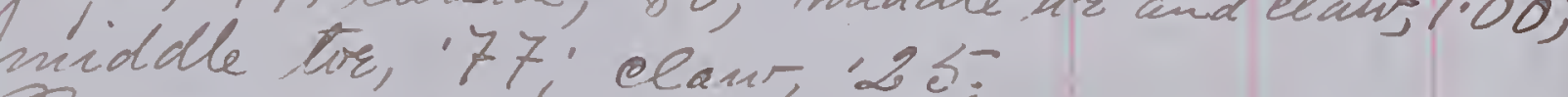
Fenāedura carolineneic. Nov.39.11.7117.85 ad. Wrij, 5.65; hail, s.65; culmern, '52; ga.h, 79 , tarsus '83; middle tor and c?: 1100 ;

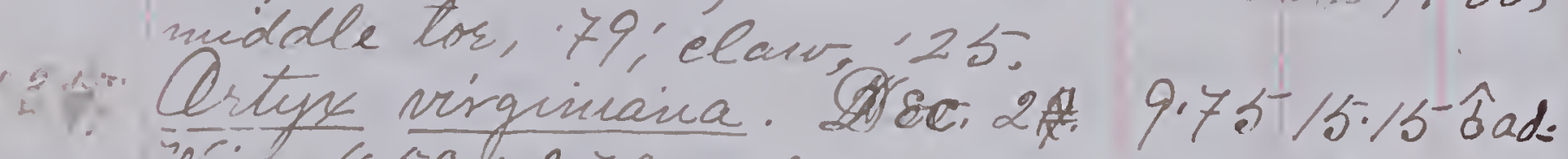
9,50;2.70; culmen, '55; jaire, 62 ,

36. Prtyx virginiana. DEc.2. 9,65 14.7. Thy, 4.28; Tail, 2.60; culmere, 'S-5.; gape, 62; lasaus; 1.25; mididle tos anch

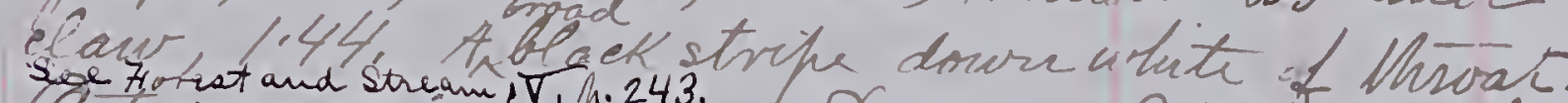

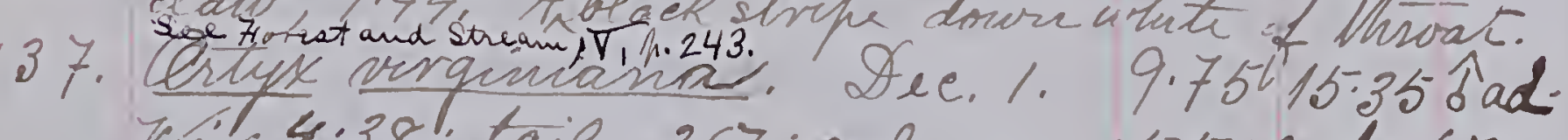
Tim, 4.38; tail, 20.67; culnuen, '55; zape; 67 ; arces, 1.29; middle tor and clavt, 11.46. Ertax viriniana. Dee. 1.9.90/5.007ad.

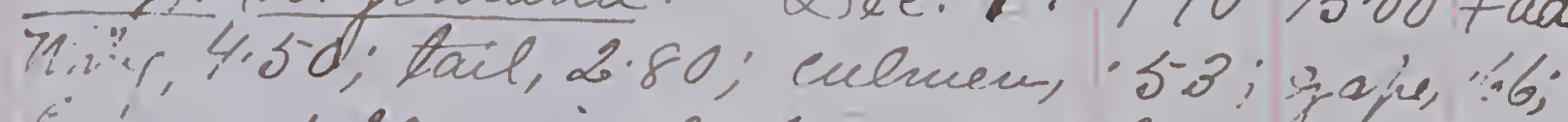
Eisus, "20; middle tor and claw, 1.3\%.

$\therefore$ 39. Ortyx irviniana. Nov.29.9.7.5 15\% âd.

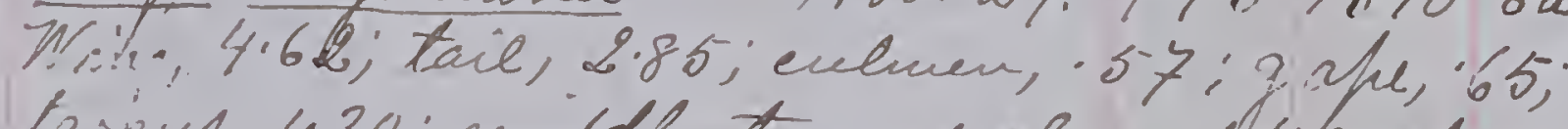
fa sun, 1.30; middle tor and elaw, N.4b; clair, 37; tor alove, /10.

$\because$ 140. Artyx pirginiana. Nor. 29.10.00i5.30 qad. Wine, 4.63; tail, 2.80; culmen, 57; gafe,. '67; tavans, 1.320; middle tor and clan-1.39;" nudidle tor 1.09; law, 32.

41. Crtix virginiana. Novi2\%.89/5109ad. Wirip, 4.60; tail, 2.88; culmen, 56 ; gape, 64; lanene, 1.25; niddele tor and elour, 1.40; middle tor $1: 9 \%$; clow, 31 .

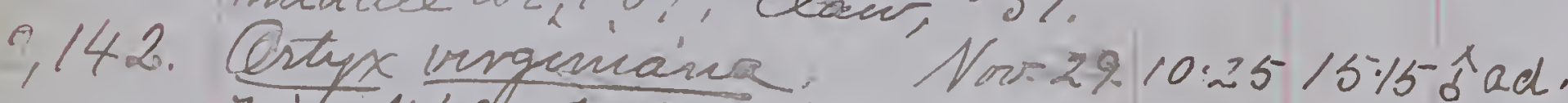
min, 4.40; tail, 2.87; culues, 59 ; aps, 64 ; tamus 1.37; middle Tor a claw, 1.48; niddle to
2,1403. Ortyx virginiana. Nov. $29 \mathrm{th} .9 .4015 .40 \mathrm{bad}$. larkus, 1.38; middle tor and elaw, 1.45; nuddle tor, 1.10; Claw, 31 . Black dashes on throat.

2,144. Crtyx virginianus. Nov,29th, 9,90 15:10 tas. Ning, 4.55; tail, 2.80; euluen, 56; gafe, 62 iansus, 1.30; middle tor and ecour, 1.38; middle Tor, 1.15; claw, 35: Drides, ńazel.

7. 2,145. Laphophames réolor. Nor.27t.6.55 10.25 sad Wring, 3.10; tail, 2.90; culnen, 48; bill from nostri, 37 ; gape, 54; tarsus, 182; middle tor and claw, 75; sniddle tor, 's4; chaw, 27 . sex carefully delesmunew.

2, 146. Lophophanes bicolor. Nou.27t4.6.85 10.75 ta? Vini 3.38; tail, 3.20; culmen, 52; bill jomustril, 42; qafe, '57; tareus, 85 ; middle tor an claw, i75; middle tor, '55; elavi, 26. Sex cantury wa

2,147. Lofhophanes becolor. Nov.274t.6.10 10.00 fad. Nining, 3.00; tail, 2.65; culnew., '50; bill from nottile. '37; qape, 55; lassus, '82; middie tor and elaw, I 6 ; middle tor, 54 ; clant -29 .

2,148. Lophophanea biedor. Nor.27th 6.50 10.50 के ad. nini, 3.15; tail, 2.97, culmen, 47, bill fin

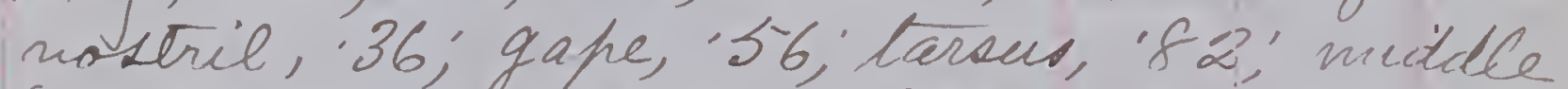
For, and clavr, .78; middle tor, 57; elaw, '27. 2,149 Sofhophanea biéolor. Ale. 4th.6.00 9.50'q (?) nistril, 35; gape, '50, tarsus, '78; mia dle is and its clawt, 65

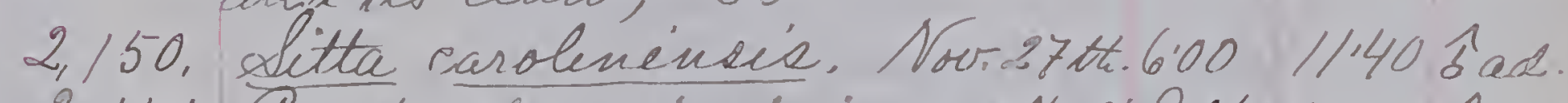
2,15\%. Cardinalis virqinuian pieNov.26.9.05 12.00 ôd. Wrig, 3.62; tail, 4.40; culmen, '70; gafe, 74; Larses, 1.02; midalle tor and elaw, 192; middle tor, 65 ; Claw, 29. 2ri, haisel.

2,152. Cardinalis nirginiamus. 110.26 .8 .7511 .60 bad. Wrig, 3.62; tail, 4.20; culmen, '73; gape, 78; tarens, 97 ; middle toc and eluer. 
2/69. Scohes asio (gray plumage). 9.70 24.25-9 ad. Thigi 6.75; tail, o.60; culmen from frontal feathers, 80 ; from cere, 55 ; cere, \$0;

tarsut, 1.35; gafhe, 1.06; niddle tor and claw, 1.25; midde tor alone, $87 ;$ claw, 44.

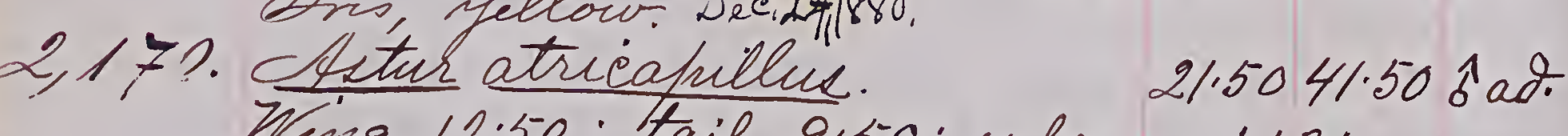
Wing, 12.50; tail, 9.50; culnew, 1.12; cire, 40 ; culmen from ecre, 83; qape, 1.25; tarsu, 2.88; middle tor and elatw, 2-2 3; middle tor, 1.75; chaw, 67; hallex, 97; claw, 1.08 ; ininertor, 1.00 ; claw (same os tarl) 1.00 ; outer tor, 1.12 ; elaw, $5-3$.

oris, bright carmine; cere, grenich-yetow; base of both nandibles, blue (execft on dorsal surface of maxilla), shading mits black rather absufty; residue of bill, lelack. Varki and tors, yellow; claws, blue bliack; convers of mouth, yellow. Shot on Conctitution Lilland, on Decunber 27, 1800. Mounted forlleis

2,17\%. Samine borralie. Dec.27,1880.9.90 13.75-7ad. Iting, 4's8; tail, 4.48; culnew, 73 ; bill measured from noriel 33; gafe, 1.09; tarsue, 10.00; middle tor bund elaw, 84; meddle tor alone, 159; claw, '28. Sis, Lark hazel. Shot by Rob. Morrio near Barrizous,

2,172. Athdea herodiae. Dec.12,1880.47.50 74.00 है ju. Wing 18.55; tail, 7.50; length from tip of bill to and of tocib. 63.00 ; culmen, 5.80; gape, 7.35; tare pact of tibia, 4.95; tassus, 7.30; indile tor and deaw, 5\% 0 ; middle tor alone, 4.45; its claw, to. Anis, orange-red. Fhis fird was shot by Smith Mandigoi, on Atu flats of Consook narah, on the 12 the of Qecenber. If uax in good condition bur evidently a stronf bird. If had been
$1880 .-181$

D.ATE. Lewngth. Strecth sex and

seer about the Consook Mareh for a good while previous to its capture. At the time it was Shot, the weatter was cold, and a good deal of iee rir the furdson. What it meant by

staying here so late is a consundrush. 142 vack was patehed with the darker feathers of the adult plumage. Sternum presterved.

The following species hav been ofserved here durnis the past wrek:-

Sidia sialis, - Bluebirds havr been seen and heard narbling thir full song nearly every day.

Regulus satrapa. - Not abundant.

Parns atricafillus, - Not abundant.

Sitta carolinensis. -

Sitta canadensie. - Culy one scen.

Certhiátaniliarie. - Not abundant.

Anorthura troglodytes hyenalis. - Cue seen Dee.27.t. Ampelis cebrohum. Cue viry largeflock, only. Lamis borralis. - Quly one seen, and shot. Nelospriza fasciata. - Dite plentiful; singing. Spizella suonticola, - Abundant.

Juneo- hyemalid. - Abundant.

Passer donesticús.

Corrus americanue. - Not numerous. Cyanocitta eristata. - Cu shot. Not very feribiful Piens hubereins. Searee.

Seops asio. - Ane in gray fhumage shot. Cirens Mudsonis - Lwo on Constitution Narsi. Iimnunculus shaverius. - Que on "Zsloud. Xstur atricafrillus. - One adult male shot on do, Larus (? argenlatus).

Chrysomitis tristis. - Ane flock.

Agiotmo Linaria. - Levenal floct wrre seen Haliöstus sides of the Huspon. Qne bira shot. 


\section{Samuary lst.}

2,173. * Astragalime tristis.

2,174. sfitta carolinensis.

only one flock of 6.05 10.90 q ado $\begin{array}{ll}5.15 & 8.90 \text { के वेक } \\ 6.05 & 10.90 \text { क्वे. }\end{array}$ Only one flock of Dueks (probably I uliqula marila) was secn - on Decembar 27 th, when the hiver was still open. The Atudson closed on the 28 th, and the phernometer ranged below zero Fahs: for several days together. No Purfle \#incher,

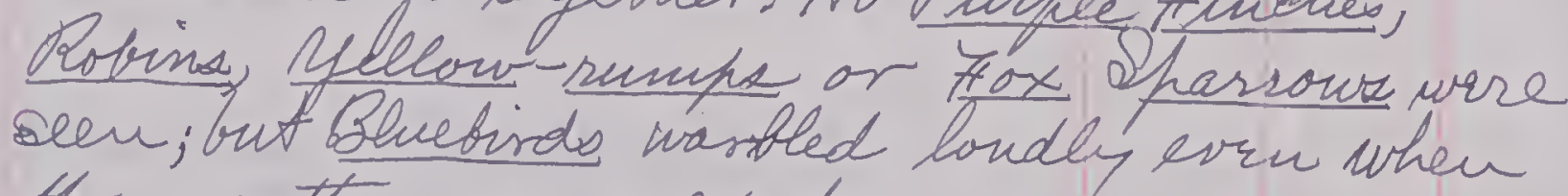
the weatter was coldut.

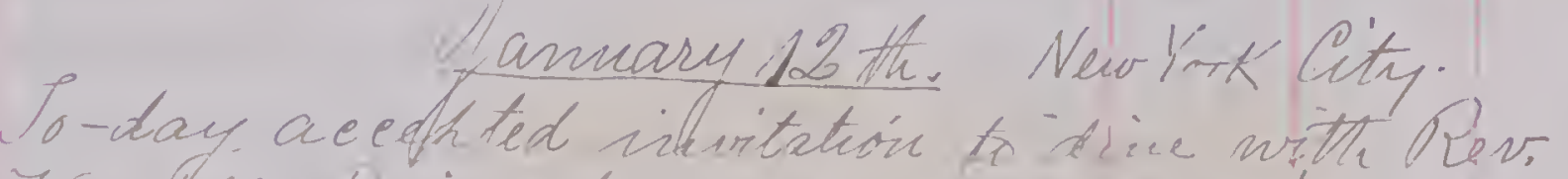

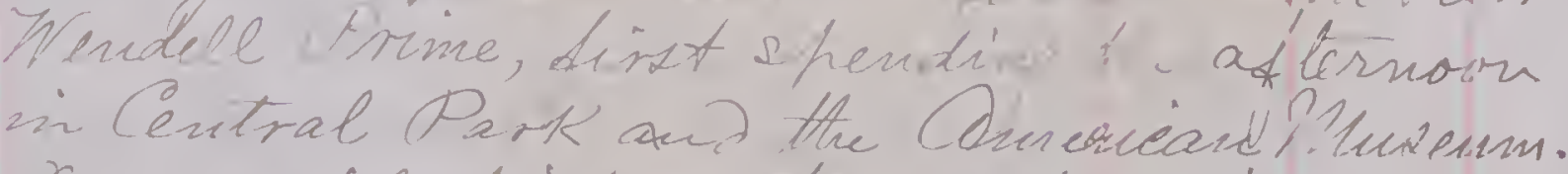
nur sfeeial otjeist wasto see what fridt. wrre win trut ure aleo wrut to hare a good

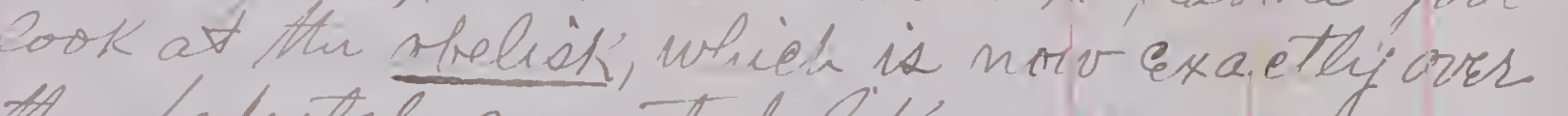
thedestal, mounted like a cannoh qu who hromised to let ue humirkiviere the thing, 7312, over."

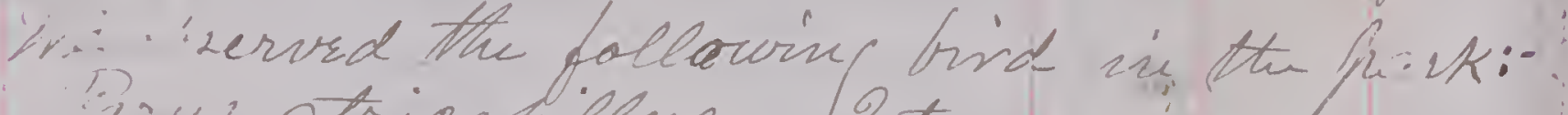

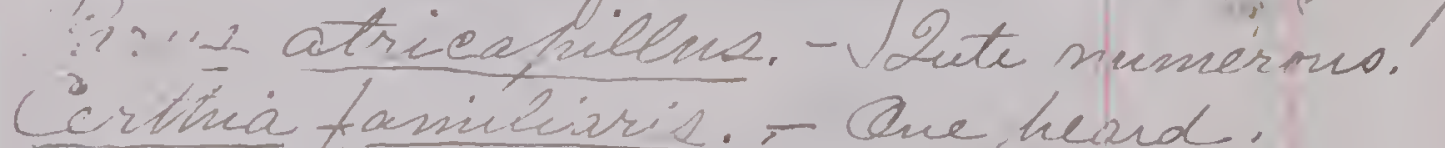
- Saster donestiér. - Sirigin quite i song. fonotrichia alócico :- White-throats secoral sem, puedin of seed of White-13ireh. Aner humbles:- Mot abundant. Cardinalio virginianu. - Nas deichted to frind orre mot two Cardinal Gropleatis in the hark on this cold wintes daw. Ihad a stronf sushicein that it initiced there, and was qlac to variby it. 2 recognizid the

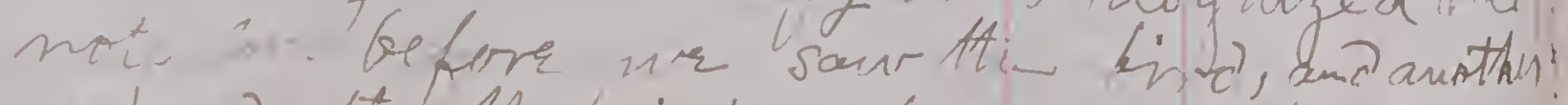

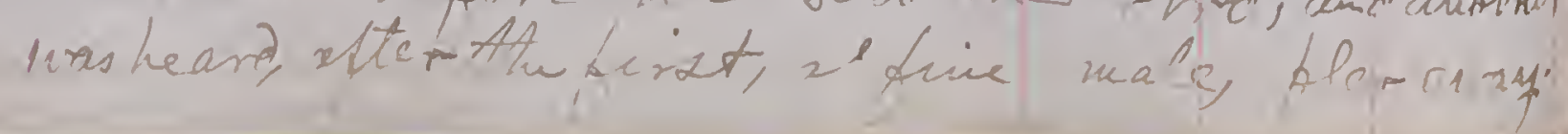

\section{5}

\begin{tabular}{|c|c|c|c|c|c|}
\hline XAME. & DATE. & LOCALITYY & Iength. & Stretel. & $\begin{array}{l}\text { Sex and } \\
\text { Agg. }\end{array}$ \\
\hline
\end{tabular}

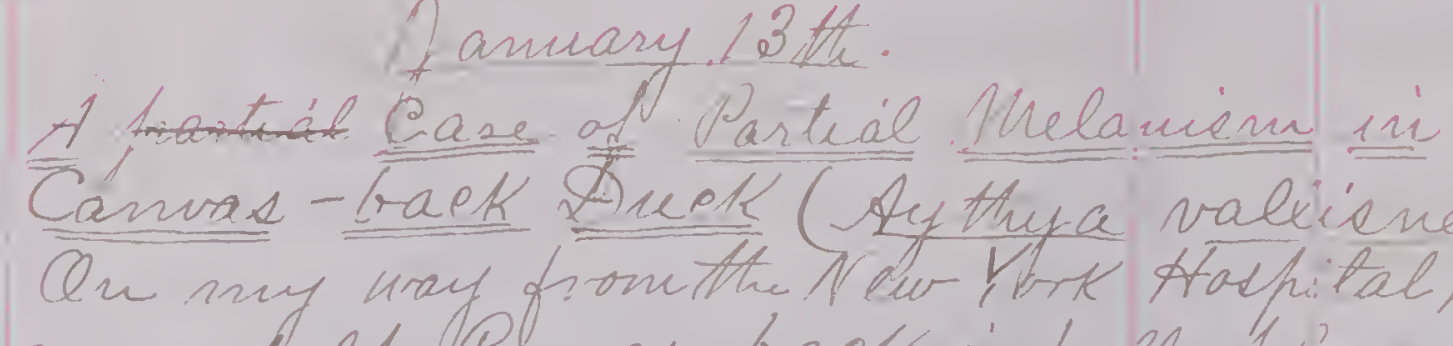
haring a hated of hlumbenu-black Lea on Ath ininder sienfaee of the bodrs is atront an inck gers,

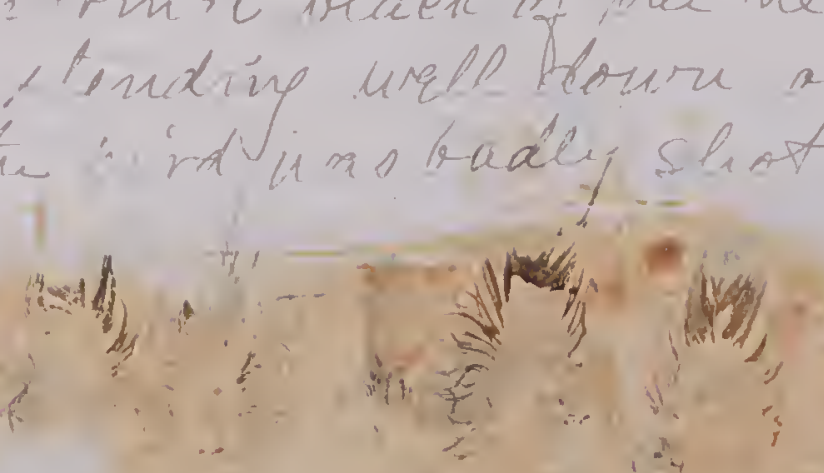

P.S. Color Apobably due to raint off of boat. lfamiare 14 ifle.

ut to Roplevelt Atodfital (59k-stest.91h Alvenue)

+ 2.30 P.M. and saiv oherations for-lacenatet ix and hesināenzon

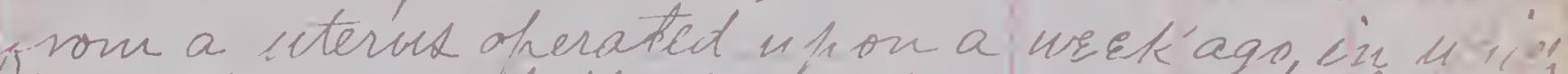
ifeet minim of the haits had recentited. o.

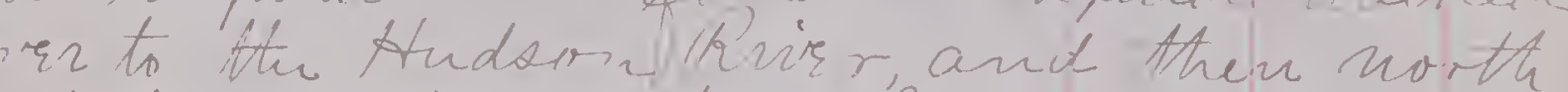

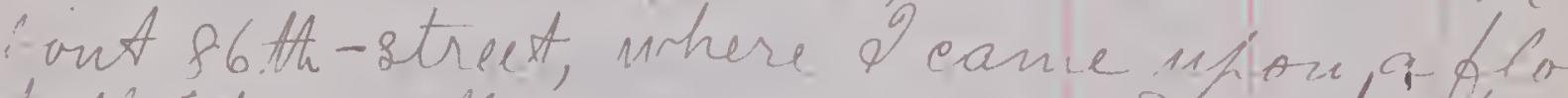

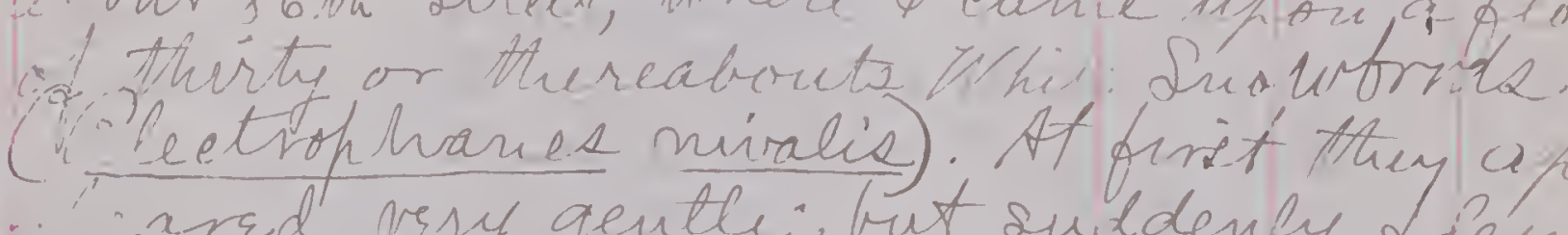

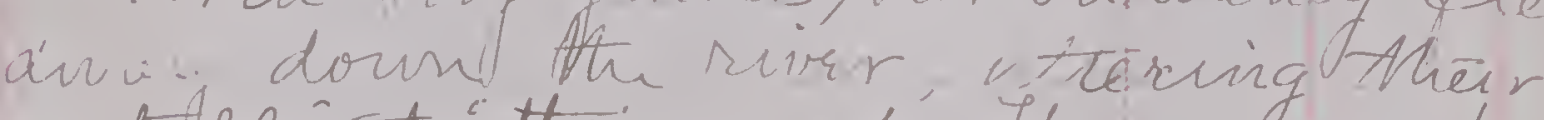
netallic trirttering nate. The urise feect.

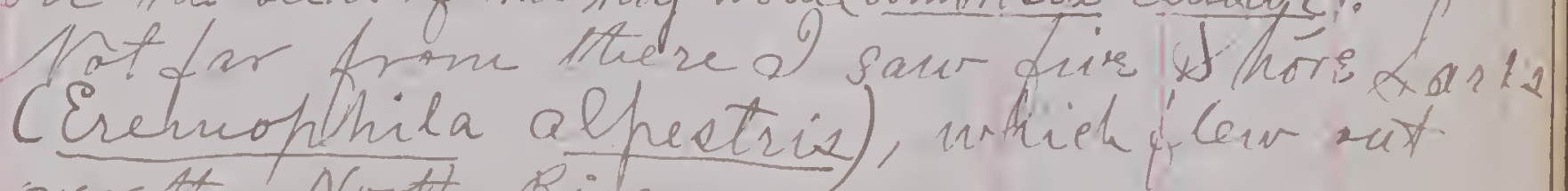
war At Norttor Riser. 


xaMk.
$1+4 \%$ 
raliee Lilled Chiblu with heam bioks, from

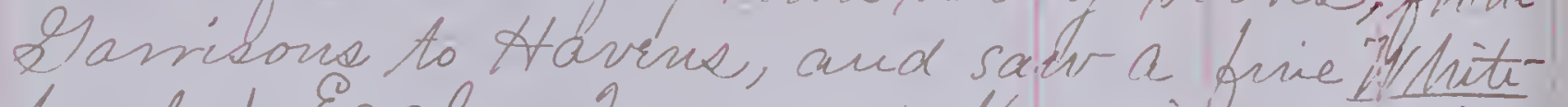
headed Eagle. I crossed the nistr again nonday suominp on the ire, and sim a splendid Pagli. A Posir was whittin. tot of a bij whit mine serth of Aarrision. I saved a seatlfor A.K. Hisker, who clalleá,

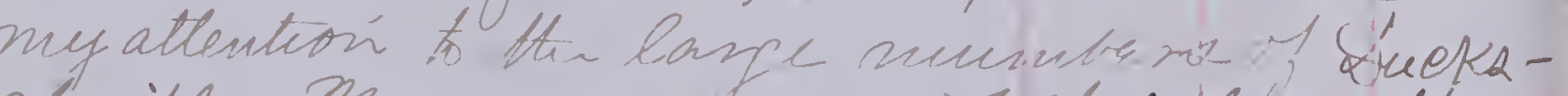
cluejly Mrengausers, and Díluisters. There corre numbers of Acrrin giels foth ow the Audson and ou totsen pirer.

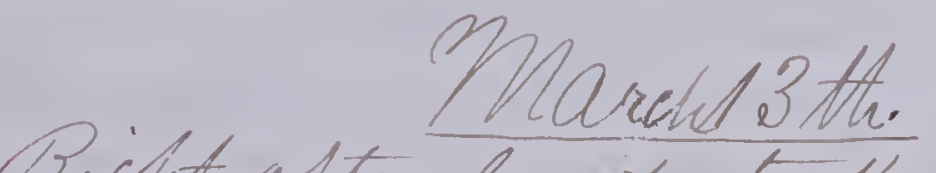

Right after lunch tork Elevated ear its 155is treet ivhece I ualked through titu woods * Fiah Aoridge turnin over Stones mi a costh-unter brook in searein of crawfish alinandere, seither of Which, howrver, found any Where on the islond. ure so turttes eitter. The soil is ind steeky", and I imaigines theindon't Livinif; still I'ghould suppose there would. frsone Saliniandere anougtith slones The vire from the resenoir attoit Bride ie superbl. From there I coasted thouph th. woods beside Atarlem River, Where th Atrrine Gulls wrre blyin, castire handsom btaek Suladowi in pou the natest. There wire sone sharrows, Wr liti-Gelied N Mt - hatehes, Whickadees, Goldur-errsted Rivelets, and Menty of Crows, arid Snowinis

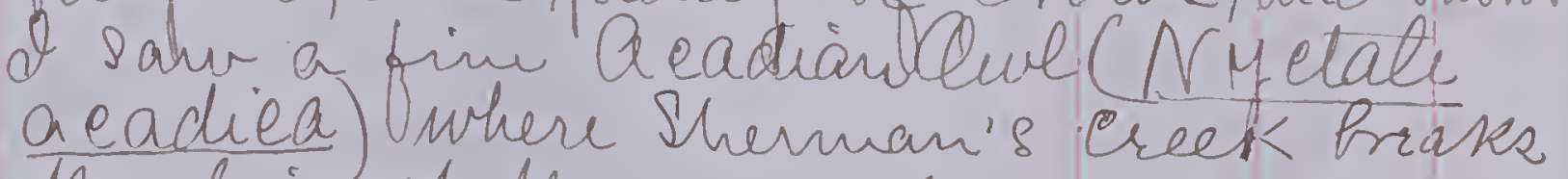
the livie of thr vire-cank, an $d a$ lave imarath is setuated which' lostels like a grod place tor Sinpes. The Curt lit or

the stumph of a tree on the side at th
amoing the red eedart. She afterituon- una dark and Clonder. It was the first Rerdiai Asve I had everseen wild. Ghere wa: Red squivel (Seinrus huds onin:) beside th Harlen Rurir, the frist 9 have seer o: NeuGork Iseand. We crossed to the trigstbridg. Road, encountering a trawk and sime very wield conntry ou the way. Then ine wrats over to the Audson Piiner side and ivalked doun throuph thi heaens, ared insug:' Andubon Rask, a lovelif hliee such as one could not inaigine to exsit nHis populous island. If errsea' and took tis lelevated road at 125 the otrest. Cu the Andsour Biver ure notieil a number of Red Squnviels and the same bivids deer as on the Harlem Rurir bani, and mi addition a flock of IV tiete Vitroated Sharrous, Orioles, Boins and mane wher-mide had left nestas mi abun- demee mi all the upher hart of ite

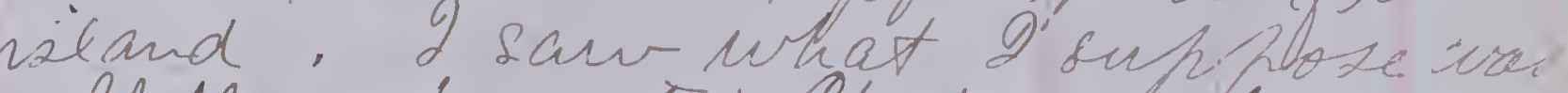
a Mellow - bresated Chat's nest, and there vire 'atbindl' and Soup ianowo' ni gbundauee, among the hateies of Grirs, eat-Griare, adnd thiekets of Luine. mixed with attier shrubs: If mas a foggy, dask afiernover sot qavorablel for bird-like.

Mareh 20 the.

whis morming, Maedowald, a young artiet

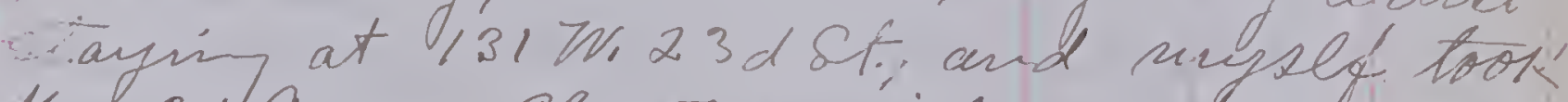

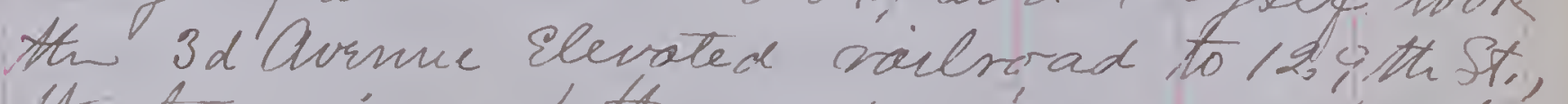

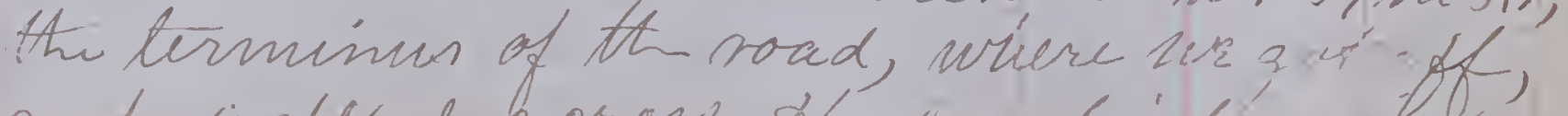


the cedar grove beside Harlem Ruvir. There the Sung frarrows ware singin and a bridge at 15 s th street, and walked cover to Macdonalix had bronaht along his sketch-book and artists siorl, in - tending to nake a sketeh of Audubon's tomb. The Cemetery is a viry metty flace. Lairge forst trees are growis abun.danty, and among then wrre some splendid Exanfles of cur native hemlod (Abrs canadensib); dunoug the native flowering treed care oinn inie blogwoods (Coms florida), and tulihtreee (Liriodendron thlipifera). Croseing th bridae over the boulevard' thet chlivides then cueteng wr strolled doun to thr rivi- Side where th Audubou vault is situated. The day was cloudy, but the Sour Sparrows wire singina cheerily, Fed Squirres could be hicand chattering siv the nuighboring Andubon Park, and Nittratehes and Clictiadees wre mating merry; the former un oufit pti branches, and thr latter upere the Pole of some handsome white-woods in which ut saur a coichle of Battinion Corides neats. Carvod in thil freani granite, above thes ruirble entranee to the ve uld urar sminhy AUDUBON.

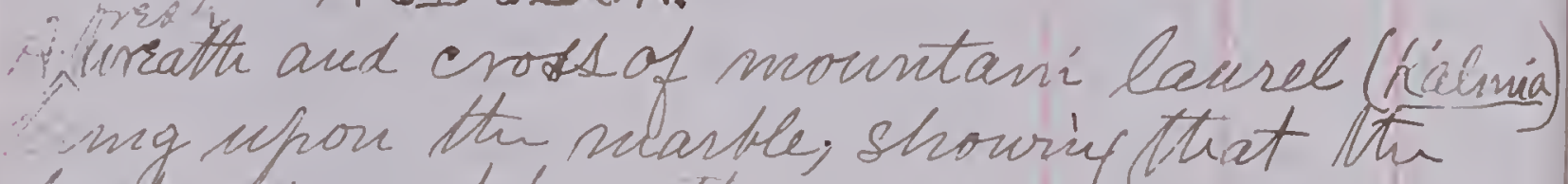
dead wrre not forgollen.

inght brlind tth cault if fiellea' uh a trairind's nest whies winter wirds had blows. from the tree overluad. Fo the reght spas de zeriel " woug the Granches af a crookist. eliestmet-then thin Sanging neet of ther Red-used Vierev; ind,

\section{$188 \%$}

Collectumg
Numler.

LOCALITSY

Leength.

sitrecth.

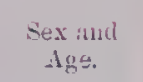

of a slender oak, there was a Pobir's nost. Before and heluind the vault stiand iturn giraestis hemloeke, and a host of little ones have s's aquel to yrour amongst the wbod hlint wi thr heasantty heglected grass brveatte Menen, in eompany with sphoutivig reornt an d-existunee. The araveyand slopes ginth dorn

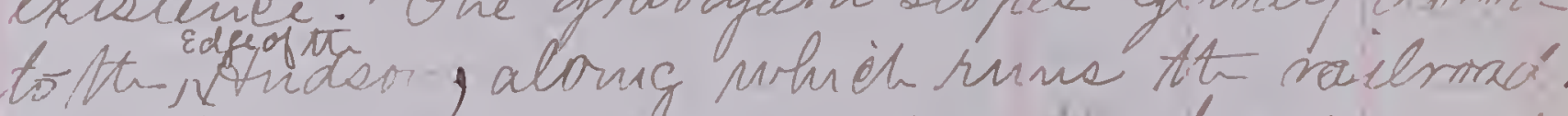
Tame hugious wre cooing upou iraek, and hicking on grain whieh had drophed Troun th cars. H one corver of the cenitcer a red cow was tied, and stovit hatein, dievin. the end. She leaves on the white-oxks sisetled his thamil In this amiet spot, brueatit the fovert trees where the Robin Red-eyed Virier, ar.d BallinionAriole may br heard singini, his the dust the grat Andubon, beside the river he coved so.urell, and a wark form th sorie and bustle of the "ity whichtre hreforded

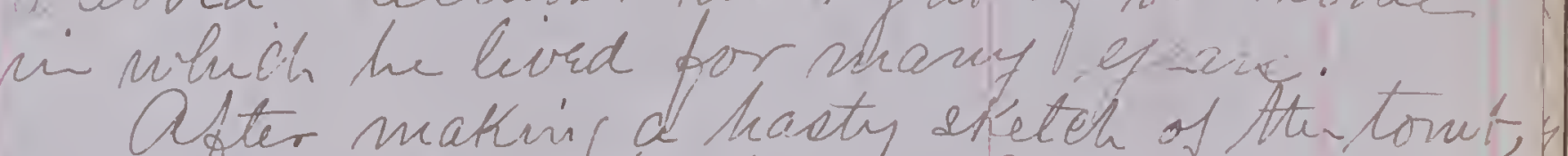
I walked about the place. She coti in the comer looked Aricudly, and wae alad uthen Scrached ita fbrte d, and strated inen

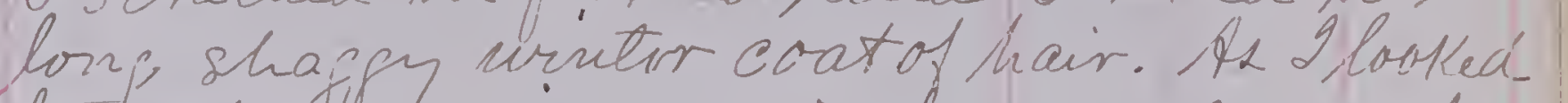
lowards the river a single vrssel was hars-

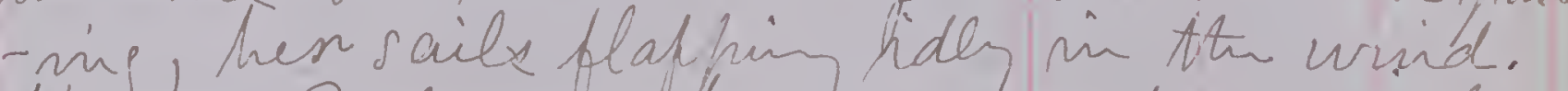
Arsing Gulls were hassin; and mi winter iagles ahe sometiries seen floairing suttled underva tomb-stove at ons-2insraeh, but quickly shourd its head agawir a.t mu call. Another Rotesiobs meat has notieed

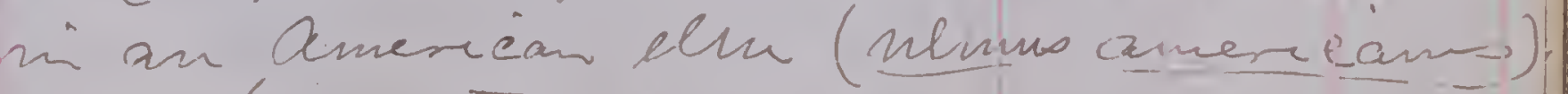




I. engerti

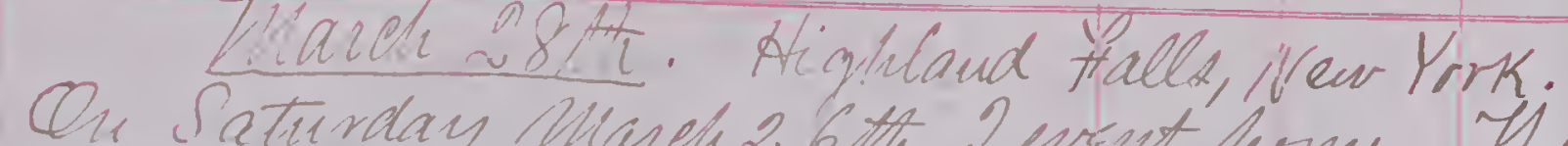

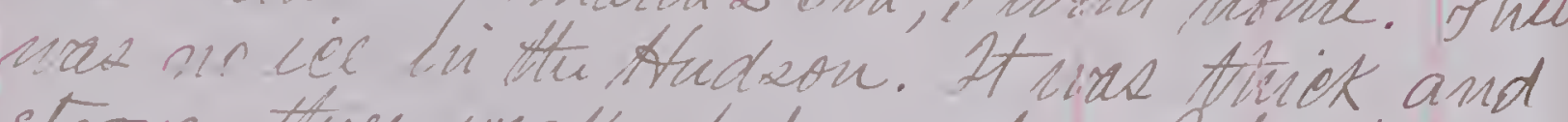
strming. Hhee wrak's before when cl cuet was at ionegurelked acrost the nires ni hoth direction?. O,ulle and Puells wre quite numerous. No Gaqlue urere scen.

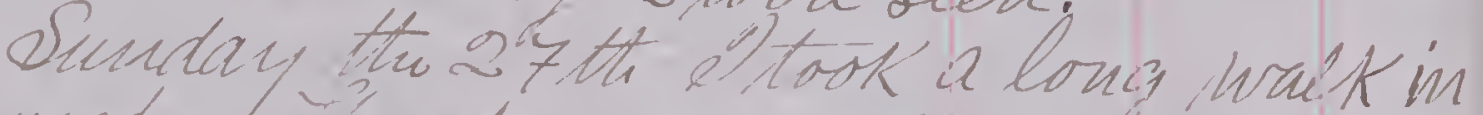
落 urods.

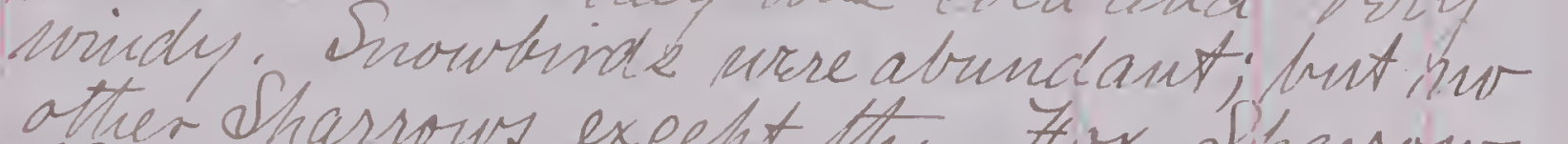
other sharrous exeeft the Hix Shansw (Passerella iliaca) vere scen. Finey Viter Singin Aty is asual, and urre seen at Acighland Halle for the fint tiviu, ar mone nore there thre nerels ager, as num last prist Rofins ware abundait every where, imt

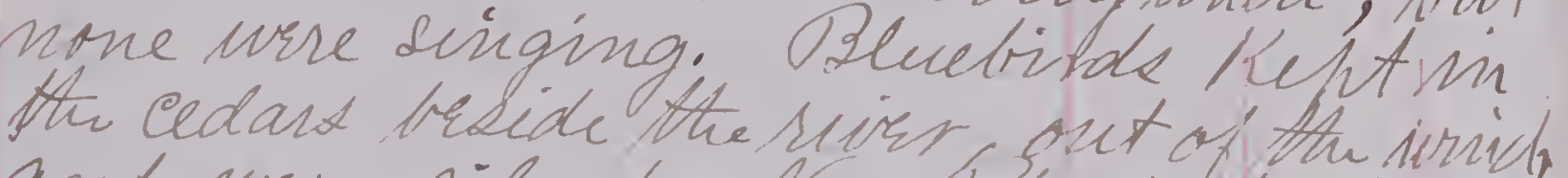
and vere silent. No Ghiretivido wre Seen

One Mareh of the saw the frist Phorbes (Sauprneis Auscus). They were calling brside th wann ledaenlalou th mir as Dwalked down to tathe sendy it Orzene. I saw a Hidh Hrint Aandivir haliètus Cordinenkis) Soarins over th bay morth of Peelickill wheri coming divin on the train. If is th anly orre seen th's year fisit of the season.

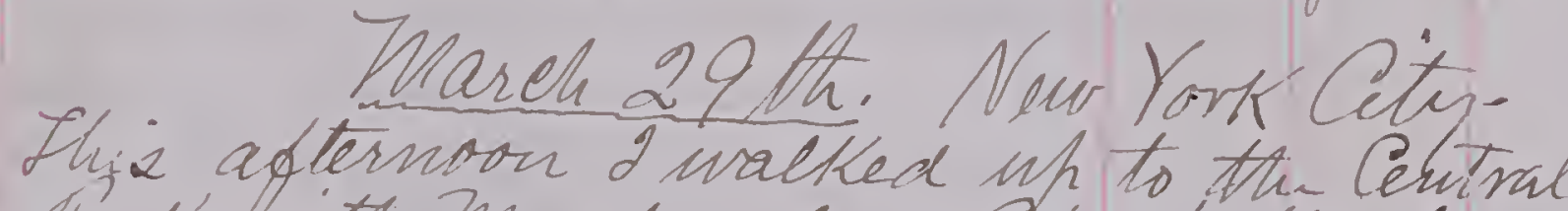
ark Erith Macdonald. About th lower lake were a leundred ar neore Enoven

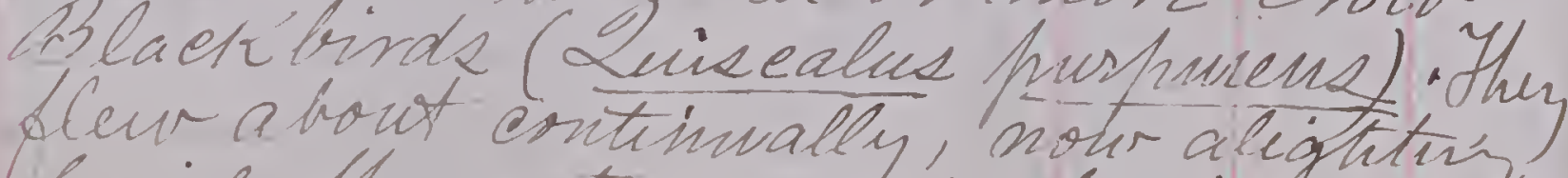

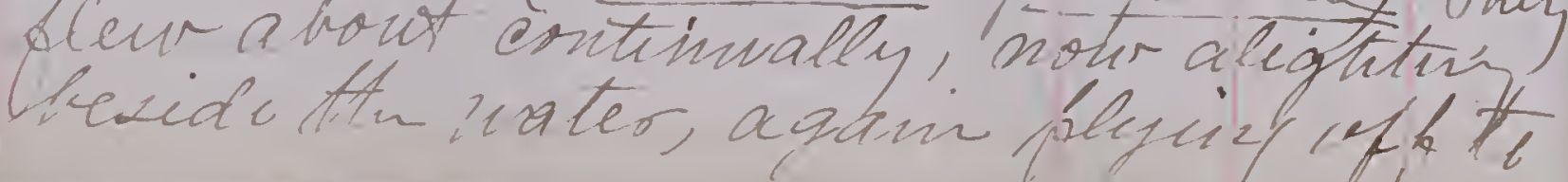


Collectuyg
Numberber.

D.TTE. TOCALITY.

\begin{tabular}{|c|c|c|}
\hline I. enyth. & stretch. & $\begin{array}{c}\text { Sex aul } \\
\text { Age. }\end{array}$ \\
\hline
\end{tabular}

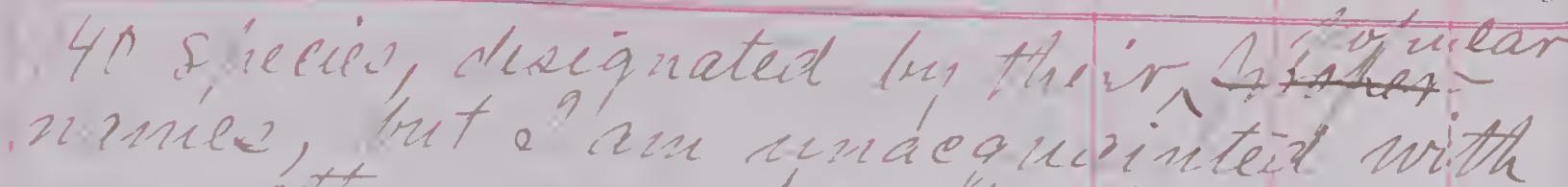

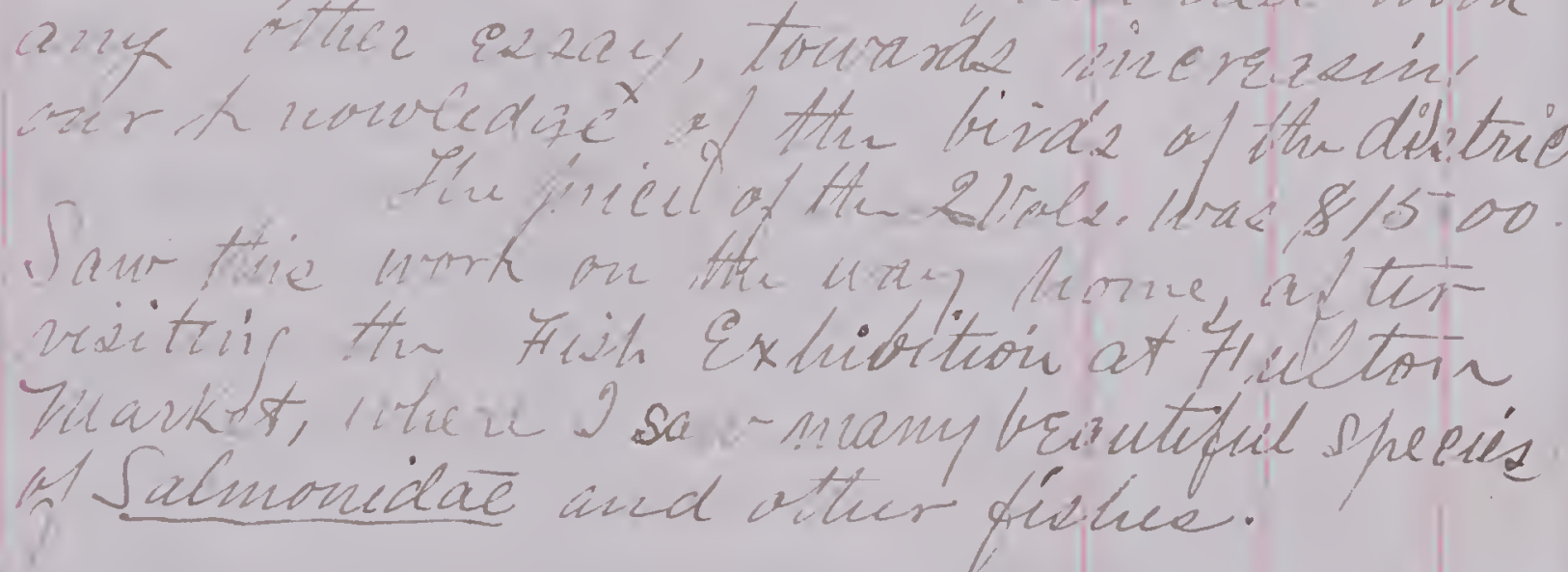
Obsarsmemente, ste., of Girds shot at 2175. Granta brimiela, (finné) Sesp. 25.4048.00 îad Wang, 13.30; tail, 4.50; culmen, 1.35; bill trom nostrit, 69 ; gafe, 1162; nail on bill, 43; masal oridice, '36l; Yarsus, 2.43. midále to cand it claw, 2.33; it slarvalone, 35; reter tor and claw, 2.16; its elouralone, :29; inner tor and elaw, 1.90; its clow airne, 33; callux, ist; its clauraloue, 22.

arides, dark' hazel.

Entire bill, leg2, feet, wrok aud torn, blaek; claves, buish-bldek. [Mubat bind.]

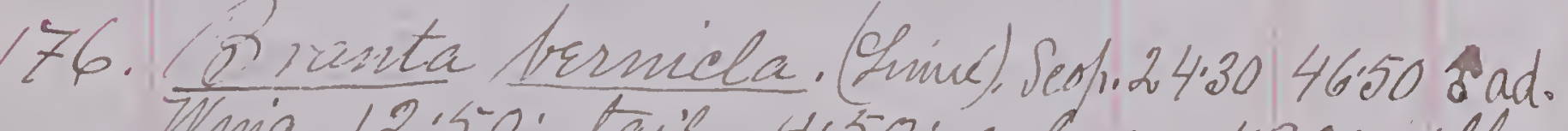
Wyig, 12.50; tail, 4.50; culmen, 130; vill

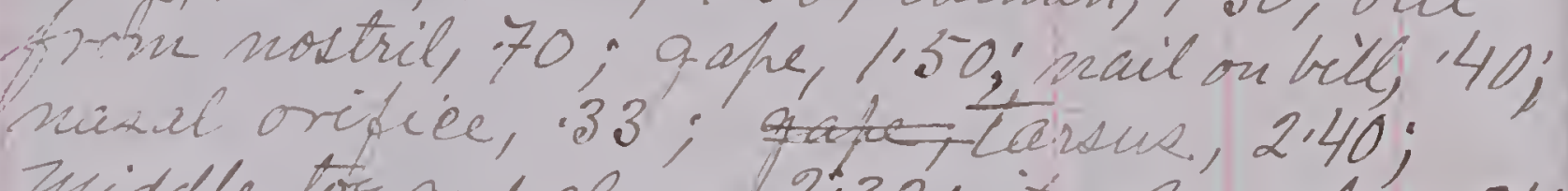
Iniddle tor and claw, 2:33; its claur alone, '36; orter tor and claw, 2.17; its elauralone, 30; miner to curd claus, 1.85; its clar alone, 33 . entive lill bag toluxtclaw'58; C2m, 25.

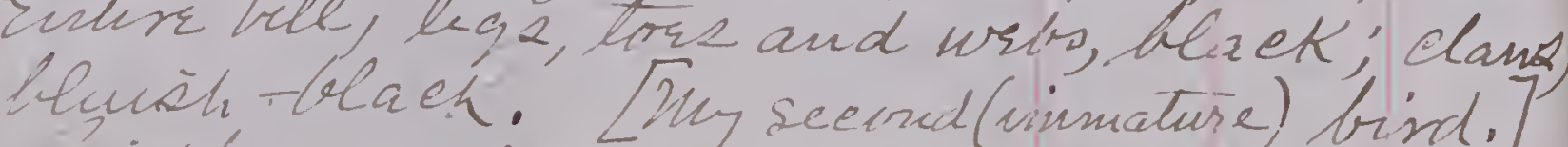

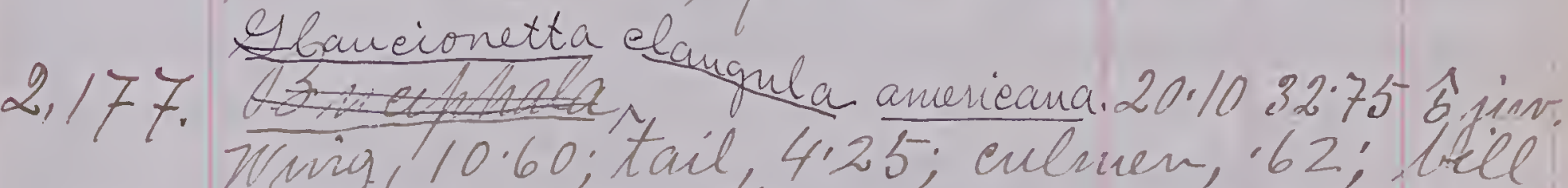

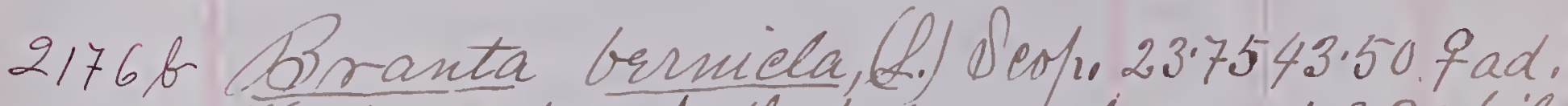
Viq, :40;, tail, 4.40; culnen, 1:23; rilk roin nostril, 68; gape, 152,; nail ou mile?, '43: nasal orifice, 32 ; treatest width of bill, 166 ; depth, 175; insus, 2.31; middle tor and elaw, 2,15; its claw, 34": outer thre and Claw, 2.00; its clauralone, 28 ;

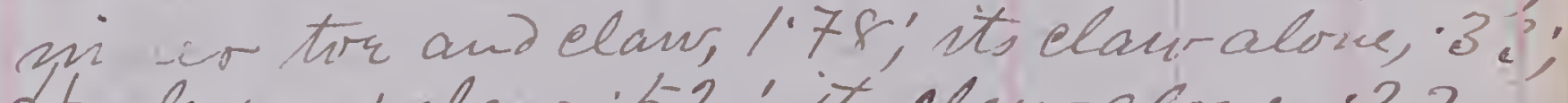
Aulex and claw, 52 ; its claur alone, 22. Colors of bill and feet same ar abror (Nó This bind monis sent with a kair to "Aer. W. Van esciem, of the Nur York Biar." Wning, 10.60; tail, 4.25; culnuen, 62; Lill from mostril, 87; gape, 3.25; nail mbile, 148 ; nasal orifiee, 32 ; tarsue, 1.60; midádle tir and ital claw, 2.95; itz cleur aime, 45;

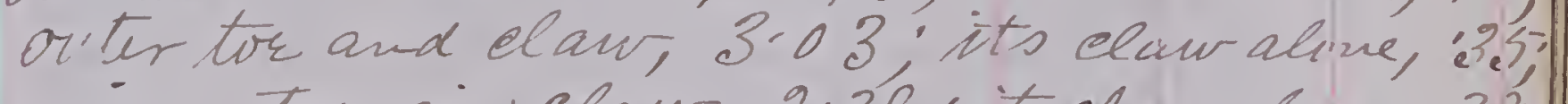
miner tor aind elaw, 2.38; its clawalone, '34", Bill, leathery; black.

His, gild. Y arie and tord, prownish-yellow; Mrsa, hlaekrion; nailo,blines-blaes. 
Hulciula mnrila. 19.20 3/50 bad. indiren, 1.72 i

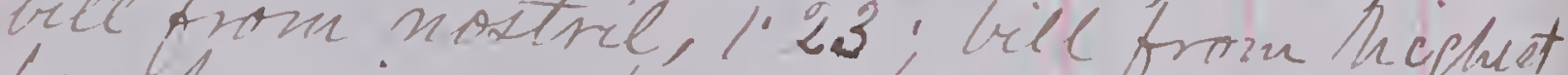
rare hrominence / name of hroes

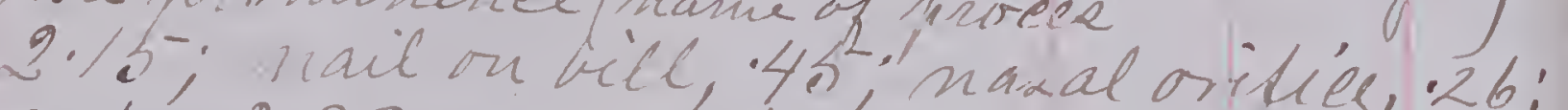
gahe, 2.22; aveatest breadtin of bill, 1.05;

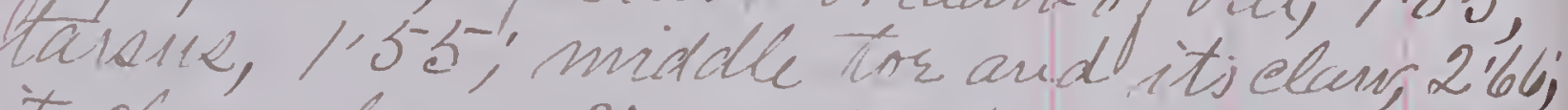
its clarralome, 37; Nuter tor and elan; 2.75; its claur alone, 28 ; nimertor and alaur, 2\%; its claur aloni, 34 ; hallox and its chain, 85; its cian alone, 22

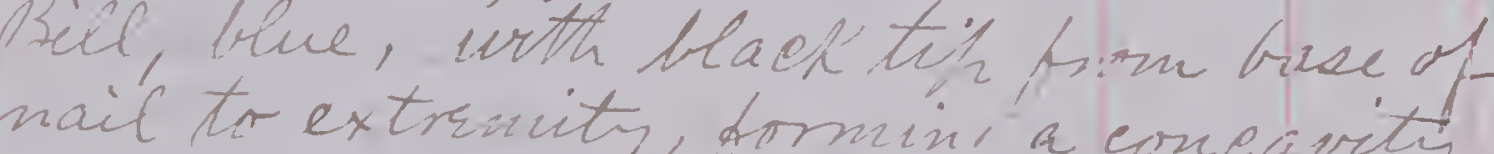
derieted. bachwards on either side of nail. Posterior asfeet of tarsue, miden sede of tras, and both furfaces of urelsir, bla dx. Anterior surface of tarsus, and suferesir surtace of tore, bewich lead-erlor; Clanns, all blaek

The Geese (ibranta canadener-i) wre in trusande on the bay, nuaring wh mi

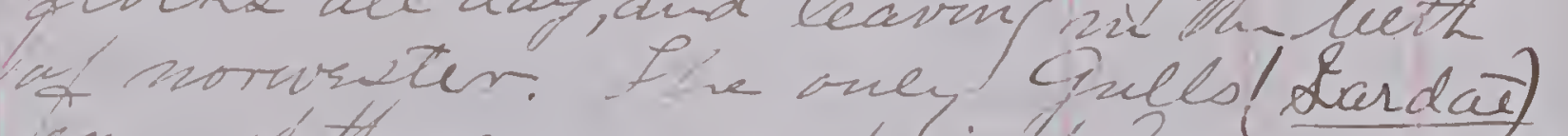

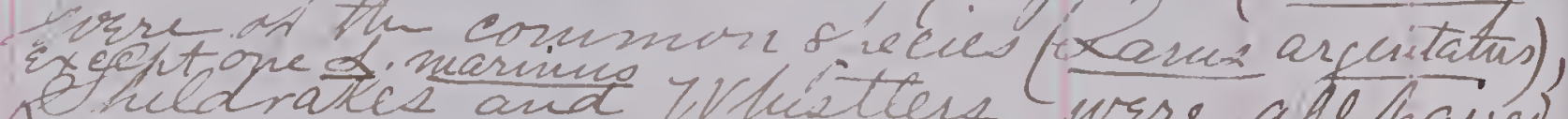
r.tetrates and Vhaters wre all paired

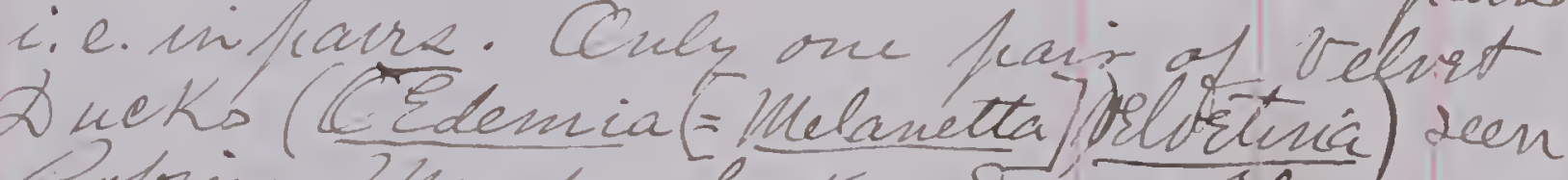
Lobina, incadonifarta, Son $V$ fras Sparrown all suinin; dend the Hellow Shatled fickers vere all eallis

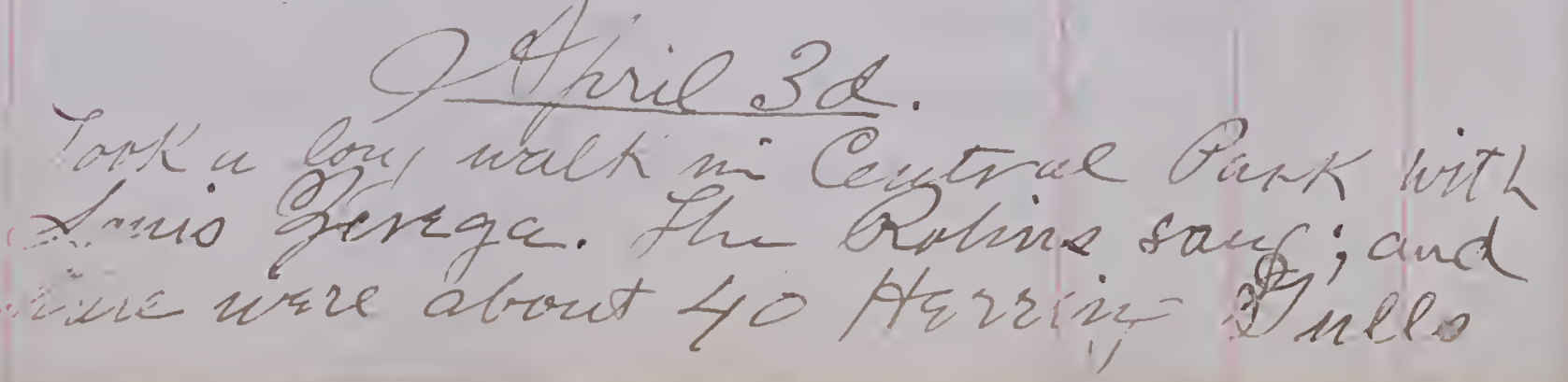

Collectumg
Sulumber:

DATP. onth whluer

A Cowaroues.

\section{Bprietith} od. In-itted a Red-tailed Hawk', shot at

2.19. Buter Forsalie. 42.00 .50 .909 ad.

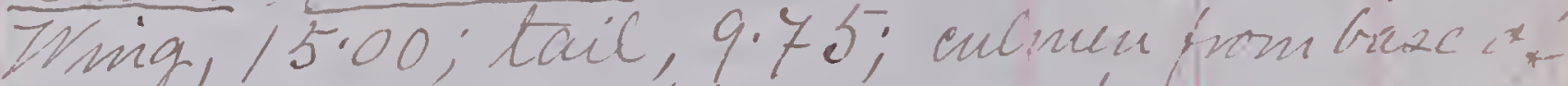
cerc, 148 ; cere, 55 ; culmen from cere, 1.10. gafe, 1.80; tarsus, 3.20; middle tor cund clan- 2.30; its elarwalone, "84; outer tor an' claw, 1.75; ito clawalone, '70; inne, tir rind claw, 2.03; its claw ai one, 1.12; hallux and claw, /.92; its claw aione, '.25. Q. ris, hazel. Cere grernich-yecilou. Biil, hale-hue, shadin snadualin inito biue-black at extrustity, Tassi anit tore,

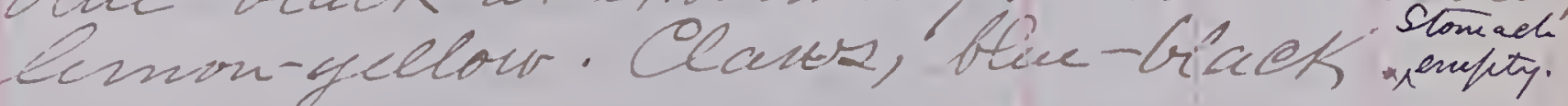

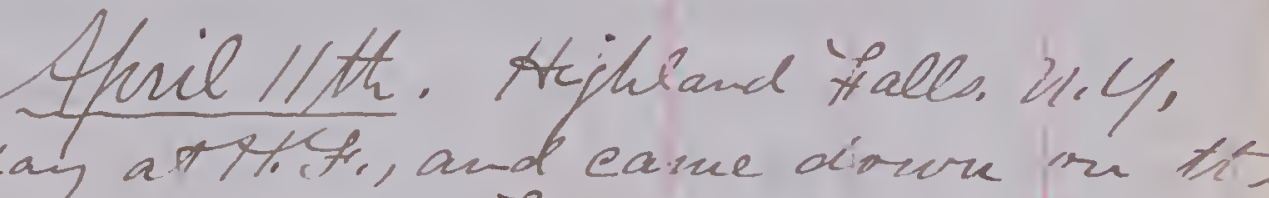
first train as noual. The invids see yesterday ingreas follows: -

$\because$ rdue migratorine. - Cere nias singer'y at dists as late as 7.10 R.m.

Sialia sialis; Corvus amerieanus, irilding. Tur atricafillus; Passerell ilciea, Anneo hyemalis, van abundant: Sayomis sosens, plentiful; Seolecophaqus gerrigneus; hie pes serrator. - Cene floek mi dot eores som Texnak Lsland.

- Lle hiza nuloda (= fariata).

ingrafueis varius. - Hor seen tojetten,

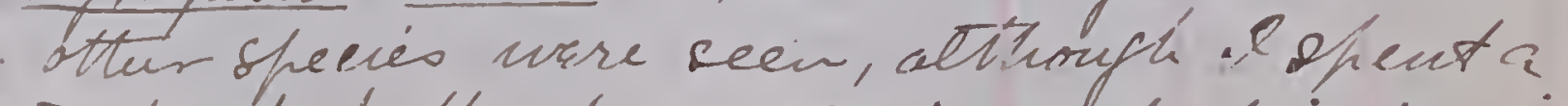
gove hart of the day waltinif and dirizin rivis 


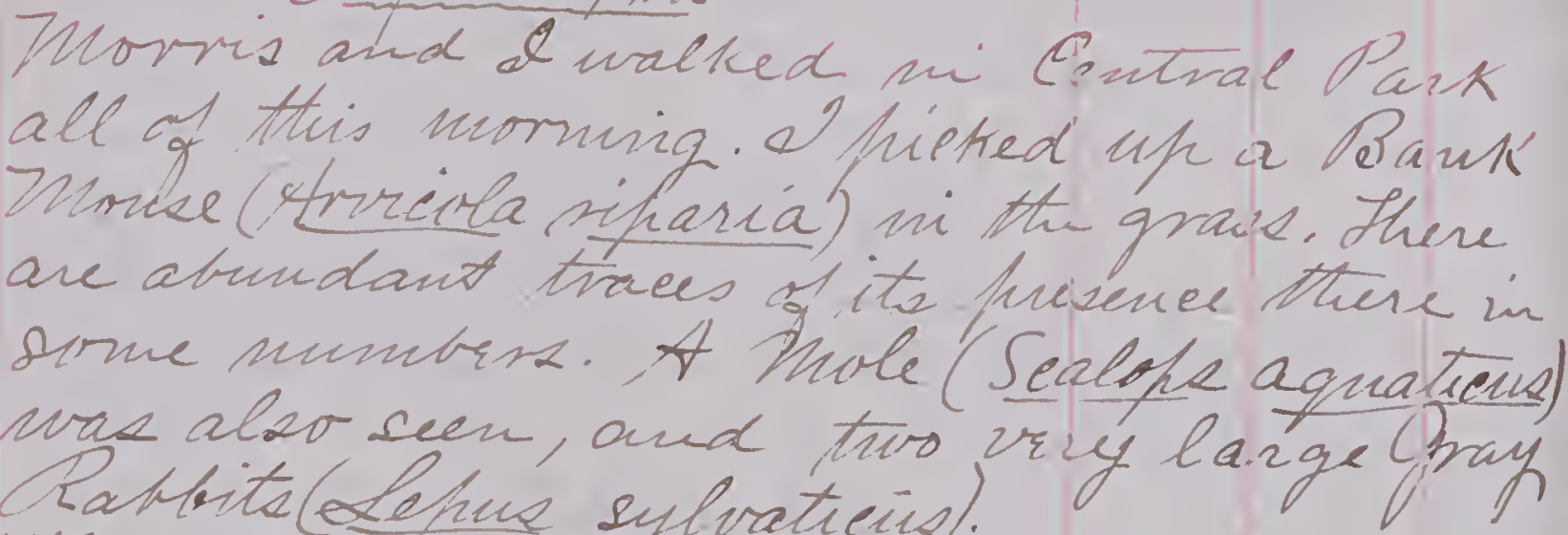
We entered the Park at 6 the arrue, and ualked around the fows lake. Near the ridge a Black Australian Pwan was sitting on a Éngeinest of straw air a vock in the Auiddle of heek conneting the turo hacts of the lotser lake.

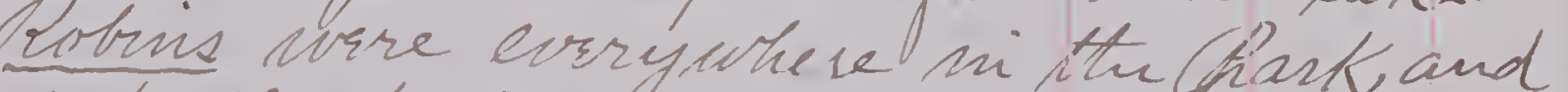
in full string song. IV maiteted the Wood Ducks and several other shecie muoup uhich uns a Lange bind winé' I torts to br

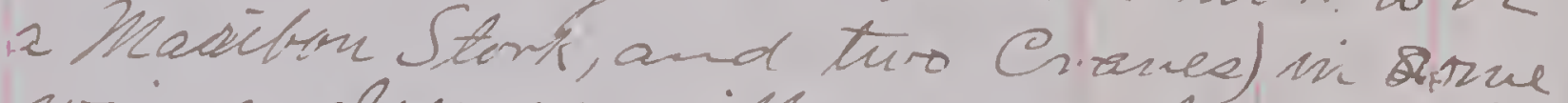
wir enclosures with suall. froude ini them. Thistwood Xueles ure sine in, and the Genales talked to thenselvel as thysum so gracefully abrut wittiout the sle cilteet olszarent effort. While watetien them Hic male tred bird (Sardinalis vinginiams). there uras a Brom Crecfur (Centtic Lamikasis

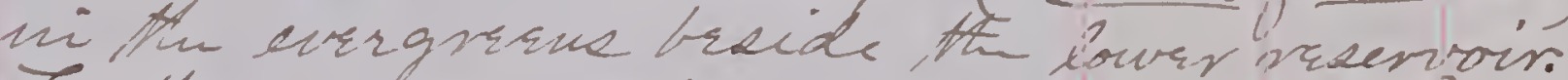
Firther sontte, an the urat wide of the Park, of sar a viry unusuall. layse Robbit, and followed it in to get a betier zricur, int inot as I found it again muz altintrowas ealleld avay in a neur inid's soug. torting wh, saur a facir of elecans). Tealled Rot and ur sat down m. nelks and wateked the jerir, and fistered to them singin. Hhe wise ving gitte, and we of thin eame blose, m, pand

DATr.

tugged away at a big feather in a buah clos by ns. Four other Golafiches fluv prast, ushils wr ware watehing Atris hair we for ind ivo

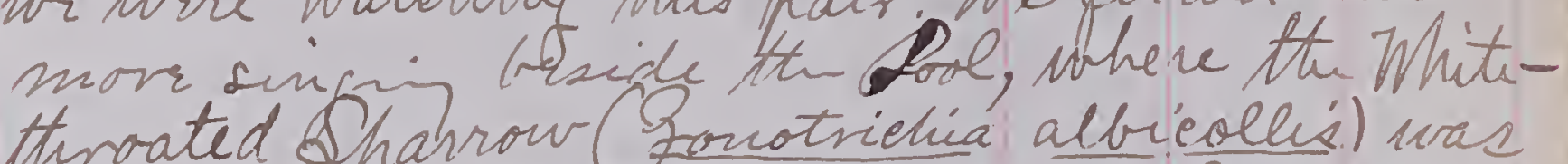
also singing ito full opring song. Threo

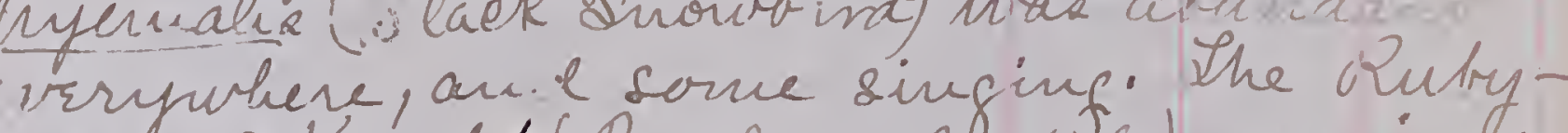
crovirud Kinglet (Regulus calendila) uras singire 'e the Dool, and the Hclitem crested 2? ratrapa) pirere about the same sfrot.

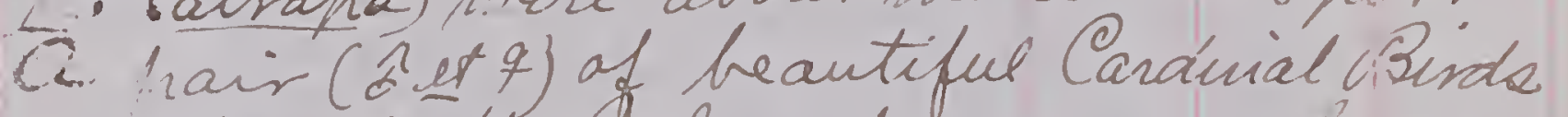
ie brside the fool, and wrere very...

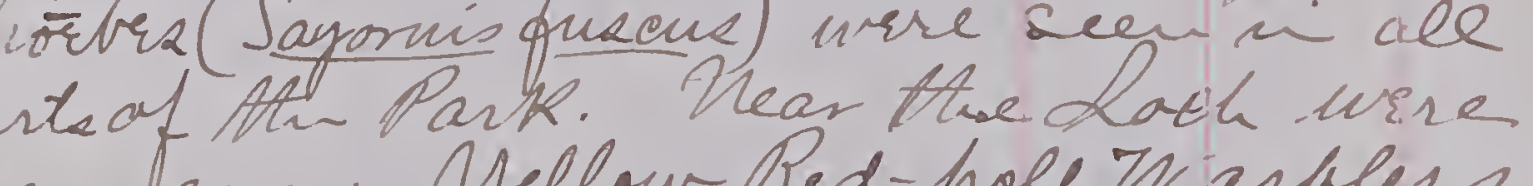
secu somi Yellow Red-foll Virralere Dendrorea Nalmarmm); aud a Tointer

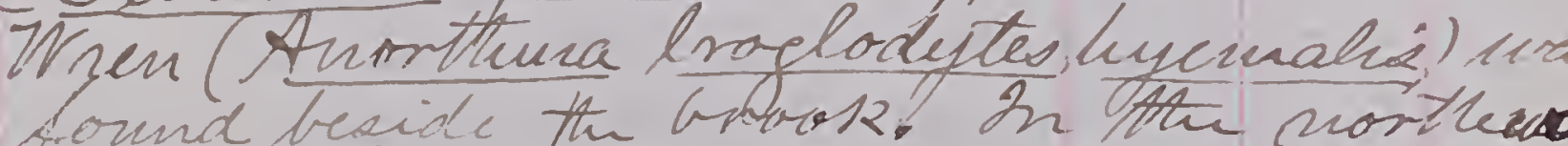

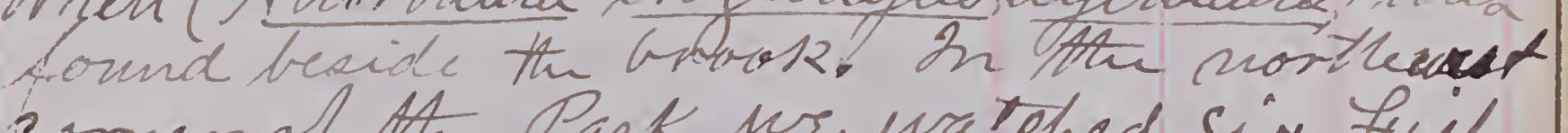
anver of the Park wr watehed six fiolh

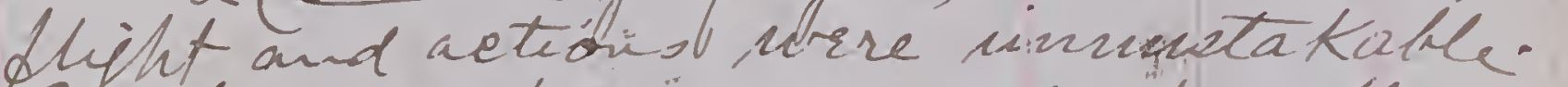
Adurterni cart, caine around minere tixen vere and frifhteind trers. Hivy lectst.

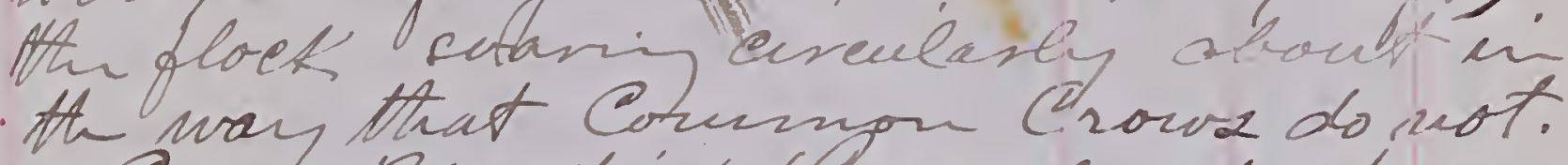

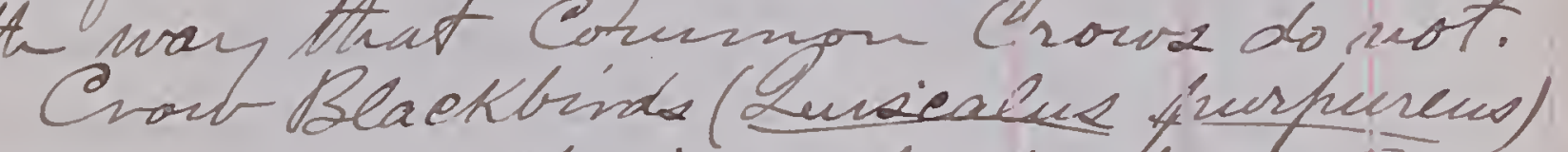
wire abundaut mi all parts of the pask They sat orn the floatrin boxede ni the lake. ques $\nabla 2$ weks. Que of the durans wax sithi an on island ont ni th tak. a Lew Purple Fincher (Tarfodacur hurturene) were seen; and Lonf fiavons ures singin everyohere. These nere no Anels about the Resesoris.

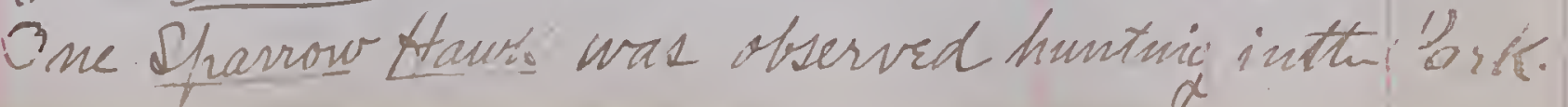


This morming opent in Central siak. Euted at

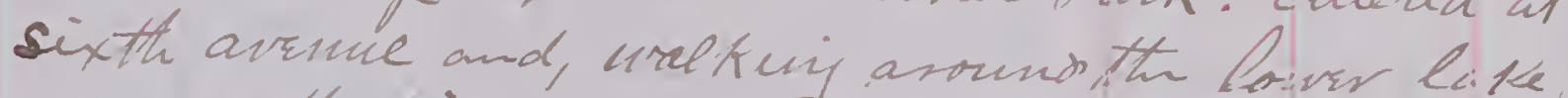
crosed the bindfe wheret the Black Surar was sitting on ken neet ou a voek out in the fow A

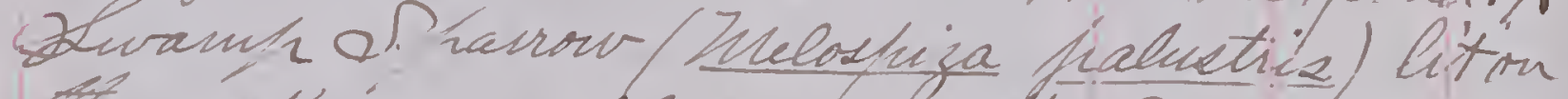
th roek, sem all arrind the fuan's mes.t, and looked at her in evident surpise. minis nre sue in evry hait of tim Park. Che rasi was buily mqaged in buichini a nest in inhit-rak tree, uluin war nearly evinfleted. Siveral Af singig all orrer the Park Sevral Aeruut Dmushe2 (Surdus hallasi) wrze seen a bout the Pool and woch, and wrre ving Son Sharrown (Melophizadasciata) wrre ersyphen un ibundance and sinfirl, and giete a hum-Fir of swoun Lharrowe were aiko deen.

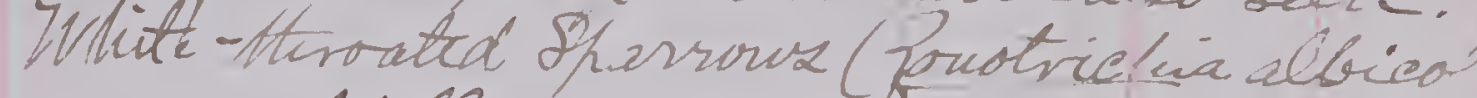
une whisting on erry side.

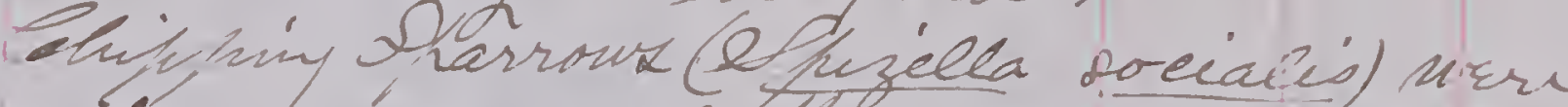
pute numenous in the epher hast of the

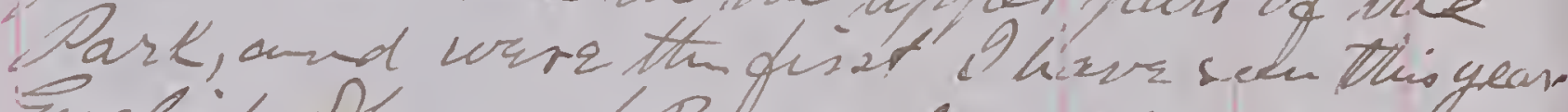

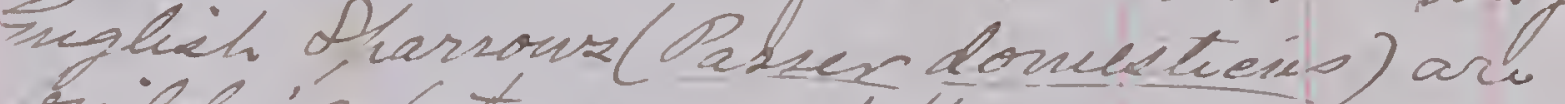

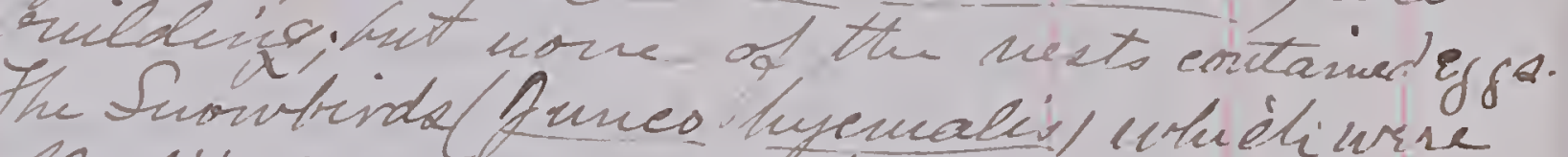
lentiful a wrsh aga liad, appareuthy al hassed on to th. Worth and none wresem. The Cardinal Red Binds (Oarduialie singinianuel ware siepi abrut the ghe, and urre scen armot'th rot and rach.

regane, stefhems) was singhi all ovr in' in wpin end al the Park, and Blocks wo frequentes secu ollyi-, overliead. A do not

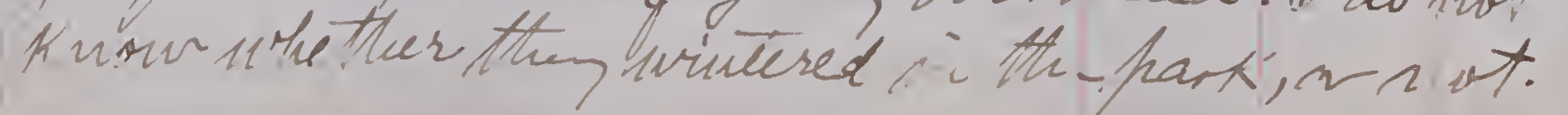

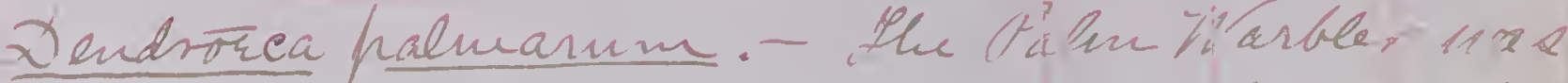

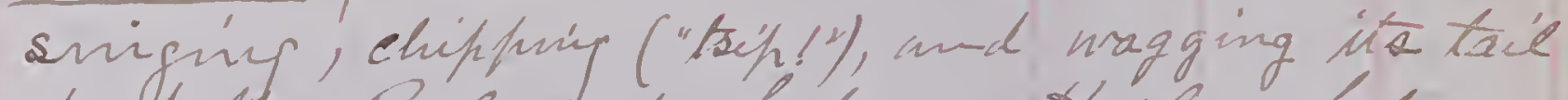
atoub At Paol and Soreh, and trarlem shoke. Xendrorea coronata. - The Mellour-sumpit. Warbler nxa abundanst, and sang in aCl harte of the Pir-k.

Regulue calendula. - Singin and uttering its Wren-like note. Carturdacur hurpurens. - il fie old mate alghted close to where on stood.

nizealus hurpurens. - S pakend ull orer the hark. Que flock lires about the clake; and a hair had settled to hansekeefunis. Thotothrue ater. - Surall enramis of Cow - Cirds wrre suen in different piaces. The

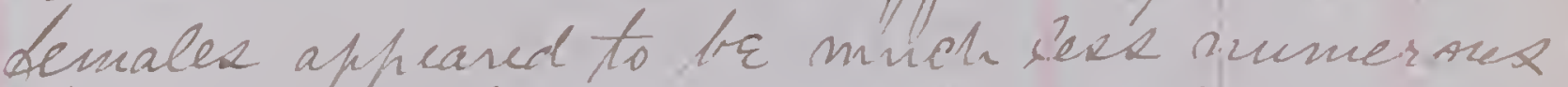
thar males. Uttered a vattu' noise Soymis fusens. - Turo scen.

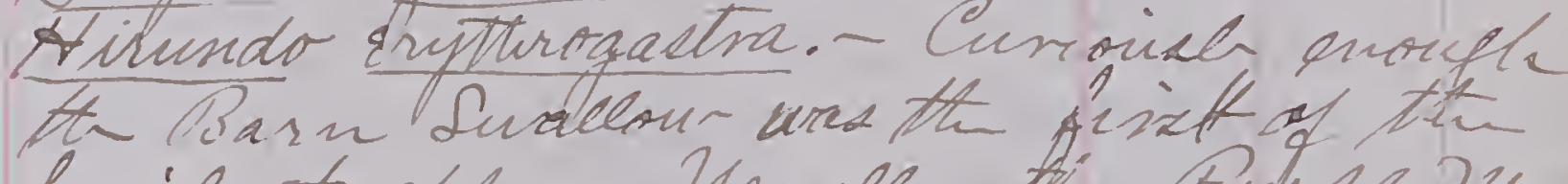

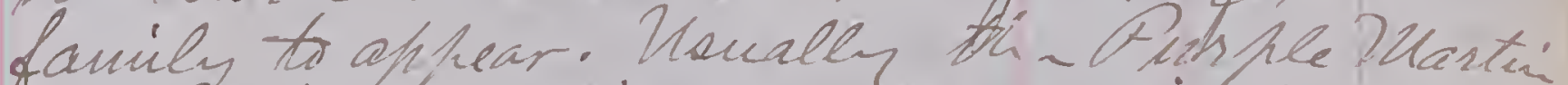
and DI hite-trallied suallow orrie fusit. Hu firat Bam Sualearurat Alni alone

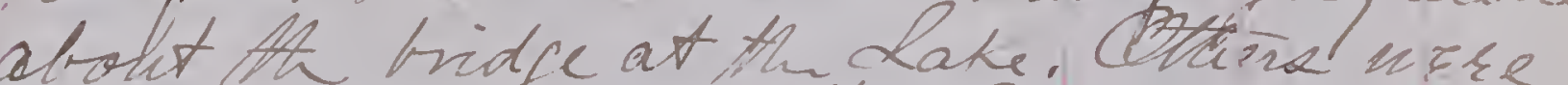
cet the worth and ief the Park.

Cerjle lialía. Sirino.

ceryle alcyon. - Que hiniffistur, a fencale,

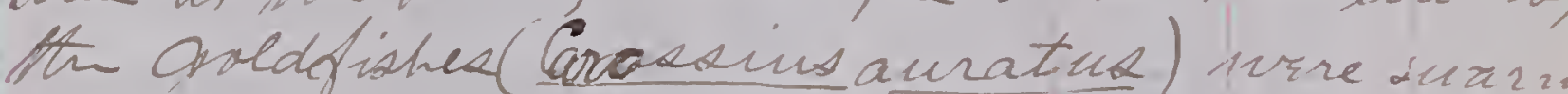
- vin, and of all sizere.

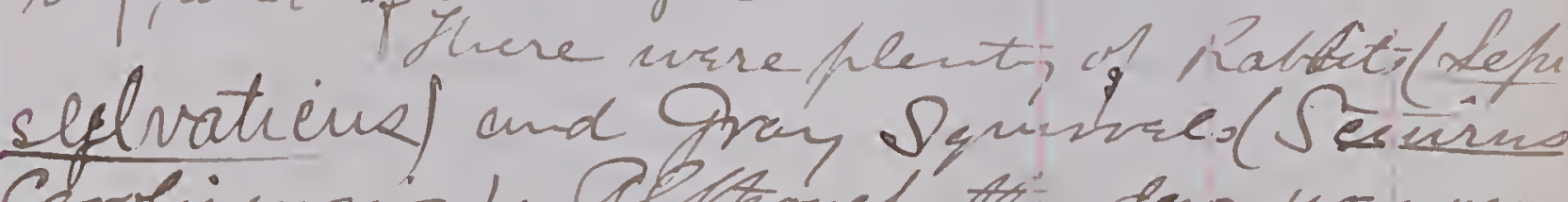

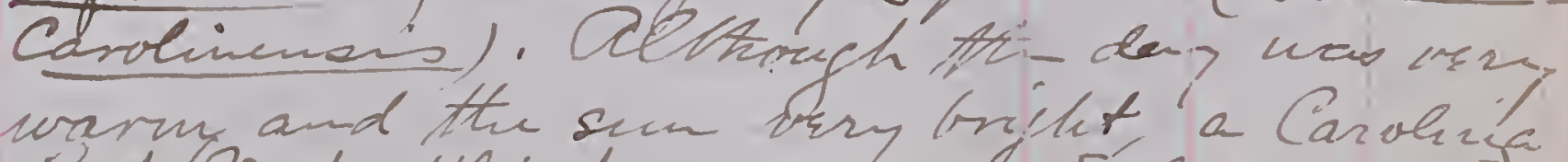
Sat (Espertilio fusens, seavor[ [arolinensi2]) 


\section{thil of 8 th. Neuryork Oty.}

coric and of stated for atriel Park, put regided to fo to the end of the Elevated and uave a good walk on the wher irart of the sland. We gat off at 15 st the street, a... nalked cerosk to stritt Cenetar.. (A2 ur entered

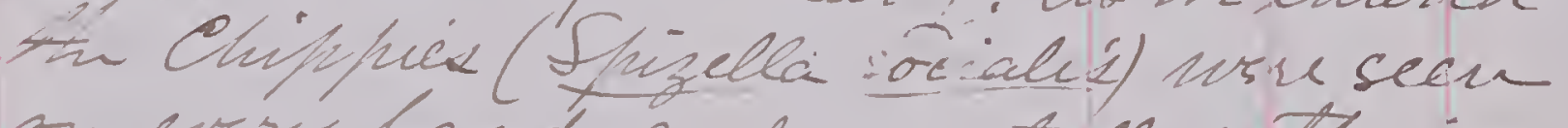
an eveny hand, and urese trielu's thein sinfle dith ever." here. A fat torn:

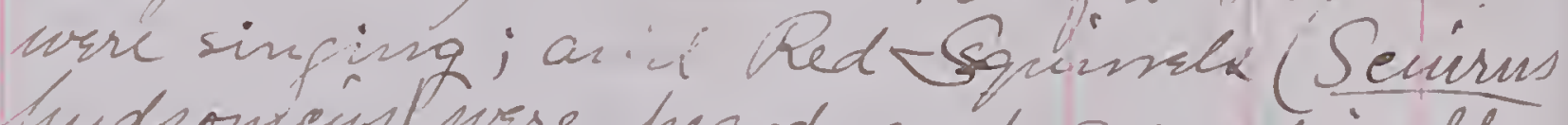

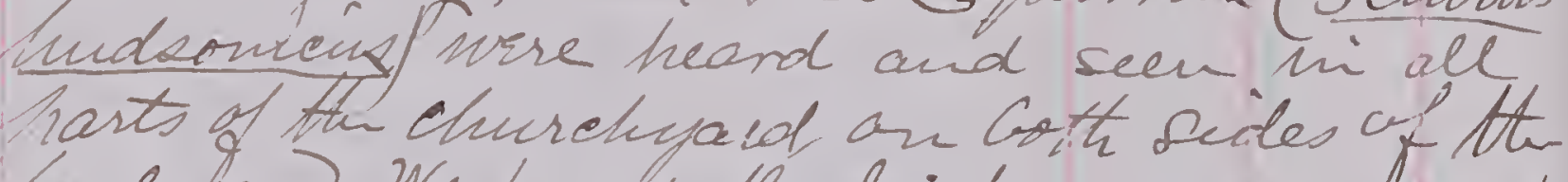
roulerand. Wh heard the firt min grawnip at a sut, and had some trouble in seeing itit; uot, at leupth Nomis dexeorsent it ina thes hemloek. Another was sue in ms diately aftervarde on a low tranch and a thind man aerosk the mad. He Sonf Charrow Dhishing fasciata was singin, and Afellow-bints

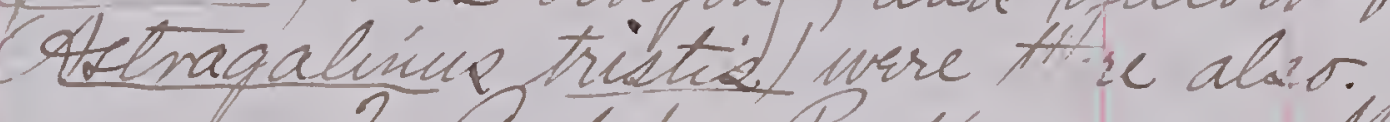
In Andubon Park we saw the gindt

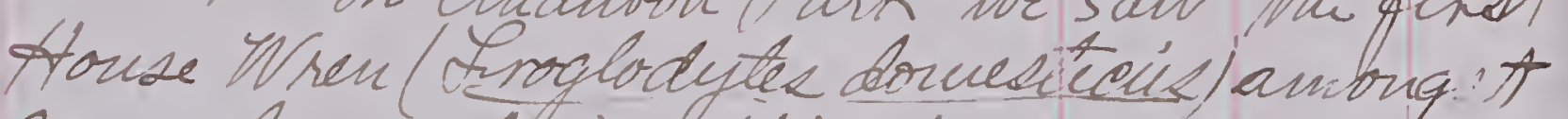

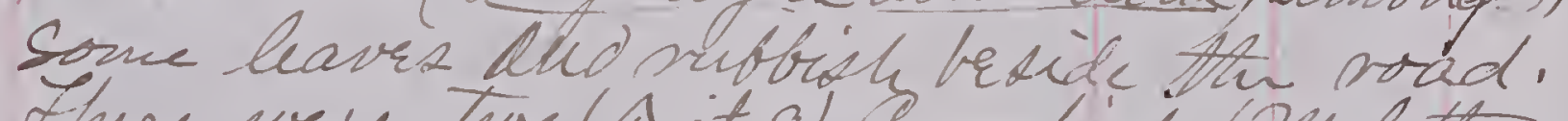
There vere thr (s it q) Caur=brinds (Puolotions ater) near the same sfot. Hee nake sat A true ntterin its chanacterisicé notee and surlling himeelf ut an he tid co If mittur mi glouf the Atudeon ive heard trun of th. Querican Tedictart Setophaje miticilla) also the of int of the season. Ne sone came uf porth him, -n frive prale, and watched him catetrin $\because$ Af wann sundhine amour thal

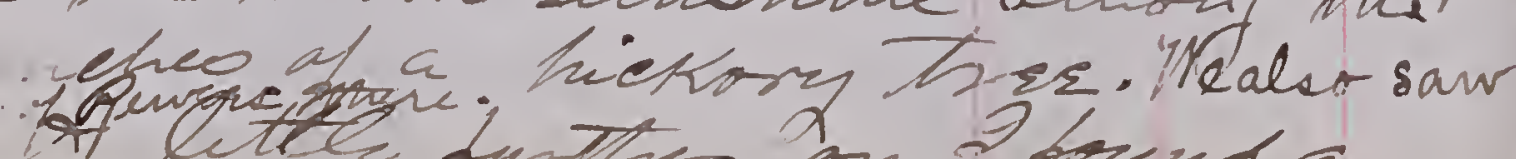

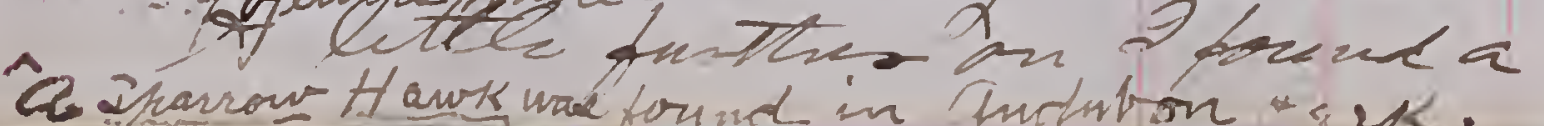

small trook, and fint our het spottid fu the (Vanemus quettata) into it. If froylit it doun from Af phland Fialls serrval urak iqo.

A Crow which was seen beside the Rurer

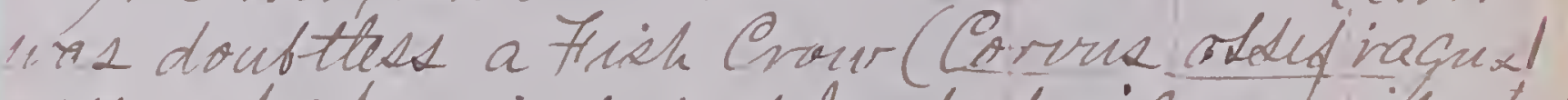
withrugh it maintained perdeet silenel, its shight size, tail, and mamners usre Mrood to we that it urez not C. Suevionus.

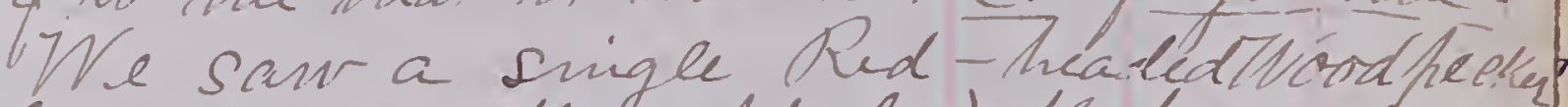
Mennerhes enjthroehhalus) that eroreced -d rattled amoupot sonve tizll, rak'tised - tol of the hile. A Humnemis-bind inochilius colutris) and tí- falden-wriépet oodpecter (Calaptes amatus) conpleles.

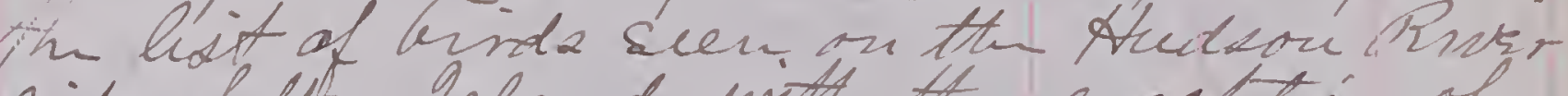
sice of thi Asland, with the excention th Cardinal Grotbak Caritinaliz Oripeir- iampl which whieted ito berutiful.

notes elear and lond down in a ramme. ine erobled over to starline Riner abour thith Arridge, and dound one Con- mon Onow (Corvus frugivinzal. Selour

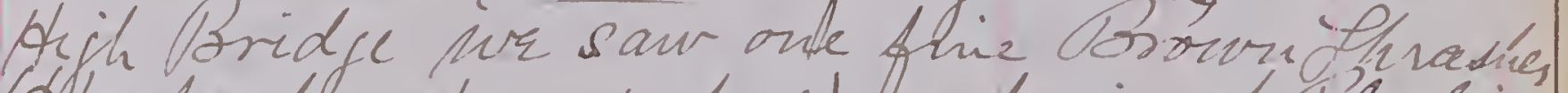

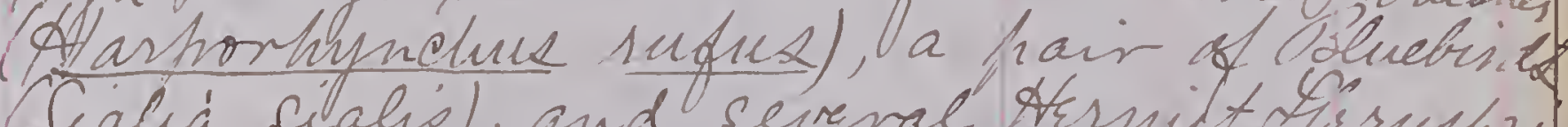

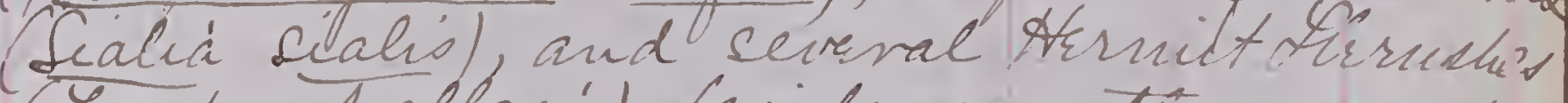
'Gurdur hallawi) resides comytêcs numbers * White-Throated Shavrous Goreotrieléa Alricollis and a sunale floek ot Eacien Suowirdz ( Mmeo hifemalie) whieh have stajed vathet late for tiun'. Then ur carne to a large swarns at ireld azam,

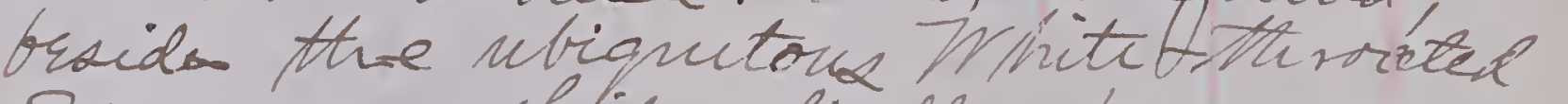
Sparrows which whixted posn cvern triekt, a fuiro of. Candinal Prowferki Candinalio vinginianus). Evenghere 


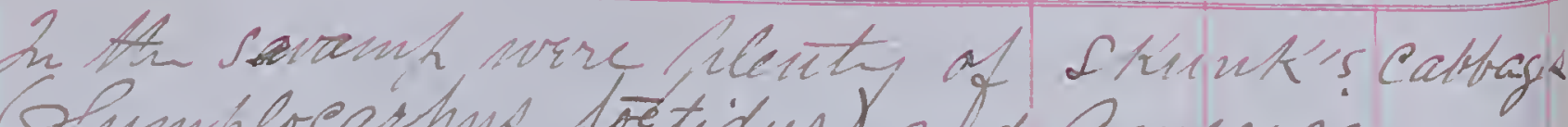

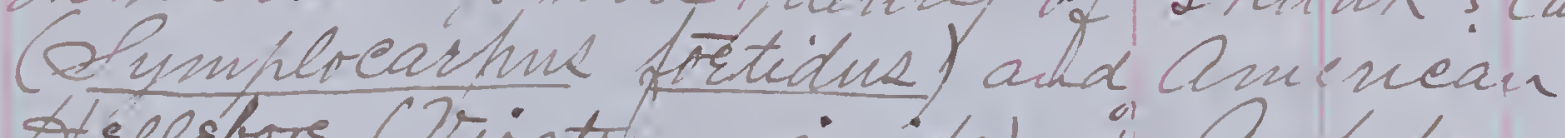
Acelebore (Viratrum cirvide). in Autubor Park, alow the Audson wre large prde of Adder's Ionguevand violet. Alorf thr forlm wre Dutchman's Breches (Diechtori cuenllaria and Anemonee (Anomone nemonote) There are large ratetes of Noe" Pear (Opuntia milgaris), ourtoniz s/reis of tus Thush Lurdure upon a viautificl yifood and saw a mumber of Cleimney fivits Eractura helaquea). There mire thice station, "ne the Aarlen mareh. Coming dery an. thi "El" wr saw the Purple Nartinf Vrogne Pronethene Moth (Attacus prometheis), whidh was attached to Spuei burh Sinzoin adorifermm) which wre covered with Mellor blostons. Hiis moth aluont mivarcably

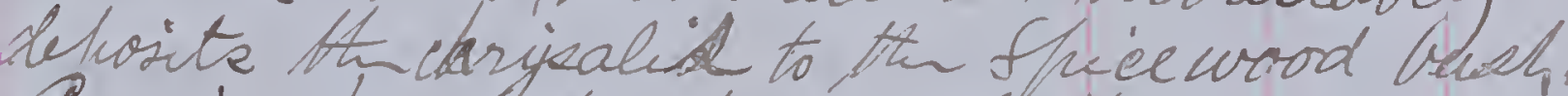
Costine from the tudson to tárleu ns ound a frett oflowar, the osluets Houstonia corruleal groviny in the meadows. This moring, Owhile sittie si mersom, we saw Purfle Nhartins blifin or the housetops and one Ifhavrow Hawk flen overkead. Park, enteri if it at 104 th St. About ith Pool ware an abundaree of Mellour-1num

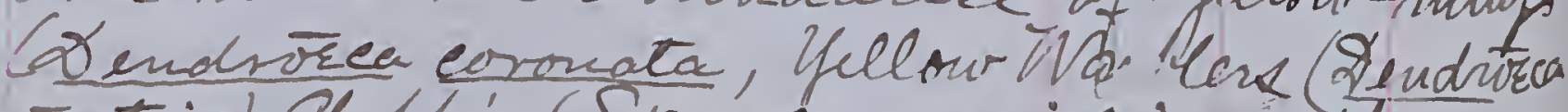
arstria), Chephis (Spizelea soecelij), catorido

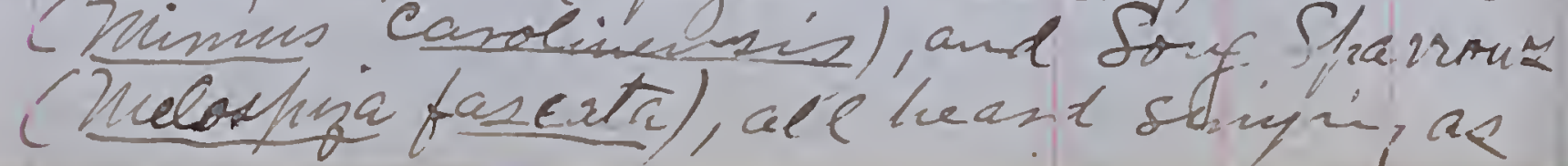

DATE.

As soou as of entered the Park'.

Tue fallowing or rds urire seen: -

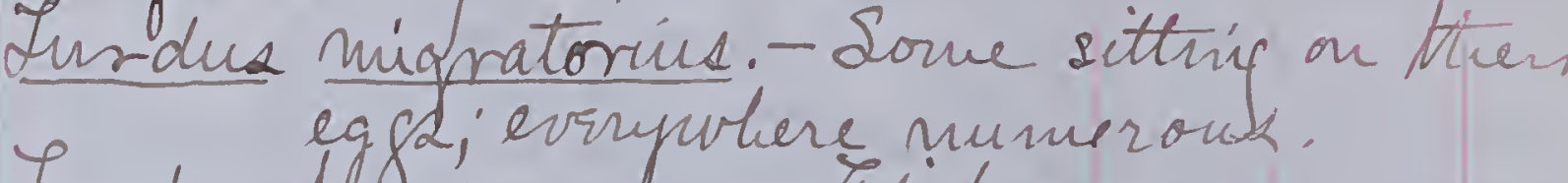
Lindus audedeces. sthundant about Atarlenitake.

Inrdus mustelinis. - All ovir in montt end of *arporhinchus puqus. - Liete nuruerous.

llimma carolinensis, - First see. eeritriá Lamiliaria. - Cue seen fride th Pors?

Dendrarea nestiva. - Fist deen Verm abundaut in all horts of the Mak,

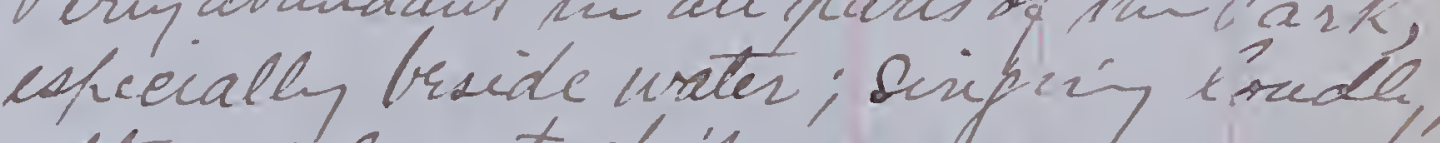
ittirs a suant clié.

Dendrora conpuata. - Evrymine abundaut, singin, and flyceateín

Xendrozea diseolon. Cue alifited clese is. - Side ne below torlem. Sake, and? watehed it for a lonf timi. Atoits? thougles it was a Cathe istar, Thasiles?

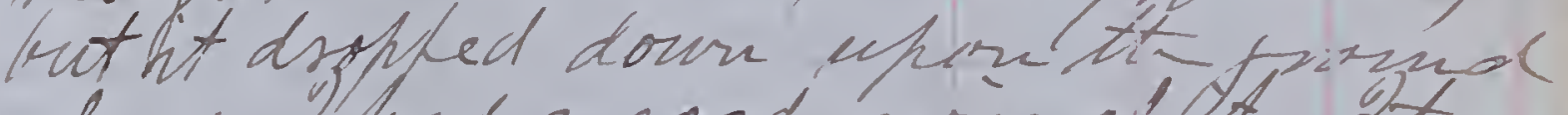
wherc thad a food vriur at of. 27 cau miseds very sapidly in the trees, oi in came down to levid finma, and went

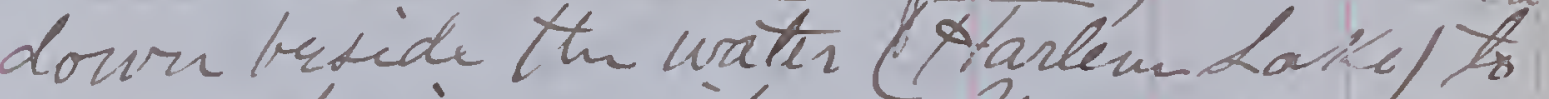
makle firinds with a Muasyeand Helont-timat, and hopked out ma a roek in th lake alon, witt its nis

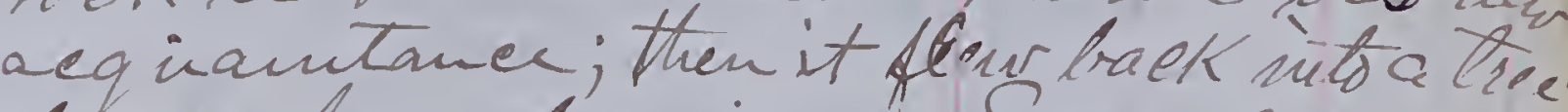
Dindreca heminlinuca - Surnal scen

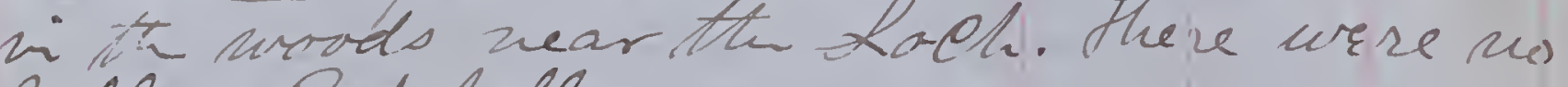
Hellow Red-holls.

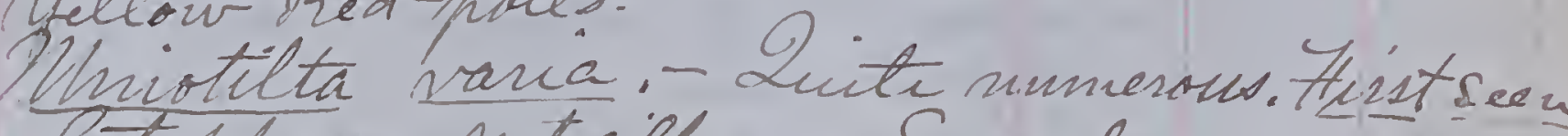
efetiphaqa mitieila, - furral vere seer. Perula onvericama. - Finit seen. 


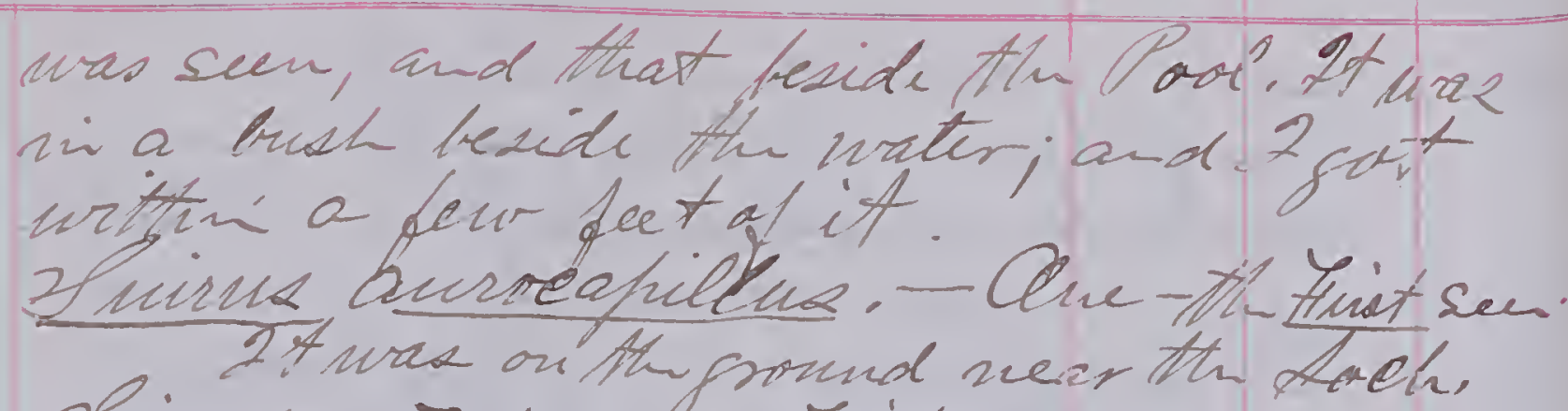
Qimur näevins. Finit Seen One on the broot betivern thr Pove and toch, and surval about Har lem date. Seothlyfie trichar. - Serval males abont the marpin of tarlem clate.

Hirindo hoseonim [erylliogastive]. - There wre a number scer, aboit a froolin a vacant lot, grom the Elevated; ind there wrje a munter at the porl and tarlendake. Orier flavifonx. - Hiret seen. At titu doch. Vires solitarie. - First sum. E Evrywhere quite plestidul

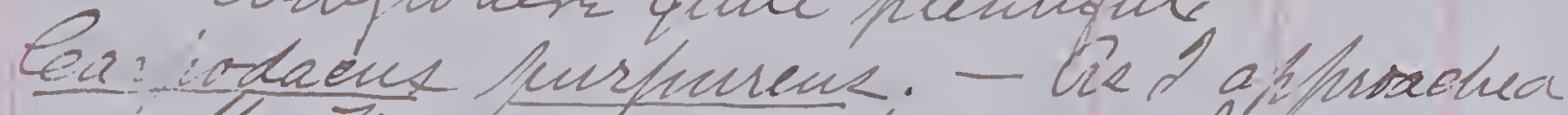
the Thood Xuet's foud, is hirdure ieard singir hich wh ni the ais as it deacended; lit keht glyiuy up in th air ons the trees and sincin londly demale purke trinch. If sood closeto it, and voudérad that a feuale deried sing so foud and susetty

veside the ool is a guwarkable suiner Zuloshiza calustrix. - Lite munerohatrid Pirzilla socializ. - Humerous

Bonotrichia albiellis. - Stiel bentivul. Cardicialie virginanus. Ien Vrside Pipilo eryttiropthalmus. - Diste numurons a a rout the fochortarlem Lakis. Paser domertueis.

Mteetuig

entridowat mis.

Enfridonax minimue.- Init seen

Abundant akout the Pool, fock ritarlemitake Iniealus hurpurent. - Lots of iem. Pandion haliaitus carolinerisie. A beautifs

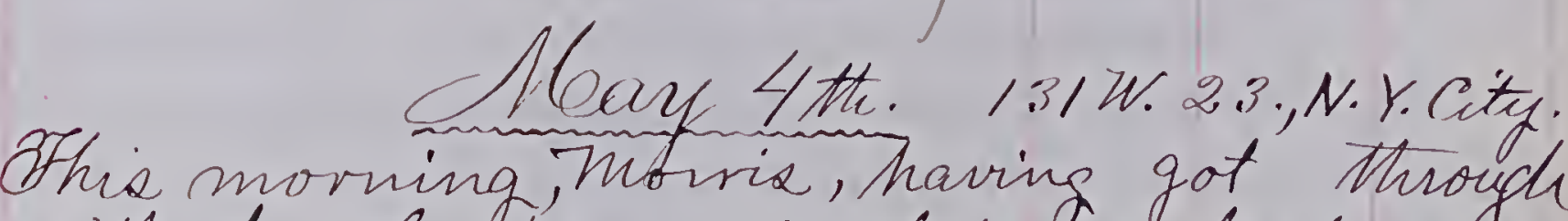
with his last examination cyesterday, shent the moving in Central park, where he found at large mumber of warblers wire Black-Ntroated blues (Dendröca caerulescens) in abundance, and some Dlack and Yfellow Warblers (Dendrorca maculosa). There wat one Baltinore Oriole (Deterus galbula), and. a Mingbid (Iyransux Carolinenaix): Materia Huedeca in the morning, and Practece of viedecine in the afternoon. If fimished the latter at half-hazt four o'clock, and, gu fettin to mu hroon, found

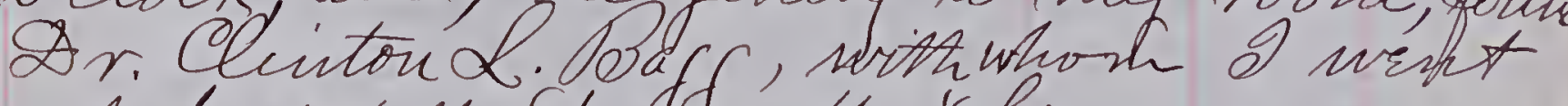

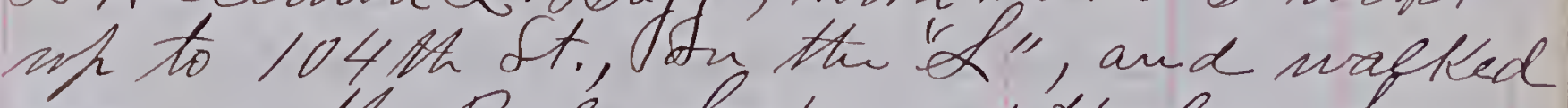
around the Pool, Loch, and Harlem Latke. The following birds were seen there:Invdus mig ratorius. - Sniging. Qne sittrig on its nest curdus mustelims. - Abundant.

curdus fuscescens.

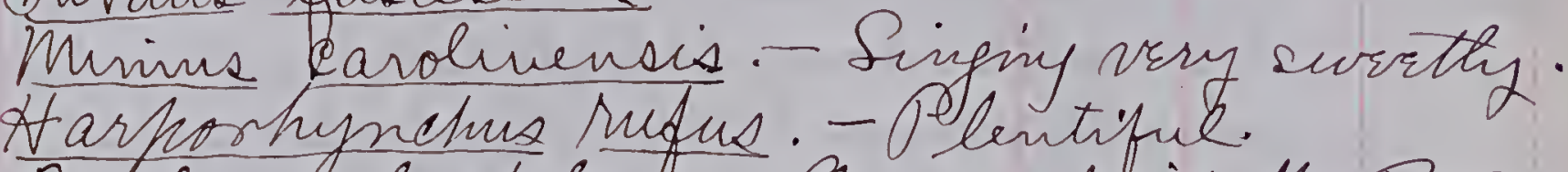
Reculur calendula - Qre sur beside the Pool. Mirotilta varia. - Dite abundaut. Dendrôca àestria. - Evrrywhere sinjingin numbirs; intters a shaifh, loud "chies". Aendrorea coronata. Abundant; singing. 
218

219

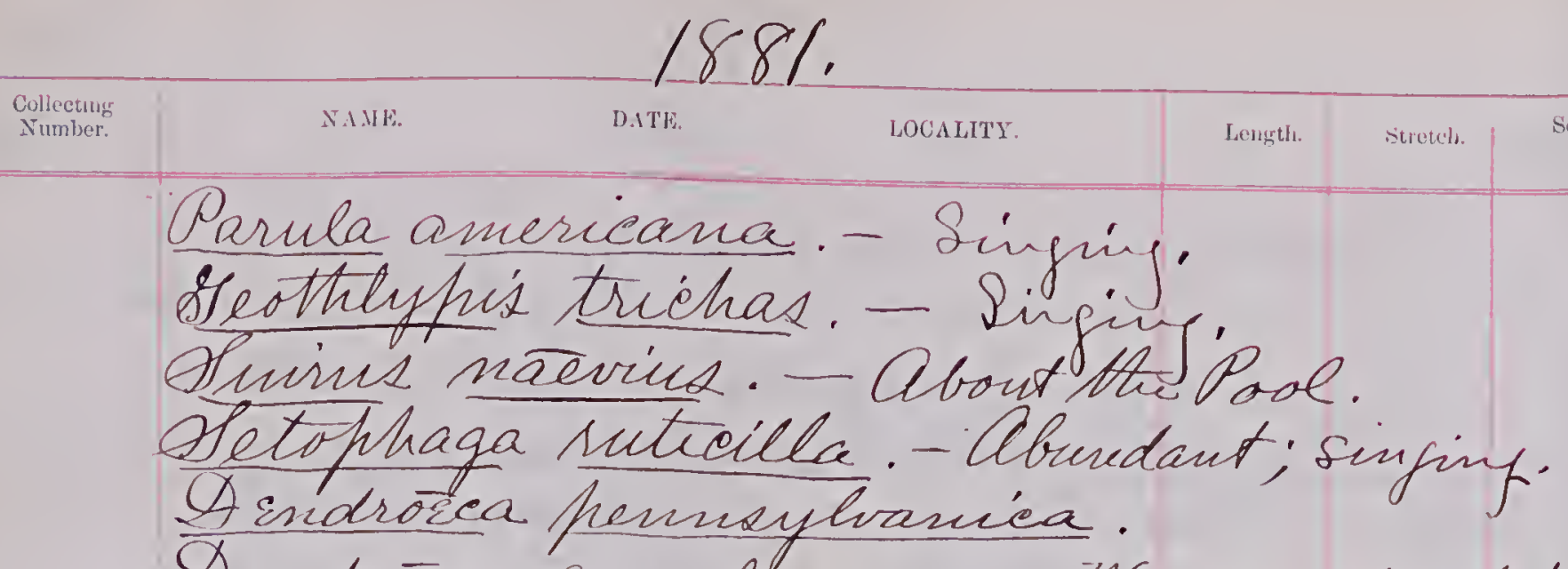

Dendrosca caerulescens. - We saw on by the brook. Alirindo horriorum (E erythrogastra).

Drier flavifrons.

Virro gilvus. - We only saw one, at the Pool.

Nine novboracensic. - Nowis saw ane in thi morning.

Carduelix le elane. - Singing swrstly about I Adragalisius tristio.

Melospiza falustrix. -Abundant.

nelospiza fasciata. - Snigin.

Ofrizella docialis. Snighing.

Passer domestecir.

Molothrus ater.

Zivisealus furpurens. - At the pool.

Emprodonax miminus:- Plentiful.

Doramnus carolinensis. - Sevsal in th rifper frast of the Park.

enactura pelagica. - Abundant.

May 6tth. Arighland Falls, N.Y.

Leaft New-york City in Steanboat "Lhomad Cornell",ou tmie at I delock P.M. for At juland Falle. No binds brsides Q Sorst and Mingfiders wre seen on the this. We rialled Cozzendat 4 o'elock. I $\mathrm{m}$ th evining, I nalked about the fronds and wooda, and noteced the following birds: Lurdus nifratoruis. Building Ysujin?.
1881

NALE.

LOCALITY

Surdus mislelinus - Suigin.

Harporhynchus rufut. - Singeng.

Mimms carolniensis. - Miging.

Aralia sialis. - Nestring ni the birdhonse ofvglodiftes domestiens. - Singing about the

Setophaga ruticilla. - Sing

Dendrotea evronata. - Very abundart.

firms motacilla. - About Echotake and Bele'sa.

Simms aurocapillus. E Sining.

Anindo hovronim (= eryotrogastra).

Ampelis cedrorum.

Carpodacus purpurens.

Astragalinus tristris.

Melospiza fasciata. Arizella sveialis. - Very abundant. Singing.

gnowiduc albicolles. - A few.

sipilo enfturophthalmus. - Humerous.

Aqelaens /phovicens. - Singing nie the old ovehard.

deterns galbula, - Wother saw the first, after

Comars agothome, this afternoon.

Coprous frrigiónes.

- Aayornid forscus. - Breding under the eava, on the water-thife-

Empidonax miminis. Cbundaut.

Errchilus colubrie. - Ino seen. Cur in the backlot, and one near the house.

Cryfe alcyon. - Que at firan ferit, scen S from the Steanboat.

Colaptes auratus:- Calling in Ror's words. Chordirles virginianus. - Ftrist heard.

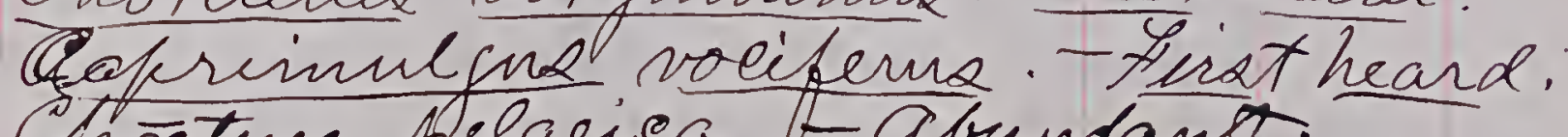
Snaetrra pelagica. A Abundant. the foliage it several days more adraneed

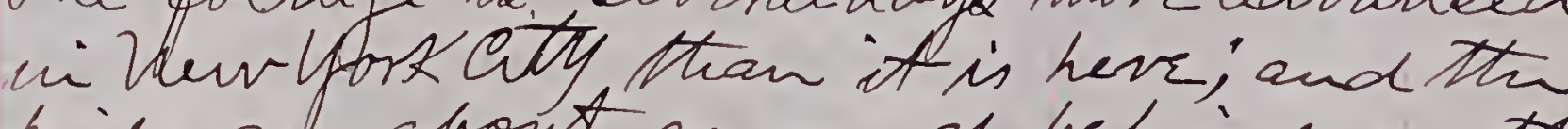
birds are about as much bahind as th vigetation is. 
220

221

1881

$188 \%$

TANE.

LOCA LII'Y

Lengtlı.

\begin{tabular}{c|c|c} 
Stretch. & Sex and & Uollectung \\
Nige. & Number.
\end{tabular}$$
\text { Highland Fralle, N.Y. }
$$

The following birds wre seen to-day:Aturdue migratorins.

ifurdus mustelinus.

iturdus fuscescens. - Hirt seen here.

Mimns carolinensiz. Aarporhynchus rufus.

Froglodytes domesticus. Parula americana. -

Arhminthophaga mifiéapilla." - Diute a

mmier wrebseest in in the apple trees about the fouse.

Ariminthophaga peregrina. - Cue was sur in the sasue flum - treewhere? shot the parteal albino of this speeier.

Dendrorea aestria. - Auly bre was suen, and that near a pool bride thu Andion Dindrorea coronata. - Exceedingly connon Dendrorea hemsylvanica. Che', tur seen

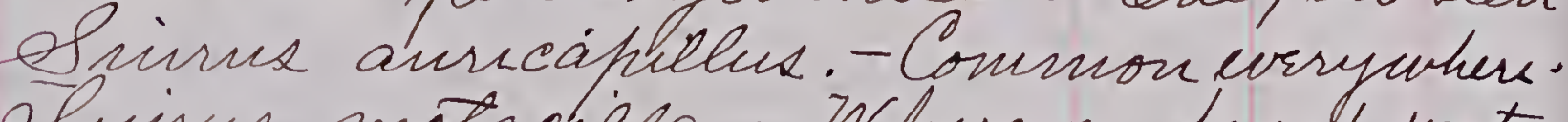
Strinus motacilla. - Wherever freste water is found, there the Large trilled Acdentor's son may be heard, loud and clear, all throngh the heat of the

Seotilyfix tridhas. - Arly a feur wre sech, and those wre all in Consook Marsh. e cterrá virens. - Hist seen.

Petofitiaga nuticilla. - fining evrywhers. Pranga nubra. - Just come. Ficde seu. *trundo novrorim.

Ampelis cedrorum. - Suale blocke are quite eonnin. Their brsast are mueh fales than in autumm. Carpodacus purpmens. - Sinjing.

Atragalinus tristes. - Scattering flocks.

- Nelospiza dasciáta.

Ofrizella sockalis.

Afrizilla husilla.

pnotricha albicollis. - Anly turo seen. Gasser domestréns.

amelodia ludoriciana. Firt seen.

ipilo in throphthahus.

Molothrus ater, - Scaltered flo-ek; A gelaens phornicens. - About the house mans Gorvus frugivorns.

eyamins cristatus. - Mvoflocks of Blue Aop wre seen hassing nostwwasd. On my way uf fron the nirr, I tirewa slone into althiek cedar tree, thuthis that a nest in it micht be nevely brilt, for the purfise of slarting of the old bind ta bird (Blue fay) ded tlof, out of thic tree close to the veat. I elinibed he, shating the tree and making a food deal of noise, as the tree wos a hrry conpalet, dense one. I saw a fayz bill and tail slietrig over thel eldge of the nest, and could Wavr easily captuted the old bird had I not suffiosed, from her position on the nest, that shevascled. She plew away, and did not veturn. trought the rest and its set of Sogptione. Sigranms carolinensis. - Eue harir uas seen brside Echotaki ivry quiet. Sayormis fuscus.

Enfirdonax minimus. - Abundant. Enordeiles virginianns.

Eaprimilguk trociferus.

Eryle ateyon. - Levaral seen.

Ardehilus colibriz. - Liste mumeroux. 
222

223

1881

Chàetura pelagièa. - Abundant. Pieus jurrocens.

Elapte auratus. - Callniy.

Fingoides macularris.

il walked all over Consook Masch without seeing any Savanna Sharrowz, Swank Sparrows, or Massh Wrene. The Shad-fishermen are on the island. Thee told ine that both tinds of Bturgeons, fork-tailed (atfesh, and Driphed Bass wru Ah only fistes they caught, trisides Shad, The Shad blossons wre out, on Cousovts Island. While there, I took a bath in the Audson the first of the season, and such a eald one that I was plad to get out of the nirr and into min elothes. the wille colurubind are just be firming to eone out nicely, and violets bere si (their prine. It Law, Prsides the abour species, a fine White-headed Eagle (Haliaceitus encocefhalue). It was sailing circularly, and descended to the bank of the rives.

Marj 9H. Highlaud Falls, N.Y. Surdus migratorius. Inrdus mistelinus. Muimus casolinensis. trarporhynchus mufus. - This evinimg fecished sevinal out of the huskes by on roadside about half-rast eidlt 'elock. They Alegr off chattering at a ont at vate. inlia sialie. Atave boury nes. Parnt atricapillus - Luo pairs. ivoglodiftes donesticis.

Munotilta variá. - Very abudant; singing. $188 \%$

NAME.

DA'T.

LOCALITY

Length.

Pamla americana. - Very abundant,

- Aendrorea catrilescens. Abundant. Fust seen

here Sniging

Dendrorea coronata. Abundant singing. Aendrorea striata. - Frist seen. Culjone. Dendrorea pernsylvaviea. - Singing loudly everywhere.

Dendrorca maculosa. - Huit seen. Culy one. Hinns auricafillus. - Singing and abundadt

Sinins naevris.- Inst seen. Only ore Riirns motacilla. Singing wherers there is water. found a nest nithinia pew feet of thel spot when I found the last one coutainn youn ones. all aloug muder the bantk brside feft vest wittiont descorrring it; at last as o was leavidy the slrot 1 a smale brook emptying virto a layge one Affew rods from Atur nest - Saw the ald thrid sittri ufon its iffo, which as near as I breld see wrthout disturbing then wre fir in numkes. I) visited the rest just at dust tormglog. the old bird left the nest pistarlof. was puttin my haand oves ift and san down the Ged of thriram, utterng a shar cliphing note. Shen. it carke flutteriug byth nito minface, and fraskd ovir my thad. It themplem

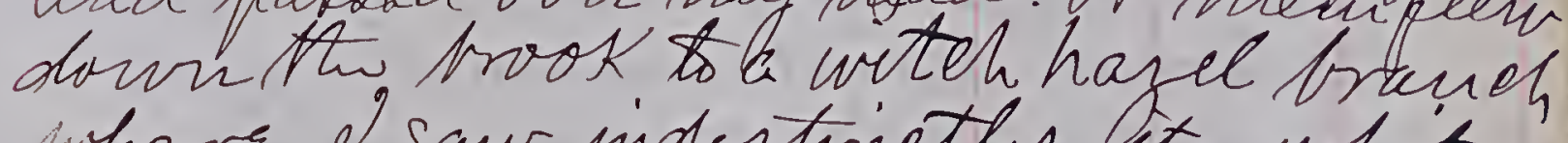
here I saw indestinetly ats whit brast undulating as it fowrd in and down in the moonlight.

Sesthlyfiri trichas. - Atas now got is on hijh sound avrery frouh tore 
224

225

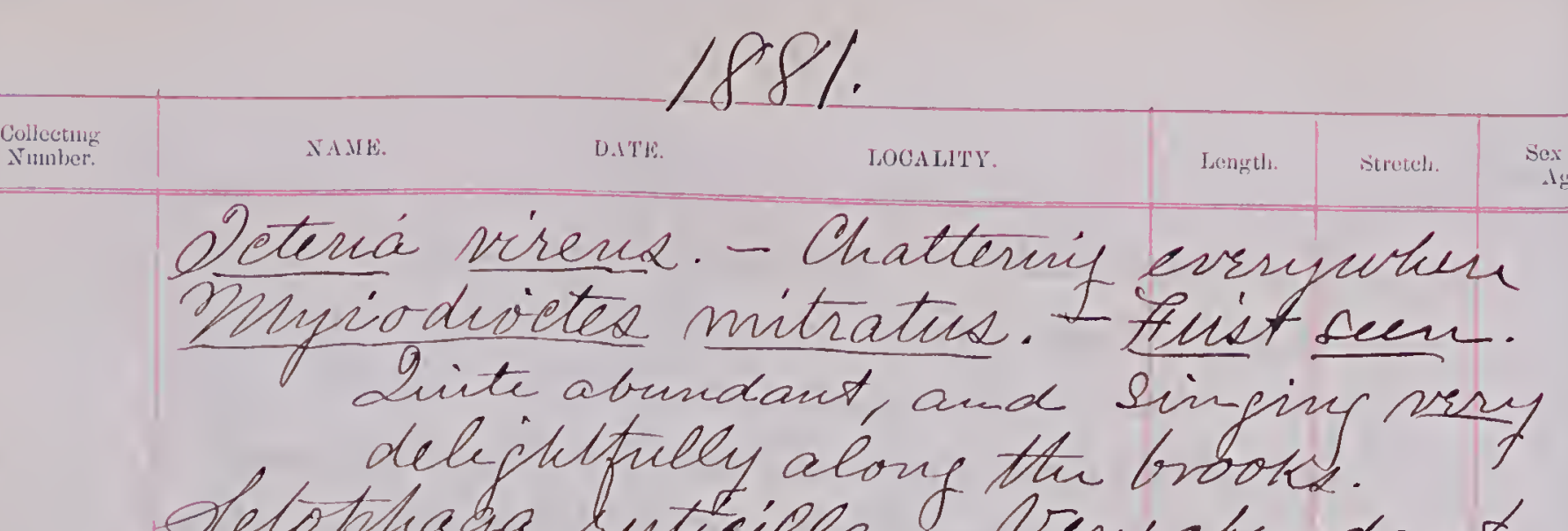$$
\text { Setofitiaga ruticilla. Very abundant, }
$$

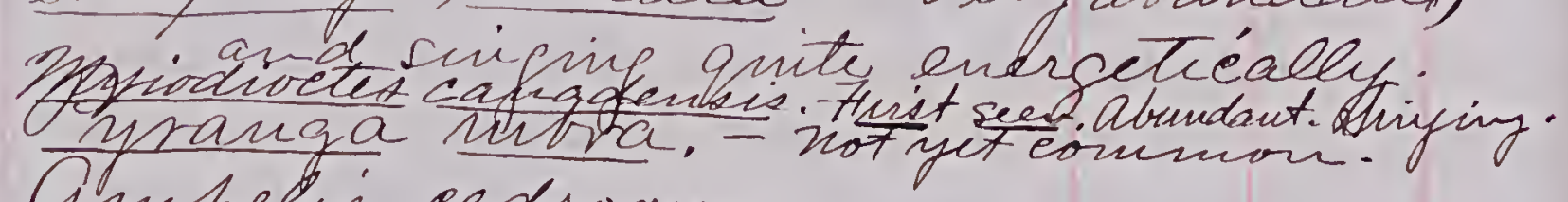

Ampelis cedromin.

Pires olvaceus. - Firat seen here

Vriev gibux. - Finst senhere

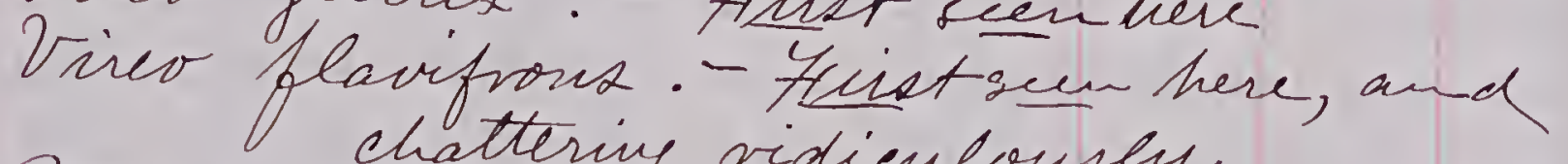

Pirir solitarniz. Finst sensen.

Trires novboracensis. - Hust sem.

Carpodacut furpureus. - Singinf.

meloshiza fasciáta.

Affizilla socializ.

Offizella pusilla.

Dotricluá albicalliz.

Pamelodia ludoviciana. - Cue senoney.

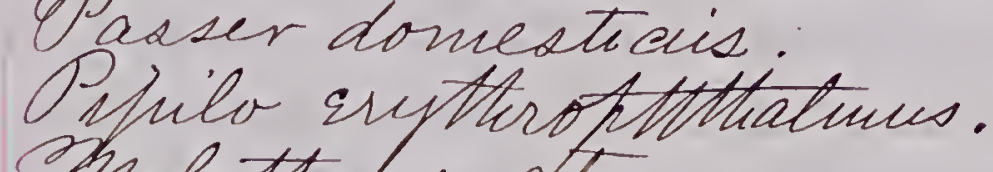

onolottirtes ater.

Octerus galbula. - Very abundaut. Females. Eorrus fringivorus. - Brot ove wild old chat.

Eyanuhus cristatus. Ifrannus carvinensix. - Ouly one seen,

Sayornis fuzcus.

Ezhidonas minimus.

Caprimile virginianus. - Alyin at dust.

Caprinne gus vociferua.

efractura pelagicial.

Irochilus colubri.

Ceryle alcyon.

Cocenzus anerciams t Feritheen-
1881

LOCALITY

Ceocenzus enthrofhthahme. Huit seen.

Preins prbescens.

Colaptes auratus.

Dhelievr these may fifty-foursfecier, sevral in advance of tht muncor seen yesterday, attiough a munber of the shecies notecedysterday wre not obenturd to-day. of vecinrd a notée this evining that my examinations had born satisfactory to At Haculty of the College of Phypichant and serryous. Then I want to the Water Thessh's nest, and notee'd brsides that the inerating Rovin Ihrashers sleep at might in blsthes, as wrll as (or mistead of:) on the ground. The Whiffoorvidls wre calling everywhere.

2,180. Coceyzus americams. 11751675 - Fad.

2,181. Samelodia ludoviciana: $8.00133 .35 \hat{b}$ ad.

2,182. Buyiodioites canadensic. S.65-8.5 ŝad.

May 10 th.

Was broy about the flace all day, and the only new arrival noteced was Letens spurins (Orehard Criole), thu finit sem. Lhis evrining of trid to eatoh the Water thrush mi a net; bint it has prown sluy, and Aluttered off the nest, and. swam doun th Grook hrsyprafidly. This one is th anly bird wr havr that delibrnatily tates to the water, resenblimp nie this stofeet the siphers (inclus nexicams).

Bliafilth.

Indus sutionsovi. - Friat sen. 2iste numenow Hehnitherne vermivorus. - Firat sem. Hehmonthephaga chryeoptera. - Irist seen. Dendrovea pinusybanieus. - Cue that doshot was in the flemage that 2 deseribed in the 


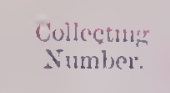
$88 \%$ DATE. LOCALITYY.

Bulletui of the Nultall Ornittiologieal Chut, vis. : without the black and chestnut maiknig. Dendrorca caevulescens. - Now vrry abundant. Qudrovea maeulosa. - Leite hlentiful. Eeothlyfie trichas. - Now abundaut. Mjüdio etes mitratus. - Abundaut, and si

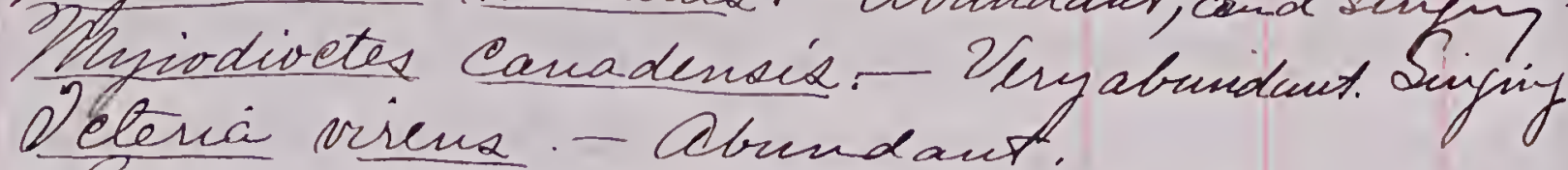

A iurus motacilla - I shot th fenale as she flew from the nest, and took the mest with its five efg2, which wrse secured pist in timie for preservation, as onbryos were consederably adrance of. The old bird had prown quite shy. She left the nest by suming and surimsinif dom

Orimur natrius, - Culy one seen. Melosfiza halustrix. - Que seen mas the stable. Her fist seen here the's season. Here wre none on Cansook Marth. Auneo hyemahie. - A firc ald male was seen min. the fath before the house. Alate oul Eormas. A flock of enouz wire soarif

cisieularly ovhrhead, and esoathin areacionaley. I am nearly certain that some of then, at least, wre Hide Crowz (Corvas ofsifragus).

Andea tritacens. - A fine Grem

tiaron was seen at Miorgan's brook. Hu Friat seen this year?

2,183. Aimus motacille. Fear 6:201020 fad. $62010207 \mathrm{ad}$
row mostiel, 40

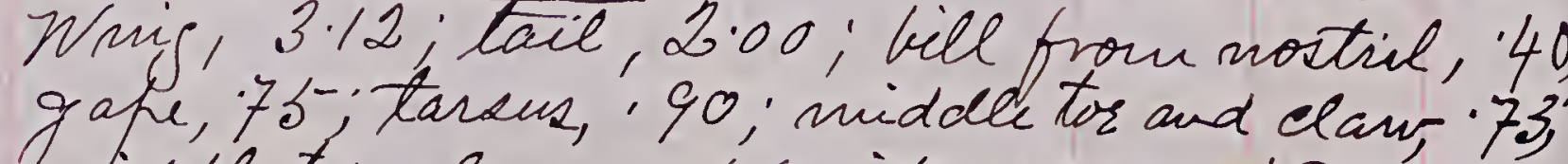
middle tor alone, $5 \cdot 6$; its clow, 18 . Ani, dark hazel. Maxilla and tifh of man-dible, blackish; basal one-holf of mandith flesh-evlor. Legs and feet, fleat-color. Taten with
1881

Collecting
Nuniber. DATY.

LOCALITT:

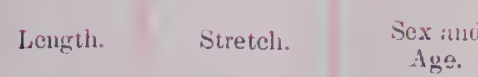

2,184. Hest and set of 5 egge (No.163 $\left.\frac{2}{5}\right)$

2,185. Aslinitherus vermiborus.

5.10820 ôad. 5.50 8.65 fad.

\section{Whay 13th, 1881. New York City.} Hhis morming early, bring unable to sleep, 2 rose and brearfasted, and then staited for the upper prout of Central Park, takeriy the revatid Rovid to 1014 th strut as usual. The foliage was wrll out, and the air nas filleb with fragrance, and sounds of singing boirds. I velached the margin of the Pool, and soon found myzelf, or sather lost myselt in the middle of a thieket, trying to identiby a new bird's note. The vocée that prizgled mu was shasp and metallic and its owner froved to be the Kentudiy Warbler(Qporormix formosus), and a bird never yet ceenasfar stortt ad the Andson Aicheauds. There were two of trem; and their shasp call-note ditfered miffitoh and quality from anytting else that of have heard. They wery shay and not disposed to court the society of naturalist. I soon lost sight of them; but vefore o could extricate miself from the langle into which I had plunged, I had noted Warblers (heeies of our family of Amencan crourned Warbler (Dendrorea coronata) frell spring dress, accompanied by females hin Waines garb, singing a song thatt, if not reniarkabe of itiself, helpe the general chorus. They wre hovering over the wate, Slutiering amouf the lerminal, Granclex. abov it, or flying out in cueles after miects 
Then there wre Manjland Yolow- Troats (Aeotheifix trichas), Canadian Fly eatehin Warblers (Mniodioctes canadensis) Smallbilled Accentors or Water thrustex (Livrue naèviul), Summer Yellowbirds (Eendrorea aestria) Blaek and ithite Crephing Narblers Moviotilta varia), Bhe Yellow-backed Warbles (Aarula amerieana), and some Black-froel vrarblere (Q endrorea striata).

The Mood Chrusties song heard; and so wre the Cattrid and Brown. Thrasher singing On a thee beside the Sool a hair of Enopedu - oedfinches (Carduelis Elegana) wre singin a spingth sory resembling anr Lfeloiburd's. As I walked doum treside the brook, and the Soch, atter Harbles, ar the Clestints- sided (Dendrorea hemmeghaniea), and the Slaek-throated Blue (Dendrorea cirnelescens), wre sem; and the lond song of th Golden-erourued A cecutor (etirur anicafieles) was heard on the hillides abovr th savine. A beautibul Aliee's Llirush (Lurdus Suxinsoni glieias wasfound at the head of Xarlem qake. There all the binde secued inspired to Moduee ther' frices melody. A frair of other baek and forth aerost the ravine; and four of the Vrieoz, vis: the Recl-Eyed, White-eyed, Warblin, and Villow-Ntroated (I. V. V. Nineo ohiacins, noviboracensis, pelvus and flavifousl wre filling the woods with shelody. Even Ath Pedotart, emulating the example of better sergaters was makin musie that exeited noy admivation. The East side of Harlem Lake is a favorite freaee for burds $\frac{1}{v}$

OCALITS

cougregate; but mytrime was to short for a thoroush Expleoration. The birds whose presence was evrident nirtiout nuaki sgareh ware Robins, Catorids and Lowhed auntrig. The Chippiswre trillu' on every bishe, and a few fory sparrows were singin; but there was mone amory them all hose sons could mateh that of the one whose nest is brilt near eighter avrnue, rside Atr pool. Small cobupanies \& Cowibirds (Molotterus ater) wrre ckecurripi about, and there were som Cruobla efebisbs Gisealus furpurens). A few hingbinds (Lyramus carolinensis) wre scen; and thu $\alpha$ cast Hejeatehers were huntini ni pairs at the hach. As of passed th vol, on my raturn, a hair of Layferilled Eecentors (duins motacilla) vere noteied on the brink of the Pool. Chaetira. ? reacheat the tran in trie to get dongr and dress ni time for the schearsal for our collye Conmencement exercises. Mn the evenime I was decorated with ou of the Harsech Prijes (the third, and smallest ine) forttu best refortinin uritini on the medicial and Surcieal elinies held at Atu. New York tiospital durning the hast winter. I secirred a Harsendislowa, mi addition to one from the Colece, and a bronze suedal, all of which teikled me immensely. Prile Partor * muself wrre goniyhome from the Receftion at Prof. Muartior's house si

3oth strut, wr heard the Niflet havtes crying overhead, althoufh it was a dark right and after hireve oreluets. 
230

231

1881.

$188 \%$

Sunday, May torthe. Higheand Fales, N.Y.

Look a lony drive with br. Chace mut to the Forast O'Dean mines and then to Hoot hoontyony and arisited a munber of patieite:

Niar the Innes wr sour a Dobin's nest

brilt under a bouk brside soad, whener dirt had bacn earted to make the road. The nest was built under a soot, in troh a spotas the Sarfe-billed Aecentor Ite saw one Irhite-crowned Shasrow (Zouotrichia leneophriple) on a fence

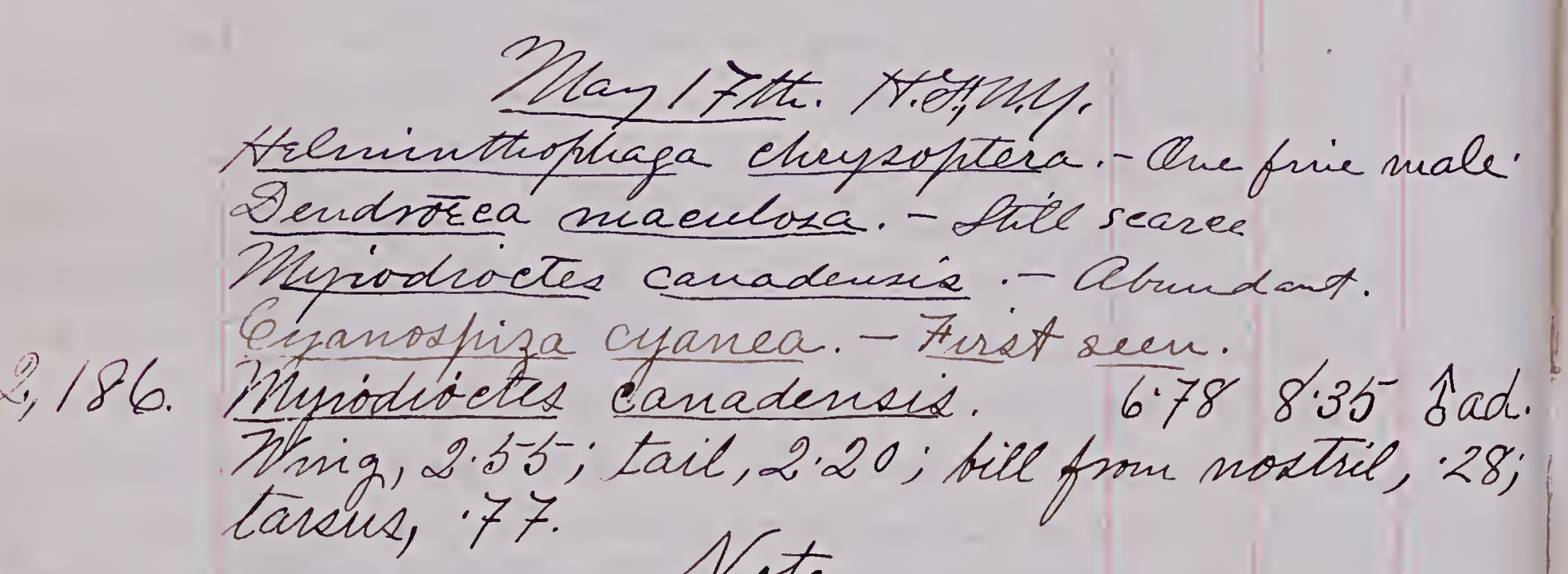
larsus, 77 .

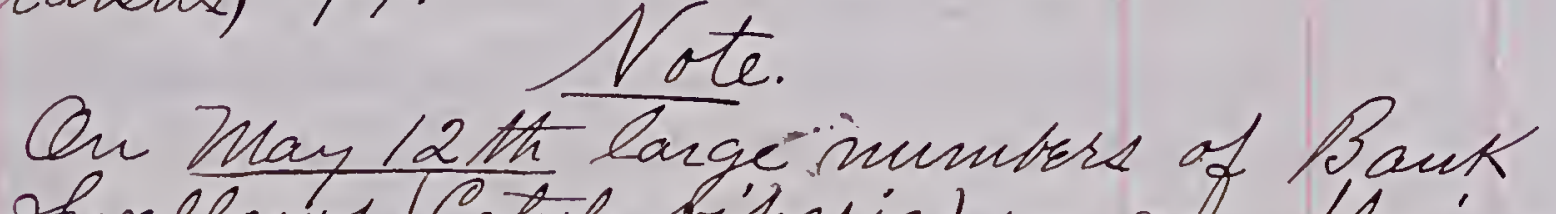
huallows (Cotyle hiparia) wr sedn Glyin. about the sandbants morth of Bteehatriel. near Mona 2 sland which 2 sufpose to have a Carolna Irebr (Podilymbus wodceefre). On the nornin of Mllay 12 , a large floek of Reve Acyte (eylanveitta eristata) were seen to lalifht otn the bawk of th Pinr. They wre evidently micratein; and why shoned so may floeter be swovin are ineutatisy or have young ones inth mid.
Surdur suamioni:- Plenteful

Iurders suamsoni aliciat. - Dute

Mniotilta varia. - Now broming less numesons.

Parremamericana. - Shigring. Surval. They rarely sing in the breshes, but fly to a tre and ranain prettes quiet, so stat it is diefficult to discover one, ever when it is singing. Dendrorea virens. - Aas not bern sen yot this year, Nether has

Sendrorca corrulescens. - Not vry numerous. Dendrorca coronata. - Nat veryfentiful. Dendrorea pennsylvanieux. Mated, esinging. Dendrozea maculosa. Putter abundur Dendrorca striata. - Fist seen. Abundant. Shings

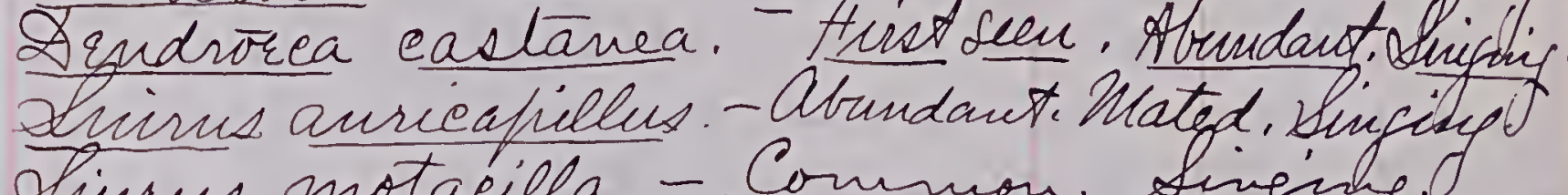
Liinus motacilla. - Common. Singing. thirrus naevius. A Aneard the lovrey song of tine. It brars little, if any, vestublarce to the song of Sirrus moldeilla, except in its wich suellow quality. It is supert.

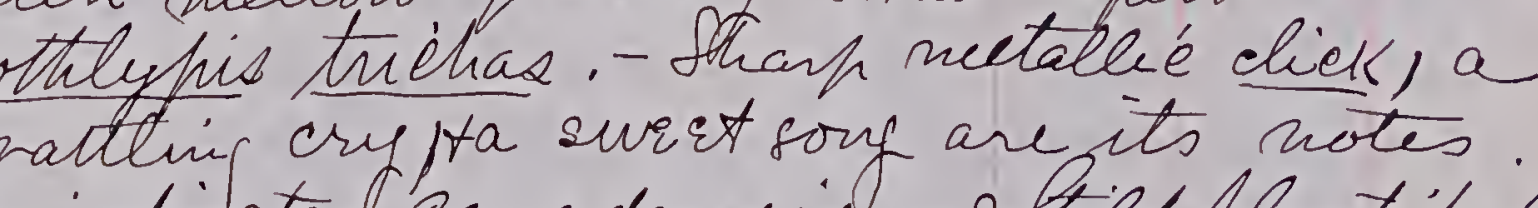
Myiodivetes canadensis. Ctiel flentifiel Injiodivetes mitratus. - Common, Dinfing.

Deteria hirens. - Less muerous. Letted doun Pyranfa nibra. - Lot abring thiekets.

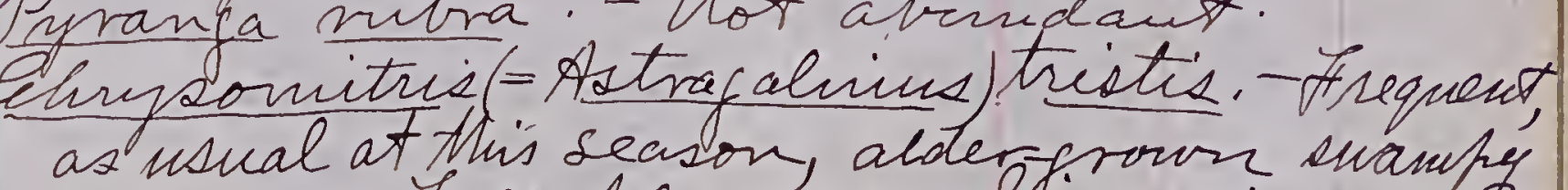
pastures. Anll flumage. Shing vivacionse and eonstantly roring about. 
232

233

$188 \%$

1881

Sonotrichia albicollix. - Afew.

impidonax minimus. At dusk last evening (7.45 P.M.) a Leact tilyeateher fluw high wi im the air uttering a lond note rafidly repeates, mitil the litll fellow got away uf tin the air; then he came down ittershy his shasmoche two syllabled note in such tafid successin and so fervently as raaley to froduee melody. thevidently thouglet that the wos performing a rapturois lotur-song.

Chondeiles hopetue (= Airfinianus). Aleard at nightifall.

Afrdea virescens. At Morgan's brook.

Dingoides macularins. - Arand at dark,

2,187. Arlining orer sone high field neas the Pris .

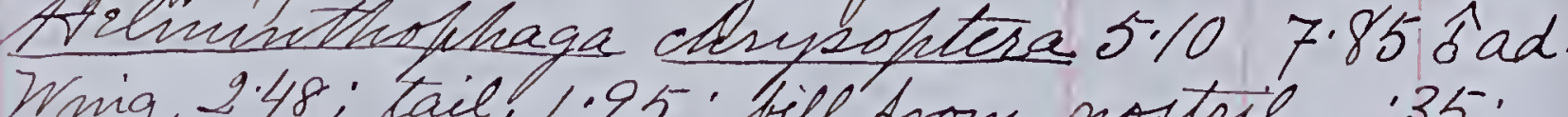
Wrig, 2.48; tail, 1.95; hill from nostril, '35; culmen, '53; gafe, 60 ; tahsus, 67; middle tor and its clan, 's-6; Clavoralone, 19.

2,188. Dendrorca castanea. $6.009 .50 \mathrm{bad}$. Ning, 3.00 ; tail, 215; bill from nostril, 34. culinen, 32; gape, 61; lassus, 75; middé tor and claw, 62; chaw alone, 20.

2, 189. Dindrorca castanea. $5.658 .95 \%$ ad. Winig, 2.87; tail, 2.12; bill from nostril, 30. culmen, 47; gafe, 59; lateus; 75; middle

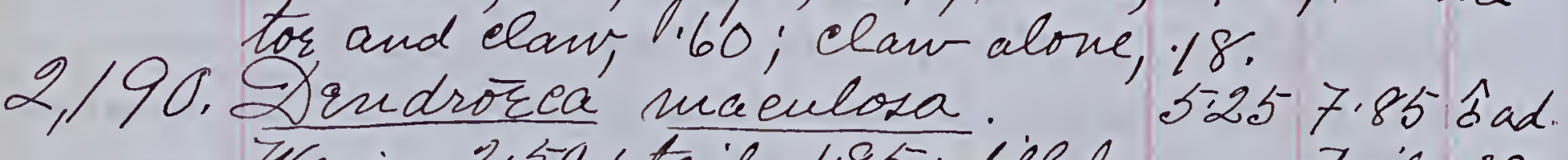
Wring, 2.50; tail, 1.95; bill from nostrie, 29; gahe, 53; culmen, 45; tarshs, 72; mudide tor and claw ss; claw alone, 16.

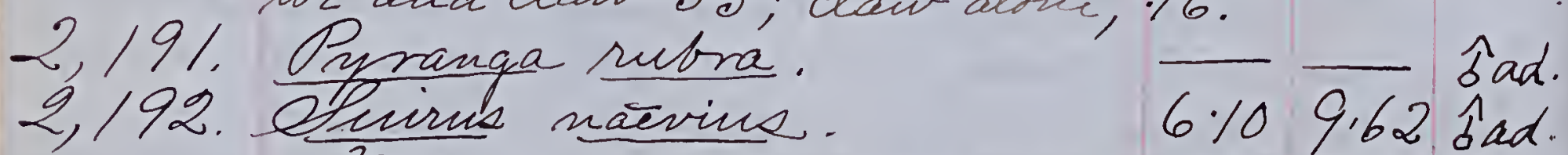

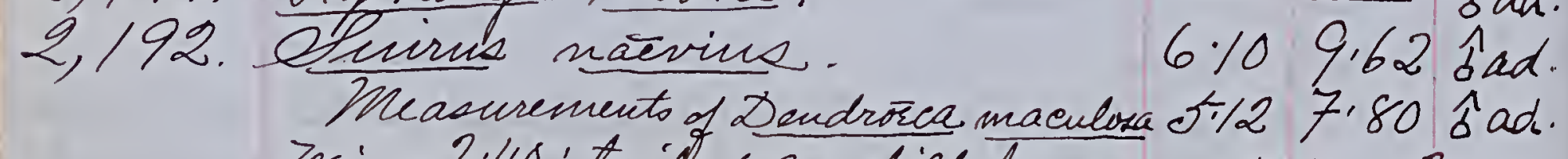

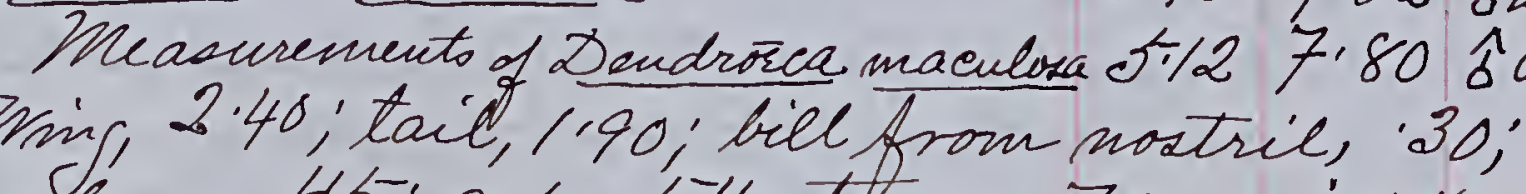
culcuen, '45; gafe,'s4; tarsus, 70; middle tor and elan, 55 ; clavalone, 17.
May2/st. Netyry.

Arove to Mosea Clark's with Pr. Enace. Heav his house Helminttophaca chrypoptera was heard; and an Dliv-sided Ailyeatoher (Contopus borralix) was sittrig on a finee-fost with a bif bumbliter in ital brak. It was the first sen this season.

Anne 3d. W Sthy.

Jo-day want to NEwbirgh by train. At the montt of Ondian Fialls Brotok, an White-headed Eugle (Haliāeitux levereefhalus) descended and seried some object which was unable to rise with. It was in ferll virur of the train for a distance of half a mile, suring whoch time it kelpt conseäintey hapling and tring to nige. It had $t$ donbless graffled witha larce fishrerhafis a suoter, which nas too heary. Lvo otier Eagles ware sittini on the stins. O sured the sfoot where I shat my first adult Eajle near $D_{1} Y C_{1}$. function. At Newburgh, in the ginastore Isar a "Rin tailed Eafle" Aquila chrypaitus) which wos saik to hav bean shat on the Hudoon brlou Newbuzh. Its tail was vry broadl, bandich, basally, with fime-white, with a brad Pachish minal band of blactish. of pair of great toresed Flycatchess heve baru abouts hing house for beveral dayz, and will firobably bresd ni the vieinits.

Aclminthofhafa chyoofitera is. still here. A har are irelentty loceding below Anisley's house, where D hars heard it sinfing sevral suceesene dayp. 


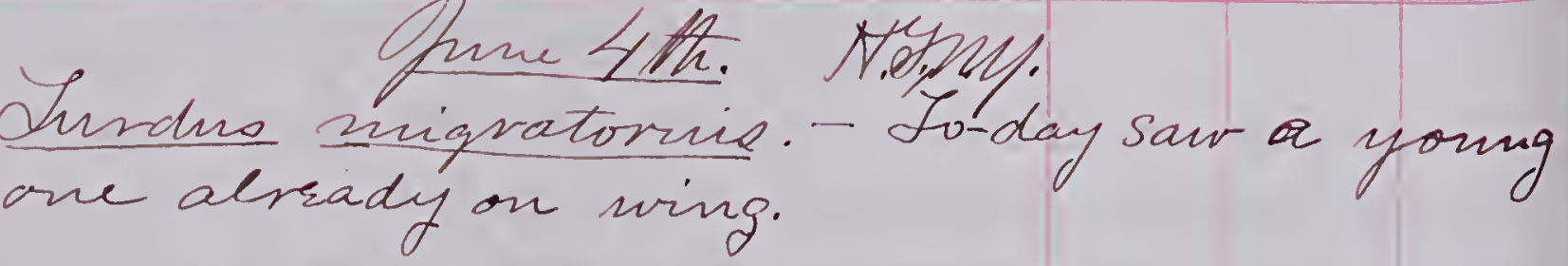

$$
\begin{aligned}
& \text { Anue (6th serny }
\end{aligned}
$$

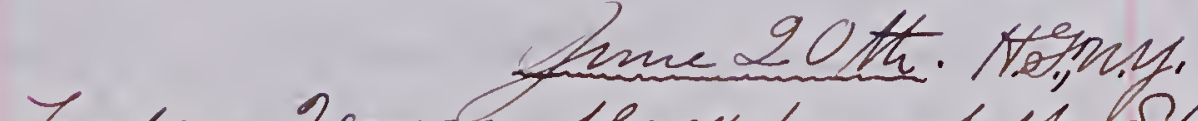

Ir-day, Isaw a black hen of the ofranich breed, lay aw egg. Another hen that was sitting ufon a nest bascle the soek wher the trumpet one growz was seen to nush from her nest in, seuningly, great lerror, with loud outoryin. I wint to the nest to see the cause of her alasm, thriking a suakeor wrasel must have disturbed her; but found ouly a hen engaged in farturituin. She showrd no fear, and did nof pay attention when of stroked her Aeathers themong way with a steik, but seemed to be abrorbed in the business on hand. The labor hains eave on rafidh, and, aftes surval forcible efforts, the egg prophed outs and 1 was able to cee disthiclty; what caused Prof. Opro. Daltonpo much labor, viz: that the esf eame out small end first. 'He egg was Carge, and considerably rounded at both ends. It is preserved in my cabinet.

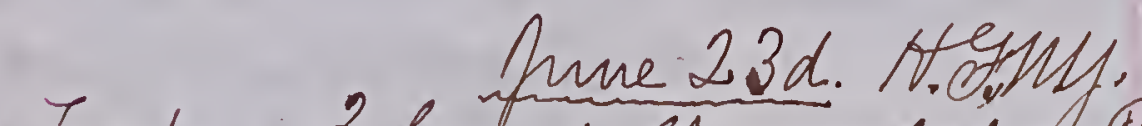

Jo-day 2 fortud the rest of a Purple 7 mids (Carpodachs purpureus) on a low hint of an apple-tree, and saw the fermale ottrinig on her eggs. In the aftervove 2 loaded twoschells, tov heavily alas? and repaired

\section{1 \\ 2 - red featter in the erown.}

to the nest. of drove the female off of the nest, and made a sercefung noise with nuy lifes, suckiniz air throngh theen, and funally suceceded in attracting thi make bird; but it was ni the frumage of the ferrale, so that 2 was lead to breive that there wre two neste. After a frolonged effort to attraet any sed hlinnaged males, and notieving the devotion of the two supposed females to each other, and their evident nutual interest in the nest, of breaue convineed that oue of them must be the male harent. Hoth binds were then shot, and one showed funia farcier evidinee of its maternity, while th other bivd, although in conplete feuale drest, extribited an absence of the characteristied noted on exammistion of the feruale parent's abdomen. An dissection it froved to br a male flumage. He only external oharaeter it frossessed which would br a clue to its male sex, was a solitary yellowish Wing, 3.10; tail, 2.35; culncen, '46; gope, 36; bill from nostril, 34 ; Tarsus, 65 ; middle tor and elaw, ' 71 ; tor aloue, '5-4); elow alone, 20. Iris, hazel. Bill brownish-black on maxilla and tifr of inferior mandible; the basal two - tticide of the lovir mandible, horn-color. Legrand feet, browin. Finale fiarent of set

\section{2,194. Earpodacus purpurens. 5.90 mitidad $\hat{\text { a }}$}

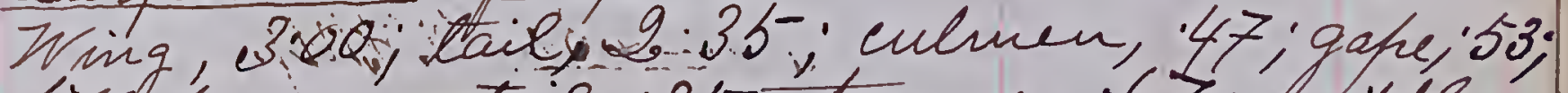
fill from nostrie, 35; tarsus, 67 ; middle tor and elaw; '73; elaw aloue, 22; tor alove, 52 . Jis, hazel, and other evlors the same as N0.2,193 above exeept that Dir horn-color on the leves bill exlends nearly 
236

237

1881.

Collectung
Number:

NAMF
LOCAIT'YY.
1881 to the tif of the bill, blending gradually into black at the tifh. The above tho speonint wers the parents of the nest and set of egga,

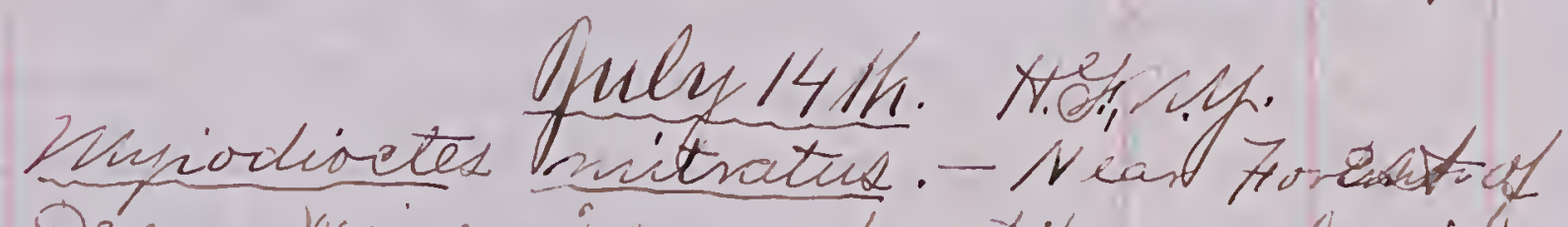

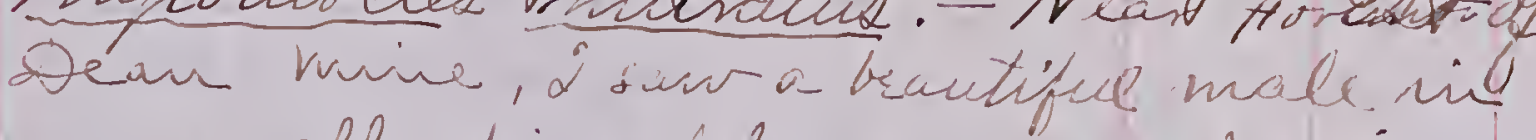
misually fine phimage, and singirs. dirirn motacilla. - Avanalalong Dioplen Crek. Aarporhynchue rufut. - Ad Dr. Chacer D drove nome fiom Horst of Bean at nuidday, the daybing uncomsnosly, hot, and the sim atiming with burning heat wou thi. lusty road, a number of these birds wre seen drotivig thenseless in the road, where a thermomiter placed in the sand would

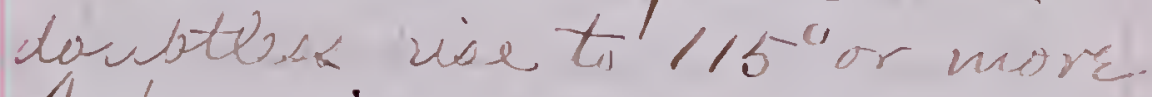

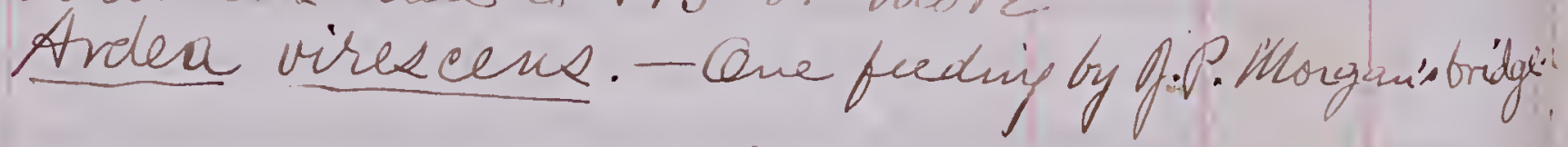

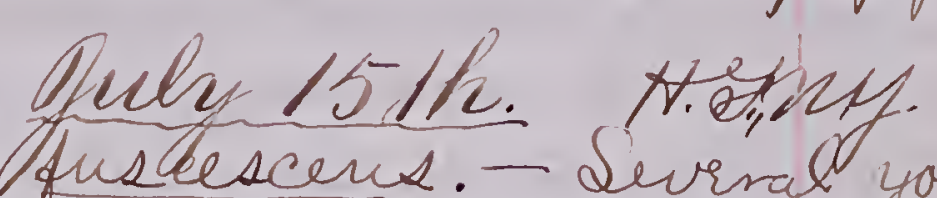

throlue fustescere. - Sivrral young ores were sech in thin respberires near thimined Helnitterus vermivorus. - Che near Mu mine Empudonax minimus:-Cue seento fly to

*arporlupuelue nufue. Dogrus were in the broildis in milde of the rovad

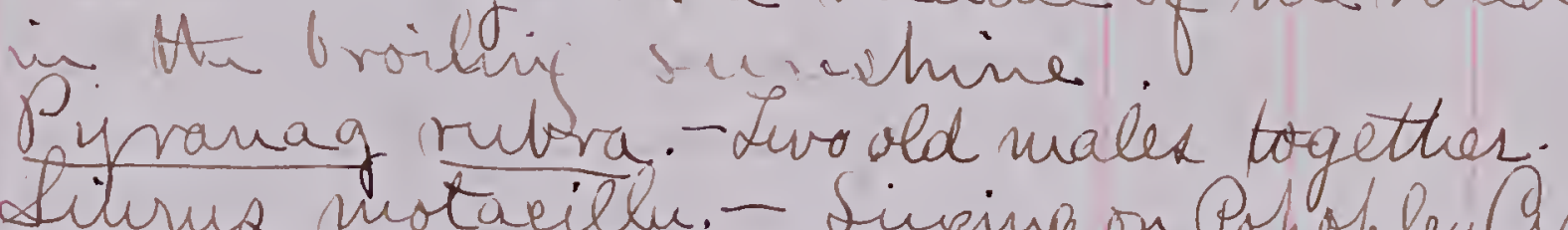
Liliris notacillu. - Siging on PopoplenCreek.

Jo-dar Angust 16 the N. Nithy. Jo-dar Mi. Thu Tedrier pisinted me witt a tolerabe wrel st inned preinm of the Avrercean Egret (terodias alba egretta) angust 9t, 1skt, at Popsplen Pond, Orang'
Collectmir
Xumber.

NAME.

DA'lli.

LOCALITY.

Comity, hew Yosk, from a floek of eight. The wire first slen ditting mork the trectops mear tor dam, but when the Apcimen was shot they were feedrig monthore. The wat, or ahallow water adong in matar to thír bodies.

2,195 Popoplen Pand, Arape Co., N.Y., sept. 9 the, 18 s.

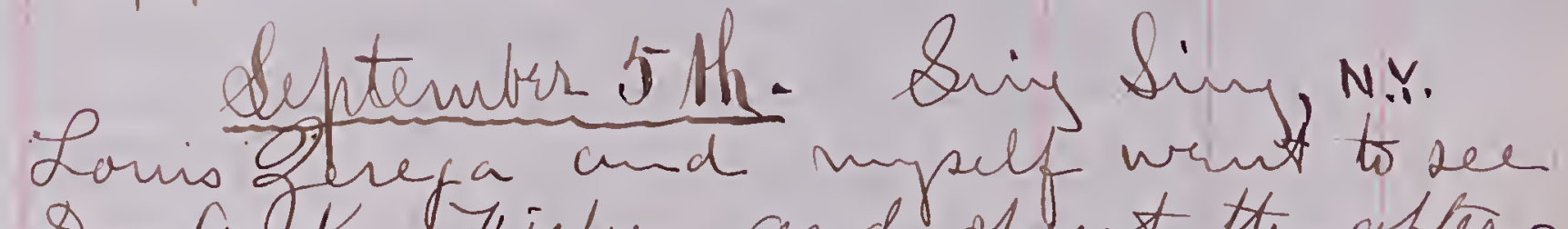
An G.K. Fisher, and optut the ofter - nover shotrigabont Smishig where we zaw four Ruffed Gronse Lonasa nubillus), and nilverbus Mieies of tuwke. in a fild contaimin af found the deviry sided H lyeatehin Sontopio borralio, vary con mon, and chot a king Gird (Yrannus carolinusis). An. Fislers showed us the ground where Pforormes formosur und Empidos Ceacheins breqd do connmone every a similar charaeter about Atifheand Halls, and 2 deen it viry doutteful if more than an vecasional sltofglen of either apicies ever aceurs about there.

Sefitember Bth. Nighy.

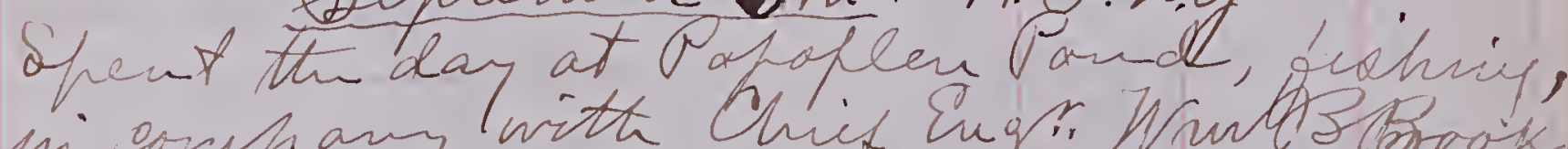
K. S.N., and his two bork, and Nir. Lowis A. Lerga. Somio Shot a M aoderck in a etrifield, and I shot at me in an. onion field mear by. Que Great Blue 
2.38

239

S\&I.

1881

Arron was deen, and a Bittern had bros shat at a day or two frevoish on the Oreek. We a aw numbera of Kinjbids (Iyranmus cavolineriais). A fisherman on the Lame (Oapoplen) told un that he had not see "Mun Whit Cran" in four years when the flook of eight apheared there this ounumer. Ar stated that a floek of four of these birde (Arrodis alba qgratta) wothe about this fond four

2,196. Ampelis edrorim. 7.37 1200 今̂ad. Popoplen Poud, sept \%, 1891.

Seftember 8 th H.P.M.

4. Lo-dar, vide to Zuensborough to ser pratients. Lied my horse at the bride pee, and be far . casting for trout (Salmor fortinalis) of which 2 sam sevaral vice opecumins. vithilcogiting Dheard the sharp, netallee note of thr Hooded Warber (Aluideioder mitratur), and ioon thad th peeasure of secing a fiue ald nale in brantiful Dlumage Corini a both. 27 bathed anonopt thi smootiv Leanes where the woter was shallow and kept is ferfect fountain of Shray going around it ale th twive.

Night Htanki Chondeiles popeture) were flying in the trilight ao 2 sode tione; flewrlow. Atuminingbirdo (Lvechlus eolubrio) wer seen about the cardinal flowrso bride the brow ip Iypranme carolinensis - a fer still remain.

Serteruber 10 th. H.Si, hy.

Antrostonns voeiferus. - Stele common, and tuard vary might.
Trochilus Colubris. - Still Mi

Empidonax minimas. Stie here.

QLeptember 28 th. AtMY.

This evming, wiile riding uf from fort.

Montgonert, 2 heand th note of a Night tran (Netiardea grisea mầvia), and soon pas able to distrignish An form of a solitany herou, blying as suiftty as hossich loward An Soutt, Atteling. its quack at rifrequent

Cetober 6 th. Foratof Dean. N.Y.

2.197. Sturnella magna. 10.8816.75 1 rod. Ning, $4.88 ;$ tail, $3.30 ;$ culuen, $1.42 ;$ gape 1.50; tarslis, 1.73; middle tor, 1.12; middel to and its claw, 1.55. his, hazge.

October 7th. HYing.

- Io dar want shootri sirth Mr. Ridner. We shot a Suf Inck (Pelionetta perficillata) brow Iarrisons. It was Akulking behind a

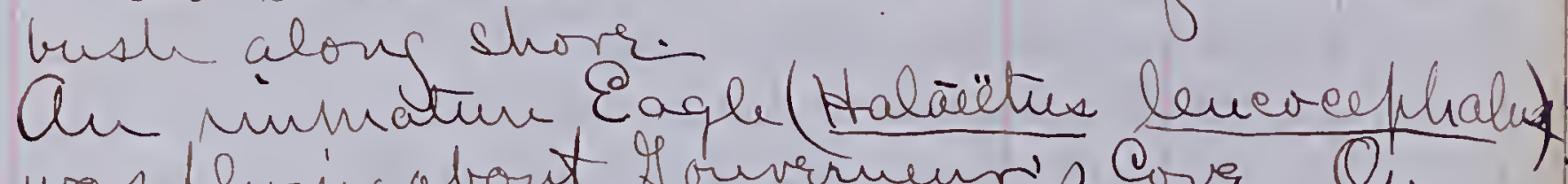
was flyin afort Is ouverneur's cover. Qu Constitution Lland th dog treed a Night Haron (Nyetiaidea grisea näevia) and

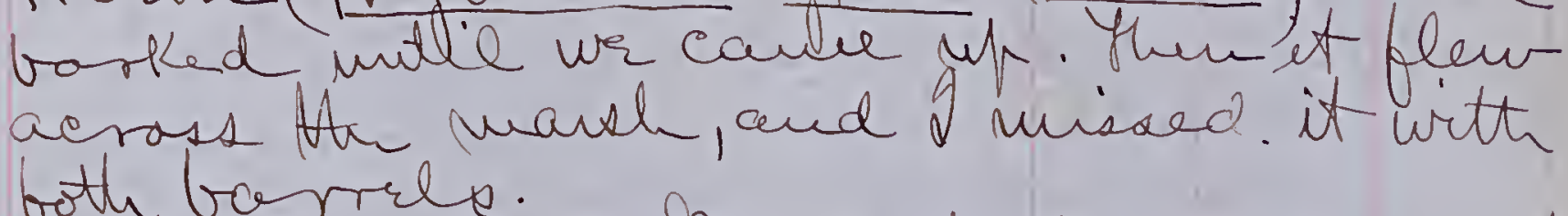
both barrile. kile an. A Rail, probábly Rallus virgmañ flew acrois the creek; wr put ten dog mi Hu rerds after 't, and ande ve saw it rins twough the rushes just in firont of Dashio wose, int wr could not get it to fly. 
240

241

1881

1881.

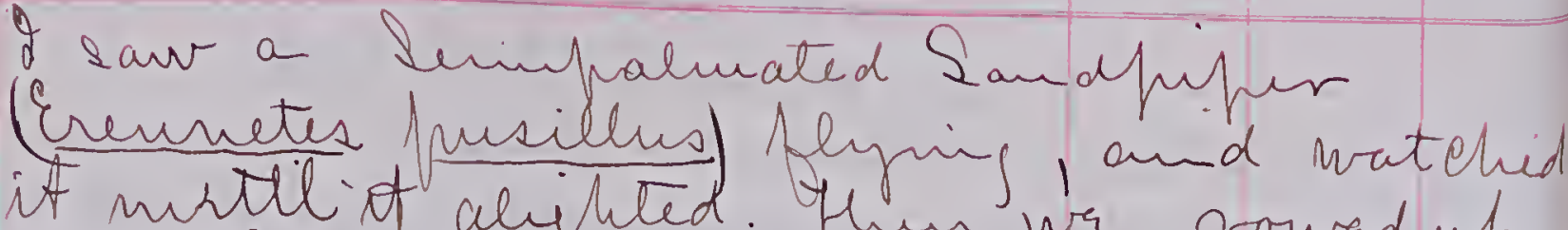
it mitil at alifited. Hem wr cowrd ut und. I sheot it on the wreds, when cnother one arose brside it and d killed that too. 2 have mever sen the epeeies in the Heglands but onee bapore (see artia h. 90). IN irs an a male Black - Mroatid Blue Warblir Dradrorea caerulesceng) in full fhing

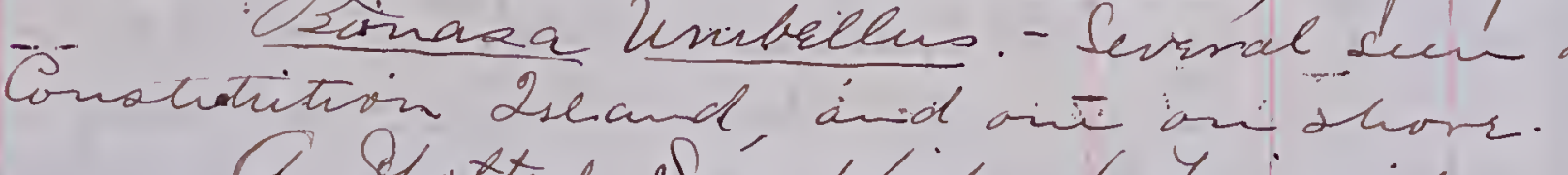
A Bpotted Sandfifer (Aripoides kasenlarnss) was seen sitting on a stowe ou shore, and I got ready to shoot it when it flew; but it had barely gone a yod Atarvir (Asalon columbarius) darted swift as thought in hot pursuit. He terrified Sandplifer nistantty dropfed to the water ma dired. Hee trawkw reached th spot just as the Suify got jucler and mif charge stimek it jist at the same monnent; but the shoft were No. 12 s and the Hawk flew a little war Gaek $\therefore$ to the noods arla alighted. The Paudiph whe to thi curface, and ramained on bts vater several minitis before it could

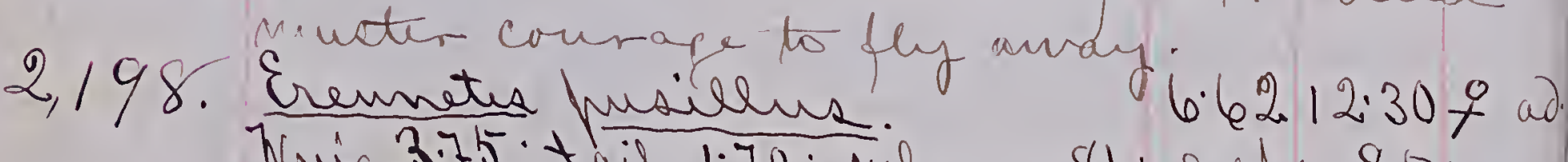

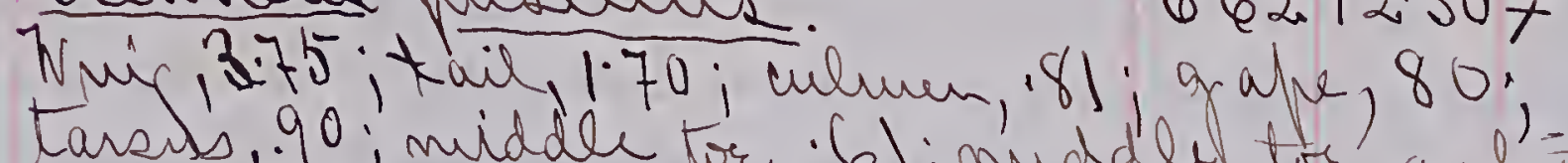
tarsus, 90 ; middde tor, i61; muddel tor and' its cour. 78. his, durk hoyel.

Envites pusillus. 6.3812 .25 今 ad

2,199. Wiv, 3.80; tail, 1.80; culmm, 71; gape, 70; tardus 88 i middlé tor, .63 ; midele tor and to chan, 80. Zris, dark hazel. Rill, blaok. Lepa + fut, Glackiah' lead-color [one with hrokin bill,
2,200 Pelionetta herspicillata. 17.6531 .00 f

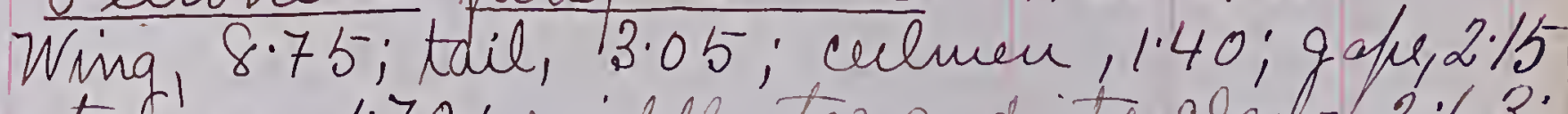
; tarsus, 1.70; middle tor and ita clarb, 2.63; claw, 31 .

Qetobar 8. H.A.tu.

Ardea herodias. - Aue sum flying orer the boure Corr.

Qetober /1th. Hettr.M.

Prizella monticola. - Thequist seen Aneo hyernalia. - Seen Cet. 6th for the first.

Octobir/4, Atom.

The Ruby-crowned Kinglets (Reguluo ealeudula) are now present in full teec. So are the White thrrated Sparrous Zonotrichia albieollis for thu hast wrak the Yellow-brlleed Noodpeckes (Sphyrapieus varius) has beren extramely aburdant. You can firid them in the apple archard any timie, and also in the woods, where o rhat an ald. male in an elmitree with my poevet shot-gun.

No Warblert save Dendrorea Coronata was see during a long walk; Tht thitternict Hhrushes (Lurdus hallasi) is very abrudant: The one revorded bilow was the fist bird shot at with my litth gun.

2,201. Jurdus Ldelasi. $7.4011 .65 \hat{3}$ ad. Wning, 3.65 ; tail 2.85 ; bill from mortril, 38 ; gaply.80;

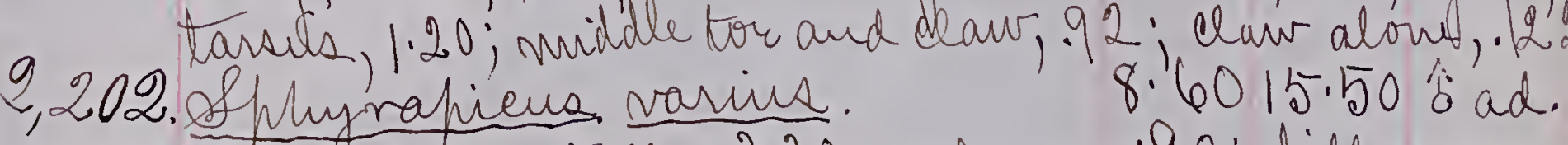
Wing, 5.00 ; Tail, 3.30 ; culum, 90 ; bill mearused front mostril, $76 ;$ i ape, 1.05 ; Larsus, 76 ; middle (buter) tor and ito claw, , 80; claur alore, .34;, tor wittout Claw, 52. Dris, dark reddish' haze. Dill, duatey hluish-hum-eolor. beps tfeet, had-color. 
242

243

1881

1881

October 15 th. H.Siny.

As 2 was fishing in Popophin' Crask a brautify little Blhe Yillow-backed Warbler (Panla anemiana) flew into a willow bush and brgan reareching the leaves for sissects. It was only a fur feet from she , and chourd no fear. Jilis is my latect dateby one wakk (Qet. 8, 1876;8, 1878).

Cre Catbind was makrig consedirable novise in a thieket by thi roadside, no retured. The only late date givin cin my list is Oet.16,1874?

Qctofer 2/st. N.Y.City.

Zo-day Lonis and o took the elevated road me to 1s-s-the Strut, and wrint therough the swarnh brlow Aigh Bridge to see what birds. ware about, and to try to frocure a Red-bind (Cardinalis vinginianus, but found nove, althry ver? numesous in the Atiekets, and we thought wr freard the note of a Candiual Groblicak Robins vere in preat plenty, and vare found evryohere fetdin neu the brricies of the doghood (Domus). Crowz were conmon, and lare floces of Purfle \&raekler (2uicalud) folew ovtruead. A few Caltrids wrre rech, and a mulv of Atruit Lhrusles and Golden-wrijes Doodfecters wre fieding on the dogwoods.

Octobir 22\% nel. N.Y. Qity.

fo-day foins anz I had wothing to do int mjoy ourselves. do wr. decided to go ou a fiemic

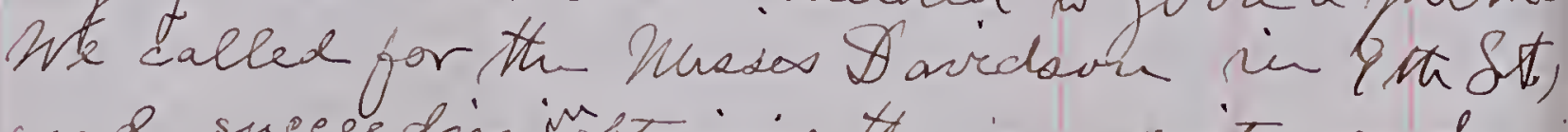
ande surecedininistaining therr tosity, and took the \& road from there of 15 s the \&. .
We wont through Drinity Cenctary, and Hence, after visithin Andubon's tonnes, sholled Virongh Andubon Tark, where I succeded in bringing doun a fine specinen of the Redheaded tV aodpecker (Melanerfes ery hrocephaly witt Sonis, big horse fistol, whieh made a rnoise like a cannon, theked furroüsy 1 and doubttess aroused the fears of al? Sharrabitarts. Wr fornd White-Mtroated the cubilhishment of Sovis' cabrict. Ve linehed on the rveks bride the tudeon, fiet bilow the West Enditotel, and walohed the boys frishing, and retting shrimfs. Red-headed Woodfeckes were in proat plentr, and we watehed me storling uf foot in the erack of a the: Puen, ware hivaly, noisy and inle of lefe as ever. Broun Crefers, Robins, White-rescied

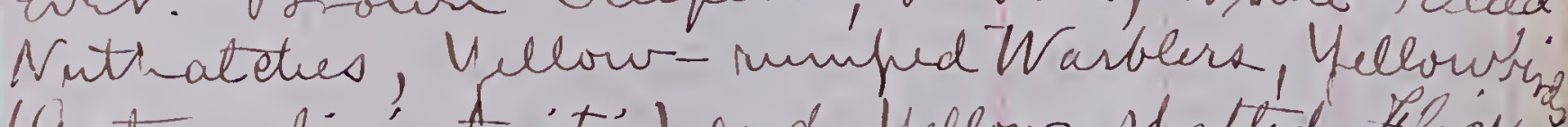
(Antragalimis tristis) and Yellow-shafted Hickers were also quite inmeroux; and obe divenufs Sparrow was seen in titus marah bracde the Hodson. Our fienie was a onecest, andic got haine just in time for the 6.30'train whech 2, 203. Nuelanerpes Erythrocefralus. 9.7517 .75 . D juv. Wring, 5.25; Cdil, 3.25; culmen, 1.08; bill from nostril, 80; gape, 1.25; tarsus, 95; midd, or and its Claw, 1.02; Claw alone, 37; tor alone, 70; Zis, very dark brown. Bill, buich horn-evlor, with ridge of maxilla, termuial Lalf of maxilla ind tetminal thind of mandise Plachish. Leqs and feet, Cad-color. Shot in 'Andubon Park, New) tork' (Manhattan) Mseand, in company with Wisies fonisa and Naney Davidson and Mv. Lonia A. Zeriga, with in 
244

245

$$
=\quad 1881 .
$$

Hur. Reduer brought me a Meadow Lark some two wraks aco, and told me he had shot a Coot (Fulica Amerieana) on Popoplen's Creek or Pond.

Qctobrr 25: H.Y. N.Y. Popophenis Sond

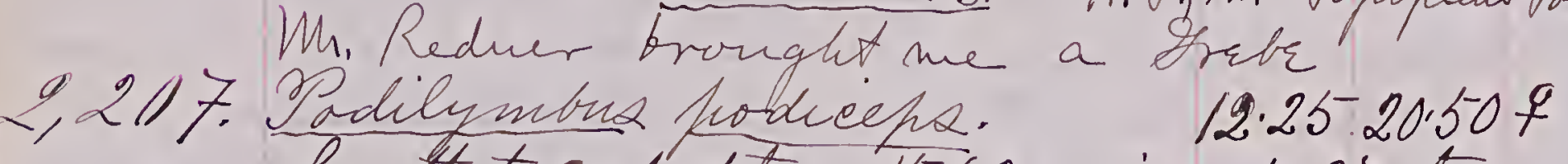
Lurgt to sud of tore, 15.60; wing, 4.87; taneus, 1.33 ; nute. 1.90 ; mt, 1.70 ; clewis, 25 ;

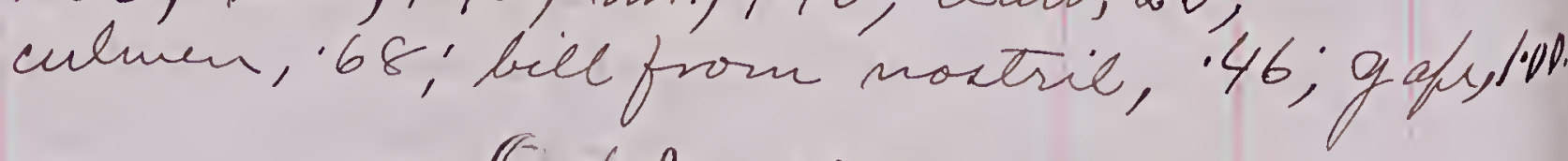

Octobir 27 th. Nig,ny.

Regulus satrapa and $\mathbb{R}$. caleudula are quite abundant. Novi:2,1874, is my tatest autumn record for calendella. Bonasa unbellus, - 2uite s searee. Oue seen torday. durdus miegratorias. - Not verny numerous. 2, 204. Lurdus mignatorius. 10.0015:90 f Wrig, 5.00; tail, 4.00; culmen, 79; fill from mostril, 52, ; tarous, 1.40; middele wiot and clavr, 1.15; Hor alone, 85; claw alone, 30 . Jris, dark hazel; bill, beackilo, with ex lieve base of under mandible, yellow. Sarsi and tors, Blackish, with roles of feet, yellow.

Qetoter 28 th. H.T.N.Y.

Regulus calendula. - Liite a munbre stiekers.

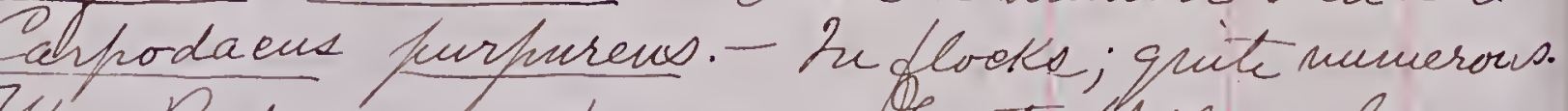

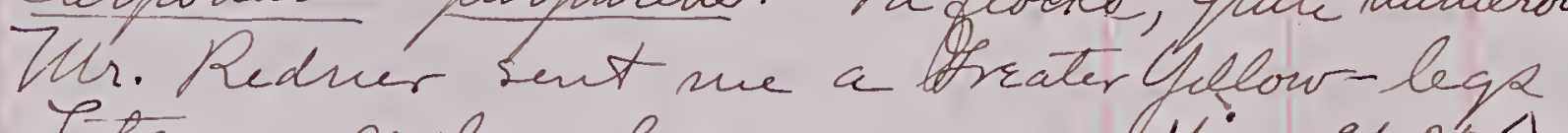

2,205: Cotamus melanolencus .14:0024:25 Wni, 7.25; tail, 2.95; culmen, 2.20; gafe, 2.5., bare hart of titia, 1.67, tarsus, 2.40, midide tor and claw, 1.53; middle tor alone, 1.30; its elaw, 24; outer tor and claw, 129; inner tor and claw, 1.25; hallux and its ceaw, 433; clawalone,.13. Lis, viry dark hoyet. Bill,
1881

DATH. thish-black. Farsi and tora, graznish yellow; chava, black. Shot at Bopoplen's Oond, Nit.

Qetoter 3/st. Hetsm.

Drove to Cantertury to-day. Burid seun curbe Iundus miscatorius, Dendrórea esronata, Iurdur Pallasi, Bonasa mubellus, all conmon brsides otter ondenian sfeccies.

Q Novimber 1st. Atony.

Pegnlus calendula. - 2nits a number are flying about the house, ntterniy, their Wren-like note, and once in a while singing.

Norrubs-2nd. H.e.t, N.K.

Cequlus calendula. - Tinte a number wren noted mi the ofple-treed about the house,

and in the woods. Firt seen. Riete a gardrizid floek was found. Then, whurred throw/4 the bruath like amall paitridges, uttered a loud twrit, and a lond cliekring call , borrows from the Broun Lubaher.

Sfint the alternoon in the woods. Hive following birds were been:-

Iurdus inigratorius. - 2nite sommersus at various Coeleities; miland thery songht shets from the cold wrind in the the ketes, and down by the Miven in the red cedars. Turdus Mallasi. - Still quite connon Sialia sialie. - Collectuig in large flocke, hrepaning to magrate, norbehing and chatternis constarth Rejnent satrapa. - Searee. R. Calendila has not 
Sitta cavolinensis. - Not abundant. Dendrorea coronata. - Not as abundantas befor Ampelis cedrornm. - Large flocte. Carpodaens furpurens.- Connton. Heede on secds of the tulit-tree:

Astragalinus thistio. - Has lost its sunmer heurnage. The tirie of enange is thi

Melospina the etobit.

Nelospiza flaseciata. - Not mugrating, thneo hyemalis. Viry abundant.

Spizella montaria. - Cne seen on Consook Island

Spizella fusilla, - Sevinal seen.

Passerella iliaca. - Numerous.

Donotrichia albicallix.-Oni large lloer. Coovus frugivorus.

Cyanveitta eristata. - Common.

Dins hubrscens.

Finlica americana. - As o walked alous

Consook marah, a Coot flew nh trom thi edge of the bouk and was shot, bing worluded severely, it swam out on the mud flats, and cost me a wrttrif to get it, as I had nop boat. Buefphala clangula ameriéana.-Surral 2, 206 . Inlica americana. $\quad 13.80 .24 \%$ \& ad. Wing, 7.00; tail, 2.30; culmen 1.50; fiel from nostril, 52 ; qup, 1.20, tarsus, 2.00; bare hast of tibia, .80; midale tor and clau, 2.98; tor alour, 2.55; Claw alone, 45 ; outer tor and claw, 2.50; tor colone. 2.25; Claw, 29; niner tor and claw, 2.40; Cor alove, 2.07; claw, 40 ; hallux $1: 18$; tor alow, 90; claw alone, 33. Mor, or clish from. Rill, Whith llesh-color, with base of maxilla,

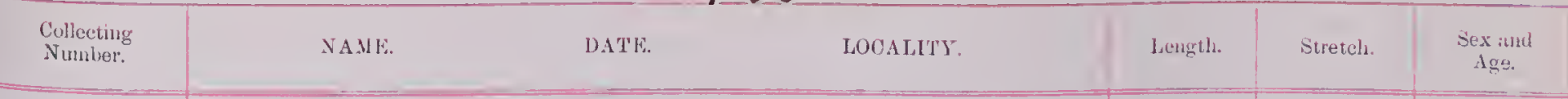

pateh on maxilla midwan bitwren montril. and forint, and Rmalles spot on cach side of corresponding fortion of mandible, red.

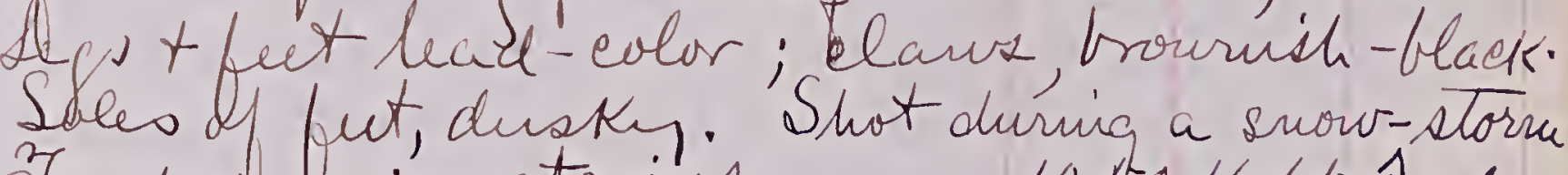
2,208. Iurdus furigratorivis. Shot durnig a snow-storre Whig, 5.25; tail, 4.15; culmen, 80; bill from nostril, 52 ; qape, 1.10; tirsus, 1.40 ; mild dle tor and elaw, 1.14; tor, 89 ; claw, 31 . i) ris, hazel. Yarsi, tors \% nails, beack Bill with upper surface of maxilla, and cxtreme tip of mandible, blackish; dides of max illa, curd all save tip of mandible, yellow; insidi 2,209. Mridus miaratorius. 10.0018 .52 \$ad. Wing, 4.87; tail, 3.80; culncu, 88; bill from nostril, 's5; gope, 1.15; tarsus, 1.27; middle tor and its claw, 1.11; middle tor, 83 2,210. its claw, 29 . Coloss of parts rame as abore.
$10.25-19.25 \mathrm{o}$ ad. Wnin, 5.00; tail, 4.00; cuhum, 96; bill from nostril, 62 ; grape, 1.20; tarsug/.35 ; middle tor and its beaw, 113; middle tor

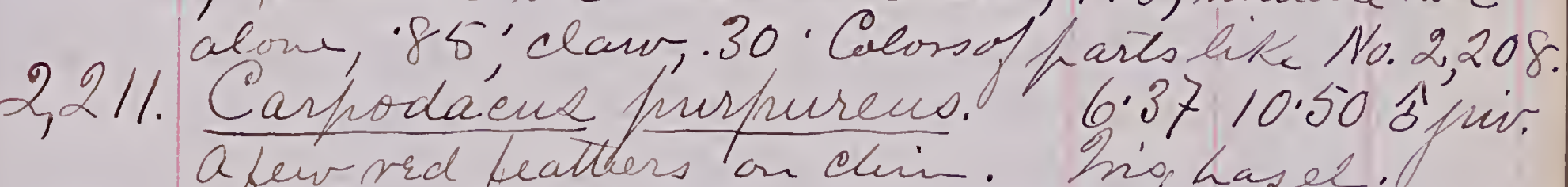
. mo, hagel.

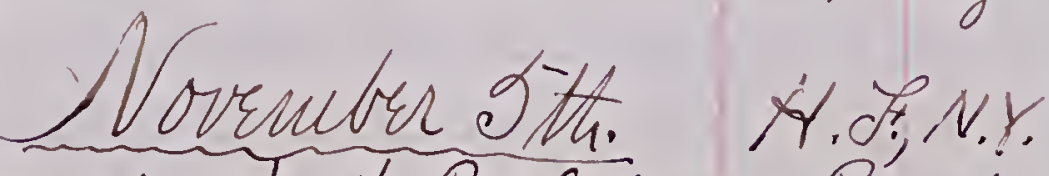

Jo-day was spent at Poplopen's Pond, pisknis and Guming. We reached the fond just in time to witiness a gorgeons aunhise, frupivorua): The first flock, we estriated, slrag fling bande tept prowing over the tof of an mountari tid Atwir wake 
(Novinuber Sth.) WiflM: Modilmons Oudicepte) sman down the lake toivardens.

2,2/2. Pond all day -rivity, for, although appanitly afraid of uk, it keft gradually a nawing nearer, by alternate shy advariees and scared retreats, until at length it was irthin raugl and a fortunate anot killed it dead.

Powards curning Mr. John Redres Came ovir, and asked mi to go forth him to th head of the lake and look op a kair of Hreater Yellow-lege (Etotanns nélanoludus) which had bran Ltaing there for a WrER or so, and which the had trieb to shoort on the day frevions. If had already. walked half-way around the foud in seabeh of silifer, and had found only somk finc leates of niea, near what is called Ising ylase spring. \& acepted the inirtation and soon shot a big Hellow-lego as it sat breide a hool in the mareh. At th head of the Cate we found three nore, that Hlew wild ly diont from ilace to hace, erying londly. Thel flace was a large trdet (sevral aeres) of fartealey sut- norged land, boggy, and mueky, th shots at the filying Grinds, as Redned hunted thenc from hlaee to hlace, and sueceeded iff Kelling two out of thi theer, at Con prange, with Nolf slevt

Wh Redader gave rive a Araat Northem Shrike (Lamid borralis') which he had shat early in the afternoon. C' Fish Hante ( Pandion haliaitis 2,213. Fotame melanolencux. $\quad 14.1025 .35 \hat{\alpha}$ ad. Wmig, 4.95; tail tust, 1.73; culmen, 86; bill from nostril, 31 ; gafe, 1.37; tarsus, 1.66 ; middle tor and its claw, 2.25; middle tor alone, 2.00; elau, 29 . Cluter tor and claw, 2.40 ; inver tor 7 Claw, 1.75; hallux and claw, 57, claw alone, 12.

Wig redish brown; Eyelid encireled by a narrow yellow rim. Bill, with maxilla dusky, highted on edgev; mandible, yellow, dustey on edge and dustry shadivis ; outer aspect of tarsho and lattons of feet, black; nails, thackish, edged with homit color.

Zotamus melanolencus; 14.10 25.35- ad ad. Winin, 7.75; tail, 3.12 ; dength to and of lors 17.40 ; gafe, 2.50; tarsux, 2.60; barl hast of tiba', 165: middle tor and elaw, 1.67; tor alone, 1.40, claw, 28, onter tor and claw, 1.43; inner tor and clan, 1.35 ; hallux and its claw, 44 ; elaw alone, 15 .

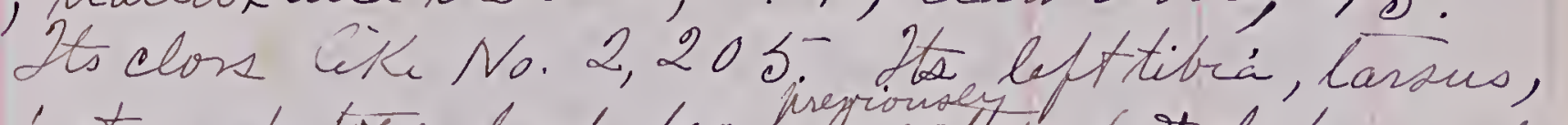
2, 2,14. fogt, and tors had brennerioneltured $v$ deformed. Winia, 7.50 ; tail, 310 ; length to end of bors 17. culinen, 2.20; bill measured from hostril, 1.86; gape, 2.46; tarous, 2.47; bare hast of tibia, 1.6\%; muddle tor r claw, 1.60; middle tor alone, 1.38; clan; 25 ; outer tor and elaw, 1.43; niner tor and elaw, 1.27,' hallewx and its Claw, 40; Claw alone, 12. Colors. life No. 2,205. Had bran previous wounded in bots tibiat. 2,215. Sotanus melanolencus. $14.5024 .75 \mathrm{bad}$. Wring, 7.50; tail, 3.00; culmen, 2.5; gope, 2.43; tarous, 2.62; bare frart of tibia, 1.75, middle tor and claw, 1.70; middle tor alone, 1.45; Claw, 28; outes. tor and claw, 1.44; ininer tor and claw; 1.33; hallux and its claw, 35, elawalone, 14.

earohinese's) was pereabout th 
250

251

1881

$188 \%$

Dovember Sth. Notry.

Colors the same as No. 2,205, onch jellow on

2,216
Courr surface of lown mand ebe towndo base.

10.3514 .457 ad.

Wriq 4.50.'tail, 4.50; culuen, 75," bill neas.

wred grom nostriv, 55; gape, 1.14 ; taisus,

1.04 , middle tor and it claw; 88; midde

tor alone, 60; elaw, 29. Basal hale of man- dible $\forall$ edge of maxilla, flestr-color, heciedue of bill, black: Iarkit bre, black. Ini, hazell

e Vorrmber Geth.

Jo-day notied, in the garden, a number of Cutphing and Field Sharrow (Ifrizila Elonestréa and S. pusilla).

alloventer 8th. Widisly.

Spuat the aftermon fritury al Poflopen's Poud. Canght a large turss of Piekerel $\checkmark$ Yeleou Sereh, and netted a coufle of Gobd-Sized Sunfistes (Eufionotus curtus) and 3 mullet suctere, and some viry large-sized, vad-finined shinero.

Went uh to the head of the lake and bound there the one griater yelow ly otamen melanolnce), that we left on tho bitt. If was shy and flew wrll out of the way the fint tim it war started n/, and, bricg alone, Idid not pursue it.

ofizillar fusilla. - A nunber werc seen.

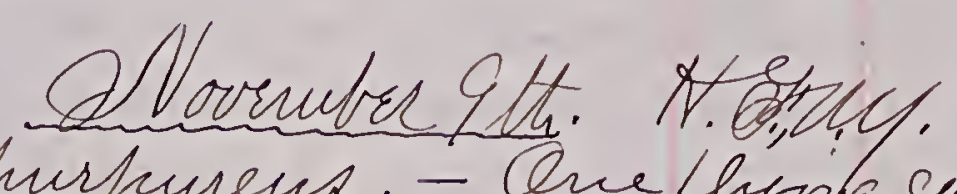

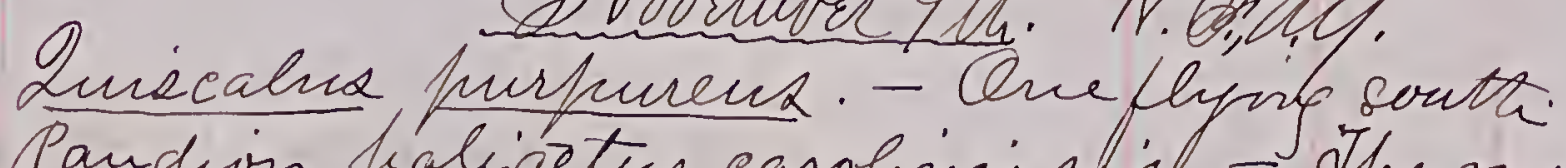
Pandion haliat tus carolinenslis. The one seen last Saturdaz (v-D) was in the same fhing, on a humber iree, Hride Poplofenis Pond.
Benig descrons to frocure thr last of thi block of Greater Yellow-lege (Lotandes Tuelanolencera) at Poplopenis Parad, id drove up there and got Dan. Reduer to get his gimand helf me hunt it. When firet started up the bird flew the whole lenget of the fond to the north end, where g shot it with a number four shot breath the wing, a side shot, passing clear through and out on the other sided. Notrith stathis two nortal wound the sispeflew a longy Lislance, and alighted brids the fond. whe - wr found At and had no nouble 2,217. Iotams melanolencus. 13.882510 ôd. $7.50 ;$ lail, 3.20; Leingth from end of bilin to end of tork, 17.75; Ceulmen, 2.05; bill measured from nostril 1.72; qafe, 2.28; larsus, 2.5-5; bare part of tiba, 1.710; midde tor $\forall$ its claw, 1.70; midple tor alove, 1.4.3; it a claw, 25; outer tor and its claw, 1.45, innertor and its claw, 1.29; hallex and its elaw, 35 ; elawálone, /3. oris, dark hazél. Jarsiand tors, gresuih yellow; claus, blaek. Inin a puinum, like its four companions fruvionsly taken, was a male, afjparentty adult. My siterest with regard to the catenexi of the departise of this little floek of fir mulucky Sripes was execeded by the desibe for their tostescion as speceniens bit I think would not have bern likely to have ramained there many days Cater.

Q Noventer 12 th. Solticy.

Last mint islept on the Laland, at poploprenis band, brside bagge fir brict of logaby hr. Aemo and ilyself. We reactud the frond 
252

253

1881

$188 \%$

XII

DATE

LOCI TITI.

Length.

Collecting
Number.

AM.

DATE

LOCALITY.

Stretch.

in the evening (10 clock, P. Mr), and walked way down the cast side of the fond in search of the boat; not f finding it wat revered our dire- - and walked Entirely around th i fond, to find our boat within a stone's throw of the Spot wi had reached when we first t staid out. We set a gill net, and caught during the night several "mullets," a common sucker, a pickerel, and aural french. We slept bride a large fire of loge during the rest of the might, and caught about

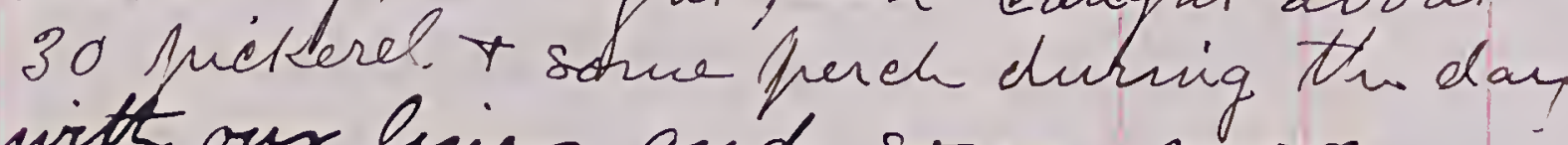
witt our lives, and sone sore yellow french, mullet, and a couple of "mullet" and sucker in al extol.

Shigella socials. - Here e wire seen near Poploper. Pond; now Extremely scare. The did not see the Fish Hawk today. It rained sone during the sight find heavily ale day.

ONovember/Sth. Nestor.

Lo -day rode to Fort Montgomery, where Itunced ny horse into th wo sk, and came suddenly upon two Ruffed Arouse (Jonas unbrellud) in tho small cedar, eating "many barrie". Then of rode witter a few feet of a il Pigeon (Eetopistes migratories) that was situ on tu ground vineatt the thickly growing hendreko. It flew on to a branch. Itedtol my horse and walkmig close to it, threw a stone at it, when

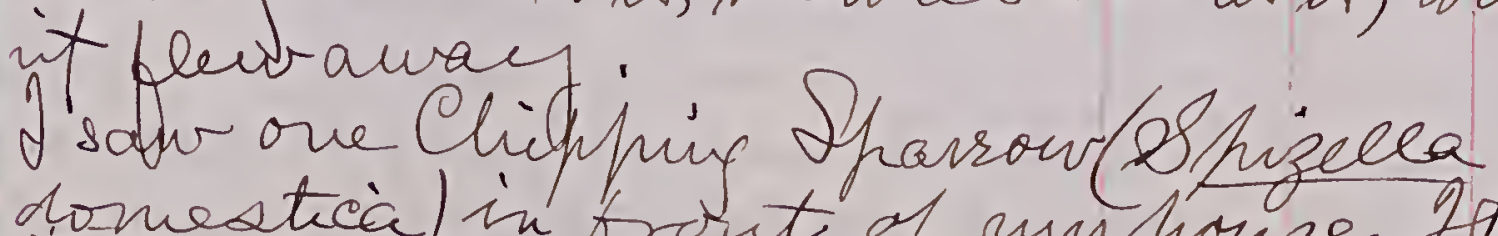
domestic) in front of mylionse. It wax si the homage of a bistro of the year. Thebridvindarge floes, feuding
Hovanbar 2S th H.F.,N.Y.

Qfiabia sialsi. - In large flocks, feuding onbrries of the sumach (Plus).

Pindus mignatorius.- Afraid about house everyday. Eendröéa evrouata. - Nat seen since November 22 nd. The ground has beam covid with snow for two day.

November BOtt. N.Y. City.

This afternoon Louis Jerega and myself wee walking through Central Park together when? saw a Mocking-bird (Minus polyglottus) sitting stile upon a low branch of a tree, but was not quite certain about its identity, as it flew into a thicket. There, however, we got choke to it, and sat down within a few paces of it and watched it eating some Red berries resembling bitter swat. I gathered some and afterwards showed then to Prof. 0. M. Wheaten, M. D., and he told me the name of the plant. It is the Burning -Bush or Wahoo (Evonymus atropurefurene) [Gray's "Botany of the Northern United States," $h$ 81.]. The shut or small tree is very handsome when laden with frit in autumn. I have never seen it in the thorn Highlands. I This is the first red hoestrig-bird I have ever see w alive. The northern locality is interesting, at troy Vire Eugene P. Bushnell has taken it a far dh ut the Hudson River as his residence at tiverdale, NY.

December Dst. Baltimore \& Clici-Railroad. Near Deer Park, "Saw a Hawk situ. quietly upon a tree mar the railroad, which 2 believe wat the Rough-lyged Hawk. Archibuteo Cagopus saneti-johahnia), in very light plumage. 
254

255

1881.

Collectui
Number:

$N \Lambda . W$

DATW

LOCALITY

December 1St. - Continuid.

Near Oakland Isaw the remains of a Shebird (Siaha sealin) which oue of the Shinter ( Lamins) had mipaled Afon

Going wrst on the Baltinore midllio Ruilstond o' first saw Red-Brids (Cardinalis vinginamul) at Koundsville, W. va.

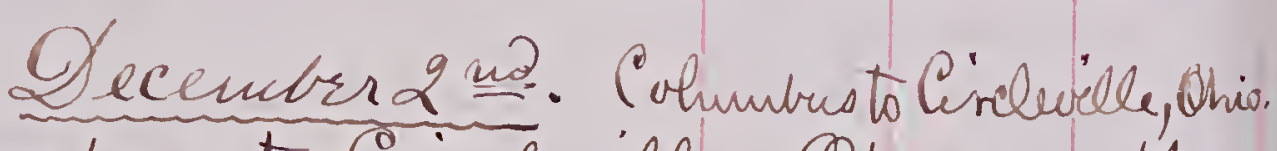
From Columbre to Circleville, Orio, an the Seioto Valley road, the following birds were

1 . Dnneo hyenalix.

2. Timmundulus spaweris. - A number seen.

3. Buteo - Zuro Buteos seen.

4. Kenà̃dura carolinensí.

5. Aturnella magna.- Common.

6. Colapter auratis. - Cominon.

Drcember Binds of Civeleville, Qhio.

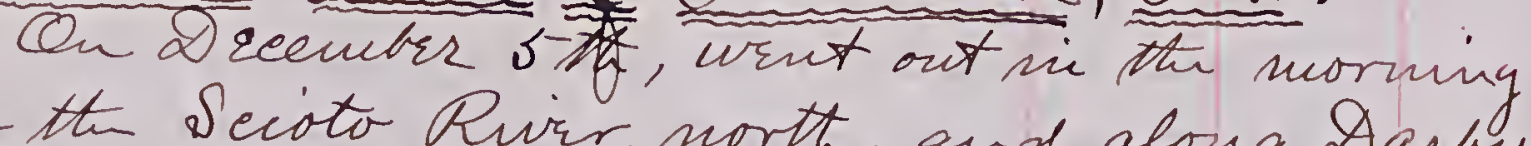
on the Secito Rivir, north, and along Darby

An Drcunber 6th, hinted on the Aulse farms; and on the 7 the we drove out to the Hlats and spent the day.

An Deceubre 10 th, I malked uf the Seiotos followrd the Darby uf into thi woods, and thew crossed ovis thisough the cone fields to the Four Mile Red Bricape; went a litile fartuer uf the nirr, and crosted over to thr frairié brside ta canal, and walted doun to Cireleville, Ohio.

Altogitter I wrut shooting only firt thines

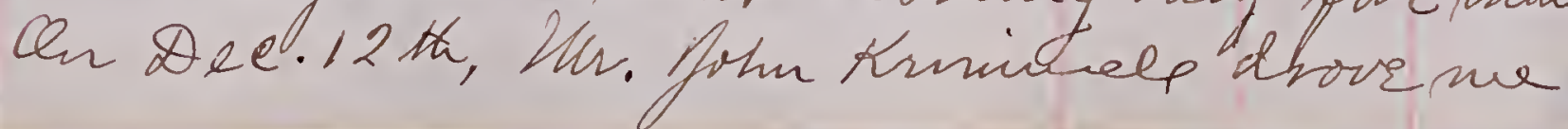
1881

BATK LOCALITY.

out to Camprell'a swampy prain's where we epent part of the aftenvon in the vain Thutrin unsuccessfully for Atarks v Ouls. shot a couple of Gray Squirials.

The following is a list of the birds seen:1 OSidlia sialia. - A good-sized flock was foun in a stumpy field, on Huloe's farm at the Flats. None ottiers wre secul.

2. Requlus satrapa.- 2uite munrous, and found in the largest teniber mi the deef wovds. 3. Sitta carohriencis:- 2uite abundant, and found in equal numbers in the shrubby thickets and in the deef woods of heary trithes No Red-bellied Nuttatiches wrel seen. 4. Sophofhanes bireolor.- Everywhere abuidant, noisis, pugnacious bud restless. 5. Parus atricafillus. Not abundant. 2 shot but one, ni a flock of Lufted Litine, on Dec. G th. 6. Parne atrocillus carolinensix- - hite rundant, and alwayss assveiated with the Lufted Lituonse. It is found alnost Eorryolere, but perhapo mont often ni the bushes, wrids and reeds aloug the swirs and creeke. The thathly-defined bliek patoh of the throat, and its nougher notes serve to distriguish it from the freceding. 7. Certtia Laniliaria. - Nat common. 8. Ithryothorus tudoviciamus. - Che was heard sniging a few swret notes, on "Qunt Aspries" farm, on Dec. 6tt. We oflerwards savi it ou the lowr rails of a Mrirginia rail-fenes edged with bushuvol, but could not caftuse it Qnother one war heand about a tuble down old house an the tome fiam, at thelse's; but bifore 8 could get to it, a Red-brllied Woot freker (Centurus eawhins) 
Eugaged my attention, and 9 newer got back to btu shat, after catelinig mif pecker.

Anortuma troglodytes hyenalia. - Only vie seen, on Bee. 10 th, dmonget some heavy loge and driftwovd bescide the Qciote Ruvir, above th Four Hile RedOSnd 10. Erenofuila alpestris. - Cue good-sisi flock of Shore Laske was seen on th 7 B 4 , as we wre driiring out to the Fats. Hey wre fljing and dhining wildelf about ltike a flock of Surw Bunting. The wind ivas blowing hand, and they flew heih suost of the tirie.

11. Lanine Audovieiamus.- Idid notser the Loggerhead Shrike this year, but several have bren sem by differest Lersone sinee Icane to Citeville. Saw one here last wirters (1880).

12. Sstragalims tristis. - The "wild canarie" were aecasionally sen or heard.

13. Melospiza Lasciata. - Arindant ivry where, thet not heand singrig. 14. Melosfiza halustris. - Noto very minerow - but connison enough ni wit places. 15. Effuzella montdna. - Rattiorabundant, and scattered; but not so plentiful as in the East.

16. Duneo hyemalis. - Lite abundant.

17. Nafserellat ihaca. - Que seen at "Aunt Arpsie's farm" on Dec.6 th; another on Darly

18. Pafser donestieina. - Lute a sun- Gir about Aneleviller Colmbr

19. Eardinalis kinginianus. - Dite irdily diffused, and in suall conpamis. Fidy flod an. Indian corn, and are very shy.O
xAME.

DaTP.

Not heard singin de hlaces biside the scioto and te tributares, but are fornd every whre. Tre cane into an afhle-truin th bick-yard at Wittide's, in Greleville, an Deccruber 13 th. Ther build nests mi to City ipe smmm -

20. Atumella magna. - Hound in th pairic grase, in eorn fields, ele. I - theer speenuns mi she ecsevir as - cushed theu ont of the hraivis ni the verning. tivilight on De ceubre 10 th. 21. Eyanoditta cristata. - Abundaut ni flvekt of 12 to 20 mi thi wovds, and mi orchands about farmer's houses.

22. Corvus frugivorus. Crows are rare in Qhio in truter. Dr. Wheaton told nue that it is gunvally breived that these war a disease aniong Ofio Orowz whié destrayed thim as chelen Chobra surefs oft the genus Gallue. This is Crof swaral years sines, as ther were fonnely plintiful in the eltate during witer, wherias they, are now extrench seáce.

a dozen flew over the Af about Harm at Aulseis, on the monmin of Dec 7 th; the sight of this flock was thereght in Wir. Aulsel to be vern extraordinary.' theve never seen any ottur eraws in the state of thio, and then seem vere mis all that inland comitry, qradrally becoming more mumatorso w. on approached the coaxt coming san anomine flocks of Crows in north- 
258

259

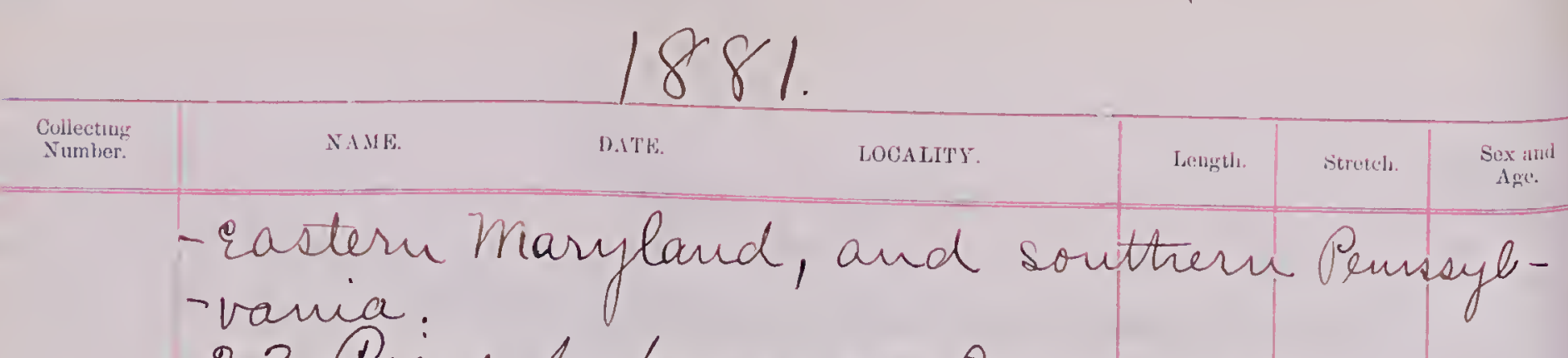

23. Pieces fubracens. - Common.

2.4. Pi ens villosus. - Not vary often seen.

25. Centuries carolinent. - Specify shot on

Dee. S th and Ft he wire the only ones sen.

Their lond cry is Easily Recognized. Dr.

and peckers wire exceedingly scarce in sumer and ratter abundant, hut not ni floes but usually fond singly sic winter, in the vicinity of Solubles. She same is doubles true for Pircleville, Olio.

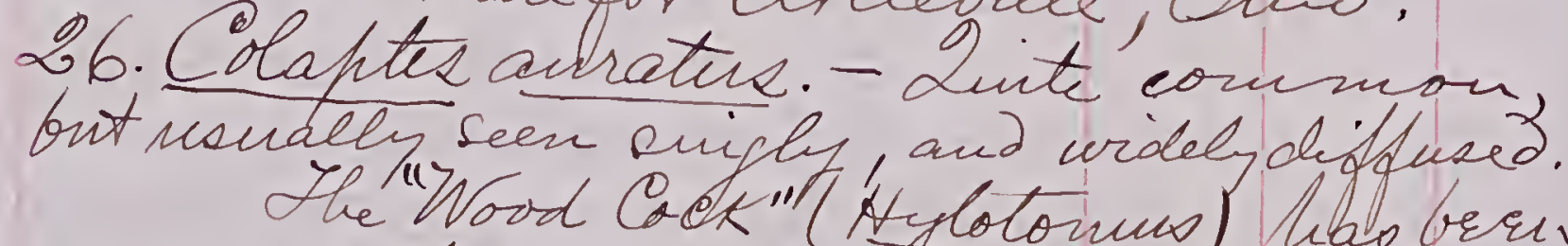
The "Wood Oof" (Nylotonus) hbo bern.

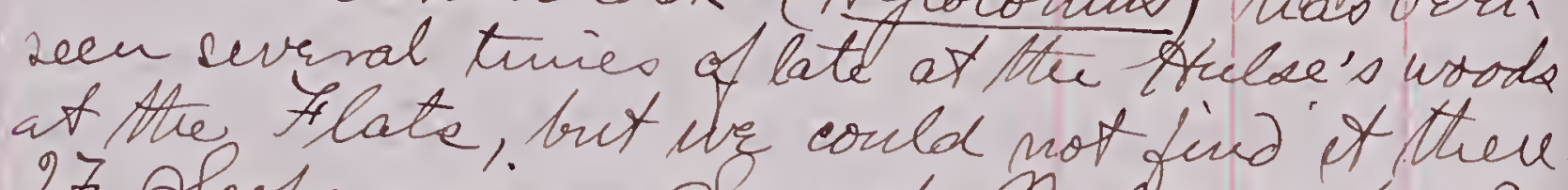
27. Sops asir. - Screech Covbrure heard. 2.8. Asia accipitrine. - Wheres then are swampy prairies, Ate "nests" of the Shont-eared Che may br seen mi Dou grass in great plenty. The forms contain excrement and pellets of hair and bones in forts abundance. Hey are gre carious, and can see very well on wet dark days. At such tries they do not in the have their plumage bragged in the long grass, and they betakes them to higher places in flock, where th grade is short, or sit on shines and rail-denees. Cecasionall a fhort-eared Que vile br seen flying about on bright days; but, ordinarily, they will not de ave their forme in the /rains grace until you are close upon them. Dr. Howard Jones has taken sets of their ego at
1881

Collecting
Number:

NAME:

DA' TH.

LOCALITY

Circleirle, Ohio, and this they are about as common in summer as during winter: 29. Asir americans. - In Dec. Fl s, while

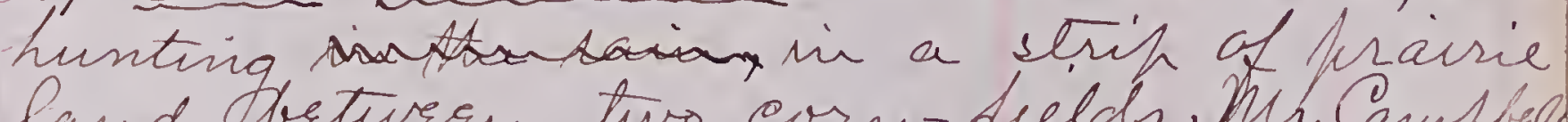
land brtevern two corn-fields, Mr. Camp bel , who was with ma, shot aldong-Eared Che in the grass. It seems to me pry musual'i to sind a Song-iared Que in such a situates 30. Bubo virginians. - Nearly er 7 words of any considerable size contain it hair of Great Atoned Que. They are always will and difficult to approach. Sher are often seen fllfrig about during daytinie bot are hard to shot. I hot th fire old male that was sitting in the to f of an enos- nous sycamore tree on Darby Peck. It a at perfectly motionless with ears ere et, and I had to scrutinize it carefully br for o was certain that it was not a pant of thee tree. When of fried a cartridge loaded with No. 3 shot, is made a great fluttering, but. succeeded m launching ont and fol a little way flew very isl; then it fra an to rise high up in the air, and, finder, sell perfect ty de ad to the ground from al scat height. Three shot wee afterwards found to have penetrated its thorax, has sing 31. Circus Andsoninz. - Common. Cue that was shot had its crop filled with mice. 32. Limmoneulus shanerius. - Pratt sittrifon the highest trie-tops.

33. Wu ter borralis. - Abundant De found a hair roosting in Pulse's woods at night and shot at them as they flew from. the tree-topo. they made a prat Clamor. 
260

261

1881

1881

34. Aecifuter fuscus. - Che seen on

5 Oarry Geef, on thu 10 the of Deceuber.

35. Oenaedura carolinensito. - Connon mi Clarge flock's along the swirs, and mi the corn-fields, where ther get most of their food.

36. Orthx virginiana. - Duaile are not numerank this season. A Lew flocke wre seen or heard. The fenuale. D) shot was seen to alight brside ta straight railfence, without any covrr. Nevertheless wrlassed the bird, ane going on either séde of the fence, serren or teight tries before tor cogld find and pult it wh.

37. Bonasa unibellux. - ire Raw about Lalf a dozen "Porearanta". on the Atulse farm at the Hilata, one of which 2'saiah At tulde

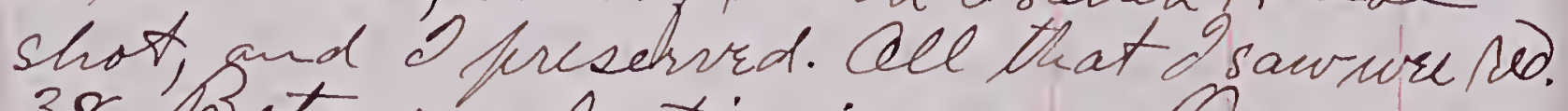
38. Ootaurne lentiginosus. Deche uras 39. Querquedula earoliensix. - Ino Orren-wnige Peale wre seen an Decem- Wr 10 th in g little creck enfitying vito the Darby. obveral flocke of of wete wire seen flying, but the frecies tion not made out. 2

Nothruahere or Warblers wre seen. Anigfishers wre als 0 absent. Furkey Buzzarde (leathartex aura) wre not seen, brot have reqular roosterig-p laees, at night, in the sef cambre trees eight hiles wh the river, and four miles doun thedeioto. Rurr. Mr. 2 saiah Atulae showsd me a syeavore- tree in which a family of Fuskey Ruzzarde is reared evrry seasork. Dr. Arowart Gones has two bets of efplatien
2,218. Mammals.

Cf Mannialia, Rabits (Lepus sylvaticirs)

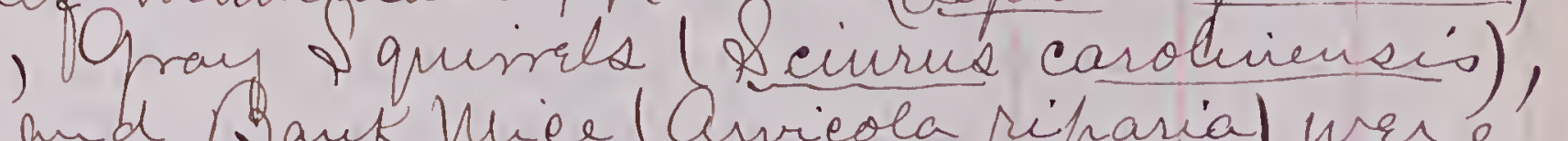
and Bank Vice (Avieola rifaria) were', Qne Thirtin -lvied Gopher (A permothilus: tridecimlineatum) was seen by Mr. 2 aiah tulse on the 9 th of Drceuber 2 saw flenty of their burrows they are very abundarts here, but seldon Reen but in Arriter. No-Chifunouks (Elamias striatus) prese sean!

Pfecmiens.

Alialia scalis. Dre. 7 th. 6.8812 .65 Sad. Wing 3.90; tail, 2.72 ; culmen, 49; bill from nots il, 31 ; gape, $79 ;$ tarsus, 83 ; midule tor and it claw, 88. Trie, hazel. 'Rill, lege aud feet,

2, 219. Reguilus satrapa. Dee. 6th. 4.10 6.65 9 ad. Thing, 2.18 ; tail, 1.58 ; bill measured from nostril, $22 ;$ gape, 43 ; tarsus, $67 ;$ middle tor + claur, 50. Pria, hazel. Bill, blaer. Iarsi, brownish-black; dorkal purfaee of tore, yellowish-prown; yudes surface, followt.

2,220. Sophophanes bicolor.0ed 6.6.45 $10.00 \%$ ad. wing, 3.05 ; tail, 2.85 ; culmen, 50 ; bill from nostril, 37; gape, s-5, tarsux, 80; middle tor ana its kelaw, 75 . mis, hazes. Bill, blue-black. Jarsi aud los blue

$2,221$. - arns atricafillms. Dec 6. 5.378.45 - .ad. Winig, 2.55; tail, 2.45; bill from nostil, 28; cultuen, 38; gafe, 45; tassus, 65 ; middle tor and clant.60; Drs, dark hazel. Bill, binu-black. Plarei and tors blue.

2, 222. Parus carolinensid . De.5.4.90 8.00 $\hat{c}$ ad. Wnig, 2.50; tail, 2.28; culmen, 36; bill measused from nortril, .28; gape, 40 ; 


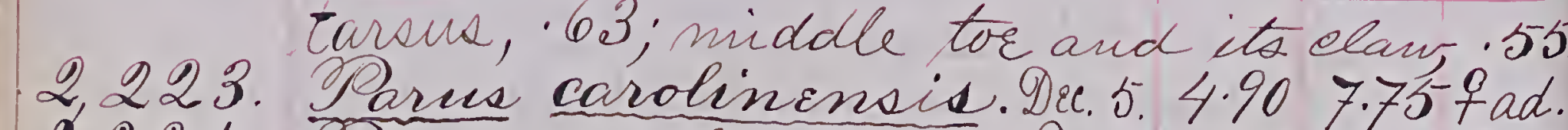

2,232. Aturnella magna Are.10.8.8513.90 9ad 7 t390,Wnir, 4.05; tail, 2.70;

2, 2.24 Danes carolinensie. Dec.5.4.737.50 9ad.

2, 225 . Cardinalis virginianus. 0.1512 .25 sad. Wing, 3.80; tail 4.35; culnuen, 75; bill qrom nostril, s2; qape, '77; törsus, 1.01; middle tor and ito claw, '94. Bris, hazel. Bill, red. Legs and heet leght frown. Efaot on Aust Arpsiés Lam DeC. 6. th.

2,2.26. Cardinalis viginianus. $8.8612 .201 \mathrm{ad}$ Wing, 3.80; tail, 4.32; culneu, 75; bill from nostril, 50; qaphe, 73; tarsus, 1.00; middle tor and its claw, 92. Colons of

0227 . Cardinalis virginianus. 9.00 12.2.5.5ac. Ning, 3.85; tail, 4.82,; culnen, 78; bill from nostril, 'so. Gape, 'ts' tarsus, 1.00; middle tor ayd lelaw, 95: Arix, ha zel. gill, red. Nege and feet, leght provel.

\%2 28. Cardinalix virginianus 8.5511 .80 tad. Hing, 3.73: tail, 4.010; culnen, 75; bill ofvin nostril, 48 ' gahe, $75^{2}$, tarsus, 96

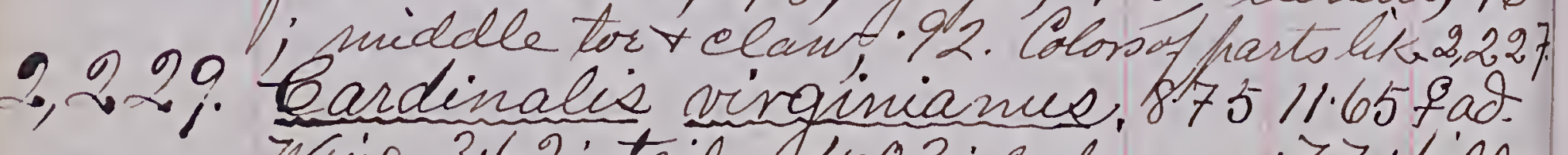
Ming, 3.62; tail, 4.03; culmu, 77; bill A vo nostril, 48 ; gafe, 80; tarsuo, 1.04; 2.30. Cardivalis virginianet. 8.7011 .60 9.2.

2, 2. 30. Cardivalis virginiane. 8.7011.60 9 ad. fron nostril, 50; gahe.79; larsus. 98; middle tor and its elaw, .94. Colors of hasts the Lame as No.2,227. No. 2, 2,2, 2, 22, 2,229 and 2,230 wrre all phot at the

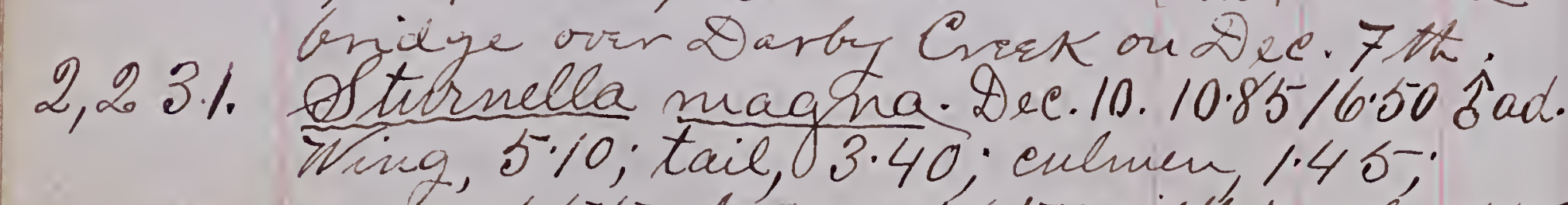

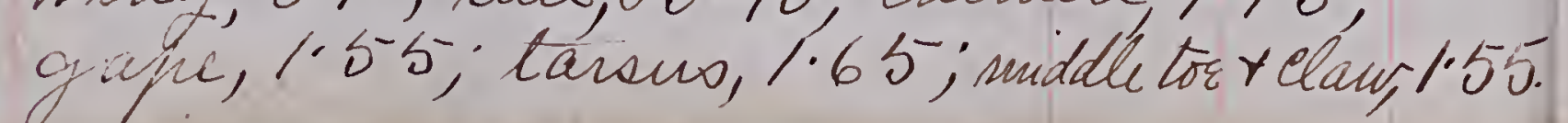
culoner, $1.14 ;$ gape, 1.22.; tohine, 1.43; middl tor and claw, 1.361 .

2,233. Sturnella magna. Dic. 10.9.8515.35 sad. Wing, 4.55; taile, 3.00; culmen, 1.25; qaph, 1.34; tarene, 1.46; middle tor and elaw, 1.45: 2, 234 . Oyanocitta eriotata. Die.6.11.15 16.00 +ad. whig, 4.90; Tail, 4.85; culmen, 1.12; billfiom nostril, 8'0; qape, 1.29. tarsus, I.3. St; middle tor and At claw, 1.05.

2,235. Dicus villosus. Deg. 9.1015 .01 fad. 2, 236 . tentirud carolime Dec.5.9.9016.45 fad. Iring, 5.12; tail, 3.50; culnen, 1.17; qape, 1.37; tarsus, 80; middle tor with ito claw, 1.08; clawalone, 40 . Mi, red. sill ano fiet, bluish.

2, 37. Centurnes carolimus.Dec.7.10.3517.35 fad. Fring, 5.40 ; tail, 3.65 ; culven, 1.25 ; bill middle tor and ito claw, 1.05; claw alone, 43; Bis, red. Bill, blu-black. Tarsus and 2,238 tors, granich-gray i glaws, bhish-black.

, 20 38. Am americames. Dec.7.14.75.36.90\% ad. Yring, 12.00; tail, 6.55; culuen measured from cere, 165 ; gape, 1.15 ; tarsú, 1.65; middle tor and itto claw, 1.72; middle tor 2,239. Inbo virainianue. De. 10.22.00 52.50 今ad. wing, 14.75; tail, 9.40; culuenfrom base of cerie, 1.70 ; cere, 77 ; culufu neasured from eere, 1.15; qape, 1.80; tarsus, 2.12. middle tor and ellat, 2.90; middle' tor alos. 2.35; claw, 1.15. Clawz, blue-black. Bill, blu-black, also: Zis, ycllorr. Stomach cou- 
2,240. Oircus hudeonins. Dec.7.18.0041.75 ô ad. Wing, 13.00; tail, 8.30; base of cere to point of bill, 1.03; cere alone, .46; culuen alone, 63; gape, 1.23; tarsus, 2.92; middle tor A Clan, 1.78; middle tor alone, 1.30; claw, 62. 'ris, yellow. Bill, horncolor at base, thaderig into blue wittin a narrow space, and breoning black on its qrater extent. Cre greenieh-yellow.

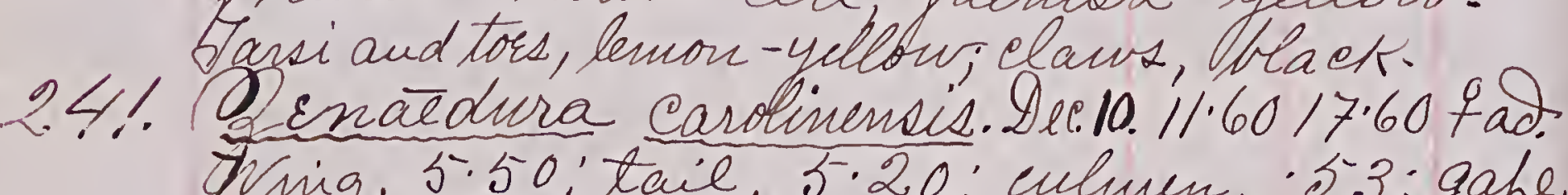
Tring, 5.50; tail, 5.20; culuen, 53; gafe, 75 ; tarsus, 82 ; middle tor aud claw, 1.03.

2. Ortefs virginiana. Dec.7.9.8015.30fad. Whitg, 4.50; tail, 2.60; culwen, s4; bill Aron mostril. 32; qápe, 61: tarsus,1.33; middle tor Y claw, 1.140; middle for aloue, 1.13; claw, 33 . Mis, hazel. Maxill and tif of nandible, black; base of mandibly flesh for tect: purplish flesty-brow; claws blactish.

243. Sonasa umbelles. Dee.7. $16.3022 .65 \%$ Wring, 6.90; tail, 5.35; bill measured fon mostril, 47: gape, 1.05; larsus, 1.70 ; middle tor and its 'elaw, 1.80 ; middle tor alone, 1.40; claw, 46. 2n's, hagel. Cencuen and extreme tif of naindible, blackish. Extremu hoint and edge of maxilla at base, and nearly all of mandible leshcolor. Legs and.fect, oray tos-blue. I Claus, brownith-blaek.

\section{$188 \%$}

Collectming
Number.

DATIE.

LOCALITYY.

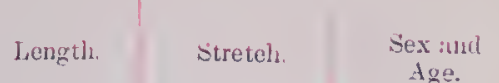

Drcember 16值. Pativore and Qhiv Railsood Coming last on the Baltinore and Chio Railroad we saur a number of binds:-

Comms trugivorue. I in easteri Mariland we first canie across the Crows in large hlack, up to 500. West of that wr had seen d bew seattered birds. From there last to Jersey lity they ware acen in large flocks Cattartes aura. An eastern Maryland. we saiv a Lurver suzzand flyishghidh never seen arle aquie before. Shorttif aflerwards. we saw a dead horse lysig mi a field; and a little later aroltier In Rey Bús gard. After that ur saur a mush ves of then before reachiy Wilinington, bit noue bast of that point. In ove place a floct was seen Salir a number secterig down nou some carion not far forom the railsoad. Sone were floatirify nfoloiless nittu air Molothrns ater. A munver seen in Marifand, Delaware ard Penushania

\section{Qccember 2./st. H.f., N.Y.}

Loos miy wipe ont shooting for the firist tive. We dhove into the wofde belofw Ho, $t$ Nontanery, and tied the horze. There wre somb Purple Finchee (Carhodacu hurpurens) and Goldfriches (Cotragahius tristis) fecding in the hembock de num- Ver of Yellow numpe Varbers Dendrveca corotiala) wrre seen at defferent porits. Leaving my wife to adhuir the vrew from Fiont into the edge of the woods. Whelest 


\section{1}

Collecturge
Number.

standirig and watehing suvral sheces of couninow winter birds, is noticed a ond flying otrongly from the North. "t alcilited in a treebtat/ near me and seerhed animated and shif; and 5 Thought it was gonig to fly, so shot it at once. It hroved to be a quie young male Lonistiana Samager ( Npradigal ludovieiana/, mi good hlumabe, and facily / hlumen and wrbll mowhishe de. Su Forret and Stream, X, p.95. Mass.

2,244. Pyrama ludoviciana. $7.4511 .35 \hat{b}$ iur Whing, 3.62; tail, 3.00; culmen, 6 s; bifl measured from nostril, '48; qape, '75'. tarsins, 82, middle tor and Ata clan, 80; middle tor, 58; clav, '2.5. Bis, hazel. Bill, with nuxilla destris brown, wh yellowith on edges; and mandible yellow. Tarsi aud tors blush lead-colort. Thi bind was mi the plemnays of the qenaly, but careque disizection preved that it was a young male.

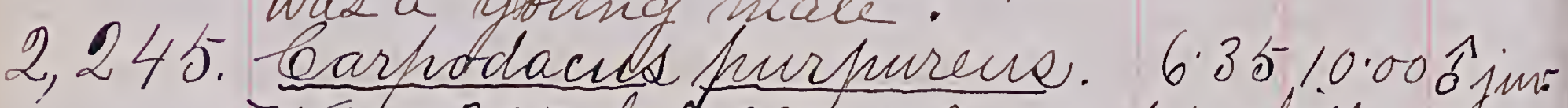
Wring, 3.05; tail, 2.381; culwen, 45 ; bill frofm nostril, 3s; gape, s5; tarsus, 70; middle tor und its claw, 75. Hrisprecuien, hroved by disidectión to br a male is midemalle hlumage, with no traee of that of the male.

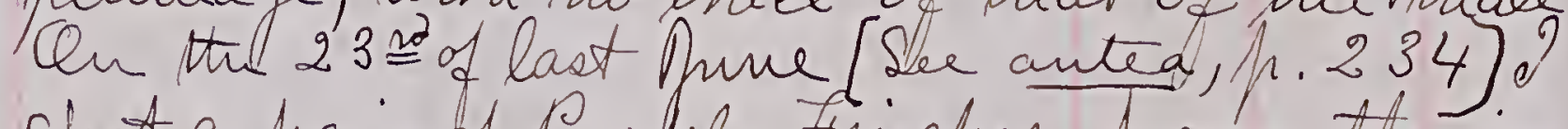
shot a pair of purple friches from their mest, the medele of which was in benale plumage, but had one yellowish-red feather 2,246. Etstragalime trietis.

$5 \% 9.00$ óad. Thing, 2.80; tail, 1.90; culmen, 43; bill from nostril, 34; qafe, 43; tarsue, 55; middle torr claw, 62. Orop filled with seede of hemeor.

\section{$188 \%$}

Collecting
Number:
Nuts

2,247. Ashagahimus tristis. 5.12 8.90 हैa? Wing, 2.75 ; tail, 1.90; culmen, 40; bill fron nostril, 30; gape, 42; tarsus, 53; midde tor aud its claw, 60.

His, hazel. Prop filled with seeds of Abrés eanadein

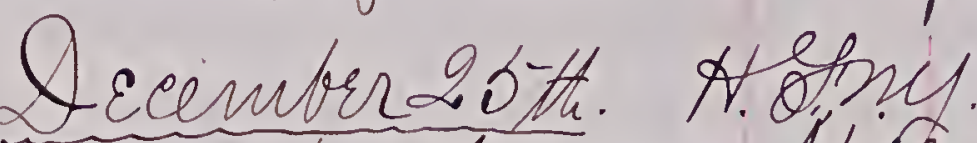

While drissing for church a Hellow-brllied Vootheeker (sthypains varius) alighted on the sugar neafile jiest outaide the wridor It allerindonds fleur to an affele tree in the arethand. At is the firfot have seen this winter. There were flocksos Cedar Orido Arufili cedrorme bout the house.

Lecenuber 28th. Hegny.

Dendrorea coronata. - Zuv wrre ni tu Vorvay spruee in pront of the harsuce, colere I shot the specinim. Hhey stulted and wero shy. 2,248. S2 endrorea coronata. $5: 759.057$ ad. Wing, 2.90; tail, 2.32; bill from nostril, 27; gape, 50; tarsup. '7.3. hiddle tor and it.'

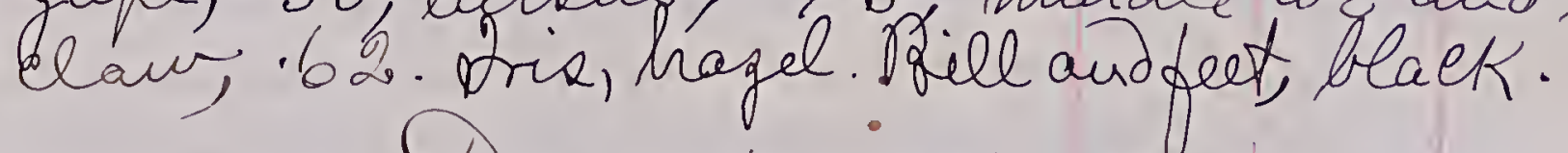

Dizenubrath. Nogrin. To-dar Lours gerega and mypelf Lfent hunt - ing Dueks. There urre 1 lenty of Cld Squaw. (Avelda glacialix) and stome Larbe blaek lookini, ducks, and one or turo large floces of Neigus merganser. We wounded tedo Clo stymants iand they aflervards Kehtud busy nearly all day trymin to cateh them. Gulls Colarns argentatus) were afundant and a hair.of White-headed Eaglex (A Aliatetur eneodthates) var seen. Ofu Constitution Hown wr plushed a couple of Gouse Bome nubelus), the sar a geev other bi shore. 


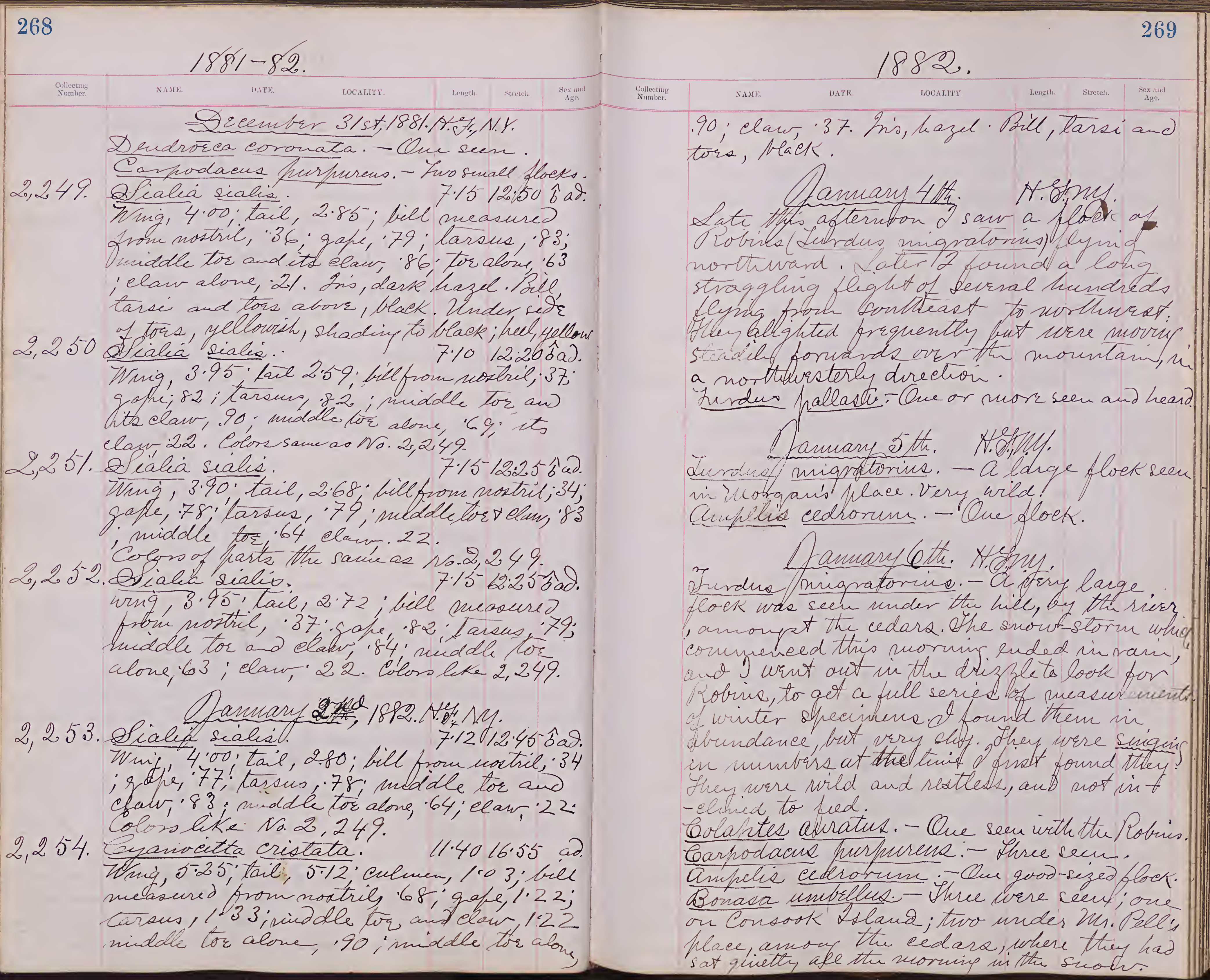


270

271

1882

1882

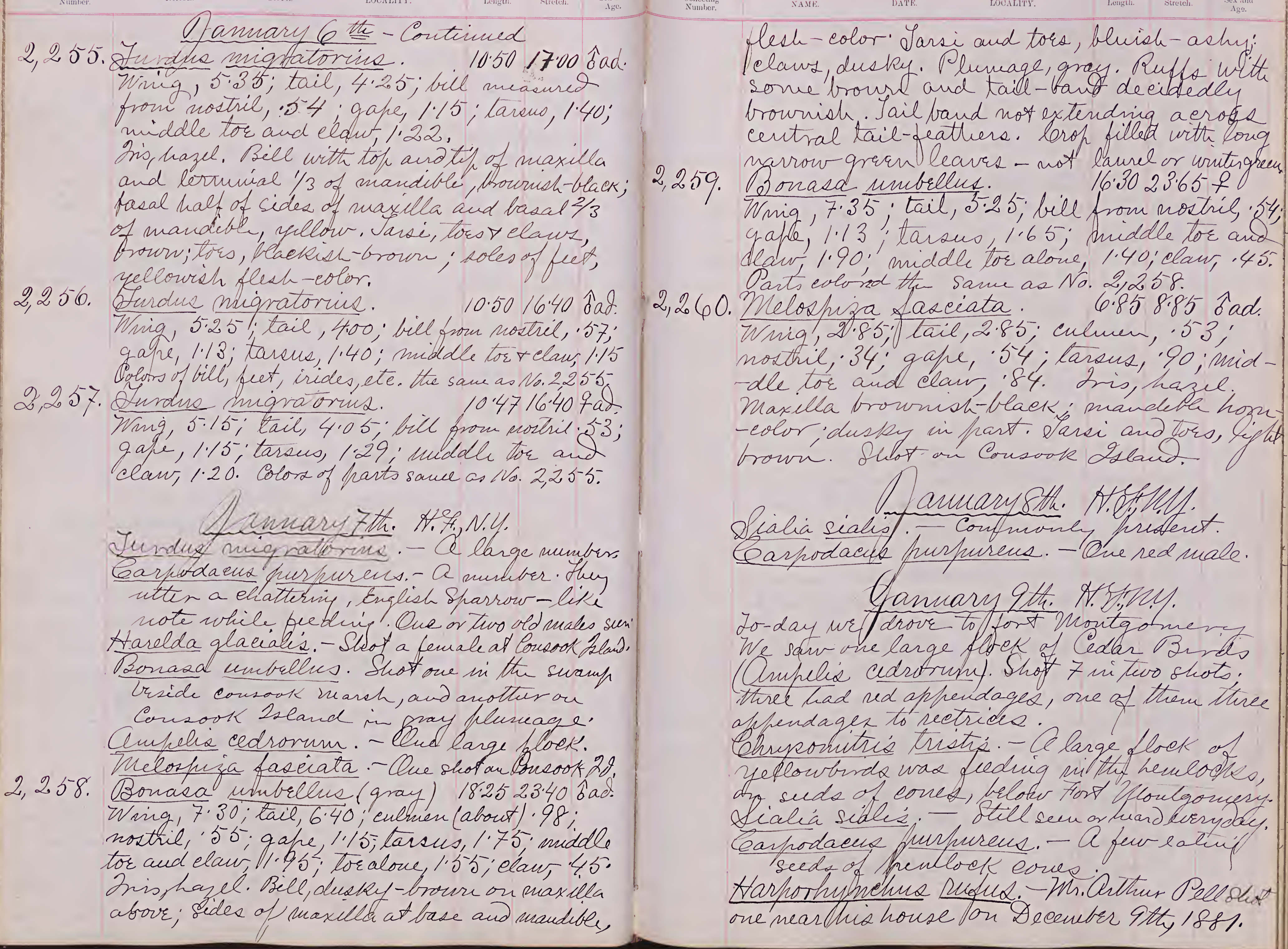




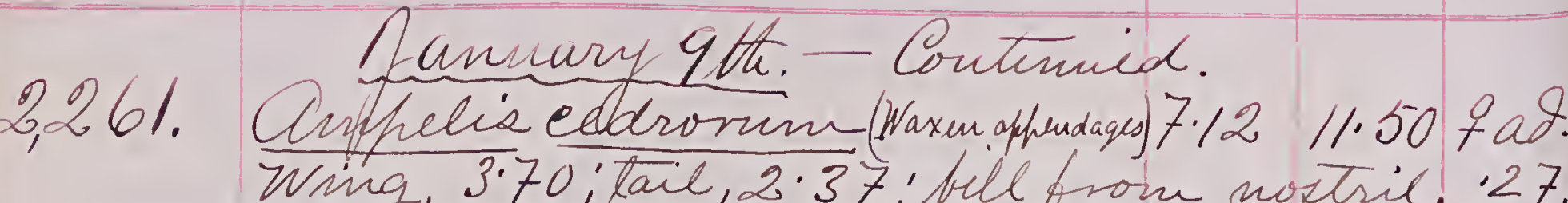
2,262. Cupre, 75; tasus, 65,' middle tor r elaw, is Wring, 3.75 ; tail, 2.40; bill nueasured from nostril, 27; gafe, 75 ; tarsus, 68, middle tor and Claw, 7 . No wax-like wingtihs.

2, 2.63. Anpelis cedronm (Noaphendages.)7.4511.95 Wring, 3.85; tail, 2.66; bill measured prom nostril, 27; gape, 73; tarsus, 68; middle tor and elaut, so. No wax-like ofpendages.

2, 264. Anplis cedrormu (Waxmaphid.) 7.40 12:30 \&ag. Winig, 3.90; tail, 2.68; bill from nostril, 29; gape, 79; tarsus, 70; middle tor and elaur, 82. This yperiven's hlenicage is interesting breanse it is a fenale, and possesses waxen afpech dages to tirues its rectriels. It has met with thir same areidert as had the Rubfed Groute (N0.2,258) which 2 shot a feut dats Scriee, viz: it must have flour ag anst a Graneh or some object bud tostur through thin skin on ito neck which was pounb in bott cases to be considerably tom, the edges of thir wound having united by plastie dollesion to the trablica of the bivel.

2,265. Anfrelis eedrorum (Waxen ofpendis), 7.20 11.80 fat Wing, 3.75; tail, 2:25; bill from nostril, 26;

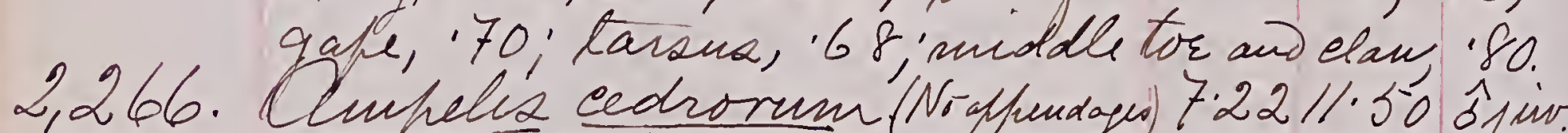
Wrin, 3.65; tail, 2.30; bill from nostive, Vs. acele, 70 ; tarnes, 69; anddle tor and daw :80.'

2,267. Cmpelie cedsomm (Nooppendager) 7.2211.75? Vtang, 3.75; tail, 8.35 ; bill from nostril, 27 , gape, 75; tarsex, 68; undelle tor and elain, 82. Sex indiseovrable upou disecetion.
1882

Collecturg
Number. xa.MI:

Wife disd o went to the tof of Prow Nest Monntain this afternoor ofter dunier. We heard a Bluebird (Sialia Rialis) warbling as wr stovo
on the surumit.

Sialia sfalio. - Drove towards 7 .

and on the war sar a Moulgowery resides a dozech or mori Yellowt numped. Waiblere (D udröea coronata), and a flock of Bedar Birds Aufilis cedronmy of Which ibife shot two specinens the two shote.

2,268: Arre atricapillus. $5.37 .7 .90 \mathrm{fad}$.

NN mi 2.50; tail, 2.40; bill from noatril, 28; culsum, 40; gape, 43 ; tarsus, 68 ; middle tor and ito deaw, if.

2,269. Dindrorca coronata. biso 8.65 fad. Wing, 2.70; tail, 2.04; bill from nostril, 29; gapt, 51 ; tarous, 70 ; middle for aud claw, 60. gris, hazil. Bill and feet, black. Hot grom a. plock of a dozen feedinity arnong the cedars. Hei 2,270. Ampelis cedrorum (nedphendages 6.19811 .50 fad. Wring, 3.65; tail, 2.20; bell nueasured from nottril, 28 ; gahe, 73: tarsus, 67 ; whiddle tor and claw, 80. Bris, neddish-brown. Beil, tarsín

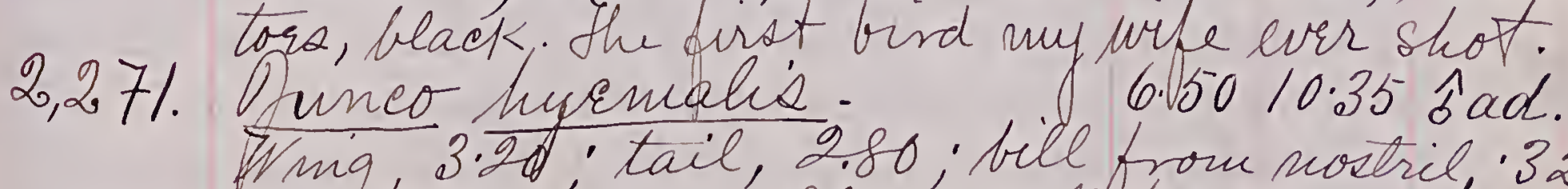
Hing, 3.20; tail, 2.80; bill from notril, 32; gafe, 48 ; tarsus, 86 ; middle tor and elaw, '79.' 2no, hazel. Bill, flesh-color, slightty tifhed with black. Sarsi and Tork, brown; tors, darkest. 2, 272. Amplis cedronm (Na waxen ofpendages) î̀ jur inounted for suy wige, who shot it ? 
Here Bleuebinds (Bialia sialis) Hre seen un the mafle-tree ontside suy windon, while the snow was lying depr stèl qalling.

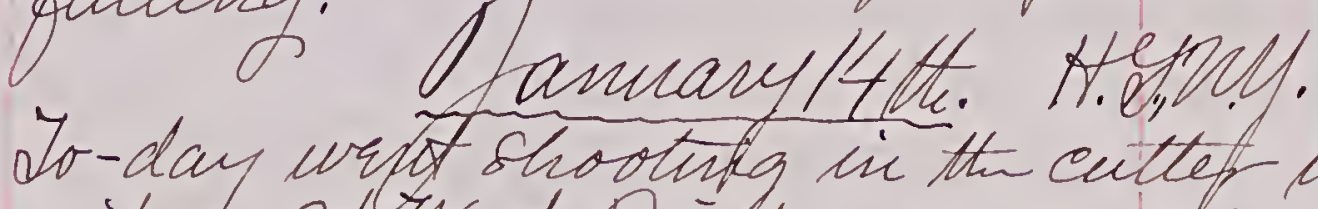
wite aft snootrisg is the cutteff vith suy est Ponts we saw two nale Heuebrds (Scalea Sialis) sittuig on a telegraph uire. A little way the wrsaur Her fenales in a chothet tree. Astragalims trietis. Lamp flocke sen nearthe cenetary af VINA Sonit. Sonaza unbellus. - Que near Vist onit. Oordo very searee in that desieteri. We seareely sawany otturs drivin thisongh. D. Pirit and horue by thi ntonitail road.

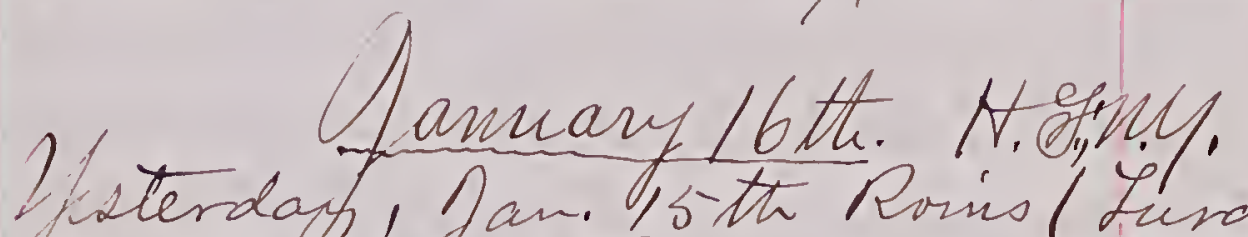
and Bluebirds (Sicil scalis) wrre seen mintorin) Iordar an suormons flock of Cedar Dirds (Eufiés cedronm) we seen and plentr. of Ronis (Iurdus nigratonis/ in govosized slook a plyin worth.

Sucirea corvata. - Aur flock of nine flijin. Dstragalmis tristix. - Oue var large flosts.

2, 2.73. Anfrelis cedromin (red appudqus) 7.0511.85-9.9. Wing, 3.90; tail, 2.60; bill from nostril, 25; gape, 72; Larsus, 66; midfle tor and elau, 80. His, reddish -hajel. Bell and feet, black.

The waxen affendix to the snallest rimige of ow

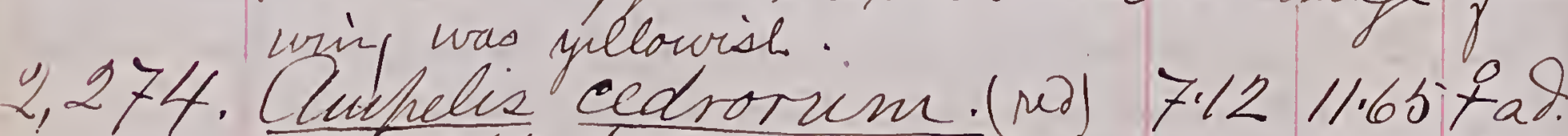
Ving, 3.65; tail, 2.35; biel from nostril, 25; qa/n, '73; tarsus, 70; niddle torandelar, 84.

\section{2.}

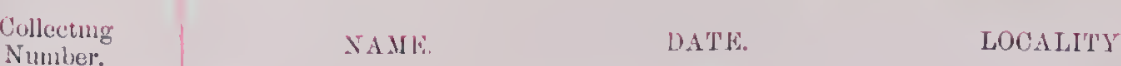
grigh, 3.65; tail, 2.42; bill from notril, :25; gis reddish-brown. Sell and feet, blaek

2,276. Aimpelis cedrorum. 7.151/80 jin.

2,277. Ampelis cedrorum. 7.0511 .60 qjiu. This specin exhibited faintty the light edging to thr lisser wing-everta characteristid of thillomg. I was probably (doubttess) a bind hatblue ldst sum

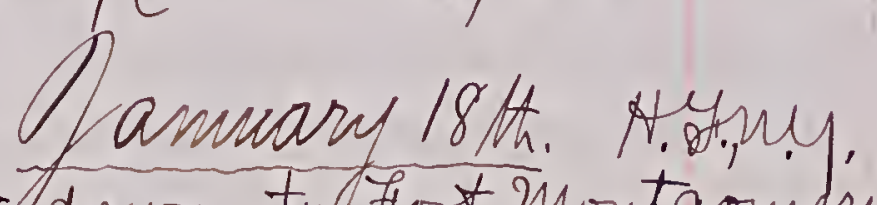

Io-day drove down to fort Montgomiry, where ur fomd the following birds allin lakge flocks:Qstragalmina tristis. Yellownind. Ampellis cedrorum. Cdar-bird. Iundus migratorirs. Robin Carnodacus durpurens. Pusple firieh. Rezides thr above a feu Bluebids (Sialia sialis) cuntrefted Grouse (Jonasa unbrllus) urrese 2,278. Aurdus migratorus. $10.9016 \cdot 85 \mathrm{bad}$. Winig, 5.52; tail, 4.60; bill from nostiel, 55; a ahe, 1.18; tarsus, 1.37; midddle tor and clau, 1.20. Extremutith of maxilla, and of mandible, black; maxilla a little brournish above; residue of bill, yellow. Jarsi and tors, dark trown; sole of bet

2,079 . Hurdur migratoriue. 10.6216.10 fad. Wmig, 5.15t, tail, 4.18; bill from sostril, 54; gape, 1.15; tavsus, 1.37; mbdle tor and dare, 1.20. Drs, hazel. Maxilla (exeptredge) and extresuity

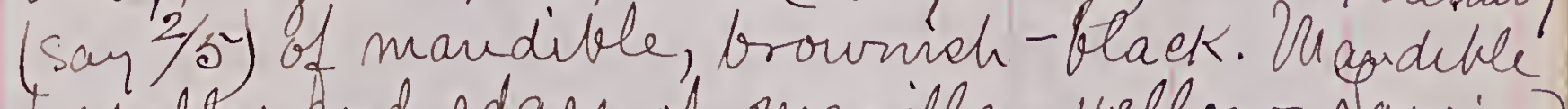
tosally and edges of maxilla, yellow. darsi and

4, 2.80. Aupelis cedrormm. Rex 7.4811.65 今ad.

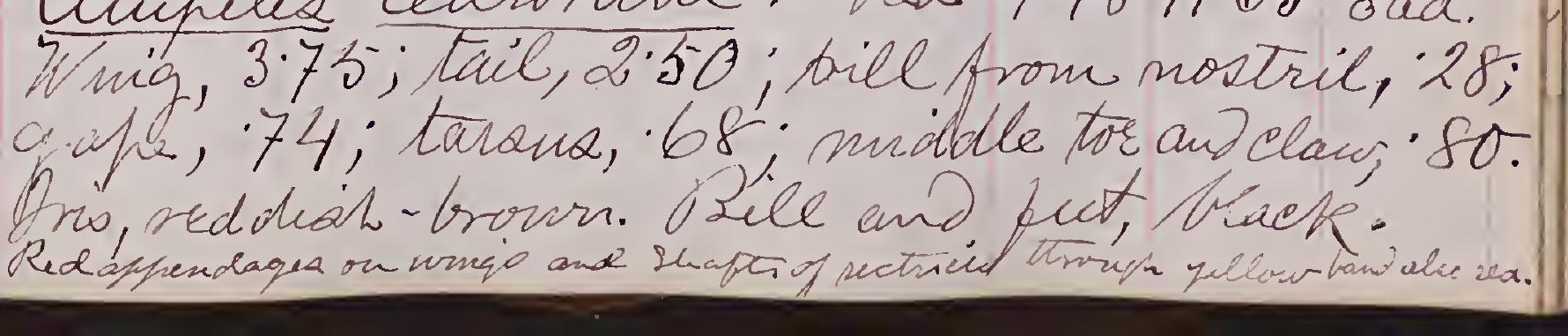


2,281. Anpelis cedrormu. Redap.7.40 11.50 9ad. Wing, 3.60; tail, 2.42; bill from mostril, 25 ; gape, 70; tarses, 69; midelle tor and claur, 81. Mis, bedidis. Bellotut,hlaets. Ouly one tor. anterioven; looks as if it wase congenital deformity Throat contanied 26 cedar brries.

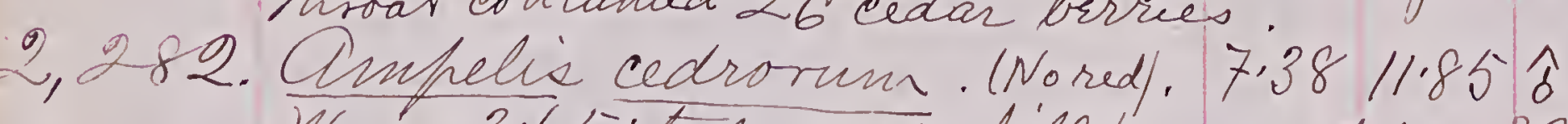
Ning, 3.65; tail, 2.25, hill from nostril, 29; Gafe, i78, tarsus, '71; inddle tor and elow, 78.
Colors, same as above.

2306

Ampelia cedrorum. (Nored) $7.4012 \%$ jiw. gape, 77 ; tarsue, 69; middle tok and claw; 77 . Gowrs same as No. 2,28\%

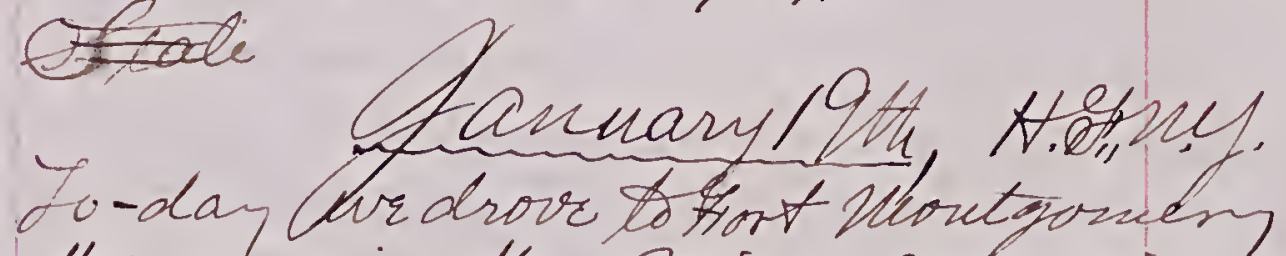

th the craning the Robina, Cedar-bisda, Yfellow rump and Suoblinds cone to roost. Ye saur the fallowing frids:-

Iturdus nigratornie. - Very good-sized flocks. Pialia siálio. One large flock

Ampelio cediorum.

aspodacus unfureus.

secria hiculactru.

Dederorea coronata. - Sun in some numbers fott in the eedars at Mr. Um. Fourd's and

Plectrohhanes nitaliz. Yisterday Ella saw a flock of about fifth Suort Bintinip ón past our west witdout; and to dary notter saw nine feeding under the grothe

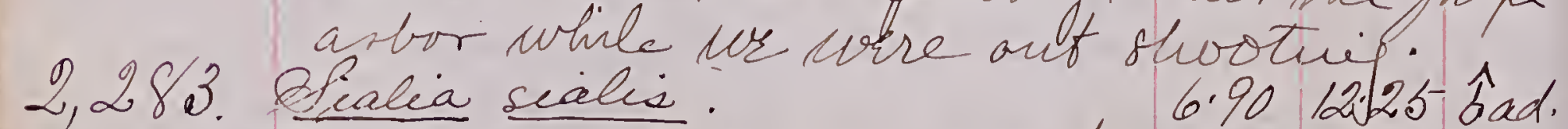
Vinig, 3.85; tail, 2.50; bill from notril, 34 ; qafle, 80 ; tarens, 82 ' middle tor and claw, is. Iris, hazel'; bill and feet, bla dk; rioide of wouth, yellow.
1882

Collecturg:

saME.

DATF.

LOUALITY:

Lenert-

2,284. Inrdus migratorins.

Wrig, 5.22; tail, 4.50; bill from mostrie, $10.4416 .50 \hat{\delta}$ ad. gate, 1.10; 'tarsus, 1.3's', middletor an) élaw '.18. Dris, hazel. Yarsi and tore, dark brown; soles of ted yellowish. Basal half of mandithe and edges of huanilla, ispecially on basal half, yellowisbsidur of bill,

2,285 Gurdus miaratoris. $10.0515 .80 \mathrm{f}$ ad. 10.0515 .80 \& ad.
nostril, $5-2$;

gafle, 1.14; tarsus, 1.31; thiddle tor and elar 1.22. 2,286. Surdind mingratorins. 10.00 1600 of ad. Wing, 5.15 , tail, 4.2 .

galle, 1.08: tarsus, 1.31; mididle tor and claw 1.15 Extranity of both mandibles, black; maxilla trowish atborr, bill ottervise, yellow. Bis, hazel. Yarsi and tors, dark brown; solds of feet, yellowih. This speerimen was enaciated and dvarped, having once had a brotem wing at the casfus, alfowing of vary miperfect mohoin in flicht. iflink this a edounts for its small size, although it isin excellent peeprage.

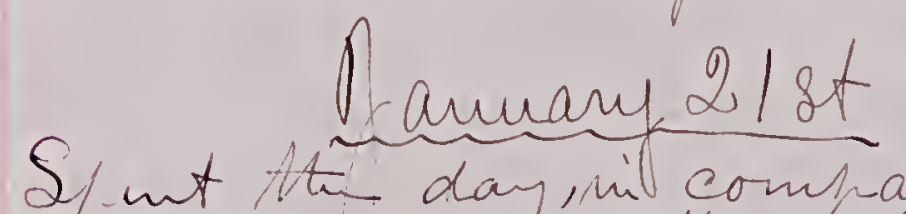

S/ nut the day, in company with in. Ofessme Dema, fistinig, throughttit ice ou Papblopen's Pand. We caught a number of Piekerel Hellow Pesch. Deaught 13 Pickerelso 2 Perch for buy baskd Anorthura troglodytes memalis mas sen in Thin brush heaps prside the pond. None others have bein seen here this winter, altrough sav it on the Seioto Privir, when in Qivis. It

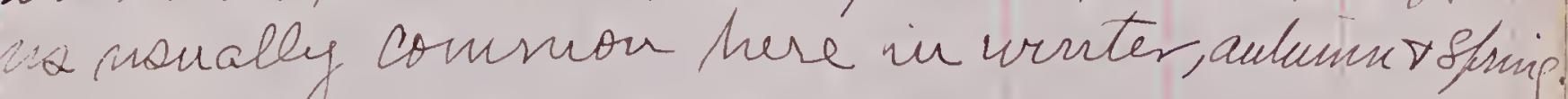
Damary 23 a rd.

Thermointer $10^{\circ}$ abtorgero in morning; 2 " below zera at 9 o'elock P. DAr. Audson qrezing. Did not go out. 
To-daylat9oichek@u. Thu pubneter stord at 80 F. bren geno. The sin was shin on it then, and it got in to $2^{\circ}$ below fry eleven -clock AMr; At 2 PM! 10 bulow, and not a

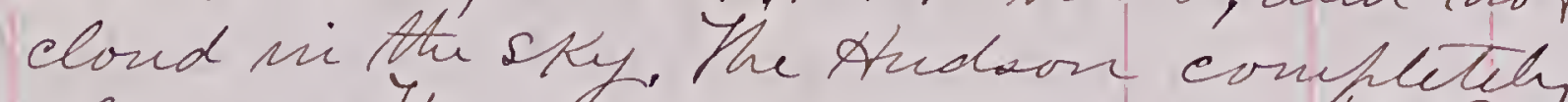
closed. Themometer 5 below zer at 9 onh.

\section{Aamary 25th. H. Hins.}

Thermonfeter 7 abovr Bero at 8.30, C.Mll.

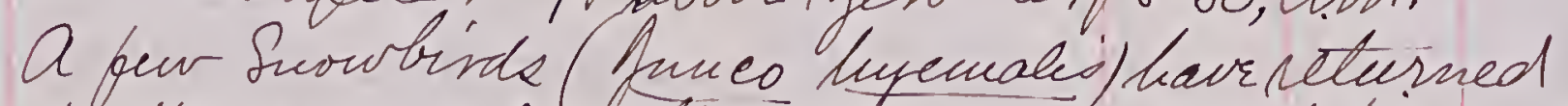
to the yand, whiell they detserted durin the bitter cold.

\section{Lamary 26th. H.ephey.}

Themonfeter cias $36^{\circ} \mathrm{abov}$ geto at 9-30 A.M. I drove dour to Hort Puoutgosury, and took a long walk at several flowto on the soad to sel what the binds liad bran doing durung th cold suak, and ughtter any of thr lede hardiy specîs ha aleft pu. Hee sfeceis sew wire as follows: -

Sturdus migratovius. - One plock of about a sundred chre feeding ii a parroter maviu down whieh d strebu houred, at whid, as Isaw by traeks thy had breu drintrip nir mintirs. They Evere sery sley aub fow out of the cedare in a seaternis mastmeras Iafhroached, so that s could not ploot a suigle speciuen. Ther wrse, as I havs. constanth noteed to br the care durin su's month, aceoupanied bef a floek of Sedar Bida Aufulib ecdrorun.).

\&. Sia sialis. - Saw a feuralery throb. Tranes atrieafrillue. Surhal flock sem. (1) helis cedromm. Clue Llock of au hundre. Gue sliot bronglet doun 5 birtes, all young?, wittrout waxeil appendages, whicle one chad

\section{2.}

xask

tocantTY:

speesially niterativg an aceount of having no yellow band on taily axceft a trace on one seather. the second shot firid after all the bisds wredrike out that could be seared away, frouglet dour fous adults nith briely-developed red of andagex,

while one had nullow tifs to wing-feathero, and another ved appendages on hebtriées. I have ofter notieid that these fine finds assoceate biettur a hart from th ill-devaloped oveo. Carpodacus purpureus. - Commón. istragalinde triétis. - Con

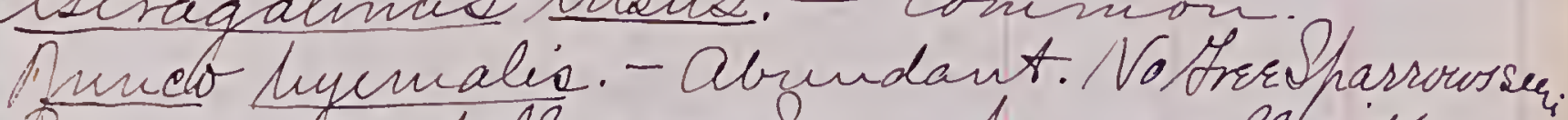
Bonasa mmbellus. - Sar four all sittrig intrees When flushed. Shot two of them, ohe of whieh earred suy shot a frefong and. drophid where Belaweed to Noure Gerost it iiest as it died.

Leindröca eoronata. - Doznoof then;

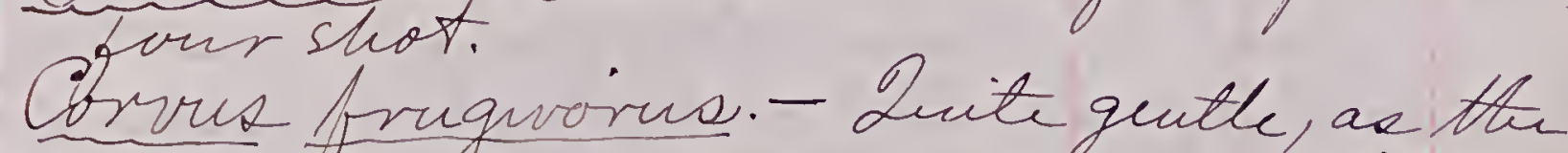

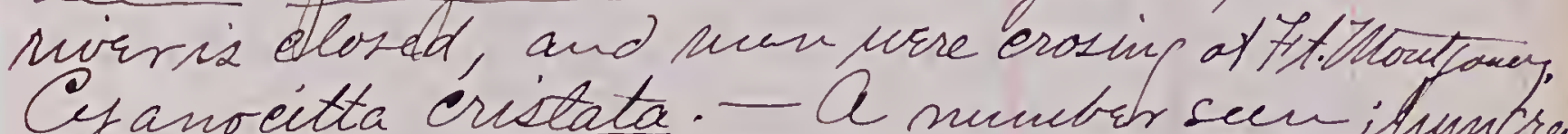
2,287. Thuco huemalis. 6.359 .85 s.dd. Winig, 3.oot: tail, 2.55; culmen, 45; bill grow nostril, 31', gahe.47; tarane, 87; middlitor and claw, it t'. Bill very seidtty tiffed black; residu blesh-pink. Tarsi, lifht brown; feet dark brown. qride dark browh:

2, 288. Earpodaens purpureus. 64010.40 ôad. Vinig, 3.1. iail, 2.62' bill from nostril, $36 ;$ culvien, 49: Gapu, s5, tatsus, 67 ; middle tor and' clair, 7.7 .

2,289. E endrorca coronata. 6.10 9.12 $\hat{b} a d$. Wing, 2.85; tail, 2.60; bill from mostril, 31, gafe, '56; tarsus, 77 ' middle tor and its chan, 62. Pris, hazul. Biel and. beet, baek. 


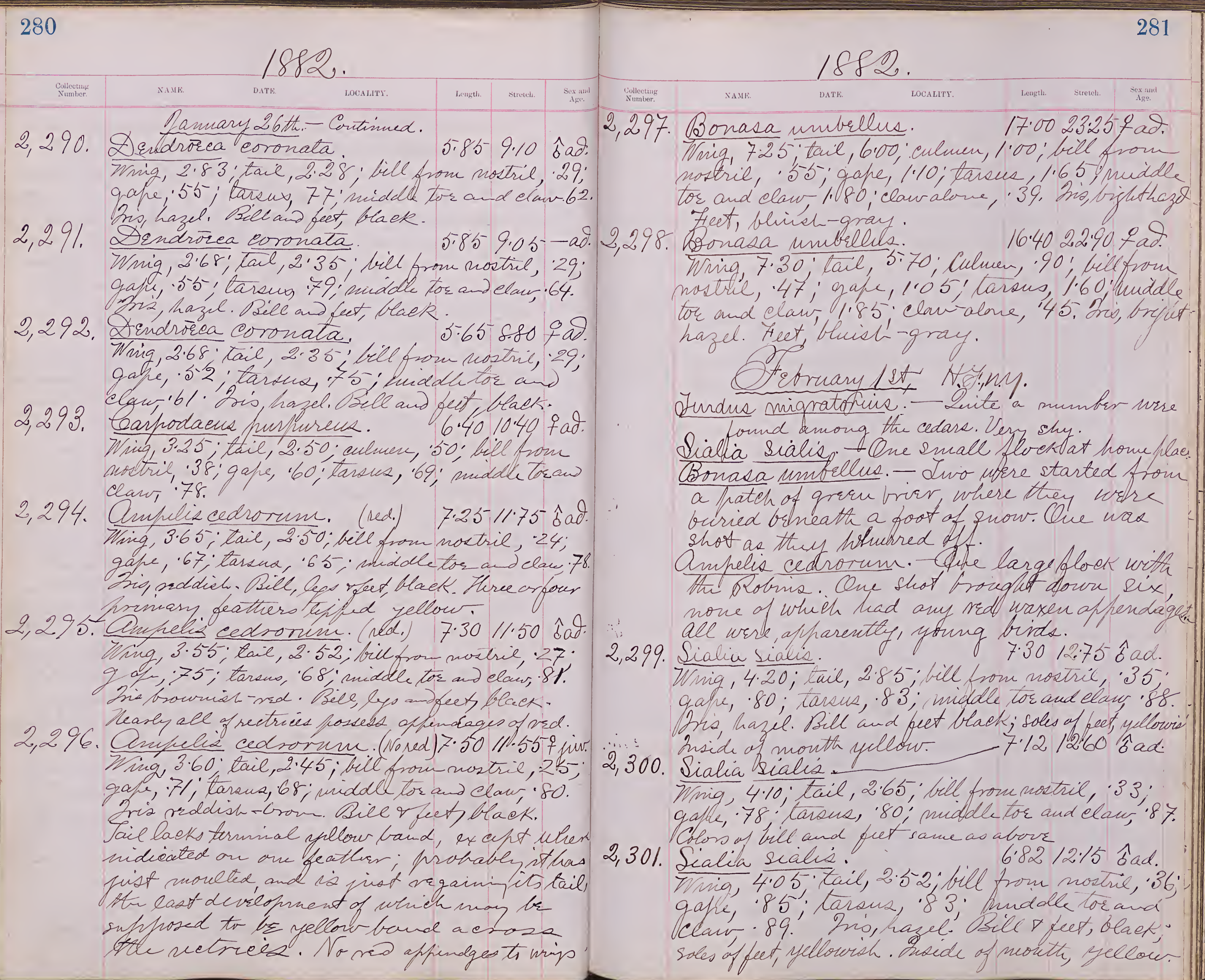


282

283

2,302. Sialia sialis. Whig, 4.00; tail, 2.85; bill from nostril. 37. gape, 82; tarsus, 78; middle tor velaw, 84. Calors, same as atorr.

2,303. Sialía sializ. $7 \% 12.60$ iad Ninig, 3.95; tail, 2.73; tribl from notril . 37; gape, 81; tarseno, 82; mididle tor velaw, 85 Prom, samic as above.

2,304 Lialia sialíe. 6.8011.75-fad. VNing, 3.75:tail, 2.53; bill from surtril, 30; gape, '77. tarsus, 77, nuddle tor and clow, .82. Colore same as above.

Bonasa umbrlus. - The cat sfiouled it. Ots muth and tail-band were brown. an old cock birs?

Iebruary 2 nd. Hithry.

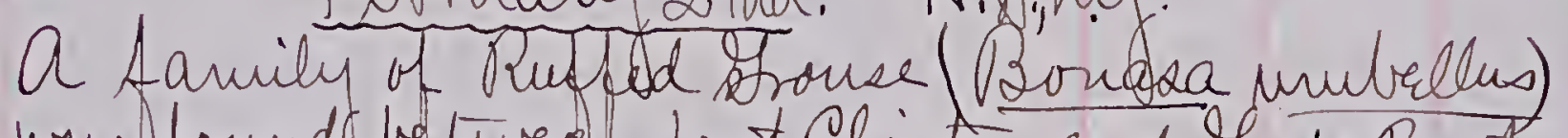
wref found Vituren fort Clinton and Pec's Pont

$$
2,305
$$

$$
\text { on }
$$
Callue virginanue. as.

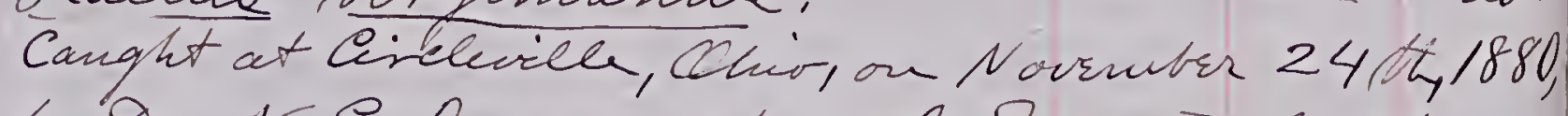
by Dr. 1. E. Joner's Shavill. See antea / 1 186.

St Itruary 7th, iteiny.

Loday walked to ller onit dith nu rith to sloot an Segle near Battery. Knox; Yoticm excellet shot at the Eagh at viry close rangy, and musied, or only woukded it of was a harge liglt. gray cager (Hallicitur leneocephatu, jur.).

Al Oblue Brido (Scialid scalis) wore singing as I walked horne.

Hebruan 10At Afyry.

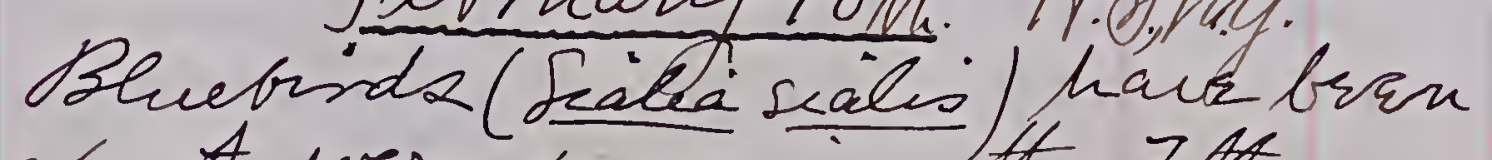
about every day since the 7 Ate.
1882.

2,307. Auneo tujemalis.

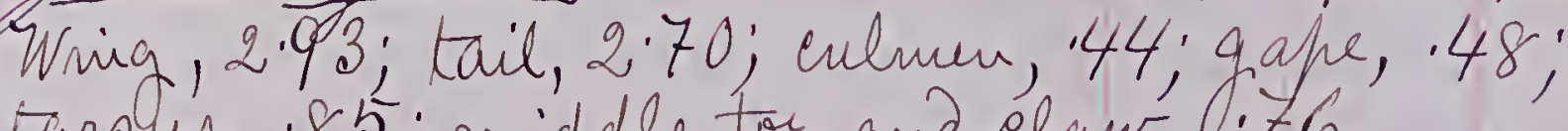
tarsus, 85 ; middle tor and elaw, 76. learpodacys purpurens. - Sircing Durnig amuary Sluebrids bavibrim heand almost daily, andyellow-rumped Warblers seen.

Detruanf 14th. H.Sinn.

2,308. Sialia sialis: $6.9712 .65 \mathrm{sad}$ Wring, 4.00; tail, 2.60; bill from nostril, 37 ; 2,309. Sialia sialis. 183; middle tor and claw, 7.0012 .38 s. Wring, 3.90; tail, 2.75; bill from nostril, 3 5. 2 10 afe, 79; tarsus, 80; middde tor and elan, 88. 2,310. Sialia sialia. inin, 3.90; tail, 2.58; billfrom nostril, 37; gafe, 85; tarsus, 73; midalle tor aud elaw, 82 , Naliaëtre leneociphalus: - Rode to West Prit , Find my hosse brekind Ft. Clisiton, and wrut to bunt my Eagle. Gat a fairly good shot at the same frid gshot at fel. F th - a brry large gray brid. Yhy bullet struek the ice exaet in mderneat. It Eagle, and as it arose Isaw that my giet shot thad eut one or two quills from its lefturing. Dendrorea corronata. - Seen on the 12 the mas Fortmontgonery among the cedars $\nabla$ Cedar Burds. Qrebruary (6t), Hots, Esalou columborins.- Cue sefu sittini on a tall mare-tree ni Fort Clinton, West Doint, and sot ctic until 2 war tyin, nuy hore greparato ry

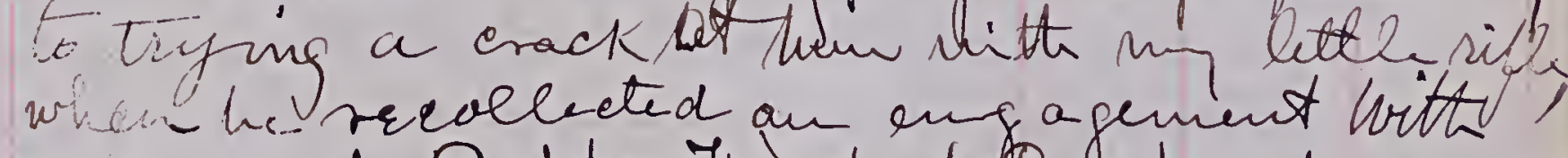

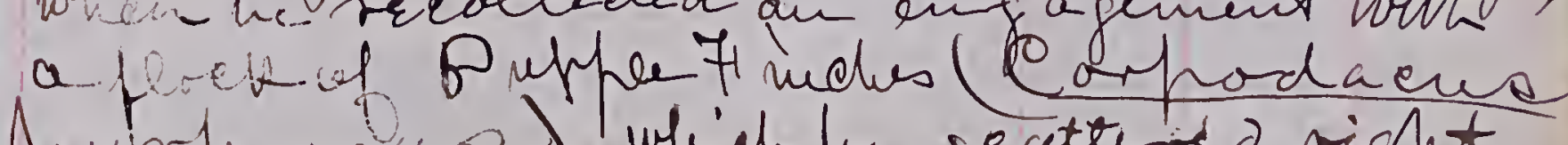

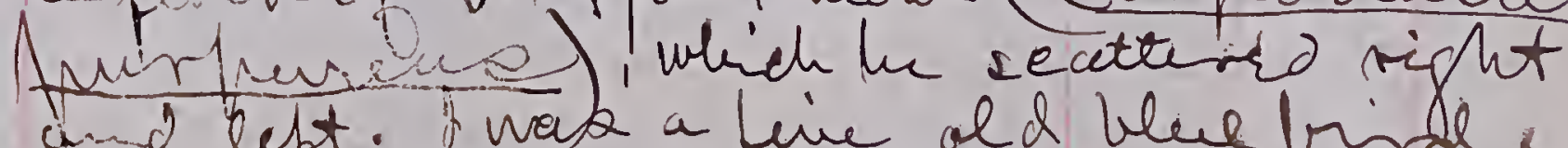
and left. "was a fine ald blue bind. 
284

285

1882.

1882

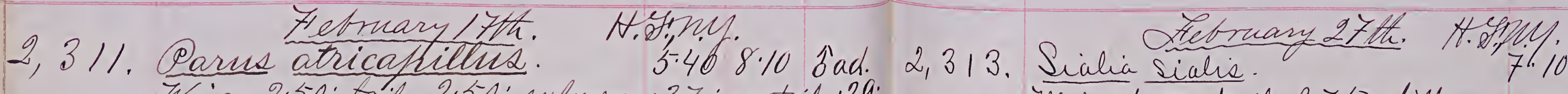

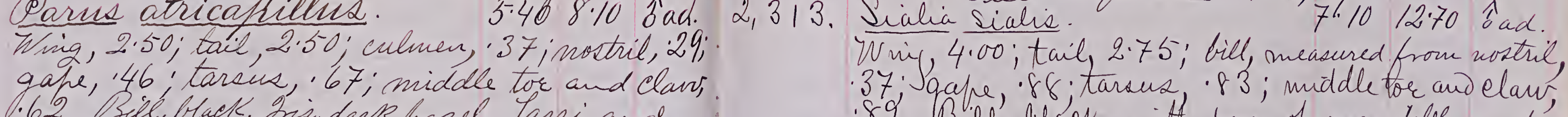
gafe, 46; tarsus, '67; middle tor and clavi,

2,312. Darnes atricapillus. 5;357.857ad.

riside of montt, yellowish. Jis, hajel Jarsi

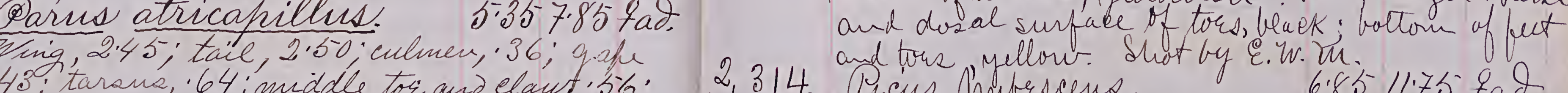
bill measured from sostril, 27.

2,314

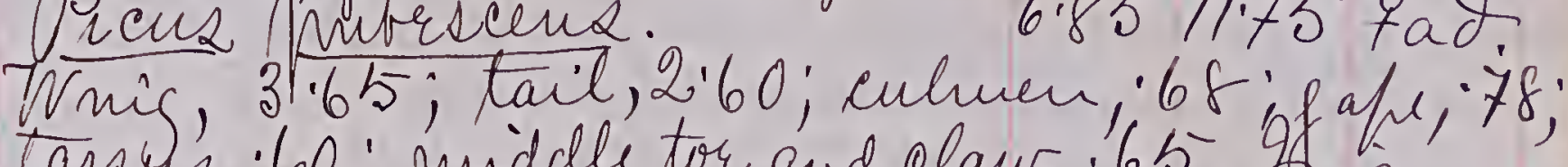

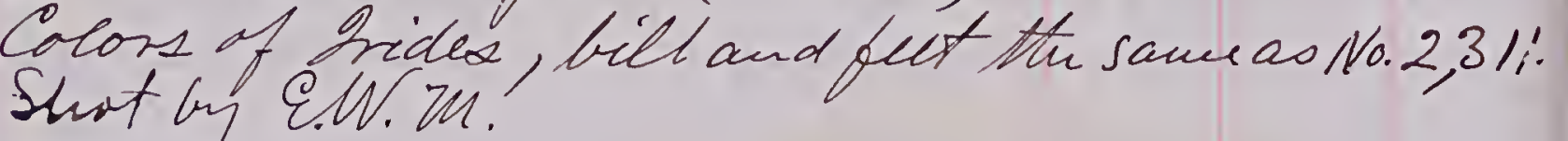
tarsels, 60; middle tor and claw, '65. It)s, tors, pluish gray. Shot'y. E. W. In.

This monning the thernometer was $10^{\circ}$ abore gero F! at ficm, and 0 rode ver the monNear cornuall D sar ou Bobin (Lundere migratorins), a flock of Purpe \#nieles

2.315

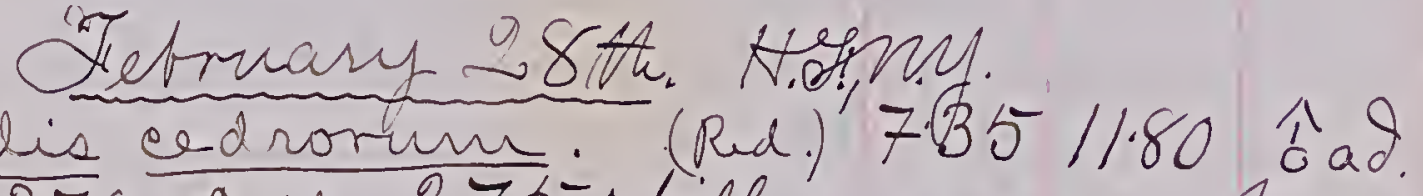
Wring, 370 ail, 2.75- bill, meacured from nostril, 27 ; gafe, 79 ; tarsus, 65 ; middle tor and claurt, F 7. Red apperidages on urnj:

Hebruare 19 th

Hiv evining fode over the mountain. kearth tof of the monntain a Clense clond or for ewroloperd wrsytinis, and

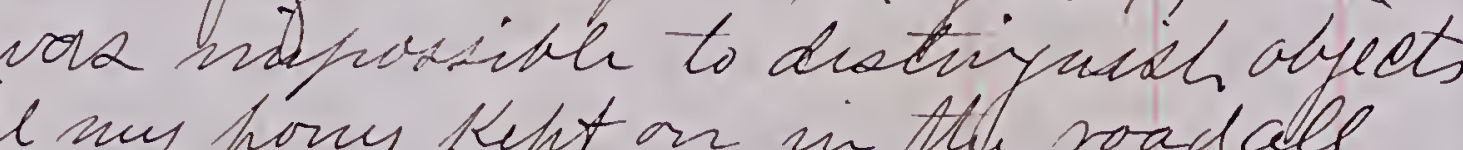
Lteil my hony Kift on in the roadall right until a flock of Cedar Zurds

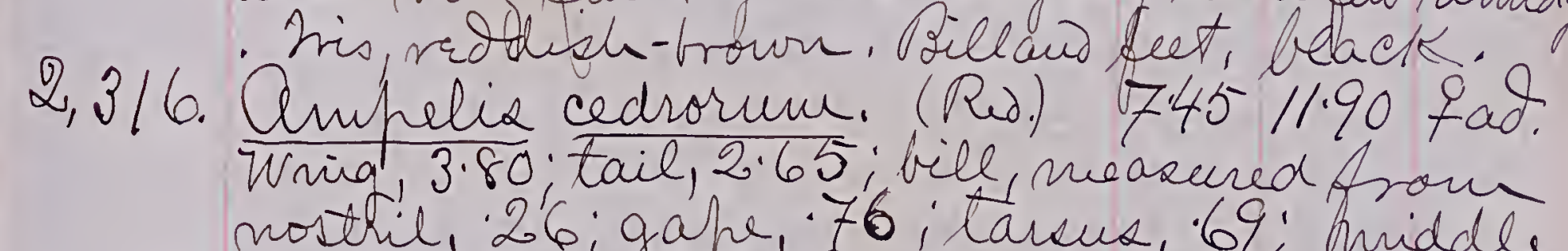
mostril, $26 ;$ gape. 76 ; tarkus, 69 ; In

2,317. Ampelis eedrorum . Red.) 7.5011 .85 bad. woitril, 29 ; iafe. 77 ; tarsus, 67 ; middle tor 2,318. Amplix cedrorum. (Red.) 7.40 11.65 Sad. the road alnost under nu hover's fut, with their londest notes which alouk fightened and alnost thien me, as whe ridu bary carclescly. Lhe Gids road, or else have yollen lont in the forgy. ving, 3.85itail, 2.60 bill from nostril, 27 ; 2,319. Anfolis cedrormu. Ro.23/5. Hellow on rerniger Win, 3.75 ; tail, 2.50; bill from nostril, 28; gafo, 77 ; tarsuz, 69 ; midde tor and el aur.80, 
Collectum
Number:

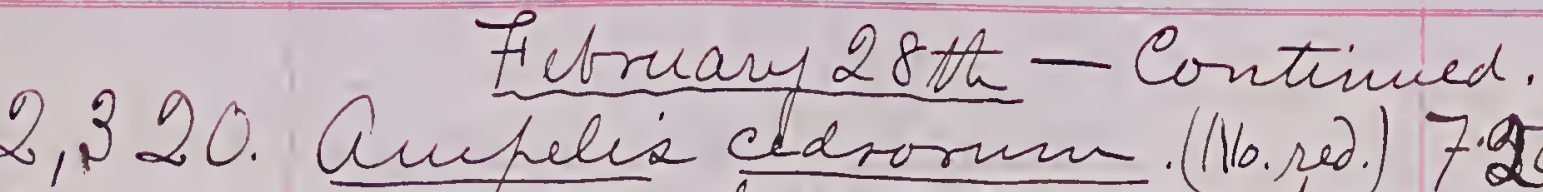

Wing, 3.70 ; tail, 2.25; bill from nostrib. 25; gape, 75 -itansus, 67 imiddle tor and claw.8\%. 1ebra of bell, peet and Diveles the sance as N0. 2,315.

2,321. Auphlie cedrorum. (No.re) 7.5011 .98 今 Wrig, 3.85; tail, 2.60; bill from nostril, 28; ofafe, '75-' tarsus, 72; midelle tor and elaw, 81.

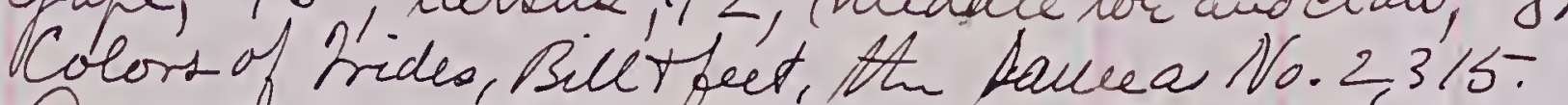

2.322, Aupelis cedrorum. (red.) 7.3011.75 F a9. Wnig, 3.68; tail, 2.40 ; bill from nostril, 26; gaf , 79; tausu, .72; middle tor and claw, 84 . oblors of hasts the same no No. 2,3/5.

2,323. Aneplic eedrormu. (Nore).) $72511.85+$ IVring, 3.70;tail, 2.38; fill from nosticl. 25 i gape, 75 ; tarsus; 65; middle tor and elau, 76. Olors of harts Atu sami as No. 2,3/5.

2,324. Nasse domesticis. $6.409 .90 \mathrm{Aad}$ Wrig, 3.00; tail, 1.55; culven, 53; gafe, 65

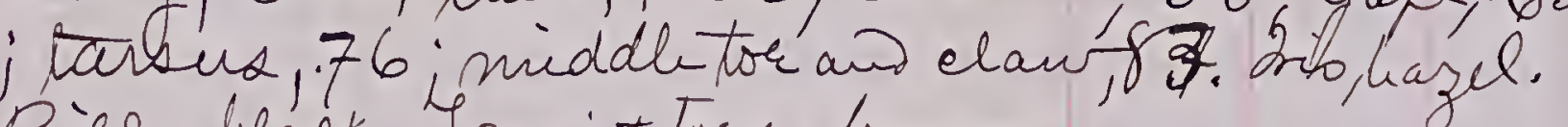

2,325. Bill, beack. Sarsittors, hrown 6409.90 今as. tring, 3.10; tail, 2.70; culuen, 44;gahe, 49 itarsus, 82 ; middle tor and eland. 75 . Ins, dark hazel. Bill, pale prik. Yassi, blesh-color; fiet, dusty-brown.

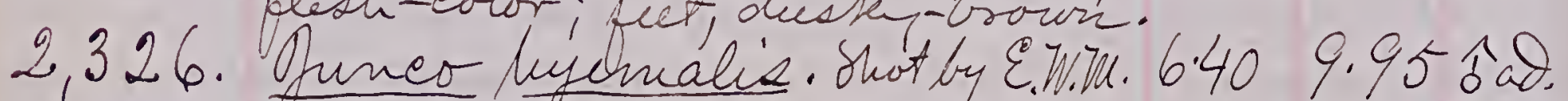
Wing, 3.15; tail, 2.90; bill (culnum), 44; ape 40 tarsuc, 83 ; middle tor and claw, 73 . dridarts hazel. Bill, pale prink. Tarsi, flesh-Bown; Let bourn. Shot by EllaW. Theasho.

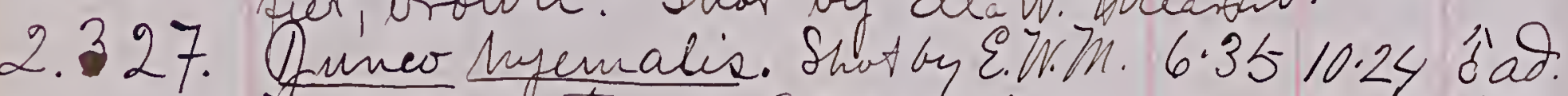
Hin, 3.12 ; tail, 2.78 ; culmen, 45; gohe. 50; tarsure, 85 imidde tor and exan, 83. Iria, dark hazel. Bill pale prik, maxilla slighth tipfed with Maek. Farsi and tors dubleif oroun. Shot by Ella W. Nearno.

\section{Sialia sialie. Shot by. E.Wrm.6.80 12.00 fad.}

Wnig, 3.65; tail, 2.50; bill, nuasured from nostril,'35 igafe, 80 ; tarsus, 80 ; middle tor añ claw, 8\%. Hrides, hazel. Bill and fet, beark; inside of mouth, heels, and "soles" of feet, yellov. Thisibidd was mated with No.2, 329, and they were husting wa nestini place.

2,32\%. Sialia Sideic. 7.00 12.00 Ŝd Wing, 3.90; tail, 2.68; fill, measured from sos-tril, 34; gafe, .8 3; tarsus, 68; middle tor and clan, 80. Colorz of parts the saue as thore of its mate, No. 23 28. Hel musurmucts (includidy tarous) exad.

\section{To-day the weatter ic still very varm}

season; Atu swow mearly acl nelte for to the warm heave rain, which has filled ally of the depressions in the fields with suncature takes. The Blue Birds (Sialin sialis) are both for breadin hlaces. Surval Eurofian House Sparrows have beren frosfucting for neetiris sitrs about the house, and have freid the frenalty of intruding witt thir SHive and liver. Cedar Birds (Anpelic Cedronum) have bean abundant. 2, shoothing into a flock, Nilled six , all immature (?) having no waxen offendages. Nost of the flock clew array; but a nuall number allighted wt a shirt distanee. Ofired into and killo firg of them, all having waxcu ofpendages. Again my wife shot mine from al hear-tru , all of whibh wre young(?) Mavin wo red aphen-dages. Thi flock then aliegled in the edge of the woods, where she Aried eg ain and Ailledisix more, four of which had sed offendages.

Agail dinting houe trom a shooting excursion we came to a large floek of Cedar Brids, sitting 
288

289

$$
1882
$$

1822.

ware the old birds, and, if I had shot into them I would have secured only wrll-devaloped speerniens having washer appendages to all of their wigs some of their tails, and a fou with yellow spots on their wigs. Out nearer the road, feeding in the cedar ware large number o of the birds, which, on bring tensed, alighted all togitur in a large tree-tof. I frrediute Prem and Killed eleven, without a singh red mark on our of them

Now it has bran my constant ex her- ieee hin winter, when shooting Cedar Parrot, to Kill all oedinits 'else all young one e at a single slot. The old birds, when feeding, Keep afraid by themselves, and are t to last to leave when frightened or shot at. A great deal of experience has made me perfectly certain of these forints.

ot is a wren or two since I saw the Yellow-rumfed Warbler (Dendrozea coronata) about. I trick that the warm spell has started them all of migration not having commenced as yet, we are left without them. This was the case in the string of 1878 .

Cur minter Robins (Lirndure migratorinz have also deserted us.

The migrations have not be gm Evan with the Snowbirds (Junco hyenualis) and Iris Sharrouz (Spizella montana); av no migrating Song sparrow z (Melospiza Aaseiata) have born seen. There are only th few winter msidents in their usual haunts, and not singing-

Grown (Cores fungitorus) are migration. in a constant, straggly maura. Hey are mating also.

No Blaedebinds, Fox Sparrows, or Phoebes have y it brim seen, although the water is so hag the ordirian early butterfly, having buffy Edging to ito chverlate-colored wing 2 war sech
today for the first tie. the piping Frog (Hyla hist heard today. (He Peking ii) were also I caught a Spotted Lute (Nawamus guttate) Hiv nothing, also the fist of the season. Ito left tore-foot was gone, and the stump had the appear- arne of bring congenitally deformed, ratter than the result of an accident.

The ce in At thadeon, which had bean be oked above W st Port has bern broke uh by the heavy ruin fall; and tiring Lull e (Larva argentatus) are flejig in blocks. Folden-crested Ringlets (Regulus saltrapa) which have been absent (?) or extremely seared this winter are beginning to cone about the house, and are seer in the woods.

White-billied Thethalches (Si ta carolinensio) Lave bean ratter numerous for some wets, no a fur have bran about ald wiretr. No Red-bellird N thatches (Seta canadensie) was sun derry last cuetiminis injection, nov have any bran sen this winter hast.

The Groom Creeper. (Certhac Aaniliairia), usually a common winter bird hast not been once seen this year; and a small number sen near Marrisous, on December 30, $188 /$, are the one y ones I have noticed this winter. the following species have be ru abuse- daunt all writer: L

Indus migratoriuz, Sicilia sialis, Carpodacus hurpurene, Astragahnio tristich, Dendrorca coronata, and unless ceerdoun, besides a 
290

291

1882

1882

Zuareh 2 nd. Continned.

Lew of the regular birdolik the buowhin v bow. trare tharrouls (Skizella montana) Mough not searee have bran much less connon than they revally are.

Piens villosus 6 have not seen this year morr than onee or turees.

The Winter Wran Anorthura troglodeftes hyenalia) I have seen but one this yrar I w Tan 21st at Poplofen's Pand. Se p. 277.

The Yillow-brllied Wootheck has brew

sum bily once this winter on Dee. 25,-1881. The Holden - winged Woodpecker Colaftes auratus) has alsobut one reevrd tor Atw last winter, viz: Gan.610, is82. Sulp. 269.

Snow Buntrups (Plectrophanes míalis)

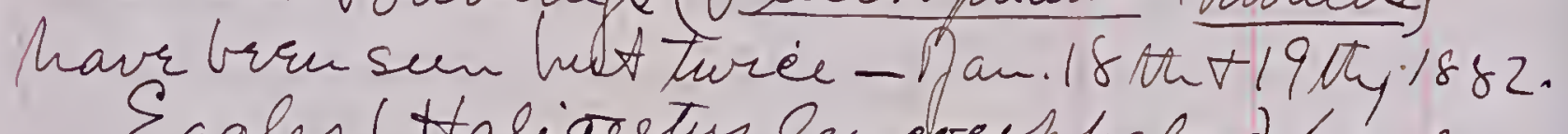
Eagles (Haliaretus lencorephaho) hav brum about all winter, probably breding,

It has bren a foor seacon for winterfinds. 2,337. Passer domesticus. 2,330*. Astragalinus tristri. 5.008 .60 . 9 ad. 42 , tarsus, .53 ; middle tor and claw. 59 . His, hazel. Y arsi and tors, hrown anterwily and suferiorly, rapectirly; flech-colored

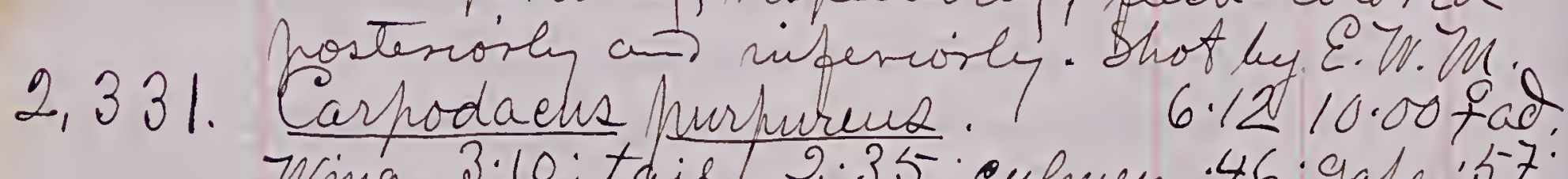
Wing, 3.10; tail, 2.35 ; culven, 46 ; gafe, 57 ; tarsus, 68; niddle tor and elaw, 70. Mrs, hazel. Bill above, dusky; below; hom-evlor. Sarci

2,332. Asufelis cedrorum. (Ad.) 7.05il.70 fad. Wing, 3.75 ; tail, 2.50; bill, measured from, nostrie, 25; gapi, 70 ; tarour, '155;

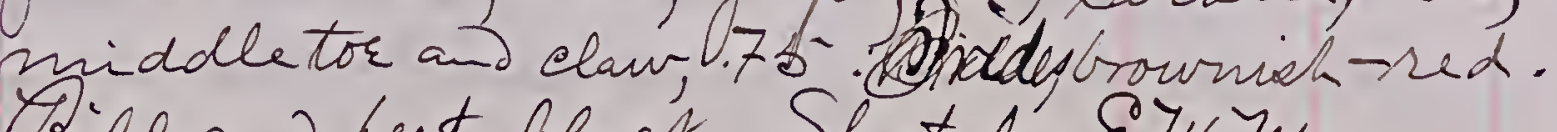
Sill and fuet, blaek. Shot by E.W. .U.
$2,33.5$

2,334

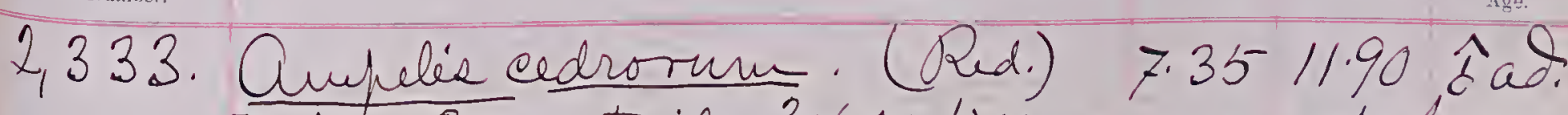
Wing, 3.80; tail, 2.60; bill, measured from nostril, 25; gofre. 74; tarsux, 67 ; midde tor and elaw, 80 . Fre, frourvish-red. Bill and fut, beack. Ita throat eontained 18 large cedar barries. Shot by E. W. M. .

Ampelis cedrorum. (Red.) 7.4011.90 îad. Wing, 3.75 ; tail 2.50; bill, meacured from nostril 27; gape 1.77; tarsus 1.76; middle tor aw delow, 1.8 st. 2riz, brownish-red. Bill and feet, black. Shot by E.W. Mearns.

Anpilis eedrorim. (Nored) 7.4011 .90 ô Red shapts Wrough the yellow tersinial bawd of tail; but, at stated abovr, then are no waxen of pendger. Shot by Ella W. Zlearns.

2,336. Anpilio cedrorum (No red) 7.15 11.50 ô Draces of brown in the blue of the rusef, which is a sign of youth. Shot by Elea W. Mearns.

Zuarch 3d. Ningy.

$66010 \cdot 15 \mathrm{sad}$. Nonig, 3.15; tail, 2.60 ; culmen, 56 ; gafe, 63; tarshs, 77 i middle tor and elaw, 8. '. Mis

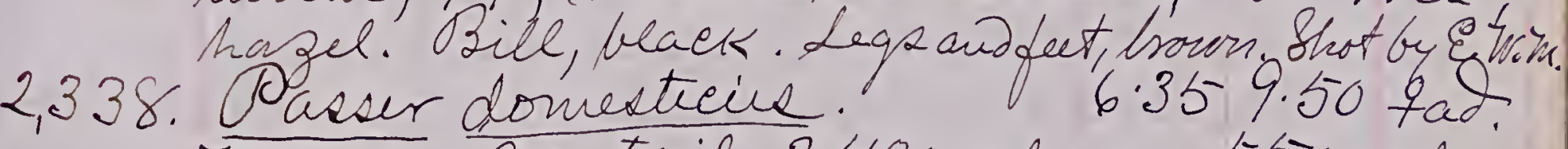
Wnig, 2.90; tail, 2.40; culven, 55; gape, 63; tarsus 7/ middle tor and élaw, 78. 2is, hazel. Bill, oliv-Grown; basal haif of mandible ard edges of maxilla at base, yellow. Yarsi and tork, bi ht brown. shot with its mate above by EllaW. Niearns.

March 4the Heony.

Passerella ilciea. - First sceh.

Cene floek of thee, of which Ella shat two. then a single bird, and another flock of four were sem. We could find so more? 
294

295

1882

1882

Warch 9 th - Contirued.

and Robinizabout th house.

A Arrat Aorned Qwe (Bubo vinginianus) was cleased for some tivice si the worde brlow the house, but was to shy to br oftained.

2,344. Cesthia Aamiliario. $5.507 .90 \hat{b a d}$. Wrig, 2. 58; tail, 2.42 ; culuen, 65 ; bill, measured from nostril, 47; gape, 79; tarsur, 58 ; middle tor maxile ecur, 164 . 2nis, hazel' Bill, with maxitte, black; mandible, Alesh-eolor, fintish. Varsí and tore, Glestur-brown. Shot by E.W.M.

Zharch 12th. No.111 E.72》St., N.Y.City. Yreterday my wife ard I cane to newifork to do some shopfing. The tide was low when ir reached the Aarlem River, and on the sund wen

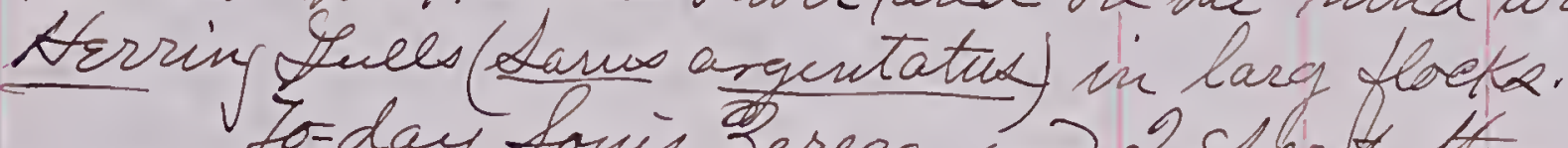
Lo-day Lonia Jerega and I sfent the afternoon tu Central Pers. Qu the central wall of the Croto Reservoir were hundreda of Sed Lulls (Larus argentatus) and othere mere seeu grayunty hassing two and fo betverew the rwirs and the Reservoir. Let the north-wat en of the Park we found a fais of them catieh goldfisheal in the "Vool". The ford ia so encale that the Hulls wrre sonewhat enced for shace in making Their aeirial evolutionic. Druas a vory prettr tining to wrateh them, ad wr could rasty see sory motion from the brite of the ool where us vare standing. The gold qicher ware seen lying in shoat water alobs this edge; wht henever one approache the surtace ouftim thir ford a tiel would suvop doure, and wr found that his chance ura about ou two. They sometries chased rach otter and tried to take a fish which the otherbird had captured, uttering sereanes

Hox. S/larrows (Passerslla ileciea) wrre munuroy and singin on every hand vrry swerlly;

The. Phorbe (Sayorni fuschs) war fowis

"Ai the dust of evaning inl a qiilet conner of "thusate" wag ging ita tail, which attra eled ourattention. He got wittur a few feet of it, but it was silent still, and sat bagging its tail rui the aldirs aloug the shore, afparently eujorpin An shadow effect fietured nie the wate tereds it of 12 the geist seen this year.

Livealus petrpurend was abuncaut.

Spent march 19tt. N.2.p.t.

Spent the whole of last wrek ni ter lrarrix of the Ameriean Thuseumi. Othe litrary is ofered of:

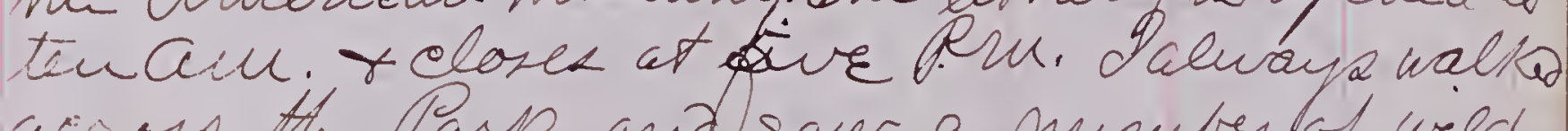
acrosa the Park, and sav a number of wild Grids. Fox Sparroux wre always hlewteful. Sou Sparrowz (Nelospiza tasciata) Jany every day.

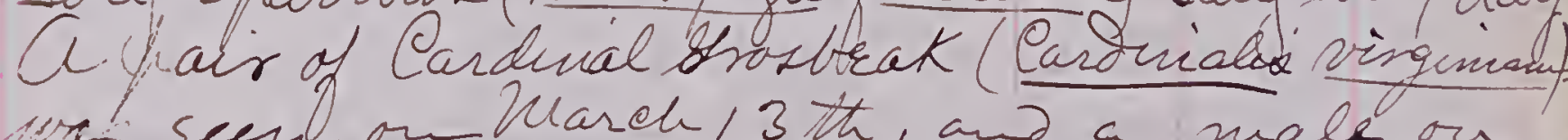

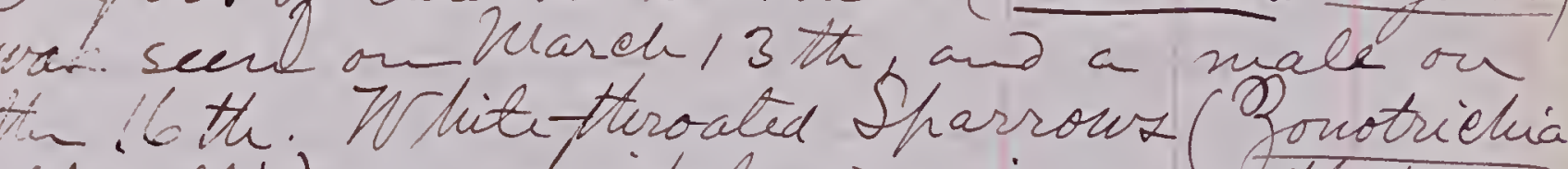
albicllie) wre first heard serifing on th 16 th. suant Sparrow was heard on the 12 th. terow-black birds (qusicalus). Wrer seen wrry tive. Eobris (Jurdus nupratoring) were singing on the evening of Marela 6 th.

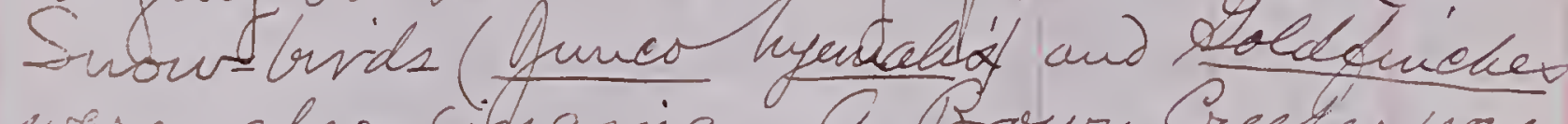
were also sifhging. A Prown Crecher var seen on the It Al Back-eaffer Oluckadeed (arux atricopilus) wre sonetrinis seen, as were

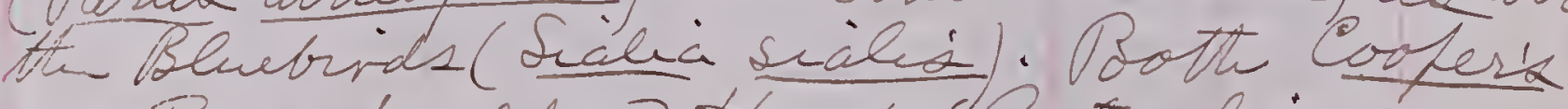
ano Red-shvuldered Hawtle (Buter liriestur) wire seen ou th 12 th. Irwallting acrozk Anpark one noming fir different Stray 


\section{Znareh 19th _ Contenive.}

Aquirels (Seiurna carohinencis) wrre seen; and one evaring retirning after fire o'elock with Lonio, wr saw a Pabblt (Ifeus sylwatrein) and six Gray of apuriels. Jwo of the latter vere playing dik kitterson the grals,

ove each othe, and fristering entertainihgly about Do-day, motter Slea and mpet 1 saw He Bluebrids (Sialia Sialio) gathering Materiols for a nest, and nispecting the sarious tiri cans which I have plaed intrees of theriase.

Cl Ser Squirirel (Senive hublsoniu) uax seen to cone and chint in the folecorrse with rose vines to the bird-house, where he may have gone to look for binds efea arto deposit store of food; ch hoskbbliciofon a vest for hinely.

\section{Tharch 20. H.F. N.Y.}

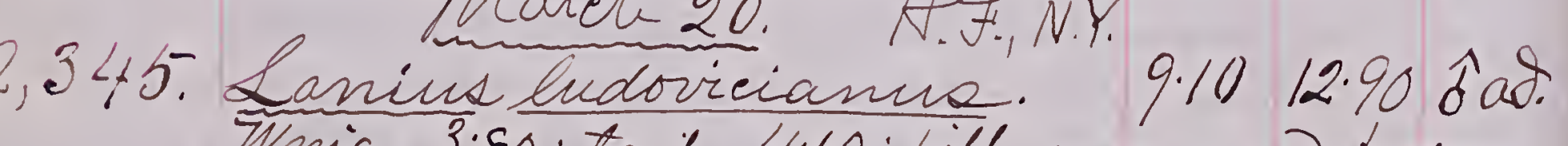
Winia, 3.80; tail, 4.10; vill, measured from nostril, 47 ; culuen, 70; 9 ahe, 98; tarsus, 1.10;. middletor an elaw, 9'3 tor alone, 70; Claw; 27 . Jiz, dark hazeh. Bill hlaek; blue at base of mandible. Jansiand tors, blaer. The labore ifecinen (N. 2,345y wad shof at Arèleville, Chio, ou Mareh 16 the 1882 , an was seut to be by mail. Shot on Campboln's meador" Ho-day a hair of Bliorbrs (Jyonid tweena), evidentty the old ones that wire in th sacue place Cast season, cauce tur. Thalornsy'2 vam ot the eno of our plaee, wherethy wire hiand before we were uf un lti=. nest at otiee. Yher are the oust seen. chout here this seasor. S savone ni DaTE.

LOCALITT:

were seen there dumig the whole of to ensuing wack; and mu Write says that none wrese seen here durihg the last wrek This moming the Wood Froga were makinig a graut racket in the swarnps where they go thbread every opring. Deafturd a hai in a brook, as I was going to fiek wh a hain of Fox Sfarrows which I hat bhot. The Ituah while the male vas beackiel. Thuy wre' copulstinig and the mall held thi feucale past while gheld th latter by the hind leg for a long tine. Then I put both inside of a profer, and when I rached howe he still was eubraenig 4... funale. I put both toglter in a jar of alcohol , and thy are preserved in the same attitode. The first Painted Luth (Chrypens was seen tho captured this moning. It wast on nimature one, and a large Alecel was atcelned to it. It was preserved with tim two shemins of Rana sifwatica abovr mentioied The Hox Shasrowk (Passerrla Eleia) iver singrig, and conere Purfile Finelea (Corpodacus hurpureux). Wy wife, conf aring At songe of the two findas and that there war the difference brtwern them that there is

betwern a clear soprano and a vich contralto voree.

Sive writing the abore of fomatth Wood Froge in large numbers in a shallow pool morth of Highland Lake, where they falily suamed, and ttui eggo ware ril lastge seen by thiwatir-whel at thwald wiel as gode past. There are still tows of cel on the side of the mountain velind the Gake, where nimatere glaciers formed decring inites. 
298

299

1882

1882

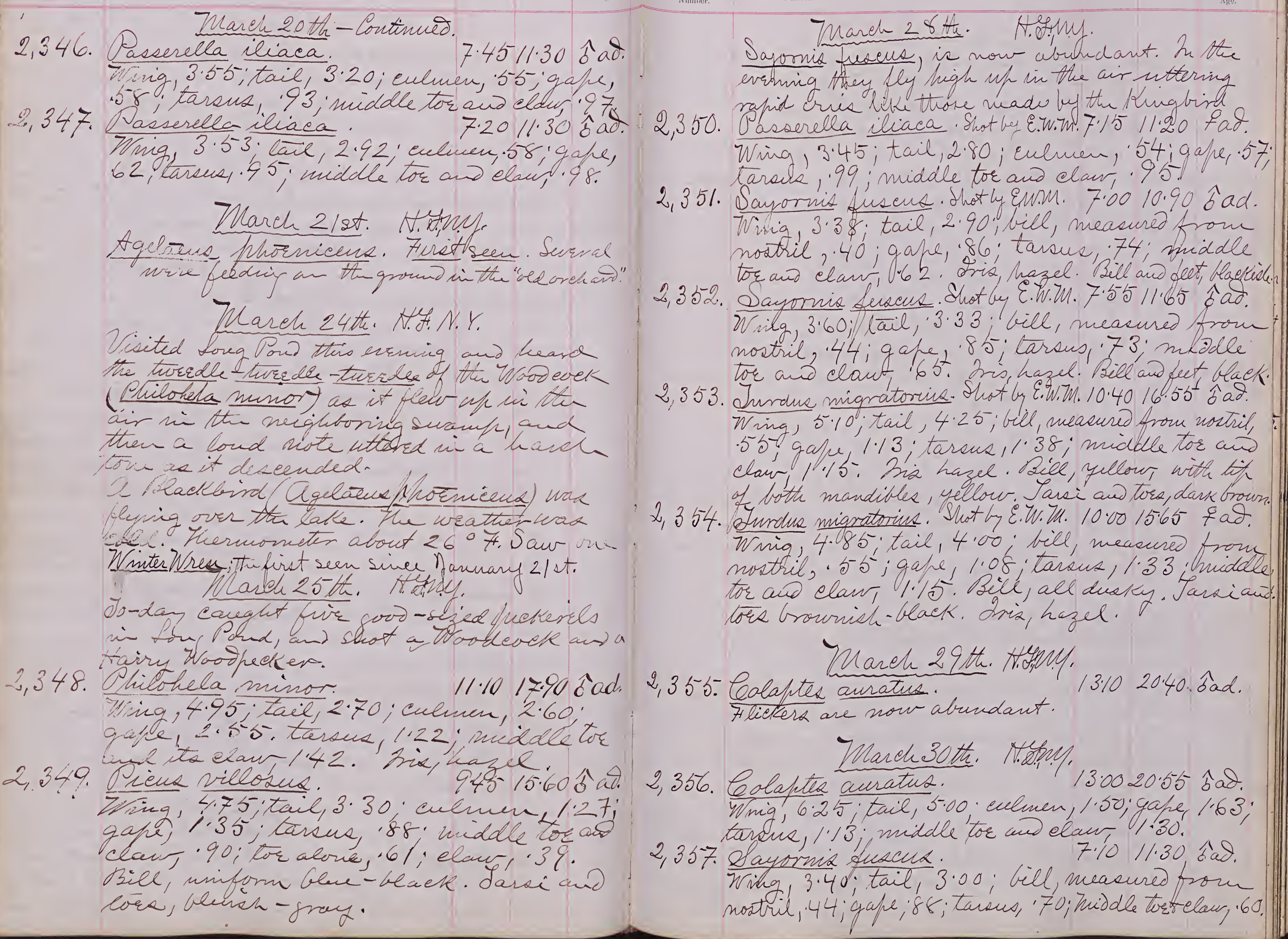


302

303

1882

1882

April 8 the - Continued

Mr. Jerome Lena told me that when fishing last summer at Lake Clecawana, in Si tram Comity, N.Y., he was was fisinnig around the conner of a high rock, when a Kirigficher swallowed his minnow bait, and was varied in, screaming an fluttering wildly, After examining this strange product of les haciatorial skite, and apologizing to it for their mutual mistake, he gave the poor thing ito liberty again.

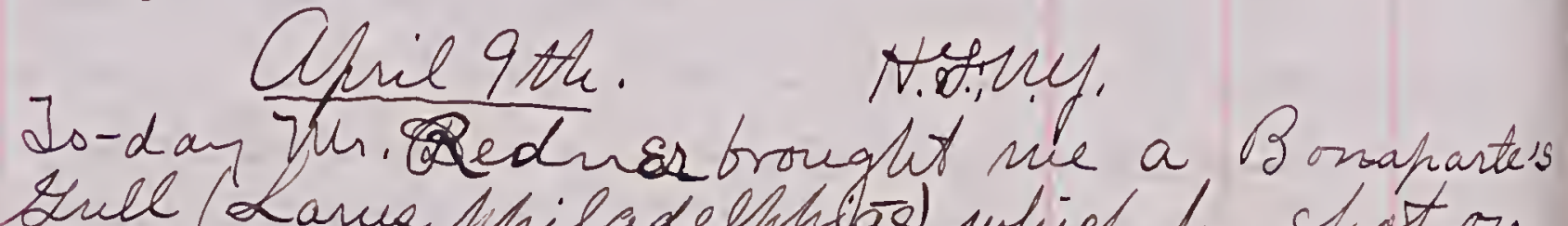
Enl (Larne philadelphian) which he shat on oplopenis Po and on April 6 th, from a large slack. Another was slot sone miles wet of Poflopew a on a small lake. The bird'sury war broken and it was still alive when 2 got it; but it had refused all foo. It shopped and bit viciously but not very severely, After showing it to my wife, \&

$2,363$.
Lares fhiladelfhiàt. $\quad 14.2533 .75$ fa ad. Tring,10.80; tail, 4.15; culver, 1.35; gaff, 1.90\%, bare part of tibia, 77 . Tarsus, 1. 50; middle tor and it a claw '1.55: Tore alone, 1.27 ; claw alone, '28. Aria, Goglet hazel. Biel, entirely jet black. Bare part of tibial, tarsi \& tors, red; nails, brownish black. Inside of mouth, brill ord. Lou que, red Shadiu, the rough horn -color to blu, and black. His specimen was in transition plumage Hs head showed an not thin of plumbrous 2,368.

ffizella socialix. - Jo-dayd learned sonvettring new. the Shifting Fharrowhas a real song, not lond, but sweet and Frich-like in addition to the surest trill which, later, be- comes so decidedly monotonous.

April 10 th. H. try.

This morning the ground is white with snow, and a tinosflere chilly; still the Large - billed accentor sing a along ti brooks. a single Rusty Pocaekle was whistling in the woods below the house. Dts notes are peculiar and exciting. Had I not seen tire bird and known it to be solitary, I should have supposed, th. sounds that this one bird produced, that at least half a dozen were whist ing at once.

2,364. Situs motacilla. 6.4510.60 S all. Wig, 3.35 ; tail, 2.25; bill from nostril, $45-$

2,365. gape, 75 ; tarsus, 91; middle. Tor and elaw.75. Wing, 3.70; tail, 2.85; bill, measured from nostril. 38; gape, 80 ; tarsus, 1.18, middle

2,366. S colecphagur Lerruginens.9.90 1515 6 ad. Wing, 4.65; tail, 400 ; culver, 92 ; gape, 1.00; tarsus, 1.22; middle tor and claw, 1.24.

2,3 Dis, hight yellow. Bill and feet, black.

8.5015 .45 bad. Wing, 4.85; tail, 3.20; cullen, 94;gafe, 1.04; tarsus, 78; middle tor and claw;.90.

Chriel3th. NEtty.

Spizella pubilla.- First sem. All torres Ares of Spizellate are numerous today. endrorca cononata. - Que seen

Shigella pusilla. Wig, 2.42 ; tail, 2.42 ; cullen, 37; gape, 40; tarsus, 74; middle tor and ito claw, 69. Arishazel. 
2,369. Wulospiza Lasciata. Ap.13.6.15-8.80 今ad. -54; tarsus, 86; middle tor and elant. 88 . His, hazel. Shot by Ella at "Ehobake".

\section{April 15th. H.y.y.}

Dafserella iliaca. - Shot a shigle bird, whech was alone, and proved on blsisection to be a female, but wae too badly shot for meseritation. This is the only one seen for a wakk or more.

\section{April 16th. H.Y.M.Y.}

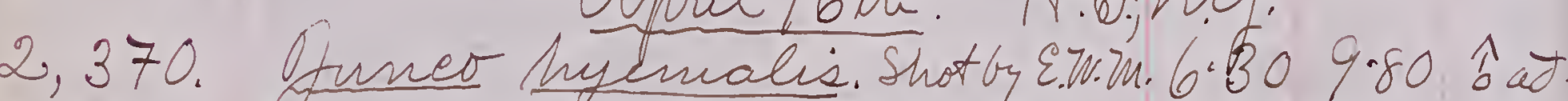
Drinig, 3.00; tail, 2.80; culuen, 45; qake, .5\%: tarsue, 183; middle tor an claw, 76 . Corvus frugivonus. - Ella fonnd a nest whieh ebutanied three egde. The ouly otter nest I have found was hot coufleted.

\section{April 17 th. Nonn}

2,371. Poorectes ovanimens. 16.50 10.65 sal Wrig, 3.10; tail, 2.70; culmen, 44; ga/e, -50; tarsus. 84; niddle tor and elow; 77 .

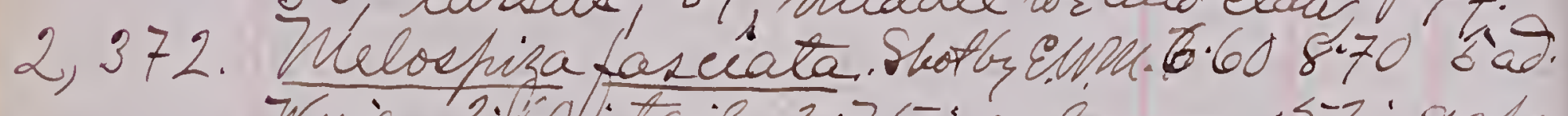

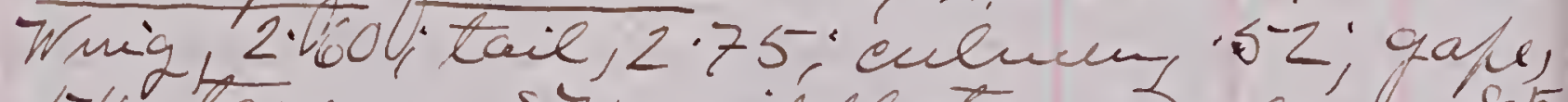
54: tarsue, 87 ; niddle tor an elaw, 85 . Potrectes graminens. - Firist seen to-day Qusiealus purpurens, Firf sen to-blay.

\section{Aprie 19At. H.KM.}

2, 373. Carpodacus hurfurens. Shotby End.6.35-9.90 ad. 2,374. Sidlia sialis. sad. Wain, 4.02; tail, 2.72; bill, neasaro from nostrie, 36 ; gope, 80 ; tarsus, 79 .

DATE.

\section{LOCALITT:}

middle tor and elaur, 86 . Cue of a hair tharing a rest in a large tornato ean in Then shot. Ch dissection it was fonmo to br a female.

$$
\text { Whril 20 th. H. Yyly. }
$$

Spent the abtamoon, with albert, at Pplopen' nond, where 2 saw four Drueks, a Sreat Blue Haron (ardea herodeas), and un a dult

White -headed Eagle (Haleacetus leveocephalus) all of these ware shot at in tirn with mo vislet. A doon Colymbus tirquatus) hag spent the provions two werks an the Cake, bot attrough my abject in goin wers to lay to choot it, the Gird conld not br found. Hellow-rumped Warblers (Eendröeo coronata)

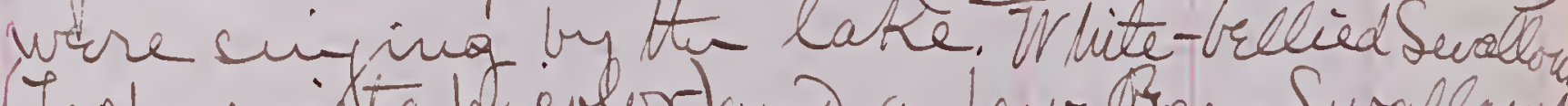

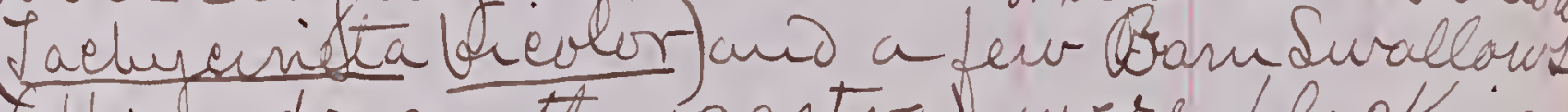
Hivando aryttrogastral were dlocking about the lake, and wre the frost Harhorhychus nfus was also girst seen. Whrie 2/st. Hest.

Dendrorea Coronata - h a fbek; simping. Harporleymetus infus. Singing as they wre yesterda Io - night brought the can containing th Benebirds nelst into the house, the semale sat close upon her nest whit the old rusty can was haken into from brikio. Then she dlew out, and was tilled: After that to my chagrin and reworst fir young oues about 3 days old were foud, dipo pet in alcohol as the brot valy of anding

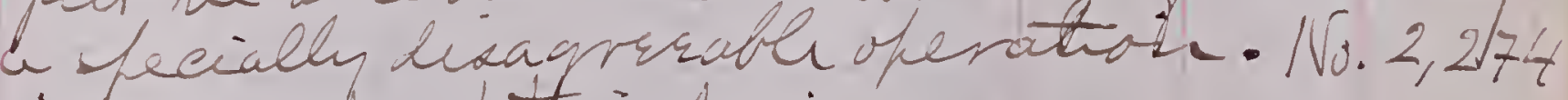
is the male of this pair. Ever suice the wiat wask in Nareh a deunale Bewebira has wisiled oro 
306

307

1882

AM

April 22 - Continued.

bedroom window, fluttered agonist the glad repeatedly and tried to enter, batty hard ag-arist the glass. This was Kept uh whose without interruption, cxeeft once for about three days, when she was not noted. She wad here as usual this morning aw may possibly br the parent wove stoke n of. She would albite an the sask and fell and fly a faust the urridow of intervals Lo r several hours, quite frequently, in this mo ruin before we ware wp. This was kept if six works. Once 2 arose and drew douse the wp per sash. Soon the Bluebird came to the stone ledge below. Thu window blew agonist th glair and tapped, then flew of to the top of the sashes i as soon as she desievorles, that the window was of en, she flew array - precipitately with a seared note.

- Sirius motacix _. - In the dustin twilight. lust night, I sou-sweral Large -billed.

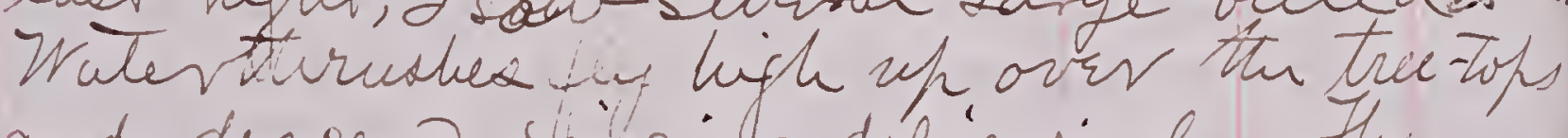
and descend afiliging dilievisely. The Corn Birch (S. aurocakellus) shared this habit. 2 would i . to Know if S. Matins, the only

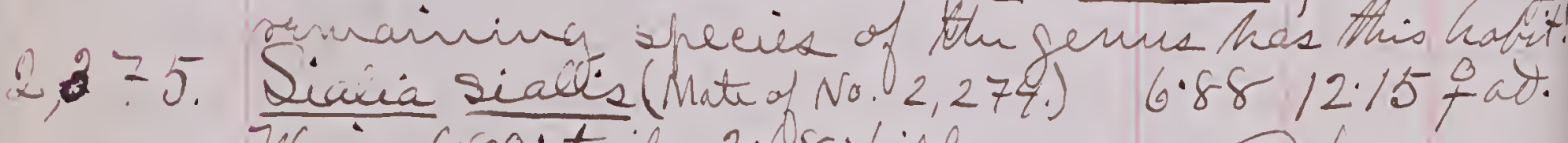
Wis, s.80; tail, 2.68; bill, measure? from notice, 32 ; gape, 77 ; tarsus, 79 middle

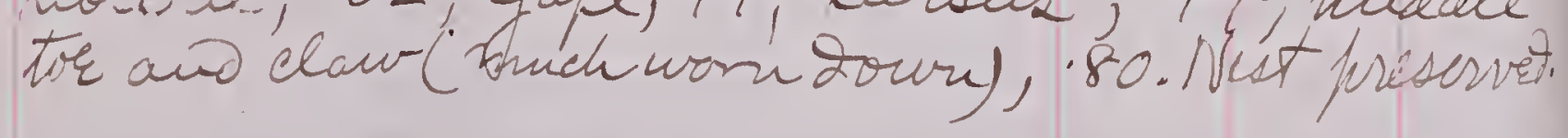

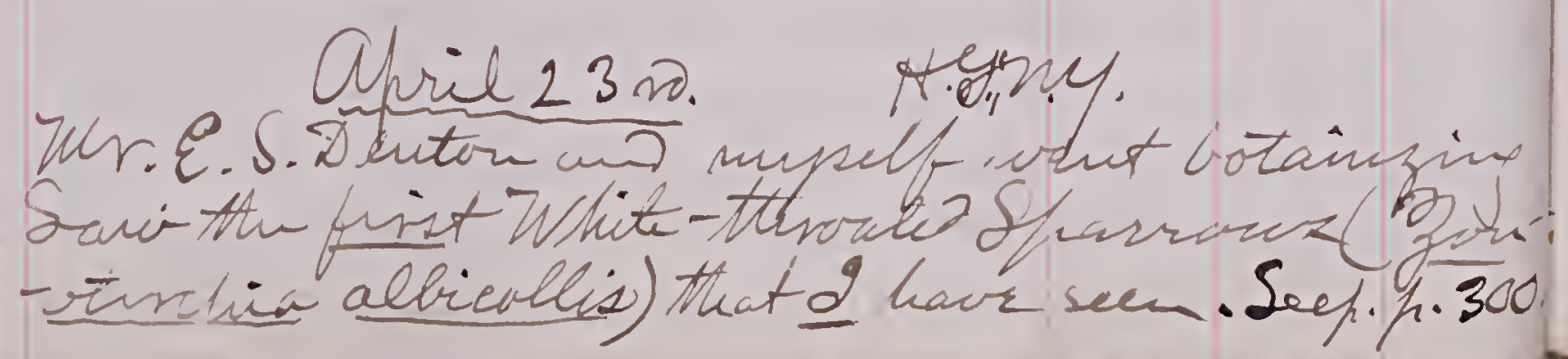

1882

DATE

LOCALITY

Length.

April 25 t流.

H. 赫rus.

2,376. leolaptes auratus.

$12 \cdot 6520.25-\hat{s} a d$.

Whig, 6.05 ; tail, 4.85 ; enhmen, 1.45 ; gape, I. 1.60; tarsus, 1.10; mid ide. tor a bo claw 1'28. Fris, dark rad.

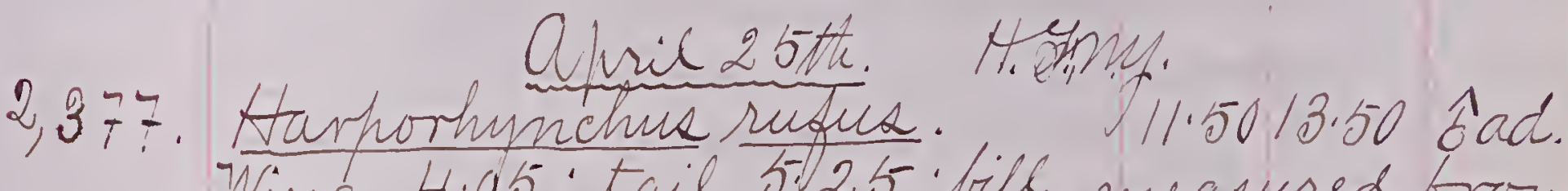
Nina, 4.05; tail, 5.25; bill, measured from nostril, 82; gape, 1.40; tarsus, 1.30; middle 2,378. Scalia chant, 1.15. Hiv, yellow $6.9012 .35-6 a s$. Wing, 3.77; tail, 2.80 ; bill, measured from nostril, 38; Gape, 80 ; tarsus, 80 ;" Middle

1.4 Tor and claw, 86.

7.0012 .35 fad. inning, 3.75; tail nostril, 39; gape, 84 ; tarsus, \&o, iniddle tor and clair, 88. This female was shot with its mate on Consook Llano, and bork unmistakable signs of maternity. Pts nest could not Gr fount. It measures larger than $\hat{0}$. 2,380. Q eqelans ptornicens.

9.4015 .40 ia. Ting, 4.75 ; tail, 3.90 ; cullen, 88 ; gape,

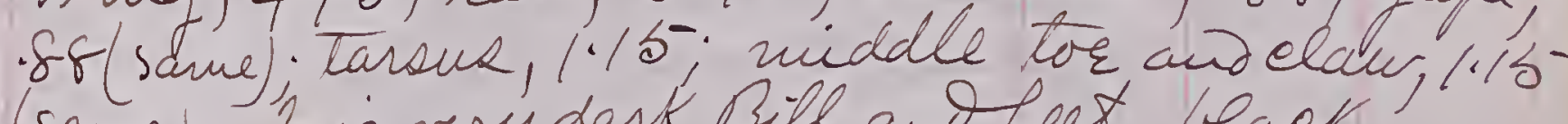
(same). Iris very dark. Bill and feet, black.

20pril26 th. Notum.

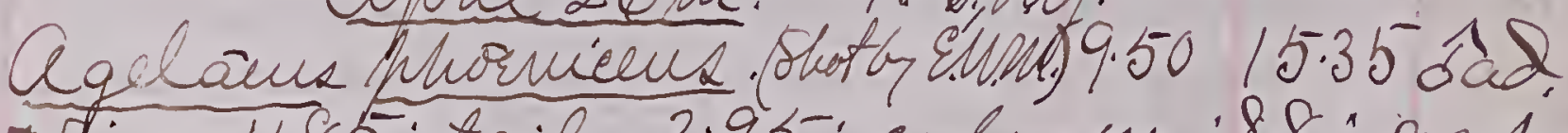
N ing $4.85 ;$ tail, 3.95; colum, 88; gape, 90; tarsus, 1.17 ; ned de tor and eld, 1.13. Lis vary dark brown. Bill an feet glossy black. shot by Ella in the marsh above the Lake.

April az. Hashes.

Spent the day botanizing, in company witt Mr. Ed uar S. Denton, of Nest Po nits 
We found the prist wild ginger inblove und e large brd of the exquisite white blossons of the blood-root (Sanginarian. and numerous other flovers.

Cu the mountain we saur a White-heady Eagle (Haliacetus leneoeephalus)

Andrea halmarmu. - Ferst sem

- enlus calendula. First sen in "Stony tonesone.", where wr writ te lovk at the Rhododendrond whose buds were wrll expanded for the deason, altionth a late one as seen be th late onuins of bott binds andlewero Several Rufked ronse (Bonasa unibeless) ware seen aingly.

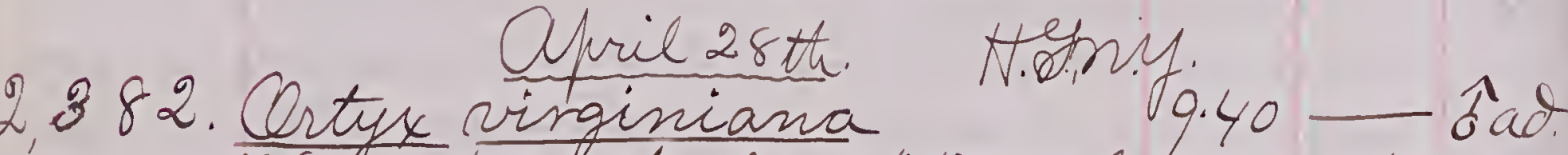
Wiita, 4.25;tail,2.55; culven, 58; ofpe, 6 2; tarreus, 1.21; middle tor a's

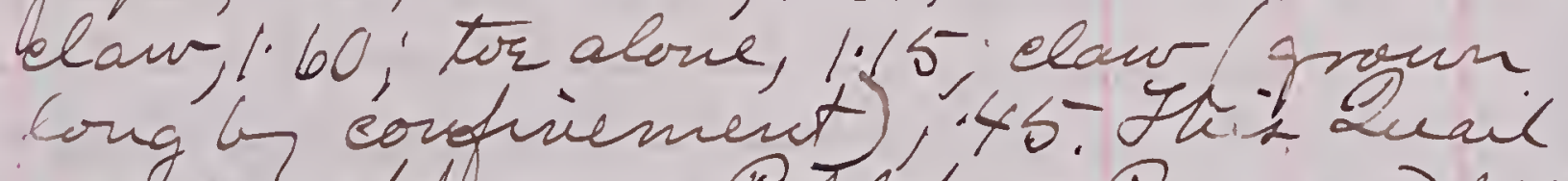
wast canght mear Poplopen's Pont, and beft in a cage since its eaptere lact fack hy ur. Serone Denua. It did and hivarit to me. Cave gring was elifled, and coudd wot be

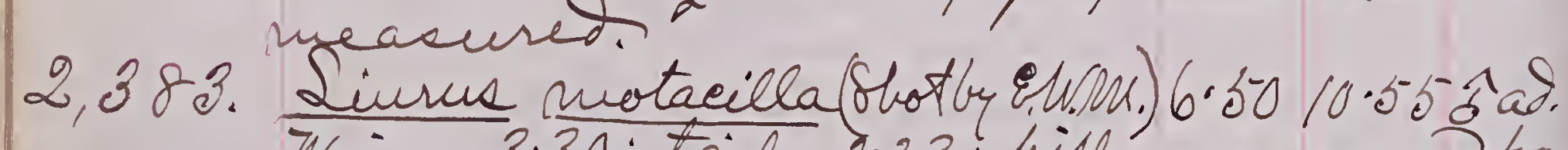
Wing 3.30; tail, 2.23 ; bill, measuseghom nostril, 43 ; gafe, 73 ; tarsus, 93 ; middle

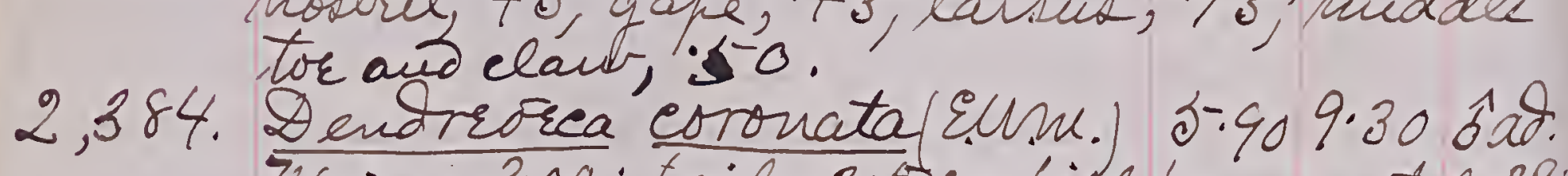
Vnira, 3.00; tail, 2.52; Gill from motril 29; gafe, 55.'tassus, 72 ; madle tor and

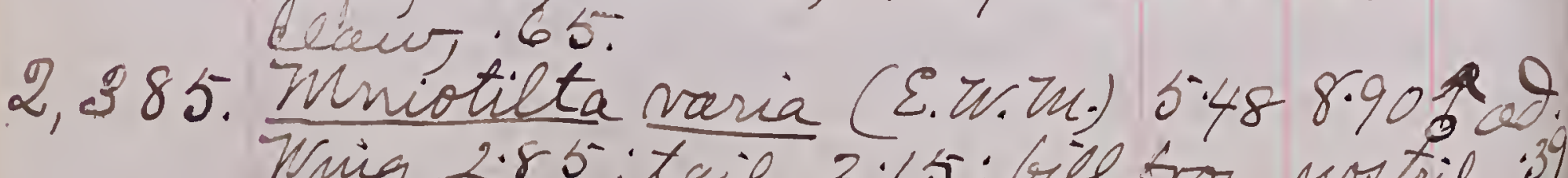

gape 66 ; tareux, 72; midde tor and elan, 71 . The first on sen this season.

2,386. R Equlur calendula. (E.W.M) 4.527.35-ad. Wrina, 2.35; tail, 1.80; nostril, 26 ; gafe,

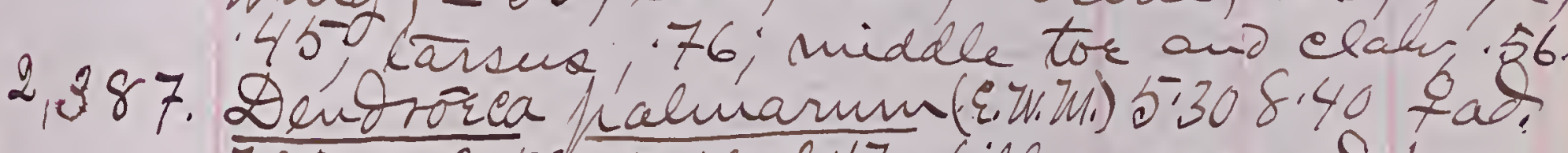
Wring, 2.50; tail, 2\% ; bill, measureg from nostril, 28 ; gape, 53 ; tareus, 83 ; middle

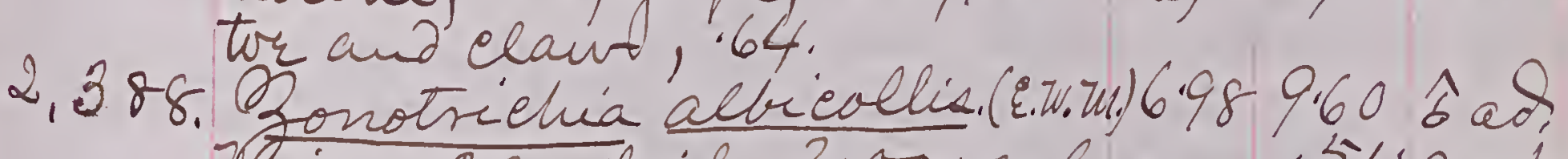
7 ing, 2.88; tail, 3.00; culuen, 51; gahe,

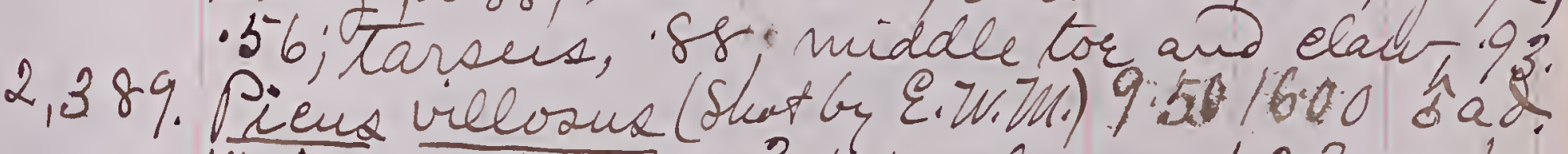
Wring 4.65; tail, 3.10; culwen, 1.2 3; gape, 1.30, tarsús, '88; middle tor and elaw, i97. Minotilta varia: F irit reen.

Pipilo eryttrofithabunk. Firt sen. Pandion halcatus carolininsis. Ecene alighted in a tree vrside the Lake, anco staled about there a long white

A Red Salamandi. Canght in Cro'Nest cavine. April 29At. Higny.

Fandiou haciactus carolinemois. Seen at Pell's pond Ir Todytes domesticus. - First sem.

Pelicetura pelagrea. - First seen by us; but Iur. Eduvard S. Deiton is hositive trat he saw a number of then yesterday at West Point. Bringoides maenlarius. Frist seen. Cue at

2,390. Lurdur hallasi. (E.M.M.) 7.2511.40 7ad. Wring 3.60 ; tail 2.90 ; bill, measured from uril. 35 ; gape; 85; tarsus, 1.18; middle

2,391. Estragalinue tristi. (E.W.M.) 5.05 9.00 ô ad. irnig 2.85; tail, 2.05; culmen, 42 ; gape, 42. Tarsuz, 52 ; nuddle tor and dean
$.5 \%$ gris, dark hazel. 
310

311

1882

1882

April 29th - Contined.

2,392. Harporthinchworufus (E.W.W. 11.50 1365 bat trong nostril, so; gafe, 1.30; tarsuo, 1.35, middle tor and eldw, 1.21. Tric, yellow. two white feathers in erown.

2, 393. Aarporhynchus rusus (E. W. M.) 11.6013.70 50. Wing, 4.15; tail, 5.40; bill from nostril, 83 ; gafe, 138 ; tarens, 1.40 ; middle tor and

2,394. Piens villosus. (Shot by \&.w.2n.) 9.35 15:157ad.

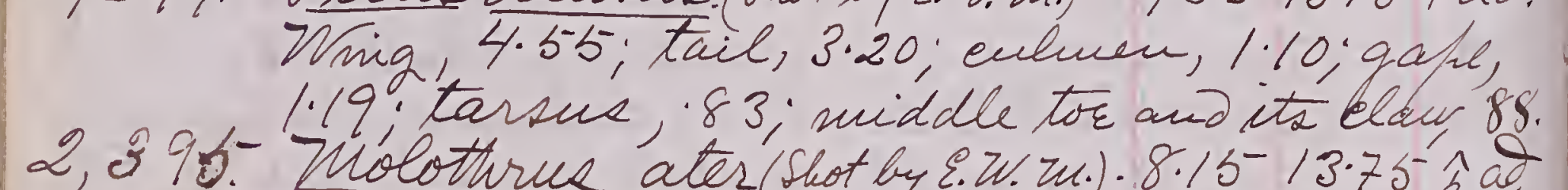

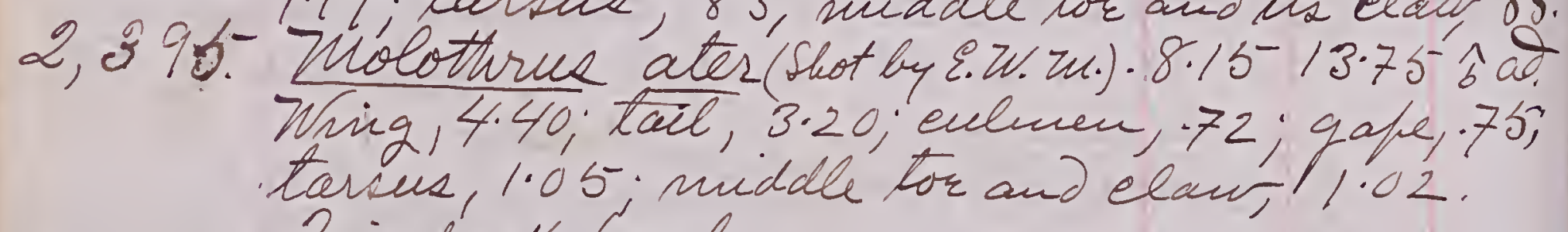

2,376. Dis dark hazel. Wnig, 3.50; tail, 4.10; evluen, 55 ; gape, 72 ; tarsue, 110 ; niddle tor and claur, 1. S S: fale brown.

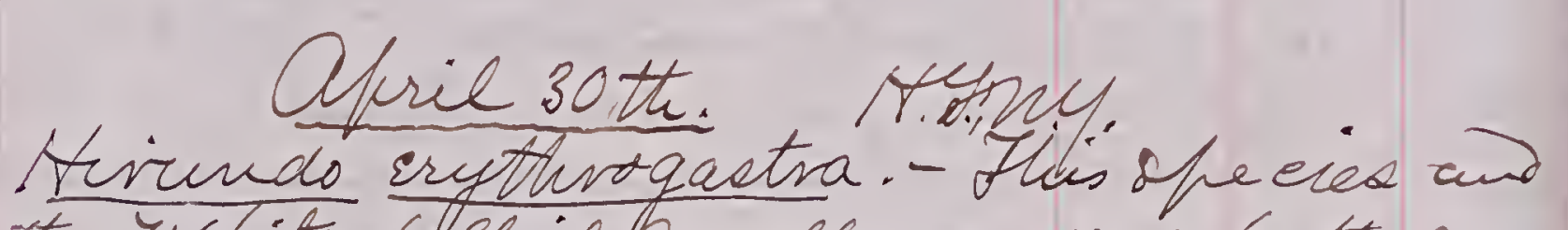
the Wottirin larqu numbers, at Paloh- en's Pond, on april $20 \mathrm{th}$ : Io-day a suigh Bam suallow was seen on the sall massh, the first one 2 have seen sinee the 20 th

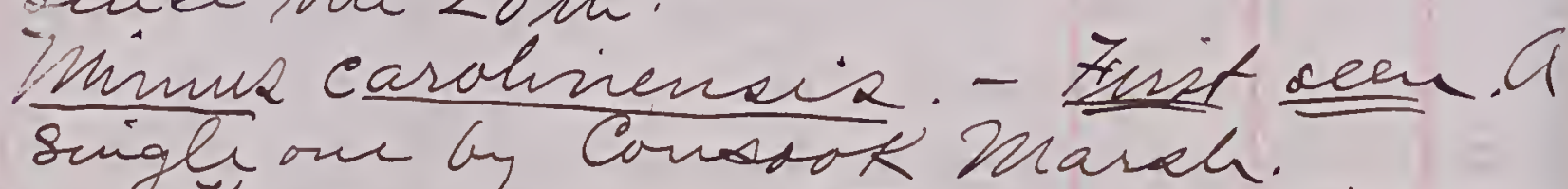

The season is Late. Surral Warblu. and other birk, wheh usually eving to se in April have cotyet arriver. Thy first shad-blossoms wregattere to-day Mhay /st. Histy. Vires solitarina. - Fist seen. Aue bird which The Goldfishes (Crassino auratios) mach take. Hhey will frobably sovn bzin thairin Ayla hickeringii is hifin about bis last. Jodds are beginni to ofawn.

trarmigr are runsing wrel in the Hedoon,

$2,397$.

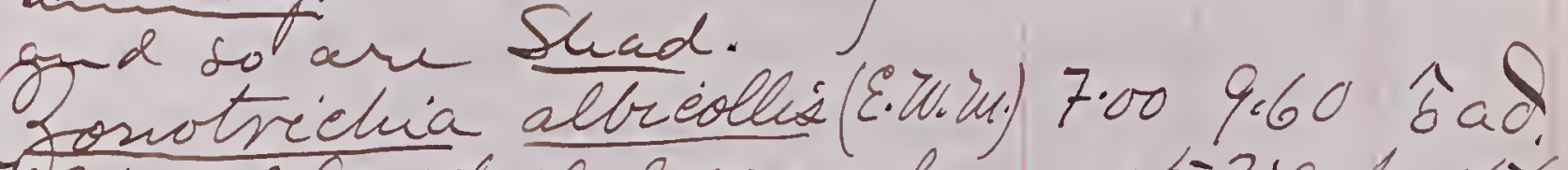

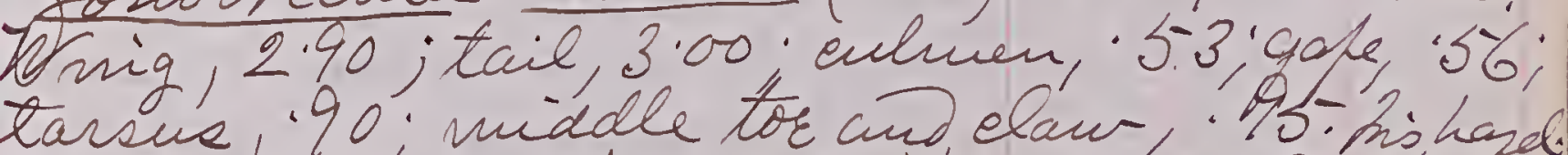

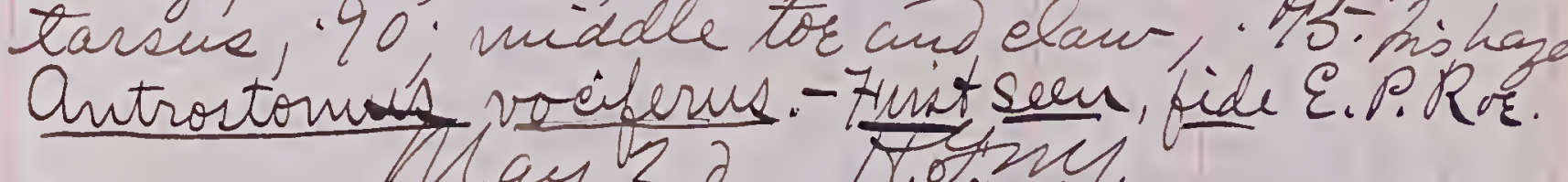
Enfidonax chinimin. Finst sein. tohhaga carolinencia. - seen ¿ireo dolitarius 3 . Firow

Iurdus mustetins. First seen. En Cro'Nut Dendrorea Destiva. Firs sen, Luvo on Moodrabren Iurdu migiatorius. - Whice walking with ws doring the trist Robilis nest, containing o egge. A large nussel as big as a gobo-sizes clan was equght alir in Mosdna ereek Alse a big Woo Lerripin (blyfluyg

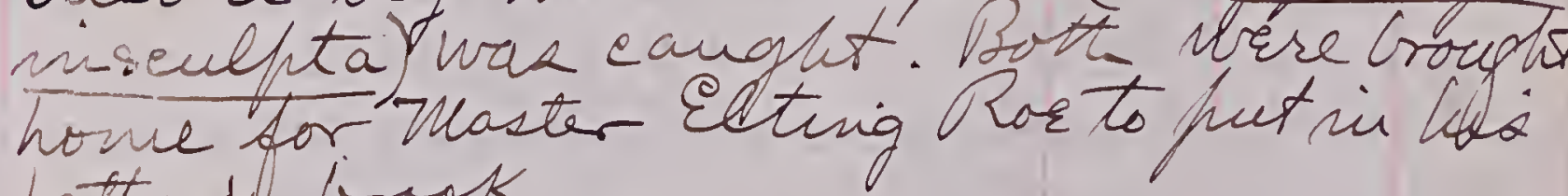
fattrit brook. Qminalus furpurens war Ius Grat White Egreto (NErodias alba Eyreta) were sun the moning in invodina Creet, 
312

313

1882

1882

by Wr. Willet $3 d$ - Contiued.

by Wr. Villets; but we ded not find them in

A Red-tailed Hawk (Buteo borralia) wax

2,398. Eendroea ástid. Wring, 2.38; tail, 1.90; bill, masurec frow nostrie, 33; gape, 56; tarser, 6 5;.

Leterns gavbula. - First dee...

Denosfiza cyanea. - Firt seen.

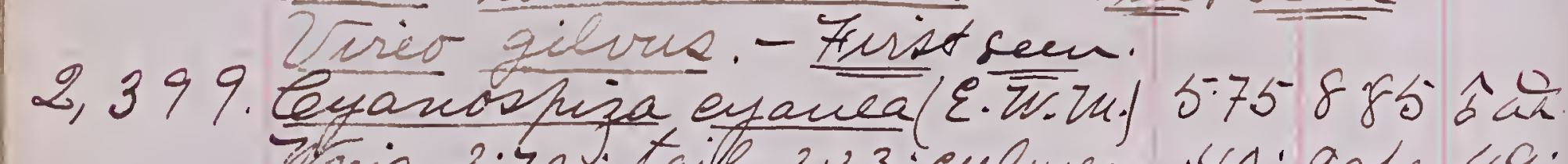
nig, 2.70, taill, 2.23; culven, 40; gope, 49;

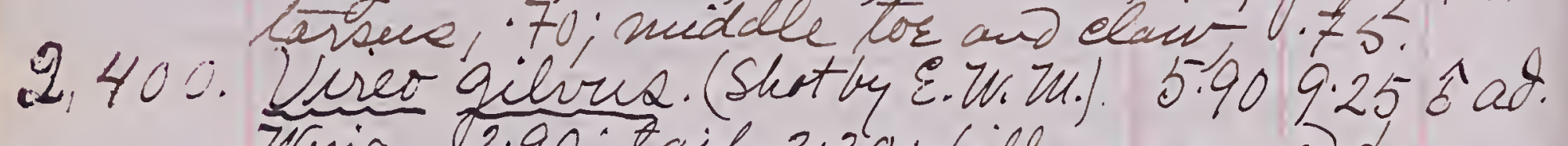
Wrig, 2.90; tail, 230 ; bill, neasured from nostril, 34 ; qaft, 72 ' tarous, 70 ; niddle tor

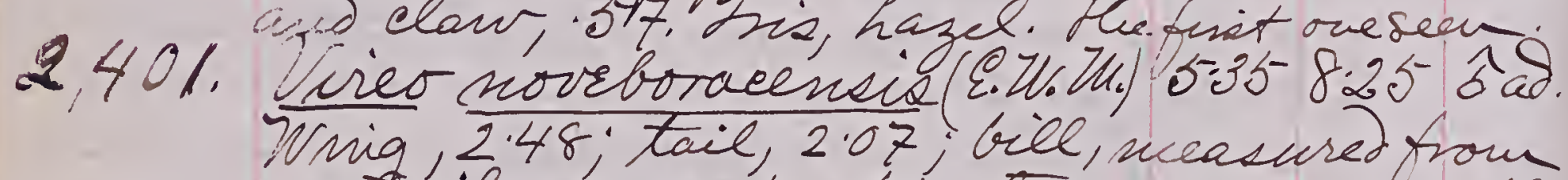
nosteil, 30, gafe, 64 . Lasue, 78 ; arddle tor and elain 57 ; Gid, white. Fint one sen

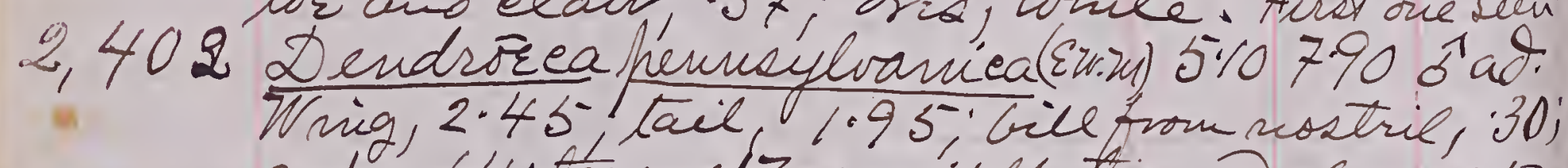
gape, 64 ; tarsus; 67 ; middle tor and elai,; 55

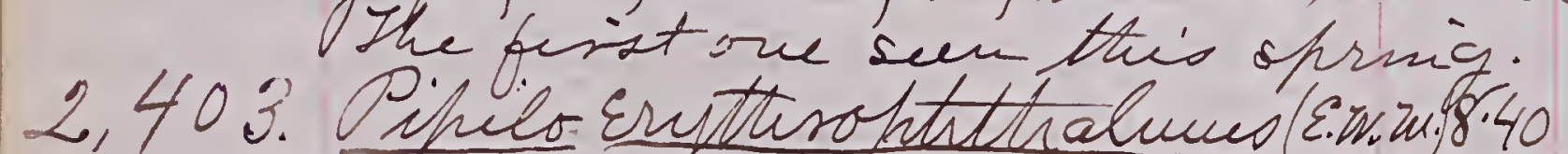

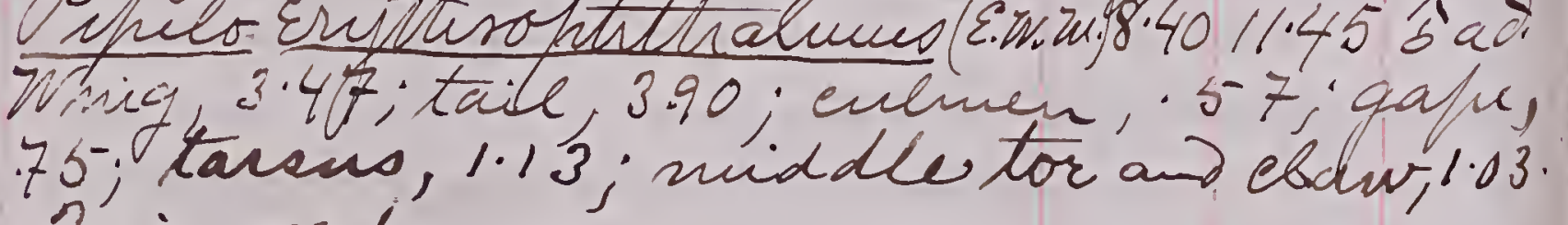
'Hia, rid.'

Dendroica viriens and D. caruleseene hav not get bran ocen, nor. D. funua. 7o-dan Wur. S. S. Denton and

if the south ravine to ero Nest and dour of the long-Sought White-headed Eagle's nest (Haliaieitus encoephalus) was at length diseovered, and the young heard seream - ring on thi ledge while bring fed. There prese two of them and they werc able to bly a couhle of hundred yards with the ne diffieulty and raturn to nest. altroudh we are still ni doubt as to the precise fot an the ledge where the nestis Feaced. We hope to get the If go next winter.

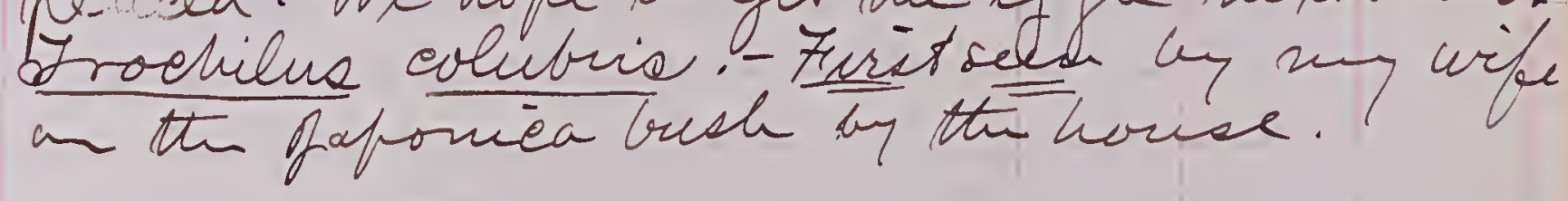

Thay 6tt. H.t.m.

a Fish Hawk Pandion haliattus earolinendid) yris-eanght by the fiehermen in al took the foor dellow ont altie and finally let biu got tree cofter anusing? Herucelves by tyhif o- strin to its. lego and allowity it to vit a shokst Then they devined another vay of sunsing thencilies. The tied a Hone to the cord. Fhe Qifrey was barely able to raise thia from the pround, and shen slowly along uritil rulled doun ishermen. In othinits he will cook twiel before he dwer for caught herrige aqain! 2 and 2 trove to the of Cro' thest to-day. Hhere was a the asaut's 
314

1812.

315

Way 6th-Continued.

(Boñasa nubsleus) nest there whè $2 M$. Dinton and I found yesterdary in this wisi; Clinbing the cast ascent to the sumnit of Erow Nest 2 saw an speciex of Qrelus growing on a danf ledge, and stoofing As he started to ds so, a hen Ruffochroust Llew with a terrible whur hastim faer bud whizzid by Mr.D. like a canson shot. We wrel both seared. The found her nest mider a fointed fur ecting storn with in as yard of whele dovas sloofin down to bok at the Clehid flaut. It ived perfectly concealed, and a lot of dry oakReaves fell ufon the eg ga ak thit old bird skehid out, so as to cover illiein. Tre conited the y.p. There were sleven. Then we left the nest, but when we erisied it to day this afterioon the mother boun had not raturtued and the ego vere otone Furdur we took them all i. Dem by cial the head of the sontiven vaine, where ive

2,404 want to see the virw-

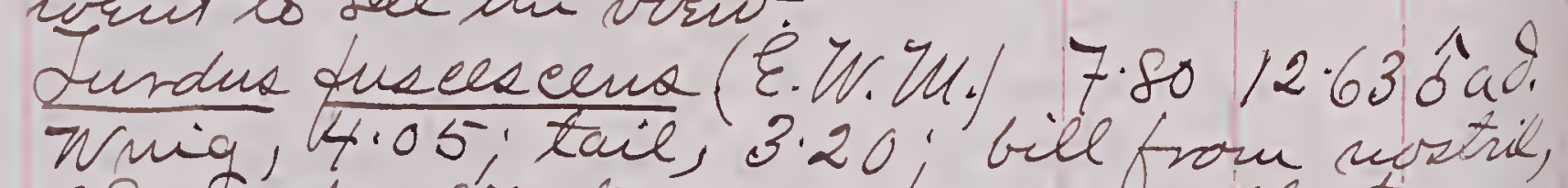
Wrig, 4.05; tail, 3.20; bill from wat 39; Gafe, 187; tàsus,

Enpidonax minimus. - Now abundant. Eupidonax trailli. Firist sem seen Last wittor. All Rinide of Atawks hav beven vare thin sfring.

Man 8th Nethy.

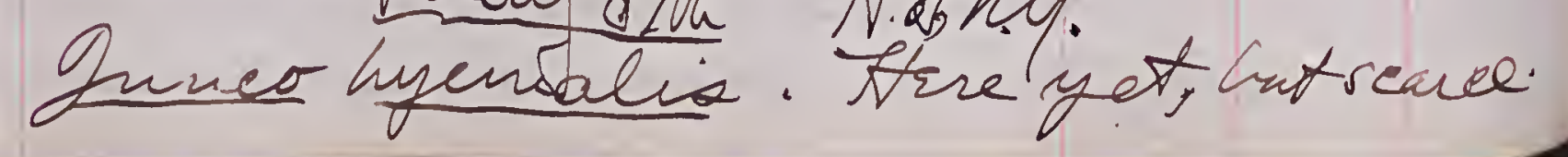
1882

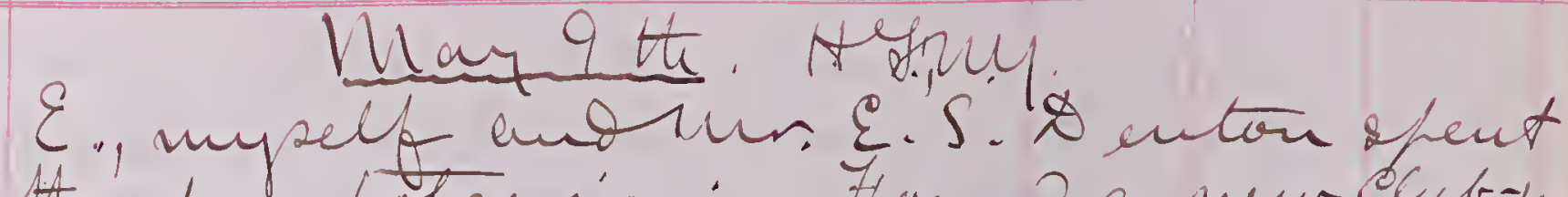
the day botamiznig. Found a nue cub-lycy

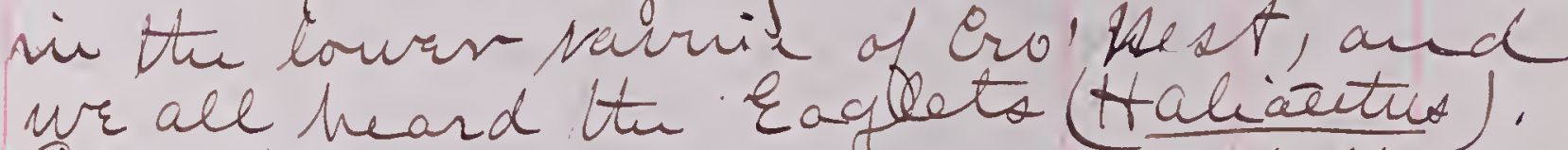
wr all heard the eacter mitratus at the bat of thiir clift. She shat three otter bides with the dette gun without a miss. Dendrorca virins. Firit deen. Qendrorea carrulesens. Frist sen.

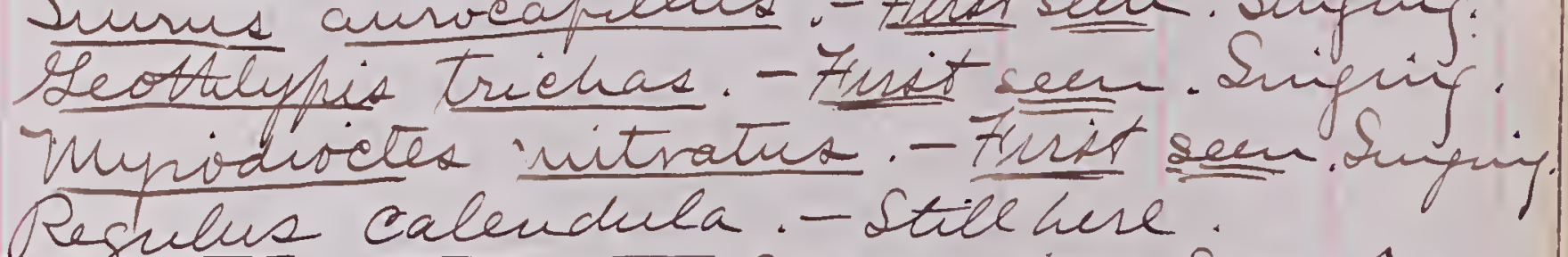
2,405. Fendrozea virus (E.r.in.) $5 \% 108.00$ bad. rig, $2.45 ;$ tail, 2.05 , bill, measured middle tor and clain, Sh. Hio, hagel. Bill

2,406. Laniviner solitarius (Evini) 5:709:40 fad Ning, 2.83, tail, 2.12 bill, measured from notrie, '24; gake, 62; larsus, 76; hidde lor and elaw, 65 ;

ineasuremento of:- (EMU.M.)6.259.80 ôd Wring, 2.95 ; tail, 2.25; bill from nostril, 38: gape, 67 ; Carsur, 88; middle tor and elow,

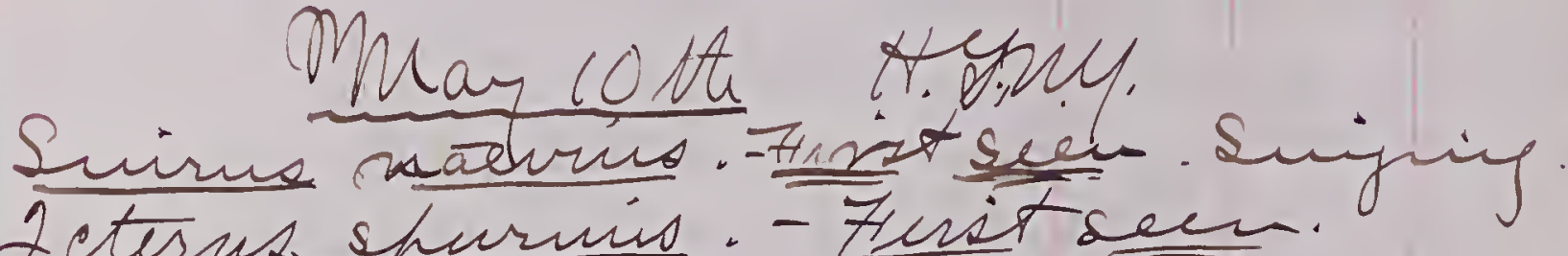

2,407. 2cleñes shurnit. (E.te. In.) 7.3510 .40 âd. Wring, 3.17; tail, 3.05; culmu, 74; 9. ofu.77; 
316

1812

317

Dis, hazel. Bill, with maxilla and terminal half of mandible blaek; basal half of mandible, blue. Lassiandtors, grafishtblu Thequst one seen, thie season.

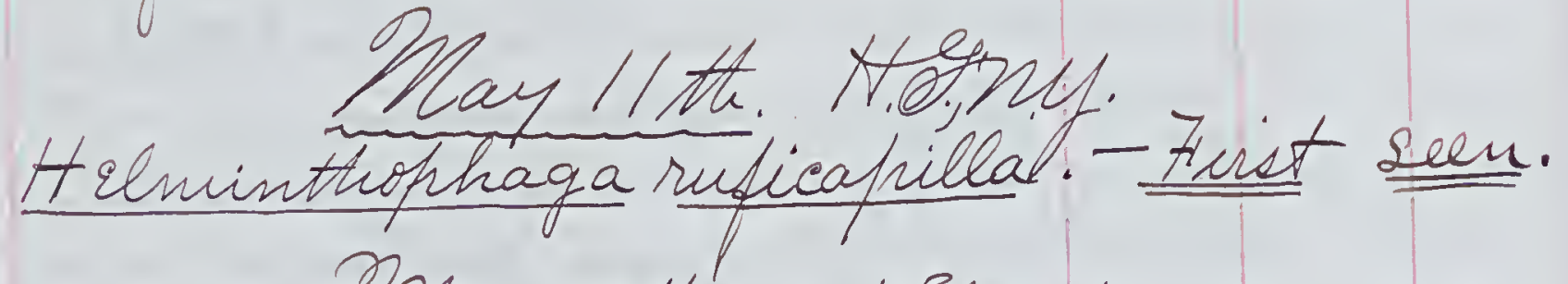

2,408. Hreminthophaga ruficapilla. H4.85-7.70 1 ad. nostrid, 30 ; gape, 48 ; tars ne, 70; middele tor ano claur.60. May 3At Hitny.

deteria virus. Erint seen. Fint sen.

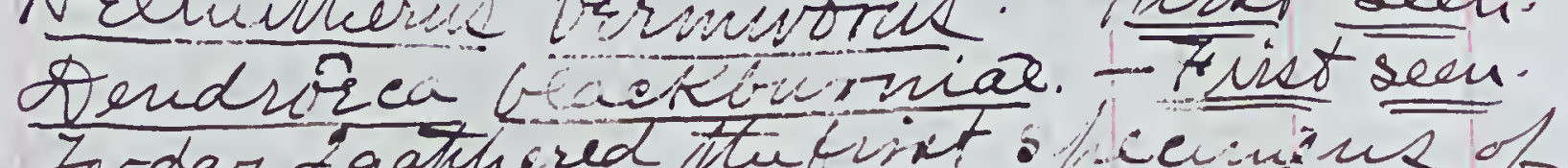

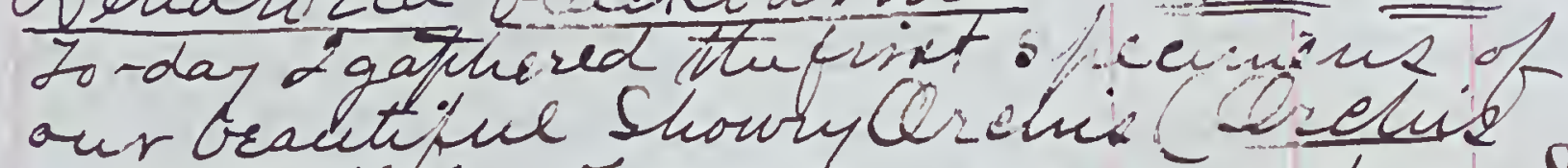
opectabilis). Four wre wric aut, and teu norr were c:2arly aut. Jur other speies wre iken in leaf.

2, 409. Androrea Plackburnial. 515 8.10 fad. notbil, 29; gape, 51; tariu, 66 ; middle tor and elaut, s5.

2,410. Aslmitheruk arrmuorue, 5.50 9.00 ô at

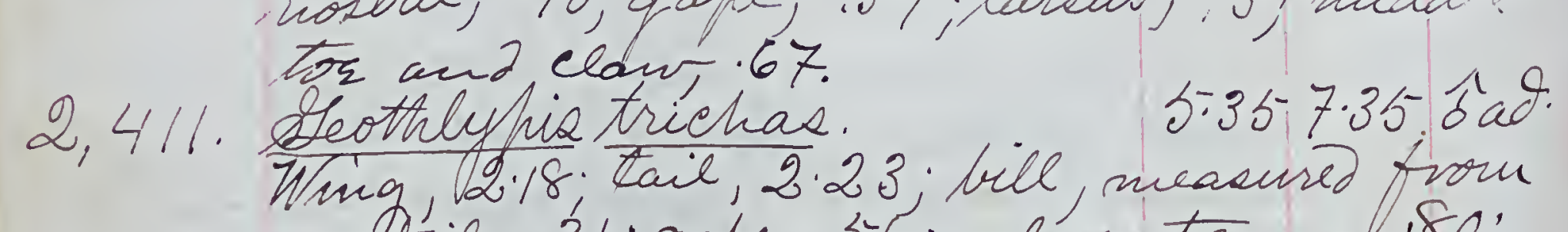

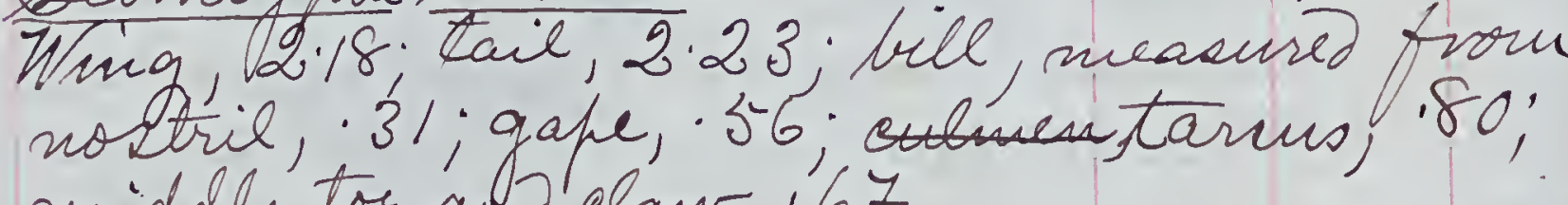

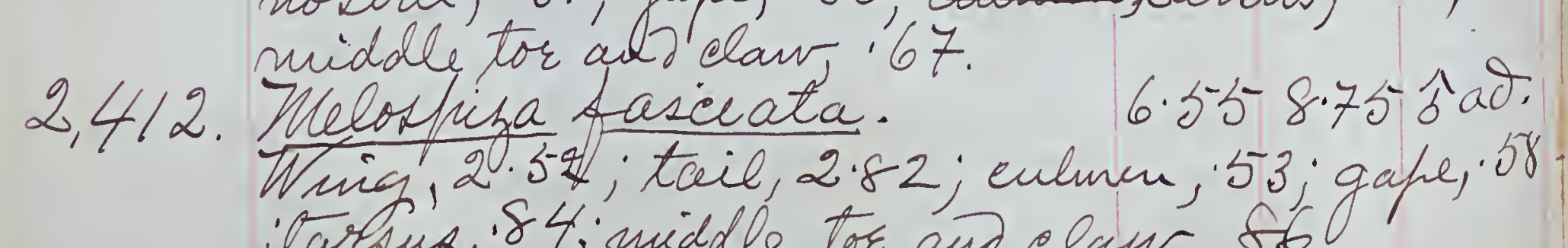
itarsua, 84 ; middle tor and claw, 86 ? 1882

May 15 th. $H$ H.t.

2,4/3. Sletophaga ruticilla. (Enm. $5.50 \quad 8 \% 15$, $\hat{b}$ ad. nostril, '30; gape, 55; tarsus, 68; middle 2,414. Vireosylvia gilva (EMM. 5.658 .90 tad.

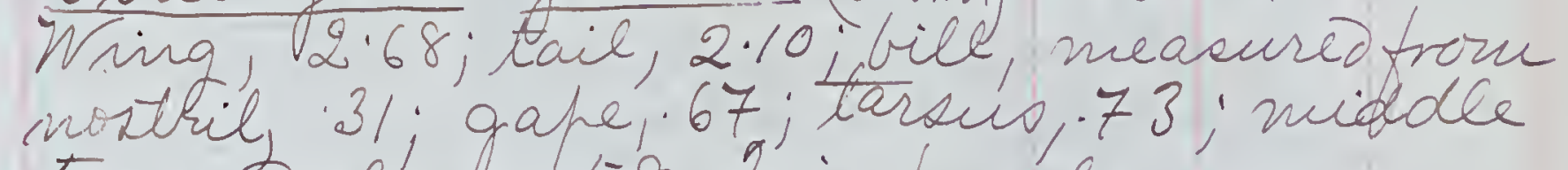
tor and claint 58. 2ris, hazel.

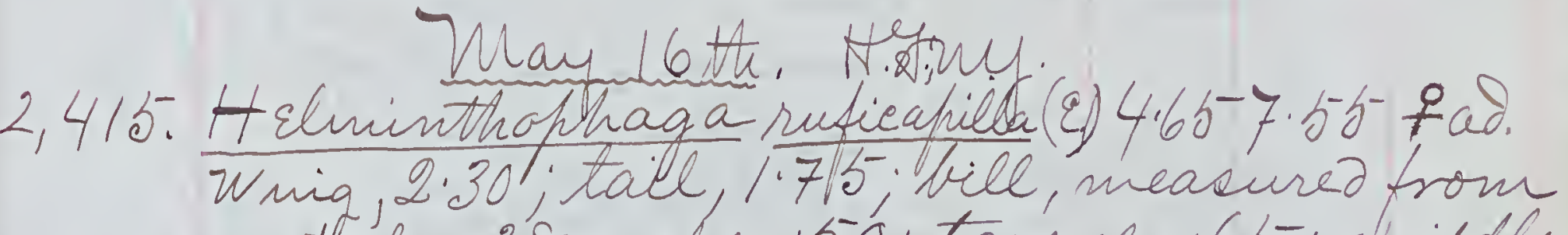
nostril, 28; gape, s-o'tarsus, 65; middle 2,416. Dendrorca, coronata (s.mil. 5.608 .75 fad nostril, 28; gafe, 52; tarsus, 73; middle

2,417. Mimne earoliniensid (MM.) 9.13 1175 tad nostrie, 45; qake, 1.00 ; tarsus, 1.18; mid-

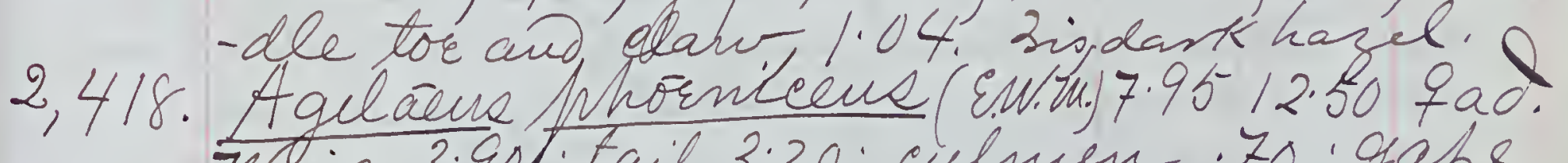

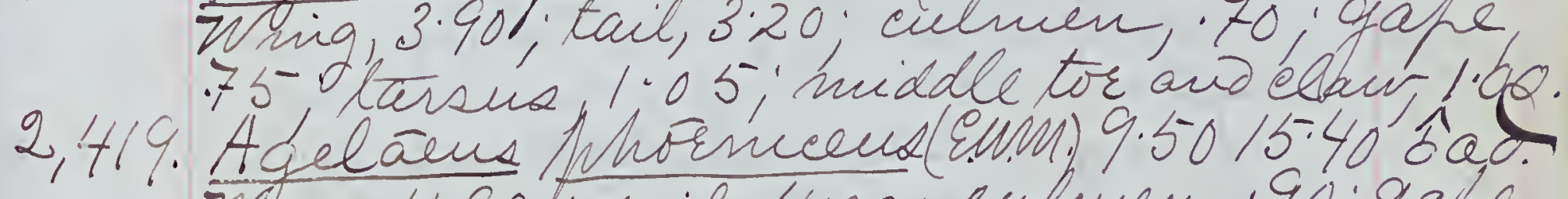

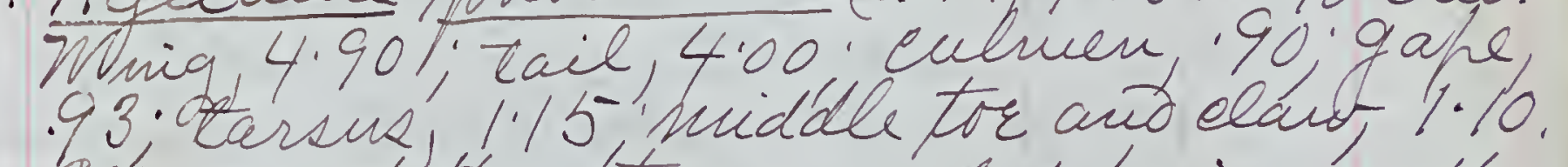
illa shot these tur, a suated pair, on the border of Consook Marah. maple inigratorius. - A nest in the silver Minus carolininsis - Male as 5 Egge: shot of a hair having a nest and one egy brsided the Powaok Narah. Cne by bte 
318

1882

319

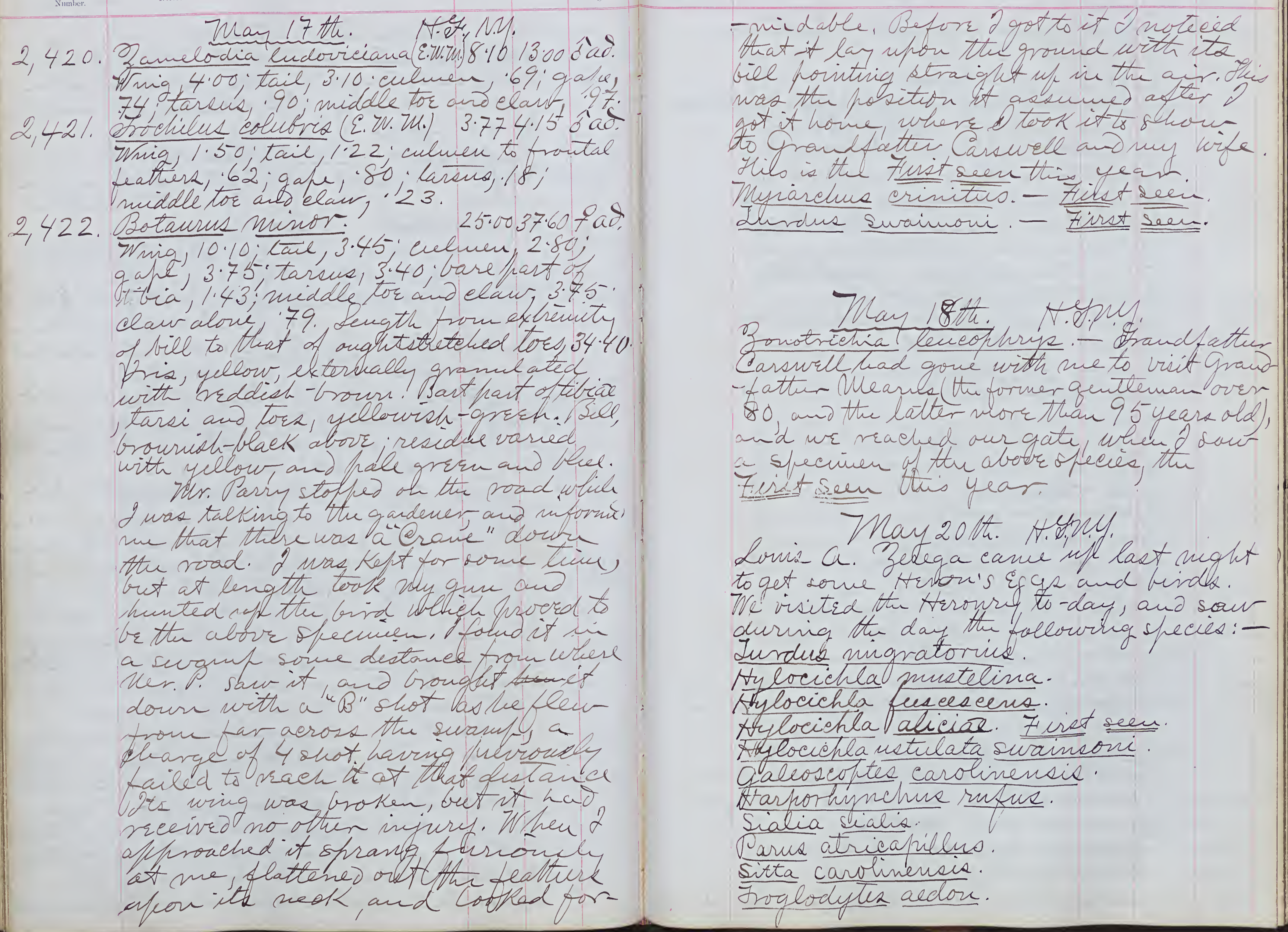


320

321

Ielmatodytes palustris. - First seen.

Parula amerieana.

treminthophaga chrypoptera. Fist seen

VElminthophaga rufichpilla.

Dendrorca âstiva - Singing

Denororea virins. Singing.

Denororea catrulescent. Suging.

Aeriororea penneylvanica.

Dendrorea castanea. - Firat sem.

Denororeablachburnace. -

Sinrus naevins. - Corstitutionluarsh.

Suirus auricapillus.

Suirus ludoireianus.

Heothlypis triehas.

Deterid vrrius.

Hujiodivetes nitratus.

Sitophaga rutieilla.

Vireo solitariia.

Nireosylvia gilva.

Aufolis cedrorm.

Hinindo injotivgatra.

Tachuenveta biellor.

Cotyle riparia. Hist seen.

Petrochilidon hmifrons. First seen

Astragalivins tristis.

Melophiza faseiata.

Welorpiza palustris. - Conilitution Sland.

Shizella socializ.

Sfizella Rusilla.

Tonotriemia leveoflerys. - Culy one

sem;shot rifou the ground aciongst

sure currant thea.

Pascrina cyanea.. Are sun

Pipilo eriftrofnthohnue.

Saniladia Ledovieciana- - Rite a
1882

NAMI:

1) ATH

LOCALITY

number stay in aur eherry-trees, and eat the blosionix.

Passer domesteries.

Agelaens phöricens.

Uoloturus ater.

Deterns galbula.

Deterus spurive.

Corvus Arugivorus.

leyanocitta eristata.

Sayonis fusens.

Enepidonax minimus.

Lypanmes arvhinensia. First since May2.

Nhyiarelure crinitus.

Fochilus colutris.

Ehâtura helagiea.

ehorderles popetue. - Fnit sem.

Trent hubracens.

leolaptes auratis.

Eeryle atejon.

Aaliacitir lenevecphalus.

Sornasa unbellus. - Constitution Sland.

Benaedura carvlinerusis.

Tringoides macularius.

yetiardea grisea nowia. - Culy a hew paris ure about the cerourn. Thet a wakk ago (Jlian 13, th) a young man by narme of Re arrum who attendea selvool in Snig Snig eane whto the heroury and took $6 /$ egse of this jueciex, and a set of 4 egfor of the prean Heron (Ardea virsecens). WC fund tivo more youngtero $\mathrm{in} / \mathrm{tt}$. surank trom th dane sehoal

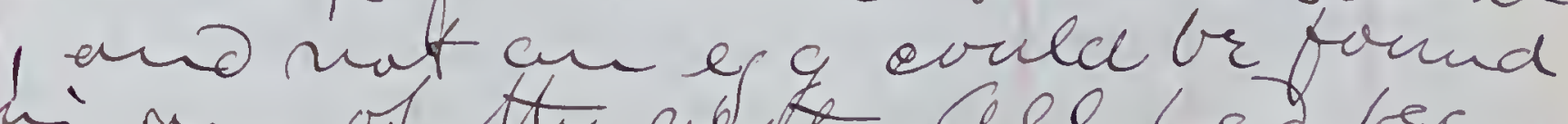
ni any. of thi adet. Ale had bern vobbed; and of feew that thin heroury wiel be broken uherotireer. I 
322

323

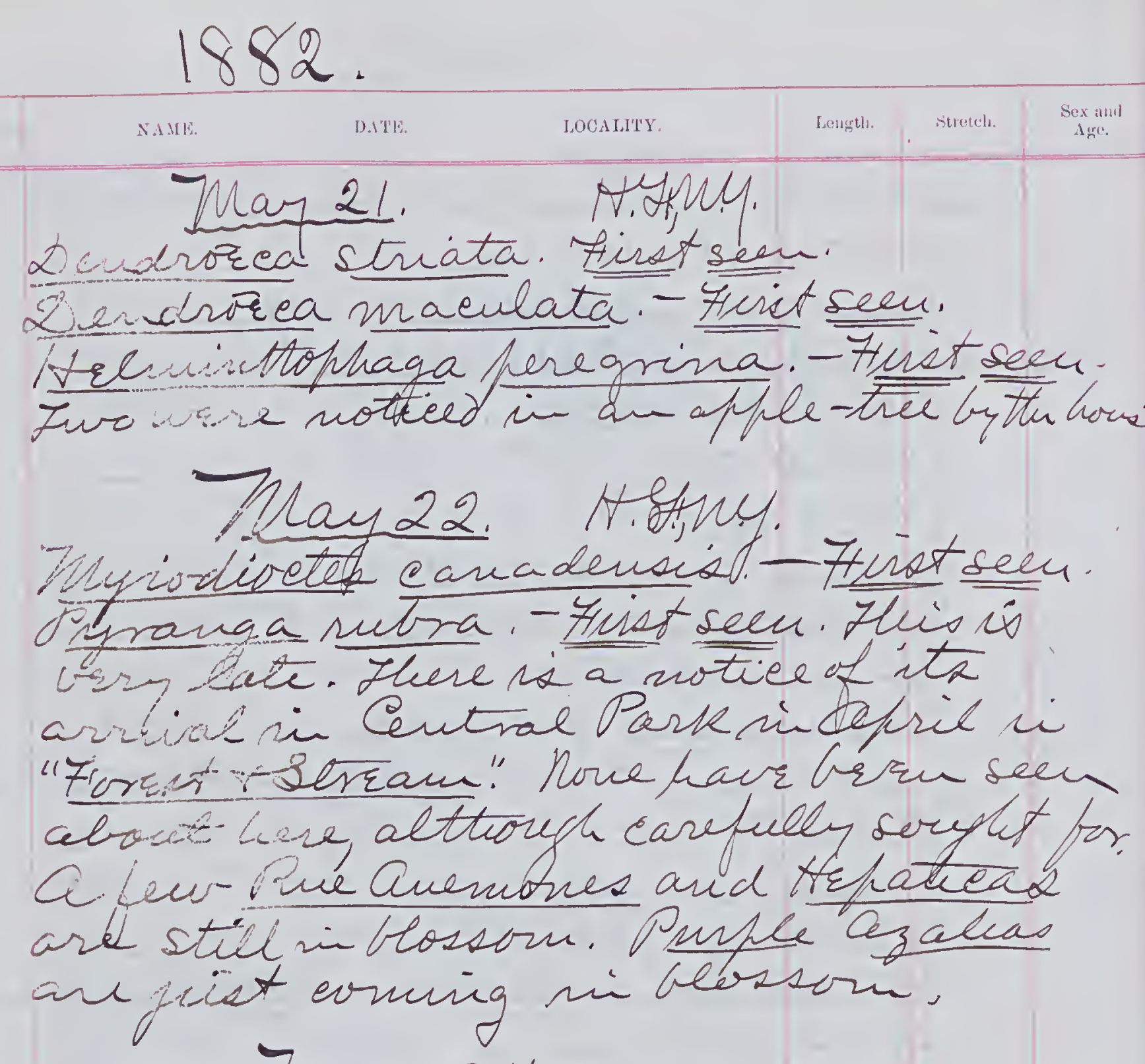

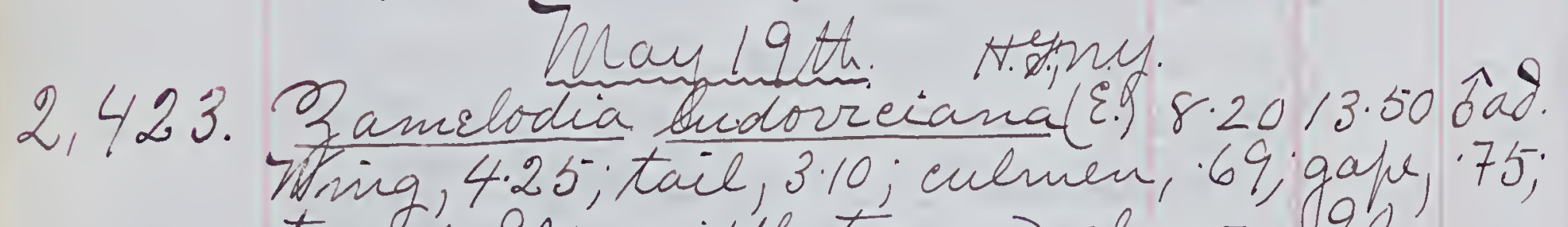
tarsus, 90 ; mid dele tor and claw, 0.90 . Ella shot two fine males in the cherry break. Senega took one of them.

2,424. Bonotrichia leneophris. 7.2510 .25 sad. thing 310; tail, 3.30, cullen, 49; qa pe, 54 ; tarsus, 95 ; nide tor ard claw, 90. strider, hazel. Bill, pale reddish - brozgri; extreme tit of maxilla, black. Tarsi and tors, printy-fbrown, darirect on tore. This bird twas shot in the same op ot where the other one was seen, and after it was shot none others wee see 1.95 .

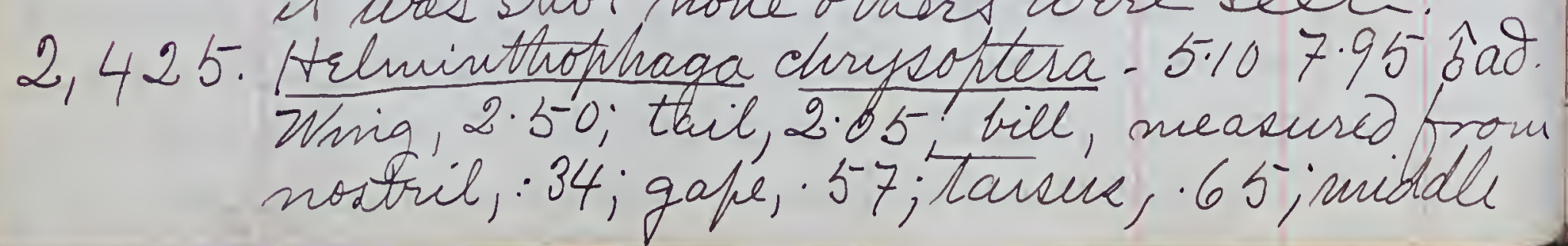

1882

24 tor and claw, 58. Dries, hazel.

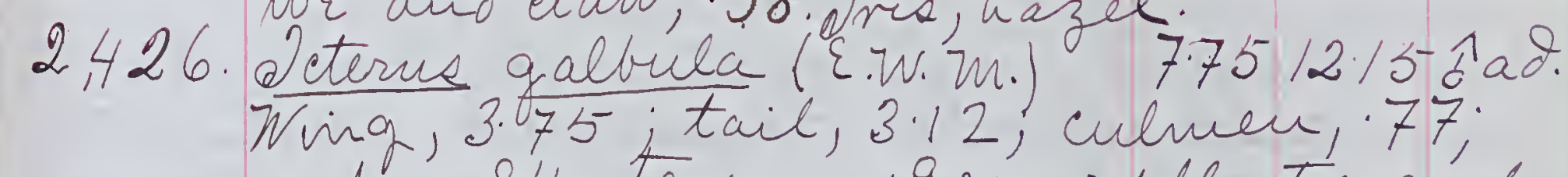
gape, 84 ; tarsus, 90 ; middle tor and side, 86. Mri, dark hazel. Bill, with blue i axilla above, black. Parsi and

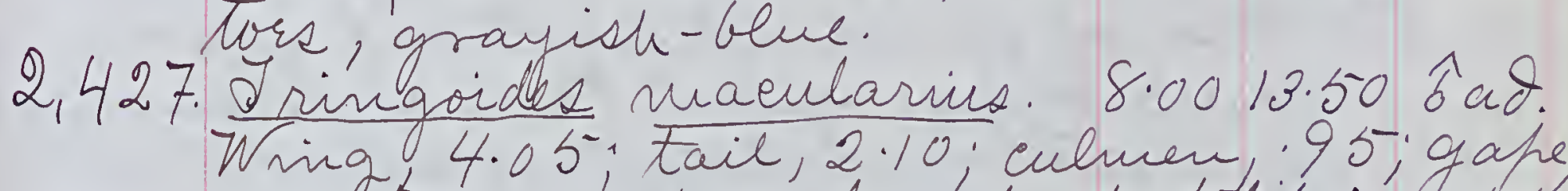
1.10; tarsus, 1.00 ; bari, hast of tibia' 55 ; 2,428. Fringoides macularius. 55.1014 .157 ad Whig, 4.35; Tail, 2.20; culver, gale, 110; tarsus, 99 ; bare hast of tibia, 2, 429. deternidde tor and slaw, 7.95 . Whig, 3.15; tail, 3.00; cullen, 70 ; Slaw, 85 .

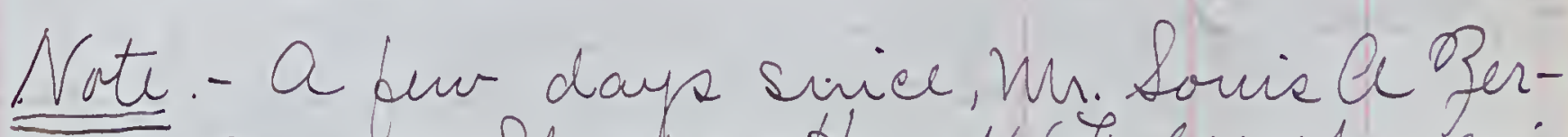

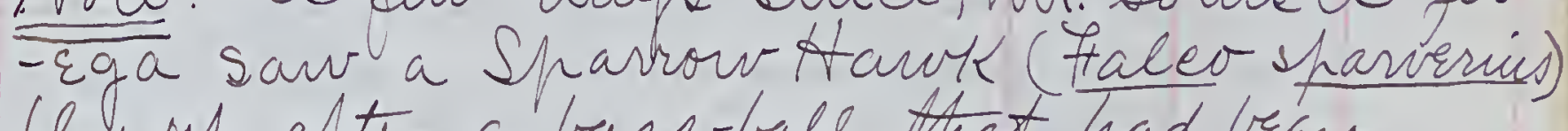
fly op after a baseball that had ben monist when it had reached the highest point

2,430. S.

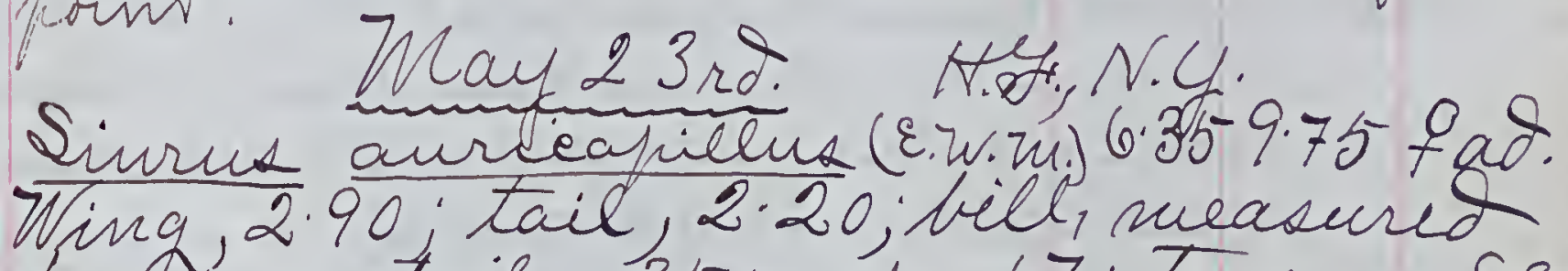

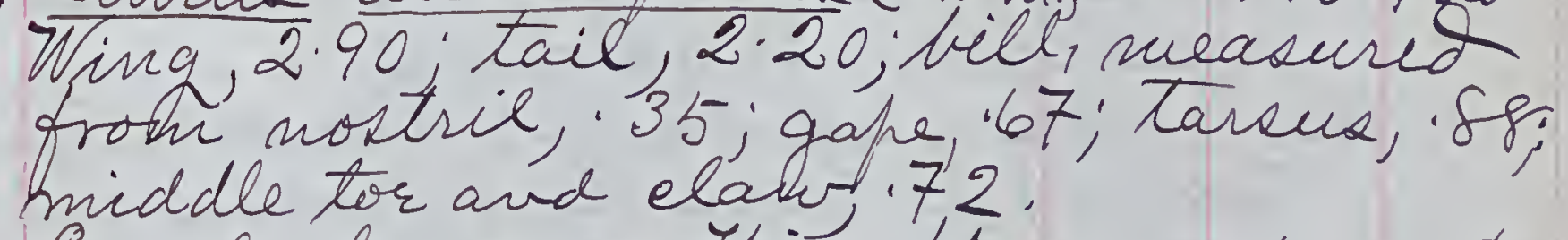
leeryle alcyone. This ofternou drove to

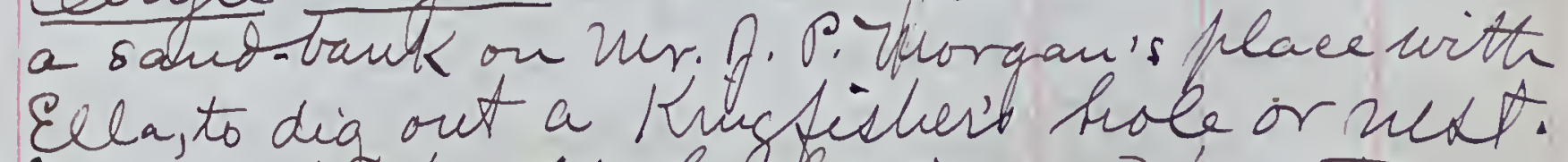
\& ran ficfenticilarly inward for two feet \& dug downriver from above upon 
Collectumy
Xinubler.

\section{Thay 23 - Continueg.}

the firrt angle of the hobe. Found the nebt, a globular- excavation, at the end of the second reach. It was about cour feet trom the encranee and with in thalf that distance of the side of the bank. It contained only four Egga, three of which wrre got but whetle While digging out the eggr, the ob bird returled, flew all abolit me and herched upon a tree near by. Then it Llew avay, and did not steturn. leoutopue virens. - Hirst seen. Lainvire Llavipons. Fist seen.

\section{May 24 Milney.}

4.31. Dendrocea catruletens (E.) 4.57 .759 . Ving,2.38; tail 1.95; bill, measured from nostril, 28 ; gape, 54 ; tarsus:75;

2,432. Beothlyhir Whiladelthia. 5.50 8.00 \$so pron mostril, 30 ; gape, 59 ; tarsus, 8I. middle tor and elaw, 76. grie, hazel. Bill abovr black; below, flesh-color. Tarsi and tors, browish slesh-color.

2,483. Myiodioctes eanadensis (E.w.m. 5.758.55 5ad. riting, 2.70; tail, 2.45; bill, measures from nostril, 29; gape, st; tarsuo, 74 ; Iniddle tor ano elaker, 60.

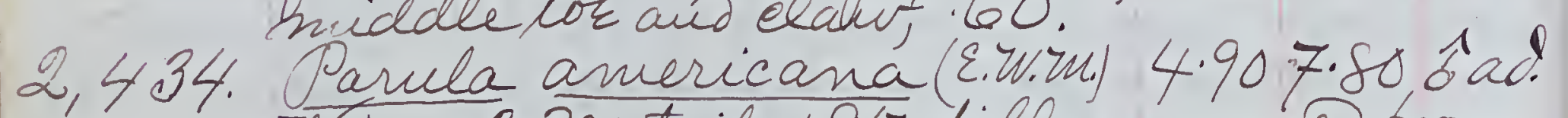
Vina, 2.30; tail, 195; bill, neasured from nostril, 30; gape, 50; tarsus, 68; viddle tor and elaut, 52.

2.435. Eleottulyis trichas (E.W.M.) 5.007.05 ô. Wing, Do7; tail, 1.85 ; bill, nuasured from nostic, 30; gape, 53; tassus, 80;
2.436 middle tor and elau, 70. Irider, hazel. Steothlyhis trichas (E.W.M.) 5.05-6.93-1 as Wing, 2.05 ; tail, 1.95; bill, neasured from nostril, 32 ; gape, 57; tarow; 80 ; middle tor and elaung. Fo. Sides, hazel.

2,437. Eolaptes auratus. 13.0520 .60 今ad. Wing, 6.25; tail, 4.75;" euluen, 1.54; gape, 1.70; tarsus, 1.20; middle tor and

2,438. Eocenzus erythrophthahne (E.) $11.6516 .007 a d$. Wing 5.25; tail, 6.15; culum, 90; ga/re, 1.27, tarsub, 1.02; middle tor ano elaug, 199.

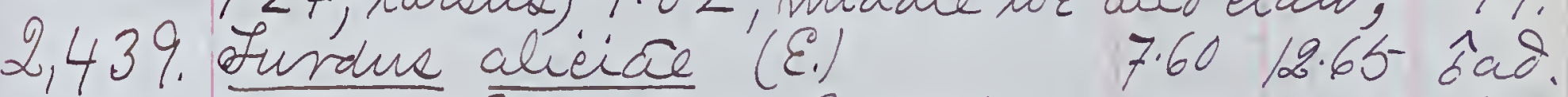
Wria, 3.90;tail, 3.00; bill; measured from nostril, 38 ; gape, 86 ; tarsud, 1.25 ; middle tor aro exau, 190; nis, hazel. Bill, with lerminal $1 / 2$ if masdible and maxilla bowrish-black; basal $1 / 2$ of anandible, yellow, Sarri and Tors, Grovon, darkest on fiet.

Heothlyfie hhiladelphia, - Cuby one, the Eerst Seen, in a suanpy vetereourse morth of Bell's poind.

boccuphs aryttrofhthalmuse. I do not rencuber having seen or heard this bind orpore this Shring. It muet have beren lat il connis ano searee.

Bonasa sinbllue. Cue at Pell's Pand. Hay 26 th. H. Why.

Virisyeria olivarea. Fibit seen. Enpidonax flavivantrio Finst seen Whivdioctes Musilens- Firfit sen. Ten shot brluid stable.

treninthohnaga humio. Fist seen. A qunalle belines the stable in birch suraup. 
326

1882.

327

2,440. Deteria 26th - Continead.

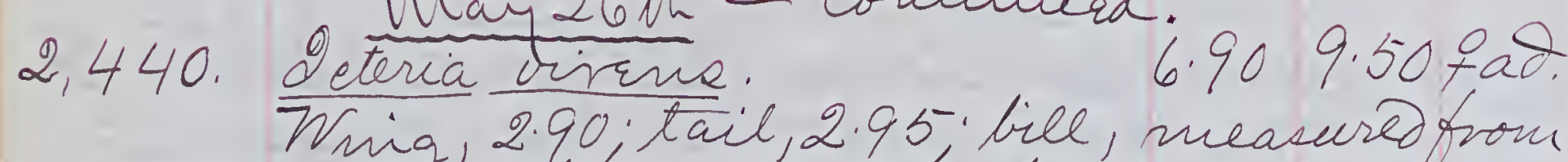
ming, 2.90, tail, 2.95, diel, measures from nostril, 40 ; gape, 73; tarsus, 1.00;

2,441. Diddle tor and elaw, 82. 5.458 .85 âd. Wrig, $2.85 ;$ tail, 2.12 ; bill, measured

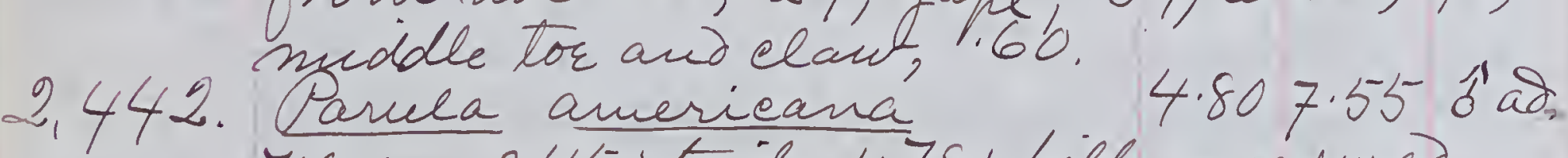
Wrig, 2.45; tail, 1.78; bill, measured from nostril, 31 ; gape,-5-3; laisus, 62; middle tor and elaw

2,443. Dendrorca maculosd (E.) 5.10 7.80 tad. from nostril, 28 ; gape, 52 ; Larsua, 73; 2,444. Dendrorea maculosa (E.j 5.007.40 9ad. Wrig, 2.25; tail, 200; bill, measured biddle tor and claw. 53.1 2, 445. Whiodivetes husilluk. 5.006.72 5at tarswa, 70; niddle tor and claw, 55 . 2,446.' Arlmitherns, vrruivons (E.) $5.65-8.75$; $\mathrm{ad}$. Wrig, 2.65 ; tail, $2 \cdot 15$; bill, measure middle ter and élaw- 67 .

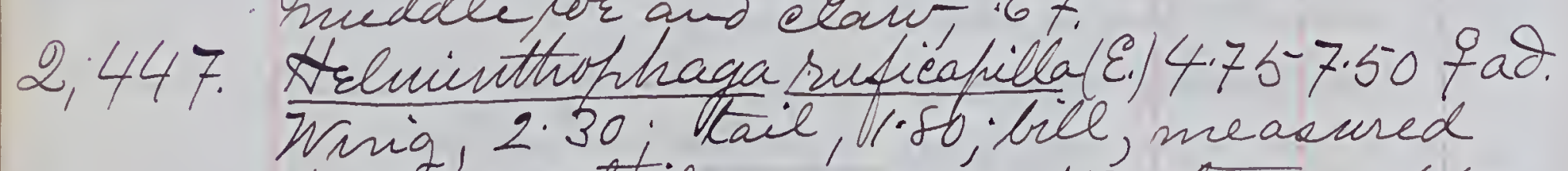
troin' nostril, 27 ; 9 ape, 48 ; larswe, 65 ;

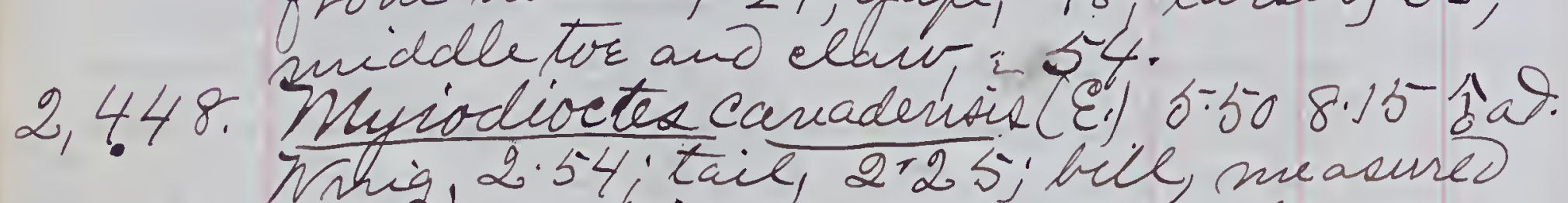
Fria, 2.54 ; tail, $2 \times 25 ;$ bill, measures middle tor and claivi .56.

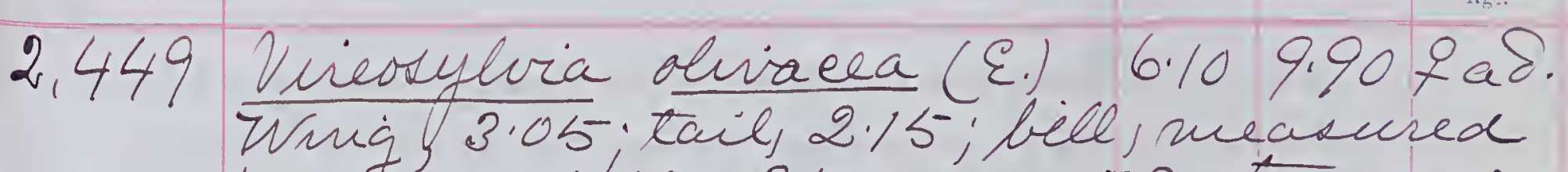
pron nostril, 35 ; gape, 73 ; tarsus, 74 ; 2,450. Lundus alieiáe. (E.) 60.7.8512.65 Bad. Wring, 4.15; tail, 3.10; bill measured \%.23; middle tor and élaw, 90.

Contopus bovealis.- Firot seen

Dindrorea castavea. - Still fresent. Myiodio-tes Carradensio. - Stile numerou 2,45\%. Darneodia hedoviciana. Saw one feruale 50; tarsut, 69 ; sniddle tor and elau, 67.

2cterus hay 3/st, N:tom.

Baltinores have beru gaptering the eal- vred. Itrieada vuvretede that 2 have tened to Shrubs in front of the house. Lhe nalee cane about too, and sang; but the nisto. I wrut to ore tree and vateto the fervale Gird wraving. She dived head first into the nest, and worked with suel which as to shake the whole branch on not usarst fy bringing materials or by wraving thich whu Aronght. Femdea 
328

329

1882

1882.

steal threads from this one, but wase drivan off by the angry propretress.

srovafaround 7th, 1882 . Eagle Vally ritad to West Point with Ella. We found a Woot Otrusher nest and sevaral bare flants, anving them the Nated Broom-Rof (Af hullon

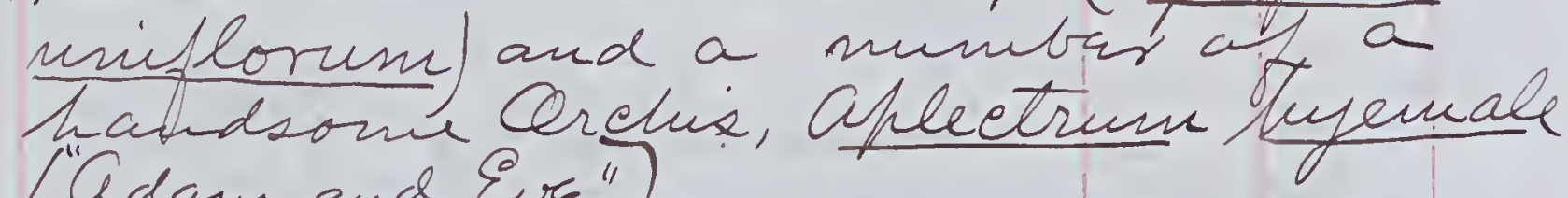
("Adam and Eve.").

awaten Srached home Dr. Chace awaited me and wished me to go at once, whthout supper, to see a wonam in labog ten suiles bask in the puountain bryond Quensbor, which 2 did. Ou the Gunev a finemalia) brside the School-houste at Treereboro, the firit ghave evar seun here in sumues. The drove a mile out of the right way trif 22 milen, or attogittirn about 3 niles driving for ne, from 4 o. In to midnight.

Oune 12th. Hitons.

2 eterua galbula.- Tork a dest and setof 5. eglop from a frear-tree in the garden Leterue shuriua. - 200k a set of 4 egga and rest from a pras-tree in thi gadden. soth sets wre selictet sinenbaled in

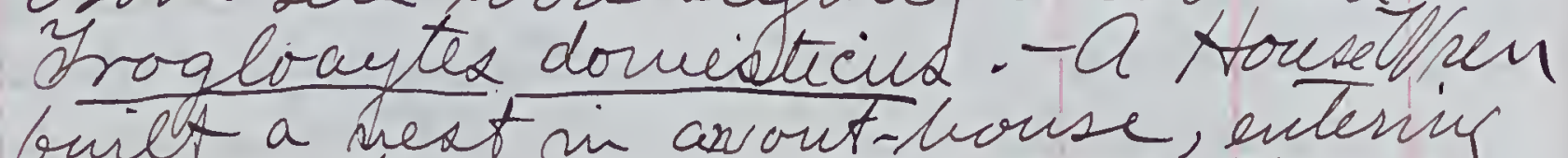

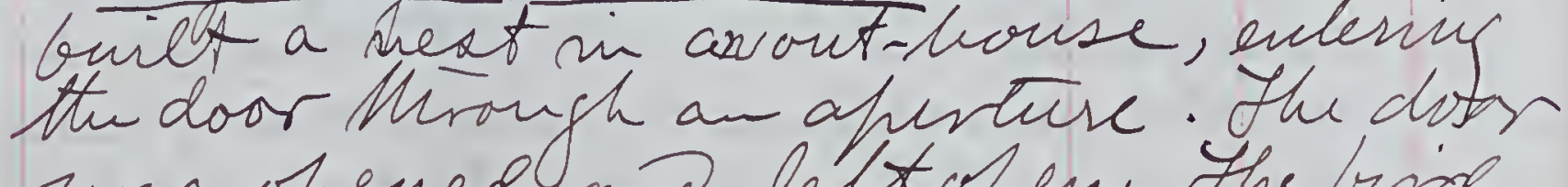
was ofened and leftopen. The bird left, but came balek and carrid

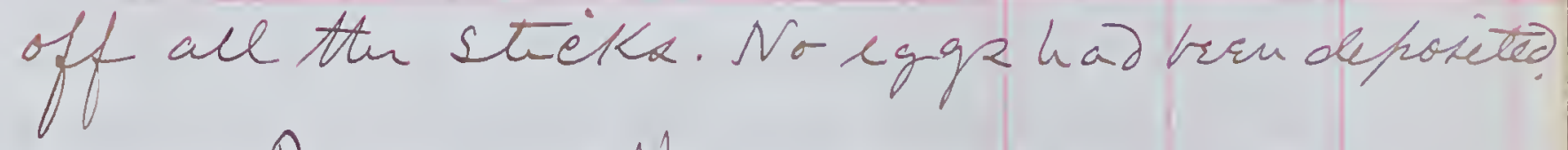

Drove Doune 17th. H.F., N.Y.

2 saw al Rouch-wrngied Hurt Mortomery Steloidopternst servipenvis) sitting upton a telegraphwire. Secinig a cirle troles in a bank, d ex anned and Soth perehed logether chon the uegraph wire ofter feying around conld get hoed of my gien both had poun anaty and did not g dug a littli nou into retarn banky a bitth then eould lasily reade Atu nest which was cov forrd entirely of dry grazas with one syall pies of of hapes evirtanied a jother one, whieh would sho thy have biru fiposited. 2.452 Stelgidopteryx serripennis 3.50 12.05 sad. nostril, 20 ; gafe, is8; (arsus, 42 ; middle tor ant its claw, 60. Irio, hágel. sill, all black. Left tarsus and tores, black but the night tarkus was Growich-black; nectatarlur, flech-color; torsiand elaves

2,453. Stelgioopterux serrifemis 5.5511 .80 ad

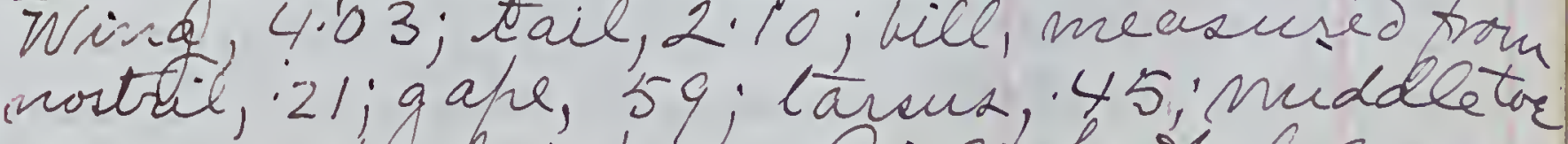
and elan, 60 . Mis, hazel. Biel Ifects blaer. 


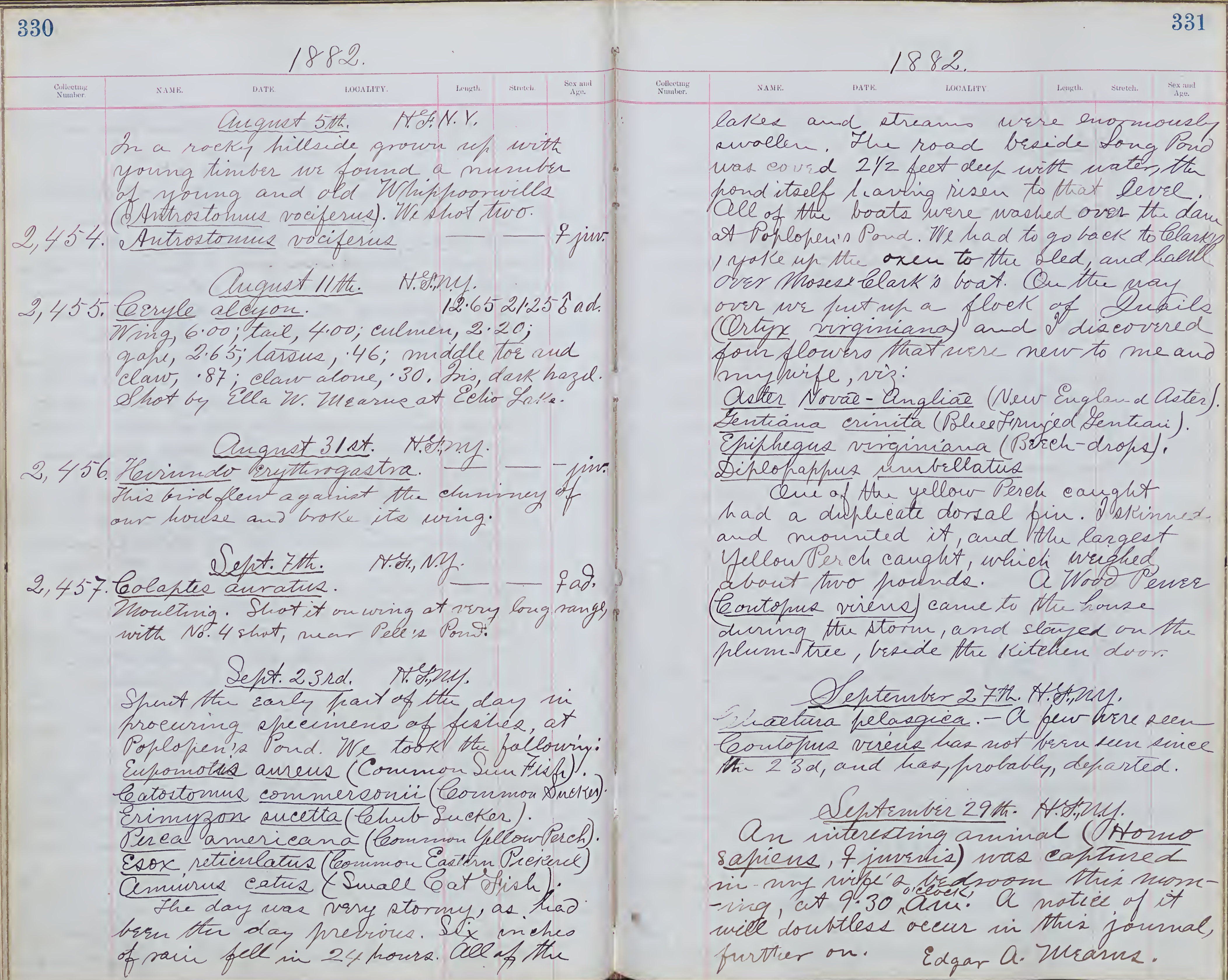


332

1882

October lat. HEMin.

Donasa unbrllus. Io -day, shortly after morning church service, Orecevird a nujstervouslooking covered basket, which con-tarried a full -grown Ruffed House alive. It arad bind of the year. The letter read as follows: "I Parsonage. Cet./st, 18F2. "Thy Dear Doctor?

Excuse me for rending You this feathered Burglar for you may deem hin deserving.

He e broke into our house this morning whilst we were all at church. We have not as yet discover e arjotter loss than a large pane of

A we have no measures of "helping life in him, and do not feel quite injinkt hough to late the life ont of him, wis resign him or eosin him to your

Witt congratuslationis to Self, Yipe and Dougleter. Jan Verutruly The bind in question, after bring duly and the basket opened and bet rf on tore ground; but the affrighted creature did not move until 2 fielded it rf and closed it nit to the ar i, wham it whirred off to the woods with the velocity of a

Che frequently hears of its flying 
333

1882

agonist windows. I have known of five or six instances of ito having bone so, ni this place. An explanation of this recurrence has frequently bear called for, and a very satisfactory and plausible one is otis: the bird, affrowehireg a house, loots town de the window of an thermic darkened apartinent, and sees reflected there an attractive mage of the landscape before it, and, mistaking what it sue for the reality, mated hoards the supposed spot. If the window-glas, yields vapor its nipetuous flight, the birdfuids itself a prisoiter within the opartivent, and, if not, itfalle

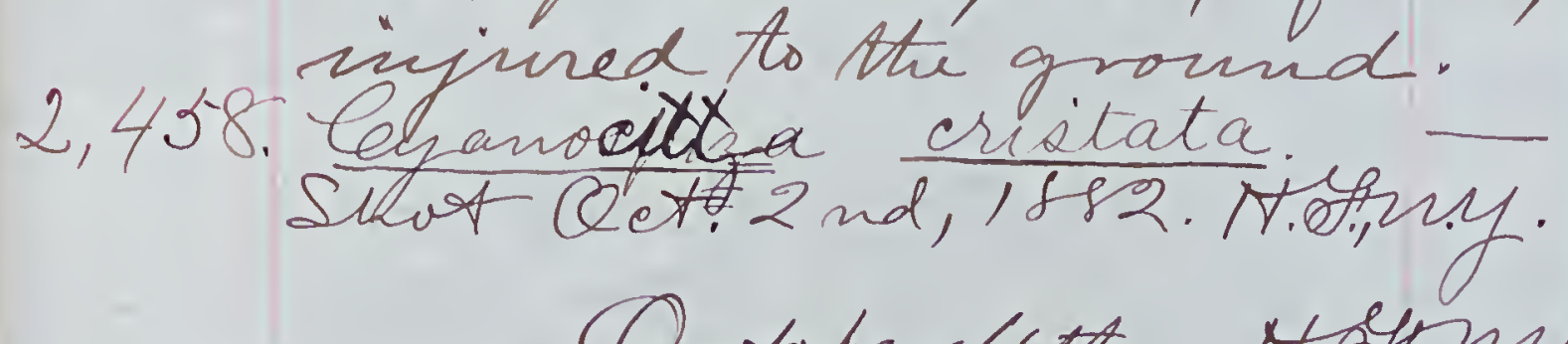

- $\hat{a} a d$ 2,459 . Cupanocito cristate. I. Fad Note. - Mr. Edward Conway, of 55 Canine st, N.Y. City showed me a counted specimen of the Barn Curl(Aluco lamberts americans), which was Brought to him by m. Joseph Wilde, on April 13,1878, in the flesh. It was shot somewhere near new -York C ty, but first where could not ascertain, singer Mr. Wilde never came hack after tie bind, which the said "was reeled just ant est" of hew york."

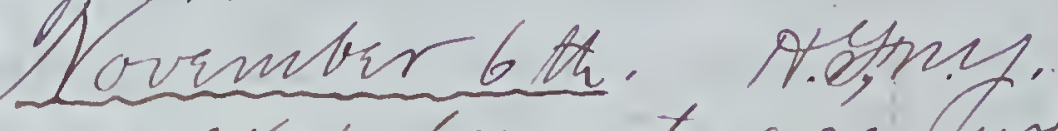

Io =day, walked down to see what progress? las bum made at the rocket, on the 
bey beardloctor:

Partanage Oct, ', Rso

Cocuse one for efendingberches frathered $1 / 3$ urglas

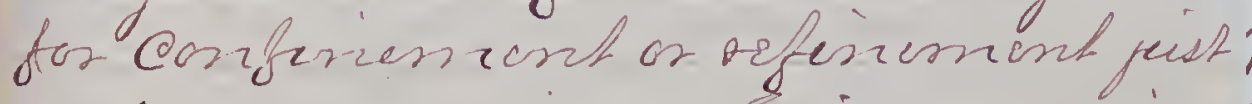
as bou may cleom hum desenverz de bote inti oun herese thes hoon euin whilst we were all at thurch. ofre have not as get riscouded any ochers lors chan a large farre of glases, As ue have nro brecano of kereping Lifiein hirn, and do not feel quite injuired invergh to take the life out of ferin, we rerign him or consegi hin tobour faxicemie bkie.

Hect congroulacur. to beef, Shefe and Daughies etam

evensbyling G.ef. Jeekain 
334

1882

1882.

335

West Shore Railroad, at Satterled's Point: and a thor derek simultaneously for breath a file of brushuvot. Asur t the sifting of Dronvov, and watched it O took ming Gen and walked blown there and flushed the bird within a roo of the down, maxing a goo wing hot of \$, 460. Philomel minor. $10.5017 .65-1$ ad. Philohela minor, 4.90; tail, 2.90; culver, 2.50; gape, 2.30; tarsus, 1.21 indole' tor,

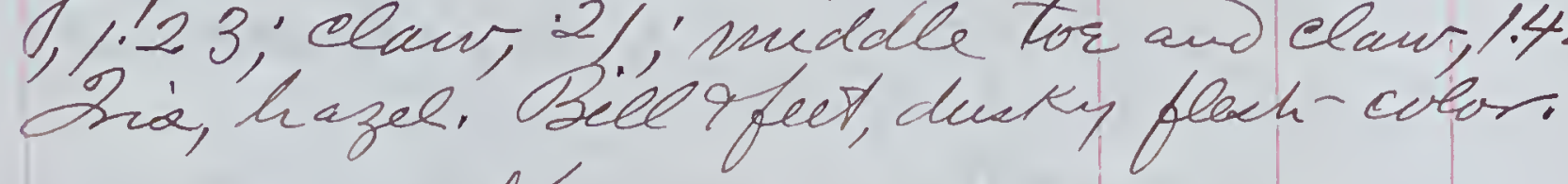

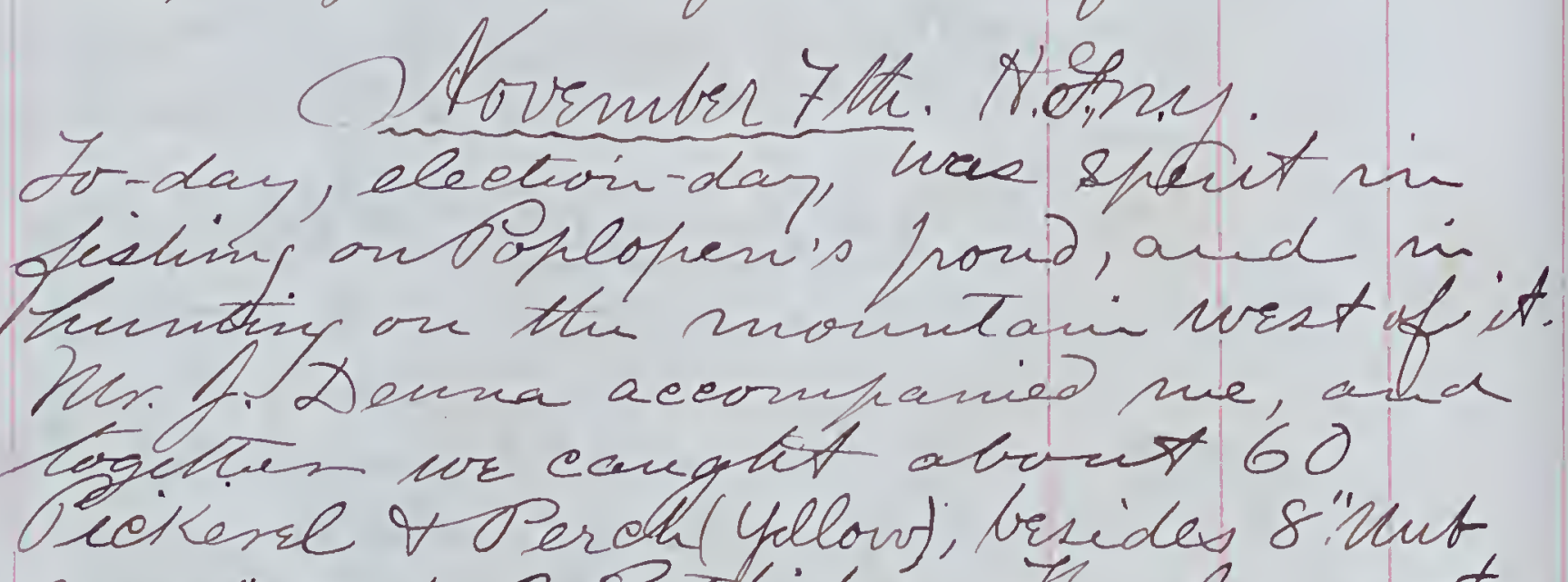
nose" and 2 Catfishes. The lan gest

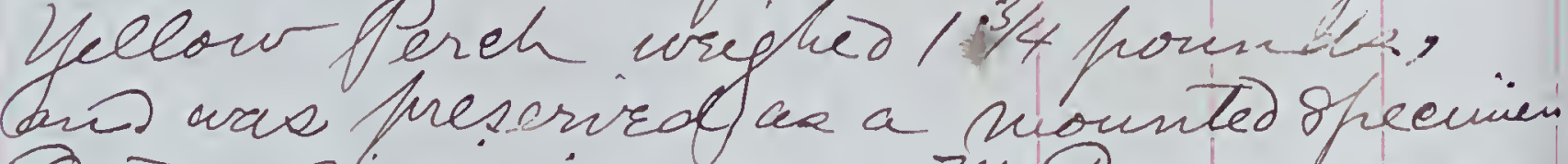

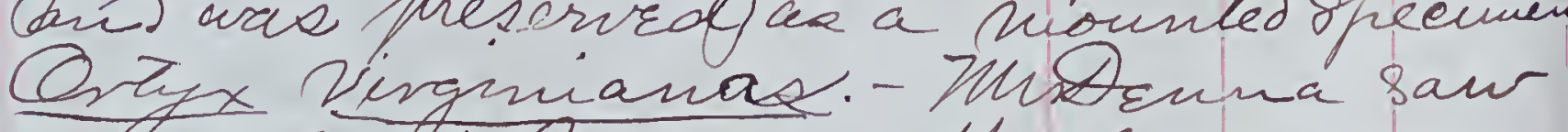
a couple of Cecil in the lane, near new boat hone to Hr. Elastin. I got

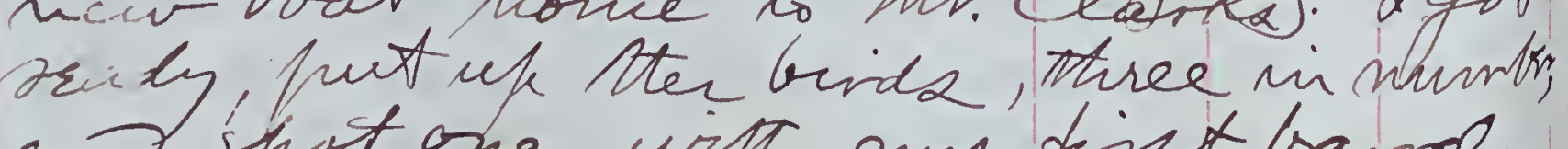
but s host one with ming first band,

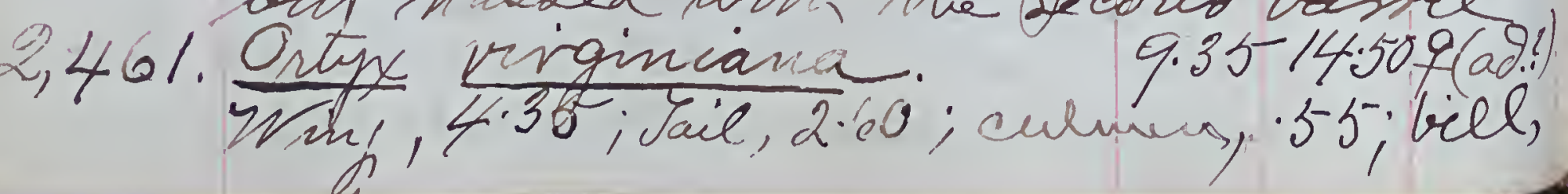

measured from nostril, 32; gape, 69 ;

tarsus, 1.24, middle tor y elm in, 1.34 .

November 16 nt sumy.

Loxia lencopterns (White-winged Crossbill). This afternoon, Elea 19 walked Hirogh Hin. Stephen R. Nor's place, opposite to ours. In a fine tree right sin frow of the house wite - ing seeds from the cones of Penis sigida to wat eh the birds. She saw three t binds at once, and thought there wee four, altogether. I gavel her the gun and she shot a female. Ne both saw it drop a few could not git sight of the otters afterwain Ella thin kt that all hire in tenable. dress, as she saw no red. We watched for shot, hoping ti dislodge the dead bird; but failing, nz returned come disconsolate. If 2 walt ed av ir, and looked under the tree hoping to find that the bird had fallen durum at the stable, and went up. Ho the tor of the tree, from where I saw it clinging to a trance, whence it required considerable sharing to dislodge iA. The bird, when dry, turned out to be an excellent sfecricm. 2, 462. Livia lencofterna. Fla shot it. 6.25 10.35 \& ad, Wring, 3.30; tail, 2.45; cullen, 65; ga fe, on right side, 60; left side, 64 ; tarsus, 60 middle tor, 46; claw, 34; middle tor and 
336

1882

1882.

337

daw, 75. Hider, hazel. Bill, blackish on maxilla montydible and sided of maxilla except near tip, hom-erlor. Tarsi and tors, dusty brown; claws, blackish. Stomach well filled with seeds of pinion rigid; fa

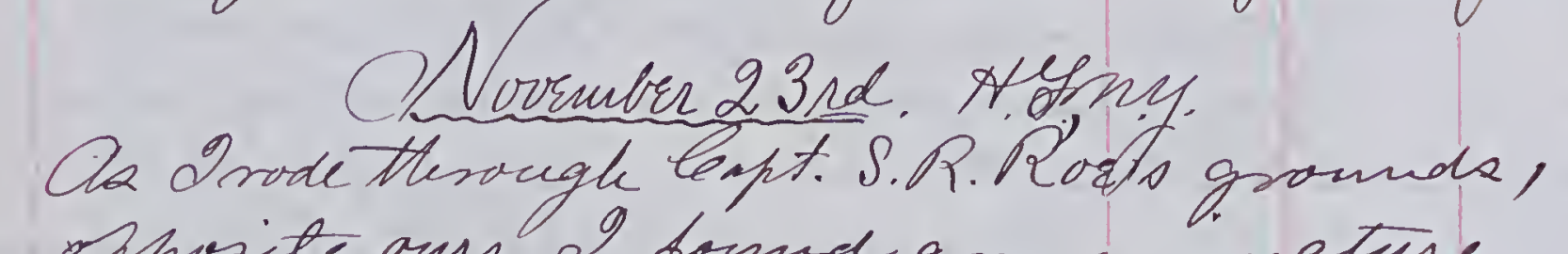
opposite our, I found an ininature levesplera) lying in the rood, between th fine the is in which Bela shot her female m the 16 th instant. Probably sher steinem, and it had flown a little nay and fallen. Its neck aras injured; bot terefuresture has bi an low for this season, and At u find makes a food stine. that it only it I found no trace of a femur. He acetate - lunk was a round hole; and the fibre bone was abortive sion that side. He signs of inflammatory actin wire found slight fold at at the point of po site the retain

- Coria but was entirely imperforate.

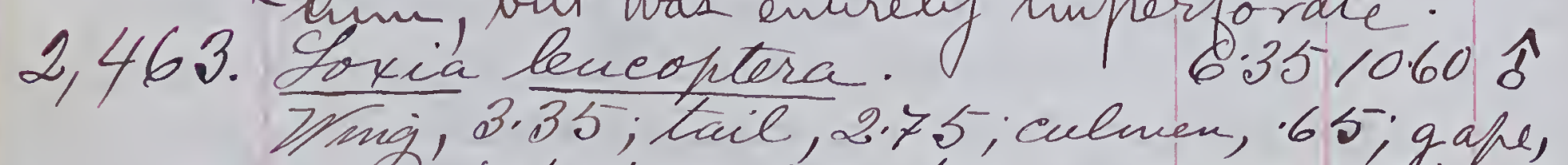

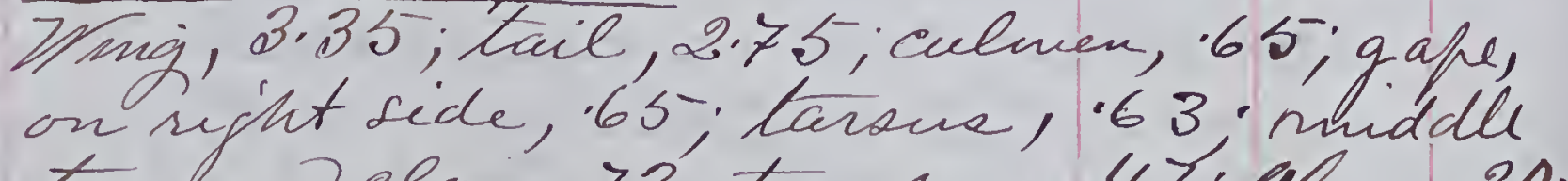
Tor and claw ,73, tor alone, 47 ; Claw, 30 . and sides of mandible, dusky; reside e yellowish. horn-color. Farsi and lore, dusky brown.
The first Pine Erosbeal (Pinicola enucleator) war seen to áay. If heard ito note before breakfast, and stepped out ufo n the frizz a and save a single one sitting

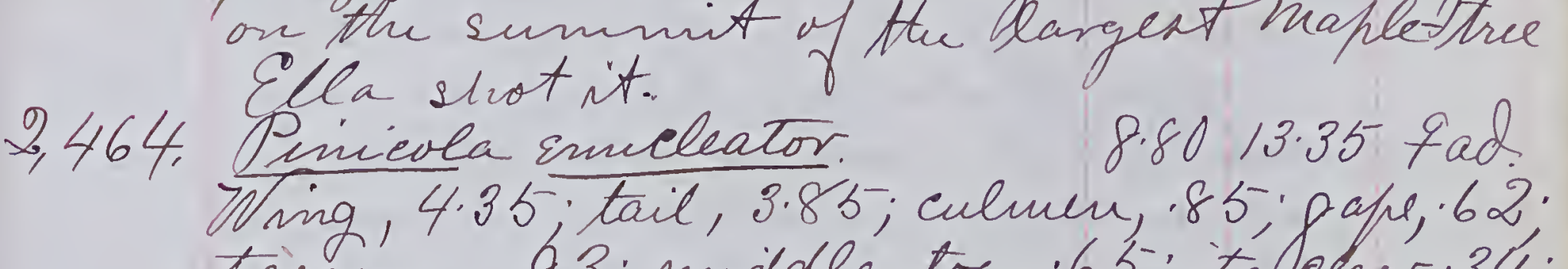
tissue, 93 ; middle tor 65 ; its below, 34; middle tor and claw, 98 . Iris, hazel. U biel, dusty; horn-color at base of mandible.

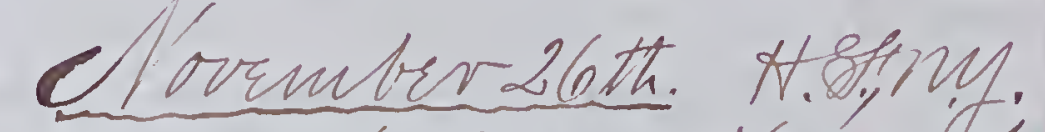

Turdine migratorius. - None trave bean or Alice marks; but I found a feds; on Fort montgomery. The stellate invoheres of the asters ar te Golden rods, as wall as the colony matrix 6) those flower till left upon this dry leaves of A plectrum hysemalt, the Adam and iv e, ore now tull-grown, and interesting.

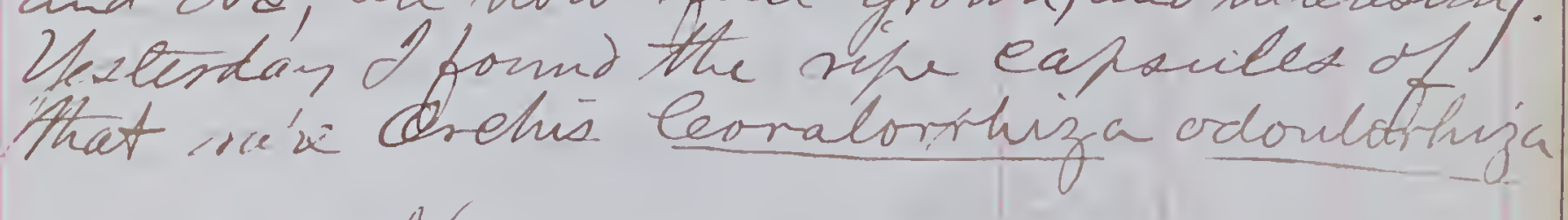

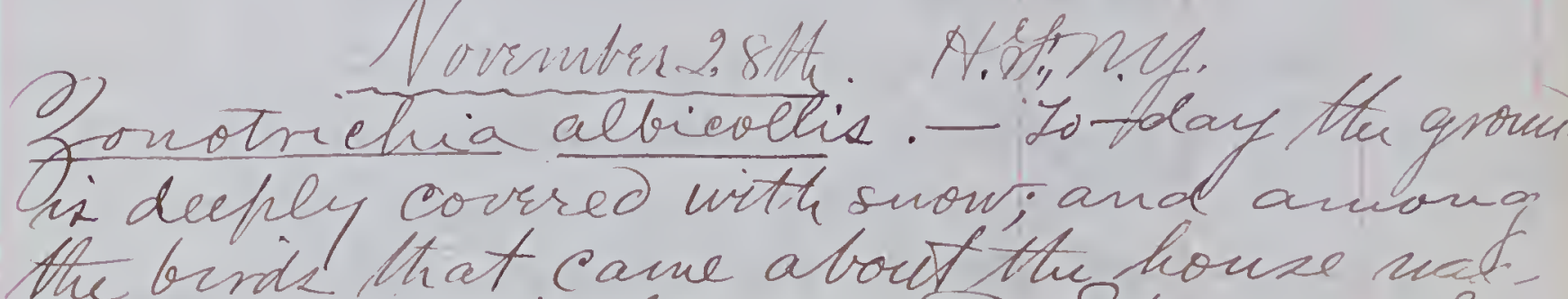
a five adult White throated Sharron Shan never seen it here late. Than of lloruber before. 
338

1882.

Decembre 14th. H.otnry.

Qinicola Enncleator:- Haekes owtwith still (II am.) The Cerows(eorrus frugiona)

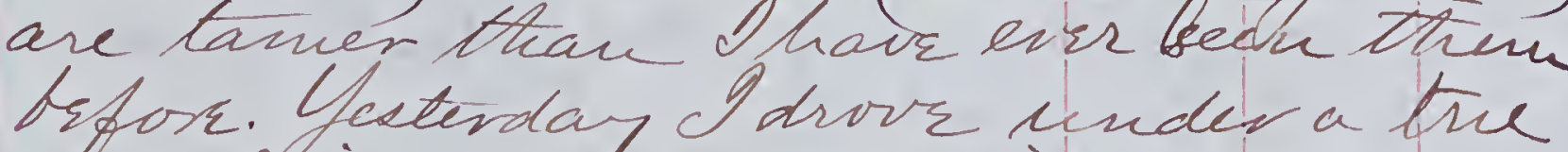

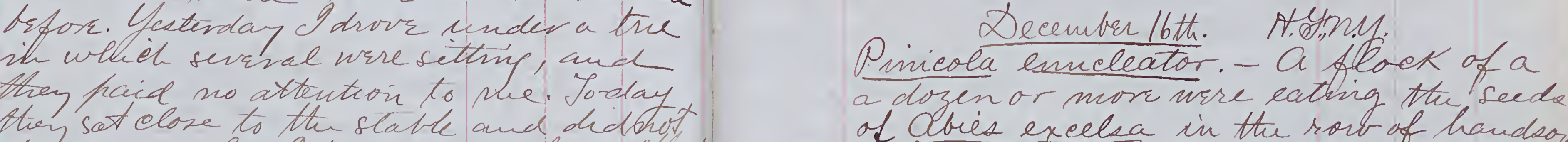

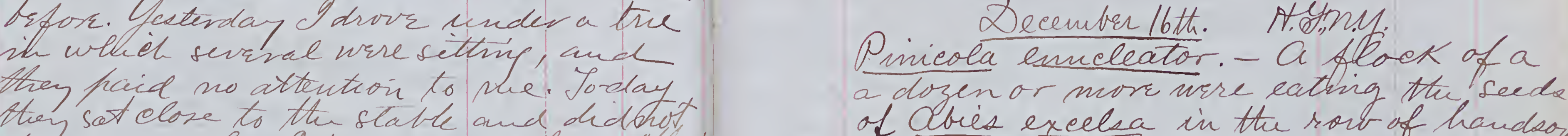

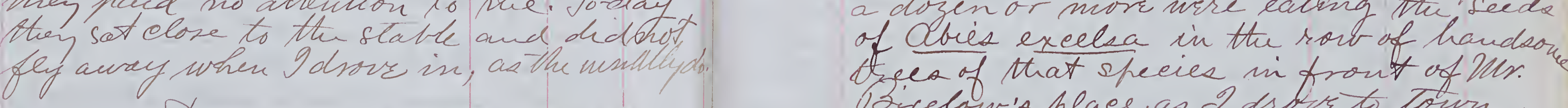

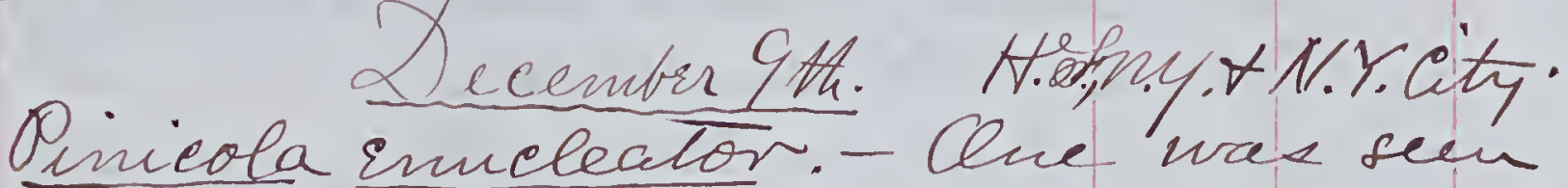

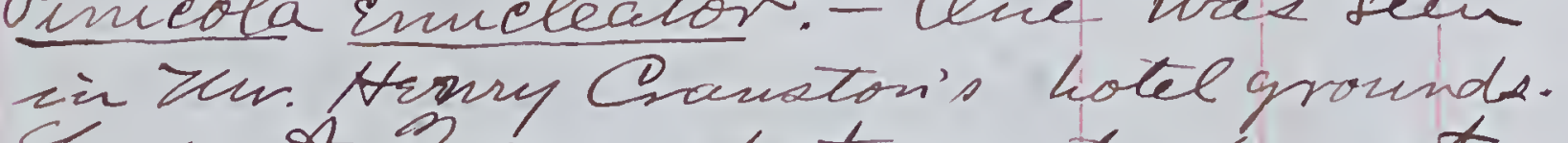
Souic At zerega shot one to-day at Festehester, in the Last Driver, N.Y. onotrichia albicollix.- Mumervno ni Central Pask, New York City. Passerella iliaca. - Serrial confaniés seen mi Central Park, nttering therr call-note vily.

this abining attended the ofering

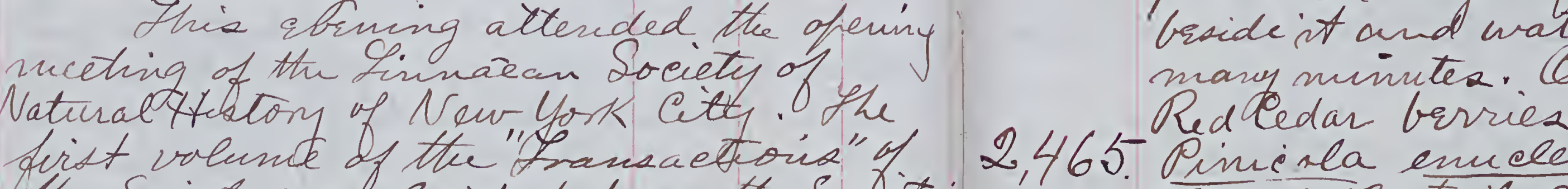

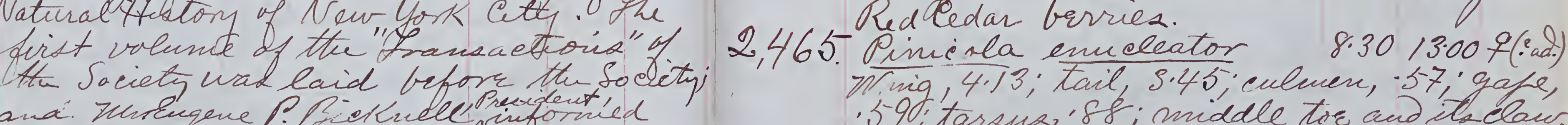

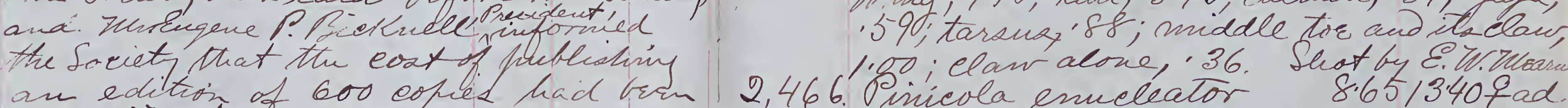

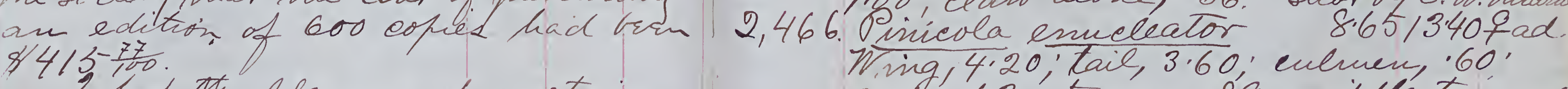

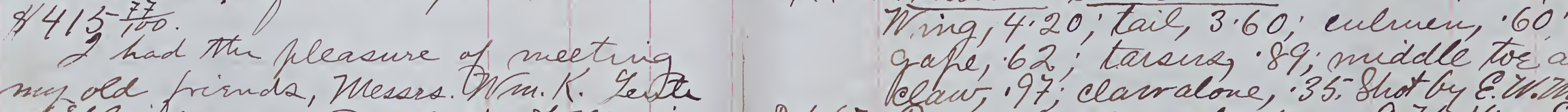
my old frimds, Messes Drim. K. Ked of Heosilea and IndC. Atartinerrian, and A.K. Fisher, brsider manil

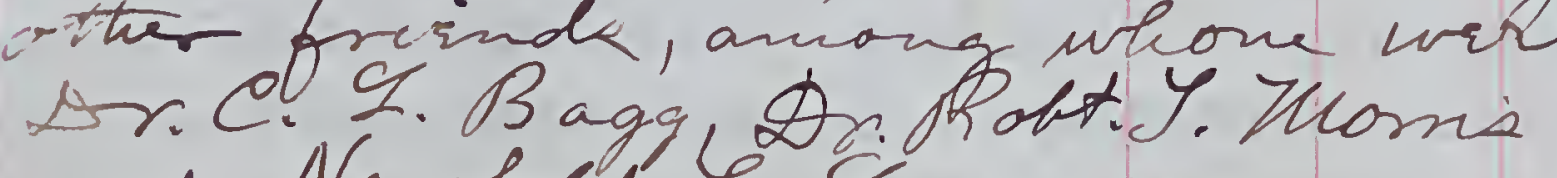
and Neubld 'S. Lansince.

2,467. inicola emucleator. $9,75,14.00 \%$ ad ning, 4.40; tail, 4.00; cnlmen, 59; gafe, 163; tarsura, 92, muddle tor and Sle a 1.03; Claw alone, 40 frot 
340

341

1882

1882

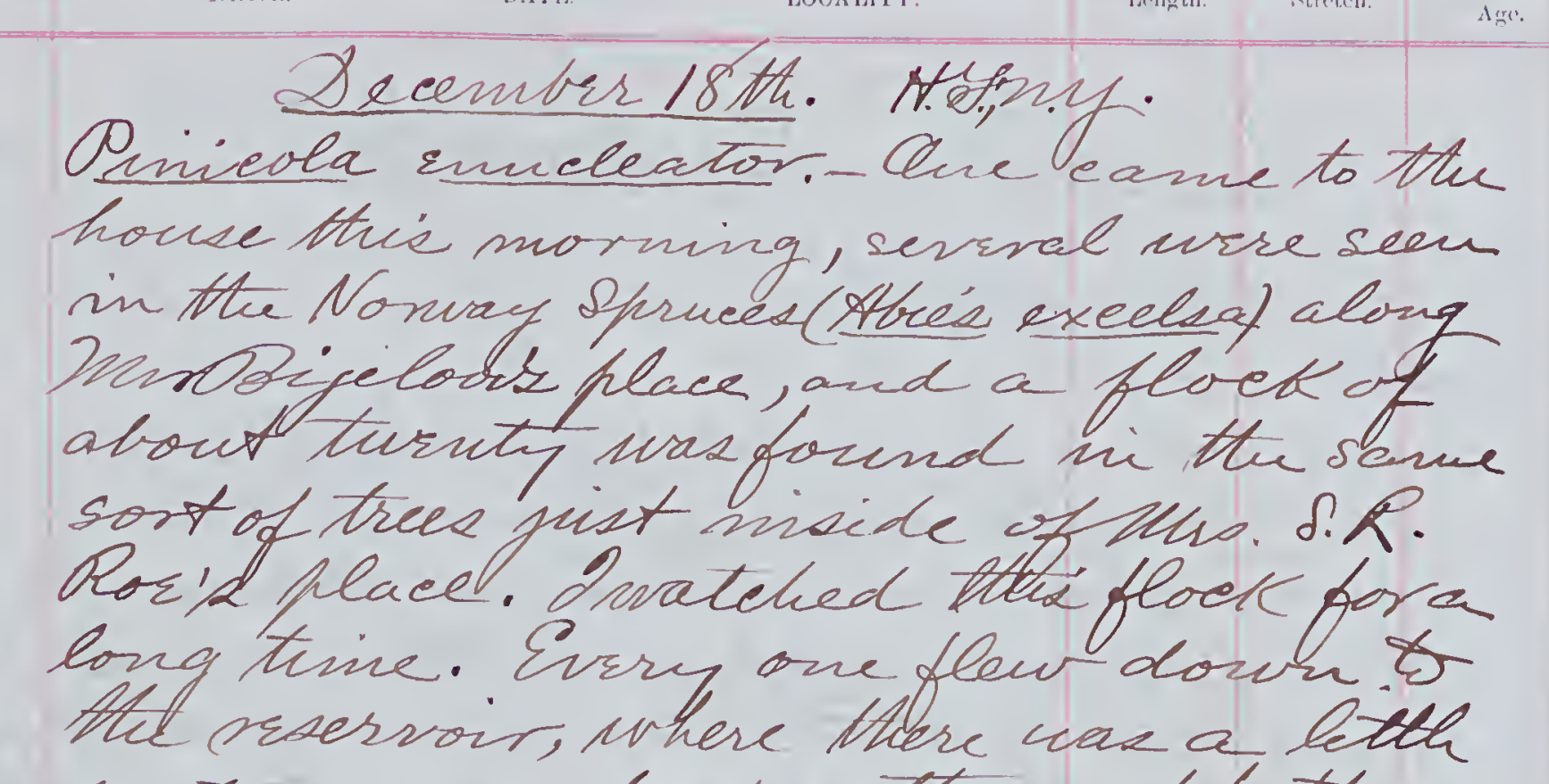
water and took a thorough bat notwistanding the sevinely obled. wrather. The sflashed the vate-about Nott a red ane anerig. Monithd to slate that the above sfulecinens (Nos.2465) of whel ar the deeds in their esopo.

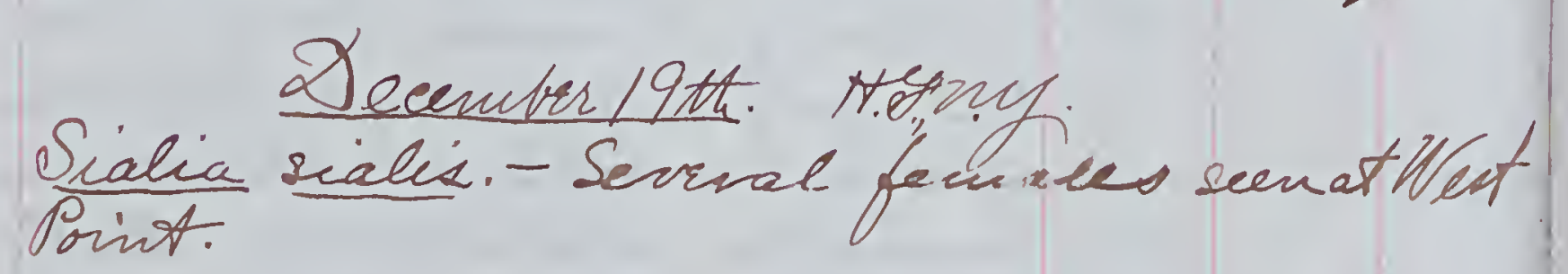

Anorthura troglodyter hyemalis. AWriter Wren was about the horse this norming,2,468. Regulus satrafia.
Wriq, 2.17; tail, 1.70; bill measured from Whig, 2.17; tail, 1.70; bill measured from
nostril, .20; gape, 44; taraus, 66;

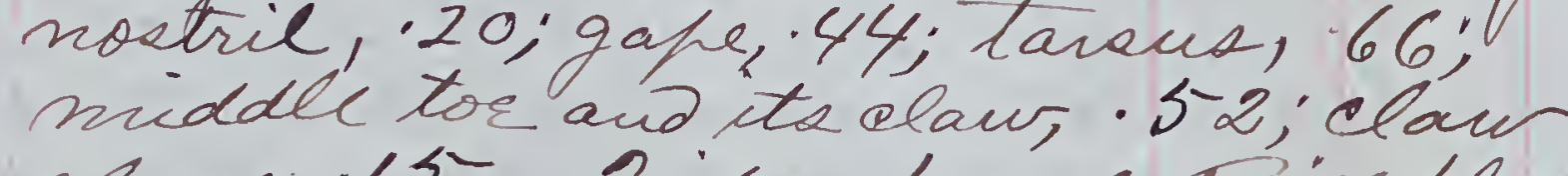
alone, IS: Mider hazel. Drel, blator. Yarsi, v tore abor, brownish-blackifeet yelowidlencer.

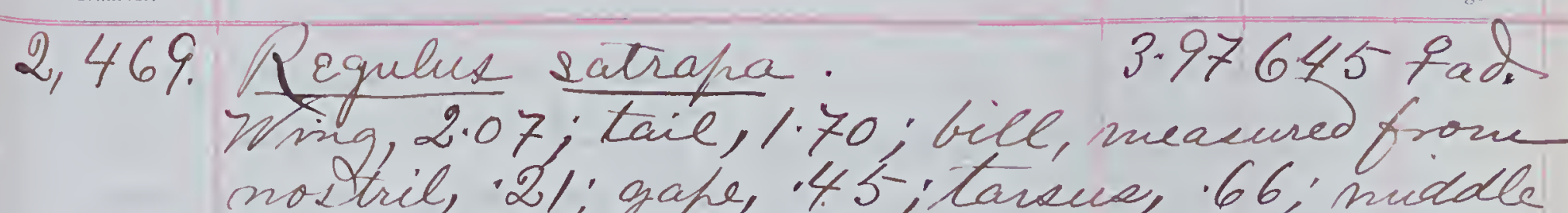
tor and claw, 153, Claw alone, 16. colore of 15 ists the same as 116.2468 .

2,470. Shitta carohinensix. Oncarna. 6.0010 .75 fad Wrig, 3.45; tail, 1.97; bill, neasured from -73; middle tor and elarb, 185; claw

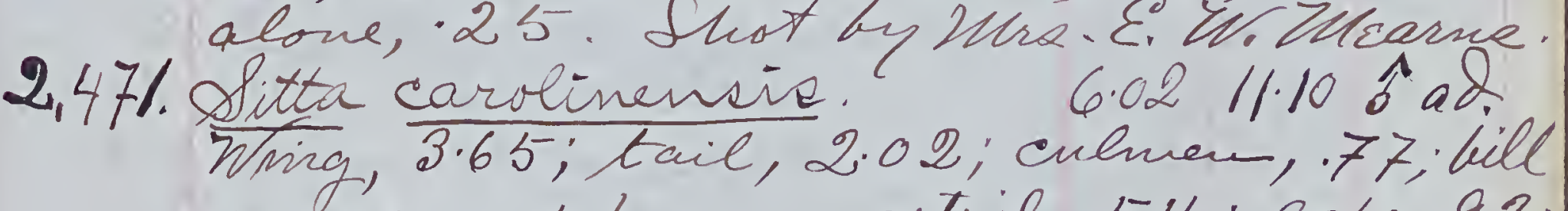
measured from nostril, $54 ;$ fape, 92 ; larsuk, 756, middle tor and dean, 92, can alone, 28. Irider, hazel. Bill, blue-black; baral one-half of mandible, fale blue. Yarsi and $\approx$ Eecenter 2 3rd. A. H. N.Y. Zo-day li's warm. Hibis are about. the houke; and Msaum a waxh blying across hemlock woods below Sfortuntyomery in search of Norttern binds. I san se- the Rev. Mn. Campbill back of At. Wouty. Ela wint along. We saw two female

Sialia sialis. - At femal (X) san madefrom the rock ent on Tursibir place to the spiling across Consovk Marsh

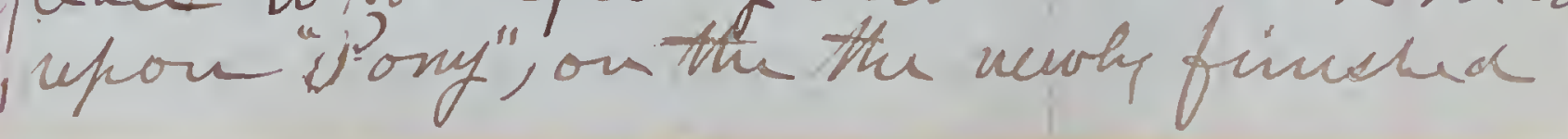


342

1882.

Whit Shore Railvoadtrack. Ot the massh saw Eola/ited auratus. Fflew deross tot the (Corwook) Lsla

Recived from Sirit. Willia Wistier a young "No.87. Ceolyubua torquatus

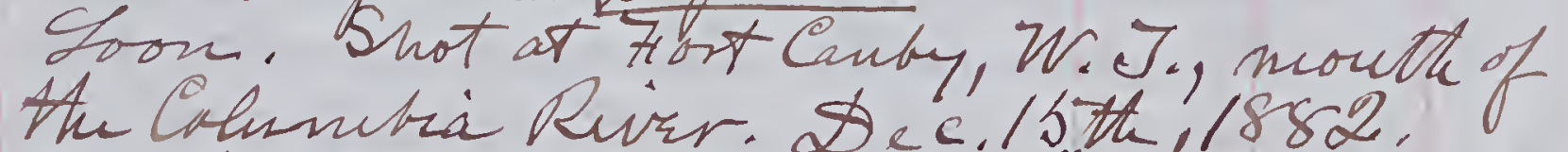
Senth, 33.00, streteh, $60.50^{\circ}$; wing 1490 ; tail, 3.25; culmen, 3.25; gape, 4.72; height of fill at midalle ff nostril', 1.03 ; wibth of bill at posterlor forden of and claur 5ilo; its claw, 57 . measuremunts ixceed thoze of Eastern shecimus of leolymbus torgutath ax

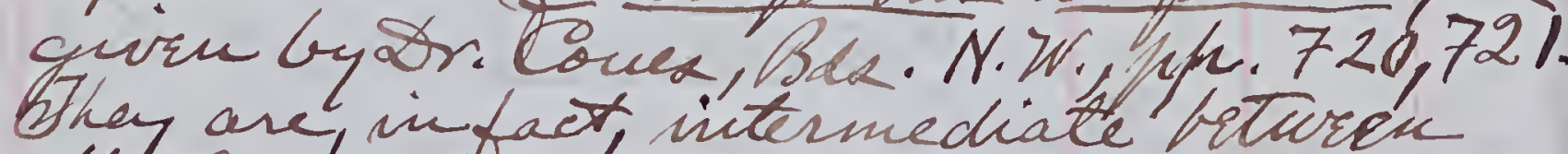
the Eastem torapotus, and adamsii. Hs bile inar the dortal surface of max illa to the extreme tip, black; sedes of maxille mearly to tip an whole of beck. Inferion suiface of tors ond whole of towter to exet/t the three drseky, of jointa) blaek. Loes above (Exeefung the outer), cale greenish - hlew, dudtif ou sides, flesh-eolor in the midele, ans se' bitly bluik above. Hallex, Hackich, forderes with browish on the outer side; flesh-eallon on the
1882

840

imis surfices. Nails, hom-evlorpt base; black at extremity.

Egiothus Linari (Linn) leat. Common Red- Wee. - Jo-day a feock of about. whon the seds of the white foride? and ware ary geute. Ci smigle shot brought doron thre speimene.

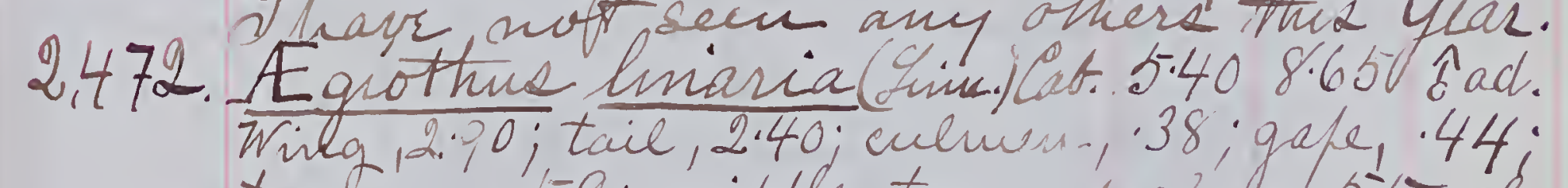
tarsue, .59; middle tor and Clach, 55; claw alone 25. Fides, hazel. Bell, with a (on maxilla) and belout (ou mandible). Yarsi 2,473. Egiothus limaria (Imi) Caban. $5 \div 128.35$ 7ad tarkus, '54; middle tor and deour, 58 ;

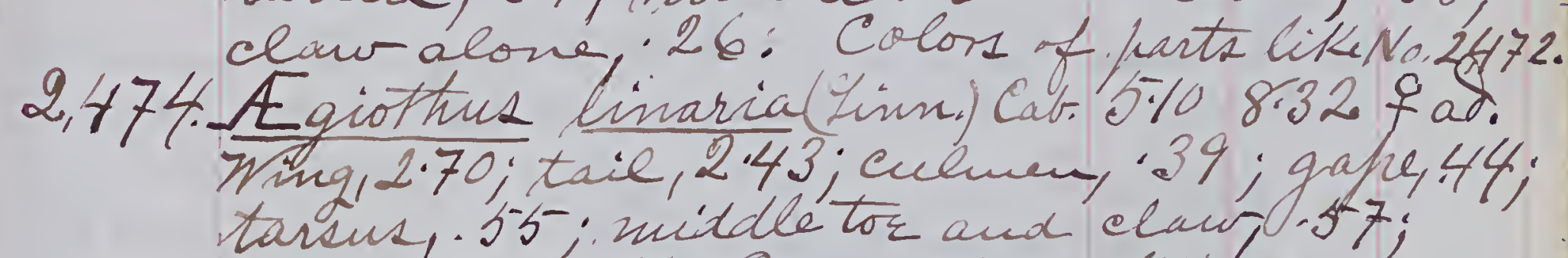
tarsur, 55; middle tor and clang . 47 ; Mr.Wm. Church Ostorn found the Suowbird (Zuneo memalis) at Lake Dholionk about

Drenuter 27tte. H.A., N.Y.

Agiollus linarias, There was a flock.

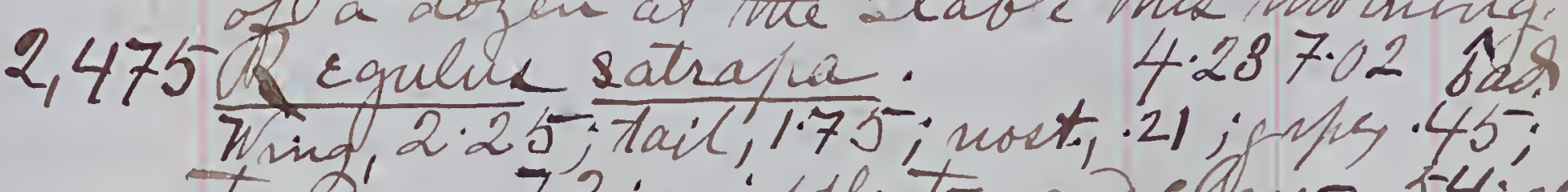
tanes, 72 ; middle tos and clav, 54 ; clem alone, $16 \cdot$ Indes, hazh Bill, Hack darsi 
344

345

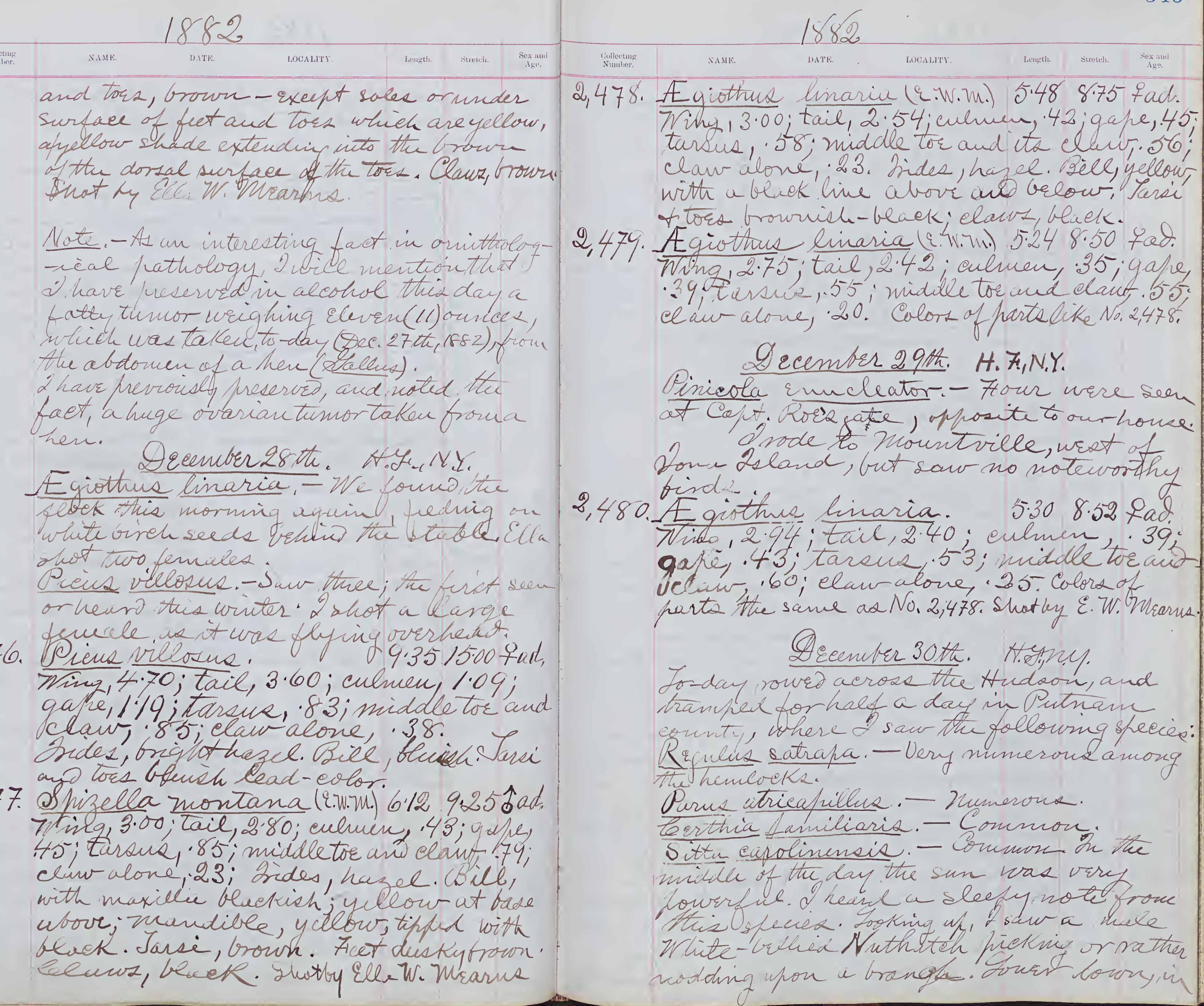


346

34.9

1882

1882

The crotel was a fenale sound asleeh, with her head traun into herfealters dreaming sevest dreane of buggy the trunks. I tossed a branch agkinist the tree and roused her frouldream- land. She flew- to the nuxt tree.

Anorthura troglodyter hyemalic. - Jur were seen neah a strean. 2 saw one on 2,483. cenber 2 /st. No othera seen Vtur winter. Pinieala inveleator. - Heard the note when in a hemever woods, but did not find the birds.

DNelospiza nelodia. - Lwo found in th cat-taile aeross the river, neth Cox's. Aner hyenalit:- a few.

Spizeder montiéola. - Searee.

Astragalinus tristiv. - Cre small flock wadfeeding whouthe suds of the alder. Corvns Augivons. - Common. Eyanvitta eristata. - Very abundant back of Asborn'a house. Three shost. Picus vilosus. - Cue seen.

Larnk argentatus. - Luro adults.

Note. Thu railvoad men ale say that no "White snowbind2" (Plectrofhanee mivalia) have barn about yet deis write.

Scinrus carolinerseis (Gray Dquirre). 2 sau-two; and resta are very abundant tyenerally distributed thia Year, on botth sides of thi Hudson. 2,481. Anorthura troglodytes hemalis, 4.236 .959 ad. from noatril, 32 ; eulnen, 47; gape, 65 ; tareus, 72 ; middle tor ane lelaw, 70; elaw a cone, 18. Jrides, hazel Bill, black abov; mandible o rdges maxilla flesh-cilor. Yari, tors $\nabla$ clark, lighttron
2,482. Melospiza fasciata. 6.458 .757 ad Ving, 2.67; tail, 2.75; culnen, 50 ; ga/e, -57; tareus, 85 ; middle tor and elaw 84: elarv alone, 24. Inides, hazel. Bié, beack above; dusky at tif of mandible; residue of mandible, horn Irolor. Jarsi, Plesh-broun; but; Goun; Clawz, durkybs Wning 5.40; tail, 5.40; culmen, 1.16 ; gape, 1.30; tarkus, 1.38; middle tor and dew, 1.15; Claw alone, 38. Wie, hazel. Ii, 2,484. Cojanocitta cribtata. 12.0217.00 1 ad Ining, 5.50; tail, 5.55; culmen,1.12; gape, 1.28; tarsur, 1.37; middle tor an clui, 1.20; claw alone, 40 .

245 Irides, hazel. Bill, lectroet, beack is 2,450. Lewanocitta eristata. 12.0517 .050 ad 1.27;.tarsú, 1.30; middle tor and belú, 1\%5; clin ulone, 37 . Bides, hazel. sile, leg.rfut, blaed.

Qecember 3/st. $\quad$ H. F., N.Y. A fock of inght or ton Pine troobraks

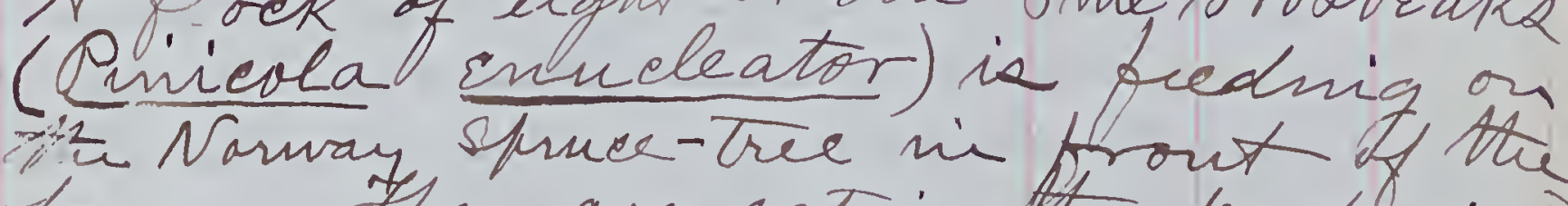
tonse. They are eating the budi ; aid none ware eatring seeds while I watoned trem. de sfecimens shot a fer werice ago, both the seeds and buda of tris tree (Abis cxular) wre found, Although hemlock (Abis nadenchiz) and fiteh frive (Pins rigida) Cones are mumerouse, 2 have not Hnown the Pine Hrostraks to fued, thia season, whon other evergreens than 


$$
1882-83 .
$$

In which latter they usually sem fond

\section{Zan.1,1883.}

At the brgining of the year, of will give a statement of the number of sheciuenr teken Each ycar sinde 1871, as the specinens colleeted inay of said to fairly repr

In 1874, a wrote at the beginning of my Gournal, voli i, a calalogue of the stinls then in my collection, whible wrs taken by myself. I did not nielude in the catuloge a collection of nounted rinds whieh othad made dusing the years 1873 and. 1874, nor the stimiz Which hax frevioushy left my cabiriet. Inid a sefarute record of a part of these specineus, which cataloguld vepurately from the balanee of ons collection, in 1880, in this book, f.1.102 to 108, using Roman numerale, Vtur making a sefarate catalogur without exvite duplicationg the numbera. Both collestions are girin in this stat- ment, only the sarkir collection is refresicuted by Roman numerald and Buen added.

1871

1872

1873

1874

1875

1876
1.

100

419

544

487.
1883.

Collectumy
Nitunler.

ther.

1877
1878
1879
1880
1881

\section{2}

Iureve years

Pinicola $\frac{\text { Anmary } 2 \text { ind }}{\text { incleator. }}$

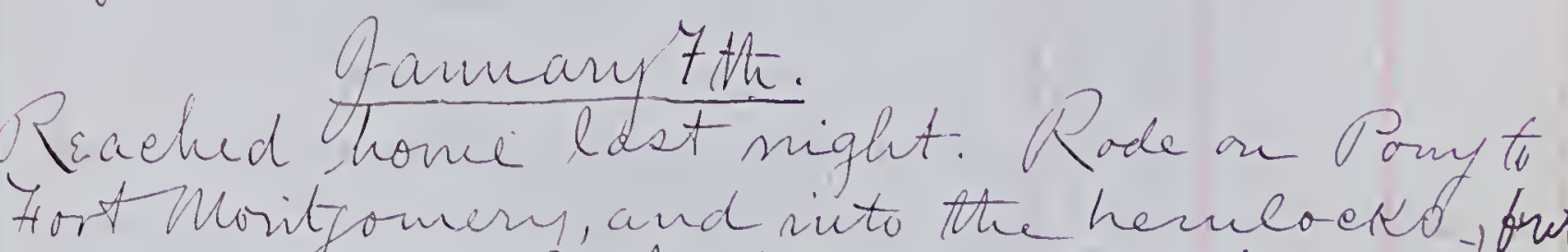
som no birit of shecial interest.

thic aflernooh ny wife, walkd downto he River. We sau one Astring Lece Lami argentatur)

The roek cut in trout of Mro. S.R.Vre's hlaee is about finsinkd; and Xavens doek coverek with varke of ties whieh will sory1. teraid. This Damany 14 th. NewYork Pity.

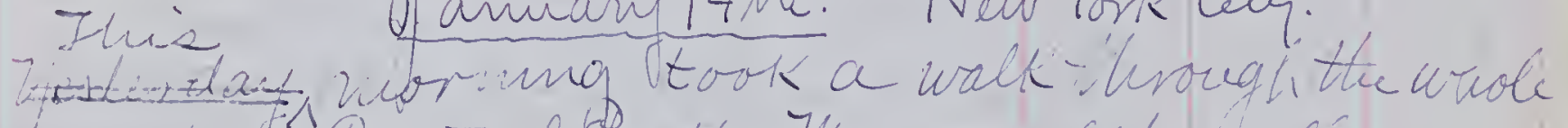
A.y te Central Pask. Wa wre wheceaty iniuca) nit the Vark. We havgseen it therr lat in L cember, and corly he fiebruary, and a to Establio itakinter pridenel iu Centinal Park. There is no record of ets oecurrenee throuflout the winter so far horth; but Mr. Arthur. A. Heelme inomed me a shost tive suex thret it wirters regularhy ore the morth shors of Soug Iscand, at his resedenec. I. Saw nowe of them to-day, however. 


LOCALITY.

The Wuikrat (Hiber gibithiens) wat quit munerous. We saw its sijno traekt abou nearly all of the watire the the Park. bay Squirrels (Seiruz carohnensialeucotiz) were abund ant. We saw turee of one tuie, all churing on hine couls of the yellow shed. lot. halkext a snowtalk thandy aco urek jist poing to send it defter onie of then wher a Pask holeceduru shouted si bu eier, und couphletely paralyzed ahiu? The following binds wrreseen: Regulue satraha. - Abundaut. Sitte canadensis. - Ene Eerthic Lamiliarid. - Verm numerouk. Sonotrieluí celbieollai. - Commor. Wuelos rije faseiata. - Searee. - veser domesticus. corrus frufiorua. - Surnal. Leardueliz elegans. - Floek of 20 at Poob. nuco hyendliá. A number. Cecerdinaldé virginianue. - Lovo were seer,

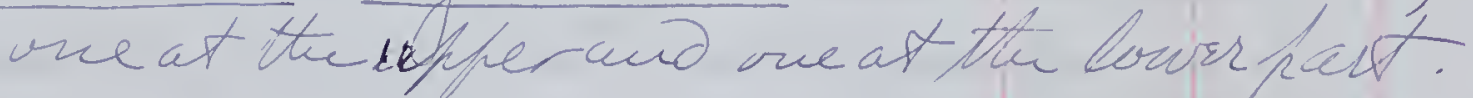

\section{- Jomary 21st. H.F.g.V.Y.}

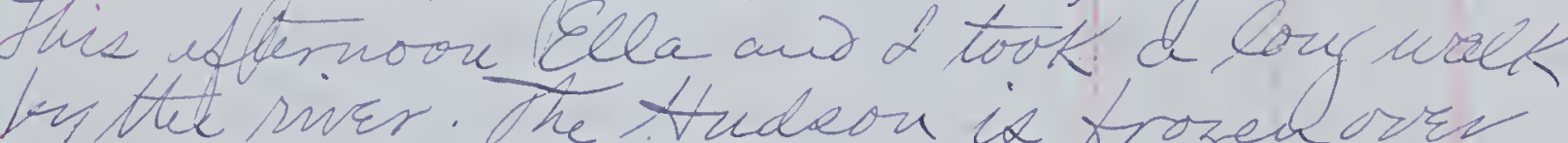
Ane people ase walting abrose it.

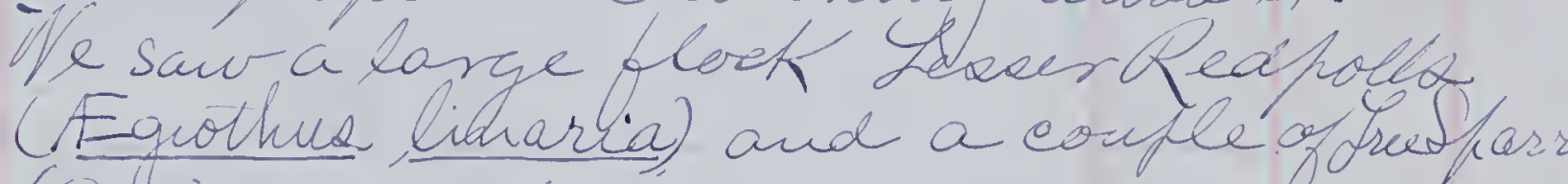
(Spizella nontana).

- Tra the dat a hadow withour ar Isat frothe ching-rorn undow, and lootivi onteides san a Jine are (Seoke aseir). If satthere for coun time. Elea got the Ori shotghu ink ficled it with a charger of aluat chov. Istinined it for heb cabruet.

\section{3.}

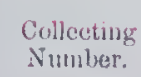

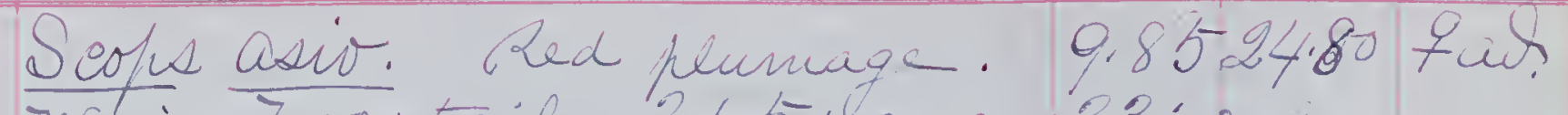

7ving, 7.00; tinil, 3.65; ere, 3.3; cunce,

measured from eare, 67; from varic of oere to

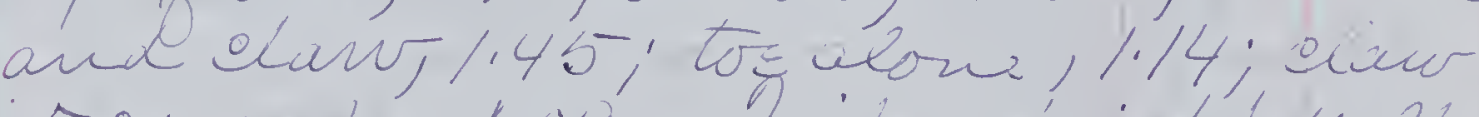

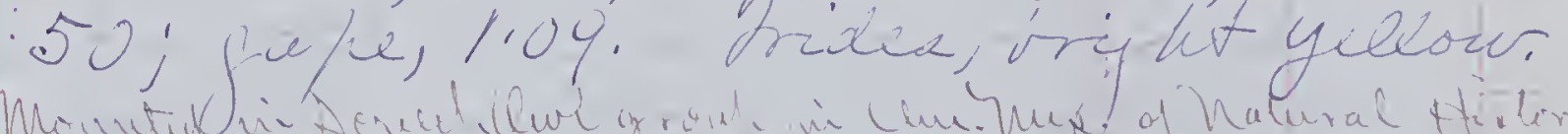

\section{Lamiary 22nd. NewYork lity.}

Jove the 7.42 a.m.train to New Yonk. Just abor Hijh 3 ridge, 2 saw an inmature White-headed Eagle (Halacitus leneocephalus), which the crain s-arted uf from the iee on the vivar.

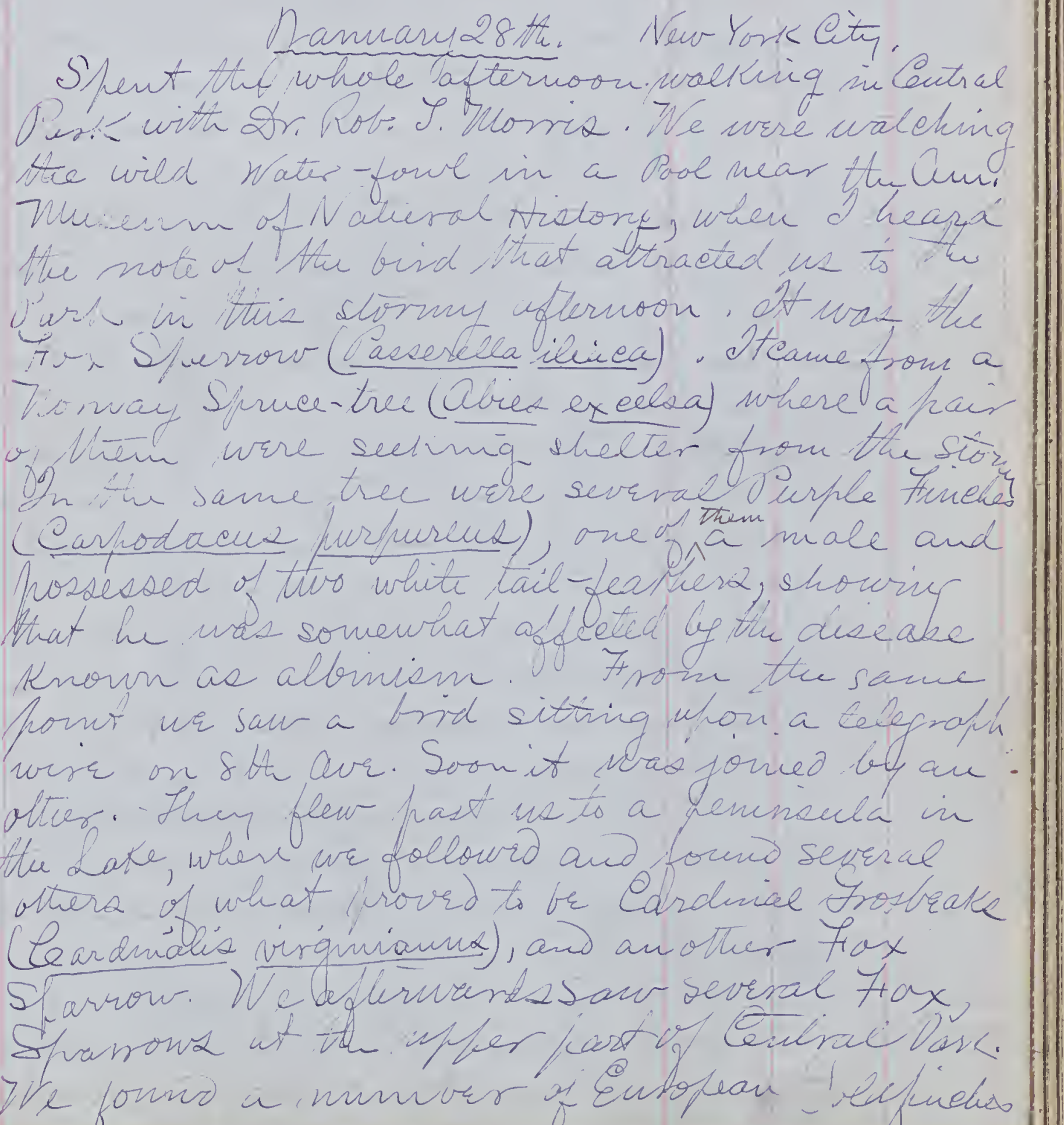




\begin{tabular}{|c|c|}
\hline Ifreugth. & sitretsts \\
\hline
\end{tabular}

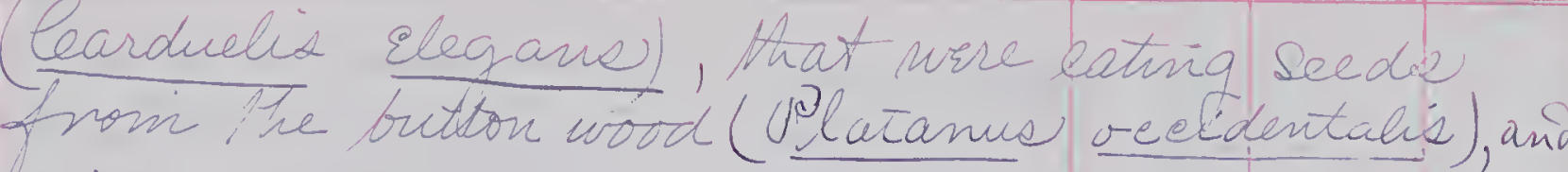

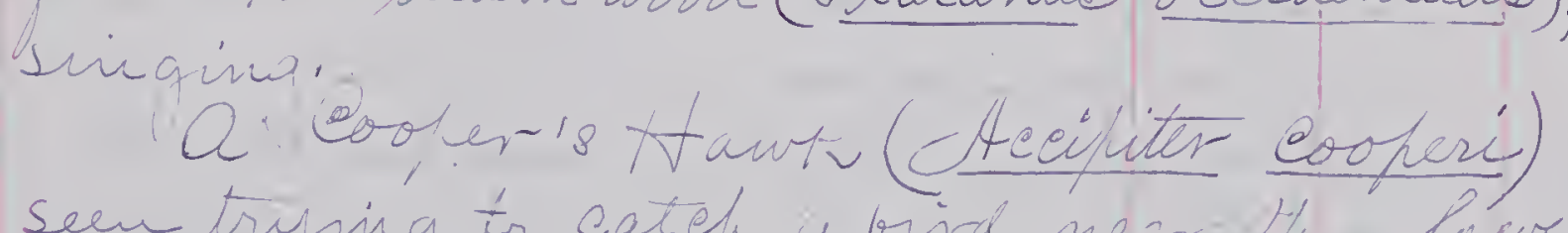
grservoir- (wast) and alighted elose to ne. We watehed him. Hewatehed us. HC, was vers bold and havosome. tE flew surftéy, whén started, arid Corr; madel a splendid, sur it

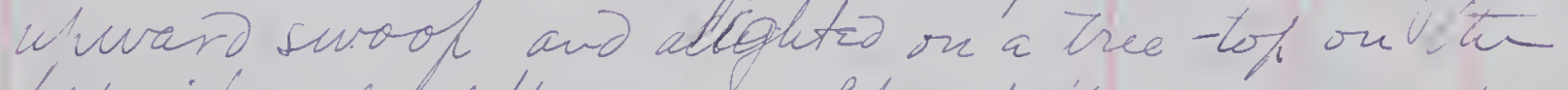
opcosite side of the gresn. It sat there nitil alu wrefthin Dray

leneotid bat the loug acorns whid arou-n Atu louver side of the large reservoir-, in die í mosky-fringed cwhe. The also eat the secke of manel of the Pine cones in Sentral Park. This themoon we saw a hair iating the seeds of the thome locusto the a.

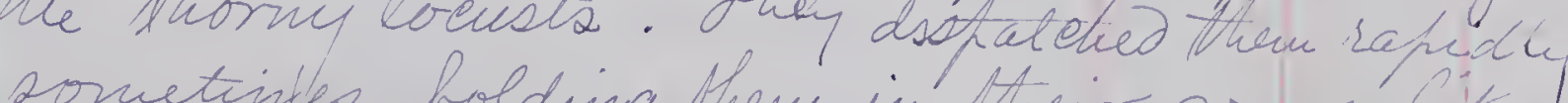
a jerfonner on the hast. Bab seffesto trat

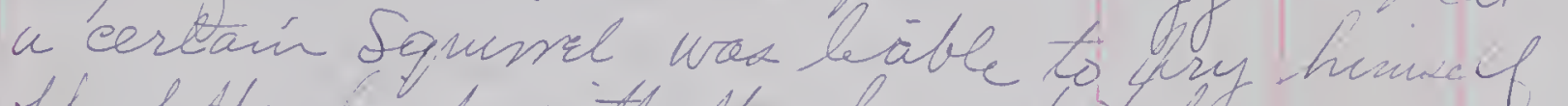
of of the inef with the huge hor he was

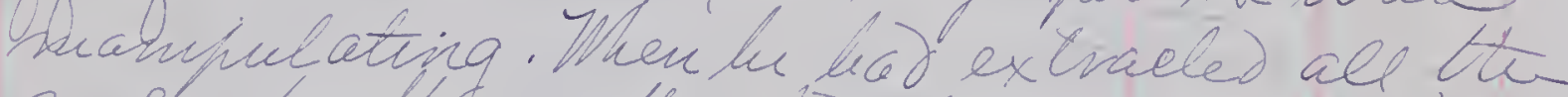
serde, he thenew the noo down at un. "Lt neasuras about a foot loufand un mo I

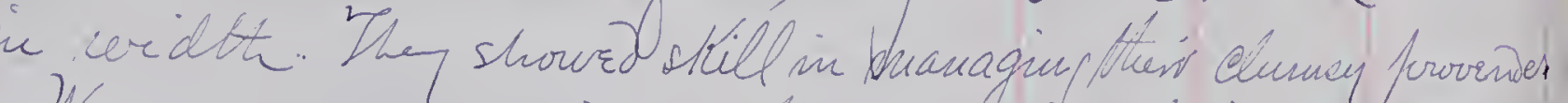
We suvr, in adsition the followin brids: I Gerthia faniliania. Arown Oreuper. jonotrielie albeollia. White-turoateds, amow. Nelosmia fasecáta. Sory Sarrou-

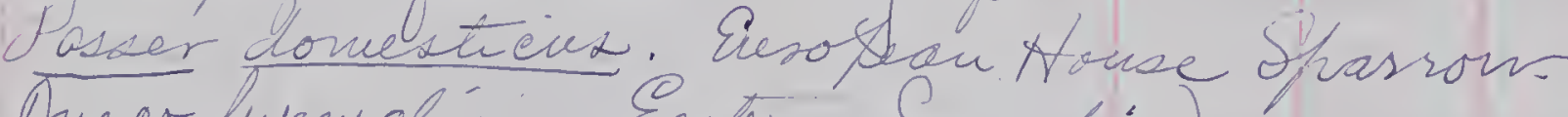
funer ujemalis. Castern Suvwbirs. Carduelto elegana. Enotean toldguidu. Passerella ilvaéa. Fox ffarrow. I have frevividey

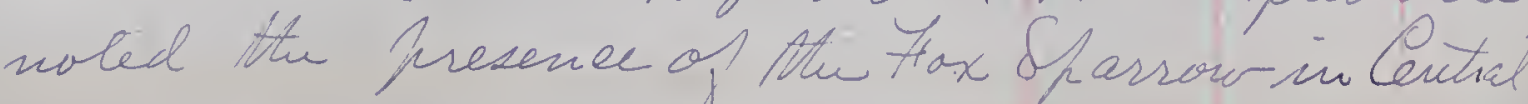

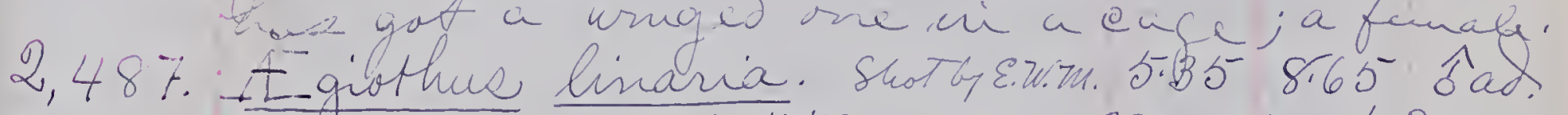
Tring, 2.96; tail, 2.45 ; Euluen, 38; gape, 42; taksis, 59; middle to and Claw, 57; elawabure, - H. Isides, hazel Bill, yellow, with extrenity A loth mundiblex especially the wper tified with

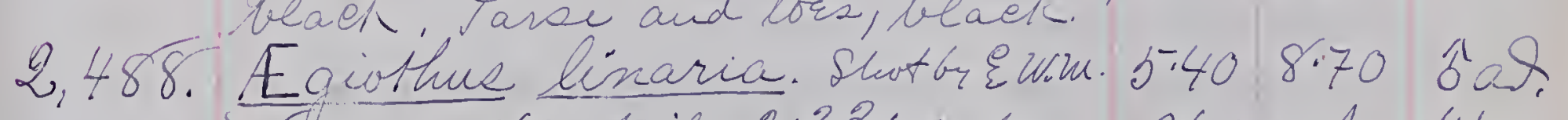
Whin, 2.87; tail, 2.33; culmen, 36; gope, 41; tarsuz, .57 ; middle tor and elui, 53 ; elan. clone, :2\%. Elors of parts the sanee as No. 2,487.

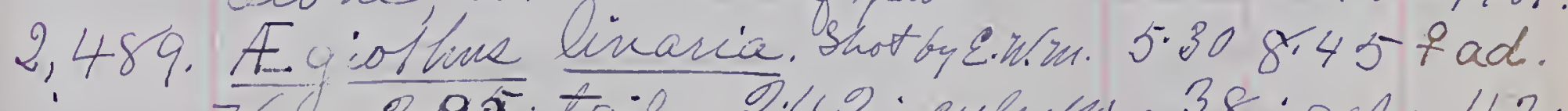
Vinu, 2.80; tail, 2.42; culnum, 38; gape, 43; tarkus. 60; middle tor and clunj-55; Claurculone, 24 . 


\section{3}

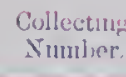

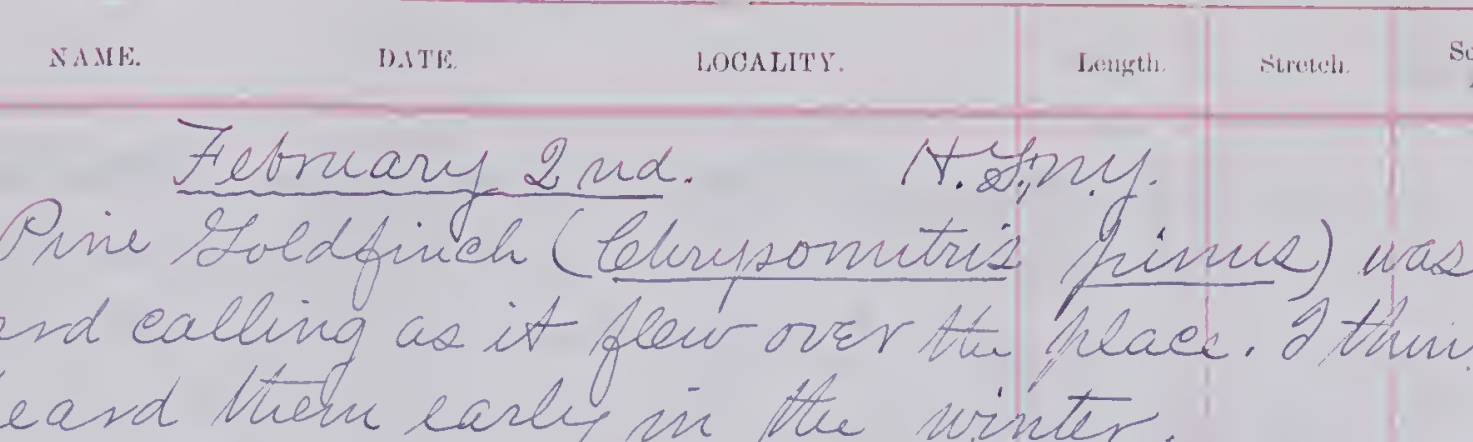

Iheard then lasly in the winter.

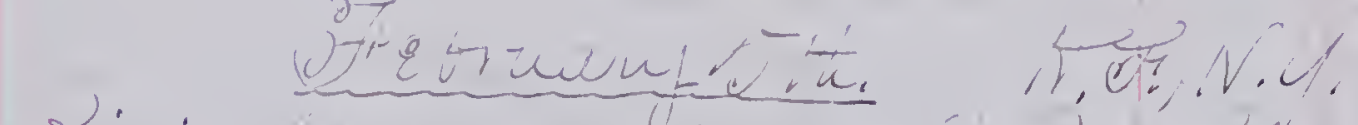

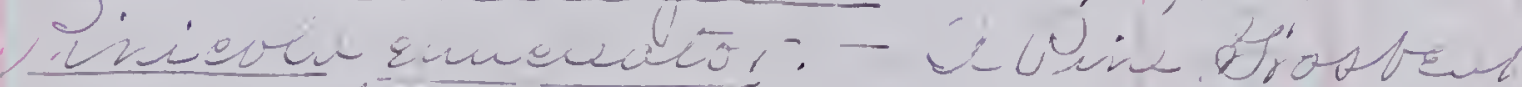

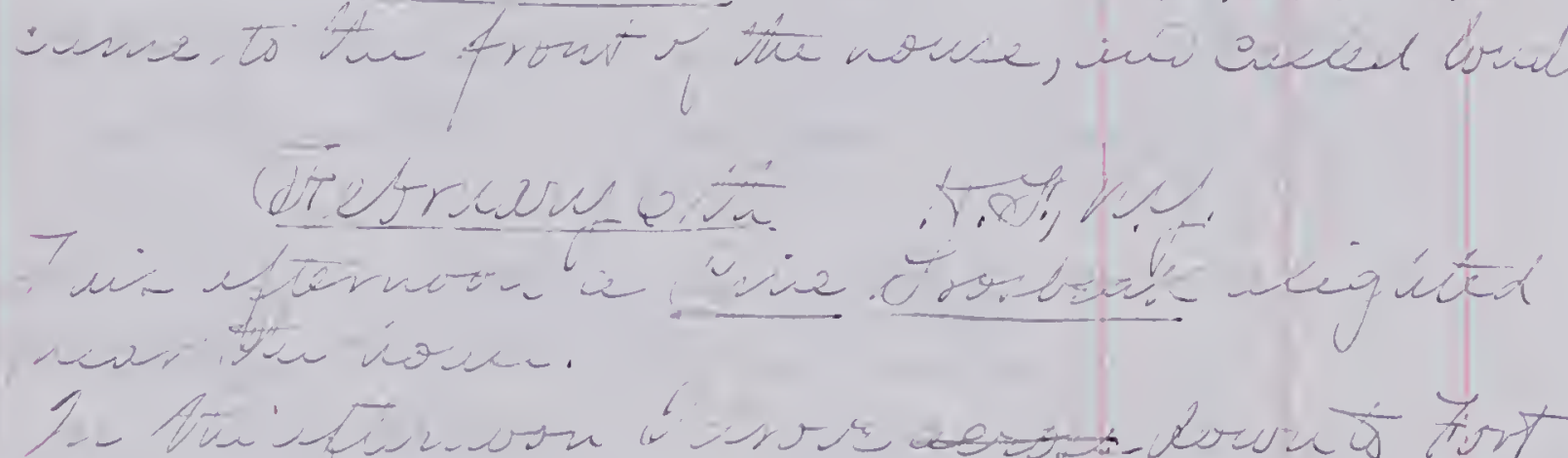

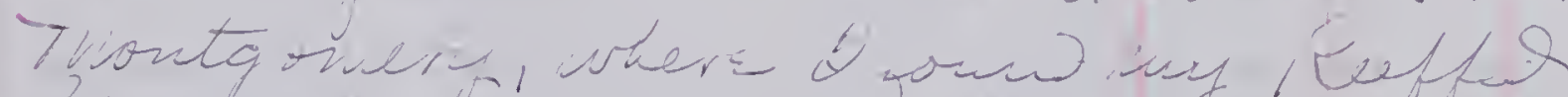

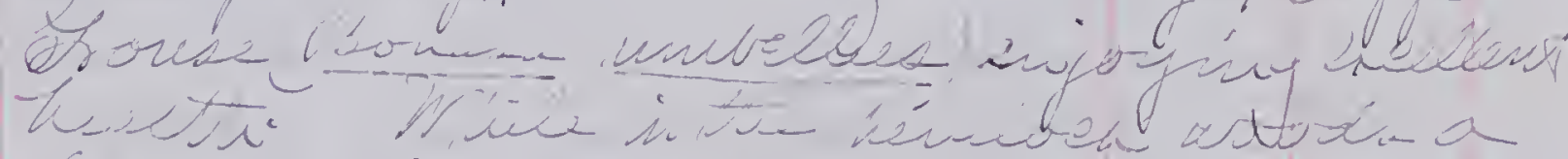

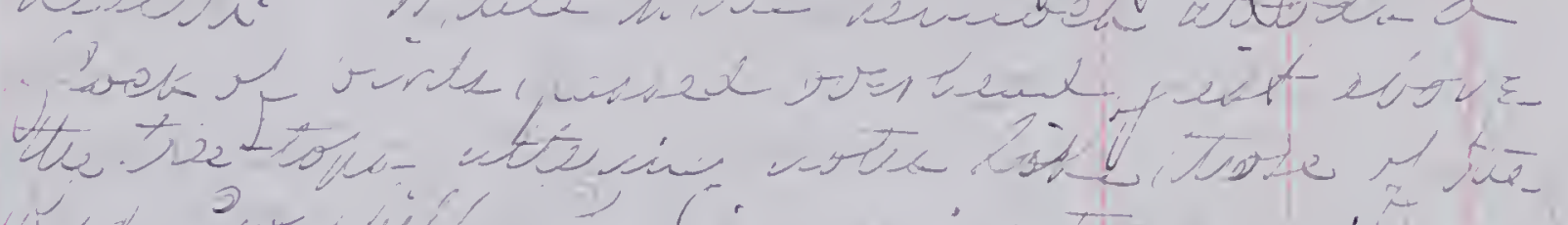

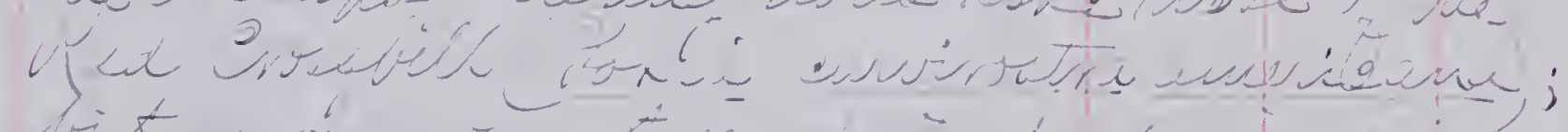

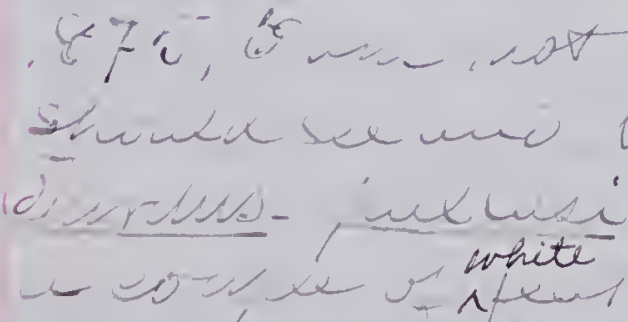

2,490. Aylocichla unalascas hallasi.7.12 1/35 1 ad. Wing, 3.53; tail, 2.82; bill, measurect from inostril,

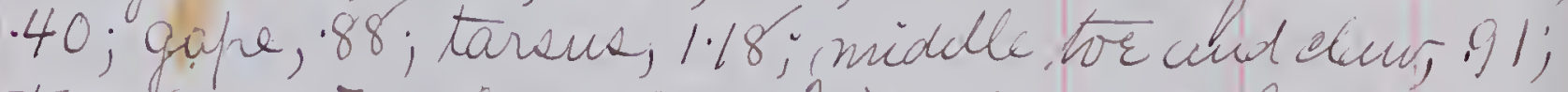
tor acone, 71 ; cluw, 21 . Jides; dark huze. Jill, birmish-blach ow muxillu and lerninal sne-haif of munible. Booat one-halet of mun-

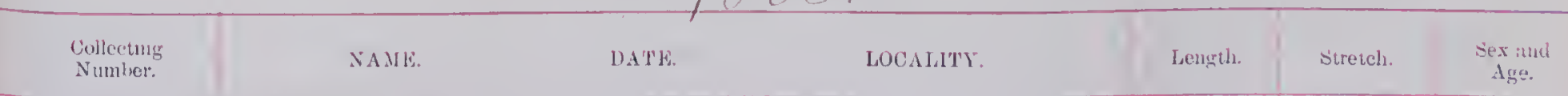

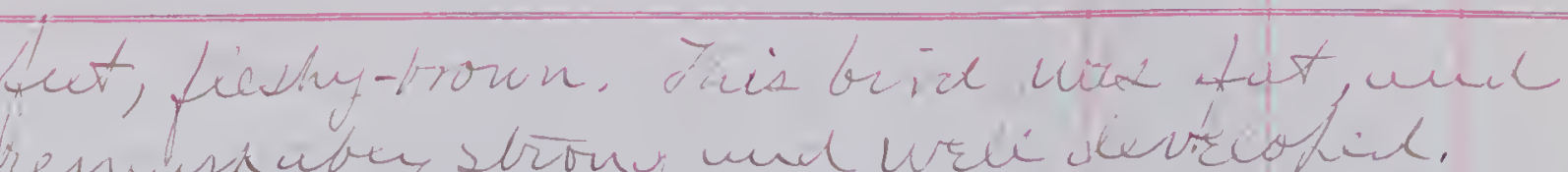

\section{OHomary8th, HA., New York.}

Pinicola Emicleator. - A munber of Pine sosbeake came about the housel thir afternoon, and ate the buda of the sicvar sicaple, and the afilles that still huing upon the trees. ClC were in female hlumage. of tried to make a double shot on tho binda that wire flymig very swigtty but Hiosed with mu seleoud banel. The last cind alighted on the big white var, ond uavitted lor

2,491,

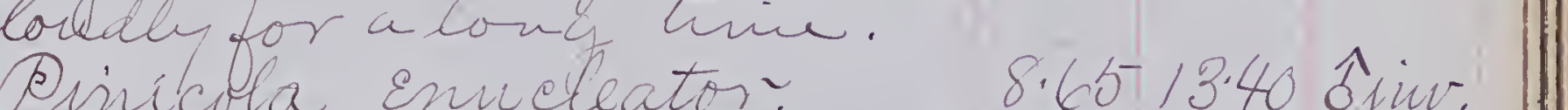
Wina, 4.25j tail, \$.50; culmen, s-9y, gapk;60; tarsusur, 87; midele, tor and cean, 195; ita claw atore, 33. The crot sthath of thia bive was fieled with and the rent of the cokhlex wrich ure wone the trees oftiel. There cers no

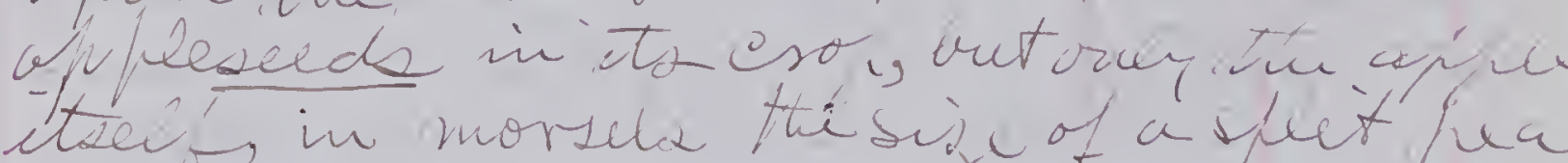

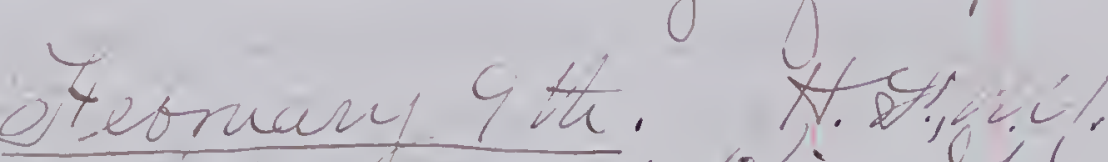

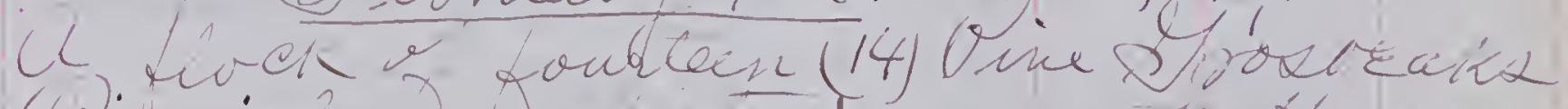

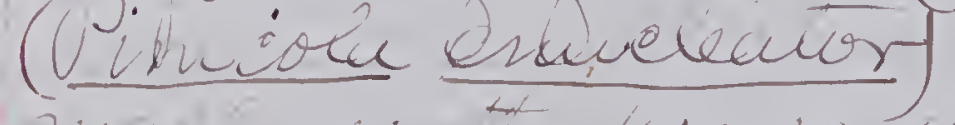
ciene, to itu decsar

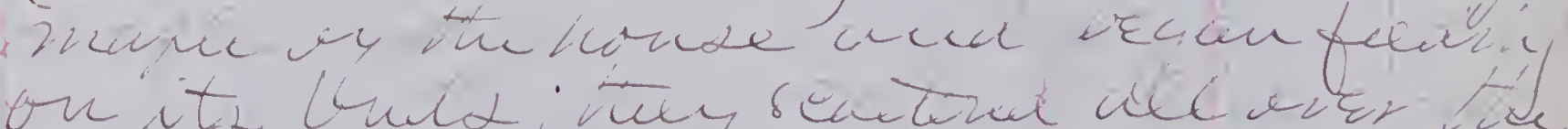

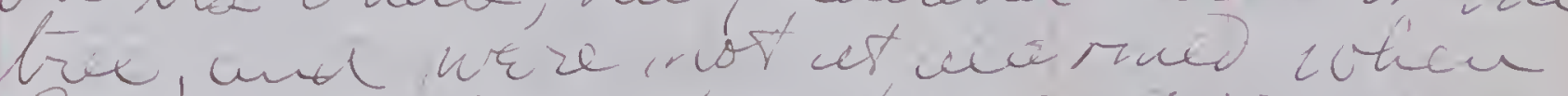

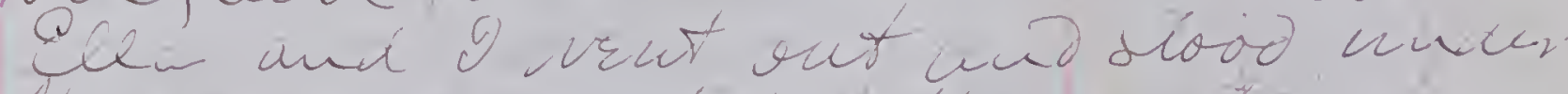

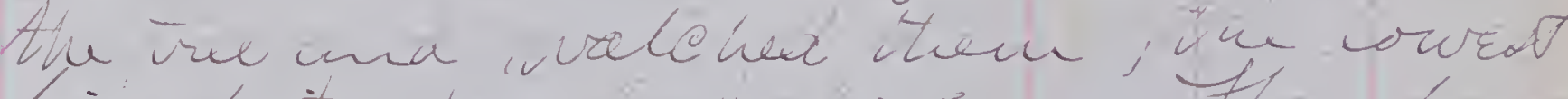

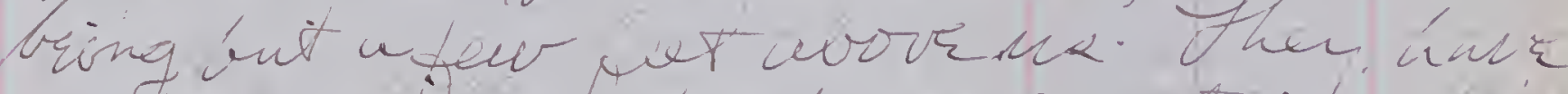

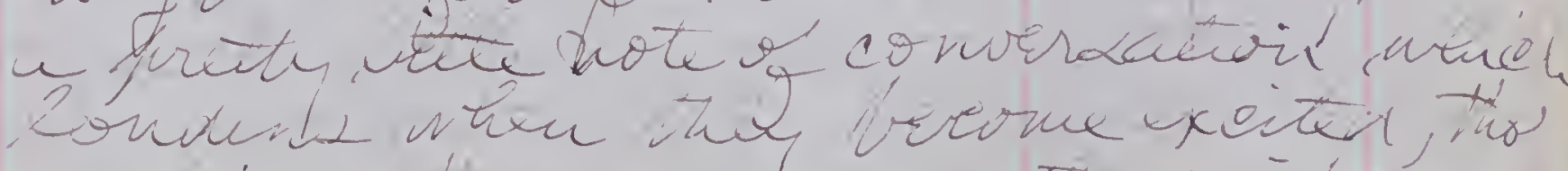

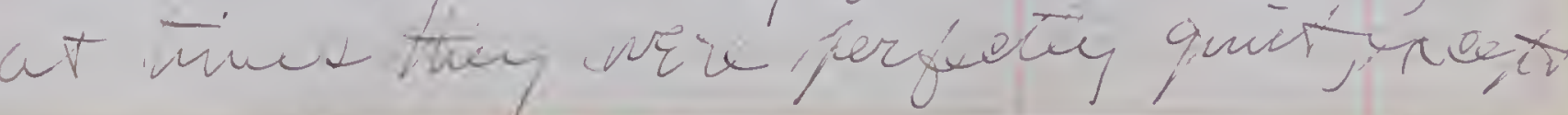


for the noite their Giés mate in bitric

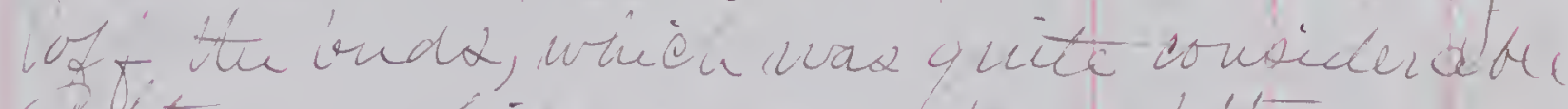
tew ther unet ite those wheid vere downltere.

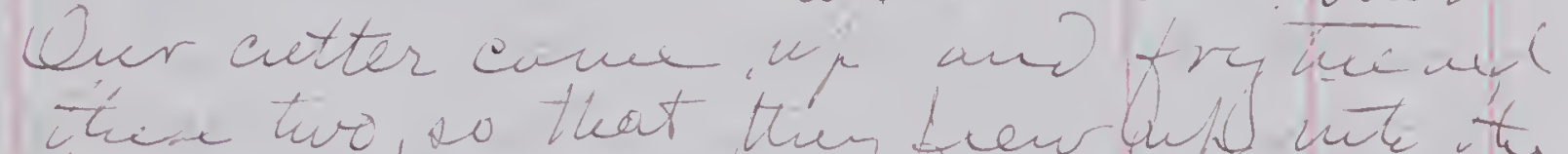

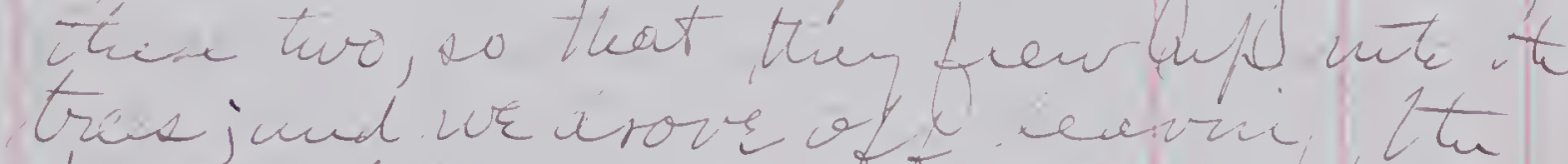
flook süil fceling, lod ar wrak in

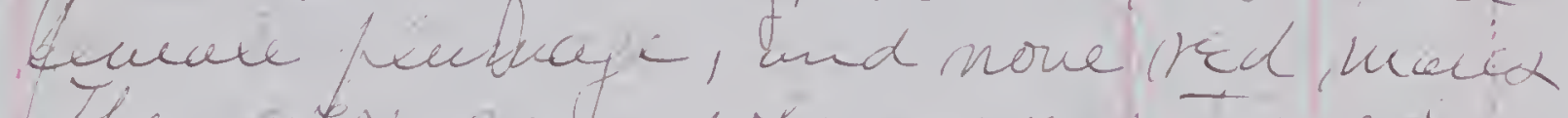
Ther weri gothe when ur setersed.

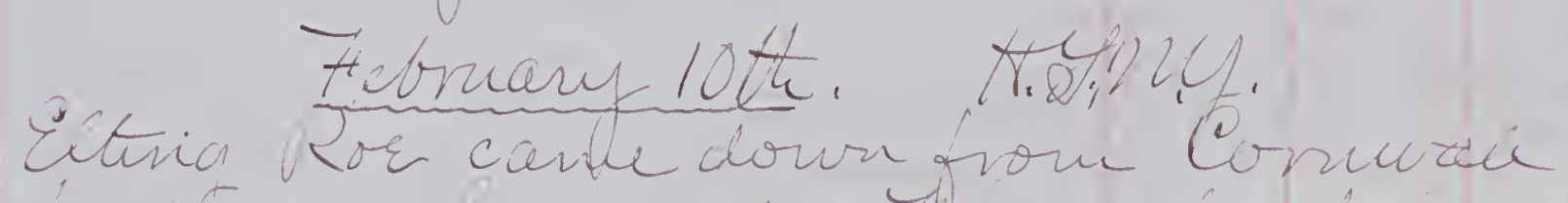

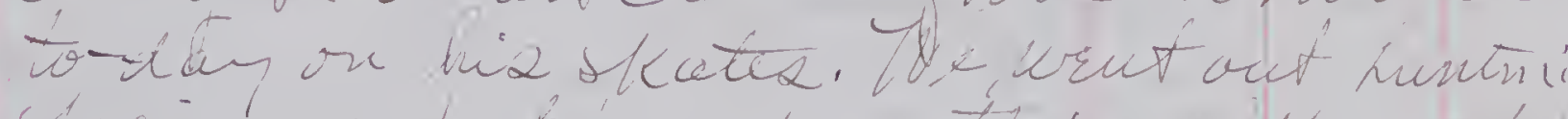
speeinent but oond wothice ettlones h

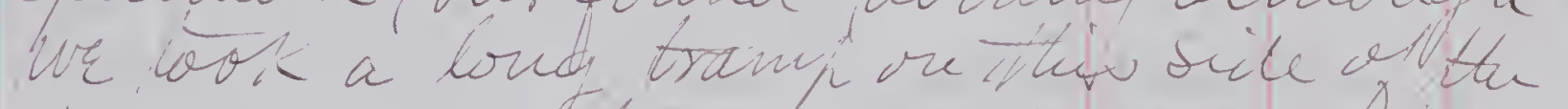

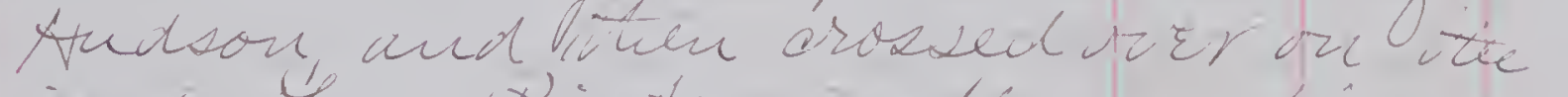

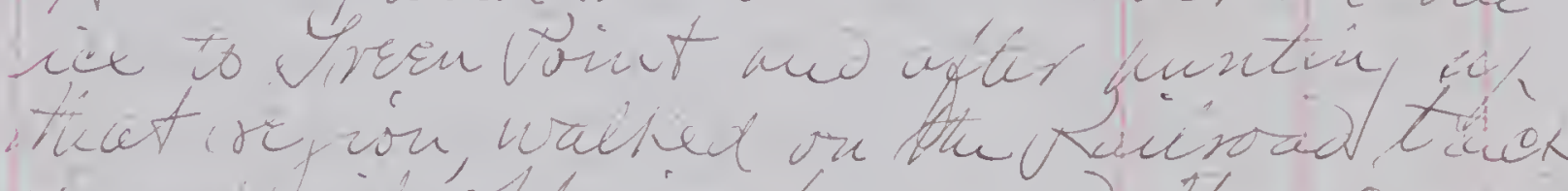
to a wirit ophosite here and then Csasco vrert. Dione of the Enviloyees on. The-

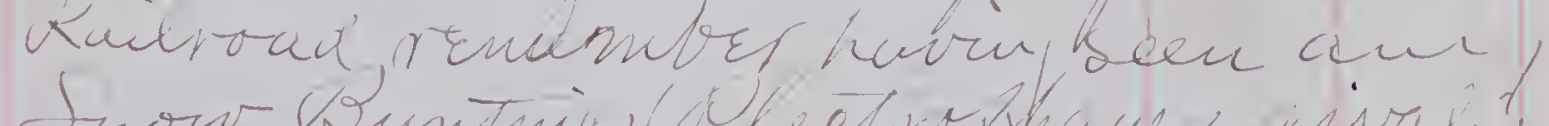

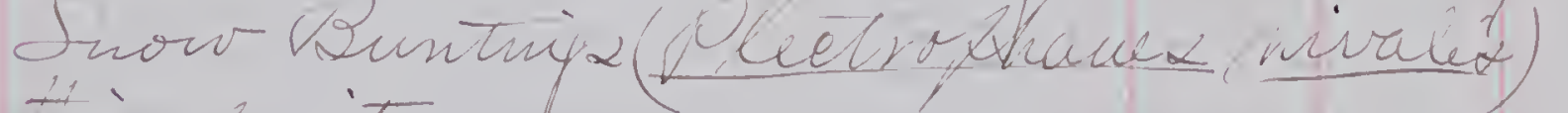$$
\text { Scalir sialid. - Eitiri sau some at }
$$$$
\text { Cormiaie, on. Thedon yesterdacf. }
$$

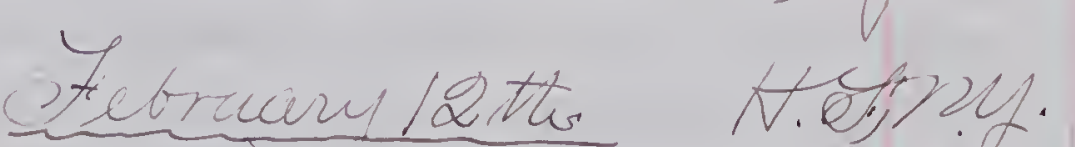

thio moming, carcy, a Carefe fích of Inow Vauntingx (Jeetro/vhunch vivacix)

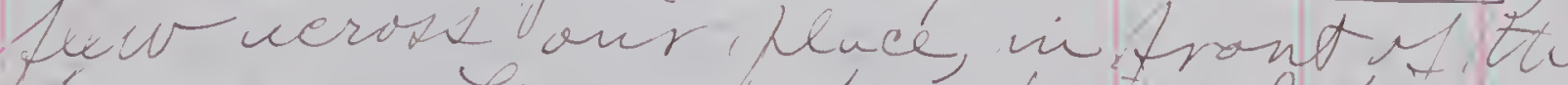
house, They are the frrate d have by whis, Hid Winter.

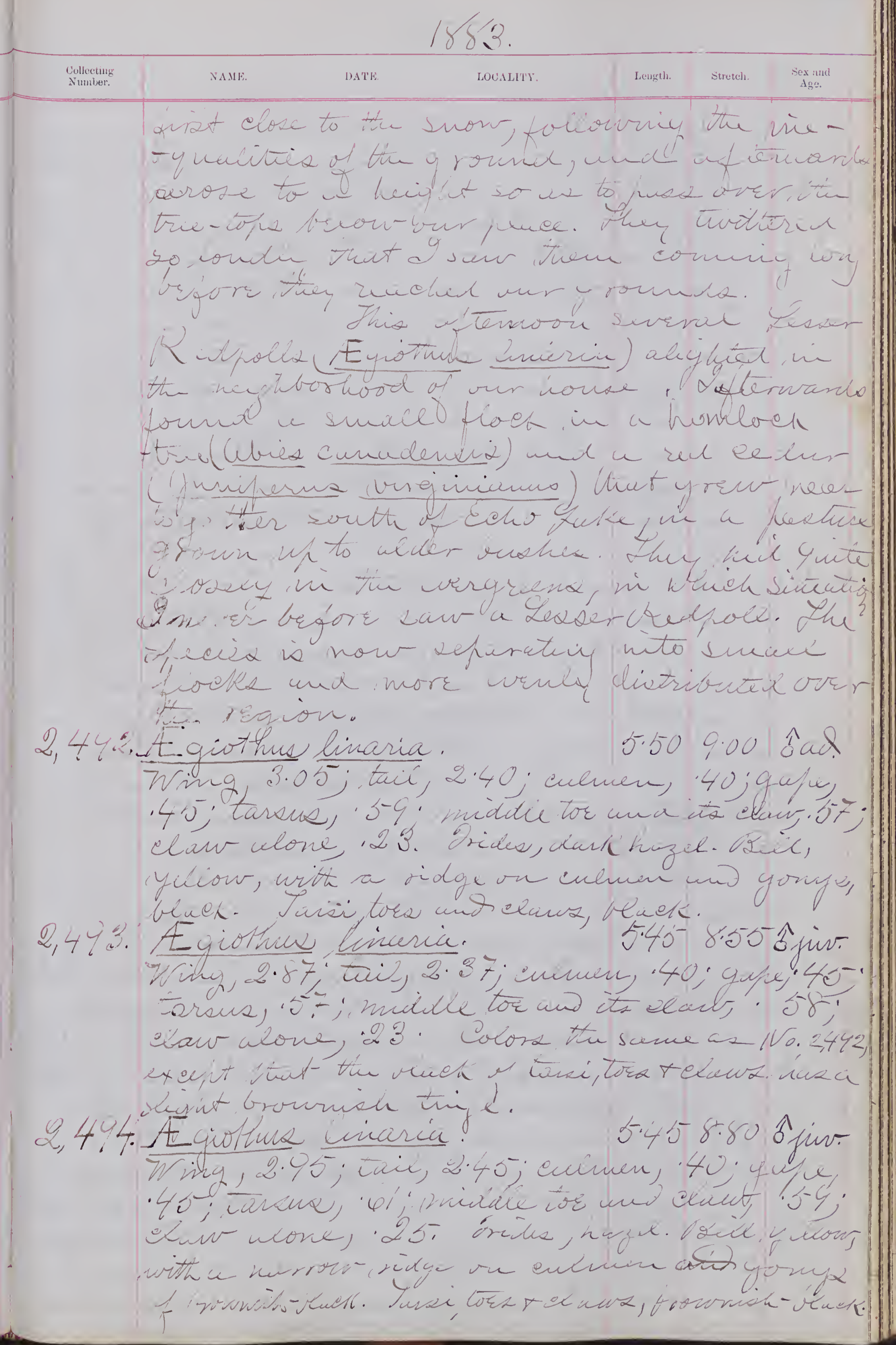

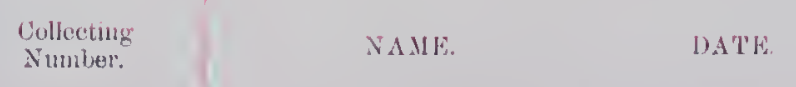

I.

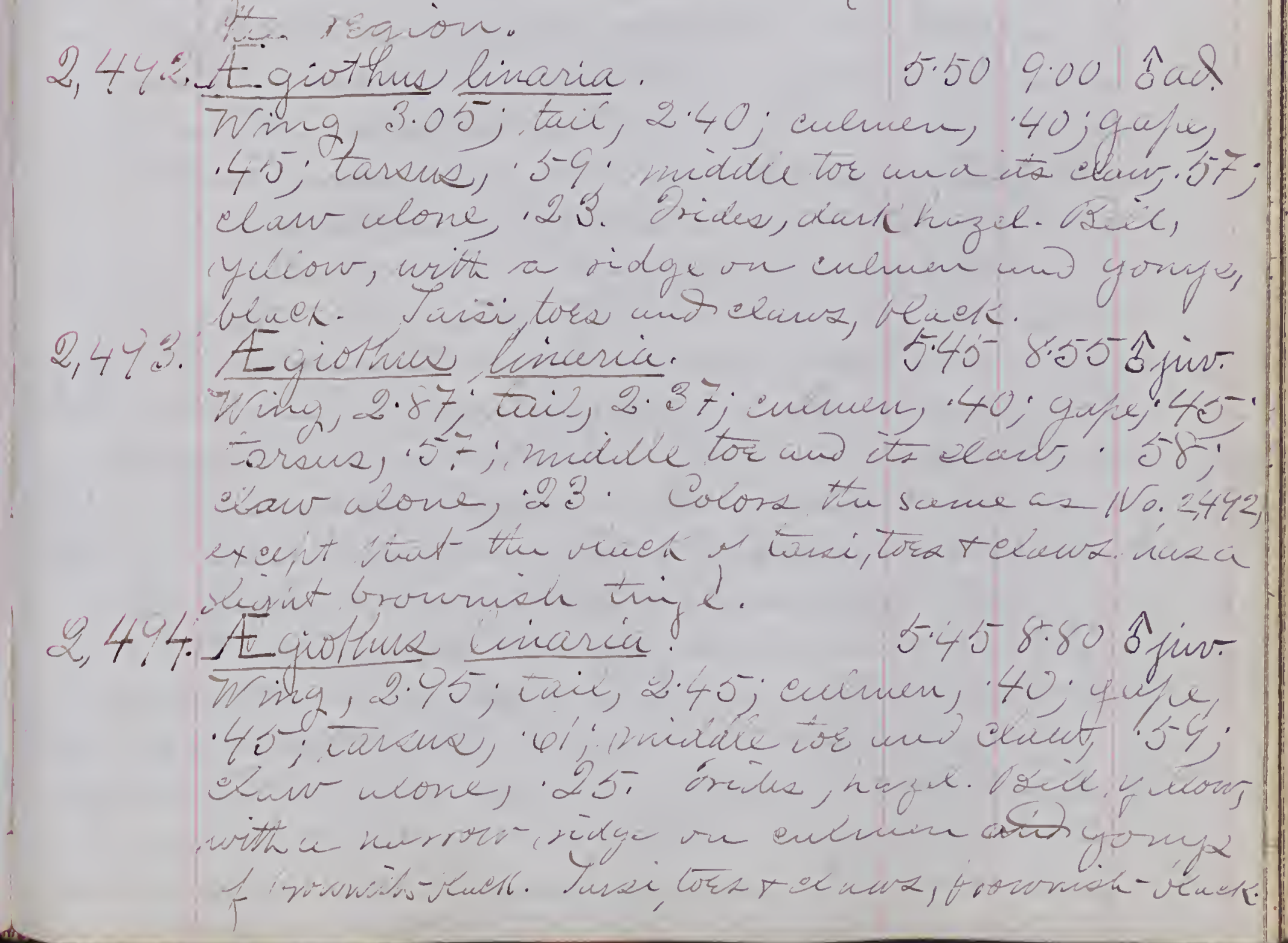


360

361

1883.

T.M. $\mathrm{H}$

Collectung
Numiner.

Zebnary 2/st-Continued.

2,496. Shhyrahicus varius 8.6015 .40 tad. Wring, 4.90; tail, 3.20; culmen, 99; ga/e, 1.14; tarsus, 75; middle tor and clart; 88; clawalone, 34. Drides, dask hazel.

Bill ohir-brown-black. Darsittora, grayish-blue; Clawz, dusty. Seefr.3og.

Tiebruary $24 \mathrm{HA}$. H. He

Sialia sialis. - The first Bluebid o have sen on our hlace snice $l 9$ returned from the citysth und of Gamany. It wak warblirig loudly.

Hebnary25,th. Netiny.

Melosfiza Lasciata: - Saw a Song Yharrow at Dr. Chace Alace this ofternore; and Is aw one at Fauroty brook on the 21st. Thea an the girst migrants. The few winter residents frabuent other situations, of suall Dex tent, which they do not leave durnig writen.

Debmars 26\%. H. D, N.Y.

Sialia sialis. Narbling swerty.

February 28 th.

Fok a long walk. Orossed the Hudson on fout. The ice is very thiek. The ouly binds oo. te seen were a nunber of sine Grabsati Anineola envelcator seen on Messro. Osborn and Fishes fremines. Also a Thite-headed Eagh nur Garroons, where 0 walked to mail some letters, the ferry having braken down. Melosfiga Aaccata- Mumestono in the Cox manh Wour Aish's. Common Cerowa (Corvis frugivorus) are tame, cind nigrattay in numbers. 


LOCAIITY.

stretch.

giving them a hem th and voeiferous naleone us thery settled down won the Alder bushex uning thenselsed. of home" at vuee. They ware therstet

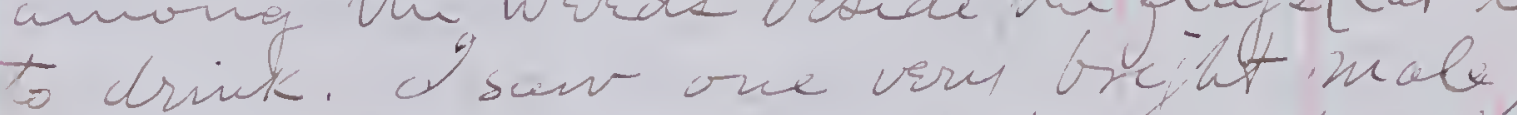

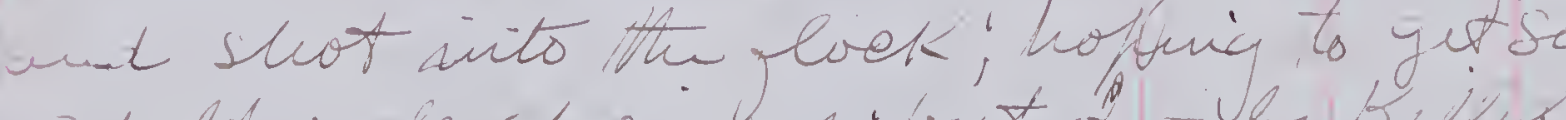

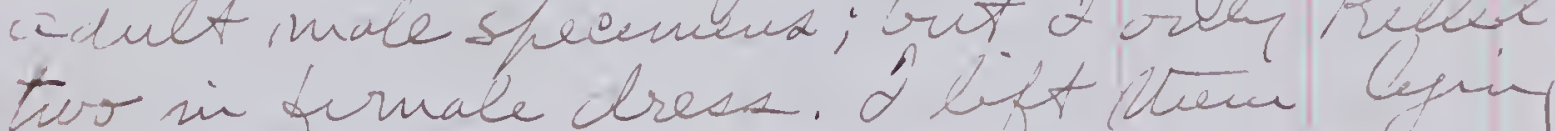
in th shallow water when nuvacula und oft six nore from the flork, ale

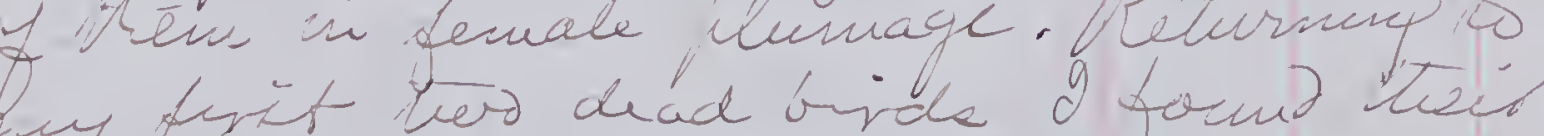
Lid literall esvered with a maso of

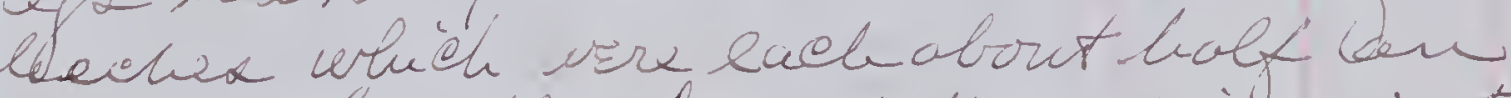
side in length. I scot these birta in the very alders where nort of muf spenuens of

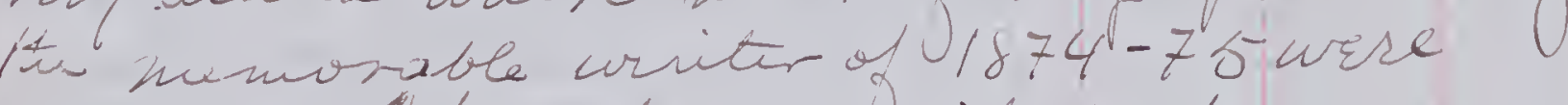

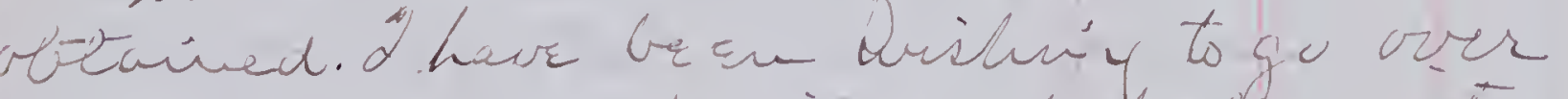
und visit the old, fumiliar o/vot all wruter,

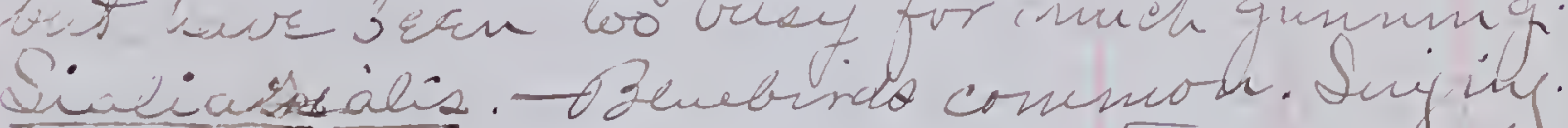
About the errit flawt hat slarte grouth in spring in thin Eocality id the S.runk's Cobbage (Symplocarpus fortides). In a suali stivian in Fiskir place, at the end of the salinarsh Isar thro tlanta, one of then four or fir moles in hicht bet not yet ni flower. Cinicola mncleator. $\quad 8.8013 .30$ îjur Wiq, 4.20; tail, 3.70; encmen,.58; gape, .63; Eurius, 99; middle tor and claw, 98; elaw alone, -38. Hides, hazel. Bill, black, with an ohve tinge on sides of maxilla at base and on base

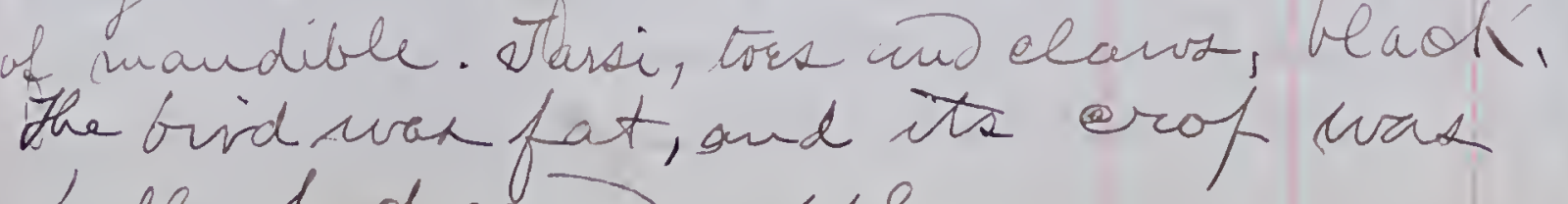
full of decajed apple.

\section{3}

2

2,498

Wing, 2.92 ; tail

5.408 .85 qad

2.30; evemun, 38; gape, claw, 22. Lis, hazel. Bill, yellow, with a hine of lackabove and belorv (shadin) to dustly towards base above. Jaisi, tora and clabl, black. Crop quel of alder seeda

2.499. E giothue hinaria. Brast, rosy. 5.12 8.40 tad.

Winig, 2.75; twir, 2.17; whinen, 38 .41; tersur, 61; middle tor and elaw, 5-5-; cluir alone, 23. Coloss, ete. as above, oney the Tarsi ure bromish-black instead of bluen.

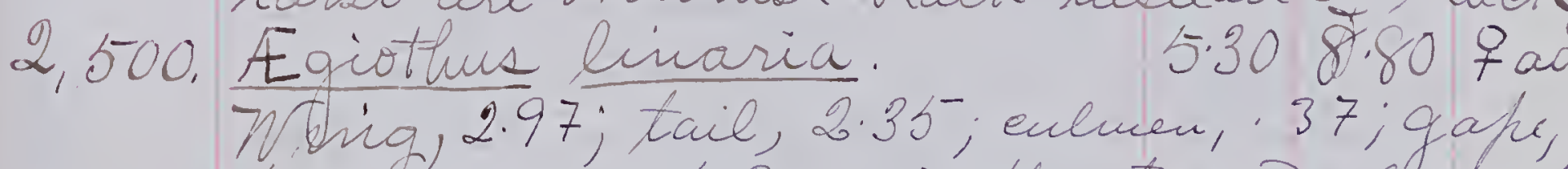
42: tarsue, 62 ; middle tor and elari, 56;

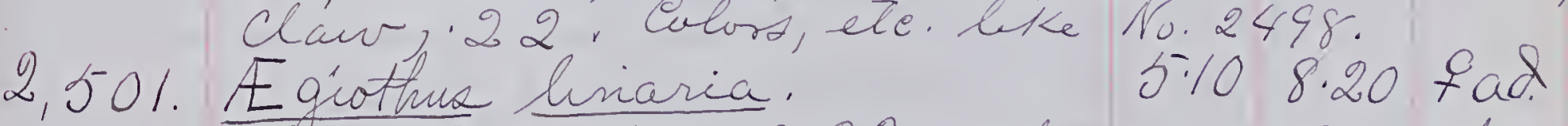
Ning, 2.70; tail, 2.22; culnen, 36; ga/re, 41; tarsux, 60; middle tor and its clawt."

2,502. Egiothus tiriaria. 5.35-8.507ad. VNig, 2.78; tail, 2.43; culmen, 39; qafe, 45. tarsus, s-8; middle tor andita claw. 58. 2,50 3. Egiothut Linaria. 9.05 8.30 .9ad." Wing, 2.79; tail, 2.22; culven, 37; qake,43 ; taroux, 57; midaleitor and ita elan- 55; Claw alone, 23. Colora of rasta, ete. CKe No. 2498. 2,504. Egiothes linaria. 5.088 .289 ad. Nitng, 2.72; tail, 2.10; eulven, 39; gake, 43. tarsus, 62 ; middle tor and claw, 5-5- Clan

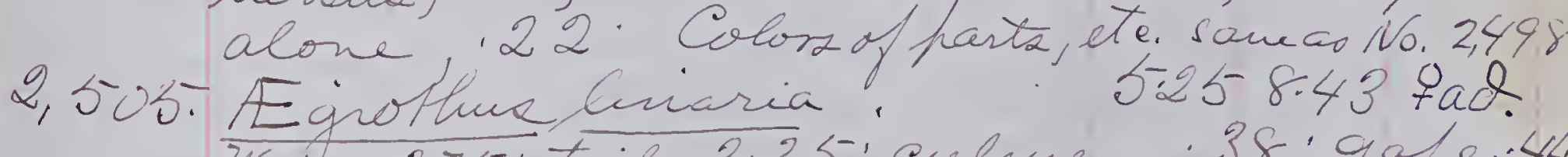
5.258 .43 tad.
u, 38; gate, 44 iardus, 62 ; middle tor and ita elaw 38 ;. clur alore, 20. Colors of hasts, ete., the sama 


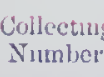

NAMLE.

D.T.

LOCALITY.

IE likes the secos of the Norway Strue

Abies excelsal whide I fid him vere muck

Ar also lats large qpeantities of aldile

To-dar is storim. The wind has blown

all day and a good deal of suow has falle d) have not bereh out; but Pobins (Nerula meiatorá) have beru numeroua about the house as have the Dluebird. (Siakia siails). A few Fox Shavows havr alser brun abut (Passerlea iliaiea)

\section{Pllasch 8AA H.YMm.}

Egiothra hinaria.-Sen Troma suow-coveret Merula migratoria. - Mobins flenty.

\section{Dareh 9.t. H.S.p.Y.}

merula migratoria. - Now quite numerous und geverally defpursed overth sepioas. Passerella ilikea. - Iur seen at ort Hontromury, anouget the cedars. Chrysomitris finue. A small flock was sen fiednig won the ferries of the sheeh bush (Viburmun lentago), at Fort houtgonery. Ifired a shot nito the bush and killed two good specinene.

lehrpomitris nimus. 5.18 890 sad. Which, 2.90; tail, 2.00; culmen, 44 .

gape, 49; tarsus, 55 ; middle tor an its claw, 60; chaw alone, 21.6 rded, dark hasel. Bill, blisish horn-ealor, tithil with blade ubove and below. Jasei, tord

and claws, dusk olir-brown.

The crop of this birt was fule of sumell

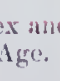

Collecting
Nounhe

$2,5 / 3$

1883

\begin{tabular}{|c|c|c|c|c|c|}
\hline . & (1) & ron & L & 5 & Sex : tul \\
\hline
\end{tabular}

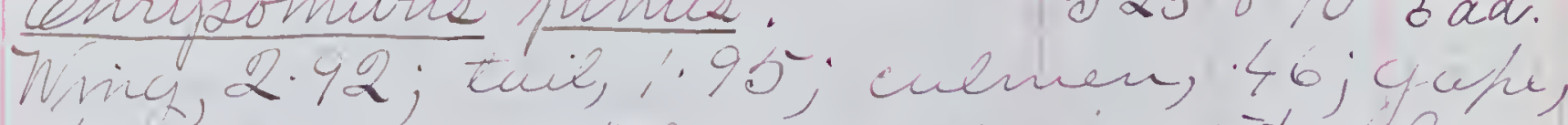
-5o; carsus, '56; milále tor its deciv, -67; Clan alone, 21. Coloss of raito 2iu $25 \%$ ot wess, irdenthy, mistaken in thinking that these orids wark fuoting wow sheeh-berriés The tlock were in a sheep bush when thery werl chot; Gut the crope $\forall$ yrainds of ooth of the Shecinens sontaried onten a multitude of small seeds, bluak ni evtor,

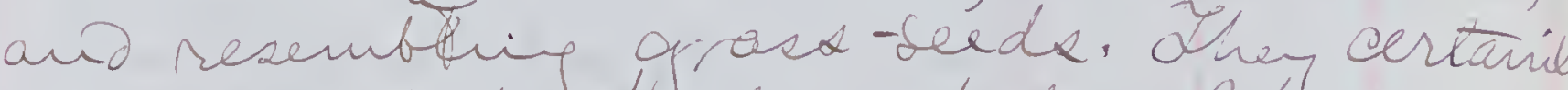
phares to bes thedrig befored tived.

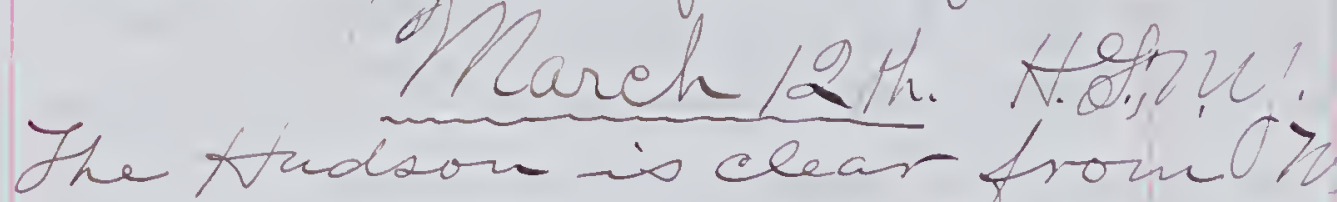
down to the southerr hoint of Consork' Sland, where the iee is filed Ms-feet high, the cakes being over a foot hiek. This afternoon sav the first Filciker-

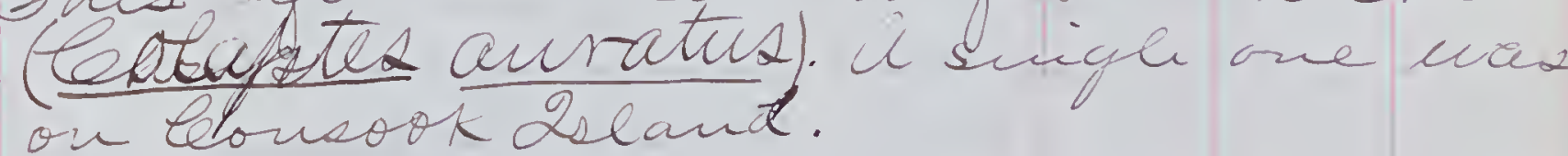

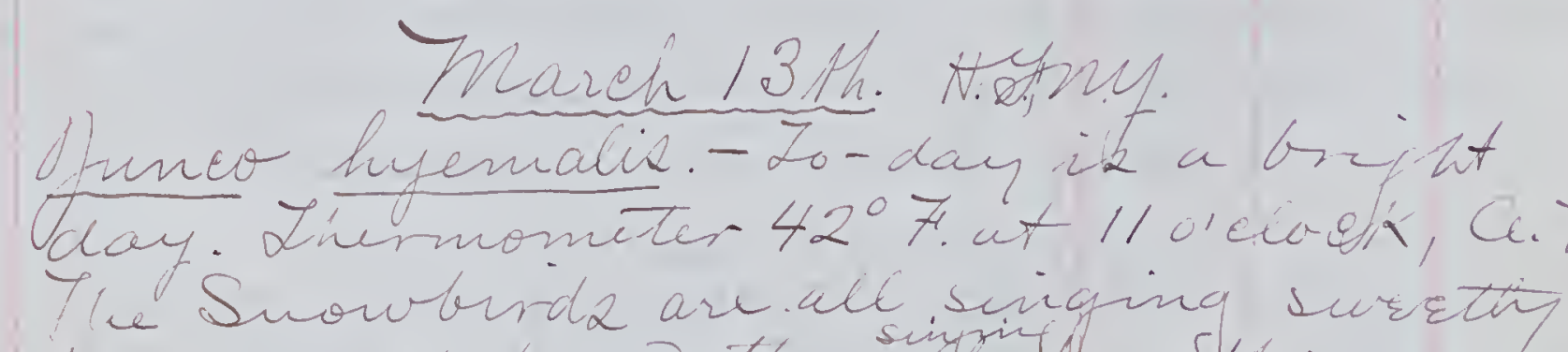
Aecifiter cooperi. - Firist seen thir spring.

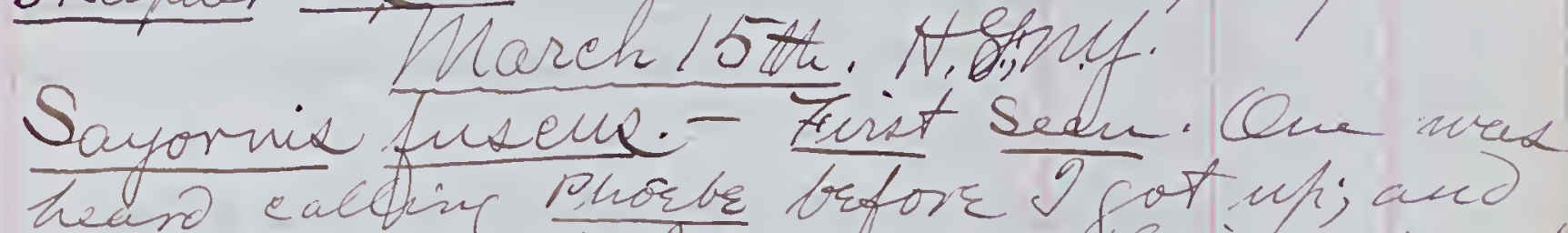

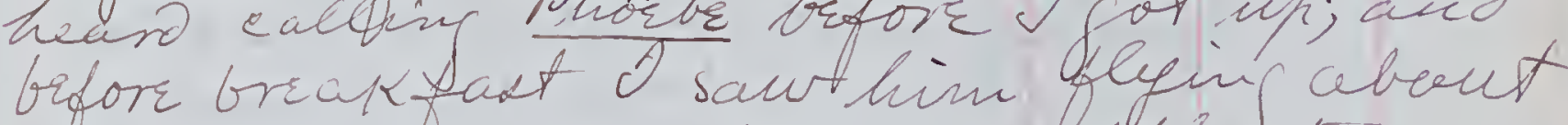
the house, non sitting on dppletrees waggine his tail. Buter Direatux. Cur wax observed to raike a big commotion amonght a floct Pobilis, atthough I did not sechin 
1583

Zleisfuiza Aasciata.

Luiscalus hurpurens. One flew over head

The Fint deen thrs seabou

oo-dan is the first real sfing-tike

by, and it has brought ita sping se

This norming Onoled the two ofitt sperig

arrevals aruong the terds, ox edftirig the

Fox Sharrow, which I saw fisit on the

17 th of trebrian,

surit the Lirt Swant Sparrow

(Meloshiza haluetris), in the eat-tails

rscde consook aland. The flecker was

wen in the same plaee on Doth Doland

As when seen thire on the i2.th cinst

4. Zu a hair of Chifmuniks (Jamiax

sinatur) on a stone-wall. The were

C....en last authum.

carly sprin butterfle, witt

th buff was scen firist thio aflenoon i... wias the Yellow Spotted Luste

ionempo quttata)

F 7narch16,th. Ning.y.

Egiothur Cinaria. - Three wore deen

fedring won the seeda of the whtero, Telow Eeho Lake.

"esserella iliaca. - Thiz speeie id

now hreunt in large numbere. They

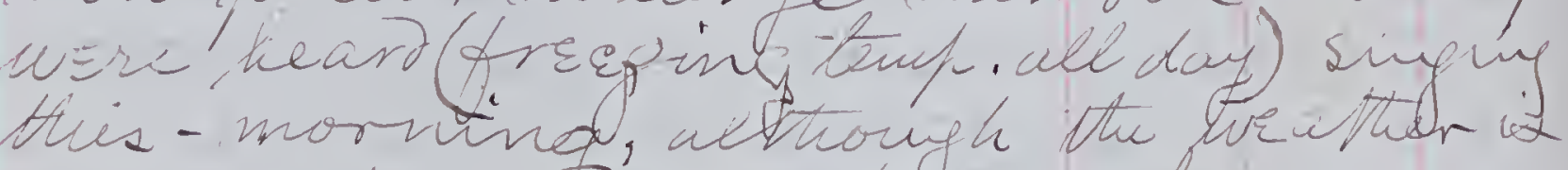

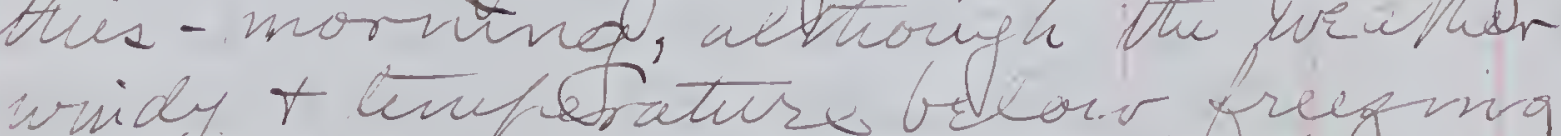
cont al dem, althouch the sing shone or cijlttex. Yesterday wa warm.
Egiothus linaria. - This afternoon wet with a large flock of say forty

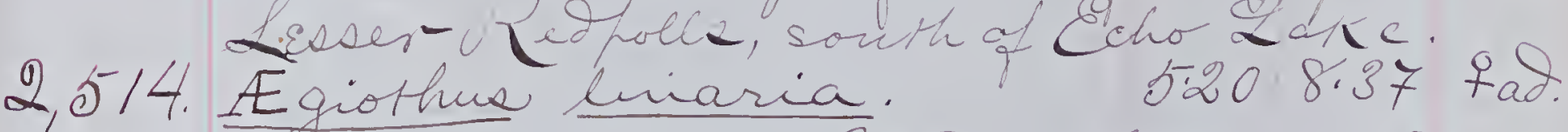
Wiq, 2.83; tail, 8.33; culuen, 38; qa, 4 , 43; tarsue, 56; midale tor and is elar,-50; elaw aíone, 20.

Dis, hazel. Bill, yellowj with a vaek lin abover vecow extendiry to the rorit Garsi tort and elawz, blackieh-brown. "The "unary willowa" were ofirt seen in bloom" und Ibrought dome, horue Lor little oivian

\section{Tiarch /8tt. NStron}

Passerilla ilinea. - Inifing shertin ael about the reace. The ddy varn. The mora - ter ranim betwian 45 and (10070

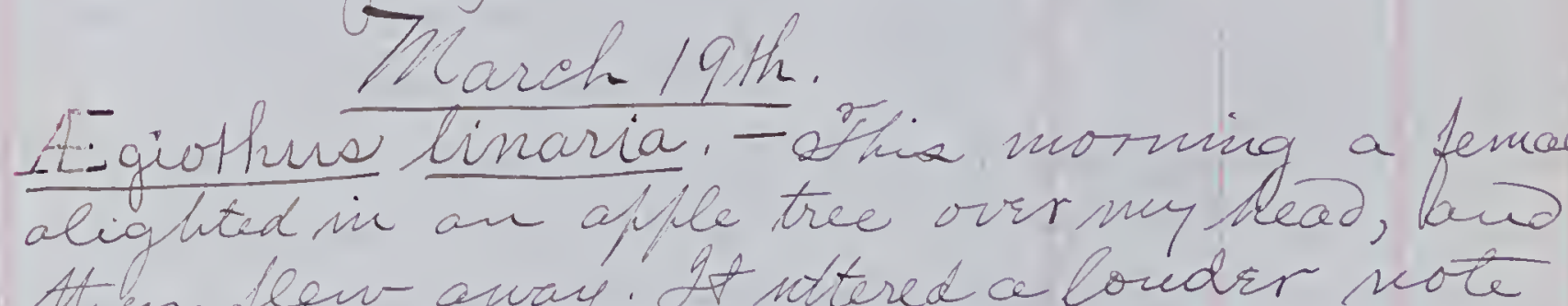

than usual. Dr. Albart K. Fisker rhorted at one of

during the past winter, the eapture of ttw Evater Rspole at Sirg Sing New ifork Io-dar is nearly as warm ab yestrday

Spotted Lurttel Nanenys quitata) are brlow our place. The forot are still frozen, and brar one's vright. The Ardson ra entivily open, init thi chanswelj but a few covat still have sonve ies in. 


LOCALITY.

L.ngutl.

(Larus argentatus) wrer seen in

the Corr above Jaspoino, wher

there ia stiele eonsidenabe Lei

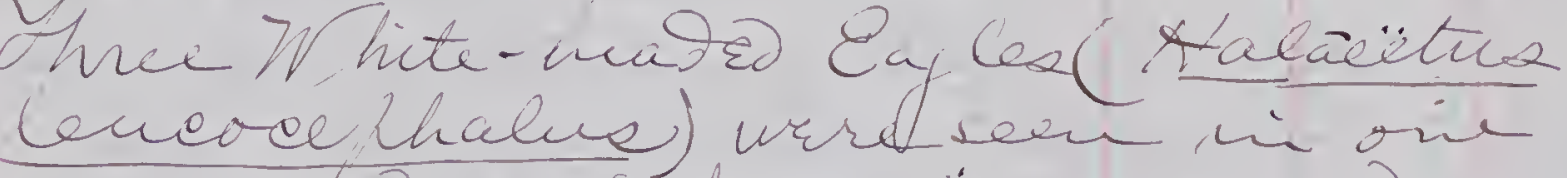

tree in Oro' Vest ruvine yialeñarz

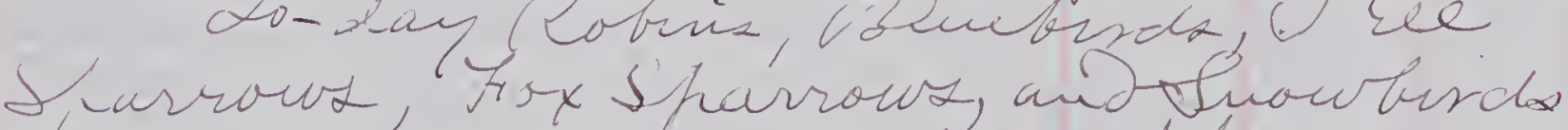

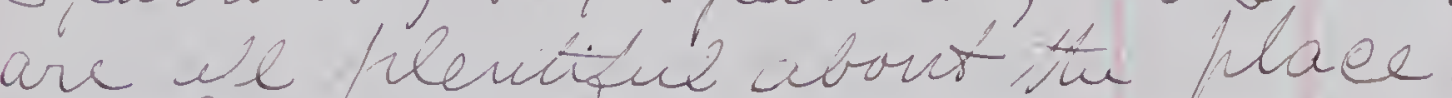

No Refine have beruheart to sing yot.

\section{- March $20 \frac{11}{\mathrm{Nu}}$ Metrye}

Egiothue linaria. - There vara a smace fevek of k2trolle in the alder-swame brlorr Echo take thic afternoon. There wré ax masy males ar Lemalek. If tood are a rock in the suant $\mathrm{v}$ ealled, then all astrind

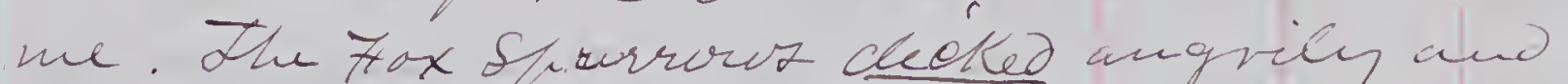
the Rolls wtierd, their nderal not und a lond wert. Foth shecies ereebo th peather ontop of thir headz. Sayornis fuacus. - Sar one; the only or Seserella iliada. - Sar one having Whit tail feathere and sump.

\section{Znaveh 21st. thotply.} Lenachiracarohinensis. - Saw th firt Thoung Dove to day. None wre scen currig the viriter

Sitta carolineruses. This enomsing, while seated at breakgast, wrsaw a tilute becliced Nithatel descers a mafle-tree bo the ground and then hop about on the hawn of or sorme inive. Thy seldom descend to the gremin. Zater in the day d sarerth sane steceis and the brickodre, botte fering

Collectung
Number.

Whon the gromid; ther were cotivig the muat upou sone refuse bouse, whech had bern Hrroure nfour the ground.

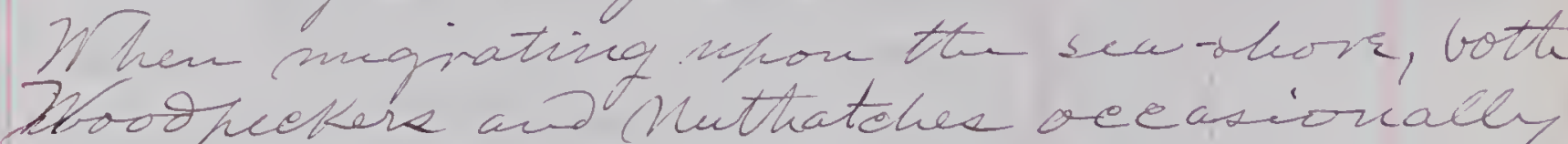

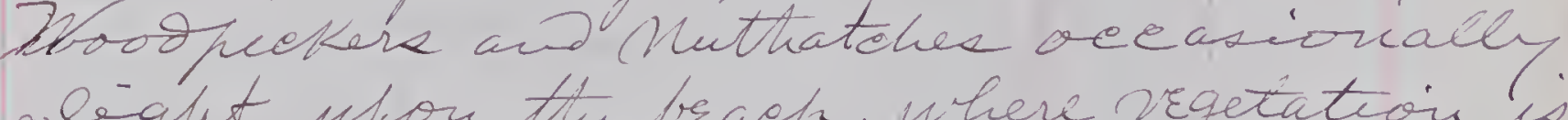
alequt ufon the brach, nhere vegetation is ie searee; but it ise numsal for then to do co at other tivies, exeept hir the case of Colaftes auratis, which is quite terrectrial. Dam sheathig oney of the sfecies of the Eastern ?inited States.

\section{Wharch 25 N N H n}

Io-elay is nearly ae varm as last Sundary. Early in the puorming ol to a walk forlow th Lake. found onc Lesser Fetholl (Egiothe enaria) acroti the lowit eno of Echo Lake, wheit qura able to cropt utron the cèe. It ures a fenat and blew down whon the grountarn th tor of a tree where of hand it ealeing

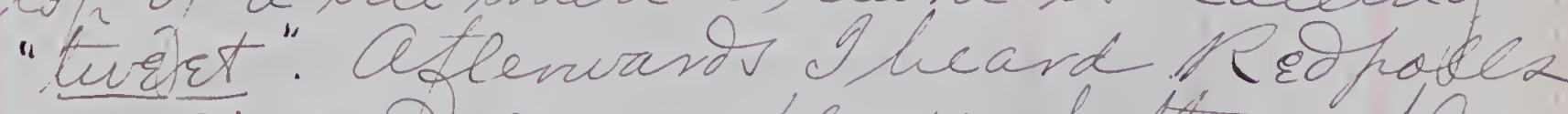
again, und san a floek of tive ile dorin annonget some alder buatheo. - wrent to the sot an har dower unore the ground neas a litte brook in utich

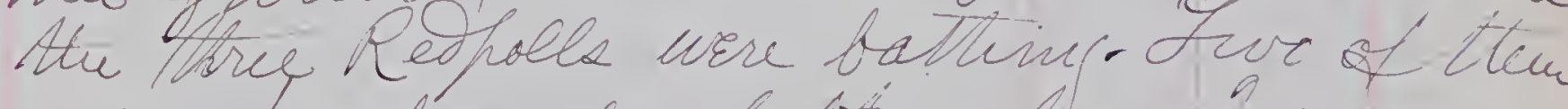
whre nendosul adubt nabes. o wrek mable to detitinguieh the klenmige

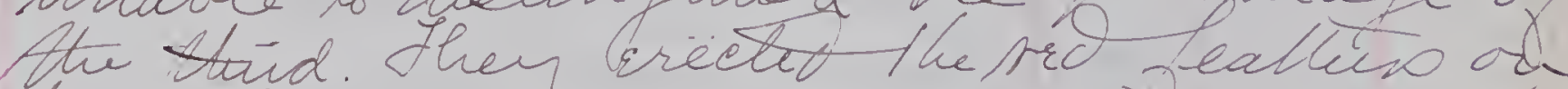
Alier heads while batting, and situerid ti risual tirittrin note and "tovert". Senadura carolinemeio.-Several seer. Sowornis descus has now freome hretty com

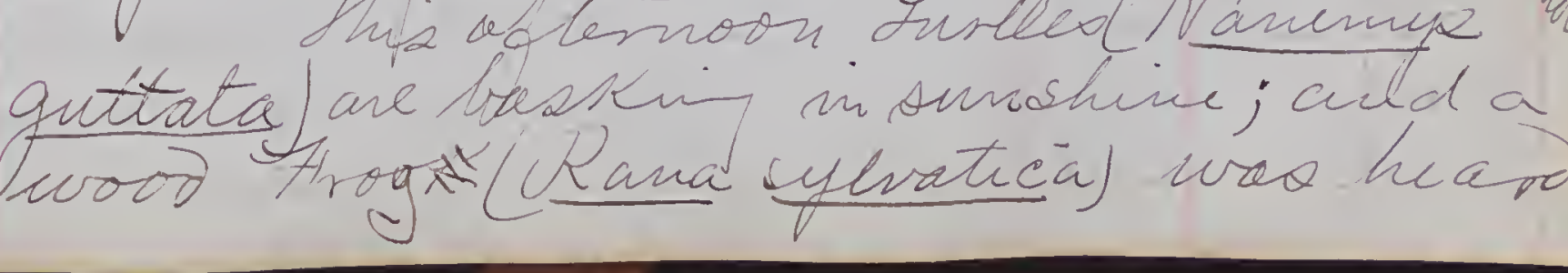




XANI:

tirttes ivere first seen; and a single "Neper" (Ayla hiekeringie) was hedrol hitmia niar the same spot. \& canglef and preseved one of the early s/hin mentioned have bequ heardfrom be o suce laat seasor

Siàlia sialis. - Bluebirds are matic or mated. A hair has beru misfeetin a galon tomator can in a hear-tree cl day long, and ther nar even have beg a next for I have sumitherm enter the can mann tivies. Que bird gors in $x$ another site on top of is while it mate is miside

Corvus Arugrosus. - rows are notir and Alejin dbout a great deal as is th. custorm cet this deavon

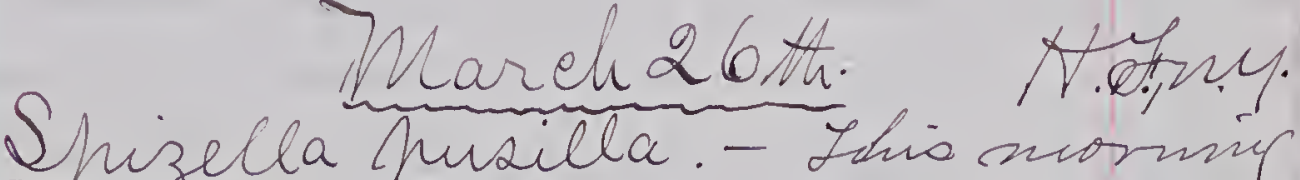

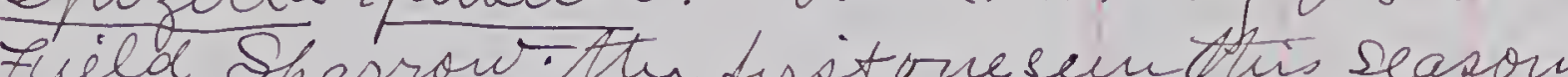
Sialia sealis. - Io-day Th Blubbinde reacu to Shy aganiet the uridows and fletter und heek against the glask hersuctentty

\section{Zuarch 27A. N.GHY.}

the vie still will brarone's wright whon Eeho Lake.

Sialia sialis. - A feruali Bluebird heeted and Jleviranizt our widow frow daylisut (shortyafter) intil orraxlastime. the Garricon Corr is nearly free of ried. Eayles are there in son mintars ond also \$reks Queld. The following was bhot itere

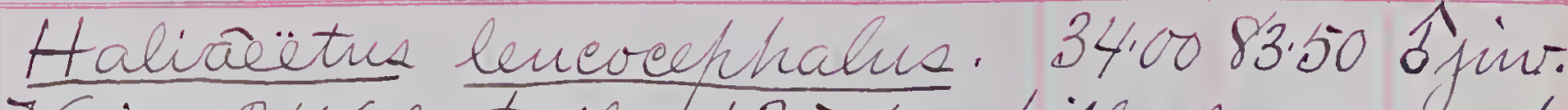
Ning, 24.60; tail, 13.75; bill, measured Arom base of cere to end, 2.50; to/ of cere, 78; culnen from cere, 1.97; gahe, 2.95; depth of bill, measured over the ind of the cered, 1.33 ; tarsus, 3.45 (the tarsus was muasured from the joint above to thi dolot of Skin which is apharrent ufon Exiluting the tors. As nearly ar I could git at thi exaet measurento it is a trizle less: about 3.25:); middle tor and elau, 1.35 . its claw, 1.60. Inner tor, 1.75 it claw 1.55; onter tor, 1.77 ; its elaw, 1. 10. The last measuriments (tors) wre taken from the mitatarsoihlialdingeal artienlation to the end of the tors above.

Colors. - Fides, yellowish, still showing sigine of hazel. Jhis sfecinien Ceadal. me to brlievr that the plumage in which it is, is characteriste of d peunage nearaly adult, than in the ldark and iniformly marked sfecinews, since the tiedes are nearly as in the adult. This firt shorws a great deal of whis' both abover belont, while ito head above ot neK (abovr) are very lifht. It has an alornistie look; but Aave seen several of then alive of Krow that is a regular Xhase of heminage, though somedrat nucoun mion. Bill, blue-blaek, narked witt horn-color yellow and presu on the maxilla; but the mangible po greenikhsellow. Yarei and tore, lenou-yellow. Lliws unipomily black, with a faint

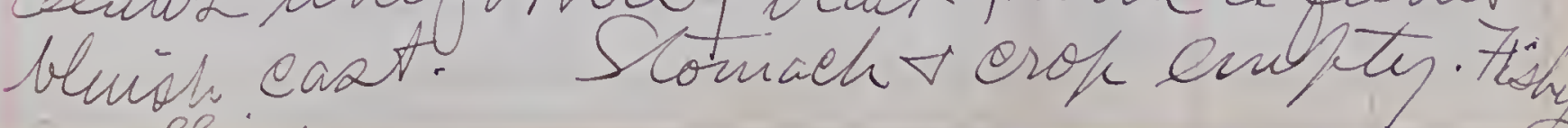




\section{3}

Collecturs
Number:

Tharch Bst \$.jon.

Sinkia sialis. - The semate Benebrid that hav built a nest in thi tomator-can near the arbor comes regularly every onornmof and brats itself furionsby aganst the winto runet. If the window is ofened half-wa counfrom the toh, she tafe at the Lower part, vecasionally celifilir whor th tod of the sash. Dometirines ste makts a shost erienit with in the soom ance thendlies away.

CYutterday it snowrd all day long, an to-day the glound is deeply eovgred. Writh syow, notwittslanding which, Lobisis, Inidus nugiatorius nere singing vajorwel. all the nominia nitil bratefaext-tince None have bren heard to sing before thio season. Cur Harch 29th Isaw thosk insects whieh wihabit clear water, and which Look like Dudy Fong-lega with ifeloate on, inev tors (.) stoling about whon Satterllk resenoir. The urst of Adve seen.

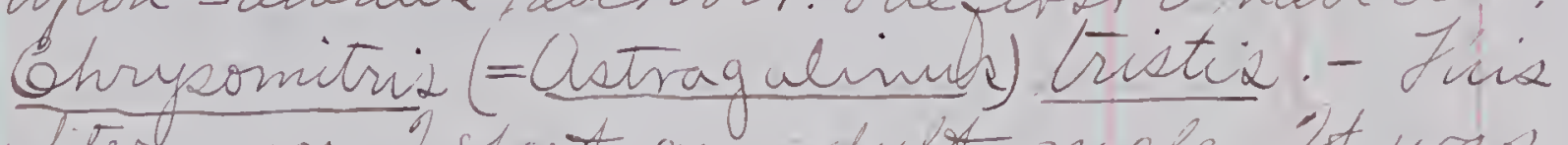
sternoon a scot on udult, make. 'At war yeting a black cak and had tivo marroriEraots of biqut yulorr breor. Ats: mm/ voat white, borehy triged with yellow, ex

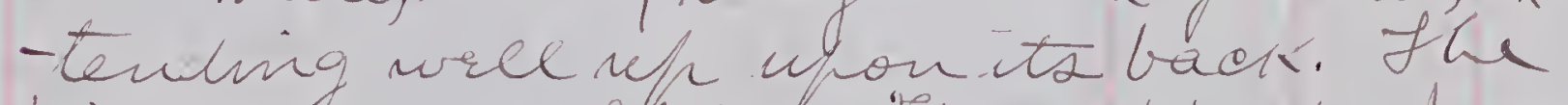
biro wos noulting. Shis efforda proot fositive that thes \&peciex, insfrinig, changis bolor by cmoultring. It was in flice sis-ry, and uttered a loud twert.

\section{Ohril ist y.M.M.}

Jo- imy is sunny. Thermonfeter $36^{\circ} \%$ at 2.39 rin. The stow has already Hinppared trome the ground in expozed
1883

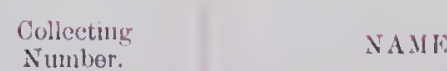

DATE.

LOCALITY.

penees. The iee has meited from ith Whole of the north halef of edio Lake; but is still do solid in the south, und that c walked sufely across it thio afternoon Iyiothud livaria - I scura fermale war Eeho take. She was atone and gentte. Utteried the "twert" and chattering note Hurttio (Numeng guttata) ere out a gini

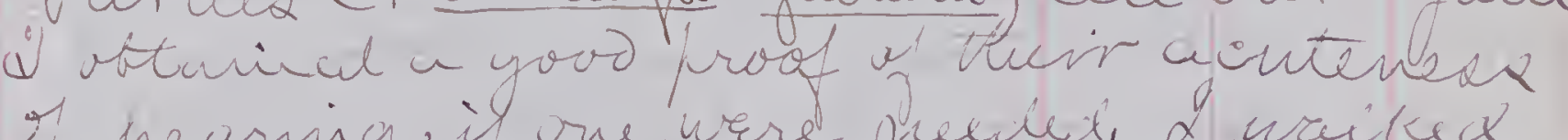
* hearing, if one, were mevilet a waikek

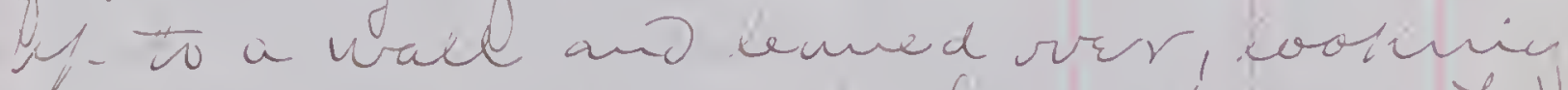
ito a swaril-hole. la o stord there a Jubte wrae M. It hid wot dee me. I made a decar. - trind, amd it nistanter tioned ita henck" Spizella domestica. - Cue. The first seen

$$
\text { Ahric 7th. N.Y. lity + t. F. }
$$

Leryle aleyour.- Sevarat/tingfienere, the firt icen the scar, ware observea along the Oliver. Ageliens thor úens. An adult male nar seen jist frlow Sexskile. The fist seen. Senetbide (2uicalus hurfurend) were seen in Coutral Rark, NewrFork eity.

\section{Ahrie 8, th. Hilpy.}

Ifo-day has pern quitebright. Hhernometer $40^{\circ}$ to $50^{\circ}$; Went to chureh this moning. This aftemoon rode around Hudeland Lak, and Hongh the hulvekes at ftort Nontarnery. the Wood trogel (kana syhatiea) and tyla fickeringii une abundaut and viciferous. iopes of the nountaine; Git none whon 


strectis.

DATK

This nomilsth-Continued. near Pell's fow I found a

large specuicu of the Large Spotted Sala-.

- mander (Anblystoma punctaturu).

This aptemoon, It tied my horse near the bridge at Poplopenix Creek, and wrut to spote on the nosth, slich bank of that siream sloking to the sun, whese I fornd the first Hepaticas (typateca triloba) just a ye astago to-dar - Saturday, Chrils t4, 1882. Lo-daifo) fornd nunbars of them in the sance hiace, burd the white onea wrre swrat seented, bot, disappointing my hopes that they mijlet

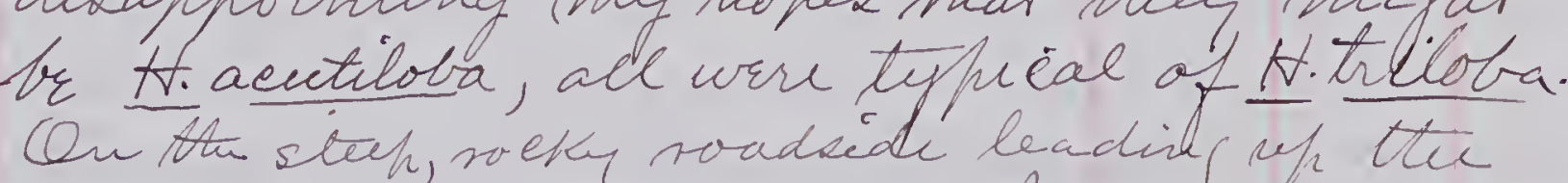
nosth bank of the stream I also fornd sern Early Saxifrages (Saxifraga viroinensix) in flower. Viry frobably they ware the very first ones to ofen in this vecion. I brought thalf of them howe along bitt a la reg bunch of leaves and floutro of the hepateca. Varroid species of alders twillows are flowaring.

The fallowing Girds wrre seen to-day. Merula miqvatoria. - Everywhere counour dinging Sialia sialis. - Kexting and seattered.

Darms atricapilles. - Uttering ito disyllabic note Anortura troglodytes hyemalis. - Ave at Atighland yus. Ifrizella unilla. Thetirstheand to sing this Dunco higemalis. Abundaut. Singing. Pesserelá ilicea. - A number seen. Sirging. leorrus frugivonus. - Mnusually common in sundel floeks, and so tane that 2 rode nucher the trees in which they Sat severat times during the aflemoon.

Sayormis furend. - On Alew with some it is briliding its nest.

sins pubrecens

Lenaidura earolinensit. A hair seen near reho Lake.

Anas obseura. - This moming \& thesked a couple of big, titrong birda flrom the brushin marin of Pele's corde. Ther irose with at me inty shlash. Splenatd bird! urns arquntatios. - One seen on the Andson. April 9.th H. Hor.

The dirst Shad wat eanght here on Ophit 7 tht Io dar d crossed the Xubson, chiely for the purfose of gatherning speenivens of

th. Skunk's Cabbage (Sy mplocarpux Aotrida) there wre hlenty of both Llowrro and Keabex; fot the flowark wark gone from such flanta as hade large leavar. The Veratrum viride was growing flestifuley, 'tho' all of those seen ware sulakl, save a few whioh wre upuards of a foot high. Both ilants Ures. lound at the lower brook in Souverneur:2 Cose, north of Yarrsons, where $Y$ also saul a dev Arhaities (H. triloba), which were whiti Finkish or vlue like those found yeterday it ioploperis Creek. An of the eather had eigh sehalk, but round lobrd leaves, and was fragfrant| In both places where these firit Arlatiéa ware found, within half a slone's burow lay vanks.

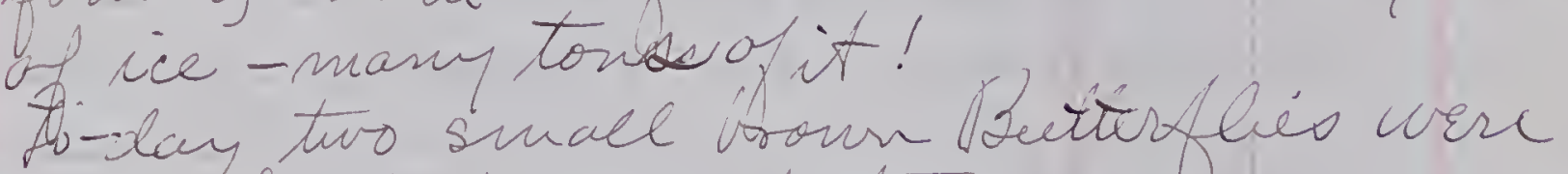
seen, havin baek shots.

thear Gavisons I found a nur jlant in bua, whiel, d have not seen clecusher.

Leite a number of Full and Ducke were 
1883.

Seen in Tauvarneur's Corr.

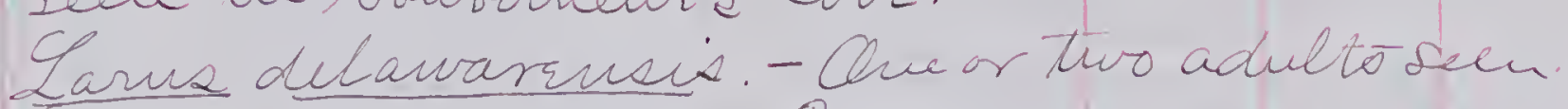

Larns argentatis. - Dite numerous.

Anas obseura. - About one hundrez Desky

Dueks were dudin in the cove. Then alnos:

ulvarp swain inlive, smiglefile; 2

watelud them nuder cover for four

house during whioh trier of var gite

nearthem. All of that tive they were

alvare surining or feeding in hise, ad

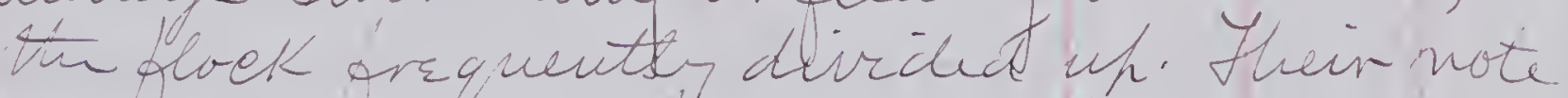

was exaettr hite the yunde of doncerie

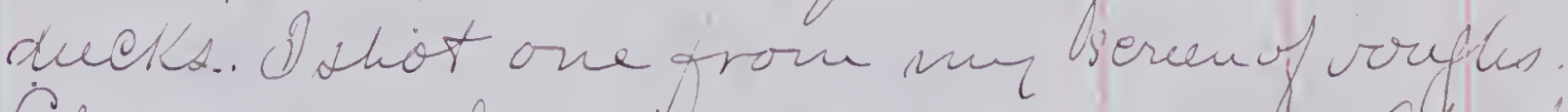

Clan ver glanerin amerreana.- About

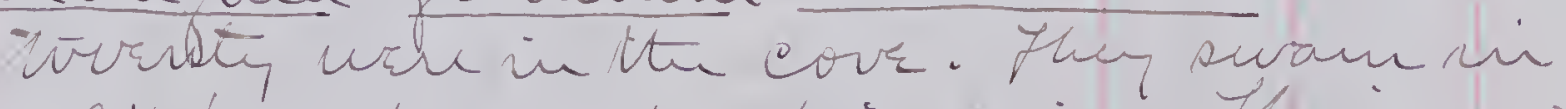

solid bunshes and not in sives. Their swot

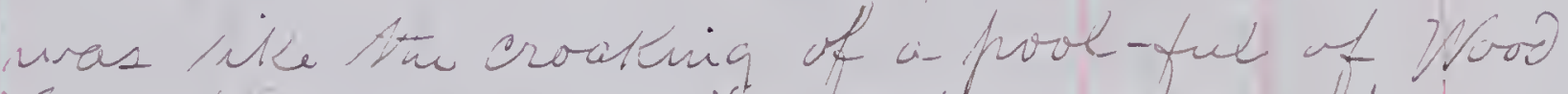

Frogal Manu sylvateca); but the wote is of shorker

duration and sharpir quscelty than thet frugs'choms. Now and then gheard a loud whistedor

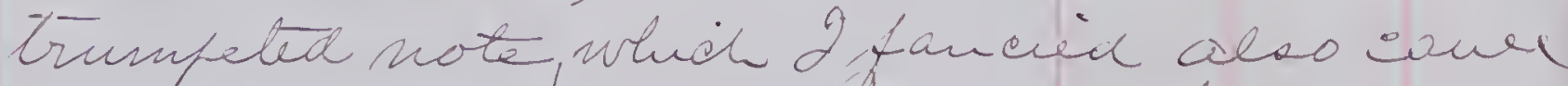
from the Golden-eyes. Brhapk it ci'frour His note that they are callid "whisters". instead of from the somo suafe by their winge inteying as de have wewayd suppose. a) also biahl kiand a hollow beaping sound from thin the trinj but ov then were sevral Shecies of Dueke neir-by couth not distrigriah whieh ofaeies produces if:

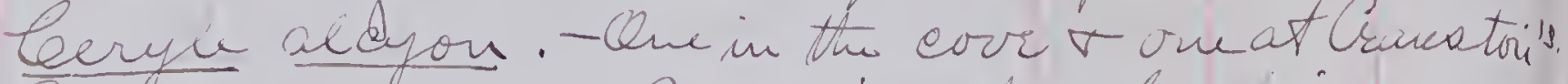
Eolaptes nulatus. - soducimp thir, lauphip cry.

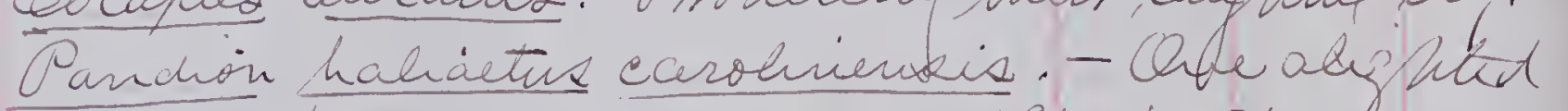
in a tree very near to me. Fhe farst sken. Scrirns carohinensis. - lun sem on the youna marthe lower falla..in thi
1883

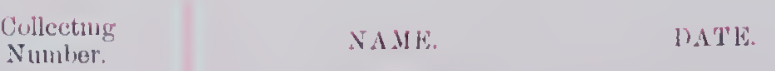

LOCALITY

2,510. Anas obcura of mel. 24.4037 .80 今ad. Willg, 10.95; tail, 4.50; culmen, $2.02 ;$ gape, 2.62 nail on bill, length, 44 ; bradtt. 30 ; tarsus, 1.88; middle tor and eluw, 2.57; claw alone, 42. orides, hazel. Bill witt maxillagrernieh-yellow, nail, black; mandible viregularly marked with ohir, yellowish and black. Jarsi, tors and theiv adjacent margirs of wibs, bright orange, wats and claws and bottom of fect, blackish. Alttiongh the flock afpeared tobe actirely ungaged in fiednig, thio bird contanied men a quantity of shark-edged, white, quartz pebbles, which ware in ta gir

Mr. Denton drove with me to Hifhearo Lake. Qt Ith Poplopenis Creck wrdound swrrt-seented, fir-lobrd shecinens of HEpaticia triloba acutiloba; and on Hit nosth beul of that strean vefornd a quantity of Savifage (S. virginiencia) durd the forit shecimene of the Koek Crecs (Arabis leprata).

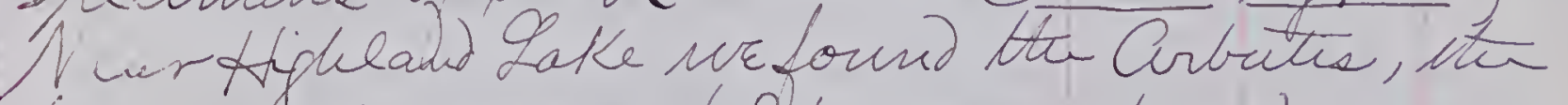
fisit of the seceson (Ejigaea repeno).

Wlobked for the Large-billed Cecentor along Pepeoken's ereek; but none have ret cenive.

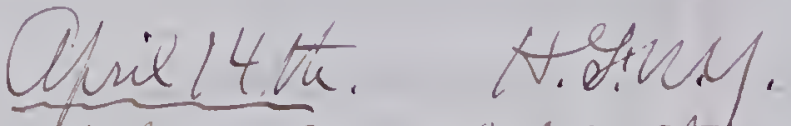

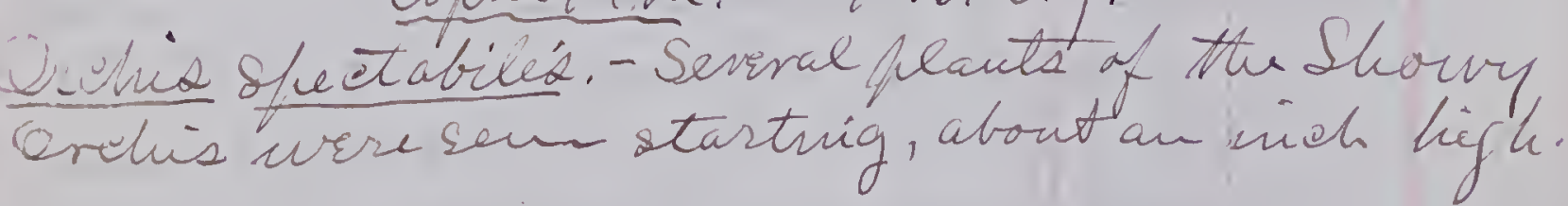

\section{Chril 17 th. H. Nony}

Sirurna notailla. - Siveral Lurge-bilhd heen- tort ivere seen on our walk. The pirit thir veason Th- Wursh'Minigolds (Caltia paluotiri) are ist about to ofen Therir buds. Xyciateá - Li bba is now in its furine 
Collectury
Sumber:

\section{April 18 tt. N.QPI, Y.}

2,5/7. Corvus trugivorus Bart. 19.10 37.35 A ad. Vina, 11.60; tail,7.50; culven, 1.92; gape, 2.20; deptth of bill ophosite base of enlunen, 80 , tarsux, 2.45, mibdle tot and clart 2.07; claw alone, 65. Arides, hazel. Bill, leg2t Leet, bla $K$. Shot while watching for a flock of its

\section{Amil 19 th. Higny.}

2,578. Colaftes anratus. 12.50 19.80 fad Wnig, 5.95 ; tail, 4.65 ; enluen, /.3/; ga/e, 1.53; tarark, 1.5; middle tor and claw, 1.32; clawalone, 46. Sides, Grounish-red. Dill, Heu-beack. Jarai and tors bleish lead-color.

2,519

Sirrur motacilla.

6.3010 .25 今 190 Nhing, 3.25; twil, 2.23; fill, measured from nostrie, 45 ; gope, 75 ; taroux. 93 ; niddle tor q elanit5.; Clavo alone, 19. Irides, hazel. Bill dusky brown, flesh-coler on basal half of mandible. Sarsidul tors, flesh-coles.

Mril 21st. H. Hu. + Comuall To=day sode borr the mountain to shem Sarbatt day with Rev. E. P. Por. The day wat brijht. Near the semmit of Cro' nest Hsaw cone fine dandehois (Tardxacum dens-loonid) in flover. On the summit of the mountain Isaw a Atrmit Thrush (Aylocichla unalaxeâe Aallasi), and another was seen in the fort on Whe Soint above Cornuall. Both the Saraxam ind the Thrush were the first seen this searry cxeapt the single ternit Fhmoh (No. 2,490) whiel I shot on February 6 th. The Marsh Mangold (Caltha halustre - was also in bloom on to/ of the mountain, brsich a serean, and was also the frititseen in blosson

DATE.

LOCA LITYY
Sex :utid
Agg.

Willows of seviral sfucies surted the air. When

Irichehed Cormuall, I saw the Dutehrnan's Breches (Dreintia cueullaria), Blood-root (Sanguinaria camadensis) and Mue Iliahetrum Seen Anis season. A sighin, Writer Wrist Inoothura troglodytes uyemalis) was seen on the mourttain: also thefirst Regulus ealenduks. After dinvier I played lawn xennís until. Eltingeasked me to go Shooting on (Purn Foint. Wr Gound four Fieh Hawks (Pindion haliaitus) earohinencio) fismin in the Bay. A Crov

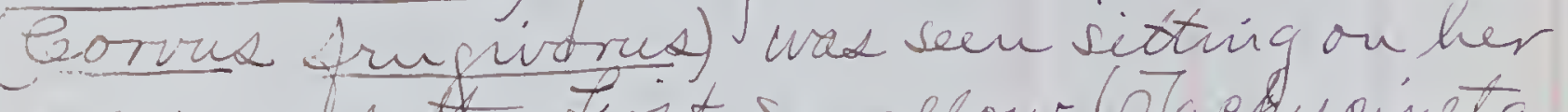
y.j2; culd the Fist swallow (Ja M M cineta Hedotor) was Sein lowards evening. Was Solitarn, and flew over our neade ni cliered for somie tiriev. In the Fort (in whieh there are suxitin (lwees for camnong) the "s eouring rush (equastimin wae very rduk mithin a sohid bed of gresen. Hefecteas and

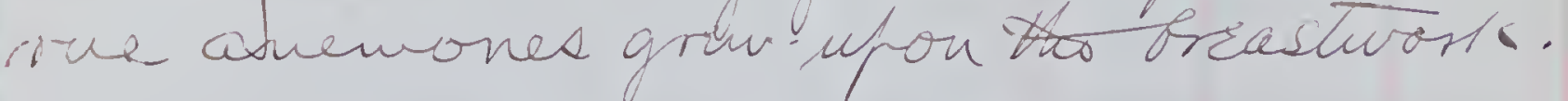

April asnd. Convall on the fudson. This moning heard Iyman Abott hreach mpeelt took a long drive along Movina Crek. We saw tet fist Chemink (Nities

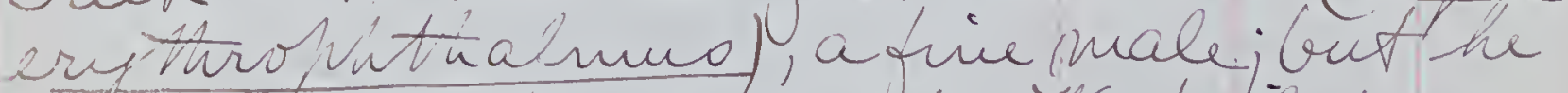
selmere silent and suoty. We failed, even by skelting unin veqoronshy wite stieks and sionex, to elieit acsyciable troqu hin. The first. Witt-inroated Sharrows (Conotricha albicollid wase also Sen in the same $\%$, s. L trive Coproy (Cardion haliaîtús Carolivensis suturn a brand o a huge plane tree. We droo to vittin easy stotgun range wher he ited and llw, but not arvay as, we 


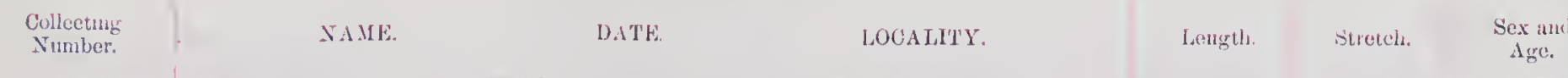

exhected he would: he came straight towards us until very near, thundarted herpendieiciarly into the strean, and would have disafpeared from viru breath ith surfaee, had crot stin woter been as clear as crystal, so that we sould dis- tiriguishboth óral and gish. Fovar and Llew down the derean fraring it in ind dew down the derean fraring if in

Adter dining. M. Ror and musel walked intotu woods: At the baek hast of uis hever ue found a Nootchuek (Metomis monax) so tame and nabituated to the diffet of man incet the secheely seened to Her ve; and - When we enosect him nito bisden ni a roeky elity 'rside tte y urden, his, hagl was seen oropping firtit oht gove creviè and then arobtedr, until he fuially tumbed clear out and veqan seratehic anoupd the leaves. The rocke cmonist whieh hedferles we covered with moist nost and that vase dern, the walking ha (Cawitosores. rhystriflus), wh wieh I gatterke a specinen Mron the ledgex ol Stom King brefound a whir of Ruffer Growne (Donark udobellus) Apil 23 rd. Comwall + N.CH, N.Y.

Friv worning odrove over the mountain It had slonined during the nifht;and the nountani-top was edpped writh wlite. The - thorign marly meltid, still hies mi virviatire glaciers rehou the north diele of stormkring. A mossy soek vesede the rous was esvered with the leabulosorna or Walkin TH riv, matin three localitix in thio
XAML The Harsh narigolds on the mountarin tay bevud in suore.

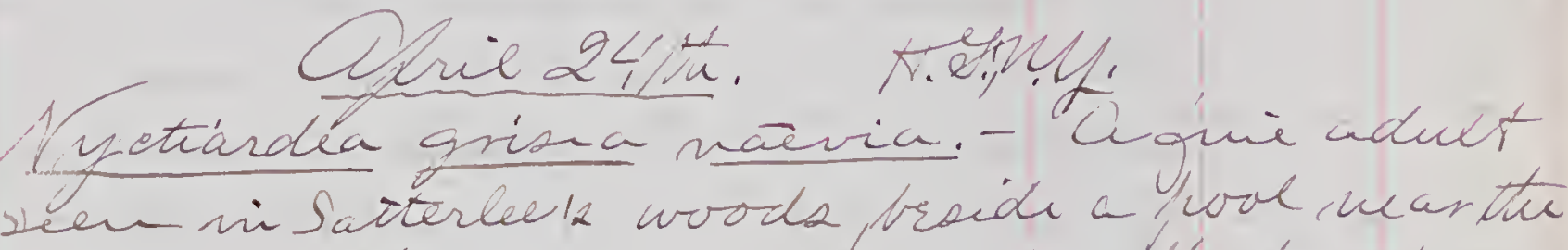
Andson. It mereh flafped we to the for ot a low Arie-tree when Ssurirized it, mefrist seen Duiscalus hurkureno,- Asur scen

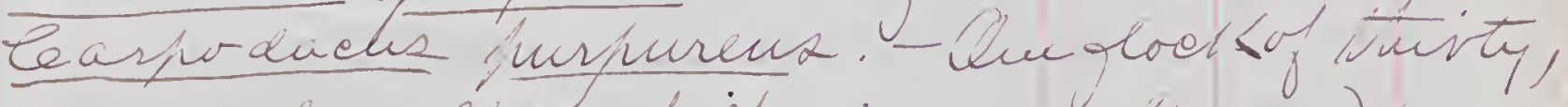
Dendrosea coronata. Yellow-rumfir first seen. Aundgut.

Summary of thr Bards Found During the Writer of $1882-183$.

The write notes may be said to have conneneed with the advent of the Nhite-winged Cerossbilt on the 16 the of Novenber, 1882 and the departire of thi Lesser Redpoll on the Ist of April,1883. I was in Kew York a Wrek in D'e ceuber"

and nearly ith whole month of Aanuany; and even when at home took Atte tivie bor stulymig the birids. Still Imade as many obsurations whon them as erceinstanes funities. blook few rides or chives, so that manes birds puay treve seaped we. Fifty-four (54) specinens Were pro-eured, und added to my eabisit.

Merula nigratoria,- A feur wre seen amongst He himbeks at Fort Montgouery until Novenber 25th. None had beren seen niv this inumediale neighbophood for two werks frevions, sand nolve ware again enountered until Mareh 3rd, when numbiro arrived suddeniy.

Hybeiehla unalaseấ hallassi. - A male No. \$.490) was shot on Febfiary 6th. Zt was not again seen until Afril 2Ist.

Sialia sialis. - Have been Ansent, but not minesons Stova bout the winter. The 


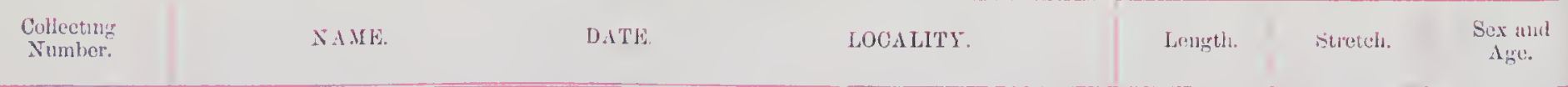

first mated fair I noted cormuced build'in a nest in a tornator-ean on Marde 25 th Cu thr26 the the Sencale harent bryan to Aly agarist on wridows, and flutter and pek agarist the glass persistentty. She continued this for deveral days, and nos, d think either killed by so doin ; or else, a eat eanght her whon her nest. Last season a hair of Bluebirds, wisted in a ean near the house; and the fermale prhaved im the solme manner. Ske notes for that tivi Regulue satrapa. - Frequent dusing the wirter. Pulue atrieafillus. - Numerous as noual. Sitta carolinensis. - Common throughout. Certhír familiaris ruta. As common as noual. Ano, trura troglodytes hyemales. - Cecasconall seen dering the wirter. Noted ou Afrie 2/St, an oltisa may still be seen.

Pricola emucleator. - The first one seen was solitary; shut by Slla in the naflebraide th house an Noveruber 23 rd. Sevrral Shecmins were shot on Mareh 3 rdjbut none were sem vater. During the wiriter Mery were tairh munerove; but wo chd inales were deen, altiough immatire nales were not rare. Notes ure seattered Dirous? tiv counale relating to thir liabito, ete. I Carhodacus hurhuresde. - mention this species in order to note what is more unarkable than its fresenee would br, $2 i$ its entir absenee diving the enteri freiog which this summary inkludet. In Cutral Park, NY. Cit howrire, I saw several hau 28 th. Here, gaw nove till lat in Glril. Mur firds whose absence is remarkable are tho - ledarbird (Awpelis cedrosum) of which? have seen not one during the given frisiod;

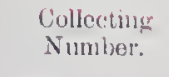
DATE. LOCALITY.

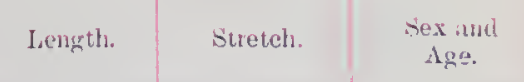

The abtenee of the Yellow-rumped Narbler D endrorea coronata) man also be noted, altiongh Mtis species is not requear here. in wilter. Then were mumerons during. Hew uritirs of $1877-78$ and 1881-82

Laxia lencoptera. - Sevrral were seen mi

some hine trees $\mathrm{ni}$ frout of the residenee of leaft. S. R.Ror, where Dife shot a hair ou Novenber 16th, 1882. None have sirier bran seen. Ithought I heard the noted of a pasknig Lloek of Red Crossbill Loxia. currivostra ameriéana) When in the

dense hemlock at Fior of hontgonery, Agiothue linaria. - Firit seen on De emibr 26 th, when a flock of 30 were seen near our stable, thrue of whieh I procured at a snigle shot, one of them an adult male: C solitary femall, the last seen, was noted on Aprie/st, the same date on which Dlast saw them in the sfring of 1875 . Ther have bren quite comnoud durnig thi winter. Airagalinus tristis. - Very Searce all vinter, in taet searcely woted at all. Cn Warch 3/st, I shot a male that wao gettri its black eap and summer heumage. this species was noted a few Cuies only, but it is generally anumon incuriter.

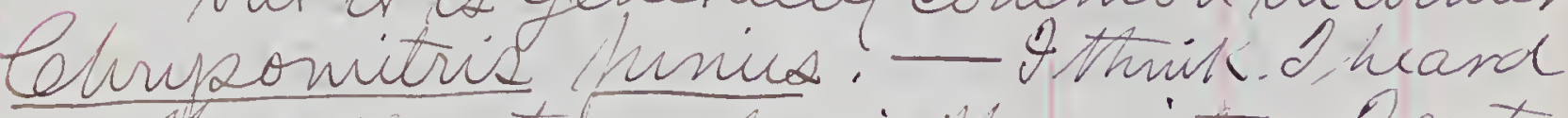
the call-note early in the wicter. Deertain did on February 2 nd, when one called "che-á" several triès as it flew over our plas ¿ saw a small flock on Ar. Osbom's plaer across Wovit, on Mllareh./ St; and on the 9 th of March, at Fort 7 ontgomery I shot ino shecinins from a snall olock. Ther have beru scabce durin thi vinter. 


L.ength.

wit 2 Th, a large flock surpt over our hlace. No other Snow-Buntinge were seen, or heard of, duri the uniter.

Lonotriehia albicollis. - The last one seen was a frim adult that eame about the back of our house, when the ground was deeply covered with suow, on Novenuber 28th. None were seem here ofter that mutel April 22 nd, after whieh ther wre abundant. First he ard sicging their ourion song ou the 24th. In Central Parkillew Gosk City ther spent the winter ar uoval. it is, Nerefore, strange that thin wereso

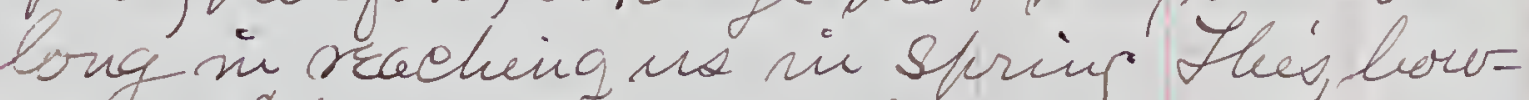
- iver I have aluaur observed.

Shisella montana. - Generally hretty coumu during the cuiter. If find Ihaveneglected ts notet the date of its arrial last autumn, nordo my notes furmish any record of its last aecurrence tere thio shim . Possibly may yet see $\dot{H}$, as I have reords of ita stayin mitil April 29th thre defferent year. Shiella donestica. - I have nof noted th date of its last occurrence last autumn; rut the furit one appeared, this sfring, on the Ist of Aprie.

Shizella hudilla. - have no reoord of ito last oceurrence last autumn. The firet

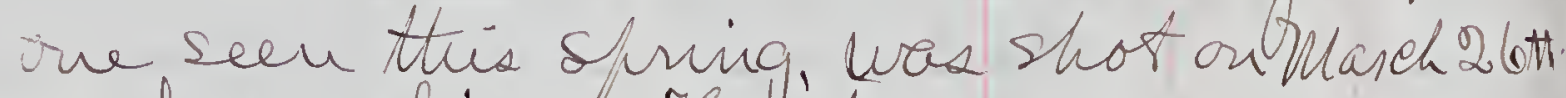
Drineo ly emalix. - Heas bren conmon, as usual all writer. At is stiel here (April24th). Qn th. 7th of Tume, 1882, g found this Suow Bird at Luensborough, near this place, out in th nountains. If wos doutlless, Freschig; but I was hastering to a patient, and had no tirie to stopand investiyate. Ihew

XAME.

DATE.

LOCALITY:

\begin{tabular}{c|c|c} 
Lengtil. & Stretcll. & $\substack{\text { Sex and } \\
\text { igge. }}$ \\
\hline
\end{tabular}

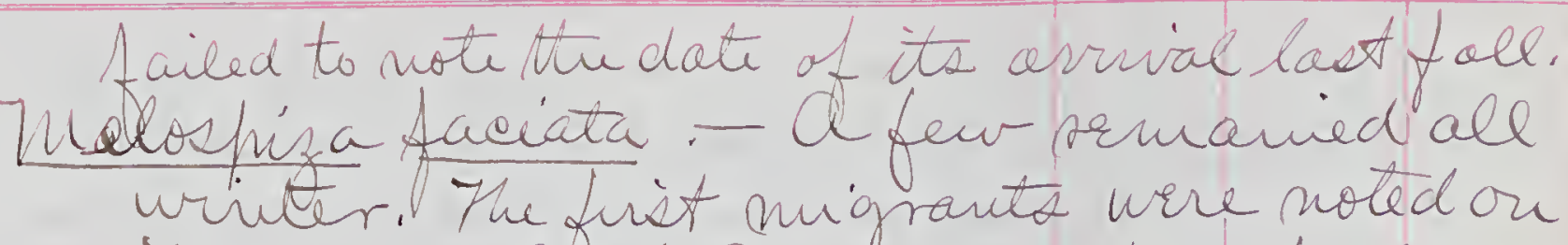
Hebruary 2 st th. Sang at our howse firit, Mareh 15 Welospiza Maluetris t Harr no lat fall date. The friot one seen this shring at

Consook Narsh, was on the 15 th of Nareh. asserella iliaiea. Have not got the dote of ito last vecurrener last y all. Cu the 17 the of.

Hebruary, i8 3, I shot a fine male sheeliven (19.2,495). Why ouly ather February record for this Specilo was Fbtruan 28 th 18.78 . This year, none were seenfiom Hebruary I bound then throughout the erinter - Mu Cential Park, U. City, for tinfirit tive

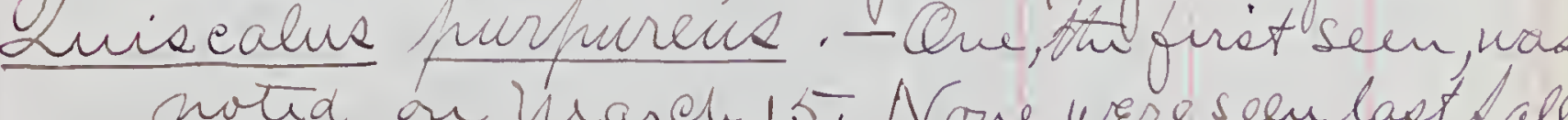
notid an hasch 15. None wreseen last fall.

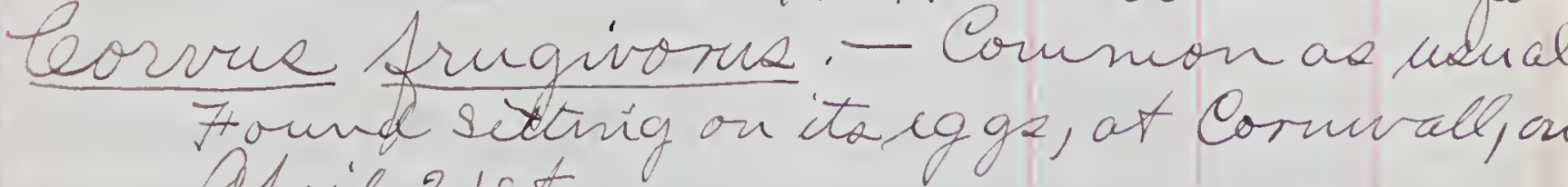
April 2/st.

teriuncitta crietata. - Common as uenal. Sujomis fuscuk. - have no late vecoro for labt antimu. This string one came to our back Nard on Mareh /5th, and called "Phoebe" bifore "was wh. She stayed about or conce tivie, and then ver sav her fly away. We did not see a wotiner until Waseh 20 th. Buth 25 the they were Pcene villosur. - Decasconally seen turoughout

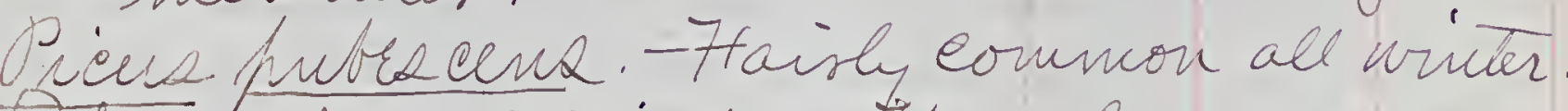

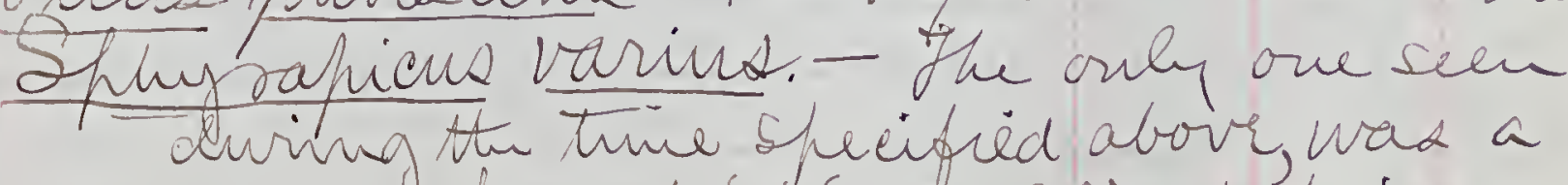
goum Lemale (No.2496) shot cir an apte

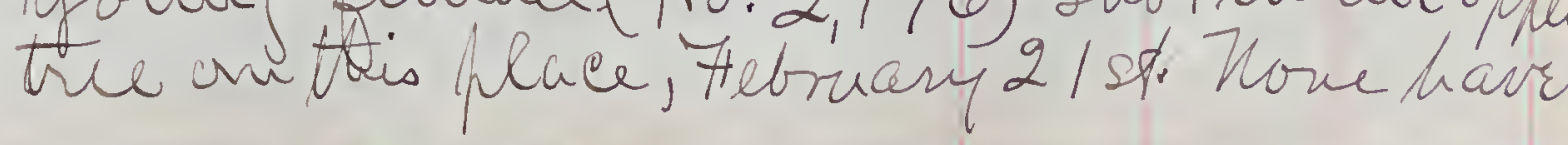


Colaptes auratus. Sam one at Consook

Marsh on Xnas day; and thik he stayed there all winter, for when? next visited the freaee, on 7hareh 12 th, Ifound one on thi Asland; and he was still tiere when Owrut again several dap later.

Strix nebulosa. - Mr. Royal Jaylor Lent a hiving speciuen to ch. Calvard Denton trom Peekskill. Wr. Denton Let it go at West Porits but it was neaphesed br a youn - oldier who Kee so it still in the basement of the baud Barracke, where Isaw it alorg vistr e whole nenagerie of amirals. nichdir atine Robin, Jur Cattrods, on Enflith Sharrov, four Flyin Syurirele, severdel RedSquiriels and Fouk Pray iquirals. The Red Squiriel bited the Gron wiongh the bass of its eage, and barke savachy The Gray squiriels were so tane as to thi all over Mr. Auton and nusels sut jine prou one shoulder to anothes. The dure was chained to a kesch, and wes punte. The ouner of this happy ganily

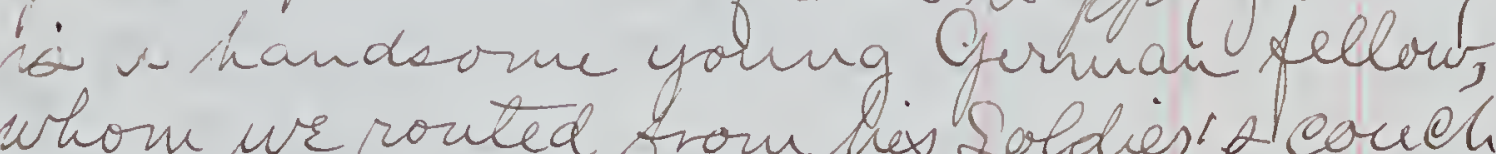
to exhibit his Cwe, whieh I wished to identify Seohs asiv. - Ell a shot am adult fenale (No.2,486) ni red plumage on fannany

Aceipiter cooperi. - Ferst seen ou March 13.th. Cre was seen in Certial Park, N.Y. Oty on Dannary 28 th; Gut nove were seen here during the winter.

Iosumedulne sparverine. - Anly one sen durnig the winter. An Febracary. 


\section{9}

somewhere in the branches. The Cornonal cut down the tree which was about 18 ineles in diameter, and secured the brit intendingīo stuth it. He keht it one dar, and the Conges he thonght about it, the laraer the jos worke; sohe gave it away to the keeferfol the Lis Saving Station here - Capt. Harriz Tho was going to get Mr. Alleu to hel/ hin sueff it dor the Cife-boat house. Thu both went kunting and forgot all about it. I aecidentath diseoverded it at the store, an carried it off as a great hise; but there are a lot of them about here and at Fort Stevers, in the string."

Dinensións. - Length, 87.00 ; stielele,34.50 Ivittiel.]; wing, 24.70; tail, 12.50; cere, 75; bill measure drom Gase of cere (ineludnig it), 275; culuen, 2.25; gape, 3.15; detth of bill, measured over the and of eere, 1.42; tersue, 3.70; midde tor, 4.25; tor alone, 3.00; claw alon, 1.42; hind elaw, 1'80. [4ad. Witken.]

\section{Afril 25 th. H.H., N.Y.}

Io-dary has bren cold and windy. The Largebilld Acentor (Sicrux motacilla) wao heand singing suretty; and a Chewik (Jipilo erythrofhthalimus), the second one seen This strmic and a female, was hard callin Beside the rumlet wroeeding from Aell's

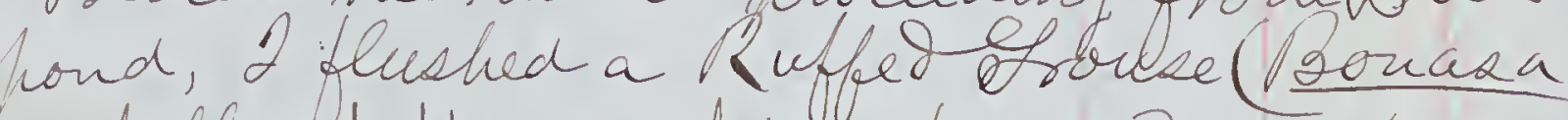
unbrllux . Her nest wes found inder the roek from which she sporing and contaried four(4) \&fe, thier of which wore weather stained from the secuft reairs, an Hu fourth apfeared to be perfecth frefl. leovire fingiorua. It thive dfo wer

\section{$2,520 \cdot \frac{\text { Scope acio }}{7 \text { ing }}$}

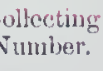
1883

bird wae sitting; their sizes.
Scoks asiv. - Che lue was fluched Arom a cedar-tree. As it Llew anary a Robin started in purault, and followrd it to thic spot where it aliflited, and wes there ginied byits mate. Ifollowid the sound of Hir seoldria vories, and thue fornal and shot thr Serceeh Que, whieh, hitiont At. Foleina' help D never could have found; but in shootirig it, I accidentally killed one of the Robitus, which idid not see mutil - started to liave the sfot, when Idicovered it Crring dead at a little dietaner bryoud H. Tree in whieh the Que had satt i) walked all over Consook marsh, but ottirirg of interest save afeursuaip Sharous (Melospiza halustris), tho of whie * cust, and noted a great chacrepaney betwer ing, 6.80; tail, 3.35 j from base of ecre to foint of bill, 87; cere alone, 37; culnen exchsive of cere.37; gake,1.07; tarsus(about),1.40; mid -dle tor and claw, 1.28; tor alone, 98 ; elaw.48. Jides, bright yellow. Bill, blineh flesh-color Fors, flesh-color: Basal one-half of elaws, Hesh-color, shading into blaek on terminal hal 2,521: Wurula migratoria. 9.55/5.62 \& a8. Wing, 4.90; twil, 3.95; bill, nieasured from nostril, S0; gape, 1.05; tersus, /29; middle tor and clawt 1.18; claw alone, 29. 2roess hozel Bill, yellow-saving the extrenity of maxilla, 2,522. Thelosing halustris. 6.258 .30 今

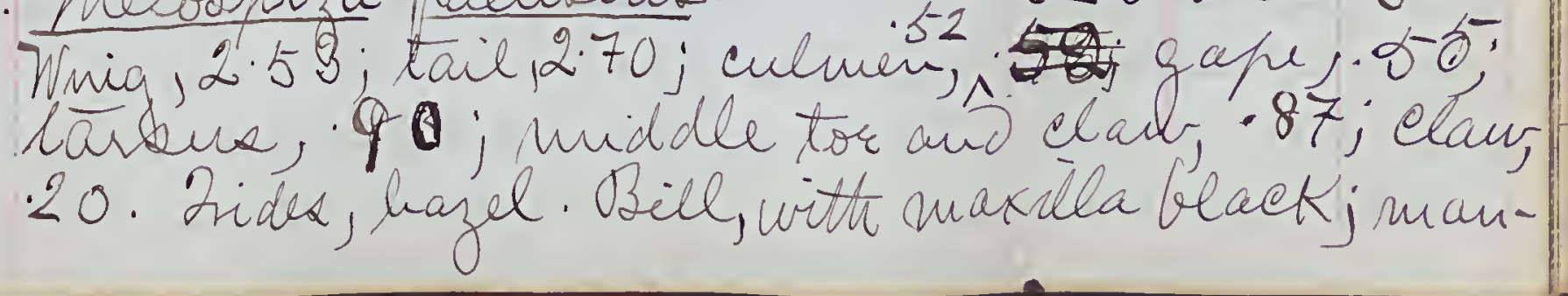




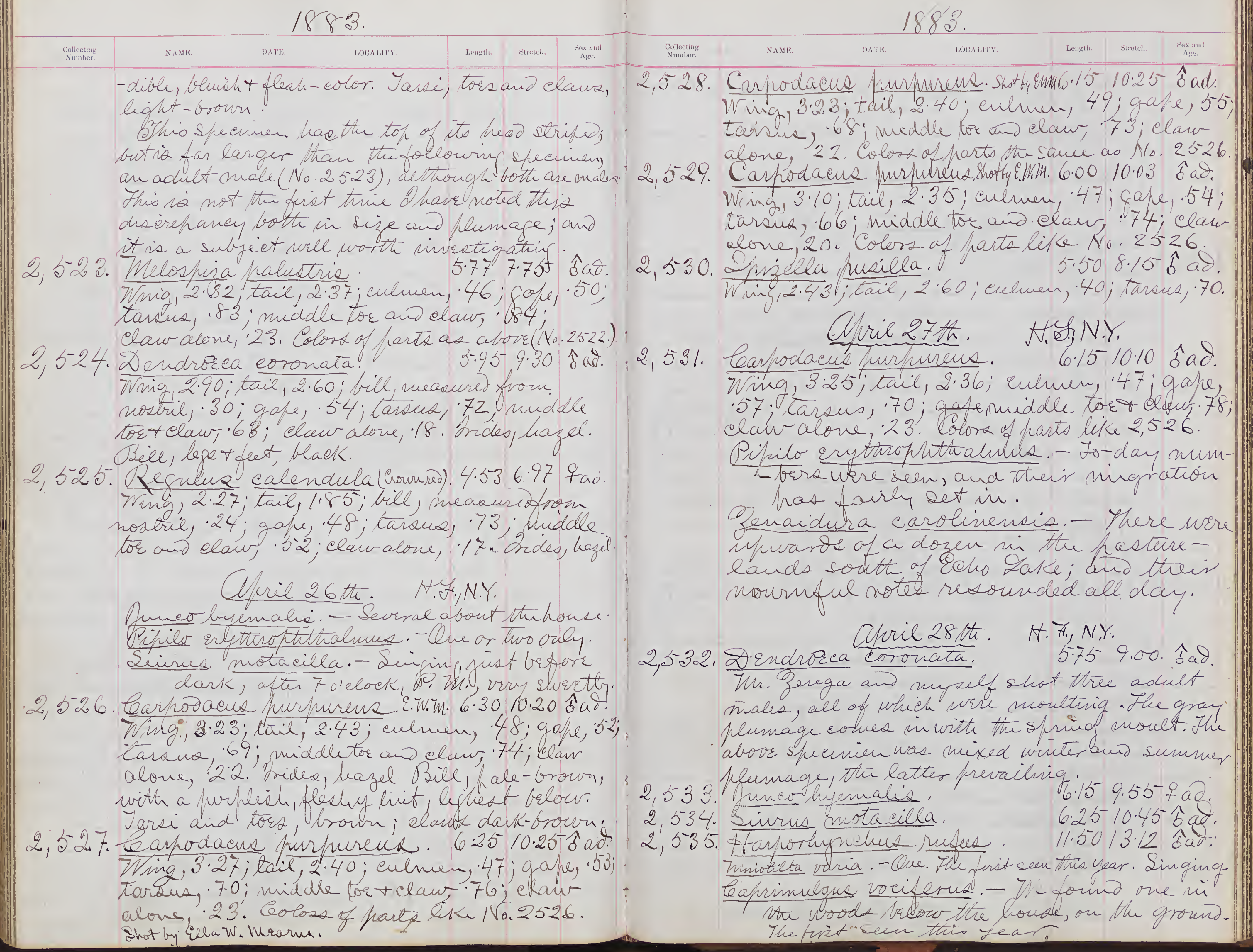


$2535, a$ Aringoides maculates. - Frist sen this year. Cowns olsifragus. - While dredging a ereek in Consook massh, wr plairly destunguished thi note of a Fish Erow that sat ervaking on the top of a fine-tree on Consook Alant. Wh. - Gercia ubocacoupanied ne went in furaint of the lerow, and shot it when soaring sory hifh in the cir. D affordo the following cinentiona:- 16.45133.009a. Winig, 11.00; tail, 6.95; culmen, 1.53; quhe, 1.79; tarsus, 1.76; middle tor and its claws 1.72; tor alone, 1.25; Claw, 52; grad- nation of tail, 77. Bides, hazel. Viell and deet, beach.

2536- Mr. Serega shot a tive bovad-winged Hawk (Auter Puncylisariens), whish dusented th

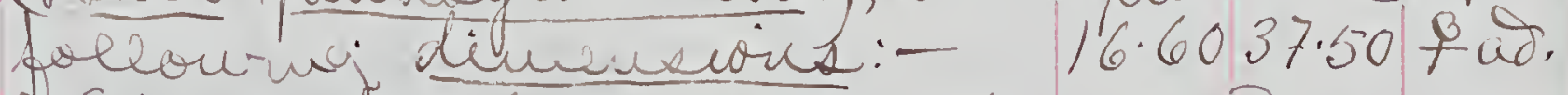

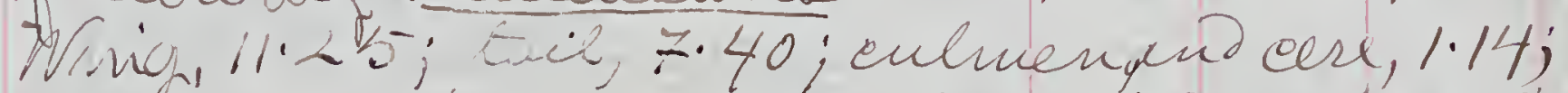

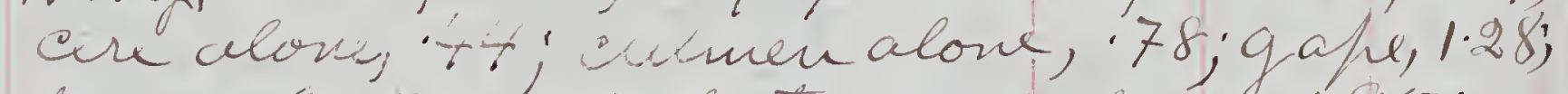

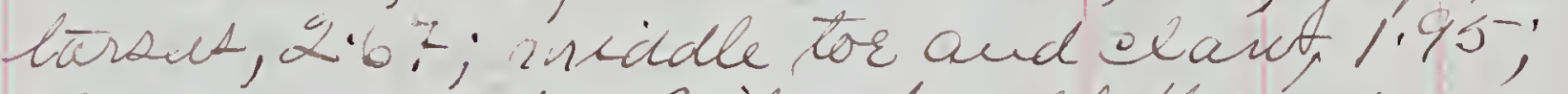
claw alone, "of. Frides hazel (the buly. sign of in materity). Cere, gremiah-yellow. vill, bue-buery exelept the basal gue-third of naudible which is hale-blue. Farsi and

2.36. Iringoides madularis. $7.8013 .50 \mathrm{fad}$. Wnig, 4.5; tail, 2.25; arlmen, 93; ga/we, 1.03 ; Caravis, 93 ; middle tor and elavi, 90 ; Stans, 20.

Heiundo ergethrogaktras. Firitseen.

\section{3}

Singe

DAT'F.

LOCALITY,

Sex : viul Wh. Lonis A. Kerega and myself spent most of the day in collectuig fiblec in. leonsook marsh creek. We took thu following shecies: -

Notemigonis Chrysolencux (Witeh.) for. - Crey one smadl specriven taken. Fundulus heteroclitus (2.) Guntter. Execedrigly numeroux. WL look a number of specimena of both sexes. \#undulux diaphanus (Le S.) Ag. Quite numerous. We took several.

Rocens americanue Gmel. R.t G. Conmon. zefonns gibbosus (a) MeKay. Luvouly. heltes quadracus (Hatehill) Jrvoort.

We preserved 100 speciniens, after connting the numiber of dorsal spines piries each; in 19 there were friv; in two there were but three. It deservea the name "inconstans" more than clora that species itself.

Wr canght one suale sheriven of the Frok-tailed Cat-fish of the Hudson. The Shad

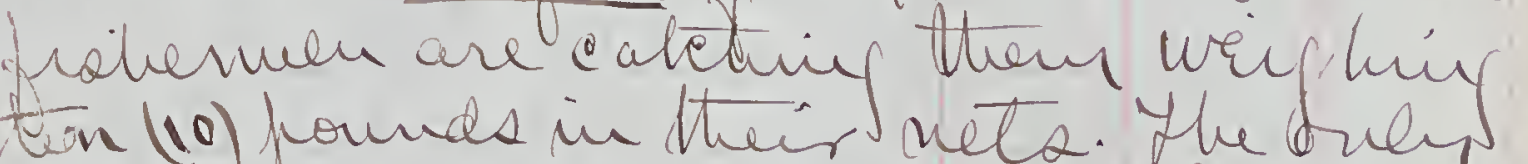
other sfecies which they take areiShad, the two "peies of Sturgen and "the Stripect Tiast. The Cat-fiah are called "Lake Cats." Wriville rostrutaber Sueur) DeKay.

Surval species of shelts and one rustacian weref also laken ar wrll as

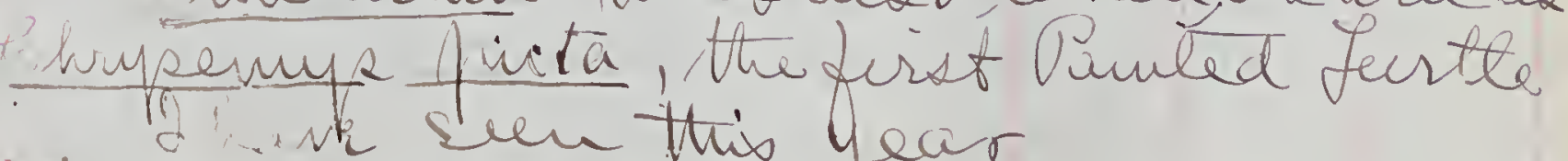

Varremir guttata was Valos found eofucuting 


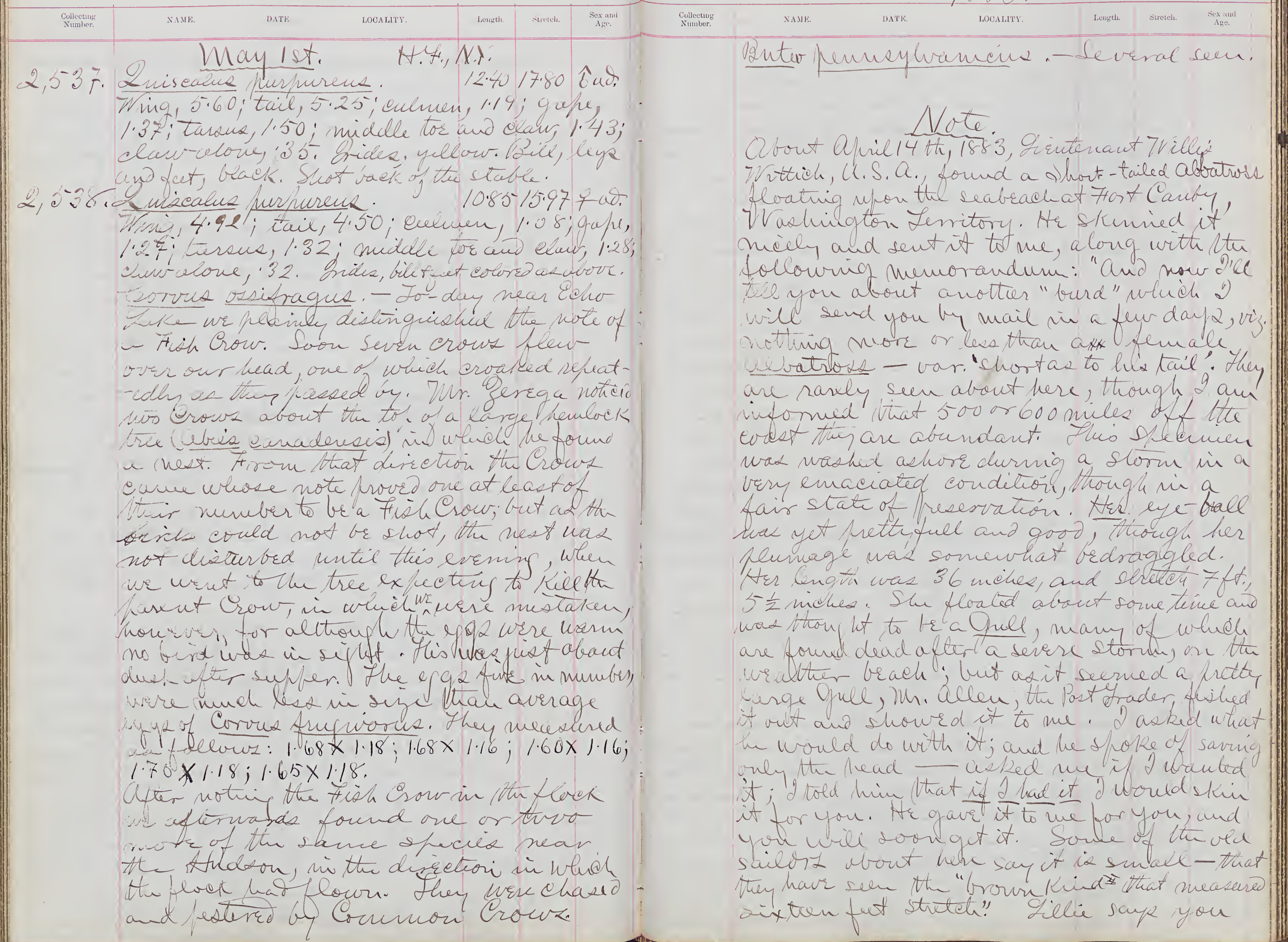




Length.

Fitrecth. Sex aurt

have two or tirce; but I do poot remencer to have seenthen ni your collectión. the find troyes to or the Short-tailed Clbatroso (Dionedra brachuna Jemm.). Dinemions, - Length, 36.00; Streteh, 89.50 ad [Zitteh]; wnig, 20.60; tail, 6.80; onlmen, 5.60 diskaner brtwral nostrild, 67; gahe, 6.20; dehth of bill at bose, 2 vo; defth of fill boirerde extrenite 1.40; depth of bill about the mid- dle 1.35-; bark fortioin of tibia, 1.30; Lursuz, 3.80; middle toz and its elaw, 5:25; cluw, 68. Whermaxilla, desh-color, with thi extrenity fir some distanee, hate; under nurdible, ros-color; with Carge hrocest at extemitu, blusi-gray. I arai and fut, Guish-blesh-colost, with tors and webs marked with dustu. Clawz brownith blaek, sbading nito hom-color at srdes, boses $\forall$ tiph. The sheemin reached un about a fortnight alter it wax shot, while in a sopt condinion, so that the webs of seet expanded perfectly, but it is probablh Hthat the colors of bill bu feet hach changed sonewthat. The dexeriftiois of the dark hortions of the felumage given hyl authors (Lauranee. P.R.R.Rep. Lol. TX,f.822 and cones, Key 1.325) difters from an bird; and 2 will therefore deachbe nuy bid!

"Primuries, tips of secondaries and tertiaries, wper edge of the wing and grater uing eovert'" and trminal ture tefthe of tabl clask. Thi dark area varies in oolor from punbrois gran to broun and black. The outer wabs of /uriaries are Glaok; shafts, whit, shading

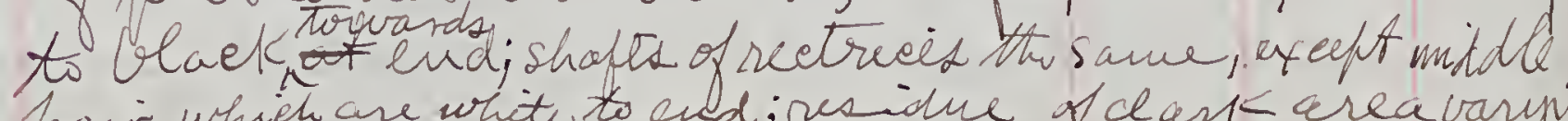
frair which are white to end;residue f chanc areavaryi phmage, hure-what Exeept hiad + veck buffy-tinted

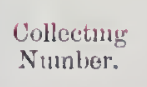

D.ATK.

LOCALITYY.

Length. Sex and
Ang.

Note. - On April

my gun and went to Hu theace, and found a bock of crovs, all but are of whide wer silent when g got near them; so I néked out. It bind g thought looked shallest and Surit it; but it got anay; and as thi Leack hot. I was unable to firid it again

Note:- en April 25, th, 1883,

of Cernsovk Lsland, in su Hedoon, Rier, a strivia of herivinteles "eqge". The ovarie

weaderred 17 midees in lehgtt. Ihave never Lonw the shells here; and hever the ovaries tiel nos. This is the specie described by De

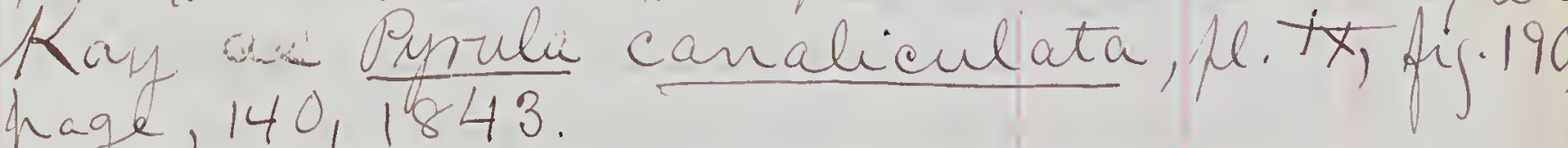
Mage, Mayl st - Continied from haye 397 .

2,539. Araina earolinencis. 11.9017 .907 ad.

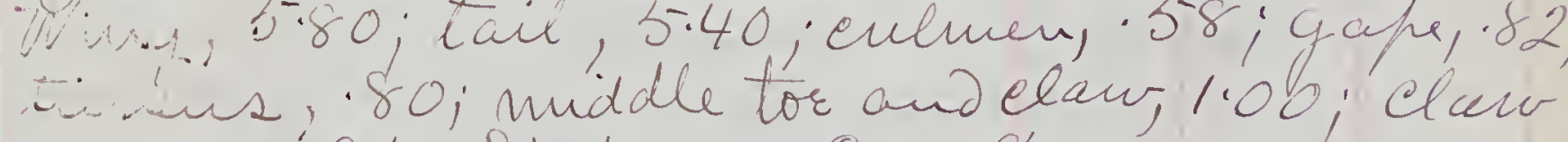
numer; hyemalid. Sevaral Leen May 2 nd. H.f.,N.Y.

- H-ims 7lr. Jeregaaconpanied me to Queent-

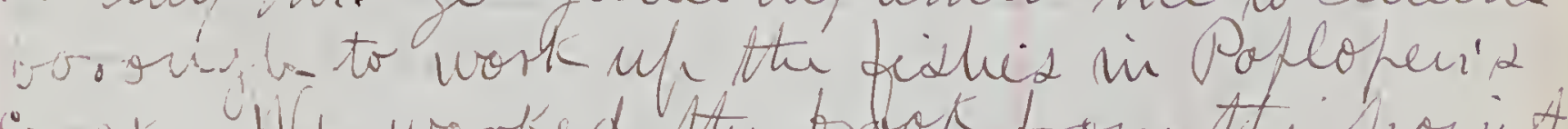
inek. We worked the fook from the soint Whie it approw hes the a forge to the Luenet. tarige, foring over the ground theth way the following species of fisher only: Semotilus corporahi (Niteh.) Putn. - ire caught a numbrr, but all ware snad shecinens. Oonu 
Neinnilus eornutux (Witelill) A. F.

We canglet sone tair suzid Ked-quid.

Then wre exquisitely colored, with criver quis, and homs (spries) on their heads. They are vigorouk biters

Lepomiz auritur LL./ Raf.

deanght a Long-eared Stundish on a Wom bait in the most sahid hast of the streauchen bishing for Lrout. We canght several otters. Esox reticulatis Le Sueur.

The joung ones are caled "Jaeks" Ther were numerords in still harts of the strau Ve snared a conple of litte "Yacte" in an arm of the book, where wr alto Took a nuniber of Crawtesties, and Zinenjetylus vividescens. The catte wrre copulatid Salvelime fontinaliz (Witeh.) Fill tor Wr saw sevral dive ones; bit they reqused to bite, so eb got no shecinema. We fornd thre species of Lurthes in the brook, las followz:Ehelopus insculptus Le C. - Thr. Berega look an unusually large one; but to estaped from the wagon while wratelund, and lould not be re-captiered. Nanemis quttatis (Dehn.) Ag. - The shell mankide trom she eniend Caken in the Clear brook uate Urre shecially clear aw bript. Elirysemp hieta (Arrm.) Ga. Sevefal. A suall crulstacean wrex defsofaken in the Grook. O cothlykiz trichax wax firit seen. A pair of Qspruse (Vandion haliaietus carolinensis. wre fiatornig ni the Oreek. Buta hennsylvanien. - A pairstayed about th brooth all day.

Anemone nemorosa.- The Wino Hlower was pirst found ir bloom lo-day, ad an
1883

DATT.

LOC:ALTTY.

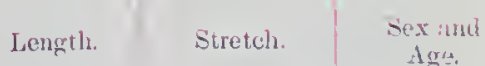

also the Dog-tooth Violet (Expthronim amer- ieamin).

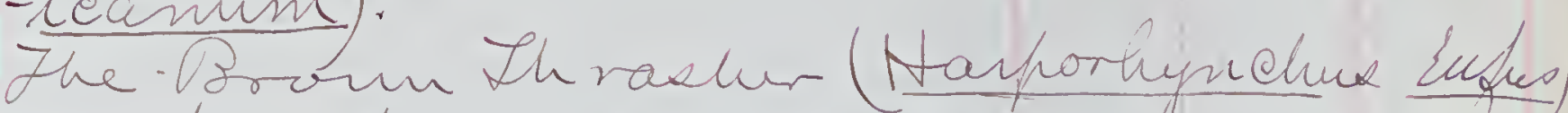
was furit heard suiging to-day!

$$
\text { May 3id. H.'., N.Y. }
$$

Coovus ossitrank. - Arand this monning. Butea hennsylvanicus. - Whistling Suime motaclila. We shent the aflèraor in Ero' Nest Ravine where we found several of these lovaly Gids. Thu serenaded us mutil the evaring tirilight; and the song rang out irth unusual eleamest and suratreas in the narrow ravine In the Ravin we found sour shecéd of Qrehids grounig: Qrehis sheclabilix of whieh there wrre soveral, Goodyearia ubracens one plant, Aplectrum hijemale perha/ on hundred leaves seen, and the Habinai viridis, var. Gractiata of which wr had mever before fomb nove than a singh speenien uns aiste mumerous in on s/ot. The hander leaver of Allium trieveemm, the Wild Leek, wre wall grown, and brantigul but vile-scented Mvnlaria sesilifolia, the Sessile-leaved Bellwort vir found kin Gloom, Gut orly a sigigh on Rannunewlus abostives and Mitella dyhlulla (tur Bishopis-Cap) were also firit

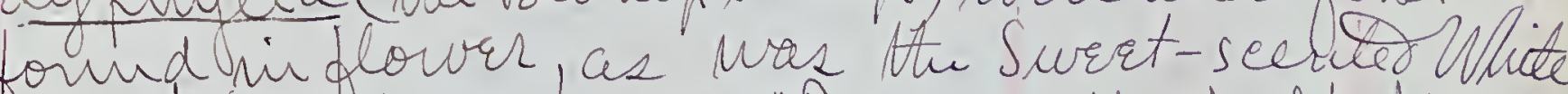
Vrolet ( D. Dla blanda). "O ack-in-the-pulfit" or the Hodian Lurnif was alsofirst flowered. a neur speeise of Crustacean was fornd tin the Ravine brook, along. 


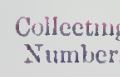
May4tth Niginy.

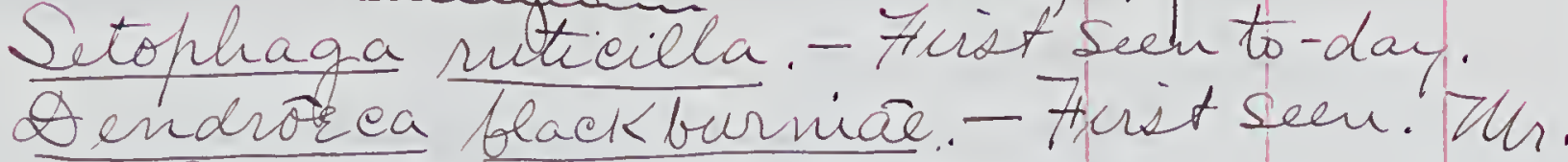
Lonir A. Gerega thota fine male. Dendrosea riens. - \#istseen. Mh. I.a. Serega shot an a dult male, Several others rere seen and heard suifing. Enfidonax numimus. - Firat sedn. Dendrorea Lunis. - Hirit seeu. Que.

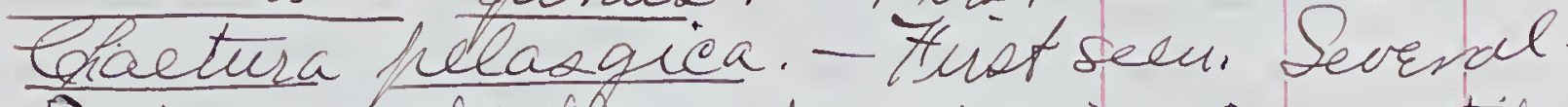
Snims motaclla. - heard singing until tairey dark to-night. long after th VAliphoor- wills brgan singing. Donaza umbelles. Hesterday gheard visited the Theasant's nest whioh found on the instant. The henbrid had raturned and laid two nork egar siner - shot at her as she dlew from the next, but hat subsequenth deserted the next, so wr took the six egga, which wrre mich wrattur-dtanied. Senolitur corporaliá. A male with large homs wer seen in Grook flownig from Pell's houd. Rana Sylvaded. Siocking in the sucunistill. Loads wrre theard yesterday.

Iroglodites donesticus. - Nunuerous. Sugingall day.

2540 . Regulud calendula. No ruby crour:4.37 7.00 t?. Vnic, 2.18; tail, 1.78 ; bill, measured from nostril, 27; gape, 50; Lasus, 76; Middle tor and clav, 54 ; chaw alone, 18 .

$204 \%$ oroglodyted aédon. Ming, 2.00; tail, 1.84; bil, neasured trom nostril, '35; gape, 68 ; tarena, 67; nudde tor and elar, 5-6; Claw alowe, is. Bidea, hazcl.

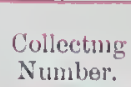

DATE.

LOCALITY

2542. Hylocichla unalaseas hallaxi.7.3511.60 f af. Wing, 3.55; tail, 2.88; bill, me asund from moxtril, 42 ; gafe, 93 ; tarsux, 1.26; middle tor and elaw, 98 ; Claw alone, 23.

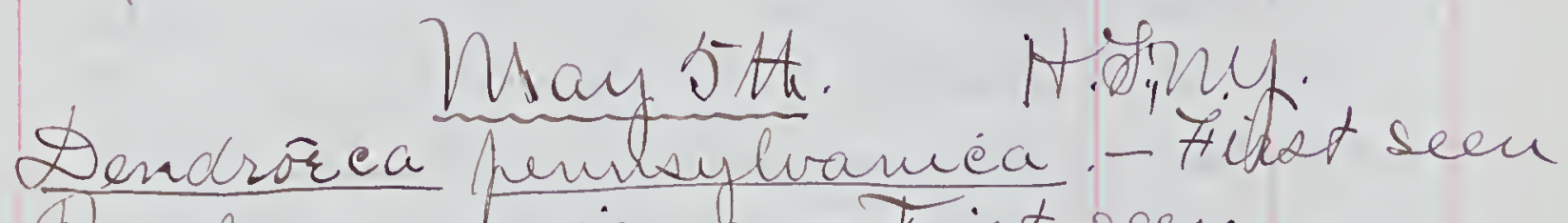
Punla amerreand Fiet seen. trenim thophaga rufdeapilla. - Firist seen Haboscohtes earoline Que was neviriq in the iilae-bestes by th house when I arose; and it was singing swertty aftes Grikfaot.

The Shad-bushes are now in bloom. I) got specmins of it (Amelanchier can adensio)

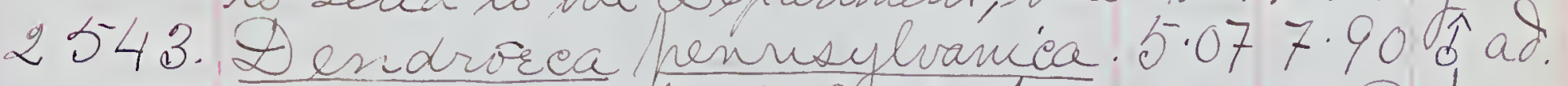
Wing, 2.47 ; tail, $2.00 ; \mathrm{bill}$, neasured from nostril, $29 ;$ ga/u, 55; tarsut, 75; dudde tor sud claw, 60 ; claw alone, 16. Ariv, hazel. Dell, with maxilla black; mandible bluiel horn-evlor. Jarsi and tork, blush-gray.

2544. Pancie amerceana. 4.987.70 d al. Wmig, 2.40; tail, 1.95; bill, nueasured trom nostril, 30 ; gape, 54 ; tarsus, 66 ; medde to: und elarv, 57; claw alone, 17. Did, hazee. Dell, with maxilla blaek, barelf edged with yellow; nuandible frejet ylelow. Javi, yellowih-Grown; Heet, Grownith-Yellow lelaws, Grown.

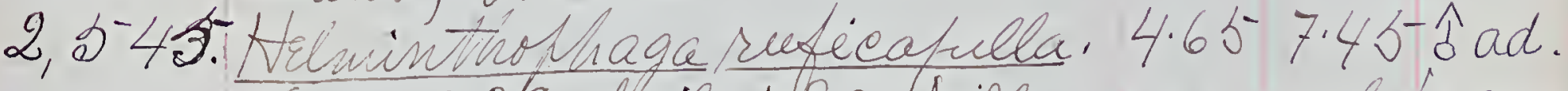
Wrig. 2.32; tail, 1.80 ; bill, measured from nosivil, 29 ; gape, 50 ; tarous, 67 ; midle tor audits daw, 5.4; claw alone, 17. Srid, hazel. Bill, with maxilla brownsh-black, edged, with yellowieh; mandible, yelerr, witte 


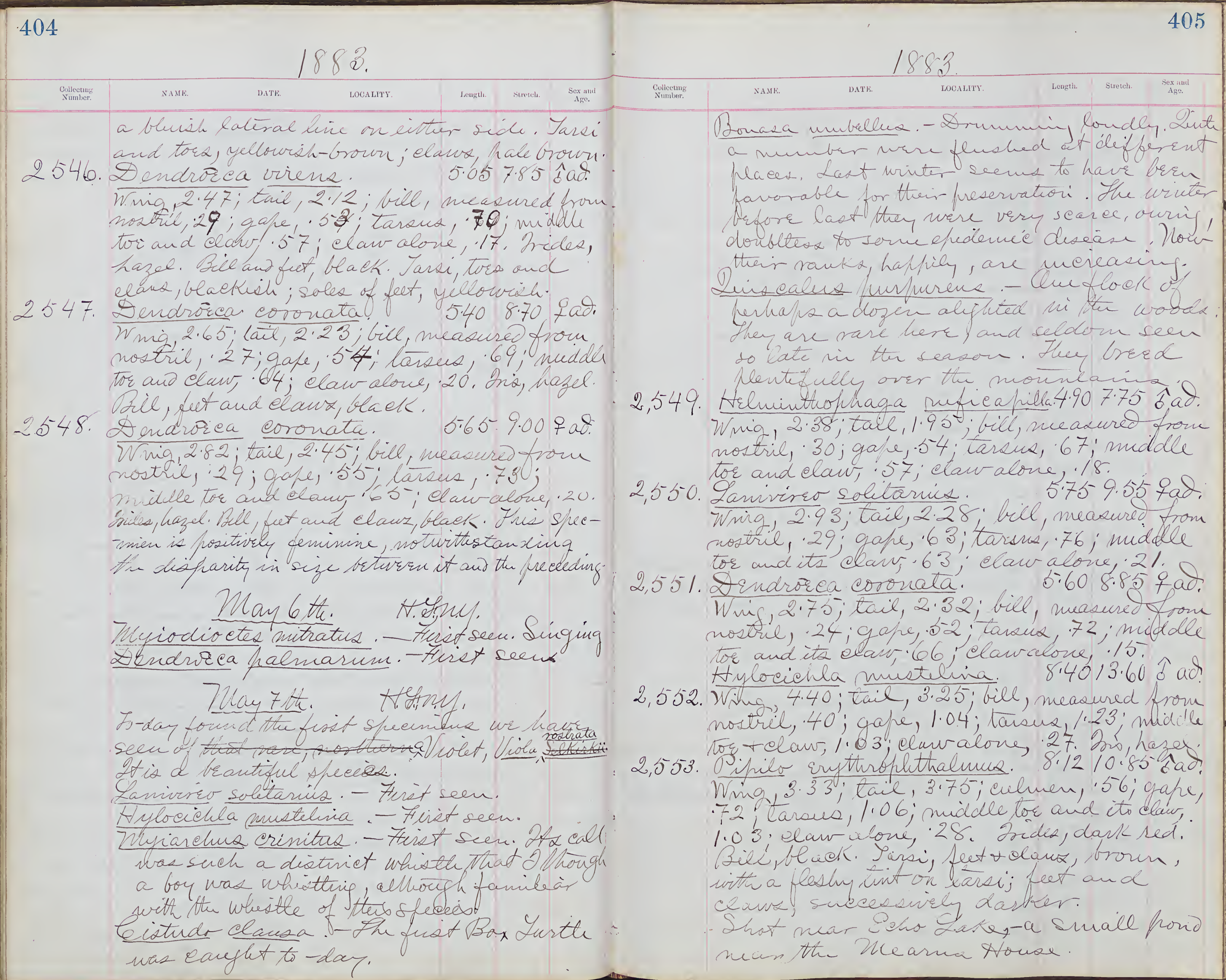


1883.

1883

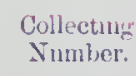

\section{Mays 8 th.}

Dendrorea maculosa. - Hirtí seen

Q eteria virins. - Firit seen.

Q) eterns shurins. - First seen

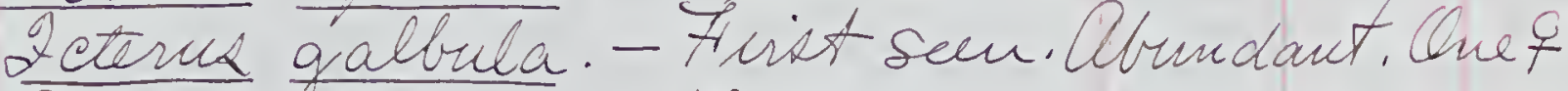

Prrangla rubra. - Firit seen.

Danelodia ludoriciana. - Firit seun Levral.

Iyrannus carolinentid. Firit seen

Virosylira olviace. - First seen.

Hennithohliaga elirysoptera. - Hist seen

Jochilus colubis. Furkt seen.

2,554. Arlminthohhaga ruficafilla. 4.70 7.25 tad. Wrig, 2.15; tail, 1.75; bill, measured from nostril, 27 ; gape, 52; tarsus, 70; midde tor and elaw . 58; claw alone, 16.

0,555 . Helminthotraga ruficafrilla. 4.857 .529 ad, Wrig 2.30 ; tail, 1.85 ; bill, nueasured from mostrit, 28; gape, 52 ; tarses, .68; middle tor and its claw,.57; claw alone, 18.

Dendrorea virene

$5 \cdot 308.10$ 今ad.

2,556

Wmi, 2.55; tail, 2.15; bill, nuasured from nostril, 32; gahe, 56; tarsus, 70; middh tor and elaw, 5-9; claw alone, 20

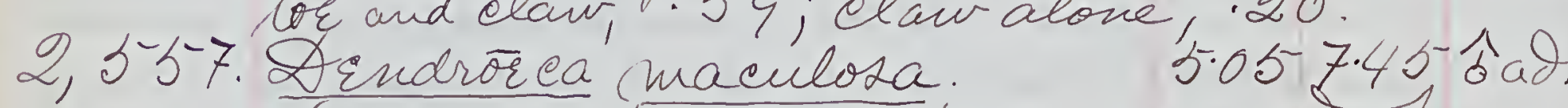
Wmig, 2.35; tail, 2.40; bill, nuaaured from nostril, 29; gape, 54 ; lärsus, 73; muddle tor and ito claw, 73; claw alone, 16.

2,558. Saleoscortes cárolinensix. 9.1512.00 9 ad. Wnig, 3.65; tail, 4.20; bill, measured from mostril, $45 ;$ gape, 96 ; tarsen, 1.06; meidle tor and claint 1.02; claw, 28.

2559 . cterus gabbula. 7.4011 .70 今े ad. Wrig, 3:60; tail, 2.95; culnuen,70; 9 ofe, 80; tarsus, 84; middle tor and its claw, 85; cauralone, 26 .

2560. Jimanaa rubra.

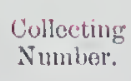

XAME:

DaTk.

LOCALITY

Lecugth. Strocth.

from nostril, 44; culmen, 65; gape, 74;

tarsux, 77; middle tor and elaw, 79; elcum

2,561. Seothlyis trichas. 5.47730 î. Wrig, 2.12; tail, 2.06; bill, neasure from nostril, 33: gape, 60; tarens, 80; nuddle tor and its elaw; 71; elaw alone, 22.

2,562. Drochilus colebris 704.10 sal.

Wrin, 1.55; tail, 1.20; culven, 67 ; gape, 79; larsur, 15; middle tor and its daw, 27 claw alone, 12

Laniviro Dlabitrons. Hing,

vire novetoracensis. - Firit seen

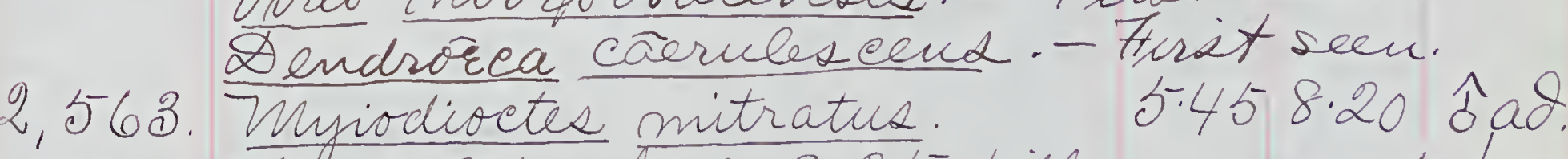
Wing, 2.60; tail, 2.25; bill, measured from nostril. 30 ; gafe, 58 ; tareus, 76 ; mudedle tor and its eldw, 65 ; elaw alone, 18. Iredex, hazel. Bill, black. Lege and teet, flesh-color.

2,564. Dendrorea caerulescens. 5.368.10 今ad. Wing, 2.50; tail, 2.16; bill, measured from nostril, 30; orape,55; tarsux, 82; nuddle 2565. Sinrus auricáfillís. $6.25 \% .60$ ì ad. nostril. 38; gape, 68; tarsus, 88; mebldle

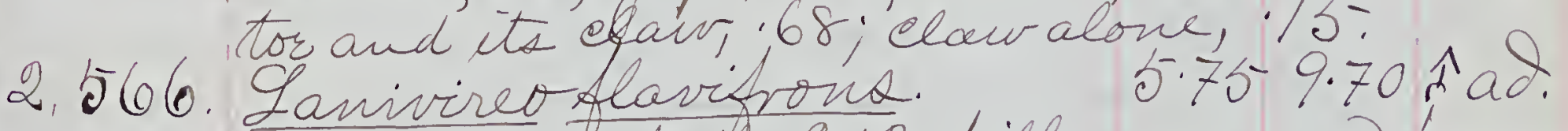
Wing, 3.00; tail, 2.12; bill, measuriofrom nostril. 33; ga/re, 70; lärut, 75 ; moldele tor and its elaw, 67; claw alone, 21. Irides, hazel. Bill, blue blaek, whitesth abu comnissure towards the end. Tarsi, deet and elawz, blinst-gray. 


\section{3}

Collectning
Nimber.

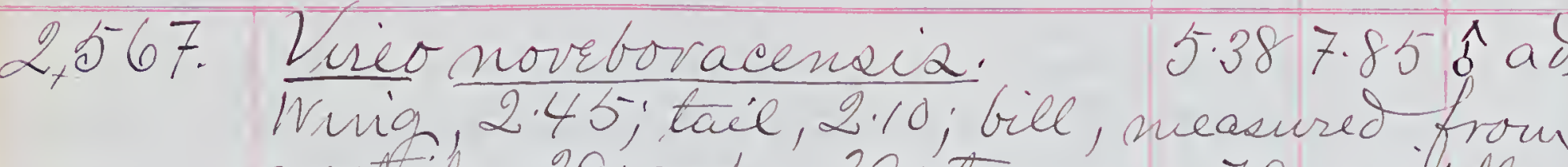
nostril, 29; galu, 39; taraus, 78; milldes tor and its elaw, 60; slavalone, 20 Judes, white. Bill, Glece-black; commis- sure white lowards extrenity. Taroi, tors and claws, buish-gray.

2.568. Felminthohaga ruficatilla. 4.907 .50 ô.

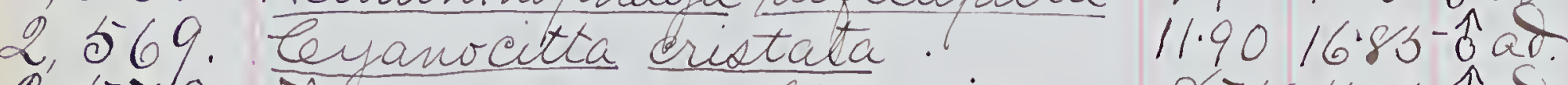

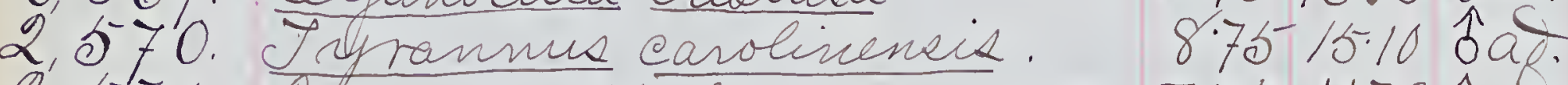

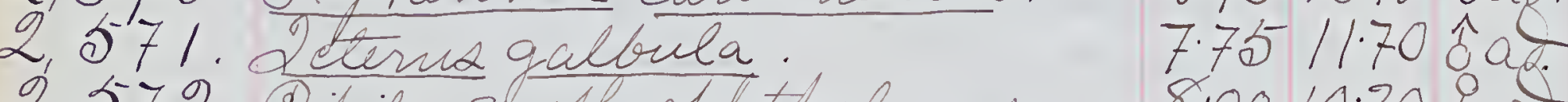
2, \$72. Oinilo snyturohnthalmua. 8.0010 .207 à. Zv-dar (Nay 9) groteeed the furit Cow-Oind (Wolothrux ater).

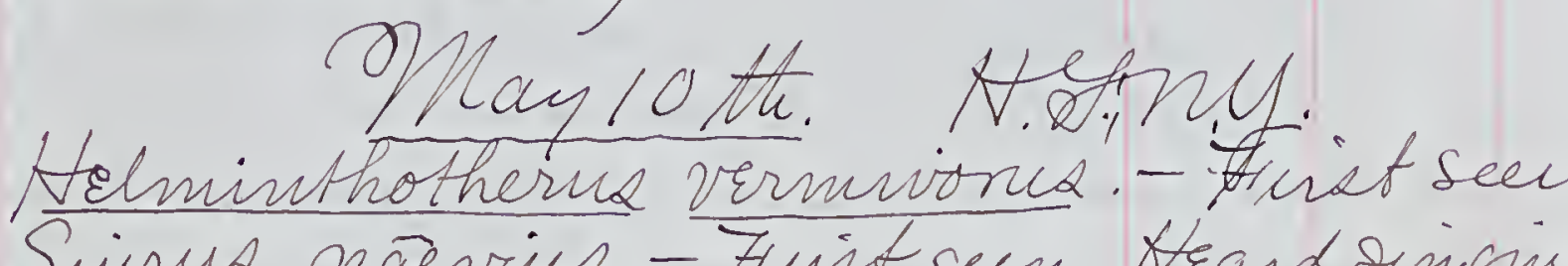
Sinus nâvins. - Fust seen. Frand singin

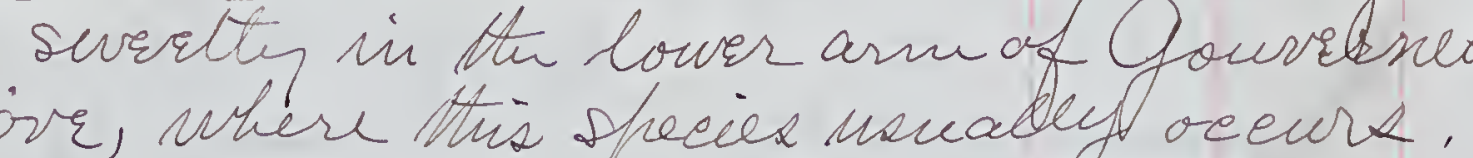
Nyetiardea qriea naevia. - Mh. Senton risited the terousy with me; but not a single trion could br found. Lovider osdifraque. - A Mair of then bives are without doulot bres dinia

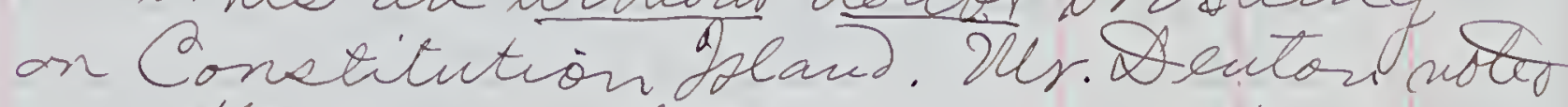
one there sone trine ago; and to-day wrfound a pair that seene? very mirstigation of the Flaud. Hey sorared overtlead and eroaked gt us all the

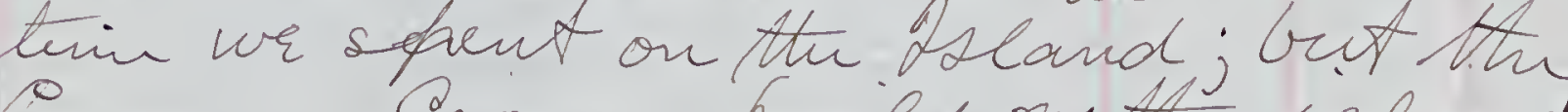
Common Qromz ouild on Athe coloma in munbers, so that we shid not, thi it worth whileto hent of a nest ginee the yfe when found bourd not te
1883

Collectng
Number:

thesitwity diolinginated fram those of eruldber seeved on the nest. At the lower and of Aouvernecer'2 Ores we fornd a small colony of Yellor

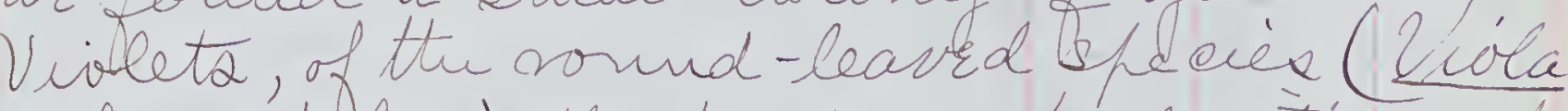
rotindifolia), the friet we had eitier or un seen grownig altwongle the downif yellow ivilet (Jola nubesens) growz ofuselu vi trí regtion. Ve aboo found sule remarkably varge ang fegltitue

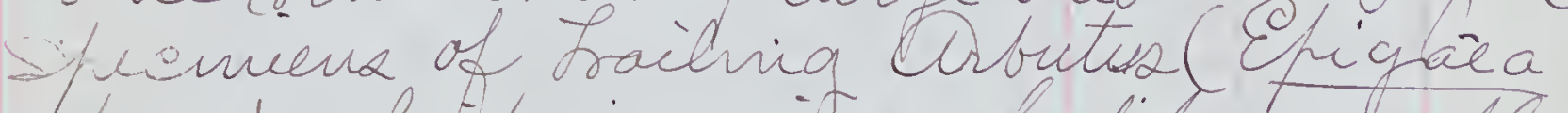

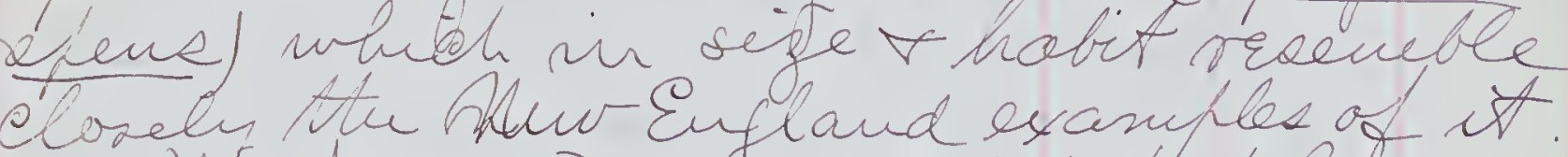

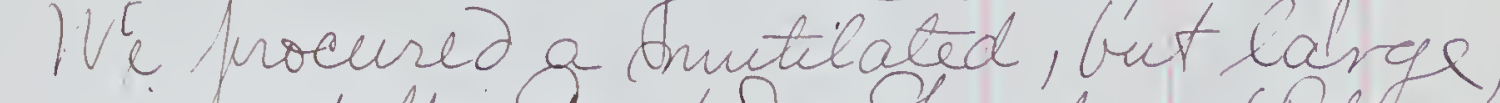

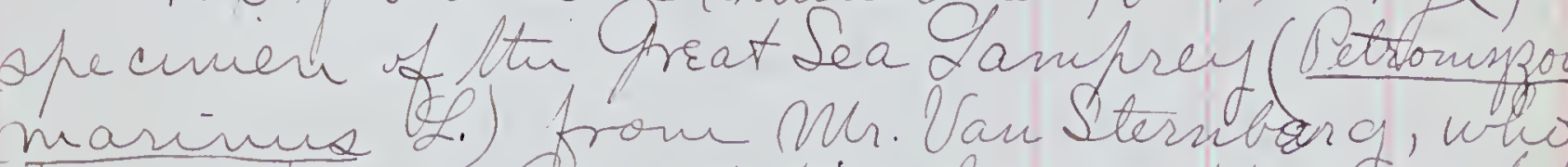

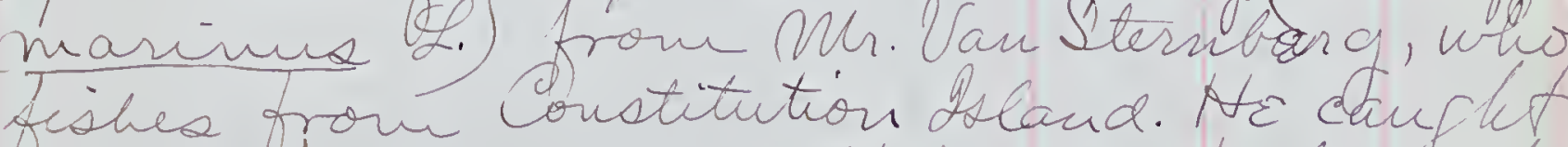
A in a fyke, and kept it for me; but sorkethe te ita tail of

- Ve called unon fue vleser Varner. Whis Ama went with us and chourd ux a

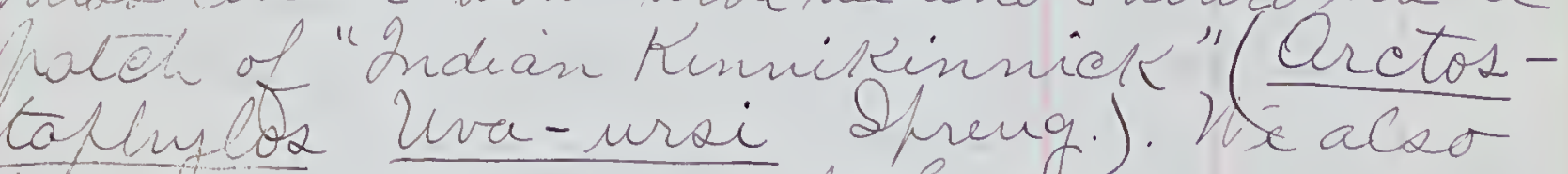

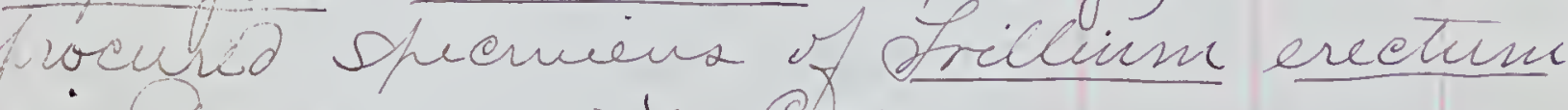
2573 vic Courerneur's core.

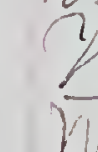
Mriodivetes mitratus $\quad 5.658 .90$ Sal. mostril, 32; gape, 60; tarome, 80 ; muddeto 9.574. treminthotherne vermivome.5.70\%.00 ô av, novtril, 44 ; gape. 66 ; tarane, 67 i middle tor 2,575:

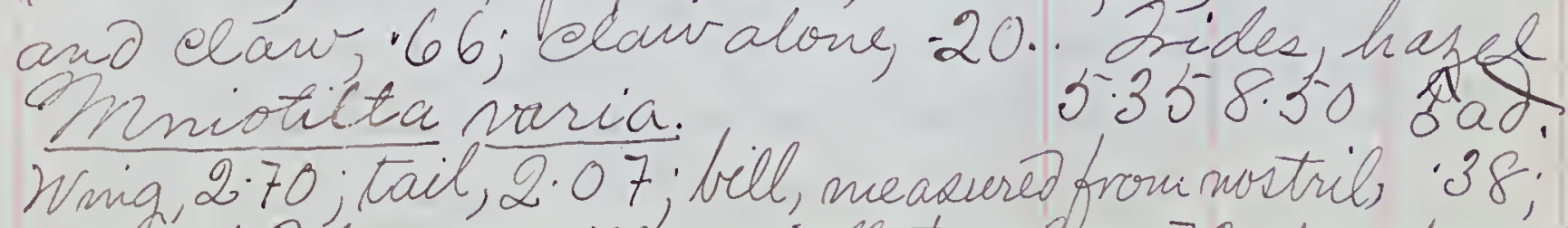
gape, 6 3; tasue, 70 ; middle tor telaw, 72; daw alone, 19 


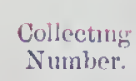

2,576. Findroeca maculosa costril, 27 ; fape, 50; tarsus. 76 ; muddele tor and

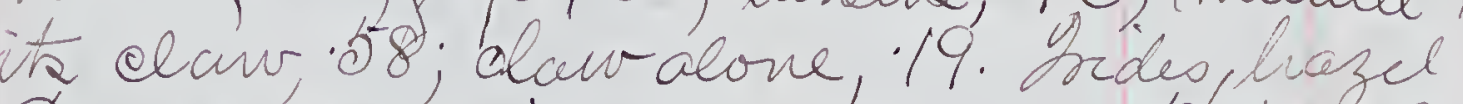

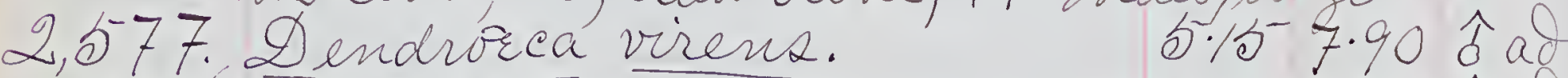

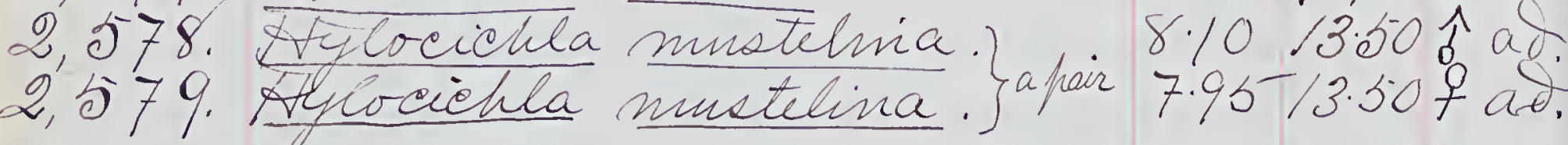

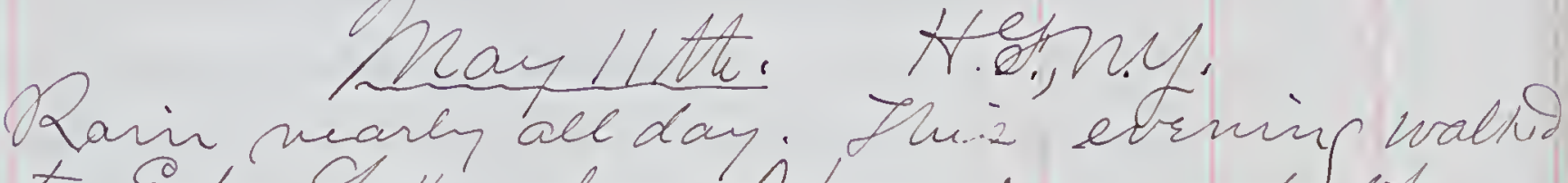
to Echo Lakey where I found an aduet Musk Ratl Fiber grbithacus) Surniming about and aerosa the lake. Squatting bside Atu larke where I had liverated sune turtes fuit brfore, I noticid the strong seent of most Gooskin wh, I saw a large Musk Rat subrimin about in fiout of me. After a chile it I suram wh to shore onley a feer feet from ne, and secelec itaelf ufor a sion brueath the surfaee so that onhitsheat nas visibh After watotiri me for sorve munited it swam withil a yard or two fast me and clnibed out ufon the bankat a short destand

$$
\text { Mlar } 12 \text { th, H. H:, N.Y. }
$$

2,580. Irranmia carveinensid. 8.2014.00 q ad Tria. 4.30; tail, 3.50; bill, neasured from mostril, 54 ; gape, 98 ; tarsus, 7.3 ; mid-dle tor + clanj, 85; clavalone, 29. Indeghazd. Bill, lego, fut + claws black. Invanne carohinemeix $8.62 / 5250$ at. Whing, 4.70; tail, 3.75; bill, measured. from noatril, 54; gaje, 1.00 ; tarawe, 78; miallle tor and elaw, 84; elaw alone, 25. Ardex, tuzel. Biè, lega,fect and ecavr, Vlaiek. othese two bide urre a mateo hair. Thi sfecenien had no miht hand, outer toé. Pabably

1883

Collecting
Number.

2, क 82 .

$\frac{\text { Coyanocitta cristata }}{\text { Nuis } 5.20 ; \text { tail, } 5.30}$

LOCALITT.

11.6016 .60 \& $a 8$. tarsur, 142; middle tor anditz clau, 1.17; Clau

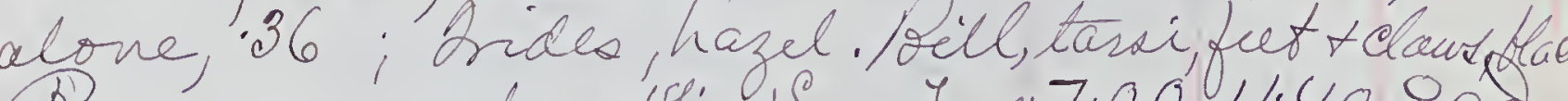

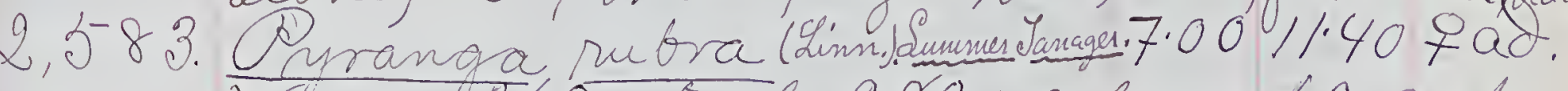
Vimg 2.60 ; tail, 2.80 ; culnen, 60; gahe, :77; tarsur, 74; middle tor and claw; .75; Claw alone 22. Aris, hazel. Bell, gresnist-ohir

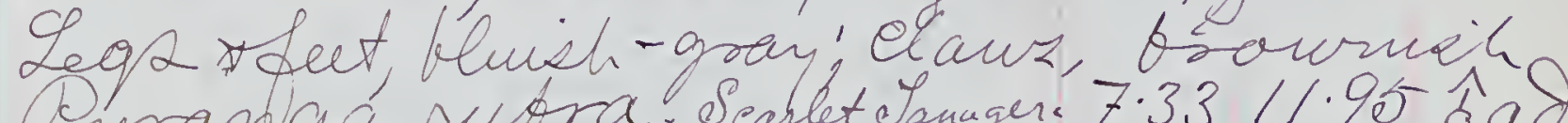

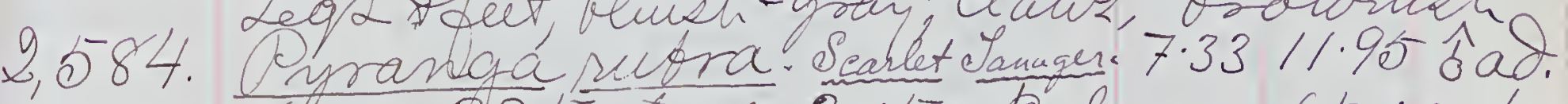
Whig, 3.85; tail, 3.05; dulnen, 65; gahe, 75 ; larene, 77 ; middle tor and olary. 72; ceaur alone, 22. Colora of hasto like No. 258 ?. 2,58 . Vuranga rubra. Searlet Yanagu. 7.1211 .35 . 0 ao. Hrig, 3.55; tail, 2.90; culmen, 65; grake, - 50 tarsus, 75 ; middle tor añ olaut, 76 ; claw alone, 26 . Colos of harte the same as No.258 2,586 . Jivehilue colubrix $3654 \%$ is ac Wing, 1.62; tail, 1.14; culnen, 67; gahe, 78; Taralis, 17, middletor and elaw, 26; clan, 12. 2,587. Dendrorea maculosa. 5.05.7.56 jad. nostril, 28 ; qape, s3; tarsus, 72 ; m ld dle tor and ito eldw, 60; claw alone, 16 .

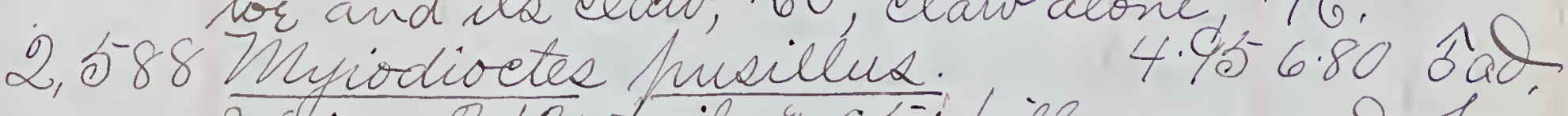
Whing, 2.13; Fil, ¿.05; bill, measured from mostril, 25; qape, 50; tareue, 70; middle tor and elaw, Y9; claw alone, /6. Fides, hazel. Maxilla andtip of mandible (1/3), Llack; mandible, yellow, otherdirie. Le pry feet, yellow Elaws, brownich.

2,589. Hylocichla alicià $7.75-12.75$ 今े ad. Ning 4.18; tail, 3.23; bill, measured from mostril..39; anlmen(about),-57; gape, 89; tarene, 1.2.2; middle tor and alan, 1.02. Claw alone, 2F. Srdes, hazel Bill, hackish, with fasal one-half of man- 


I.cingth

Collectung
Nitumber.

- dible, ycllow. Lepan geet, Rak orow Caws, fackish'. Lesticles, blackish. Munodivctes meillus. - Hirt sem. Sevral Thiodiocted eanadenaie. Firitsen. Humons Dendrorea striata. - Huist sem. One b́d Paserina eyamea. - Firit sem. Cur ôad. Hulvcichla aliciáe. Hist seen.

Aylocichla fuscescens. Hurtsen.

\section{PMay/3th. Hising}

Ceyan oitta eristata. - Solar all tu novds wire filled with Blue faef that irimpeted and sereanud by do zens at a tivin. Jave brfore noted Thif late sfruig movrments,

tot-day Ella found a Nuolet new to Mix defion, Viola primularfolia Befote vrattatet a man boughtiu nut givet Shecuicen of the Lawher-ell - Detromizon niqféeana Le Sueur). Now - have steciniens of both sheceis of tuis - mua latken mi the trighlaudal.

$$
\text { Mar } 14 \text { th. H.F.N.Y. }
$$

2590. Dendrorca Dlackburniae. \$208.05 今as.

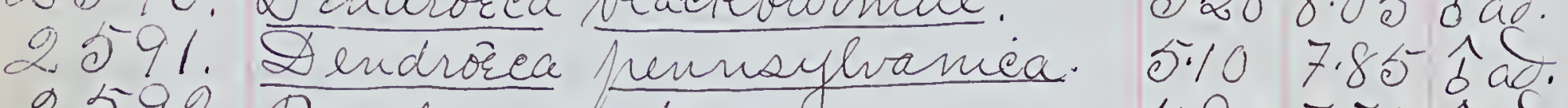
2592 . Parula americand. 4.907.75 今al.

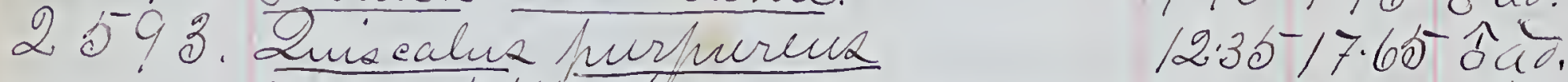
Wriq, 5.45; tail, 5.85; culven, 1.24; ja/e, 1.37; tarsus, 1.43; middle tor and ito claw, 135; clawalone, 34. Scdes, yellow. Bill, bys, geet and elawz, back.

2594 . Scoks asio. Light red hlumare 9.402 .75 - 0 ad Wing, 6.85 ; tail, 3.60 ; êre; 29 ; culmen, so; cere and eulnen, 82 ; tarsualabsut), 1.35T; middle tor $\forall$ elaw, 1.24 ; Claw alone, 47 .
2595. Jachycineta bicolor.

2596. Sirrus motacilla.

$$
\text { Mlay/7itu }
$$

2,597. Ceyanocitta cristata. Whig, $4.95 ;$ tail, 5.20; culum 1.0 8; gape,
1.25; tarens, 1.33; middle tor and claw, 1.10; claw alone, 32. Sins, hazel. Béllfeetand clawo, llack. 2.598. Cyanocita crietata. 41:2516:107a8. Wniq, 5.00; tail, 5.05; culven, 1.05; qahe, 1.21; Tarsus, 1.30; middle tor and elaw, 1.10); claw alone, 34. Bides, hazeh. Bill, legz, fut taid elawz, flack: 2.599. Dasserina cyanea. 5.50 \$.60 Sac. Wrig, 2.65, tail, 2.13; culmen, 44 ; Gape, 50 têrsus, 67 ; middle tor and claw, .69 ; elaw, 19 .

2,600. Arlminthotherus vernivorus, 5.60 8.75 t ad. Wing, 2.70 ; läl, 2.15; bill, neasured from nosth 40; $\mathrm{g}$ ahe, $61 ;$ tarsus, 73 ; middle tor and claw, -66; Celaw alone, 19. Drdes, hazel. Bill, with. wher mandible, dusky; lower mandible, fleok - evlor. Lepa, fut and claws, flesh-culor.

2601 Zamelodia Eudoviciana. 8.3813 .20 今ad. Hing, 4.15; tail, 3.25; culuen, 80; g alu. 82 tarsir, 87 ; middle tor and clar, 93 , Claw alone, 29. Arides, hazel.Bill, flesh-eoler, alightty brounish above, and duak ond lif of maxilla Orgerfut, bluish-gray; elaws, brownish 2,602. Lamelodia ludoriciana. 8.00 12.65 9 ad. tarens, 88 ; middle tor and elaw, 92 ; Claw alone, 27 . Sides, hazel.

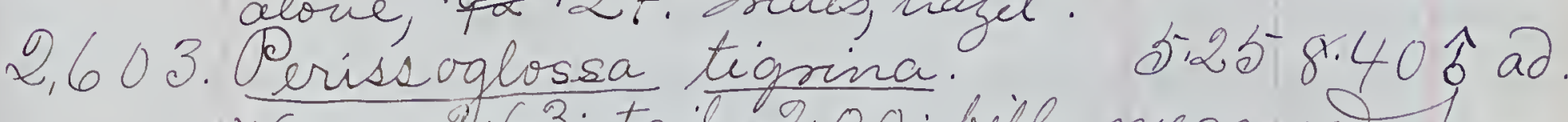
Wing, 2.63; tail, 2.00; bill, measured from mostril, 32; gape, S4; tarsua, 73; middle Tor and elaw, (45; Claw alone, 19. Side, hazel. Bill, legs, futand elaws, black; soles of feet, 
414

415

1883

$$
\text { 2,604. Perisovglossa tigrina. } 5208.42 \text { 今af, }
$$

Ning, 2.70; tail, 2.00; bill, measured from nostril, 32; gafe, 53; tarsus, 70; hidde tor and elaw, 6.5; Claw alone, 18. 'rides, hazel! Bill, legs feet and Claws, black; Soles of fiet, duskoy.

Ceyanocitta eristata. - The woods wre filled with theur to-day; and dozens of them werl timnfetirig in our affle-tresall day. Perissoglosta tigina. - Hire of these vars Nerblers wrre dhot in our eveiry trees among the Clossons, in company with Aumminybrids, Indigo Bids, Rose-brasted Irosbdics, sinfe, distinett ittered, and has the heeuliar nisect-hike tow whe he so many Warbler's somp have. Its little ditty iz constanth mpatech. Cun of the birdashot could not be secovrad. They wre the first Sen this year.

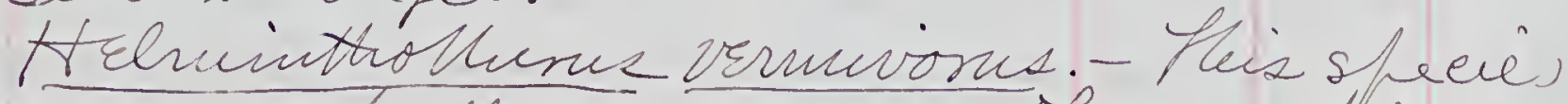
is vou / eretty numesons. Fornd of tên in dry woods, but not for from wet thlack. Ramelodia Ludoviciaria. - The bodies of Ditoxe stivined had a heculiar and statong bragnance, resembling the odos of Cherry blosoome upon wheh they feeds. Their

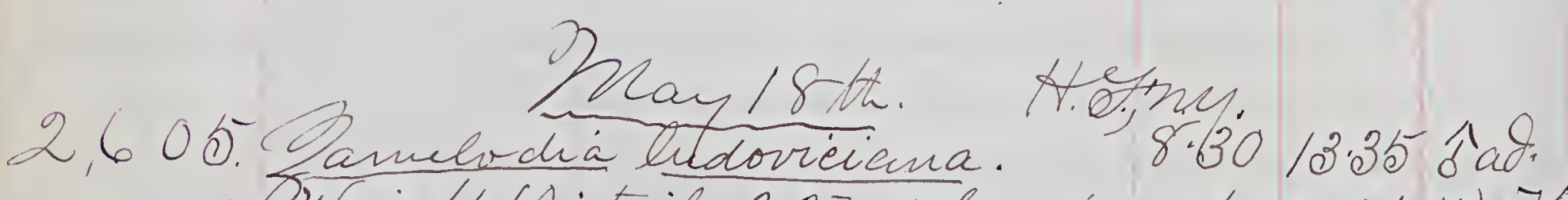
IWnig, 4.10; tail, 3.37; culmen (about, to shot off), 70; goficabrut), 75; taraw, 89; medidle tor and claw, .93; claw aloue, 26 . Irides, hagel Shot while coting oherry blrosons. Secrval. vere sen si the mountainio, Groides.
1888

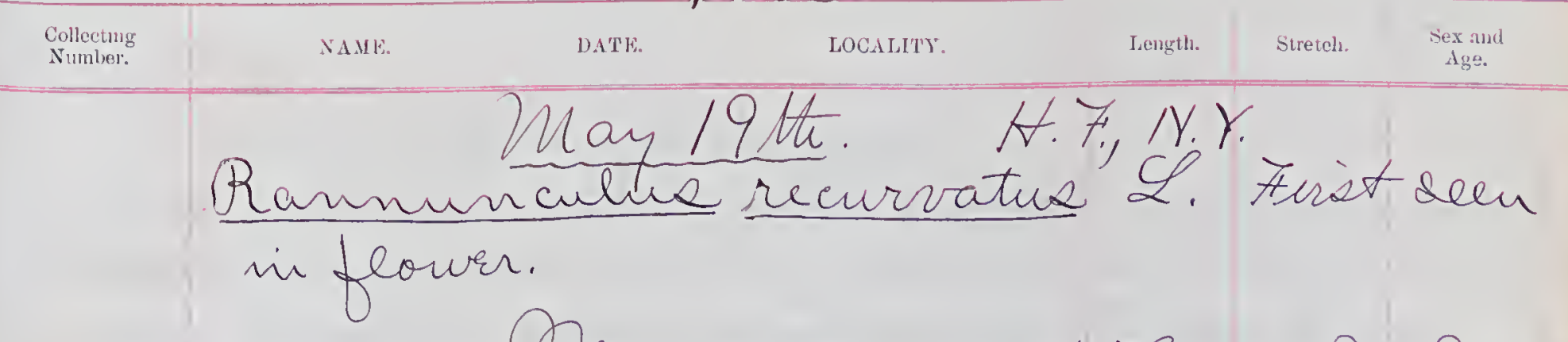

May 22 nd. A. F, N.Y,, Sing Sin.N.N. Jook 2.30 P.M. Trainifrom hew York, and stopped at Bing Bing for the falance of the afternoon. Found videa primulastolia, Vrotundifolia, V. pubrscens, V. cuenllata and V. canina. The Prinivose-leaved Violet was abundart, but not a snighe blanda could be found. The only Lrilkm ound was d. erectum. The Anemone nemorosa was alko plentiful.

I saw Enfidonax acadicus (aic d) presume. Nave not had time to look it uf) for thi first time. A single bird was found hi a deep ravine, oroun with 9000 sized herriveks (Abie Canadensis), bricd a trok. It nttered at accarional intervals a lond yelp.

Qforomia formosus was not seer. Mhiphoontills (Cafinimulgua vocifern) 2,606. Enfidonax traillir 6.409 .65 s. Wing, 2.97; tail, 2.70; bill, measured from nootrie, 38; gape, 74; tarsers, 60 ; buidde tor and elaiv, 53; claw alone, 16. Jvides, hazel. Bill, with maxilla, blaek," mandibli rale yellow. Yarki togs and

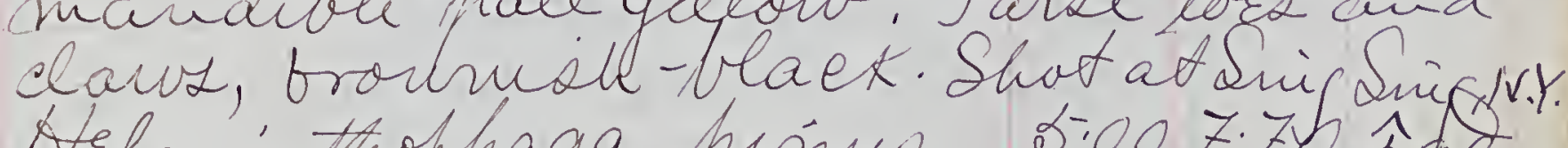

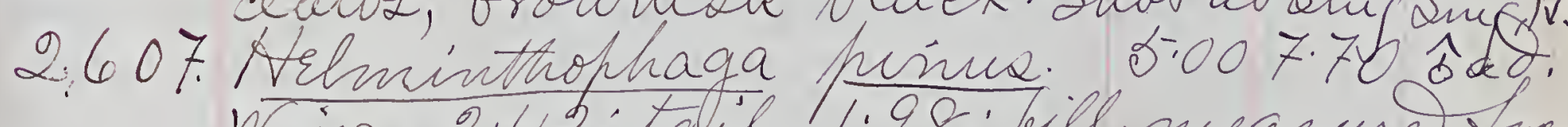
Wing, 2.42; tail, 1.98; bill, measured from middle tor and its olaw;. 58; Clawalone, 18. Dides, hazel. B ill, Vlack. Yarai, tors and elarre, duasty fullowroh-bown. Sing Suip. 


\section{May 25 th. N.PH:Y.}

This moming Elea ealled me down stars to resene the farmily of wak-old Robun

(Merula migratoria) that lived in the our house. A Red Squirrel. (Sciibus of hudsomine) had alseady bittere and throus two of the young birdd to the ground. saw the olb bird dash Aearlessly at tain it and dash it from the branch to one below whon whidh it caught, ared inmedi - ately clunibed un toward the nest, when my shot rilled it. It proved to br a large, kregnant Acuale Ret Squirel. If have preserved one of the bitten young Pobris. Bepore \& got doten, the old Robirle had once drivan the Sauiriel dowri from the nest; but it clined wh again whil Ella was looking and Atren an otter litle Robur courr ufou the ground.

2,6/4. Mnerula mignatoria. - - Pullu. Found a Flack Snake (Bascanium constrictor). lying in the raad, which measured Sour feet, ten siches. It was tos stale to Aermit of preervation. Heter dininer Ella and I took a walk, but found no birds. of interst saving the YlelowBurbated Vireo (Famibire- flavifrons) one of which 2,615. Lanivireo Llavitrons. 6.009 .807 ad. Wing, 3.10; tail, 2.15; bill, measured from nostin. 31; Gape, 69; tarsue, 75; middle tor and claw', 65; claw alone, 18. Lides, hazel $\checkmark$ Lell, with maxulla abovz $\forall$ tith, Henl-black; the reaidue fale blu, shading to whithech on middle thid of bill allong gafe. Lege and feet, dark Buish Goay. Claws, hom-color,

ectumg
nilber.

DATE.

I.OCALIT:

Length.

stretcl.

Sex and

mayked with dusky strifis.

In the craning Mr. Denton aceonerained me to Cerow Nest Raine, where wr Lound viridis, var. Evaeteata. Neah the ravine we found buds of Piparis lilifolia about ready to open, and godd sized leaves of Habenaná Laeera. In the Ravine itself we found a plant of Goodyearia pubracens, rapel of Aplectrum Ajemale having buds mearly ready to ofen, and a Lew flants of Cepprivedium mbracens, one. of milieh had an alining bud. Yhe root leavel of Aabenaria tridentatta were numeronx. Orchio spectabilis graw in fair obundance; and one olmuf of flants was the havdornex we ever sav. Sixllarge flowerin seafex, Twiel that number of unflowering leaver grew in a conpaet bunch. We dug thd whole thin wh with plenty of earth, ant shiffed it entire to Prof. WXV. Bailuy of Drovidence, P.O. thus eight specie of Orchids were found inañ about the Ravnic this afleñoon. The leaves of the Wrid Garlie (ellim trieocen. are, many of them, justorgining to fade, the Lloweral eomin but after the teaved die. He leaves of the Griger (Aarum canadense). are satimy and very brantigul now. The seed-pods of the Bloov-noot (Sanguinaria) are (le dulophyslum thali ctroided) has drophed

nost of its flowers, and the frutage byguis to apprat. We fornd Viola encullata Nalmata, the most tyfucal form, in the old spoty near the varine. Iound thin Murple Oxalis Exalis Aurpinea), the giset fomid by either of us. Mise Warne

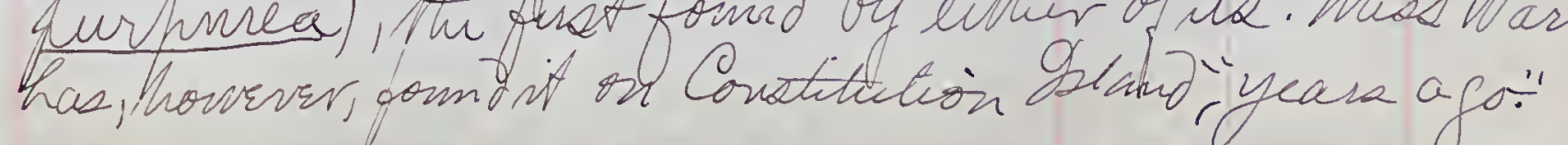




\section{May 23 od. Nitry.}

- -day drove to Dountrile (mashy 10 miled) to see a fatient whon whom wr oferated or lacerated Rerinacum last funday. In the north side of $D$ underburg Dlountain i) found a number of interestirg plauto. Anong thern vare, Goturifedin jubstcenx unite numerone and seattered, Es chis specta - bilis abundant and large, Vive primulat of -V. jubrseens, and U. costrata, the latter quite plintiful: the two firet very abundaut. Th,

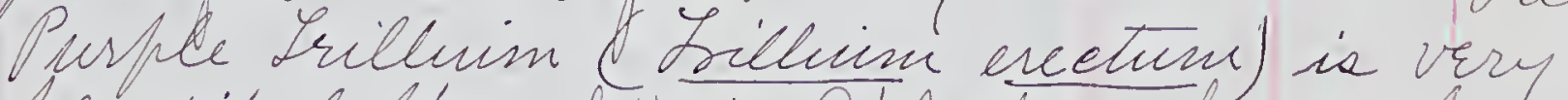
pentiful therc; likevise Aplectrim hemale Vear Afgleand Lake fonit fourtien flowring plants of iffrifedinin acaule growing within an are ten fut square.d procures a dowble shecmiere having two Lowerk 7 thio seto of leaves from onk rovot. Resides th flowing heouts there were dozene of plants hot in flower - Sterile Ca Denderber J tornd a number of Norm-Eating Narblerof (Aelminthollorue) vermivorue), and saw one bird utter refeatidly a rattling note that suggeots the "Song" a Cecada, and also reacubles somenthat in character the Neceliar notes of Nelminttestha chrefooftera and arula ancerdeana. Ihave trisd for mony years to solentify the author of this curione soma. I alvaip brleved it to be froduced by a bird, although several persons to whose attention Idvicted it suppose that it was hrodueed by some misect. - saw there an Eufidonax which frosoifh may have bein E. acadicie, but go E. Irailtii is generalle ennesono here ni spring it wres probrebly that sfeceis Hyiodivetes mitratus was muneroma.
1888

$2,608$.

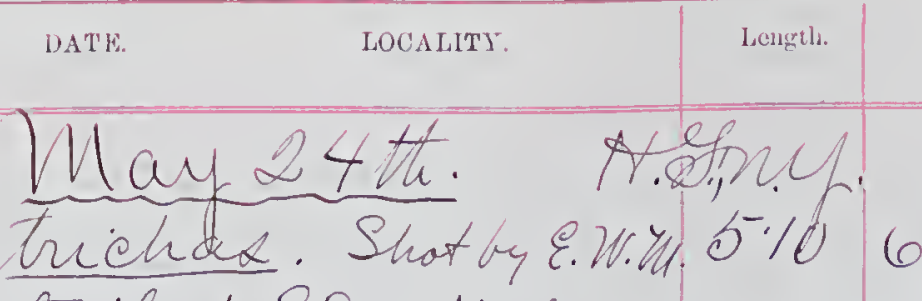
Wing, 2.00; tail, 1.98; bill, measured from costril, 31; gape, S5; tareus, 80 ; midle tor and elaw, 68; claw alone, 18. Zrdeo, hazel. Dill, buekish. Yarsi, fleoh-eolor; fut, hale brour 2,60\%. Dendrorca striata. 5.60 9.10 10. Wing, 2.90; tail, 2 .25; bill, measured fom and its clawt.68; Claw alone, 20. Bidessliaze Bill, becilish, with basal one-half of manoible vellowish. Jarsi tors and clars, yellow; th kattes boovish-yellow. b. H.m.

2,610. Duranga rubra. Shot by E.W.M.7.3011.55.9ad. Wring, 3.65; tail, 3.95; culmen, 67; qahe, 79; tarsux, 75; middle tor and claw, 79; claur alone, 25. Zrides, hazel. Biel, ohir - Grern. Tarsi and tors, lead-color; Clav frownih. Shot vy. Ella N. Nerarns.

2,611. Intanmis carolinensis. 8.1514 .10 t ad. Wring, 4.40; tail, 3.38; bill, measured fron nostril, b2; gake. 96; tareus, 74 infdde tor ano claw, 81; elaw alone, 26. Aides, haza Bill and feet, black. B. N. M.

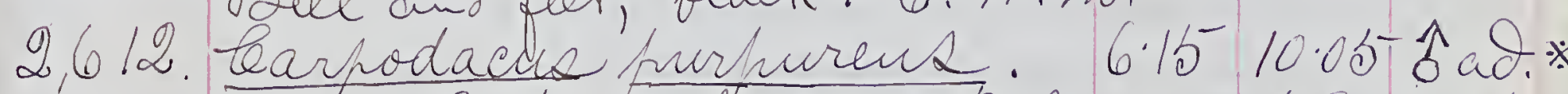
Wring, 3.05; tail, 2.38; Rulmen, 43; yahe, 55; tarour, 65 ; middle tor and elaw, 74; 2,613. Drieosylía alivacea. $6.4010 .40 \mathrm{~s}$ ad. Wing, 3.30; tail, ¿40; bill, measures from nostril, 40; qape, 81; tareut, 7.9; middector and its elaw, .65; claw alone, /9. Jrdes, red. Bill, with maxilla, blue-blaek; mandible, bluish hom-coloridepz, feet and claws, fluch qray.

Dhot by Ella W. Mearna, rnear Echo gate, Muarns torre. 


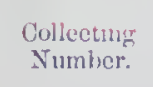
Lo-day drovet to Mountille to ser a hateint. Wefry. Mr. E. S. Denton aceompanied mé. We afteward exhlored the ravines of Dunderbirg and found abinaria vrridid das.bractedeld, Cexpripedium haviflonim, and C. pubrdecus del Llowernig.

We surpretsed an old hen Pheasant (Sonasa unbellus). She gave a lond samall, aid wherred Loudly des she brat rer unige nfor the ground in frout of us. The litth cuicke, only two or thise darjoald and about fifteen in number, at firit fiped out mont lestily in their ferst surprise and bevildement; Gut soon thir reeuvred, and piled over each otherk vack bell mell ni their efforts to escah and thide. Several of them nelud dircettirito the water of thi brook close broide whiét ue chacoveded theu. Cur suam dear across, Another was carrecd a duétanes dour the strian and then examled nuder a stone beside thi bank. Qthere hid under stones and défris in the Grovt; and oul fellow was actually drowned in cio effort to hide. Me found it floatin clead Wrou the water when we relumed to the sfot seme time attemand. The ofd bird dragge herself ovar the groming with a great Cluctini, to wrig and flew a littl way ofl, and for a bew muintes remaried silent. Ne thad cafelured three of the litte ohecí, and now exammind to seb what sort of hiehin heaces the balanee of the floot had ohvasu Cue war acked like de rabline bitwarn two slones in th frook, witt its head and a whick
Illecting
minber:

tim.

SAME.

DATE.

$+$

Nits

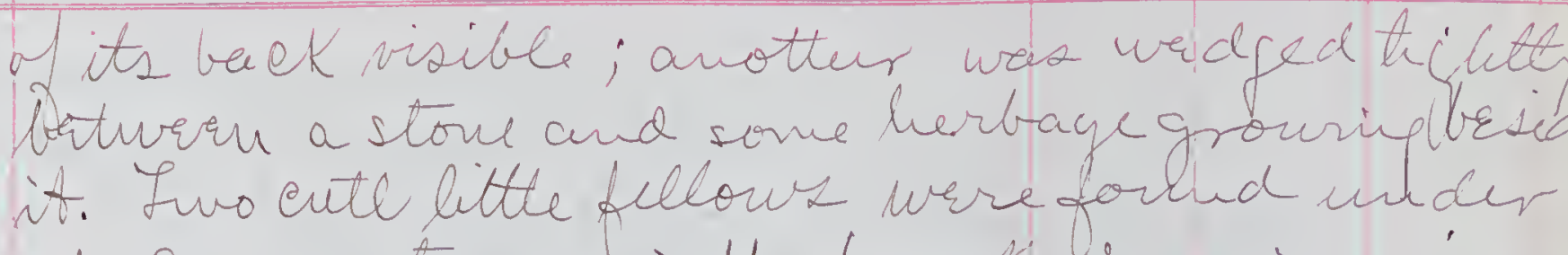
sheling stores in the brook, ruming inin ware triekeni ff of on blivd's head in sahid suecession, and it was fonnd farindrénol the hintons sitiation it would surely have che'd catur than be diceovered.

We moved a litte way from the sfor with the thre little onea chirminis ni orer

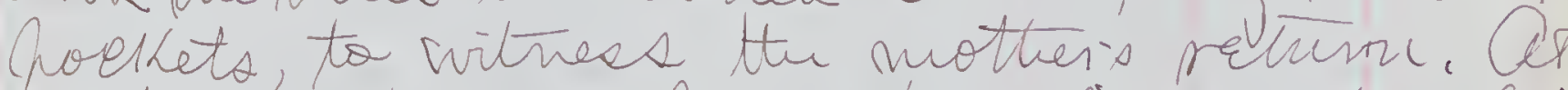
first she uttered a loud rog-like note, which der inter ireted as a wamin tu her litte one ty "lie lonv," an a drrorrition whieh they certan. keceled. Soon she changed the note to one whig

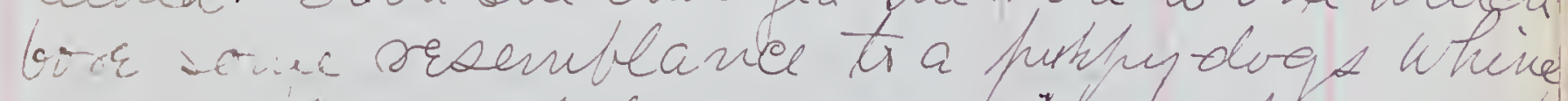
; a vatr a while, we oreasionall heard a fecble ehiphering from the chicks. Th old bin wited a preat qariely of notes, and grew cruaternal axiety more than conntertialaneed her inotinotire xear, and she brgan to aptroach, At forst slowh, until we had ter clews in vain; then rapidey and. Ararleosly she presed close hast ne, wateknif

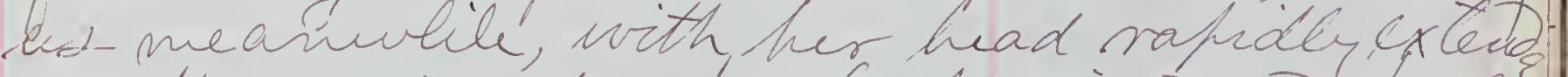
and then retracted, hertail raised and felly!

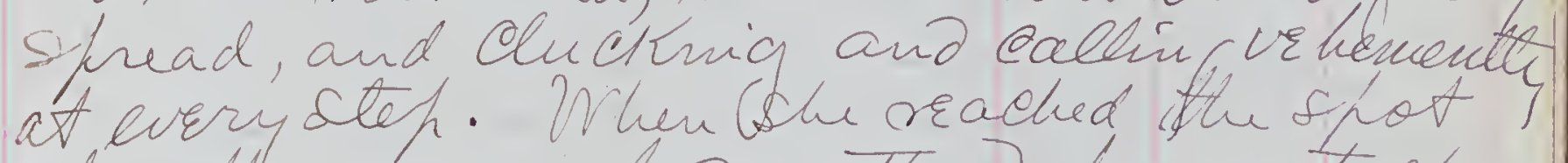
whire the young had seattere, her mote chan to a lond pucullar and diffielt inote to describ

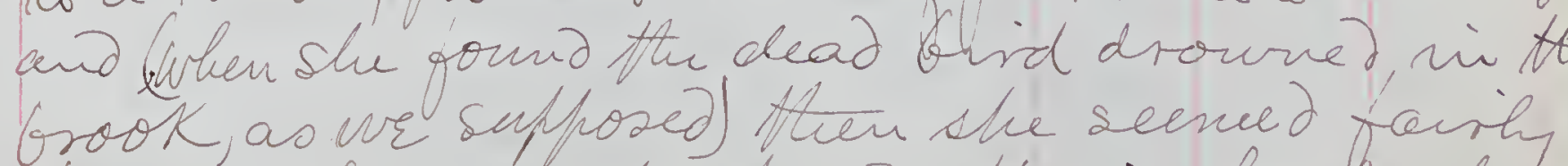

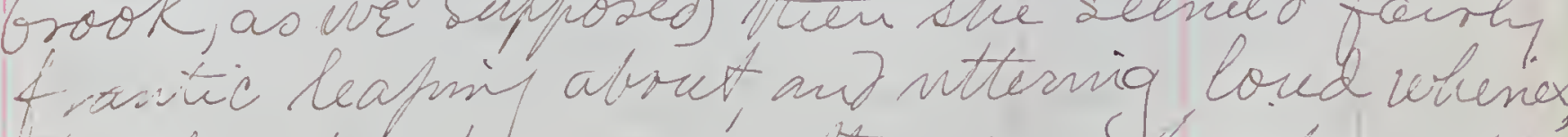
tot driaf explased vin them was heapterendic 


I.OCALITYY.

Lenyth.

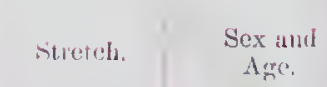

Then she slowh sneceeded sir evaxing the litte ones. out of ther vespectir holino haces, till wr could now and thin distivicuich a little Parts thold bird. She collectid and cseoskef trem to a distanes; and wr aflemands. were mable to descover them. with the now walled of teth the old orid answeredteni motter's call;and thur She came intrefudly forwart, openiof her mowth widily to adinit the same inter striellen sounds whieh wr had heand befor When she deseorrsed the drowned bird. We fut the Girds down whon the gound intengi to vestorr them to her; but she sud denly wherred off ts a stone at sone dietarel and dovd upon it watelinil us forradew

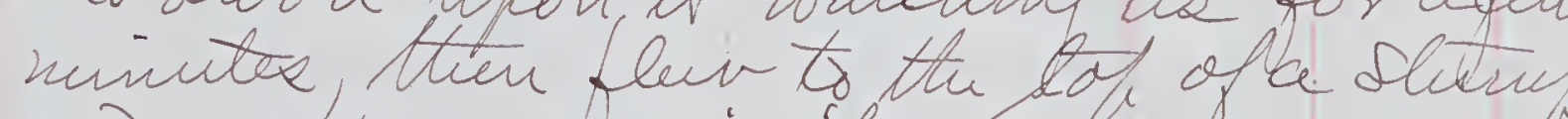
and eyed us afain. Then she vandered avar through thir hesbace Ple collowed, but bhe flent off to a distael. Hreamip she would ruot treturn of care for the littl bird we earied them home aloug with the doown orid. In the evinim wr gof one of. then to fack at sonce weat moin meal; but, cuftr Bonat, then visusez to May 28th The Partinides (Bonasa) veque ts eat. Oue of the crownid itsel in a mit of water in a sabtew. 2,617. Bonasa movbrllus. - - pullu

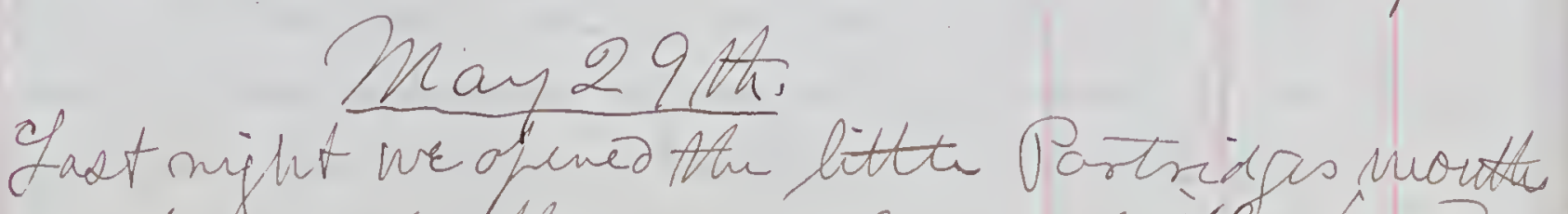
ond hiade Alum swallow a little ford; but both of them wre dea d Ative noming.

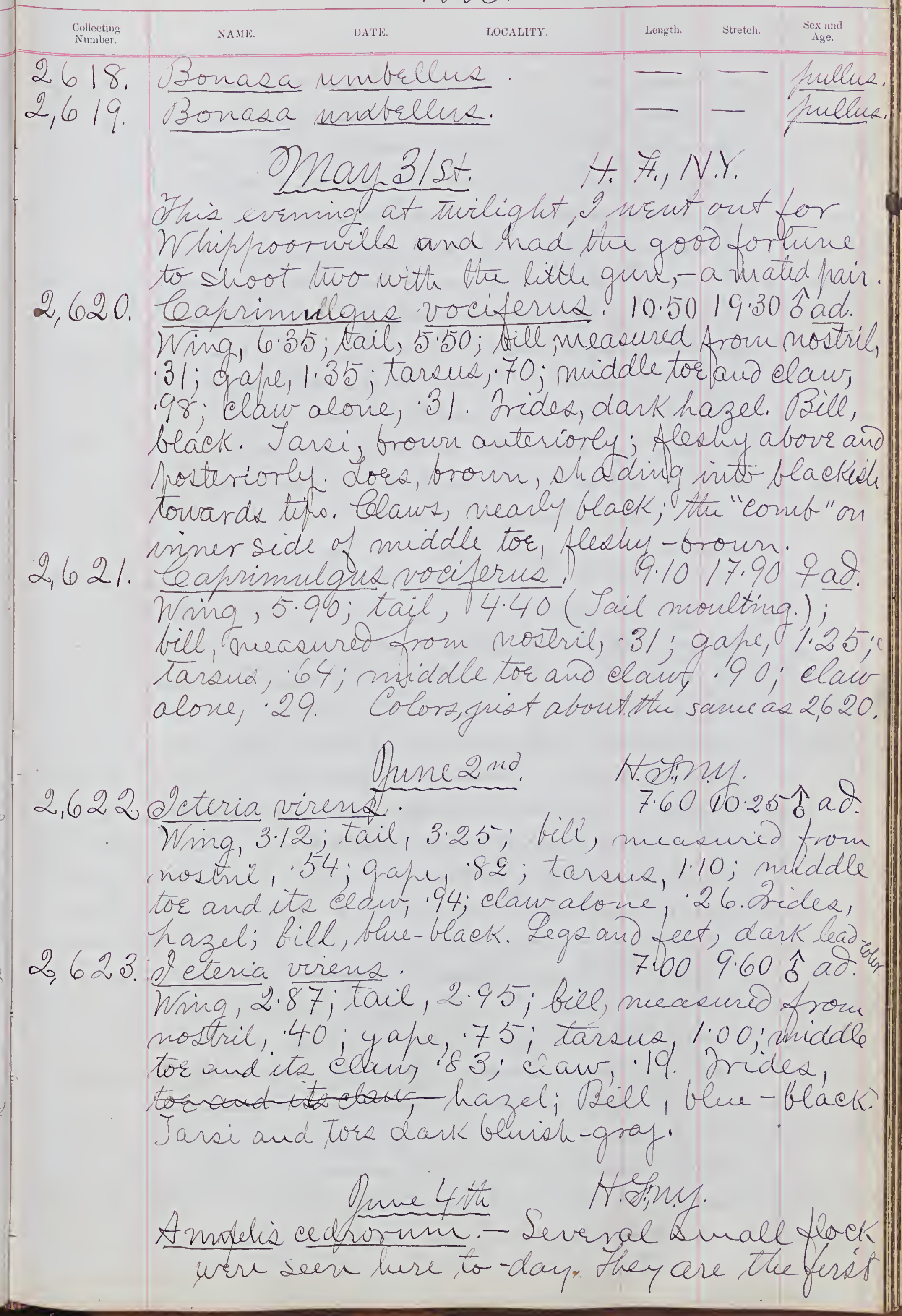


1883

strecth.

$\substack{\text { Sex aulul } \\ \text { Agt. }}$

2have seen siner last autumn. Although deollected a number of specinens of 1 is dx during the winter and spring grist rassed, this ofreies wes not oner noled, although it is neually an abundant sheeils here during the entire year. This eveming Mi. Gonis A. Gerega an myseld took Edward, the gardener, ahd drove, after tea, to a kringfieheria (eeryle alcyon burrow, which vebug out. Fth wank was a shieghtixeavation veside the road in nearly level ground, and Thu bauk

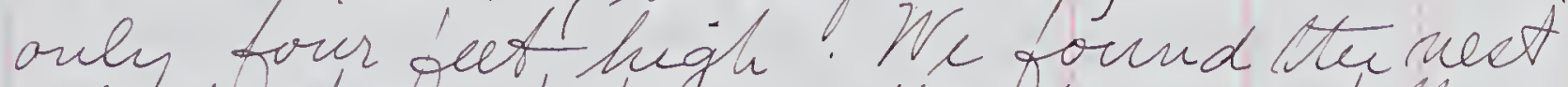
at about sex feet from the beening of the burrow. The fowrow was stracight for sive Geet then turned at a litte less than a right ungle to the ledt, wher axn axeation

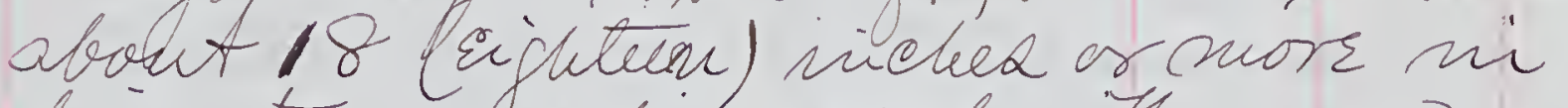
deameter was discovered. The sand at the bottorn of the cavity was losse, and, no nest-buld ding materials what ever had bern used. The nest containez only three foung brids and one nearly habetud egg, uhosk shell wascracked, an the shblets of theggs whieh wre alrady hatetud, frsides the fermale bivd, which geanght by Atu bill wron the rest, and drentort bf the hole. When jirit ofached her, could barely tonch Ate tith of her bill, which was sligutly ofin. Slle did not bite until wittodrawn from her burrow; when sh took hold of $\mathrm{ki}$. Jerega whenever oceasion odferedayobit severeh. Ne vere somy to have oferied up the torrour arice a set of lgia conld not pr outaried; wh as it would to cruel to allow thy Attle gines to slarve, in resolved, to Kill Ah Gemall

\section{2,624}

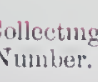
1883

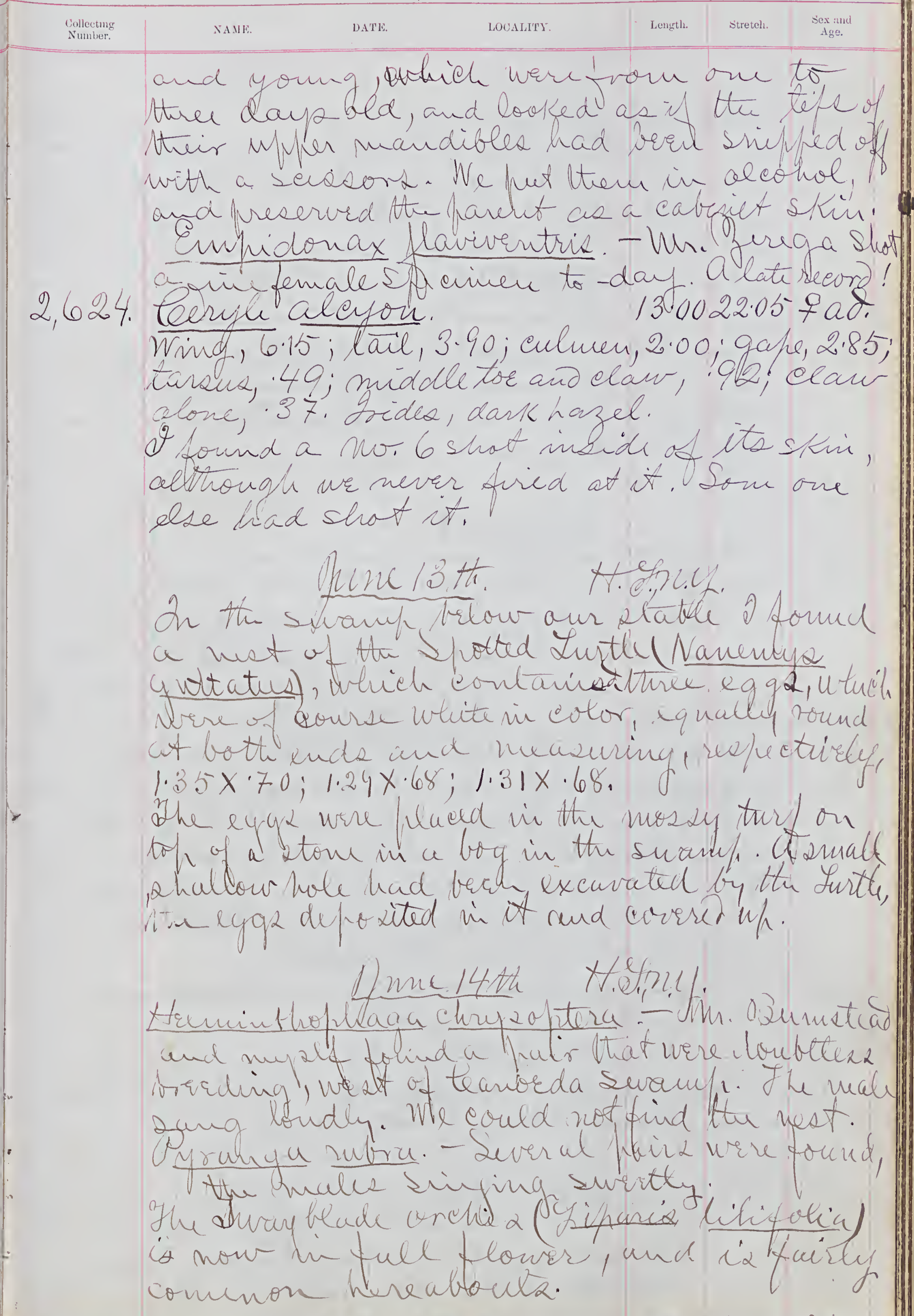


426

427

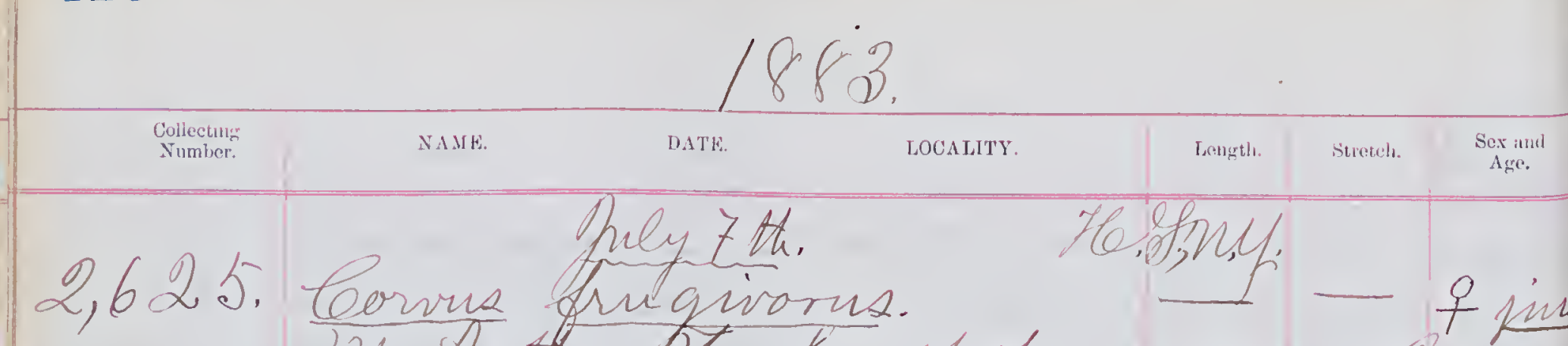

2,625. Corme criqivorns. areared the the has, and one of a family

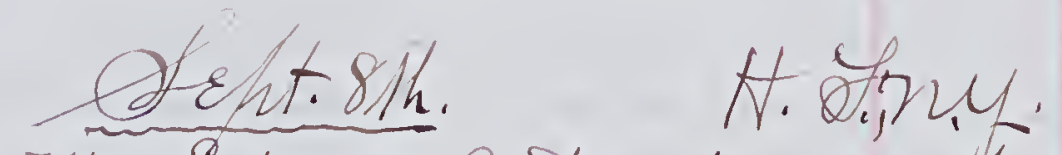

Fo-day. The Eedward S. Fentor rent me a Specunien of trehaithis giganteus whide he yot on Hadilensack Meadows where the train stofled a few moments. It is the girst 2 have seen.

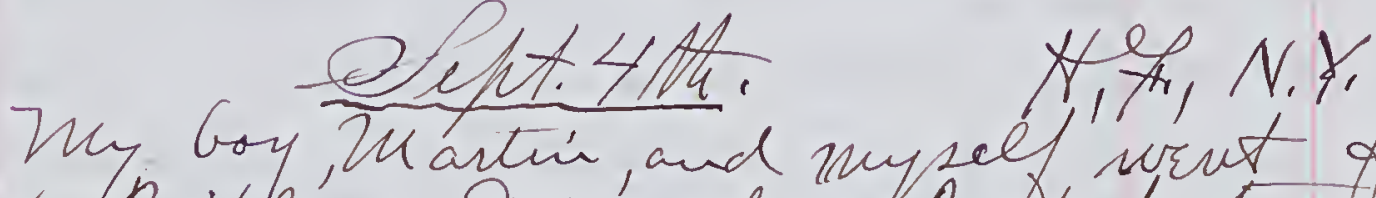

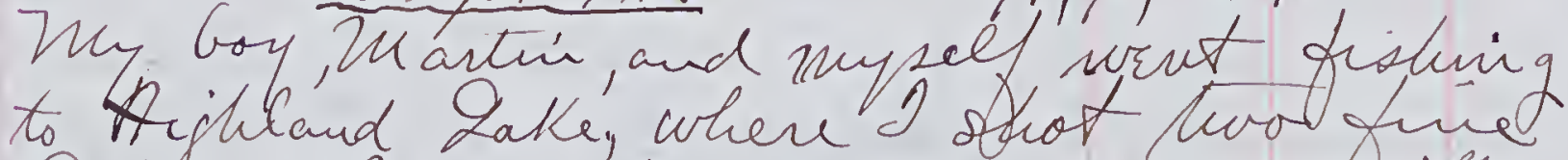

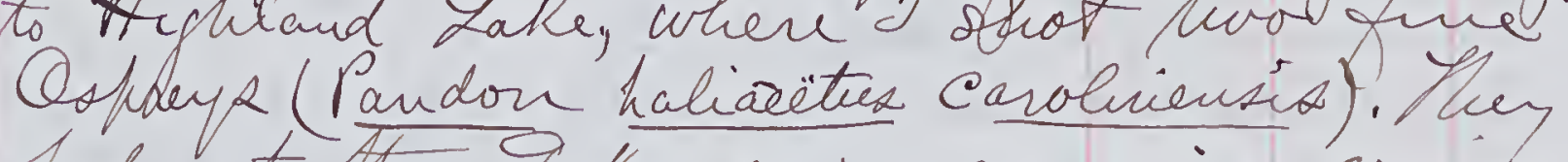
fued at the alke every evaning, eoning mi from the Hudoon howarda andoris 2, 626. Pandion haliaitus carolinensí.23.75 67.007 a\%. Ving, 18.80; tail, 9.00 ; Culmun, meanured from base of cere, 1.60; culven, 2.35; cire, 35; eape, 1.75; Torsue, 1.20; midde tor, 1.95; tta clavv,1.21; nines claw, 1.25; onter. Claw 1.27; hind Claw 1.25. 2.20, Yellon. Bill, Glue black. Heet, hale grernish. Stomach filled with fish.

Eaprimulous vocifents. - Arard.

tot. 6 th.

Ceapinuilans vociferus. Surral heard. one shot alf tighland fake.

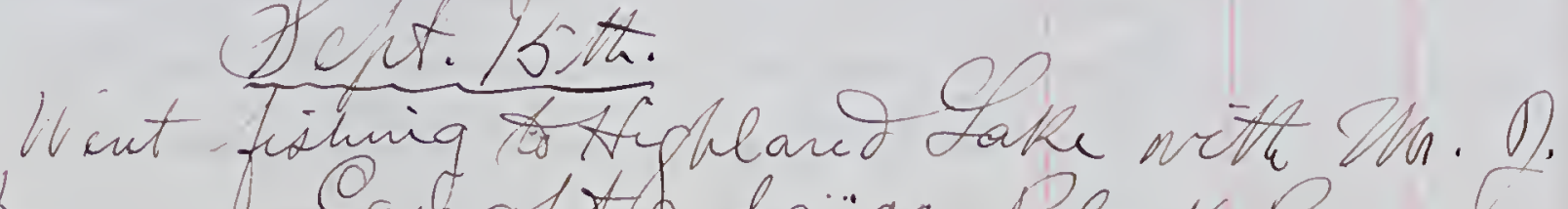
Lenna. Carlg Wt la laige Black Bass, which wrighla 3.Sla. It was shivicát
1883

mounted dry. Sex, q. Qzzand filled

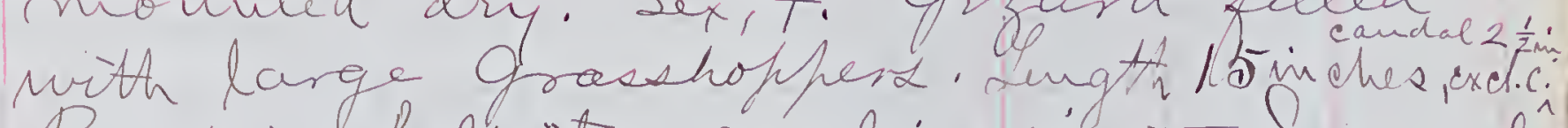
Pandión Raliaètro carohimsix. Sevaral were seen firminge the Lake and ove fine ove was shot.

An Qrchis (leovallomija odoutorhiza) whech dhave hitherto regarded as soncentut searce, was fornd in Large brds. Ścomited up to 50 shectimens growing within a shace one yard'square. Squiral (Seciurus lencotia) earohriensis) ran across thi prad brside the Lake, where there were nany fresh leat-nests. We canght the largest specinim of the cong-Earid Sun-Lish (Leponiv auritux) that "s ver sav. I have Dro balance to wrigh it; but its measurements are: length (excluarie of caudal), 6.25 ; greatest with, 2.75 .

Seftember 26/h. American Musenm 7lat to fito Ceame the York to attend and helf to found The American Qrnittologists' Mion at its trist nectring in Library of My American Thuseum, of thad the pleasure of meeting many of the omittblogists with whong I had not hreviousls net.

One of the cleledates to the Xinion was Mr. Montague Celamberlain of St: folm, huvisomsuriek, witt whopng' had long correstionded. The old orrithologiot , Mr. Lhos. Me Llwraith of Haineton, Canada West, was hresent; and If found him to be extremely agverable.

baft. Letharles E. Bendire of Fort Klam- ath, Oregon and Dr. R.W. Shuffeldt, U.S.A from Lohisiana were iresent thad traveled bll the way from this posts in order to be here. 
428

429

1883

$1880 \%$

The otter founders of the Union are :-

Prot.d. A. Allen, Cambridge, Mass.

C. Ald rich, Low.

Prof. S. 7. Baird, Washington, 2. C.

H. B. Bailey, new York.

C. F. Batehelder, Canibridye, Mass.

Eugene P. Ricknell, Riverdale, kew York.

William forester Cambridge, Mass.

Nathan lelifford Drown, Portland, Wee.

Charles. Dory, Boston, Mass.

Prot. Elliott Cakes, M.D., Washington, D.C.

Q. I. Elliot, Staten As land, Kew -York.

Dr. A.K. Fisher, Sing Sing, hew York.

Dr. G. B. Holder, New fork City.

D. C. Hart Merriam, Locust Crore, Lewis C., N.Y.

D. D. W. Prentice, Washington, D.C.

H. A. Purdie, State House, Sos tor, Muse.

Robert Ridguay, Smithsonian Inst, Nashingtra, 9.C.

Dr. M.M. What on, Columbus, Ohio.

It will be noted that the Medical

Profession was represented at the first.

congress of the American Crnildologist.

Union bo, no less than seven Doctors. the fort congress lasted Three days, and adjourned on September 28 th.

A Constitution was adopted and

the following offiecrelected:-

President, pol. D. A. Allen.

Viee-Prasidents, Dr, Elliott Cones and Th.

Robert Ridguay.

Secretary end Erasures, Dr. C. Hart Merriam.

council of the Chron, consists of the officers

ex-officio, and of Prof. Spencer 7 . 3 ard,

th. leo. n. Law rance, th. William Brewster,

Th. H.W. Henshaw, and Th. Montague Chamberlain.
Six committees ware appointed as follows:a. The Classification and Nomenclature of North American Rids: Mess rs. Ridguray, Allen, Henshaw, Brewster, Cones.

b. The Migration of Birds: Mess rs. Merriam, Brown, Purdie, Wheaten, Chamberlain, Iron- nell, Avushaw, Cory, Merrill, Fisher, Thearns, Me Jhraith.

c. Avian Anatomy: Messes s. oshufeldt, Merriam, Deffries, Cones.

d. Oology: Ynessra. Bendire, Bailey, Trawster, Ridguay, Merrill. e. Hamal Areas: Nesses. Allen, Ridgway, Cense Sharron in America: Mess rs. Alder, Birdie, Chamberlain, Brown, Betenell.

October /st. Am. Mus. Nat. Aral, N.Y. 2 cane down to the museum to arrange my collections, which I have barraged to store in in this building now, and in the future. The Tureen is to hay, me the same salary that o would receir should I accept a proffered contract as acturin Assistant Surgeon, U.S. Arum: a am engaged to label the European Stirs mi the collection t select from ny collection for the Unseam a series of specineme which use lacking in their collector. to make as perfect as possible their collector n of mounted finds.

My intention is to use as an conthority for nomenclature the "Foin" Lit of British Binds compiled by a Committed of the British Ornithologists. Union. London. 1859, as far as it covers the ground, and 
430

1883.

1882

Dressers" Birds of Europe" for the rest. spoke to Prof. Qickinorel last summer of the necessity of buying a copy of Drasara work for me to have to le se in labelling the collection. It has not copy of the Obis hist to br had. I have just sent for a copy of the Ibis hist, myself; ald have advised then ito glt a copy of "Dresses" for their Library.

October 16 th. Highland Falla, N.Y. Today i want to Atighlare, Hale, to meet Wu. L. W. leas, who wished to see our house - "the Hame troupe" - witt reference to renting it. If found a handsome specimen of the ouble-crested Sonorant which Yuri. "Josh". Ward had shot at Conn all, ops the Hudson, on Colobus 10 th. I brought it to U.Y. and had, m. Conway mount it for the exhibition

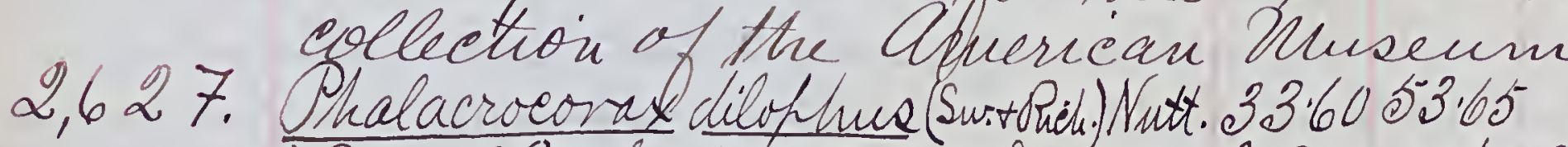
hal 12.90; tail, 7.80; cullen, 230; ga fe, 360; tarsus, 2.40; middle tor and claw 3.2. tor and claw, 3.90; Claw alone, 38; 2 nd tor $t$ claw, 2.33; claw alone, 47; hallux claw, 1.57; claw alone, 50. Iris, green. F w and claus jet-black. Hula sac, orange. 
432

433

1888

wat the beautiful carpeting of gran chot-nosses. When shotying, the same genus at home in the Highlands - The genus glyesfodium - I had often rimembras and spoken to my wife of the beauty of those growing so luxuriantly in my y rung fath eh's old woods; and we wondered if some of the species would not prove to be new to us. Sure enough, when I can ce to scrutinize closely the cantal forms of the cycopodiums under the big hemlocks and amongst the riches and maple suffixes, where they yow Luxuriantly, $I$ fond a species that we never suv in the Highlands of the Hudson, and beside it were each - Ht e four species of the gems which the before thew. serval otter interesting plant we noted casually, some of which 2 will note here, with the Clus-nosses:Lycopodium heidulum, mich. In fruitage. Lycopodium dendroideum, mich.

lycopodium complanatum, Lis. - Share never seen thin species growing so lurariently, nor have seen it fr fore withe the fruitage attached, and these- for guttered ifecinene for our collection. Fy do rhodium cluvatrun, Lin. This species, , to uncommon in the Highlands was also rather rare here, all of the other sheri ting consuon.

Scopodium annotinum, L. This she cia war abundant and very beautiful. It wis also fruiting in considerable quantities? Ne have never yt sum the fruitage of 2 . clavatuni bo of $\frac{d}{1}$. dendroidenen, but havesfecinuma of the fruitage of the other there species.

honotropa hypopitys, Lin. The largest specimens of the thrany-flowered Indian Pipe that d ever saw were growing in a ravine in the woods - last summer's plants, of course. lehimaphila untillata, Nit. Abundant. $I$ did not see le. maculate, which is abut- daunt in the Highlands.

pola rotundifolia, Linn.

Ouprola elliftica, Nit. - Both species wire pinite plentiful.

Efigàa refers, Limn. - Cue day dolor t hake vile with my cousin Carrie, and wE found arbutus growing plentifully its places beside the roads and hi l funce-corrers-localitis in which one would always boo in vain in orr Highlands where it prefers north slopes of hills under laurels (Kalmia Latifolia) and shruf-oaks.

Witilla diphylla Lin. Abundant. e amptosorus rhizophillus, Link. We found a quantity of the walking fern growing on a lathe rock near the Lake at Lakeville, where 2 collected a specimen which I afterguard lost.

The end of Nov enter is not a favorafleseason for botanizing. I should like of visit the woods in string and summers the pineifral forest trees are oak, burch, hickory, birch, maple, white ash, and sycamore. She conifers are: Samaraet hemlock, balsam spruce (P. Holsamea), and White fine (Pines strobes). A peculiar forty of the forests these is the constant inters tingling, in each bit of woodland, of coniferous and deciduous tree $a$. 
434

435

1883

18803 The following Mammals wre noted:-

Sepre americanne.

Arvicola riharia.

wilhes fulvus.

Wephitis mephitica.

Scimrus carohinensiz. A black sheeimen

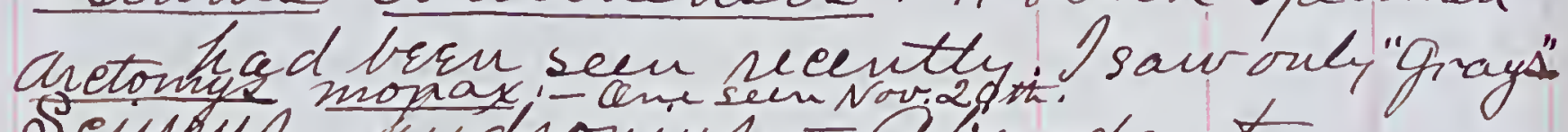

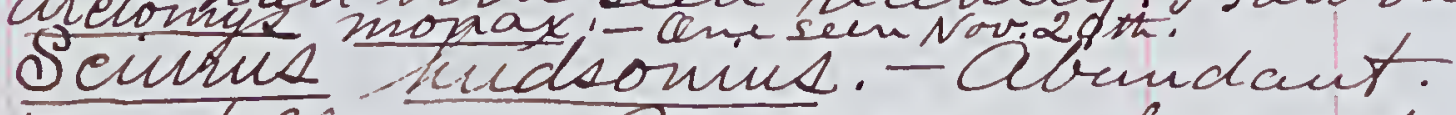

The following girds were oberwed:Siatlia sialtio.

Requins satrapa.

Sitta canadensis. - A number of these meiny little binds were found difforting itumiselves amongst the hemlocke sin Yrandfather' woode. Hey are great

Sitta carolinensis.

Pinieola emucleator, - S saw a small flock of Prine Grostrakt, near some Nonvafop/unce rees wilch were covered with conee, a little way south of Albany, beside the Audsou, on, vord 18 th.

Astragalimus triets. - Noisy, restless, roving Altoks of the Yoldfrickeo were seen in the wodds, ithere they wre feeding unclusivaly ufor the seede bo a large thek spectis of birch-tree. Out of the woods Is sw them eating seeds in the garden, and feeding on the alders beside the Kills or creeks.

sfijella montana. - Lot numerous. Nunco hyemalix - not connon. Melospina fusciata. - Abundant biside Hee tudsont at fort niller. Passer domestiena. - These feste wore abundat of Fort Edward $\nabla$ at Dilles.
Lamins forralis, - Aue seen near Lakeirlle. Circus hudsonins.-Sevral seen biturese. albany and ctroy.

Duter borralis.

Buteo lineatus.

Haleo eolumbarins. - Aneseen near Albary. Aecifuter fusens. - Cue secn.

Bonasa hubrllus.-Coumon.

Anas obscura. - A flock brow albany. Dodilymbus podicept. - We had rare sport with a little fellw that we corresed in shallow-water beside the tudo on south of Fort miller, on the 20 th.

Lams delawarensis. - Very numerous whon the ciee bilow Cartteton, and noted all the way from Poughkeepsie to Hray on the 18 that.

leorvis frugivons. - Etremely abundaut in mench peaces ufor the ice. Larus argentatus. - Utrundant as high as Albony and noled above erroy. teyanocitta eristata. - Aturdants Chus atricafielens.-Abundant, and never so jolly and confanionable. Pieus villosus. - Culy one frair in a w orchard Piens pubracens. - Cney one sheerinen. Aylatomus fileatus. Ancle will saw one in his orchard a shost turie ago. leirfle alcjon. - Near Clbany Nol.18 Bt. 2629. Sitta candedensic. Nov, 20. 5.00 8.35 5ad. 2630 picus villosus. do 9.5 $15.70 \mathrm{qad}$. 263\% Astragalimus tristiv. do 5.358 .95 sad. All of the atove sheciment, including the tongh Hairy Hodpecker (N0.2630) iore shot with my minature shot gun, with abarrel buly fiften inches in length, and dishig dest shot. 
436

1883

437

$$
1883-184
$$

November 24 tho New-York City.

Io-day, as 2 walked seraight a crosd the Oik from 72 nd $5 t .+5$ - the Avenue, Inoted a small oflock of Eurofean Goldfinches (bardrelis legans), and a pair of Cardinal Grostraks (Cardin- blis ristiniamus, and he ard buth the White-throated and frox Sparrows sniging suretly. I counted no lese than ixten Gray Squirrels.

D. Novinubis 25th. New York City. Quiscalus furpmens. - Jubo Cram Plackbirals were noted in the Pask; und the Curdinals wrre seen near the same spot where brfore seen.

Decenter 3 rd. New York Eity. A suall flock of fire Cow Blackbird (Molothrus ater), two males and three finales wre Reen near the Lake in intral Park. They wre hirby, and actir. I have neres sem them hereso late, altrough of saur them in some numbrrs in Muryland, Delaware andde Serithern Pennsyleramia as late as At Decenter, 18818

Lecenter $23 \cong$.

Ane Prie Grosbrak sinicola enucleator) was seen ahd it was heard at an other feace. Bids of all inds are ex ceedinly

Decunter 3/st. H. H., Wh.

Lonix A. Berega and nuprelf spent the afternoon in collecting birda, but saw nothing of special interest. Song oparrows (Melospista Lasciata) were quite mumerouk aloug th border of leousbok Marsh, where 2 shot turce for the furpose of adding their dimensions to takles Which of am making, with a viru to exhibitrig the variater in measurements botweru writer ahd semmer birds of this speeies. I have prepared sinilar tatles of measurements of the 2 luebid (Scalic inalis) and Robin (Lundus migratorius).

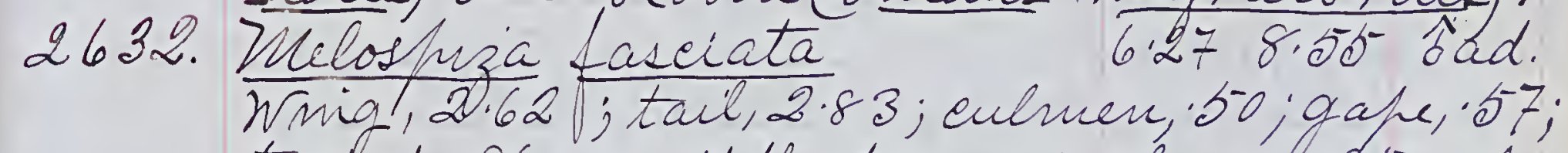
tarsud, 86; middle tor and claw, .85; Claw alone, 22. Consook massh. Min, hazel.

2633. Neloshiza Aasciata

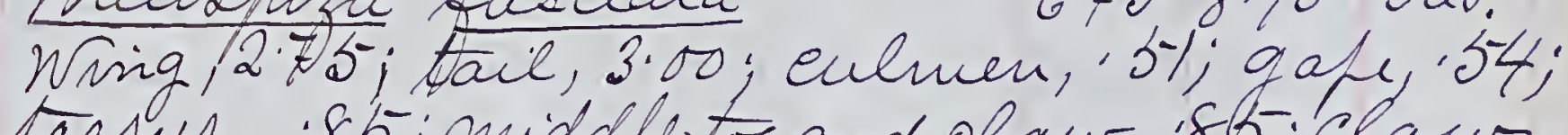
tarsus, 85; middle tor and elaw, 85; Claw

2634. aloze, 23. Fis hazel.

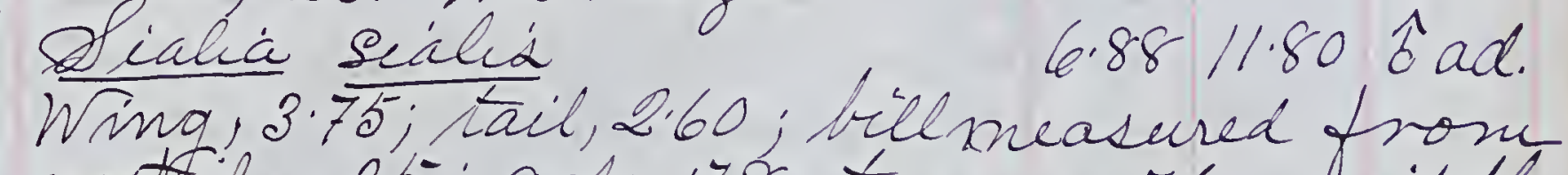
nootril, $35 ;$ gofe, 78 ; taraus, 76 ; phiddle tor and claw, 85 ; Claw alone, 22. Aides, hajel 2635. Aialia sialis 2.63 ; bill measured from nostril, 35; gafe, 81; tarsut., 76 ; middle tor and its claib, 85; claw aloue, 22. Mredes, hazel.

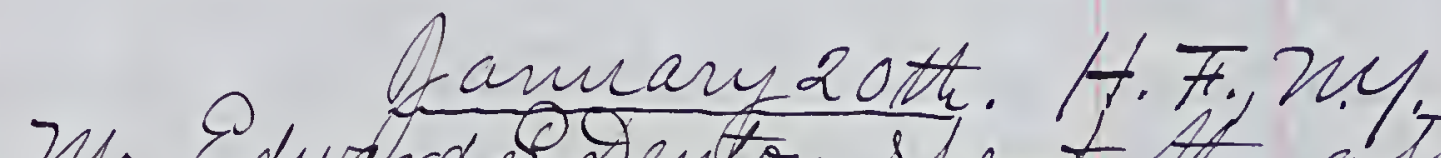

Mr. Eduatrd S.Denton spent the afternoon

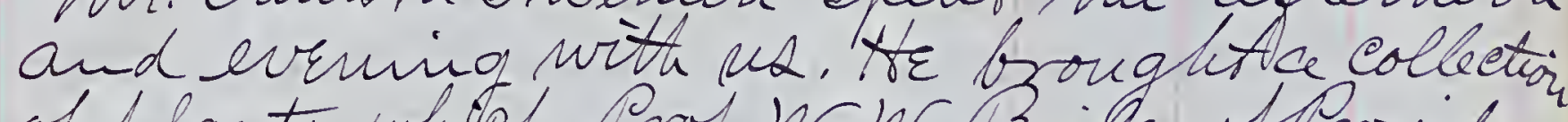
of flants which Prot.W.W. Bailey of Porrdene R! I. had sent hin, and whick ke sin- sisted won our sharing witt him. ir eviry edse where there atere duplecaled; Anong them wre a large number of tyfex of genera, which will br a grtat helf to as in wortining ap aprassert sedoges. 
Dimig the afternoon a flock of Sine frosbaks (Pinieola esuchator) afpeared in the Nownay spruce tree (Abis excelsal in frowt of our house. Ella saum then, affd postited ont an ald male. I nas anxious to procure an adult sed male; fut when If found my gun and saw that it was enfity, und all of my cartridges had berze fried, and these was so shot in the house, the irospect of getting this bird did notlook gavorable; bet I found Atree old shells which belonged Dor. Merrian's littlegexter Smitt shotoun with which I killed anceagh and Dr. Merriam Killed a Bear, and Sorn exptraeted the shot and loaded three cartidaes for my ten fork. By the tine gwas prady the birds had left the Nomay Shruee, lot wre found eating the seeds of the conet, in al large Whitt Pine (Pnis strobur) on the north sede of the house. Ella warlooking at then when ter left the Shruee-tree, anv said "I expected to see the male birid fly fist aind lead the flock, but the ferkales Glen anay first."

Beforel could see the male fird the whole flock flew baek to the Spruec, where If irabl at th red fird as it sat on the tofunost branesh of the trie. Nen shot wounded ft and killed a young male vi fenale drest. By ter quathers which drothed,i? wat fortunate enough to track and secene the red one, also, for it fell at the end of our hlace, where fly a goot forture if jooted. Alu spot whon the shor dead. It froved to be an minsually
fine adult red male.
Anicola enucleator

$9.201425 \hat{b} \hat{\mathrm{s} a d}$ hing, 4.60; tail, 3.96; culnen, 60; gape, 60; tarshs, 86; middle tor and elaw, 95; Clawatone 36. Nis, hazel. Bill, blackish, witt an ahir tinge at the base of the lower mandible. Legt Let and elaws, blatek.

2637. Pinicola enuch ator

$9.05-13.80$ sfiu. innig, 4.30; tail, 3.85; culnum, 57; 9.44.60; tarsels. 89; niddle tor and elaw, 90 ; elavelone, '36. Dis, dark hazel. Sill flackish, witt an olir tinge on basal half of lower nandible; the bill is not so blaek as rin the adult, and the olir more extended on the under bill, fegt seet and claws, black. The stomachs of botte Preemine contained seeds of the Whote Pine (II strobus), hoonay Spruer ( . Exeelsa) and mafle (Ceer I?).

Aamuary25tt Central Park, X.Y.Coty Ceardinalis virginianus. - A hairseen at the northwest comer of the Llake, mear the bidge, Where Inave sleen this pair nearly ersiy day during thin winter, fut never singin. Thir ouly note is a sharh chic. Yellowblds (Astragalinus tritis) are seen evsy day, fudilg exelusiring sum the seeds of foretetre Nate: - Cun Dre. 31st, 1883, sonu Eider Ducks (Somateria mollissima) were sent to Fulton masket, new York eity. I huch ased two females. Thes wre shot in Clabrador abotet Oce. 25 the 1889. They were Th. leonqais place to fe stivined, and ase sout in my collection.

2638 . Somateria nollissina $263 \%$ Somateria mollissima
23.0097 .00 tad. 23.0036 .00 tad. 
440

441

1884

1884.

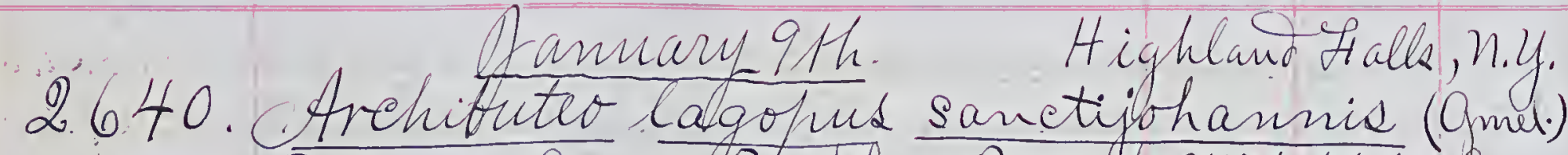
Ridgnay. Americandsughlegged Buzzard. 34.7555 .509$. Ting, 17.25; tail, 10.00; Cad men, including gape, 1.73; tarsus, 2.65; middle tor and claw, 2.25 ; tor alone, 1.52 ; claw, 83. Irides, pale frownish-yellow. Cere, grenidh-yellow. Bill, blue -black; had -color at base except on maxilla in front of else. Feet; lenon-yellow; claws, black. Shot at For st of Dean, near Highland Falls, by John Redder, who brought it to ne.

Walked Aa cross He Henson from Has ns? Dock to etarrisons. Or hill waiting for the train I walked from Garrisons station down to Nh. Qsbonis house and into th premises of Mr. Hamilton Fish, then returned to the station rest in time to catch the train. The following birds were noted: Spizella montana. A few wee found

huddled w/2aganist the cliffs at Benny Havens'; and Ate. Snowbirds like wise Sought shelter there, rousing to the bitter cold, for the Hudson ia thickly frozen over. Liner hyemalis. - Was desoseen among Itu

Astragalinis tristis. Feeding, in flocks, arrow the seeds of the ham lock (C. Canadencin) Thelosfija fasciate. I Cue upon the Railroad, barpodacus. mormons. - A few worsen on Aanitetor \#ith's place, where os saw them fueling in the same treed with a flecklof Pine Grostrake.
Pinicola enneleator. - A good-sized flock wat seen feuding r en the seeds of the Sugar

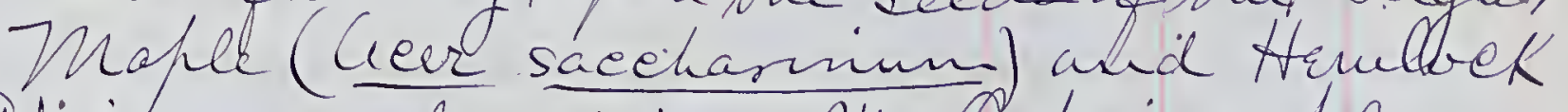
(Abies canadensid) on Mn. Cabot's frae. An other flock, smaller in size, was found in Th. Fish place. They wee very gentle; I saw two fine red birds at or ce; and I thrice there were more. They wire actively engaged in eating. the tender buds of at number of handsorne Norway Spruceesbies. excels); and did not pay any attention, so far as $b$ observed, to the seeds, although the trees wee leiden with cones in abundance. I watched them for sone trine.

te rows, Blu Jays, and Chickadees were the only otter birds. seen, with the exception of a large Buteo or Archibuteo.

Many ice-nets were set through the ie e, but a fisherman told me that their catch was very small, as the fishes were not sussing.) 2ce-bots are plying; and tears are crossing.

library st. H. F., N.Y.

My wife shot a Red ingle Pine strostrak! 2641. Binicolla inncleator. 9.2513 .80 Sad. Wing, 4.50; tail, 3.80; cullen, 59; gape, 61; tarsus, 92 ; middle tor and claw, 914; daw, 31. Stomach contained seeds of the Silver Maple (Acer ). Bill, hedekich, horn-eolor on basal one -halt of lower mandible. Le gr, fut and claws, black Shot by Ella W. Neeasus.

New York City.

Passerella iliac (Herren) - Saw the first Fox Sparrow of this year in Central art. At uttered its clickiting metallic note ts harp tret. Mi. Sanders - son Suit Saw the firs it Robin on Staten island. 
442

448

1884.

1884

A List of Lifidoptera, Collected at.

Atighland Halls, N.Y., dirring the . Dapilinmer of chin.

2." " asterias, Hab.

3. "eresphontes, leramer.

4. Melitaca phacton, eramer.

5. Vanessa antiopa, Lime

6. Limenitis unsula, Fab.

7. Desia buffaloensis.

8. Ophinx cinerea, Harsix.

9. Attacus lima, Doury.

10. " folyphenne, trat.

11. Arctia vira OLin.

12. Saturina O5, Lim.

Hebruary $2 L^{\text {st }}$. Acighland Falld, N.Y.

2642. Minicila enueleator

2642. Pinicola enucleator

Warch 1st. Highland Fiall, N.Y. Pincerla enucleator. A Alock has besn reen about our prace mearly evrry day sinee Jan, 20 the When Ishot the first Afrecimenz. Ela has shot foch others, the horise, eating seede fmaflen sefon sjiv.

fad.
The Pine Xrostratts (Pinidola enneleator.). still remain atout the flace.

We left Heighland Falls in the 1.07 P. M. Train on the West Shore Railroad in route to Whiphle Barrache, Prescott. Arizona Serritory. Ife swow was deef on the around in the Heighlands; and we drove to the defot in a sleigh. whete ne retired and arvoke in time for breurf st at Bunberland Ind., from Which felacel te Straftow, W. Va., the modentarn scenery in many flaces witta heavy gowowth of the in mododendron or Isze-Baif Shododendron maximin) and Mnountari Lamel (Ialmea Slove in a def ravine beside the $B .3$. and $Q$.

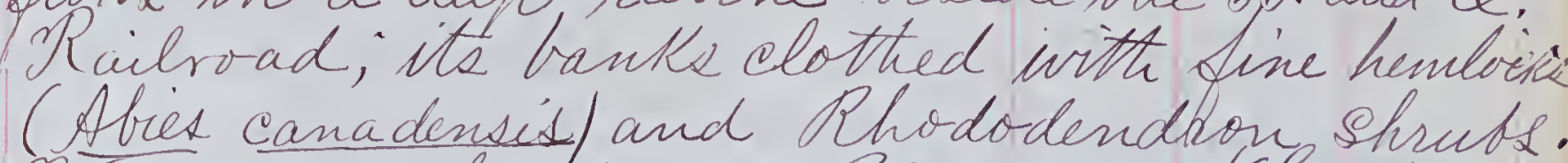
He saw a hasdsone Celit-moss (Lycopodium) upon the bank. protably L.. Clavatune, and a lamel-like

whech wr failed retognize. from the train, qoing down the Headsontefor

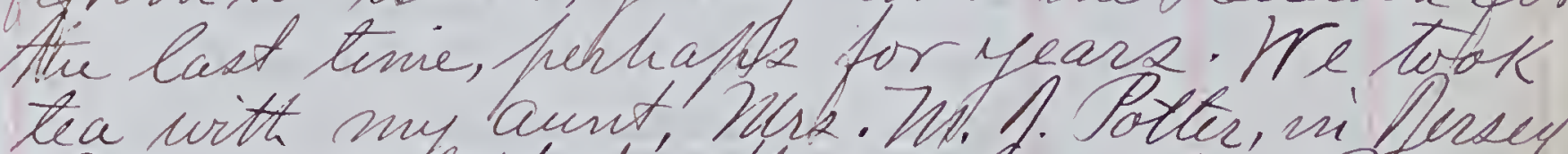
leaty, and left for the . Sest on the Baltestion and Ohiv Railriad at 7.12. P. M.

Znarch 12 Seunbrland, W. Va.to lemeinnati; Q. A large flock of Blackbrids (sfecies not determinis)

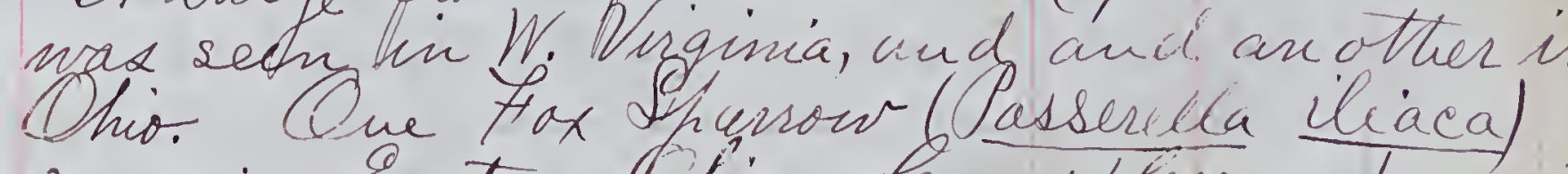

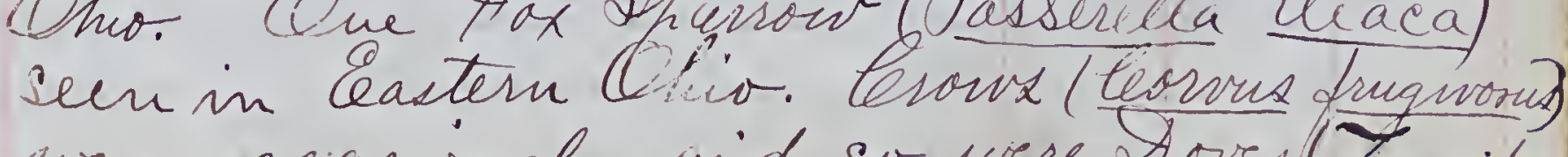
wire oceasional, aid si were Boves (Z 
444

445

1884.

1884

carohinensis). A thing fisher (leerple alcyone) was observed in the wosptin part of West Orginia; the first s' have seen this Year. wire all the birds noted along the wad. celt rough in watched carefully for them. She connery along the fantont bent the beautiful Rhododendrons in flows. They wet abundant in many brealite's Hitonghout the monitaris of all of Wrest

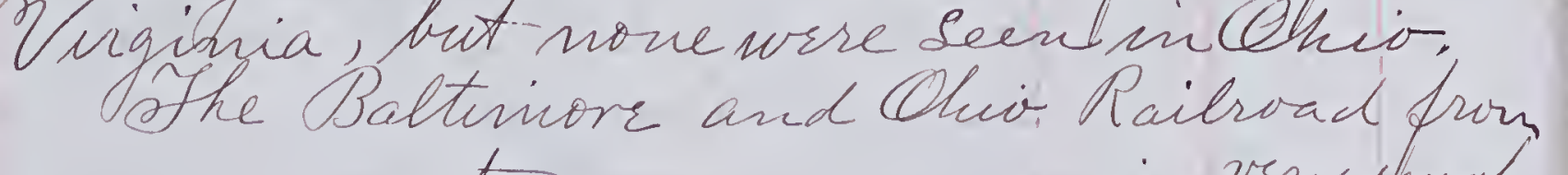

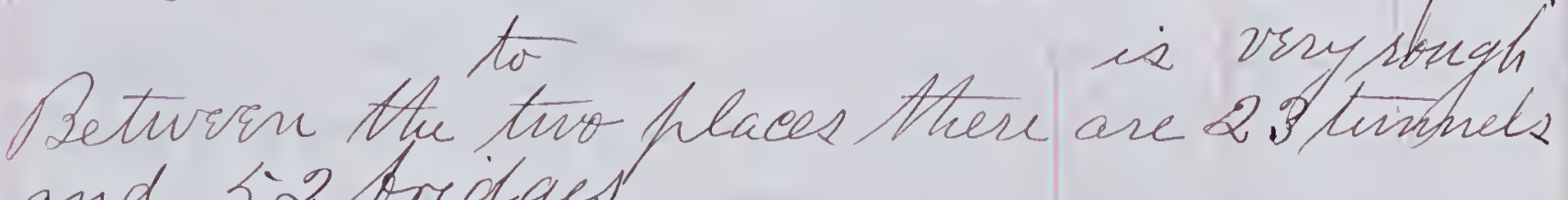
and 522 bridges.

one crossed the Ohio at and saw evidences of the great flood of the hast month. Heel Railroad entantment side, and, for a wist br more the frassengen on the B. and C. had to transfer on fobs section of usually dry lond was insulated We slept from tariaimati, Olio until wi wire nearly to belay Ally, Illinois, and so missed the Indiana scenery, which

Wee dressed and looked ont of the cars at belay city. Ne wire passing through a. heavy forest, with the ground beneath the trees coterie nth water as far as the eye concert reach. On the tops off one of many huge dear' trees, Standing beside the Rail ron pilatus). As the train passed it flew nit the forest, its red crest gleaming in the sunlight. Thence to St. Loris ur saw $x$ heard many meadow Larks. Small flecks of teronshladrbirds wee seen frequerthe as species (I) only recognized specifically one Ted-headed Woodfteker (Helandper enthoufh- Plus). A few Doves (Lenaidura cholenensis) \& peke wee seen at a distance. Ow o large Suteos (probably Buteo borates) were Grassed, mi tries quite close to the track, whence that taking to flight. Starisome Po bine (fundus migratorius). English Dharrowx (Passer dontesteis) ire abundant all. along the line, and other small frasserin along the line. Crows (Co one pugwoins) numbers. No Quails (E ry virginian) have so far bern noted. We fore now, and She ut the afternoon and incoming pleasantly

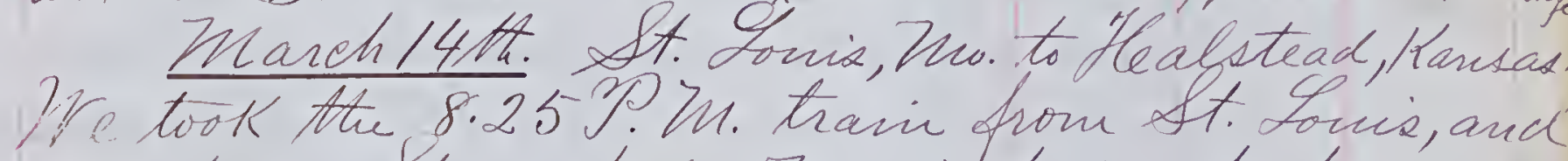
reached string field, Wo in time to breakfast He wester one-Thind of Thissomi and eastern trforr Lark, and retiring for the night at Hal stead. which I was able to identify ale they flew. little fellows that looked lith Litlartes. 


\section{4}

1884

Collecture
Sumber.

1) Ahought I sam Lark Tinches (Choudestes qrammiens (Say) Bp., but was not hositive of the identifieation. I saw a Lew Cled-taild Heawte (Butoo borralis), one or turo Pharrow Heawts (Faleo shaverius), heenty of Theadow Larke (Stumella - .?) and a Lew Mearsh Heawtis (Lureis hudsomis). Flocts of Dnctes of sevrral shecies wrre seen ufon sone seedy marshes on the stream near Cronogor, Mv., frut the only sfercis recognijed was the Aolden-eye telarigula glaccume). Terows (E. fruguoins)., which were searee through Chia and W. Hllinois, wre exceedirigly a-bundart in large flocks in the Corn-fields. Robins (Lurdue mignatorvis vere also hlentiful in enormons floeks obsered in hlaces; and the sfeccis wax seen as far wrst as tte Eastern border of Coloradt, where Inoted them on the /stit. oferral wre seen at Ceoolidge. Blue Aayi. (Ceyanverta custata) wrre abundant mitho., and large floers of Bluebrids (Sialéa sializ) wrre seen, las well as large flocks of Red-wnged Blaeterids (Agelaehs thorricens) and Crow Blackbirds (Luscalus purfurens). Plovers of some species ivere frequentty seen in flonghed fields and grassy Mrairie. A large, long-winged fird, whieh I quessed wes. Santrams IIfland Plover Satramia longicanda), a bird which I have never ofteruise seen was also. aceasional. The only Woodpeeters seen ware Hellow-shafted Hlickers (tolaftes auratis). and they wrre searce. No sigins of mammath on Ransas as far westas Wachita the following speeces utre observed: -

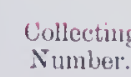

Theadow Lavics (Lturnella Tob finging all the way. A Hew virgincaina). Near Anghista, Karsas, three Ptairie Heens (Cupidonlá Cupido) wrre seen the flist by me! The on furst obsured flew wh Veside the track and around behild the train, soaring with unigs set as it disaffeaie The other two Surre squatting close to the grom in a corn-field. Af Sw Bthe farp ni the -astern hast of the Itate. Isan a number -' Sigion Hearbs ( Esalon colunbarrix), alvays in Rairs, one Vongh-legged Hawk (Chohibutto lagopus sancti-johannis) near Firedonci, K., and a few Dharsh Hawts (Cencus hudsomis) bith blede and frown; also one Bed-laill Buted brralis). I few Ghikes (Lamins ludovici- anua [exenbitoroides?]), alwas solitary, wre seen haunting the hedges which are much used in liew of feneing through tansas. Larke

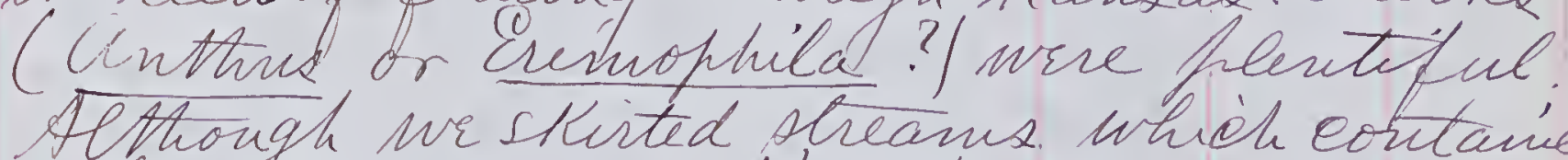
a bews nets, no Mnigfishers wre seen since the one observed east of the Mistissifp A sulitary Antelope (Antilocapra aniri - cana, Ord) mas seen near fall Mnird, the first is wer saw, and the ouly winamsnal aeen gi Kansak.

Saltinore Civiles' neste wire numesous in wooded hlaces. Ory Ked-wing and a few Plovers as far as Wachita, near which Hew a muntir of singing bivds wrse heard and seern but sot codsutified.

Thongh Vestern Nissouri some heavy trivir is found, which de ereases ni size and extent as wr approaich the Kansas livie, except 
along the streams, whiele were bordered by lar of sycamoves ( Latanus occiderutalis) ardd other trees. Sradually. The Senet Caks disaffear, and frairies of larqe extent become more munerols; and when one crosset the Tansas line, hees almost disafpear, and when fresent inde éate the fresener of a stream whore bankt ther fringe.

Herough the Easlem halef of Tansas long stretehes of prairie extind as far as thy eje can reach and form the horzion bowndary on every bite. Hres only grow biside streanus. The grast is fientiful and affrarently good. Lowns and shnches abound. The thatirie grass was burned in many filaces orer large areas by. thu inhabitate on account of the brseffit to their land from thic asfes. Emeighant trains and single wagone wire frequent.

Ve setirid After leaving Hoalstide, having watehed the buting grase in the Arairil Ares which surtrounded us, for a long

Mrareh 15 th. Healstead, Corl. to Las Neque, N. Fast night we travelled from Healsteabi to Aubraby, Kansas, and all sleft sourdly We avothe whon a level frairie, covered thiekly with cattule; and many carcasses of dead brasts from the "hoof and movtt disease" wrre shen atong Att soad. At teoohdge, near the Ceolorado border. ive broke our fast to the extent of a sanduri. and enf of coffee. Betwrin Aubrey an bol save broad, tongh blade armed with a thear

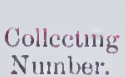

LOCALITY

Length

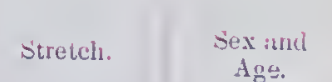

or needle at its foint. The roots are strong and fibrous. Amall flants remind one of the fini-copple. This sautiful bngtht grien plant soou became a connsons feature, and wr found it at the highest altitude of the spurbof the Rocky Mountaris which we crossed (17000 feet) When coming soutty inte Aewnesico, and in hew thexiedo tose far as ifton, where darkness overtook us.

crist noted the Cotton wood hees ulus ofremonti) near leooledge, Tarsas, and ive canne to the low, gnarled lecdars of Atu foot-hills of the Rockies neaz ofhatehfer, leol., lex ecfting Dlow willows (Aalix) alorlg streans. The Ceotton Woods ware quite tall and sym- mictrical, and qrew in broad betts along tie Arkansas Mirer and other streazse The first Cacti were seen neas Las thimas Gol. Thby wre covred with long, tharh sfinis. woolly gray. of got a shecinen of forints, of course not yet in flower. Hiri cactud (Cpuntia idfmenguin) covired the ground in many fil aces at far as the monntains. Although there is much desert land though Geflo rado, where no argeta - toin can br seen at thiz season, a gotd Sacist of the country is clothed urith Aurigrast on which many clattle graje. Large aslas of sandy sage hlains were crossed. The colon b. Atu grass land are bright and bailift thy colord with sed, brown and yellowsin varying shades.

Betwren Sranada and La funta the fist Prairie \$ogs (leynomye havricianns wrre seen: Heere wire sevrral large vellages, and the inhabitante idid not seem in thileast 
disturbed by the frassing train. Sone sat wh erect and looked towards it, others sat nfou Atu giound eating and othere wrse Shawled flat acrosk the tot of thier mounds. As the train frassed by thely woruld frequent ginh freaffully is in the ais. In Volo. -rado, the last Praicie Dorg village was noled near Earle fructioni ni ther southern hart of the state.

A large facth Tabbit Lefun texcanue was sefn nelar Jrinidad, Coolorado. A Luall burrowz wre abundant all though olorado, along the roid, and wrre ferobably muabied by bofhers eren atefinhas. , a few OThins ritle Larks of sone sort were abundant through Coolorado: Alfew flocks of Ductie wire seenaling the Arkansak Purir, and a feur Crowz near La funta, hese Rough-legged and gnotter lafge Howk which I thik was Swainson's One Gand ( Huto Surainsoni) wre mumerous. One Huebid (frobably Sealiá aretiea) was seen lugh up in the mountains of Ceolorads. If sav the firet Maghee (Reá nusticá hudsonica) near carle Annction at a Nexican'sranch where brvelh had born slanghtered. Shere yas not a tree within sight of the flace. A. Lew is -thers were seen bitwern there and Jinidad, alvays near Nuexican durllinigs. Their langs. rould neste wrre munesous about Imindad. and thenee over the monntainix into New Tuexiev, where there vre trees.

In Atu monitains the first trees seen wre the cedare of the foot liells. As wr ascended wr fourd fines si abundance and

vaMIF.

LOCA LITYT.

Alex aud

tall sprna trees. On the high mountani slofes wire stunted oaks and firistors

The Mexican inhabitants hird in durllinige varying from respectable adobr mansions to mere burrows in the ground.

Ve hassed Albiuenge, hew hexcér duri the might, and wre in Westem hew hexceiv when wr awok next Honizos.

In wrstern New Nexico wr noted the brantiful shapes and colors of the sand ston walls Strock, and the vlecanic character of the trgion through which wr hassed. These wre vest lava teds whioh seemed scarcely to have coved; mostly blackish mi color. $\mathrm{Vl}$ sau the first Ravens (eovre corax eaminorus) vout the red cliffs which walled ni the valleyr and larqu flocks of small Luok He crossed the sandy hlanis of An

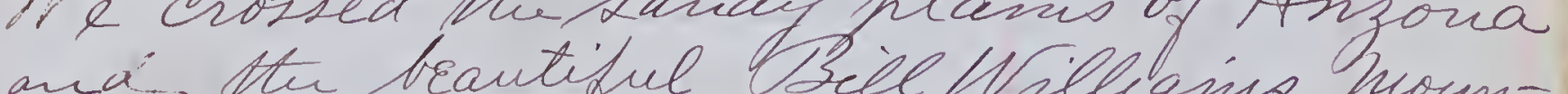
-taris which utre deefly everedurte now mue suffrorted a growth of luge and. ma:gnificent fine-trees. In the foot hille Thin vere cedars as usual, thech lown inies, and lowards the Higher frat ure tt maqnificient fries nuted above.

Brids wrest scarce, howrver, and dule a fui small shecies, some Moodhecteers whose sfecies Ioved not secergnize and ¿ large Reawk whioh may have ferntike \$uek Heawk (talev heregnins).

he reached Ath Fork ou tivie of ter o'clock PYII, and fut wh for the sugith at the "Palace Heotel; a songh A habity for the might. 


\section{DATE.}

LOCALITY:

Leength.

streteh.

sex muri
Agag.
"ne ireviously dishatched Tiley ram had nit reached Atsh Fork when wr urrived there, as the wries wre down Hes, Therefore ielegraphed to Whiphle Barracks for aw ambulanee inmediately upon our arrival but this compelled us to remain lats Ath Fork untic the formoon of the 18. th.

I Ash Hork is a typecial border toun, made if of rough poart-shantiex in most of which lequior is sold. Fis

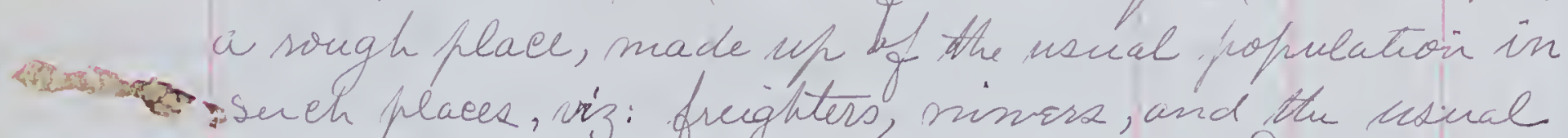

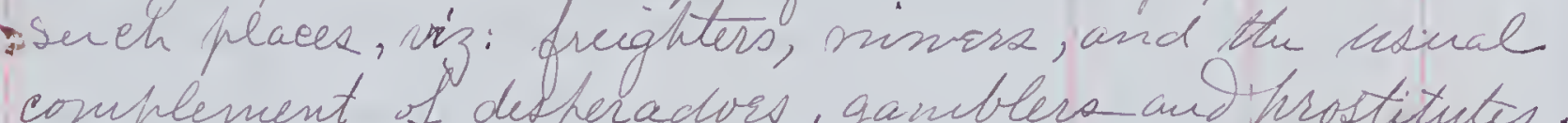
, ganblers and prostitutes. The "Palcee Hotel" to which I was confrelled to take nuy wife and little Lillian mas indeed a hard freace to take a lady unacenstomed to rough living. If few wrskd ofter wr lift, the quests of this cot ablishment enjaged in a quarsel with the propretors and Ane bhole building was Tom doive, and The fropirietors escostibl to the station unde funt on the fist train and shiffied. It my decond visit Gquirly confortable "hotel" was bing keft.

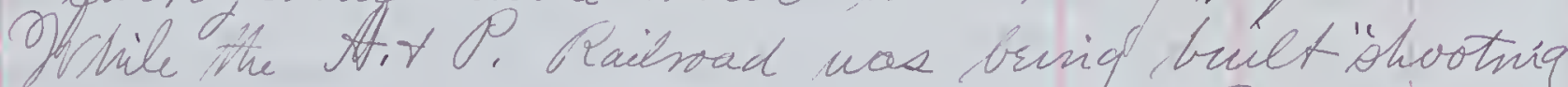
aftaris" wre of nightly occurrente. A row twok Heace on the moning after we cance. A grood deal of shooting weo done, and that tro withmin a yew cyarde of my wife and baby who wre in a car getting some mek trom a lady who ouned the inly eow in Ash Fork. One mun was shot Disowifh the arm frodueing a conshound comminuted racture of the humesna. Luas zeled in proLessionally, bot waryone was drusk and eahried a coeked fistol, and I mas glad to leave the fratient as soon as I had taken precautions aguinat thenorrhage and adjieted a bandage.

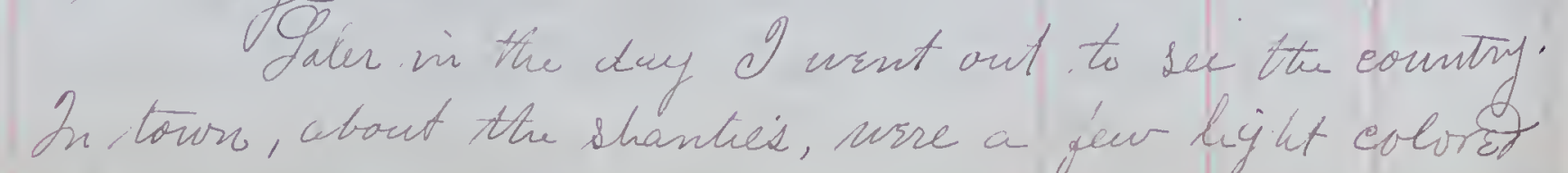

What bird Inat ni Cinizona nas the Weatern. Srats abundant about the toron. oft togetter in a wagon brliend a tean, we started and drove about kix miles to Ponstions Cañon. Ash Hook is situated reside the foot-hills The bill Willians mountaris, at quite an oltitude. The region is corred with a scattered growth of red cedars. Antelope, \&cer, Prairie Wole Hoxes are mumerout in the vicinity. The are

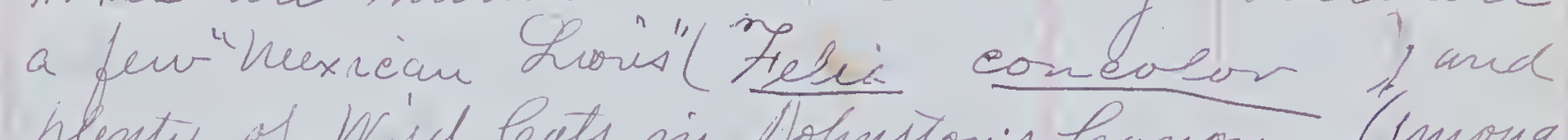
plenty of Wid leats in Nohrstonis learrow. Cmong (Passerculus savanna Dingle Saraneh I shot the of cedar-tree. Shove Larke (erenoptila alfustr chrypolaima) were numerout in large flocke.

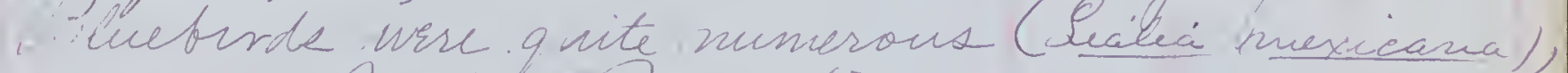

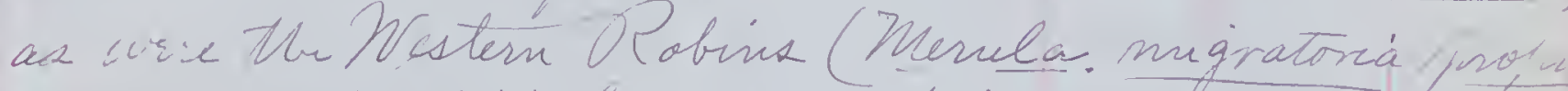

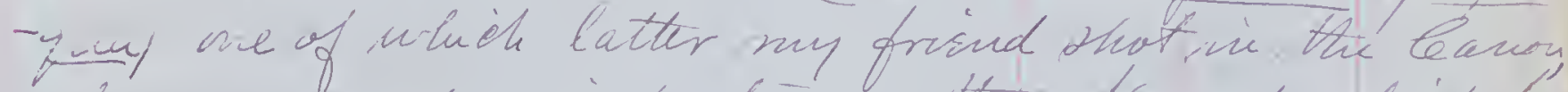
where ic Good-siject ohein then Llowed, whith a

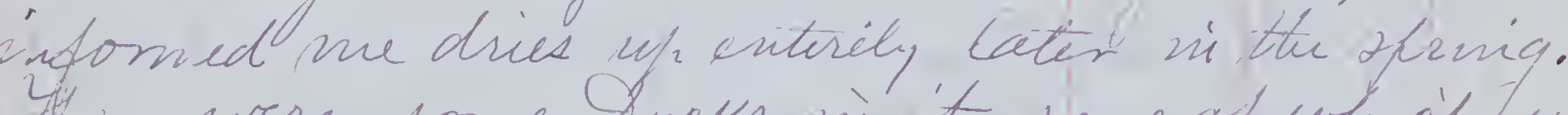
shot. Yher wore Fulix marila, but it the wharaeters exhibited by these ofeesuers are constaut they centainly should constitute a well-marsed varlely, whigh I will mane here Irulex marita

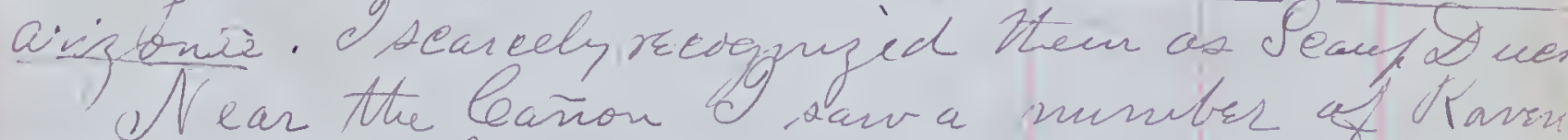
one of whily I made a good uring shot alt, and "colletid". Spyrapiens rarius mechalid was also quite numerons amon the cedars, aus

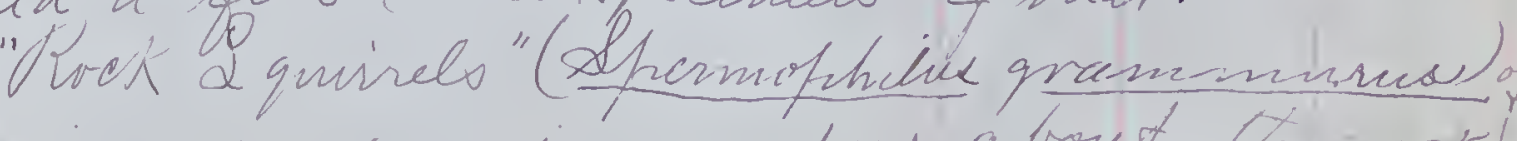
cange dize wre sein in munbird a bout the roded 


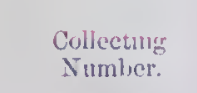

Dyurrele (Aumiat asiatiens dorsaliz

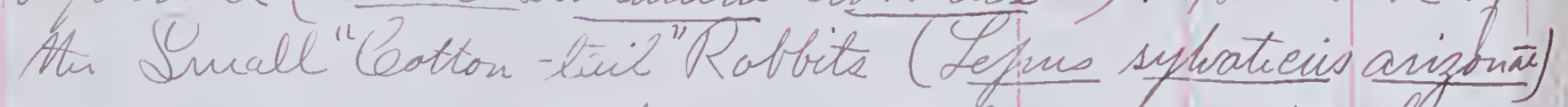
wre seen and shot, as wrre also seere the large Gack Rabits (Lepus callotis texianus) by

conchamin; but I did not see uni faok myselt until Arrached Prescott.

No flowers are in bloom at this early season; fut munbers of interesting henets wre seen, aswong them Alors, Spanish Baponeta, and leacti in abusidance

2644 . Ceorus corax Carnivorus (Bart.) Redqu.

2645. Spyrapient varius muchalis, Baird.

March 18 to. Ash Fork to Banghastis, Anzona. The umbilance got in late last night. We started about 9 olelock d. wh. For Procott, and reachedBang-hacte ranche, whene we stopped for the night and

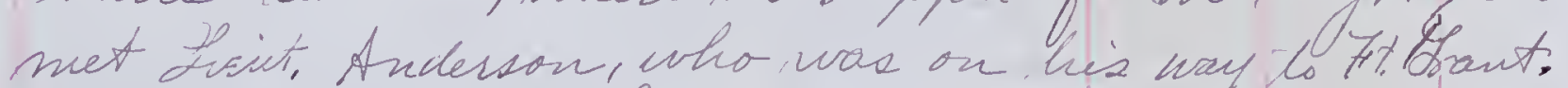
Before breakfast I tool. my gun and took a stroll ovir a stom, ecelar-eovered thill near. Ash. Fork, and collected specinens of Lophophanes inornatuc (The Plan Litmonse), and Slürielea neglecta (Westemi ineadow Lark) The only other birds seen werle Sharrow Atarvik (Airmunentw sparvarius). The leogotes (Danis latrans ) were yelling londly fand the doga in town wire all barking back at them.

OCd Pease, a viteran divermulater drove us, with a team of six mules, and wr rattled over Atue malapai soada, Ntrough sund of untriomudefts, and war roeke untel we wre all three nearly, foundid. into jilly. We crossed grassy planis and $2 a n d y$ wastes of great extent. The country near Cesh fork , howrvir, butes forited with the red cedar, with ofin spiees bolwern the wooded ones, and deeh Ceñ̄ono wire vecusionally erossed. 'the euet'. wire the most initresthin Leakere of ther Lecuenf

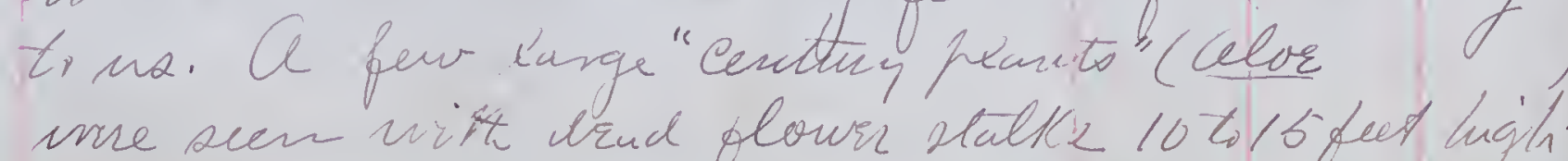

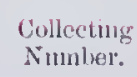
1884

LOCALITI

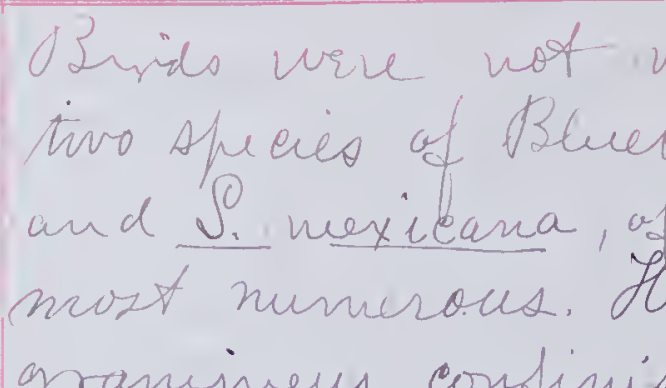

gra A Lew Snowbidds were noted funco

a small Lark was aceveroinally seen which-Cootled whe a Pipit (Anthus). Shon Lanks were in qreat

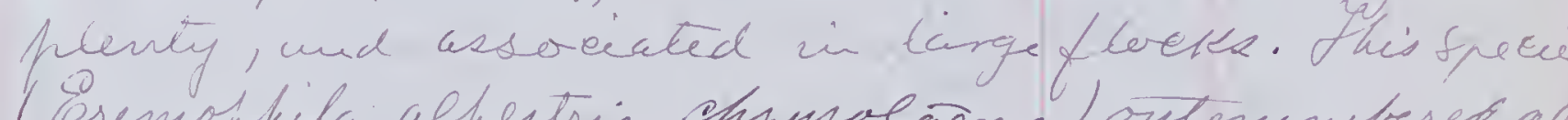
(Eremophila alpestris chrysoläena) outnunbred at the rest. A few Ravans (teorves corax camiroress, ware possed, is they zat on

We stopped for dininer at the cating station on Ceruk, a goore-sized sheam at this suason, then

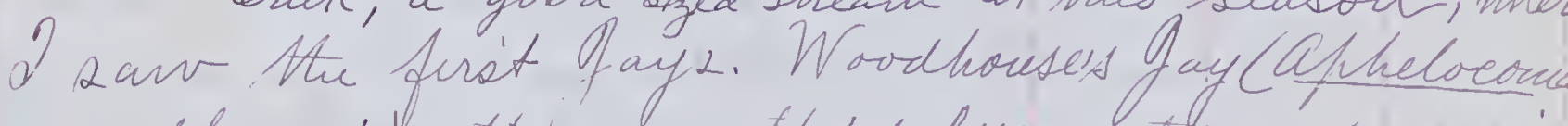
woodhouseif nttirk a catbind-lite note and a devie A hasseoviate shrieks. I ake saw a sirigle fongterested Jay (leyanoeitta dexlesi mavolopha/ at the flace. Ne then crossed a wide beet of dene cedar tiniter, ni whieh I thot mu first theemin

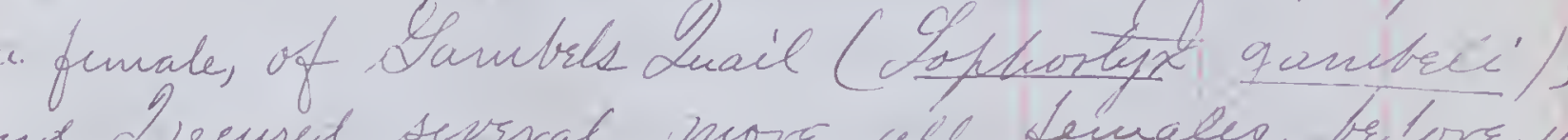
mid Iseuret sevrral nove, all fenales, before u got to Arlls Gañon, where we Gound a munber D.epta frox the only otiur birds noled wen Butess. Diurnella negueta was geen ot interrabs alony otc noo Q turnelia neglecta, etudubon. Shot in a ceclar-tree at Asle Hooks.

2647. Sofhothanes inornatus (Dambleass. 2648. jot unong the cedars at Ask Fork. Lophophanes inomatus (Sanb.) leask. Ihot in u eedar-tru at Hsh Hork.

2649. Lo jhortix q unbeli, Vutinel. sad. Acll'n Ceañón, Yurapai teonntis, Arizona. Lophoptrexedt gambeli, N nitaci tad. f a. 
$18 \times 4$.

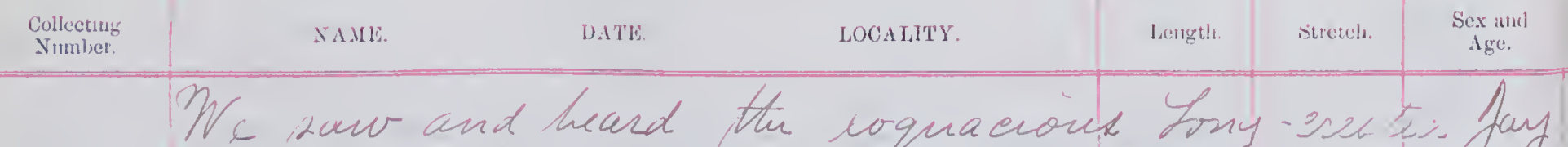

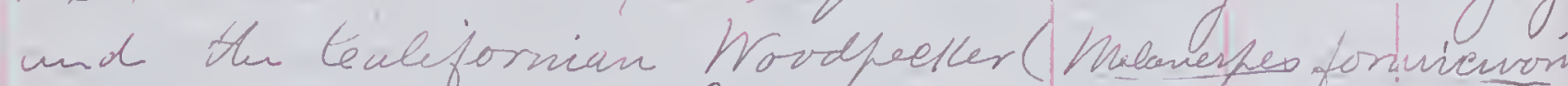
and wanderd along Hasite leriek, among the vocke, where I saw the fusit Gack Rabbot Lepus cal. lexiame I, a bruly wonderful aninab! About Prescott and Winiphe wr heard and sow - floeks of those delightful litth brids - thir Avuse Himches (Cenpodacus frontalis). Yheir song is behieiren, their chatterning like House Sharrow's, and

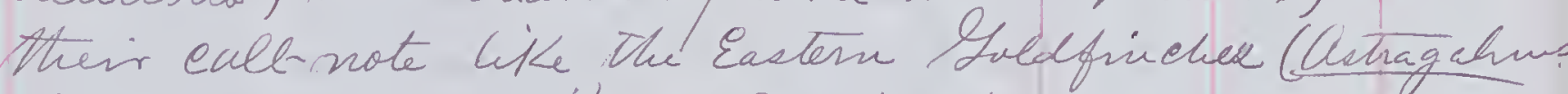
iristis). Jiging Mulhaletes wire ereefinig upon the buntes of thl huge firies, and werb noisy and restlese ni their habita, as wrll as yrgarioir, wethough single birds wre seen.

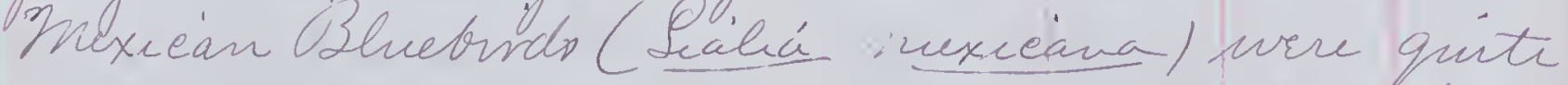
mumesous, and uttered a not somewhat ike the House Findes, and a song whis is ie like the Eastem

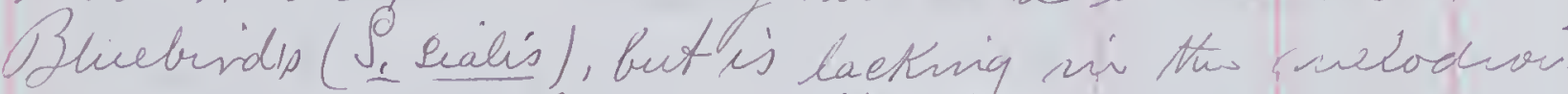
swactuess of rercoluebird. The y 2 at whis the lowir dead

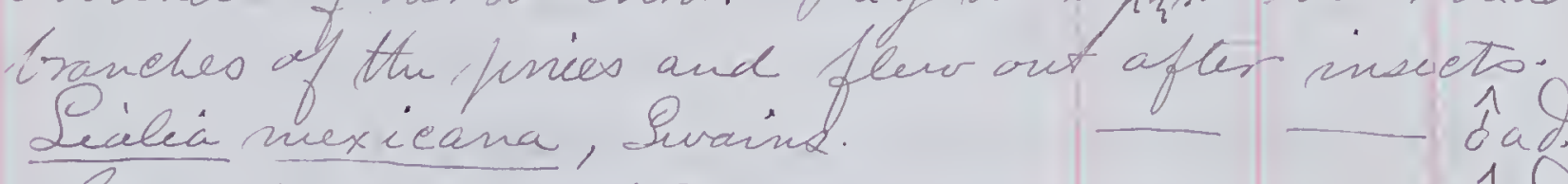

Sitta prymaiea, Vig.

learpodacus prontalis (Pay) Lray.

\section{March 2/st Prescott, Ciizona}

E. Sint the morming ini the woods about Serscott, stimined birds, and receird calls.

the House tiniches wre found in Carye Llocks, fuching whon the ground, perhaps on the seeda of the pric cones.

Woouhouse's Jay was quite mimesous, and foond inigh ip in the tall pinio, as well as in the cak-bus, bushes and whon the groond. Wherever found its pesseonate serearns "rent the air" and ite whole dimeanorie Lavage and viaseitle. The Eilifomian Woothukes was found in Some
2659 a koud whumif sound like the Ger hurpureas at

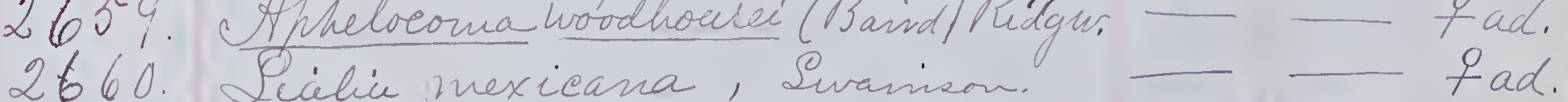

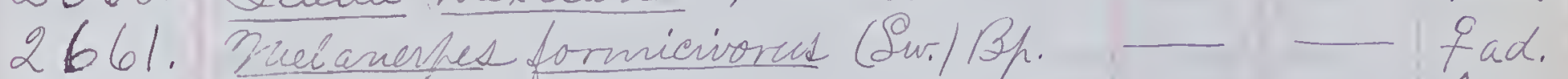

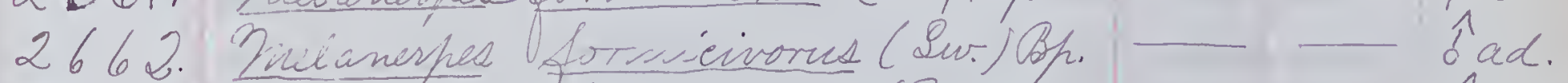

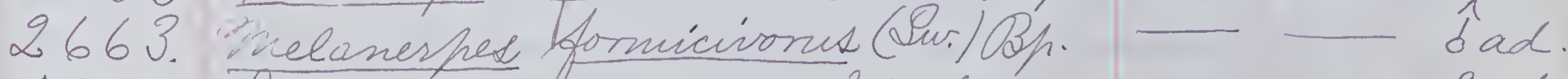

2664. Slincidium gnoma, Wagl. itad. 


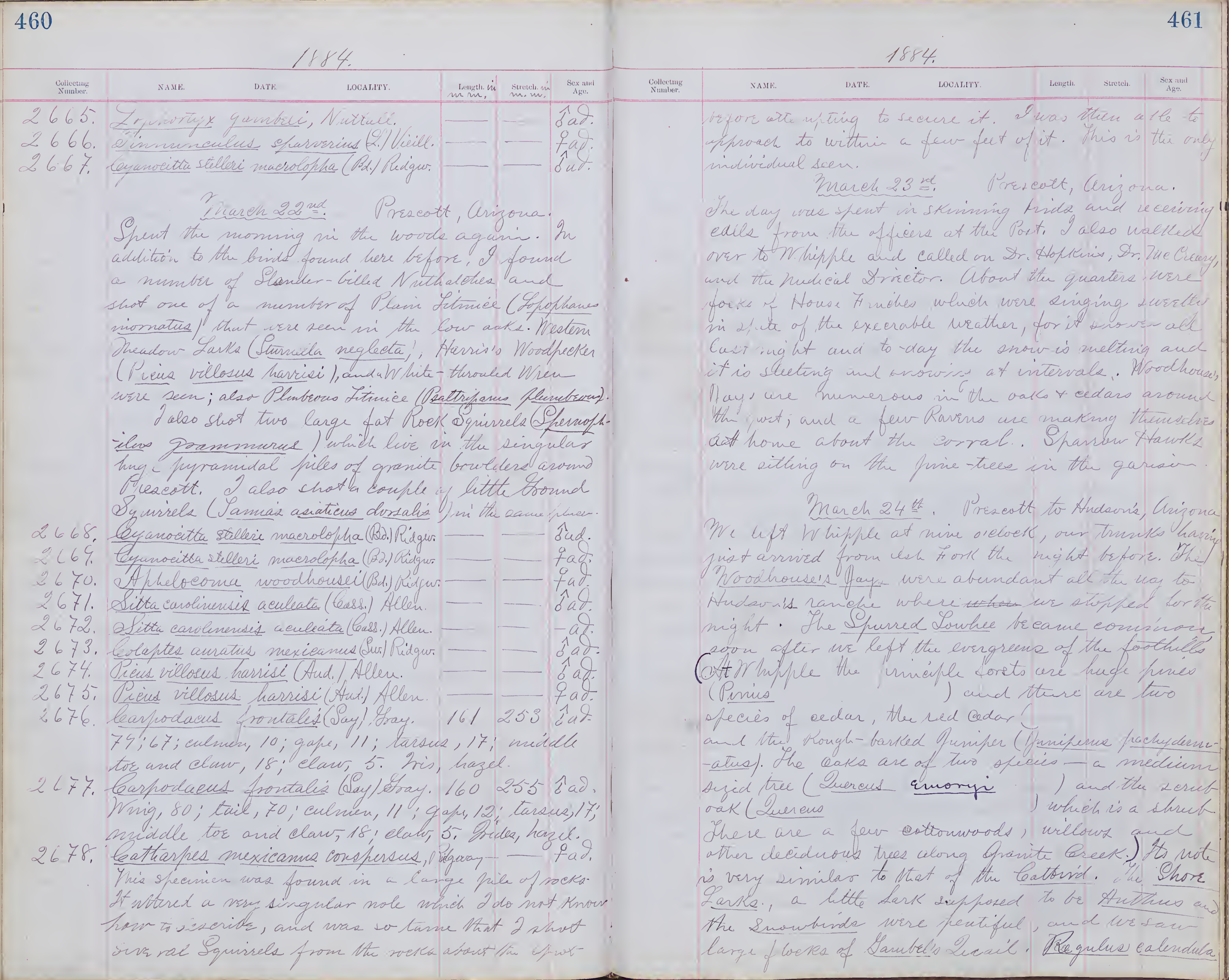




L.engylu.

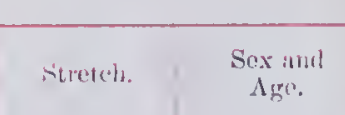

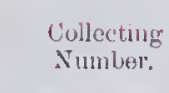
1884

war vecasionally observed all along the road to Atudan's ravehe, which is on Aste Greek about 19 miles from Fort Vorde, and where the sfeciex was visy consteon, but not heard singing. Woth Specels of bluebind (Sialia vretien) and. I. (mexecana) wrre moted at variois foints along the road. vinito dusens mesolenews, - A thecinien of this fretty Lowhee was shot anong Rone braten roeks; but it mas aflemands lost out of the cubulanes. A Kéw Mlleadow Larks and Lrafs Hinobea wrre occasioncelle seen. Some Mnanzaritas wre. the firt flowrrs seen. Wre inceched Hudsons cate in the afternoon, but in tirie to take a sanble abont the place. Woodhouse's Gays wis vocifírating,-evry hand, vond the eclex of Dambris Luaill wor heard ni all derectivix. She spured Lowher was vinf conmon unt I saw several Rect-vinted Ghroshers (Aarpor-hynchus craisalisf) for the first time.

967\% Dophortyx qambelih, Nuttabl, 877377 iad. Andson's Ranche, on Ash lereek, 19 miles from Fitillede, Arrzina. Ning, 115; tail, 107; culmen, 11; gape, 13; Larsut, 32; middle tor and elaw, 36; elaw, Grides, darts hozel. Sill, black. Yarsi and Tors, oliveceust bluish-gray: cluvs, black.

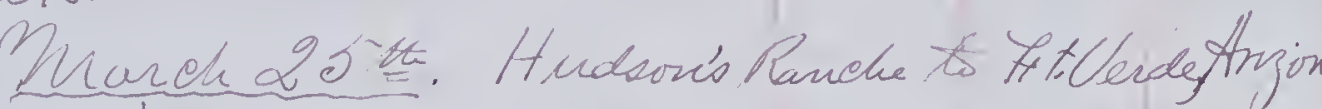
Busides the birds noted yeaterday we saw one or two qudder-backed Wroofeckers (Reus sealaris) aurto a White-rumped Shrike (Fanuis hodoriccanus excubitoricilss). The teuved-billed, pe-vinted Lhrashers (H arfor-hynchut crissalis), wrre accascoially noled, aud wre quite numerous in the veintitef Aele Creek and again in leopher teoñon where we. got our geret tinie to a vafid, muddy atream of very sesfedathe size. In the level, open spacee along $b /$ s soute wr aur

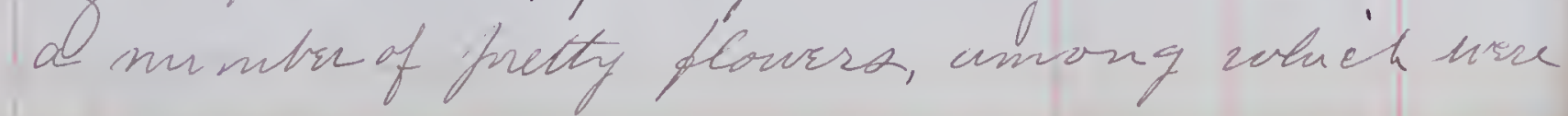




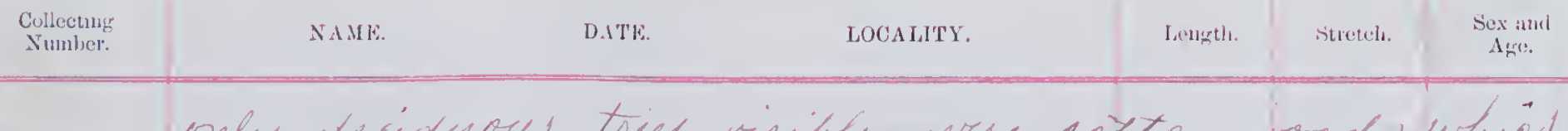

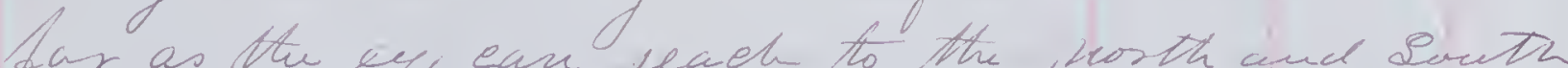
The Valby is, othermis, destitute of trues, for the ind cedark and smate finies are only found Lost-iille. At thi fost, a double rout of smate coltonvoods in frout of sifficers' Rour und a suigle scatiered bir of the same trees around the frarade yround avare the coly, trees. The altitude of Fort Verde is 3,500 Sut. It is much Cover Dian Whifile Barraets, which is feet abovs sea level; and, conseguently it has a much wamer clinati. It is said to taber the third rank in proint of heat of all Ath froste sin the U.S., Mojairi, on the Ceolorado Thir ranting fist. Verde is buelt on a. Aitte hlain in the ofen Vulley, about 100 fuet above the Bivars, which, upon the Post side has Cow sandy banks; but on the farther side the bauk rises through several irregular terraces conowned by grassy meidas to tuigh sidh and rooky walls of himestone voek, whieh wre oceufied by Ajtee nilrabitanta, whose Cave dwrelings may be seen from. the Post. In summer the Verde is a yood-sized brook, fordable anyv-there exeept where there are quiersands. At this timie it was a rushing torrout, tearning the rivir bed, surafing away great masses of clay from ita herfurdcentar banke, which the water undermoned causing to fallithemencous thuds ints the edge of the stream. Cottounoods and willows are baing tom up and cassied down the Ruvir, and the whole nvir bed ahiftrig fromday to day, so that a good crossing, one day cannot br seleed whon another.

- the river bottom is corrposed of elaj and sand, bare in large areas, in athers covered with a more or liss seattered growth of mezquite breslus and

\section{4}

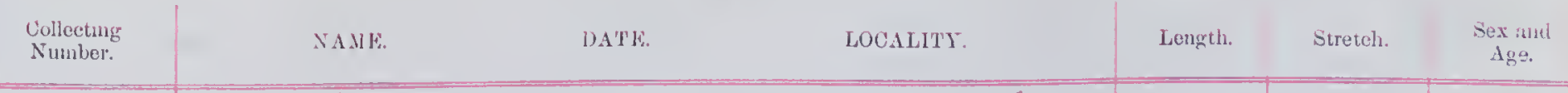

This afternoon de drove up to the Midde Verde, seir - see a fratient, in eonpans with Dr. Friék In as lewñon we aw a large frock of Sambel's Luails, which ore vary pentiful in the Verde Salley. fults wid mountanis around us are deefle evere vita snown und to-day it is haileng and eleetising the valin. I was kufing out of the anbulane throu a sl.- Ini the curlain When a brieliant red bird flew form near ns and aleghted. in a bush bise thul'hde. It was the firt Vermilon Fily ealder (ppreefualus nibineeks mexieames) that Dever sau Red-shafled Fliekers (Colaftes auratus mexicanus) and Robins (Neme migratoná propinqua) wre viry common at the ford at Paraon Bristown, where we experienced conseierable diffientty golting th ambuluner acrosh the vivis on aceousit of the hig' in water, which came nearly to the nuies' breks. Drang inale binds wre seen, but ownig to the slomvy writtier I could not wee distinietty enoreg mareh 29 st. Fort Verde, Atrizona. this oflemoon divint shooting with Lisitenant Vogele IVe sode on mules. Mine was a biflle ficte foblow with extraordinary developnetant of ear an' Tre wode dow the Valley, and along the edye of the foothlils. of

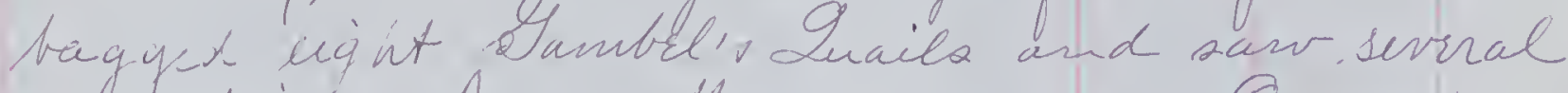
nerie firds. Among those seen wre Qrevscoptes inontanns, Regubls calendula, Sialia nexieana, lewprirus frontalis, Procetes gramment perifinis, Amphiving bilineata, Pifilo aberti, Sturnella negledà, leorru. corax carnivorus, Sayomis sayi, Preis Scalasio

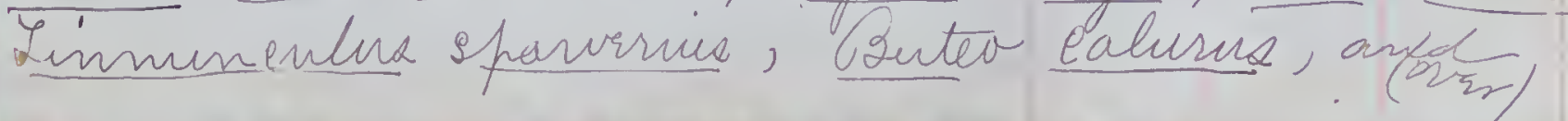


OH Hilu chrysaítur canadensiés, which latter sheies was seen within a Lew rods, flying low above my head, but, bafore of eould dismbunt and slif a, starge shot in my gum it max mit of range, I waleled the bord intel saw it joile

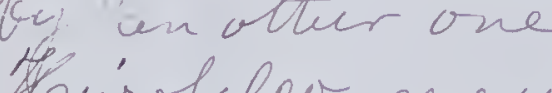
teurofaleo mexicanus holyagris. - Sevrral of of these binds in vary trate plumage usro seen about the Post, where ther have, Killed ar numbir of chickene in the yards, and ugeons abebout the corral Exyechux voeiferns. - Arand late last night, and vecasconally seen flynig utterning its lond Plartwi Cry. Numbirs of snall birds wre seen whieh wrel not identified. Rabbits of both specee L. L. arizonae arget tevianus. I ware seen in abund ance. cins sealaris, Wagl.

Vinia, 99; tuil, 6r; culmen, 21; rope, 23; tarsus 1.; indle tor and claw, 21; Claw, 8.

Urescoptes montanus (Jown.) Baind. 222323 c ad. "min, 98; tuil, 95; nostril, 11; gape, 25; tarsus, 30, vilidie tor and claw, 26; Claw, 7. Dides, yellow.

- Wuarch 28 th. Fort Verde, Arizina Devlecophagus cyanseephalus. - Cevry nonnig sniee wr have vern at Verde, wr have awothl to ate the note of this bird, and on lookting out hureseen. the parade-ground black with them. Ther use virey "Tame, coninig upon the gravilled roadd ni prowt of our quiarterk, and we caseonally evan and fud ufion the oround amongat, the horse, avoiding their hoofa with worderfiel dex-terity. they spend the dae wion the parate ground and

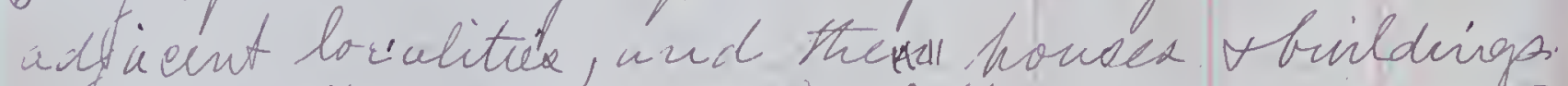

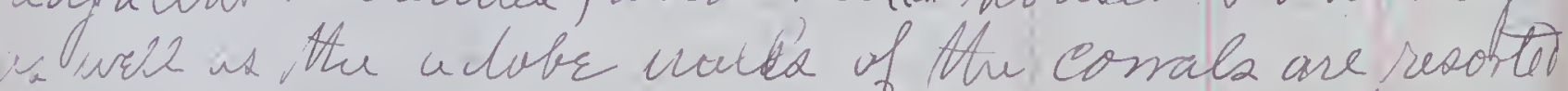
to us. favorite vosting heaect by doof, but in

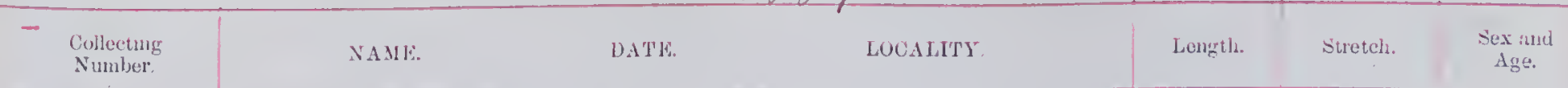




\section{Merganser amencams. - 1343, 1344, 1835:}

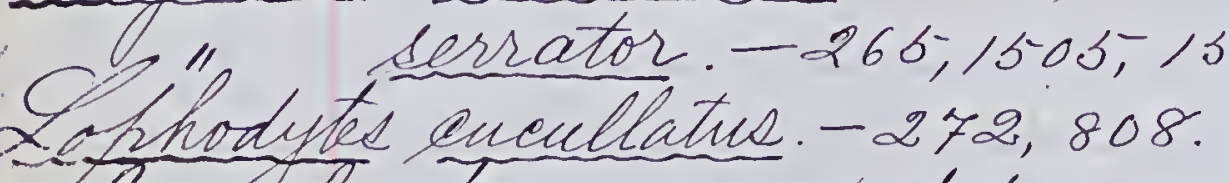

Atnas boschas. - 2059 (a hybrid or domestie duck. From Butterfase of C.8/g)

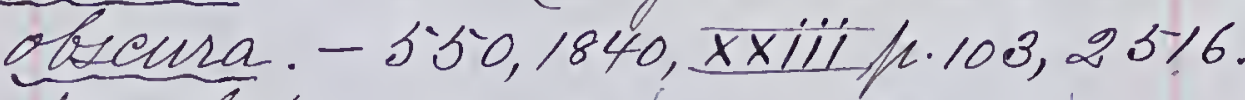

" ponclope. 1819 , americana. - 888 . eyanoftera. - 2655 (Arizona.).

Shatula Slyeata. - 1790 .

Aix shonsa. - 244,1326,1783; (CCX/f.108:-244)

Bipthija rallioneria. - 1341, 1342.

marila nearctica. $-1841,112,2178,2106, a, 2106 b$ afoinic. - $\angle X L 111 / 106-(2106,6 . ?)$

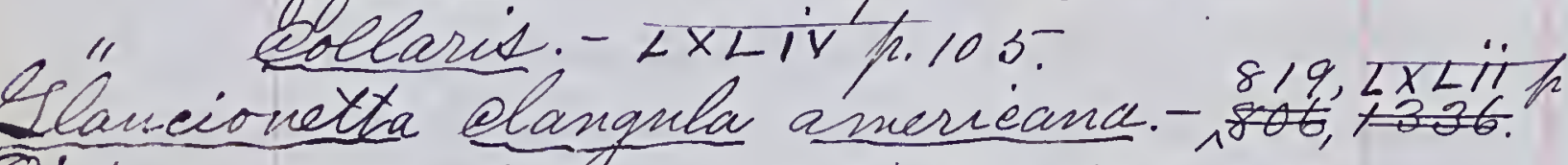

Eidemia americama. - 796,801,803,1499.

Eidemia deglandi. - 792,1500,1501,1502,1503,2110.

- Itreficillata. - 802,2109,2118, 2200.

Crismatira rubida. $-261,262,17.91$

Honateria dresseri, - $2638,263 \%$

35 ranta Canadensis. - 55\%

Ob" brmiela.-2175,2176+2 following without numbre. Charitonetta albrola $\frac{2}{1} 2^{2} 70,271, \times \times X 1$ fio3,

Cangula huemalis. $-806,1336,2111$.

Botarrus lentiginosus.- 2432.

Ardea herodials. $-196,219,1773,21723$.

Ardea egretta. - 2195 .

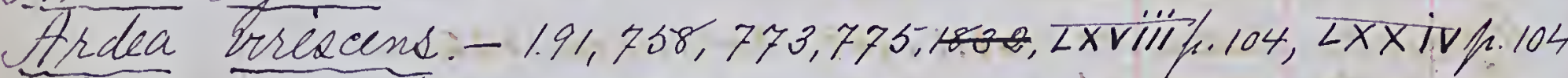
Nycticorax mycticorax malvine. $-126,130 ; 131,132,133,134,139$, $140,1448,1449,1450,1491,1719,1936,1937,1938,1939,1963$, $1964,1966,12064,206,2101$

Rallue rirginianns. 2305 .

Porzana carohina. - 170,171, 212, 213,745,764, 1252, 1307, 1329, $1980,1982,1983,0$ क्से Co7, 2078, 2079, 2080

Fulica americana. - Sor, 2206

Thilahela minor. $-267,2 \times \times V / 1.104,2348,2460$.
Hallinago delicata. - 1312, 1313,1325, 1870

Eringa eamitus.- 818 .

Erimga maritina. - $1,2 / 13,2114,21 / 6,2116,2117$

Drimga maculata. - 2093, 2094.

2hinga mimitilla. - 2090.

Ifriga alfina raafig/6, 2092.

Erennetes /usillue. -2000, 2001, 2095, 2096,2097, 2098,2099, $2198,2199$.

Hotanu melanoleucue.- 2089, 2205, 2213, 2214, 2215, 2217.

Qotanus solitarine. - 180, 199, 217, 1160, 1255, 1390,2002, LXXXiif/1.104, CLXXXiv $/ 1.107,2068$.

Afetiti macularia. - 68, 181, 562, 644, 960,973,1128,1131,1176,

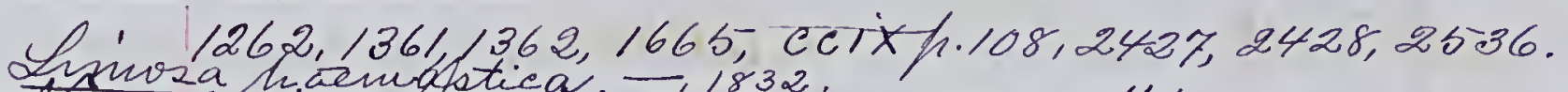

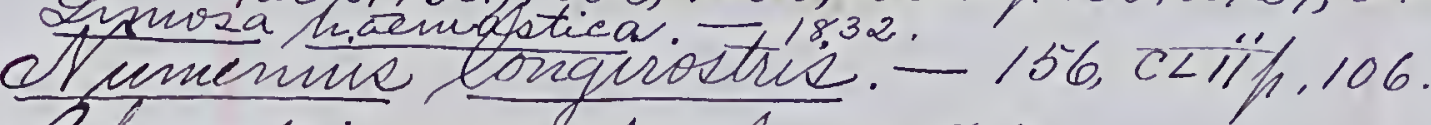

Charadries squatarola. - 817.

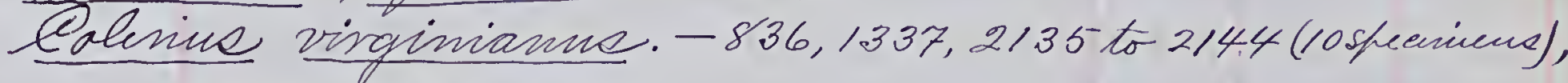
$2242,2382,2461$.

Sonasa unbrllut. - 253, 269, 273,411,469,484, 486, 876,881

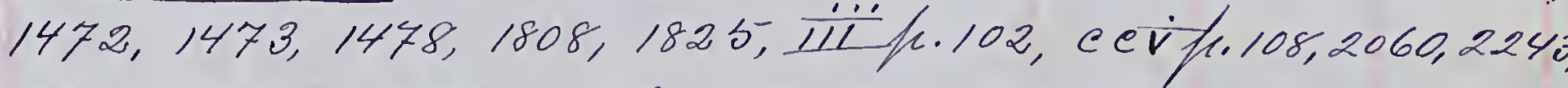

4. 2258, 2297, 2298, 2616, 2617, 2618, 2619.

bympanuchue americanus. - 453.

Dediveates phacianellue. $-1820,1821$.

Setopietes miqratorine.- 45, 46, 767,768,1396,1847,1849,185, 1851, 1852, 1869, viliff.102, civifi.105, cxLix f1.106.

Zenaidura macroura. - 537, 963, 1874, 2008, 2025, 2132, $2133,2134,2241,2361,2539$.

Bircus hudsonius. - 2240 .

Aecifiter velox. - $c L 111,169,1349,1496,1802$

Aceipiter eooperi. - 1226 .

Accifiter atricapillie - 2005, 2170.

Butco borralis. - LXL, 544,1853,2179.

Buteo loitissinm - CL, 41, 1224,1225,1229,1463,1976,2040, 2072, $2073,253513$.

Archibuteo lagopus sancti-johannis. - 2640.

Healiaiètus leucoecthalue, - LXLV, CLXXX111, 195, 495, 1222, Falco heregrinus anatim. -2100 . 
470

Sondex te Spicimens of Bride.

Falco columbarins, -2085 .

Faleo sparverict. - 1355, 2120 .

Pandion haliaetus earolinenisis. - IXXXIX, LXLI, cLi, cLXXVii,

Asio wilionianis $-2021,2062,2238$.

Asio aceifitrimes - 2119 .

Byrmum nebulosune -1328. Dufbo virginianus - $1933,1934,2169,2486,2520,2594$.
CXX1, 1324,2230

Vretea ny ctea. - 815, 2108 .

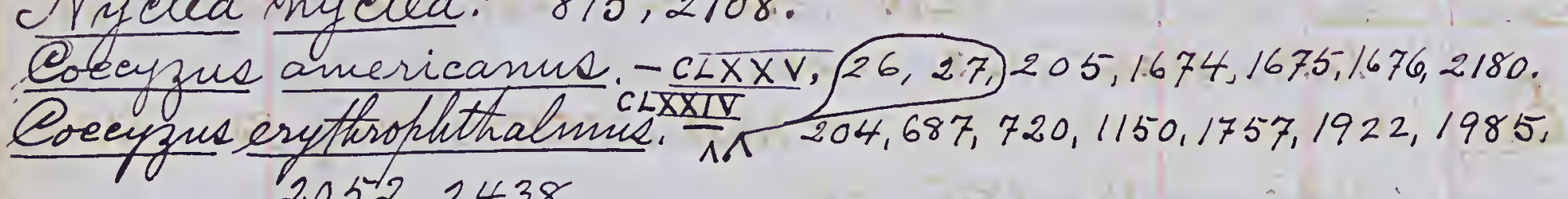

2052,2438 .

Ciryle alcyon.- CXLII, cLXLIX, 50,137,172, 173,221,257,258,665, Dryobated villosux. $\frac{\text { VXXVI }}{1333,1385,1527,1829,183 \times X 1,168,348,437,497,1330,1332,}$ $1333,1385,1527,1829,1830,1970,2010,2235,2349,2389,2394$,

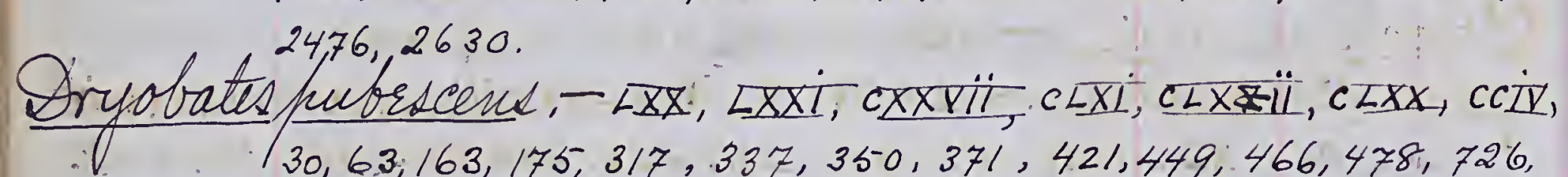
$30,63,163,175,317,337,350,371,421,449,466,478,726$

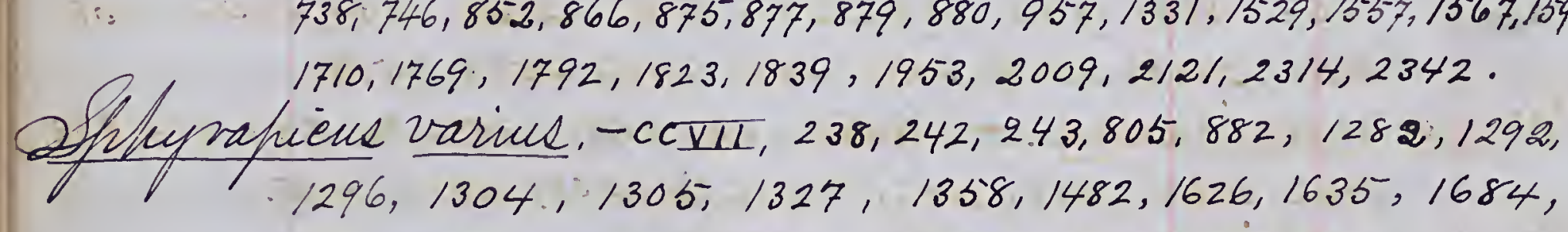
$1780,186,1305,1327,1358,1482,1626,1635,1684$,

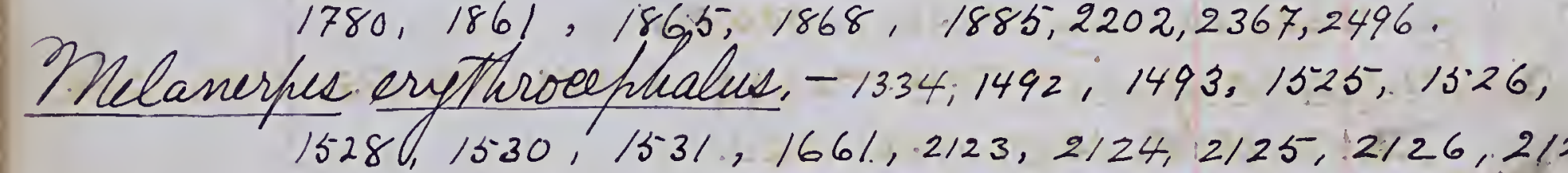

Melanerpes Carolinus, - 2122, 2236, 2237 .

Colaptir aurates, - XXXIi, LXXXIV, TLVII , 24, 25; 36, 37 38, $39,40,177,189,260,538,583,1 / 132,1320,1350,1615,1871$,
$1942,2022,2046,2355,2356,2358,2376,2437,2457,2678$, $1942,2022,2046,2355,2356,2358,2376,2437,2457,2678$.
eAntrostomus, voeiferus. $-4,65,641,785,1127,1384,1881,2454$,

$2620,26) 21$.
Chordeiles virginiamus.,-681.
Chactura helaqiea.- $X X I, 2,3$

Chactura pelagica. $\frac{-2 X I}{1903,1987}, \frac{1988,3989,2048 .}{1993,634,635,636,1741,1774,}$ ondex to Shemiens of Birds.

Ârochilus colubris. - XXVI, LIV, 1, 188,678,697, 1703,2061, $2421,2562,2586$.

Iypannus tyranmus, - LXVI, LXIX,5, 58, $128,624,628$,

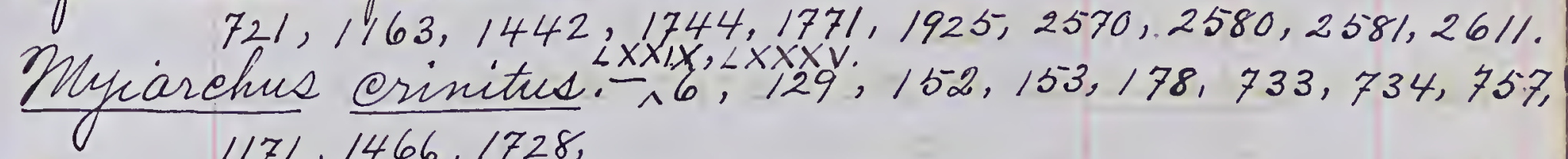

Sayornis phorbe, - XXIV, CXXViii. EXXXIX, 192, 534, 920, 942, $948,1112,1395,1604,1605 ; 1609,1611,1768,1935,1992$,

Contohus borralis, - 737, 749, 750, 1250, 1708 .

Contohus virens. - XLiv, 454, 729,1230, 1236, 1237, 1238,

Empidonax Llaviventrix, - XL11, (E) $714,781,1122$,

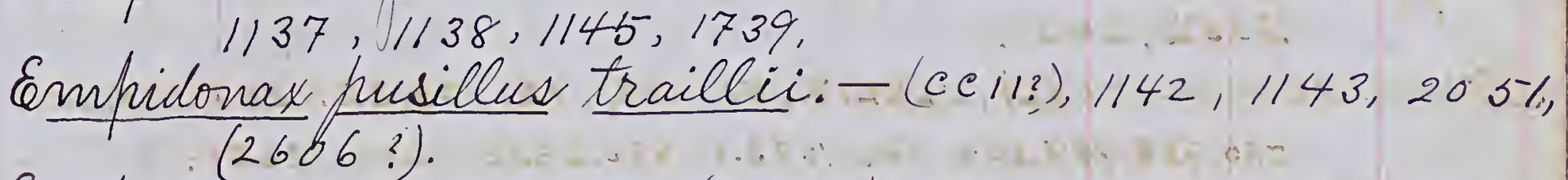

Empidonax minimus - (ee11-2), 95, 182, 185, 652, 653, Otocoris alliestris $-1822,2163,2164,2165,2166$

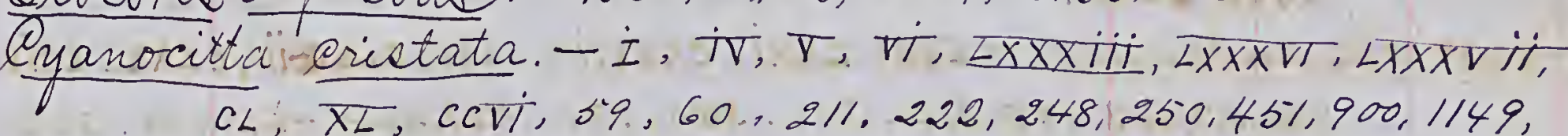
$C L, \overline{X L}$, CCVI, $59,60,211,222,248,250,451,900,1149$, $1657,1804,1805,1806,2016,2129,2130,2234,2254,2458$,

$2459,2483,2484,2485,2569,25-82,2597,2598$.
Corvis americanue - $-c<x<v 11,5: 2,234,235,236,237,813,878$, $1462,1464,1465,1857,1981,2011,2029,2577,2625$.

Corvus ossifrague . $1360,2535 . \mathrm{a}$.

Dolichompt oncliviras. $-\angle X X X, \angle X X X 1,706,7 / 3,1178,1246$,

Molothrus ater. - c $\angle 4,61,62 ; 578,912,946,966,1616,1627,1628$,

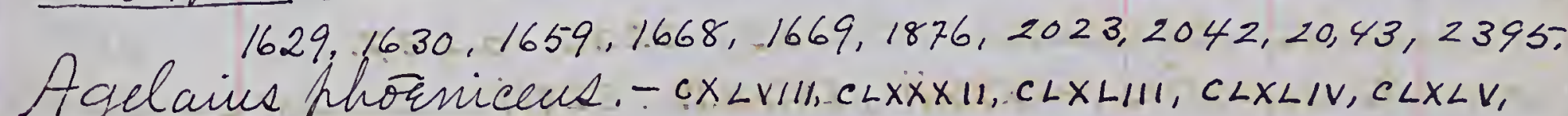
CLXLYL, CC, CCVIII, 21, 22, 164, 176, 200,201, 202,215; $218,240,508,704,1152,1157,1161,1166,1195,1377,1446,1487$, $1622,1633,1700,1701,17448,1749,1750,1949,2028,2033$, $2081,2082,2380,2381,2418,2419$.

Sturuella maga, $-1345,1620 \%, 1621,1623,2020,2091$, $2107,2131,2197,2231,2232,2233$. 
 \\ Index to Speciumens of Sirds.}

Deterus qabbula. - $x L v, x \angle v\|11, x \angle 1 x, \angle, \angle 1, \angle V\| 1, \angle x, 4$, $17,18,19,20,101,109,120,122,123,190,630,631,632$, $662,663,722,1179,1190,1204,1244,1414,1670,1690,1699$, $1721,1760,1833,1956,2426,2559,2571$

deterus sfurius. - LV1, 66, 67, 119,731, 1175, 1234, 1245, 1418, $1419,1423,1457,1733,1742,1924,2407,2429$ Q) colecothagus earolinus. - $x$ x111, $x 1 x, x \times 11, x_{2}, 509,549,582$, $807,90,8,909,2366$.

Cuicalus quicula.-XXXIX, $1826,2537.2538,2593$. inicola enveleator. - 275,276, 277,278, 279,280,281,282,

$283,284,285,286,287,293,294,295,296,297$,

$298,299,313,314,315,316,320,321,322,323,3.24,325$, $326,327,328,329,330,331,332,352,353 ; 354,355$, $412,413,469,501,502,503,504,505,506,507,841$, $842,843,1795,1796,1797,1798,1799,1800,1801,2464$, $2465,2466,2467,2491,2497,2508,2509,25 \%, 25 \%$, $2636,2637,2641,2642,2643$

Carpodacus furfureus. $\pi \times x \times 11, x \times x \times 11, x \times x v 111, \operatorname{cx} x, 224$; $225,247,402,403,470,471,472,473,531,539,540$, $693,797,798,811,837,1167,1314,1356,1523,1524,1532$, $1537,1554,1555,1556,1564,1565,1566,1570,157,1572$, $1543,1592,1603,1610,1891,2017,2193,2194,2211,2245$ $2288,2293,2331,2343,2373,2526,25-29,2531,2612$.
Loxia ecervirotra munor.- $333,334,335,339,340$, $341,342,351,356,35.7,400,414,422,423,490$, $49 !$

Loxia leveofitera. $-343,344,345,346,347,358,359$,

Loxia leveofitera. $-343,344,345,346,347,358$, Aleanthis linaria. - 300,301, 302,303,319, 364, 3, 55,376 , $377,378,379,380,382,385,386,387,388,389$, $390,391,392,-393,-394,395,396,397,398,399$,

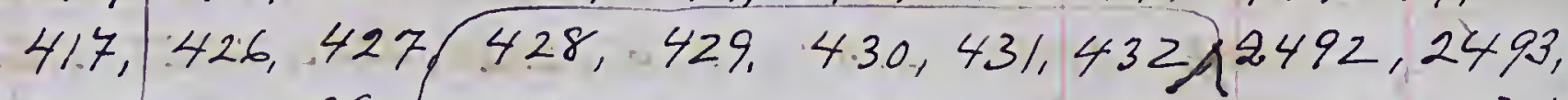
$2494,2498,2499,2500,2501,2502,2503,2504$

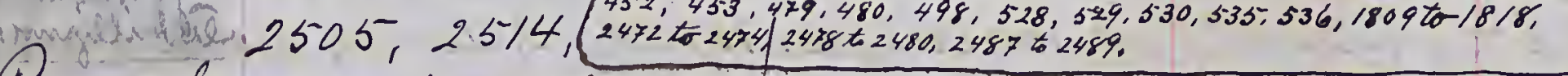
Pooeactes granimene. XXX, 564,565, 568,569,570,571,572, $580,918,925,1667,2371$.

Ammodramus sandwrehensis savanna. - 53\%, 6/3, 614, 6/5,
Dudex to Specineur of Divds.

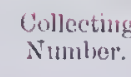

Ammodranue savamarum hasserinus, - 1715, 17/6.

Ammodramus eaudacutis nelsoni. - Cexii, 246,1495. Bonotrichia lencophrys. - 1177, 1181, 2424.

Gonotrichia albicollis. - XXXIX, CLXX.1,CLXX11,124, 127; 239, 259,

$602,603,604,605,705,1151,1168,1283,1370,1387,1388$, $1488,1785,20.44,2388,2397$. Bhizella monticola:- LXLVI1, $C, C 1, C X L 11,291,338,372,383,420$, $858,862,1520,1521,1538,1545,1546,1547,1787,1803,2015,2477$
25izella socialie.-cXLIV, CXLV, cXLV1, cXLV11, 115, 584, $585,617,774$, 941, 1113, 1118, 1619, 1960, 2003.

\$1 pizella fiusilla. - LXX11, cxL111, cc1, 69, 619,914,1116, 1288, 2047,

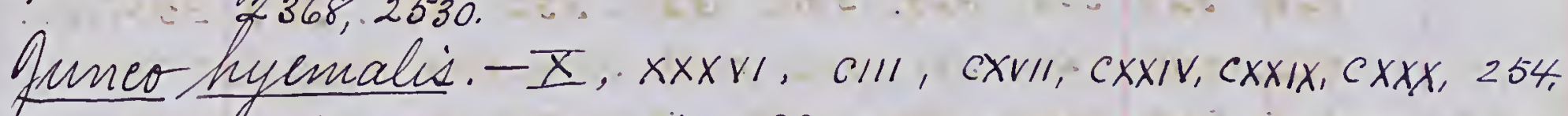
$256,418,424,456,499,563,618,850,860,867,868,4869$, $870,871,895,902,903,944,1306,1347,1607,1631, \mid 1858$, $2271,2287,2307,2325,2826,2327,2370,2533,2628$.

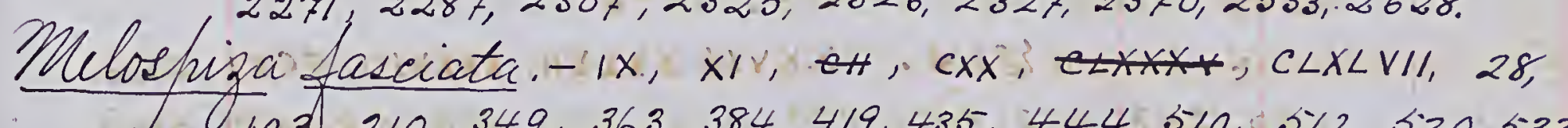
$103,210,349,363,384,419,435,444,510,5 \% 2,520,533$, $724,861,887,896,906,1577,1614,1652,1654,1828,1864$,

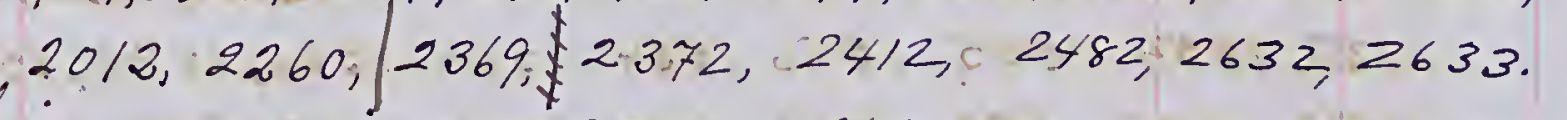

Melospiza georgrana. - c ex/11, 245, 252, 559, 560,561, 917,

935, 966, 967, 1293, 1294, 1458, 1651, 2035, 2522, 2523.

Passerella iliaca, - $c 1 x, c x, c x v 111, c x 1 x, 5 / 13,114,193,678,579,541$, $1548,886,897,898,901,1348,1507,1513,1569,1574,1608$, $1612,1842,1845,1846,1863,2013,2014,2339,2340,12341$,

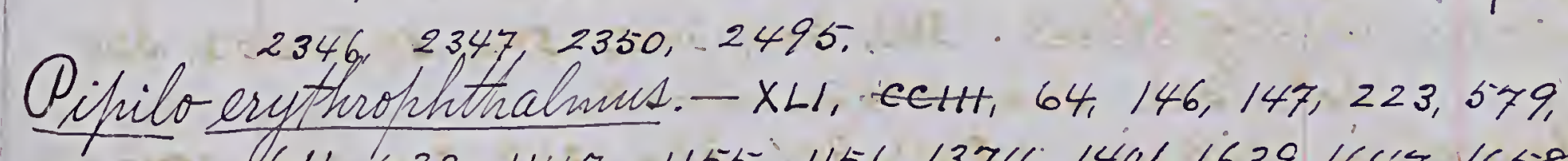
$611,6.33,1147,1155,1156,1374,1401,1639,1649,1658$,

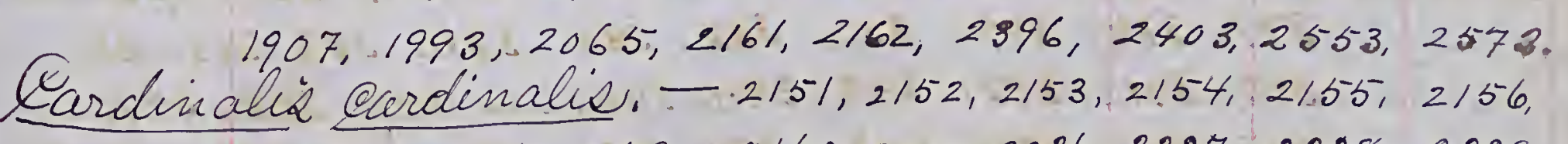
$2 / 57,2158,2159,2 / 60,2225,2226,2227,2228,2229$,

Leabia ludoirciana - $211,12,13,14,15,16,684,685,1170,1197$ $1202,1203,1420,1421,1490,1685,2050,2181,2420,2423$, $2601,2602,2605$

$1260,1643,1644,1653,1872,2102$. 
474

Andex to Sheimens of Birds.

475

Passerina eyanea, $-\angle 111, \angle x x 111,117,118,141,142,148,194$, $1218,1219,13.91,1443,1481, \cdots 1483,1.713,1714,1974$, $1945,23.99,24.51,25999$

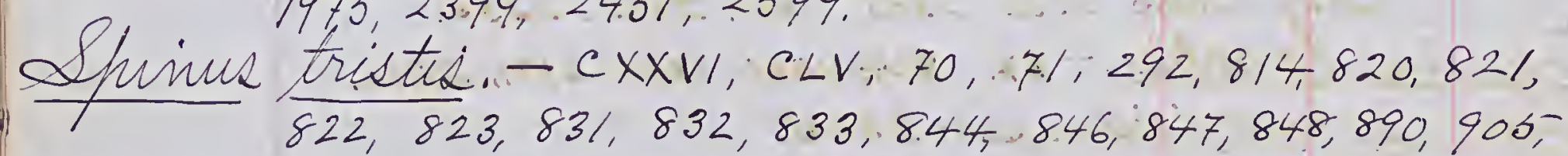
$822,823,831,832,833,8.44,846,847,848,890,906$,
$1120,1121,1270,1378,1460,1461,1633,1534,1536$,

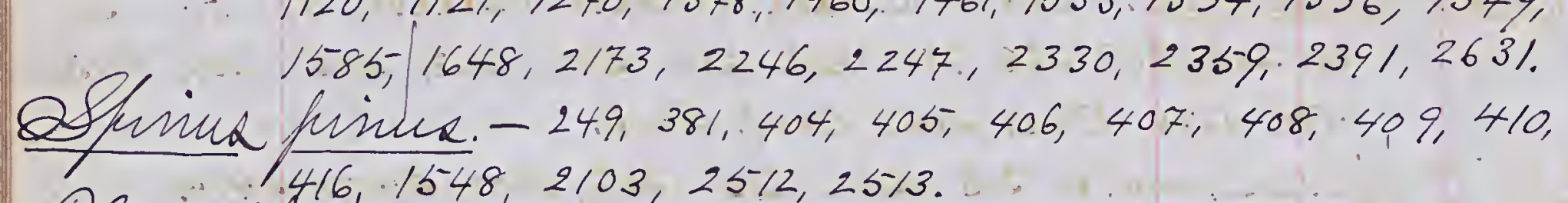
Dlectrophenax mivalix. $-439,440,441,442,481,482,483$, Passer domedticus - $c_{1}, 494,492,493,571,515,910,947,961$, $1124,15 \%, 15 \% 5 ;: 1576,1579,1580,1890,2324,2337$,

Diranga Ludoriciana. 2244. Piranga erythromelas. $-\angle X I 1, \angle X I V, L X X V I I, \angle X X X V I I I, c \angle X X V)$, $8,9,29,206,664,671,673,694,743,770,1133$,
$1169,1172,1173,1174,1182,1183,1184,1185,1186$, $1187,1188,1191,1192,1193,1198,1199,1200,1242$, $1243,1254,1403,1422,1431,1432,1445 ; 1696,1698$, $1727,1752,1758,1831,1892,1930,1931,2058,2191$, $2560,2584,2585 ; 2610$.

Diranga rufra. -2583.

Petrochelidou lunifrons. - $34,150,594,675,715,1180,1451,1452,1453,1454$

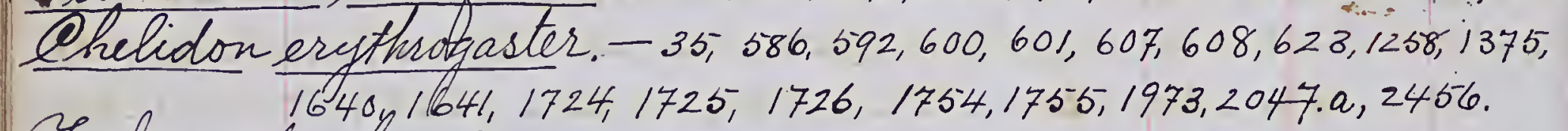
Aachyeineta bicolor.-31, 32, 33, 216,599, 595, 596, 598, 399, 606, Dlivicola 609, 610, 924, 1346, 1736, 2595:

At loida riparia.-1205, 1231, 1441, 1455, 1966,1968, 1969, 1971, 1972. Dtelgidopterefs serrifennis. - 1836, 1967, 2452, 2453.

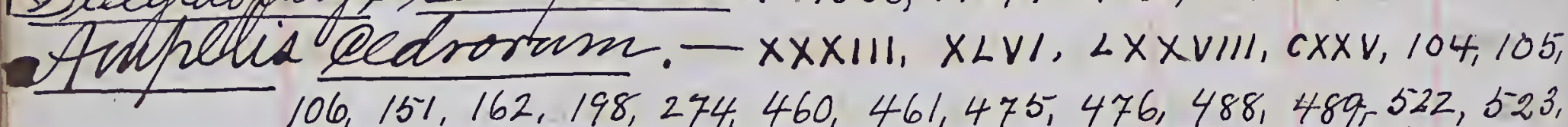
$106,15 \%, 162,198,274,460,461,475,476,488,489,522,5223$, $524,525,543,545,739,740,764,853,8555,856,8599 / 891,892$, $893,894,904,907,1235,1522,1558,1559,1560,1562,1563$, $1568,1578,1581,1582,1586,1587,15881589,1590,1591,1594$, $1595,1596,1597,1598,1599,1601, \mid 1602,1747,1761,1838,1843$,
$1844,1848,2196,2261,2262,2263,2264,2265,2266,2267$, $2270,2272,2273,2274,2275,2276,227 \%, 2280,2281,22821$
Andex to Sheciens of Birds.

Anpelis edrorum-Continued

$$
\begin{aligned}
& 2294,2295,2296,23306,2315, \mid 2316,2317,2318,2319,2320,2321, \\
& 2322,2323,2332,2333,2334,2335,2336
\end{aligned}
$$

$2322,2323,2332,2333,2334,2335,2336$.
Laniue borrali, $-x x, 824,1340,1824,2171,2216$. Lanins ledovicianus. - 2345:

Vireo olivaceous, - $\angle X V 11, C L X X 1 X, C L X X X Y 1, C L X X X V 11,57,100,136$, $161,203,209,233,709,723,1216,1241,1263,1266,1269,1413$, Vireo 1474, 1678, 1745, 2069; 2449, 2613,

2reo gilvus. - 696, 1213, 1214, 1215, 1367, 1900, 2400, 2414. Virie Jlavitrons. - 97, 98, 99., 1119, 1196, 1210,1211, 1212, 169i, Vireo Solitarius, - 7,42, 77, 977, 1111,11117, 1206, 1207, 1208, 120\%, Virer 1285, 1351, 1363, 1366, 1999, 2037, 2406, 2650. Mniotilta varia. -XLV11, 77, 575, 620,666, 672, 736, 981, 1007,

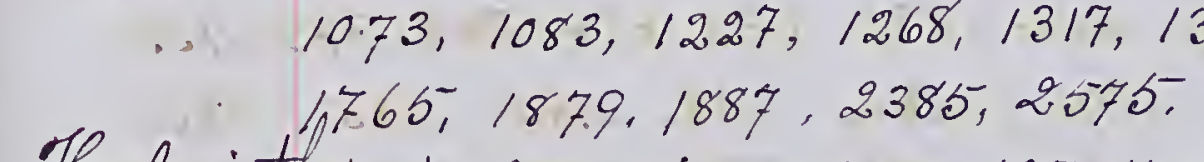

Heelmitherus vermivorus:- 107, 14.4, 174, 994, 1033,1069, 1095, Hechinthophila pinus - 1415,2607

Pelminthophila ehrysoptera. - 1686, 1.707, 1908, 1928, 1944: Thelminthophila ruficalilla $-92,93,94,639,668,66 \%$ $\frac{\text { belmintrophila rufica/rilla. }-92,93,94,639,668,669,689,}{763,974,991,1002,1074 ;, 1085,1088,1090,127 \%,}$ $1687,2408,2415,2447 ;, 2545,2549,2554,2555,2568$,
Helminthothila celata, -667, Celminithophila heregriona. - 91, 703,1279, 1289 Comprothlypie ancericaina. - $56,154,231,655,670,680,695$.

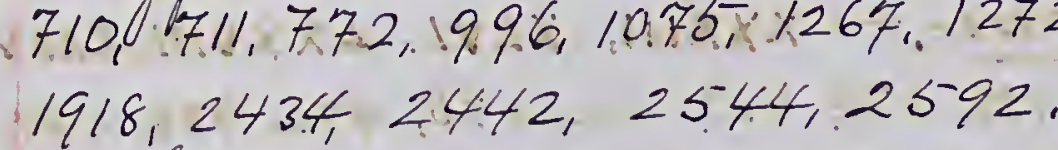

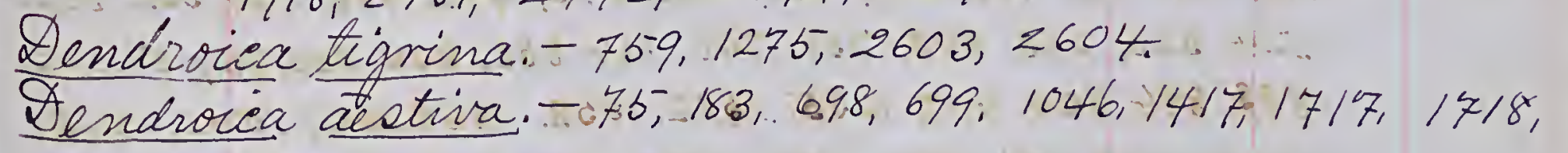
2398. 
476

Ludex to Shemine of Ninde.

Dendroica Coronata. - XXXV, 83, 87, 232,576, 587, 588, 597, $779,799,916,934,945 ; 968,969,970,980,1080,1081$ $1104,1509,1517,1544,15-50,1613,1786,1880,1896,2248$, $2269,2289,2290,2291,2292,2384,24416,2524,2532$, $2547,2548,255 \%$

Dindrorca maculosa. - 73, 74, 637,651,676,753,984, 997, $1012,1014,1017,1024,1058,1089,1264,1298,1309,1404$, Sendroica eaerulea. - 674.

IEndroica hen sylvanica. - 85, 86, 88,89, 187,648 , $692,976,1001,1035,1039,1044,1045,1261,1281,1406$, $1437,1476,147 \%, 175.6,1910,1943,2402,2543,2591$.

Dendroica eastanea. - L1x, 84, 756, 788, 995,1010,1011,1022,1027 $1028,1029,1030,1031,1042, .1047,1048,105 \%, 1067$, $1070,1097,1276,1299,1439,1467,1737,1915,1920$, Asndroica 2086, 2188, 2189. $755,762,776,777,778,1013,1026,1040$, Dendroica 1057, 1440,1470, 1921, 1923, 1926,1996,1997, 2441, 2609 Dendroica blackburnat. - 96, 207, 208, 760, 985, 1005, 1006, $1008,1009,1015, \cdot 1018,1036,1037,1043,1054,1059$, $1062,1076,1099,1101,1103,1108,1290,1291,1405$, $1409,1410,1424,1425,1429,1738,1740,1743,1979$, $2409,2590$.

Dendroica priens. - 47, 57, 138, 143, 647,691, 747,752, 780, $784,975,979,1020,1079,1086,1091,1094,1265,1271$, $1273,1280,1301,1433,1484,1692,17 / 2,1886,1894,1897$, $1979,2038,2039,2084,2405,2546,2556,2577$.

Dendroiea irgorsii. - 589, 741, 930, 135-2.

Dendrorica halmarum hypochryea. - $C 41 x, 90,599,612$, $1394,1494,1497,1634,1645,1866,1998,2018,2019,2024,2047.61$, 2387 .

Dendroiea desteolollux. - CLIV, 55; 625, 761,1004, 1021, 1038, $1071,1092,1228,1368,1369,1380,1889,1904,1905$, 2430,2565
Endex to Shecimens of Dirds.

Deirrue novaboracensies. $=992,1063,1066,125 \%, 1257,1392$, R. 1638,1642, 20,00, 2071, 2/92.

$220,574,621,725,936,949,950,955,964,1068,1110$, $1353,1379,1489,1624,1632,1636,1637,1677,1697,1877$, $1901,1902,2031, \mid 2032,2034,2183,2364,2383,25 \% 9$,

Eoothlyfir philadelthia.- 1000,2432.

Seothlyfin trichas $-78,626,627,999,1019,1064,1072,1098$,
$11105,1240,1364,1382,1459,1480,1666,1899,1929,1954$ $1955,1959,2083,2411,2435,2436,2561,2608$, Eeteria vrrins.- $79,80,682,1032,1061,1485,1709,1729$, $1882,1909,1940,2440,2622,2623$. Elyframia mutrata.
$728,978,993,1025,1060,106,1065,1084,1107,1223$, $1426,1427,1428,1475,1662,1663,1680,1681,1682$, $1683,1688,1689,1704,1705,1730,1731,1762,1766$, $1767,1912,1913,1941,1947,1907,1958,2063,2074$, $2075,2563,2573$

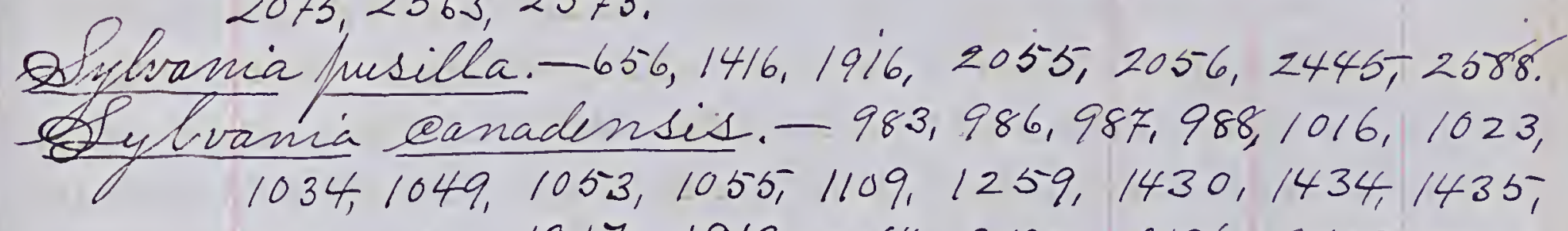
$1438,1911,1917,1919,2067,2182,2186,2433,2448$. $\frac{\text { Setophaga }}{748,} \frac{\text { ruticilla. }}{1003,1056,1078,1365,1373,1377,1646,1679,}$

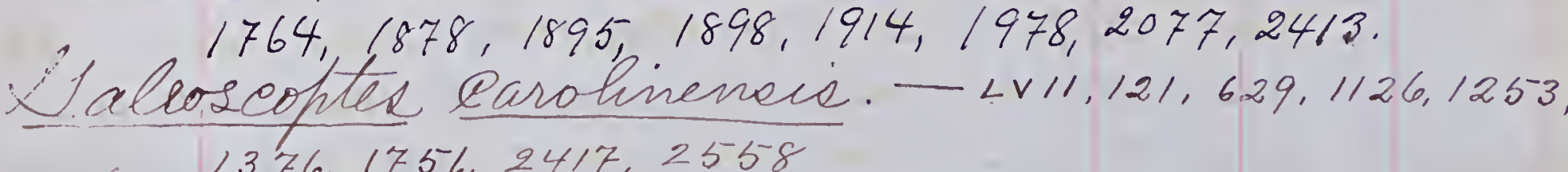
$1374.175 \%$. 247

$\angle V, C \angle X X I 11, C \angle X X X, 102,145$, $2393,2535$.

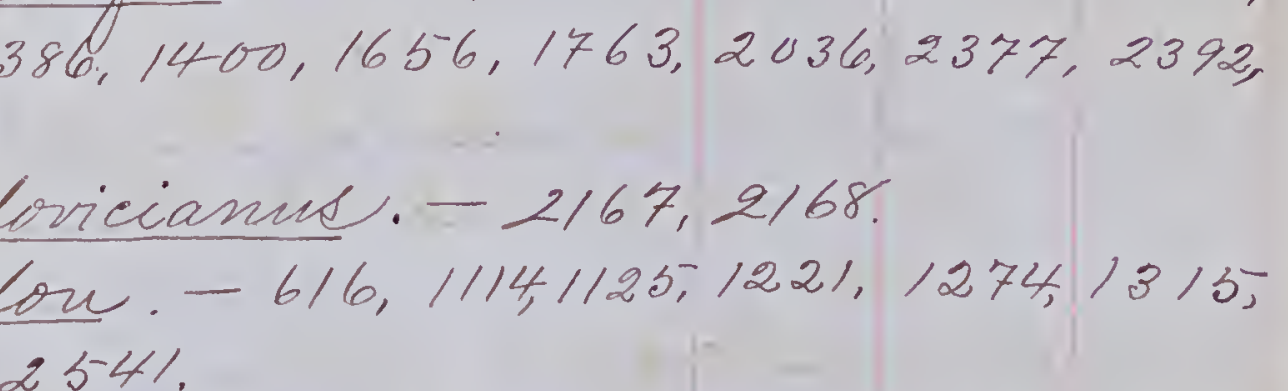

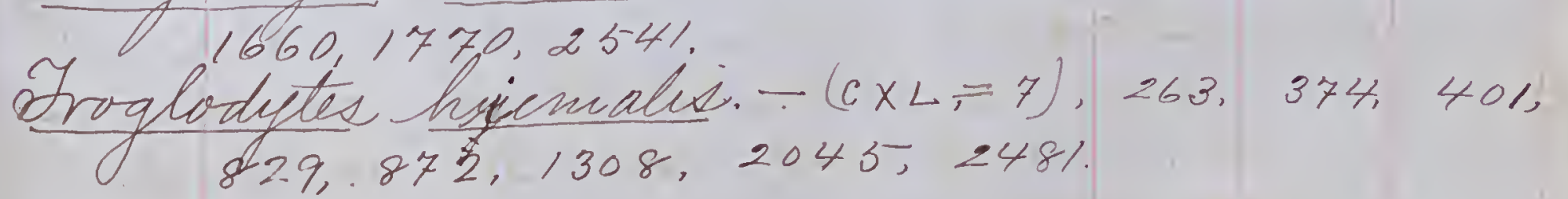




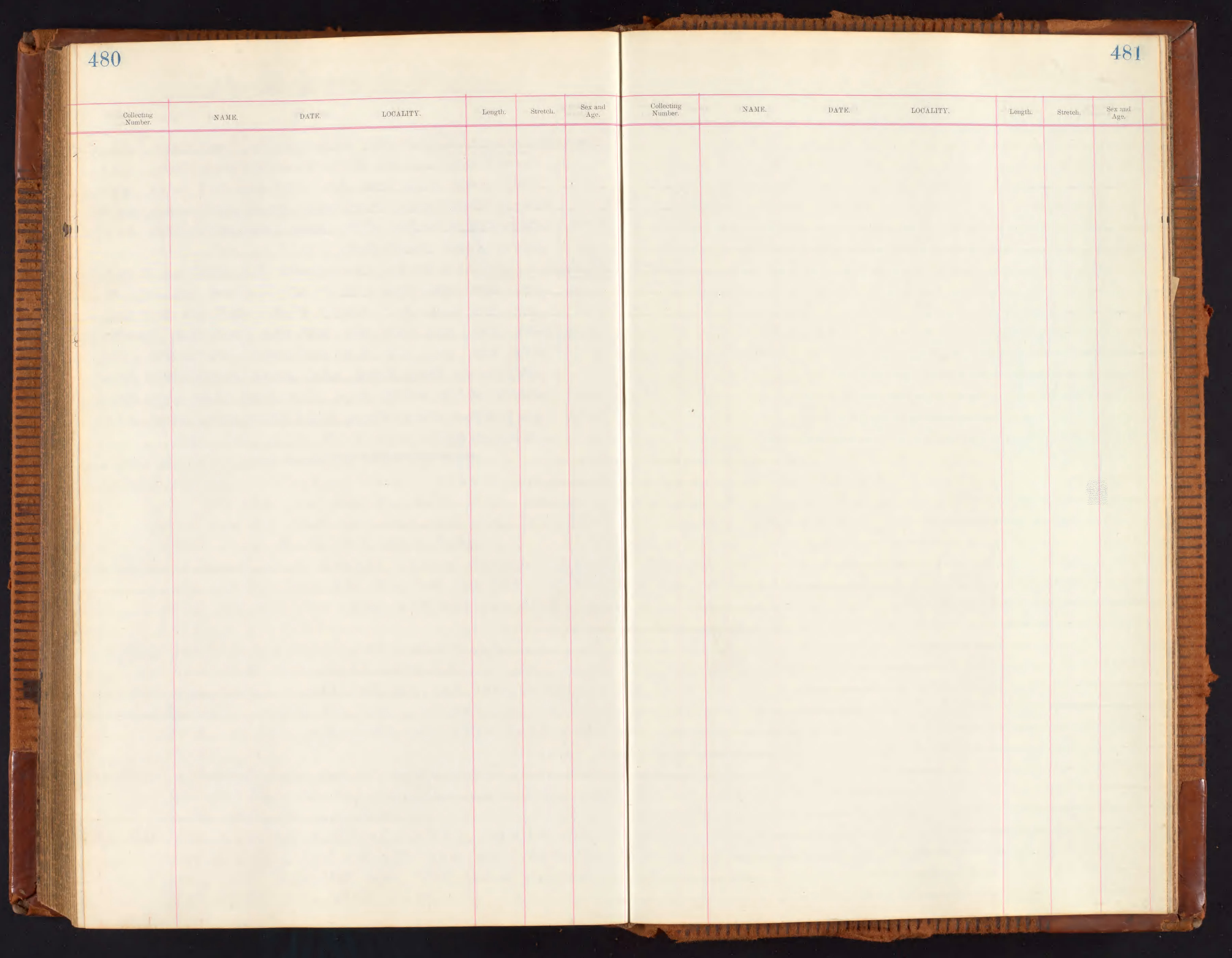




XaME. DATE.

LOCALITY.

Collecting
Nunutber.

NAME:

BATE

LOCALIT:

Lengtl.

\begin{tabular}{c|c} 
Stretel. & Sex : ind \\
Age. \\
Age.
\end{tabular}




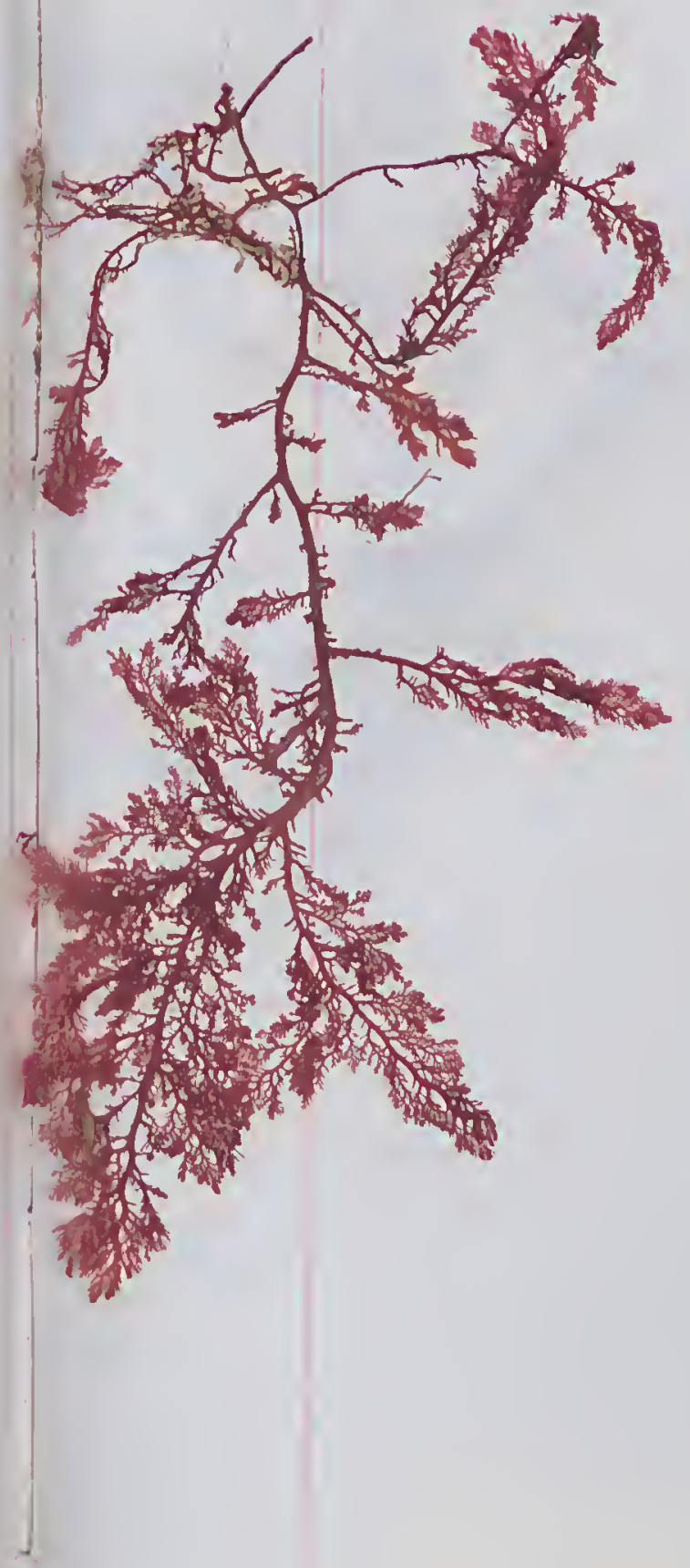





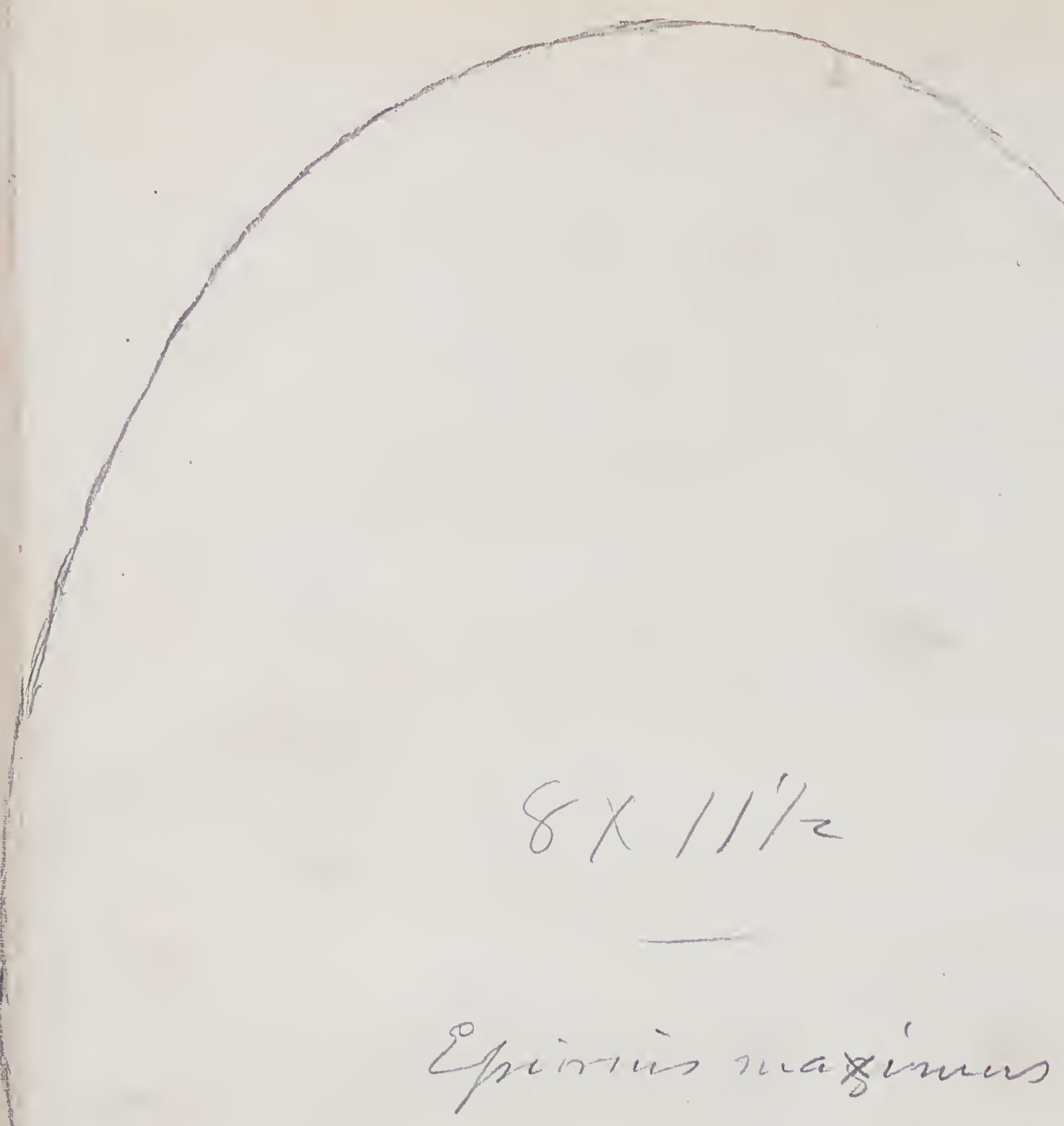




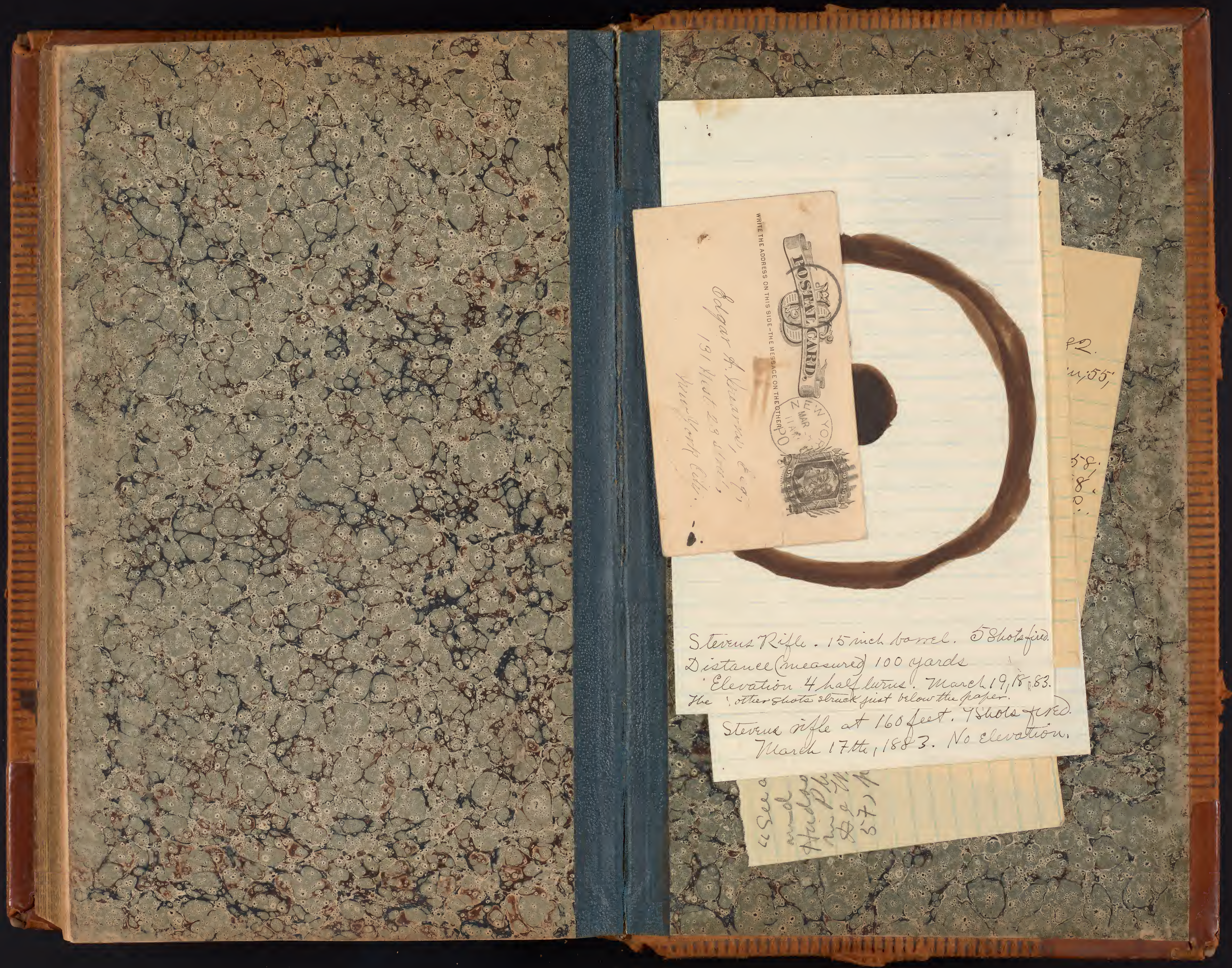


\section{QUESTIONS RELATING TO BIRDS AND}

PLEASE GIVE WHAT INFORMATION YOU CAN IN ANSWER T ANY AOOITIONAL ITEMS OF INTEAEST REGARDIN MAY BE WRITTEN ON THE BACK OF THIS

Name of species..

Name of person furnishing the information Address

1. The average number of eggs in a set or clutch

2. The largest number of eggs in one nest?

3. The earliest date of nesting?...

4. The latest date of nesting?

5. Whether this species has one or more broods in a season?..
Noter on Citu Birda Clitäide tin rask.

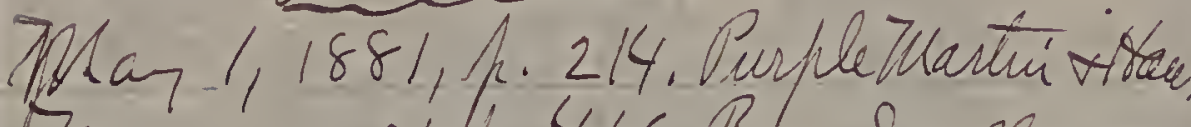
May /, 1281//2. 4/6. Barnduallowr.

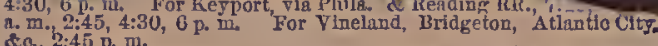

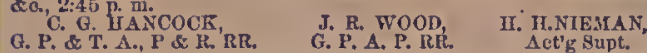
TEIV YOOLK CENTRAL AND AUDSON trains will ieave Grand Central Depot:

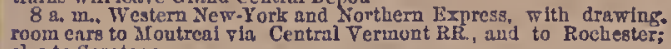

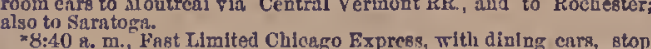

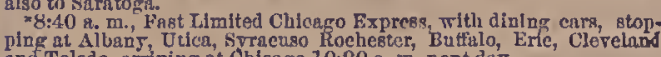

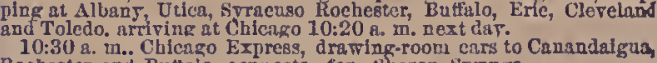

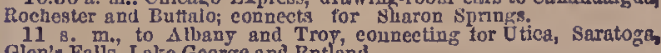

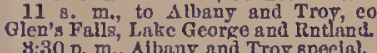

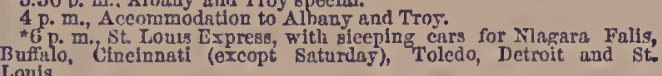

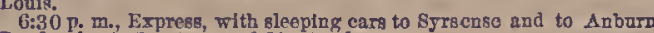

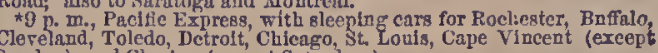

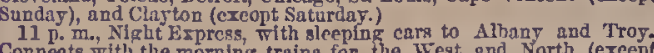
Tickets on sulo at Grand Centrul Depot, No. 5 Bow lin

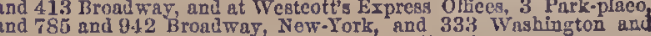

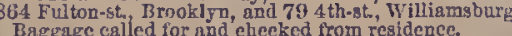

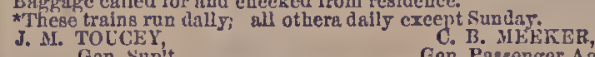

J. M. Gon. sup't

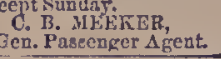

PENNSYlVANIA RaILROAD.

AND GITEAT TRUNTE LINE. ROYTE 
"See a list of aumal prjetato

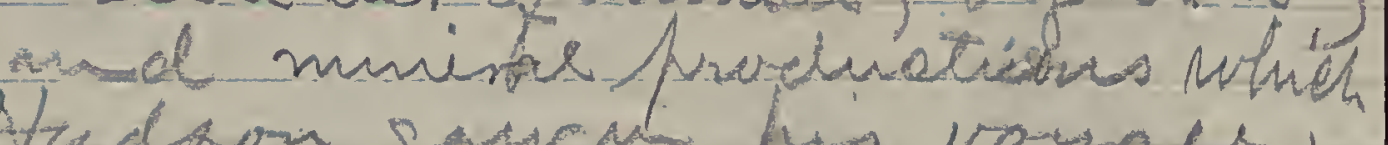

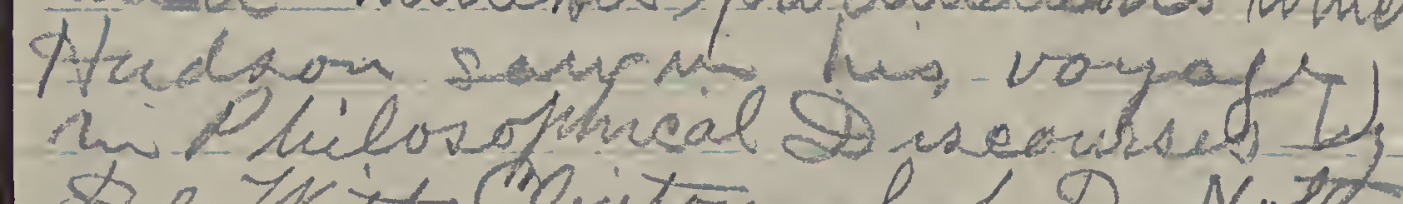

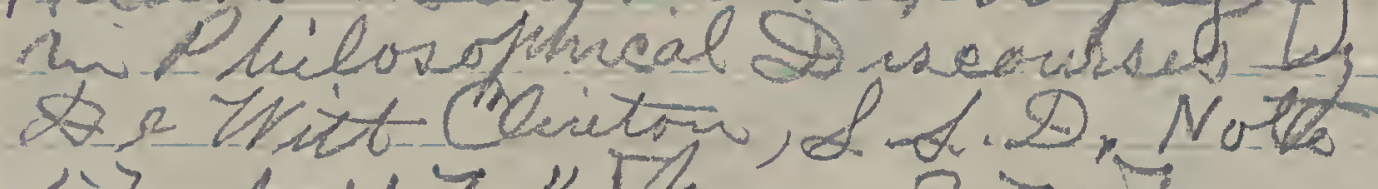
57 , $117 . "$ Dha 2707

2346

2340

Hox Sharrow. Mareh 20,1882.

$7.45 ; 11 \cdot 30 ; 3 \cdot 55 ; 3 \cdot 20$; culmen;55; gape, 58; tareus, 93 ; nute.97.

Hox Sparrow. 2347

$7.20 ; 11.30 ; 3.53 ; 2.92$; cul., 58;

gape, 62 ; Larsus, $95 ;$ inte. 98 .

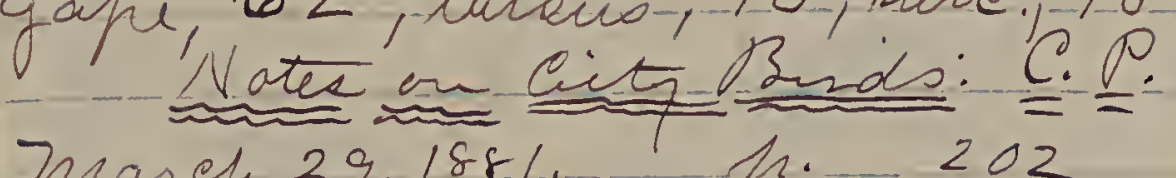

$\begin{array}{lll}\text { Znarch } 29,1881 . & \text { h. } & 202 \\ \text { aprie } 3,1581 . & \text { h. } & 206\end{array}$

aprie $17,188 \% \quad 208$

Apiril 24, 1881. hi 210

Thay $1-1881.214$.

May $4,1881 . / 18.217$.

$\begin{array}{lll}\text { Mat } 13,1881 . & h . & 227 \\ \text { Noventer } 30,1881 . & h & 253\end{array}$

Novouber 30, $1881 . \quad h \cdot 253$

Whareh 12, 1882 Z1.294

Noteson Birds outside th Park are not here indexed. 
clafield \&/nil/2, /58/

Yollow -belléd Waotueker

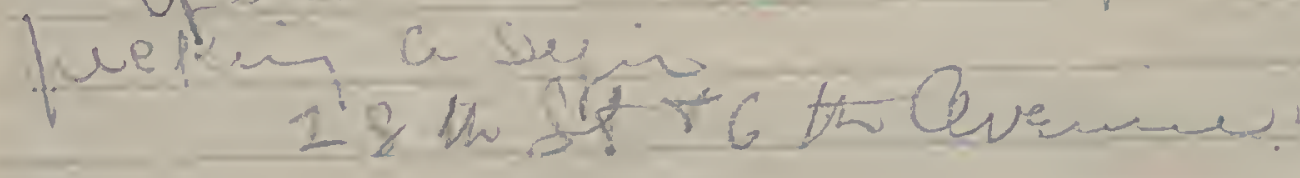

Fishes of the Hudson River Valley.

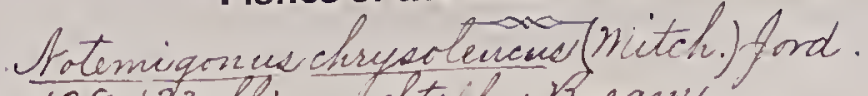

No. 128-133. Shiner, Sticte; Breann.

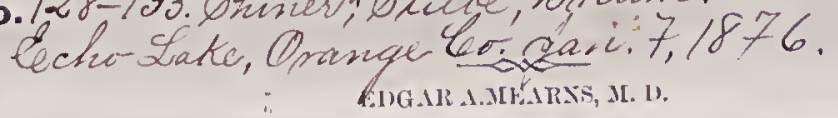



MEARNS HOUSE,

HIGHLAND FALLS, N. Y

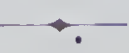

Office of EDGAR A. MEARNS, M. D.

Znareh / 6 the, 1883

Dear Sir

Will you Aindly send

a copy of ve on: the

"Prosecdiniga of US.S. Nationial

"Musunn " and very gratty

blige.

foura very resfeelfully

Yospti Stencer f. Oarid Weathin Ston D.C. 
Stevrus Rifle. 15 mich barrel. SShotafind.

Distanee (measured 100 yards

- Elevation 4 half lurue. Nareh 19,18.83.

The itter shotes seruck fiut bilow the paper. 
WRITE THE ADDRESS ON THIS SIDE-THE MESSACE ON THEQTHERP

- Gogar A. Lnearno, E.q., 131 licat 23 atseel, hewriont cille. 


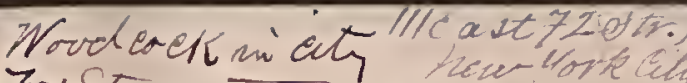
7.t Strean V/228. in, icn, -

out 15. - L " "wrete Pink",

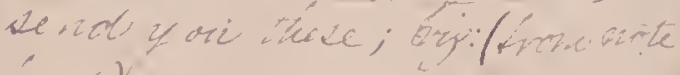

wetrat Parte

Aimunde timperztum.

Amicalue fur murere.

Mayt:

simnde terreorume

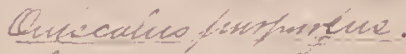

Chaetura fulaquia.

Exfect sinoturno

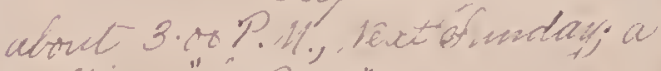

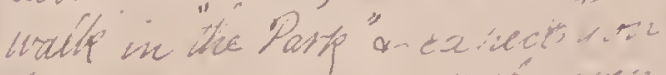

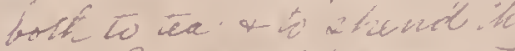
ing. Besure come,

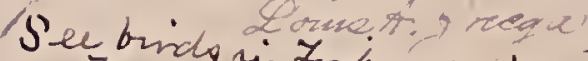
Fonsentand stune building Ethinarme: 


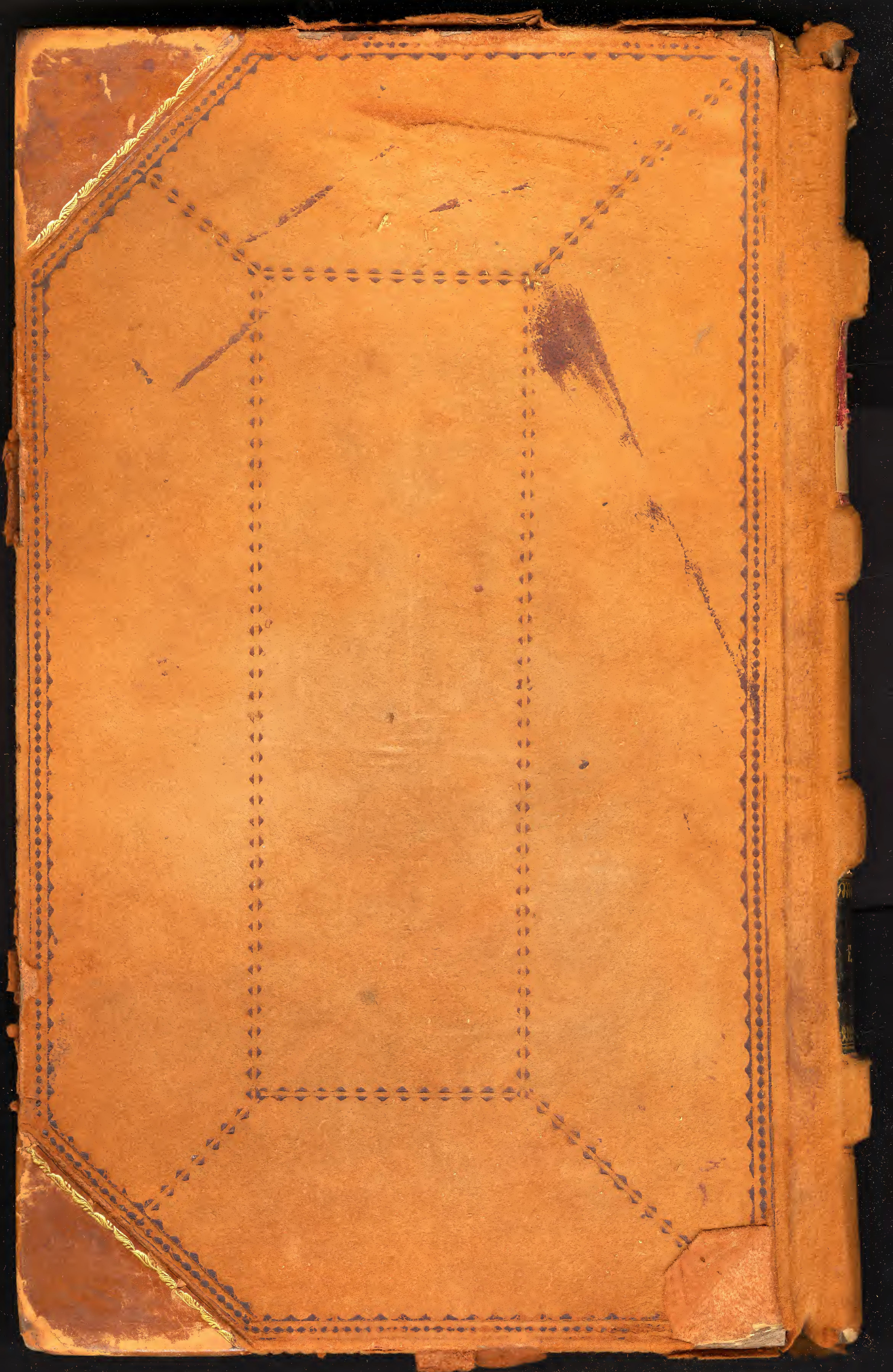

